
Mateusz Michalski

\section{GEMATRIA, GEOMETRIA I INNE FENOMENY W ARCHITEKTURZE JUDAIZMU}


Recenzenci

Ernest Niemczyk

Leszek Ziątkowski

Opracowanie redakcyjne i korekta

Katarzyna Sosnowska

Projekt okładki

Janusz M. Szafran

Opracowanie techniczne i projekt graficzny

Małgorzata Szafran

Janusz M. Szafran

Ilustracja na okładce

Vogel Z., ok. 1797 r., Gabinet Rycin Biblioteki Uniwersyteckiej w Warszawie, Inw. zb. d. 10173.

Wszelkie prawa zastrzeżone. Żadna część niniejszej książki, zarówno w całości, jak i we fragmentach, nie może być reprodukowana w sposób elektroniczny, fotograficzny i inny bez zgody wydawcy i właściciela praw autorskich.

(C) Copyright by Oficyna Wydawnicza Politechniki Wrocławskiej, Wrocław 2020

\author{
OFICYNA WYDAWNICZA POLITECHNIKI WROCŁAWSKIEJ \\ Wybrzeże Wyspiańskiego 27, 50-370 Wrocław \\ http://www.oficyna.pwr.edu.pl \\ e-mail: oficwyd@pwr.edu.pl, zamawianie.ksiazek@pwr.edu.pl
}




\section{SPIS TREŚCI}

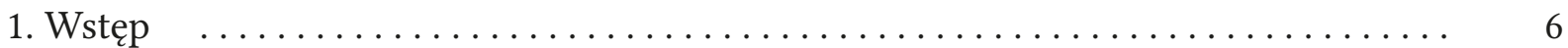

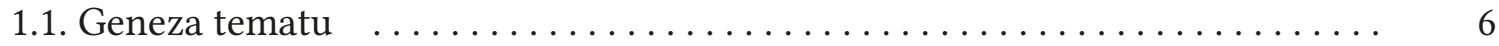

1.2. Stan badań nad architekturą judaizmu $\ldots \ldots \ldots \ldots \ldots \ldots \ldots \ldots \ldots \ldots$

1.3. Synagogi w Polsce i Europie $\quad \ldots \ldots \ldots \ldots \ldots \ldots \ldots \ldots \ldots \ldots \ldots \ldots \ldots \ldots$

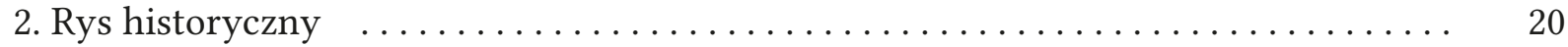

2.1. Zarys sytuacji Żydów w Rzeczpospolitej $\ldots \ldots \ldots \ldots \ldots \ldots \ldots \ldots \ldots \ldots$

2.2. Kabała i ruchy mistyczne i mesjanistyczne - podstawy teoretyczne i zarys

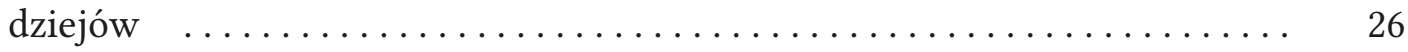

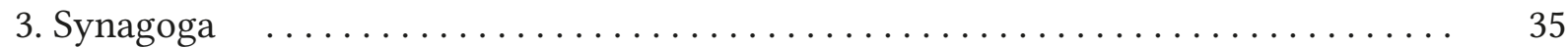

3.1. Elementy synagogi - uwarunkowania religijne i kulturowe $\ldots \ldots \ldots \ldots \ldots$

3.2. Układ przestrzenny sali męskiej do końca XVI wieku $\ldots \ldots \ldots \ldots \ldots \ldots .40$

3.3. Układ przestrzenny sali męskiej w synagogach w dawnej Polsce ...... 43

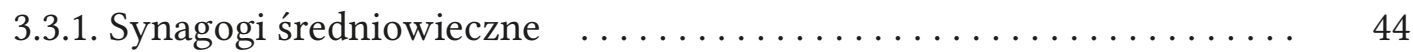

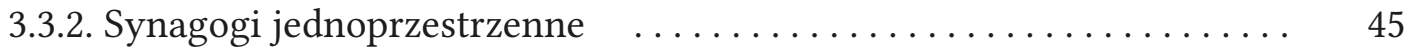

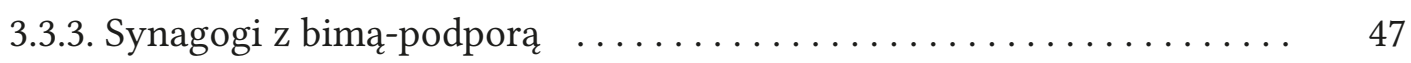

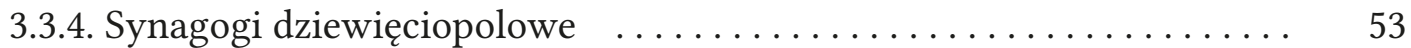

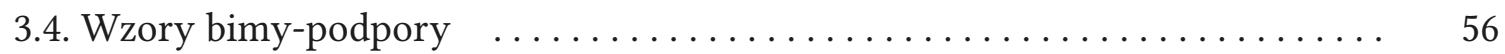

3.5. Geneza układów dziewięciopolowych $\ldots \ldots \ldots \ldots \ldots \ldots \ldots \ldots \ldots \ldots$

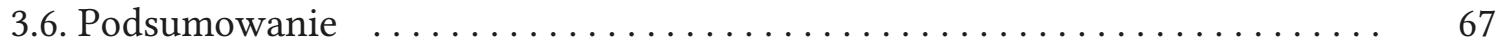

4. Symbolika dekoracji i wystroju XVI- i XVII-wiecznych synagog zachowanych

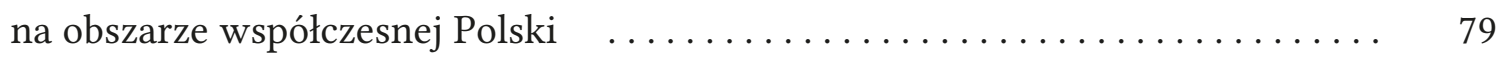

4.1. Dekoracje wnętrz synagogi i ich symbolika $\ldots \ldots \ldots \ldots \ldots \ldots \ldots \ldots$

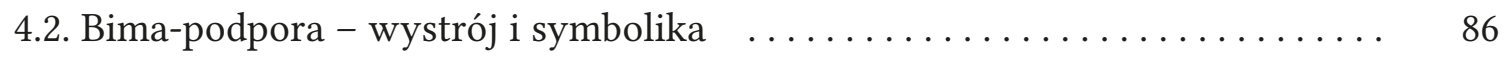

4.3. Aron ha-Kodesz - analiza dekoracji i form z okresu XVI-XVIII wieku $\ldots . .99$

4.4. Kolory i ich znaczenie symboliczne $\ldots \ldots \ldots \ldots \ldots \ldots \ldots \ldots \ldots \ldots . \ldots \ldots$

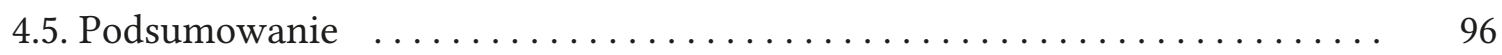

5. Proporcje architektoniczne XVII- i XVIII-wiecznych synagog zachowanych

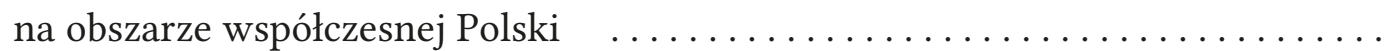




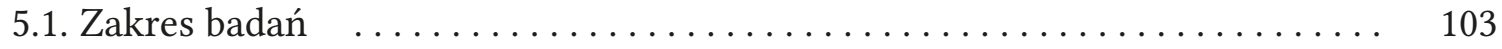

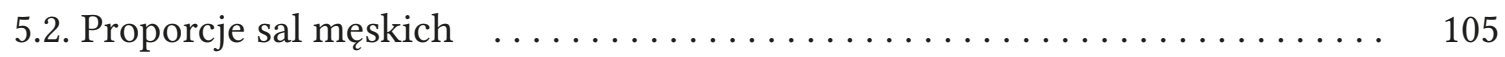

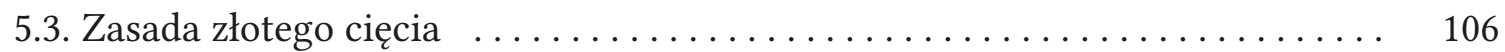

5.4. Złote proporcje sal męskich synagog $\ldots \ldots \ldots \ldots \ldots \ldots \ldots \ldots \ldots \ldots \ldots$

5.4.1. Złote proporcje sal męskich synagog z bimą-podporą $\ldots \ldots \ldots \ldots . .112$

5.4.2. Złote proporcje sal męskich w synagogach dziewięciopolowych $\ldots 116$

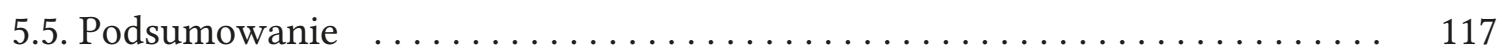

6. Oddziaływanie świątyni jerozolimskiej na architekturę bożniczą $\quad \ldots \ldots \ldots \ldots \ldots \quad 121$

6.1. Związki między świątynią jerozolimską a synagogą $\ldots \ldots \ldots \ldots \ldots \ldots . \ldots 121$

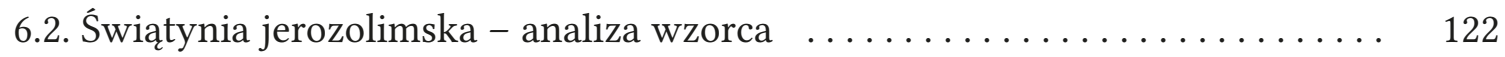

6.3. Rekonstrukcja świątyni jerozolimskiej według Villalpanda i Prada . . . . . 127

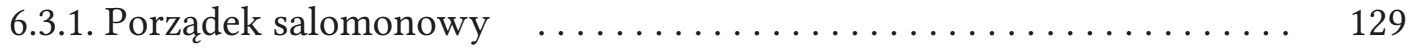

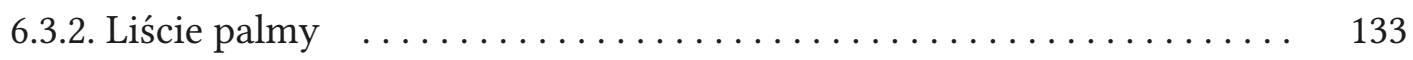

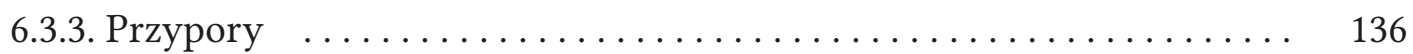

6.3.4. Układ dziewięciopolowy u Villalpanda i Prada a plany XVII-

i XVIII-wiecznych synagog zlokalizowanych na obszarze Polski $\ldots .139$

6.3.5. Złote proporcje u Villalpanda i Prada a XVII- i XVIII-wieczna

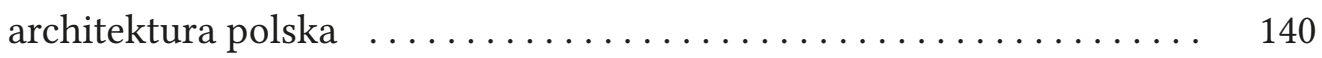

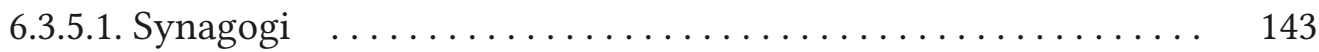

6.3.5.2. Kościoły katolickie (ze szczególnym uwzględnieniem kościołów zgromadzeń kontrreformacyjnych) $\ldots \ldots \ldots \ldots \ldots \ldots \ldots \ldots \ldots$

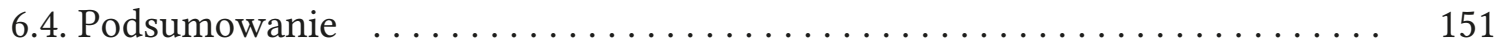

7. Plan koncentryczny $\mathrm{w}$ architekturze synagog $\ldots \ldots \ldots \ldots \ldots \ldots \ldots \ldots \ldots$

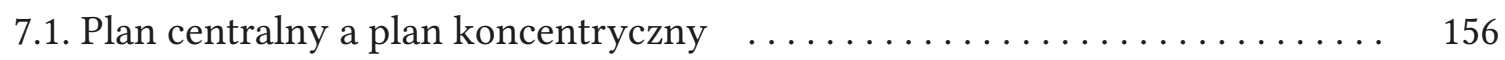

7.2. Układ koncentryczny w myśli żydowskiej $\ldots \ldots \ldots \ldots \ldots \ldots \ldots \ldots \ldots$

7.3. Teoria a praktyka - układ wnętrza synagog $\ldots \ldots \ldots \ldots \ldots \ldots \ldots \ldots . \ldots \ldots$

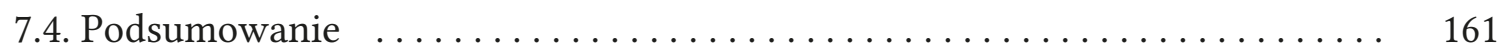

8. Gematria w XVII- i XVIII-wiecznych synagogach zlokalizowanych na obszarze administracyjnym współczesnej Polski $\ldots \ldots \ldots \ldots \ldots \ldots \ldots \ldots \ldots \ldots \ldots \ldots$

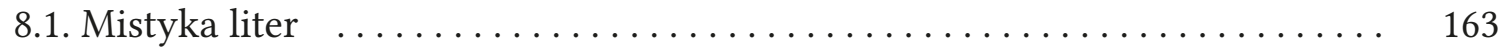

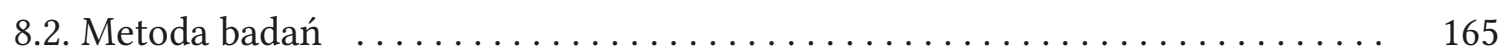

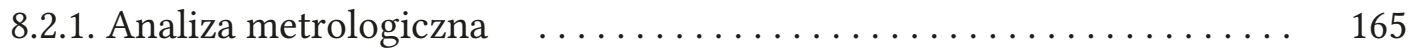

8.2.1.1. Miary uwzględnione $\mathrm{w}$ analizie metrologicznej $\ldots \ldots \ldots . .166$

8.2.1.2. Materiał do badań $\ldots \ldots \ldots \ldots \ldots \ldots \ldots \ldots \ldots \ldots \ldots$

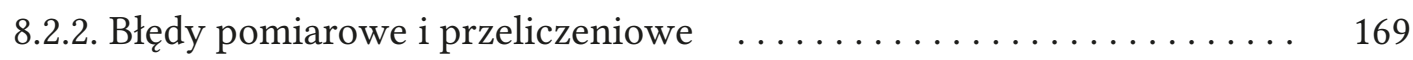

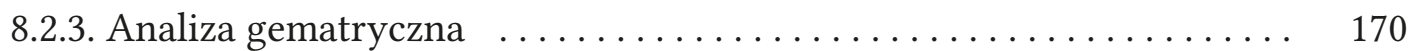


8.2.4. Analiza metrologiczna $\quad \ldots \ldots \ldots \ldots \ldots \ldots \ldots \ldots \ldots \ldots \ldots \ldots \ldots \ldots \ldots \ldots$

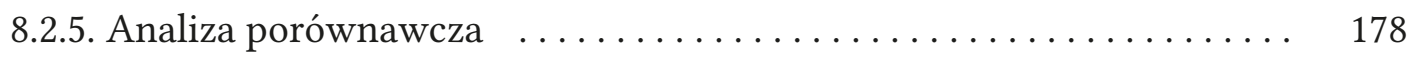

8.2.5.1. Synagogi na Ukrainie i Białorusi $\ldots \ldots \ldots \ldots \ldots \ldots \ldots$

8.2.5.2. Kościoły polskie z XVII i XVIII wieku $\ldots \ldots \ldots \ldots \ldots \ldots \ldots 181$

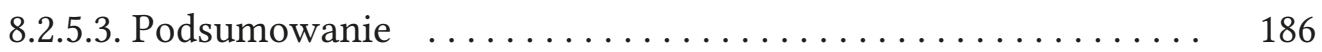

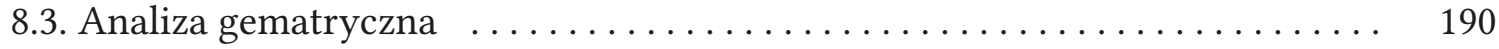

8.3.1. Częstotliwość występowania poszczególnych wartości pomiarów $\quad \ldots \quad 190$

8.3.2. Częstotliwość występowania podstawowych wartości liczbowych w wymiarach synagog $\ldots \ldots \ldots \ldots \ldots \ldots \ldots \ldots \ldots \ldots \ldots \ldots$

8.3.2.1. Częstotliwość występowania podstawowych wartości liczbowych w materiale porównawczym ............ 194

8.3.2.2. Podsumowanie .......................... 197

8.3.3. Analiza gematryczna modlitw ..................... 199

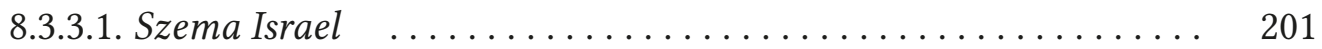

8.3.3.2. Szemone esre - Amida _....................... 207

8.3.3.3. Lecha dodi ............................ 226

8.3.3.4. Kabalat szabat _....................... 230

8.3.3.5. Tikkun Chacot .......................... 244

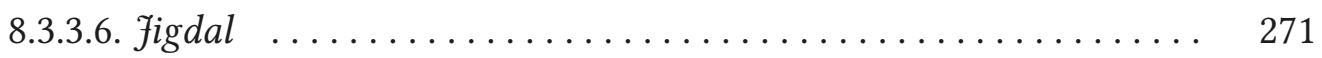

8.3.3.7. Szir Hakawod - Anim Zemirot _................. 275

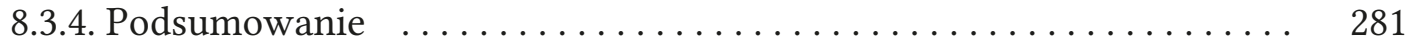

9. Gematria i inne fenomeny architektury judaizmu $\quad \ldots \ldots \ldots \ldots \ldots \ldots \ldots \ldots$

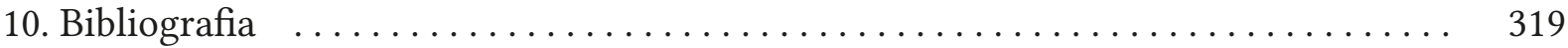

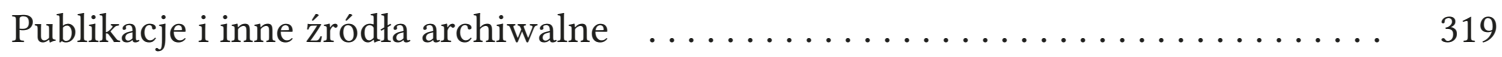

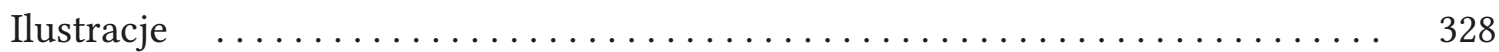




\section{Wstęp}

\subsection{Geneza tematu}

Niniejsza monografia powstała na bazie pracy doktorskiej autora, zatytułowanej Architektura judaizmu - wybrane aspekty zagadnienia na przykładach zachowanych synagog $z$ XVII i XVIII w. z terenu obecnej Polski. W obu publikacjach autor próbuje pokazać za pomocą pewnych fenomenów, czym właściwie jest architektura judaizmu. Pod względem semantycznym zagadnienie rodzi więcej pytań niż odpowiedzi. To przychodzące na myśl jako pierwsze dotyczy powodu użycia pojęcia architektury judaizmu zamiast pojęcia architektury żydowskiej. Architektura judaizmu implikuje związki z religią. Odnosi się do przestrzeni, które służą rytuałowi nie tylko religijnemu, ale i społecznemu. $Z$ tego względu znika problem żydowskości architektury, a więc jej przypisania konkretnej grupie społecznej. Jest to o tyle istotne, że na skutek ograniczenia dostępu do cechów rzemieślniczych Żydzi zwykle nie byli muratorami. Z tym związana jest niemożność zakwalifikowania bożnic do architektury żydowskiej większość z nich została bowiem wzniesiona przez chrześcijan. Jeśli jednak bożnice wznosili chrześcijanie, to czy można mówić o architekturze posiadającej cechy odpowiadające judaizmowi? Trudność w sformułowaniu definicji architektury judaizmu uniemożliwia natomiast określenie jej fenomenów.

Mówiąc o architekturze judaizmu jako o przestrzeni przeznaczonej do odprawiania rytuału religijnego i społecznego, nie wyczerpuje się - jak się wydaje - tego zagadnienia. Opór środowiska naukowego stawiany dążeniu do legitymizacji architektury żydowskiej znacznie ogranicza jednak możliwości jej definiowania w oparciu o dostępną wiedzę. Analizy przeprowadzone w kolejnych rozdziałach monografii mają na celu usankcjonowanie w nauce i kulturze zjawiska, jakim jest architektura judaizmu. Najistotniejsze wydaje się rozdzielenie architektury żydowskiej, która kojarzy się jednoznacznie z obiektami wznoszonymi przez społeczność żydowską, od architektury, która służyła tej społeczności do realizacji celów liturgicznych. Architektury, która skupiała się na telos. Architektury, która jest oparta na takim kształtowaniu przestrzeni, w którym - jak można się przekonać - forma pełni drugorzędną rolę. Czyżby więc architektury bez architektury?

W tytule monografii zawarte jest sformułowanie fenomeny architektury judaizmu, które ma charakter antynomiczny. Zawiera bowiem określenie fenomeny, które z jednej strony $\mathrm{w}$ literaturze przedmiotu nie zostało zdefiniowane i w związku z tym nie jest w niej stosowane. $\mathrm{Z}$ drugiej jednak - ze względu na brak jasnych przesłanek - trudno zaprzeczyć ich istnie- 
niu lub je potwierdzić. Rozstrzygnięcie wymaga odniesienia się do konkretnych zagadnień. Wybrane i omówione w pracy fenomeny mają pomóc w odpowiedzi na pytanie, czy istnieją cechy architektury bożniczej, które mogłyby zasługiwać na miano cech konstytuujących ją i świadczących o jej odrębności od głównych nurtów architektury w Polsce i w konsekwencji umożliwiających jej klasyfikację.

W celu uzyskania pełniejszego obrazu opisywanych procesów oraz zagadnień przedstawiono rys historyczny dziejów społeczności żydowskiej, ruchy związane z mistyką żydowską, a także omówiono zjawisko architektoniczne, za jakie należy uznać architekturę synagogalną. Poza wprowadzeniem w zasady wynikające z przepisów prawa religijnego ważny wydaje się proces kształtowania na przestrzeni wieków wyglądu sali męskiej. Jednocześnie warte uwagi są rozważania dotyczące genezy pewnych układów funkcjonalnych i konstrukcyjnych, uwzględniające teorie, które przez lata narosły.

Kluczowa w definiowaniu architektury judaizmu wydaje się uwypuklona w tytule gematria. Słowo to pochodzi od wywodzącego się z języka greckiego słowa geometria i to z geometrii planów wynikają pewne przedstawione w pracy zależności gematryczne. Aby zdefiniować pojęcie architektury judaizmu wybrano szerokie spektrum fenomenów, które są nierozerwalnie związane z przestrzenią sali męskiej.

Bet ha-Kneset (heb. בית כנסת), czyli dom zgromadzeń, inaczej określany był jako dom modlitwy, nauki czy szkoła (jid. szul). Synagoga (gr. $\sigma v v \alpha \gamma \omega \gamma \eta ́)$ jest terminem wywodzącym się z języka greckiego i oznaczającym również dom zgromadzeń ${ }^{1}$.

Analizując architekturę wznoszoną w Polsce na potrzeby gmin żydowskich, należy odnieść się do kilku, jak się wydaje, istotnych zagadnień. Pierwszym z nich jest z pewnością sposób kształtowania układów przestrzennych na przestrzeni wieków. W kontekście przemian, jakie na przestrzeni wieków następowały zarówno w społeczności sefardyjskiej, jak i aszkenazyjskiej², można stwierdzić istnienie pewnych związków z głównymi nurtami architektonicznymi danej epoki. Układy przestrzenne synagog nie podlegają jednak przemianom opartym na klasycznych wzorcach architektury. W przypadku architektury judaizmu można wyodrębnić raczej dwa typy działań: trwanie (polegające na wykorzystywaniu układów wypracowanych wcześniej) oraz innowacyjność (opierającą się na zupełnie nowym podejściu do kształtowania przestrzeni sali męskiej). Oba uwzględniają niezmienne przepisy prawa halachicznego.

Przemiany zachodzące $\mathrm{w}$ architekturze bożniczej miały z pewnością związek również z przemianami społecznymi. Wpływ ruchów mistycznych na liturgię synagogalną oraz szerzenie się ich wśród społeczności żydowskiej każą przypuszczać, że kabała odcisnęła swoje piętno na architekturze synagonalnej. Mistyka żydowska będzie wspominana właściwie w całej pracy.

Na przestrzeni wieków wzniesiono w Polsce kilkaset domów modlitwy ${ }^{3}$. Trudno uwierzyć, że przy tak prężnym ruchu budowlanym w społeczności żydowskiej kahały nie partycypowały w procesie budowlanym. $Z$ danych uzyskanych dotychczas chociażby przez Majera Bałabana wynika, że starozakonni chętnie pomijali pewne narzucone z góry parametry, które spełniać 
miały Bet ha-Kneset. Takie działanie może wpisywać się w związek między wizją chrześcijańskich budowniczych a światopoglądem żydowskim. Oznacza to, że ta sama forma w rozumieniu chrześcijańskich muratorów i żydowskich odbiorców miała zupełnie inne znaczenie.

\subsection{Stan badań nad architekturą judaizmu}

Pojęcie architektury judaizmu nie jest dzisiaj szeroko rozpowszechnione, a jednym z powodów jest brak jednoznacznej definicji. W publikacji Adolfa Szyszko-Bohusza pojawiło się pojęcie architektury żydowskiej, a samo zjawisko autor analizował bardziej jako manifestację kultury społeczności semickiej zamieszkującej obszar Polski, zaznaczając jednocześnie, iż „kultura ta nie była na tyle silna, by wytworzyć własną architekturę” [172, s. 1]. Patrząc z tej perspektywy, faktycznie można odnieść wrażenie, iż sposób kształtowania form Bet ha-Kneset, podobnie jak detal stosowany w tych obiektach miał ścisły związek z architekturą rodzimą ziem polskich. Według Szyszko-Bohusza jedynym przejawem architektury żydowskiej są elementy ściśle powiązane z rytuałem i „wschodnie zacięcie w traktowaniu ornamentacji” [172, s. 1]. Sergiey Kravtsov uważał natomiast, że tym, co łączy tożsamość ze stylem architektonicznym, są elementy dekoracyjne. Cechy baroku i neobaroku odnajdywał w architekturze charakterystycznej dla tradycji chasydzkiej i ortodoksyjnej, natomiast neoklasycyzm zaspokajał, jego zdaniem, potrzeby maskili ze względu na swoją „niekoszerność” [93, s. 88].

Anna Kubiak pisała, że „tylko układ, ale nie wykonanie wnętrza [...] był typowo żydowski zgodnie z wymogami rytuału i obyczaju" [101, s. 128], co potwierdza opinia Adolfa Szyszko-Bohusza i Zygmunta Glogera. Drugi z wymienionych badaczy w swych rozważaniach twierdził, że właściwie nie należy analizować budownictwa synagogalnego w oderwaniu od architektury polskiej, gdyż prowadzi to do całkowicie błędnego rozumienia go jako zbioru obiektów zakorzenionych w sztuce żydowskiej [48, s. 25]. Zygmunt Gloger powoływał się w swojej teorii na Kazimierza Mokłowskiego [120, s. 437-438], który negował wiązanie przez Mathiasa Bershona [16] bożnic ze sztuką żydowską. Zarówno obiekty drewniane, których układ odpowiadał rodzimej architekturze dworu szlacheckiego z narożnymi alkierzami [120, s. 437-438], jak i synagogi murowane „odpowiadają doskonale stylom historycznym panującym w Polsce w czasie ich zakładania” [120, s. 438]. Mokłowski wyrażał przy tym kategoryczną opinię: „Niechże choć na przyszłości separatyzm żydowski przynajmniej na koszt bezstronnej nauki tryumfów nie święci” [120, s. 438].

Richard Krautheimer pisał w swojej książce, że „formalny kształt budynku, ukształtowanie wnętrza oraz jego elementy składowe, formy dekoracyjne nie narodziły się z kultury judaizmu, tylko zależą od przestrzennego i czasowego środowiska, w którym obiekty te powstają" [91, s. 12]. Maria i Kazimierz Piechotkowie, tłumacząc ten cytat, zwrócili uwagę, iż ponownie pojawia się w nim pojęcie kultury żydowskiej [134, s. 34], a nie kultury judaizmu. Nie jest to oczywiście błędem, wszak fudentum można tłumaczyć dwojako. Pojawia się więc 
problem semantyczny, który w gruncie rzeczy zmienia punkt widzenia oraz sposób definiowania. Wszyscy autorzy publikacji zamiennie używają pojęć kultury i religii, co jest mylące.

Izrael Abrahams zajął bardziej radykalne stanowisko, pisząc, „Co do kształtu synagogi, żadna specjalna forma nie może być nazywana żydowską” [1, s. 30]. Poparła go Carol Herselle Krinsky, kiedy stwierdziła, że „żadna przestrzeń i forma nie jest typowo żydowska” [98, s. 353-354]. Ze względu na różnorodność kształtów i organizacji wnętrza, które wiążą się z czasem i miejscem, oraz wpływ lokalnej architektury sakralnej nigdy nie mógł rozwinąć się jakikolwiek jednorodny styl [123, s. 43] - nie tylko w architekturze, ale generalnie w żydowskiej sztuce wizualnej. Próbując zatem zdefiniować pojęcie architektury judaizmu, należy opisać ten stan rzeczy i odnieść się do filozofii żydowskiej [162, s. 11-20], która może się wydawać pojęciem podobnie ambiwalentnym i w pewnym sensie niezdefiniowanym.

Majer Bałaban wskazuje dwie przeszkody na drodze rozwoju sztuki żydowskiej. Pierwszą z nich był nakaz zawarty w Piśmie Świętym: „Nie uczynisz sobie posągu ani żadnego obrazu tego, co jest na niebie wysoko, albo na ziemi nisko, lub w wodzie poniżej ziemi” [137, Wj 21,1] natomiast drugą ciągnące się od okresu średniowiecza wykluczenie Żydów z cechów rzemieślniczych [8, s. 40-49]. Podejście samego Majera Bałabana jest jednak zdecydowanie bardziej oczywiste. Uważa on bowiem, że „wedle ogólnie przyjętej normy jest wytworem sztuki żydowskiej przedmiot przez Żyda stworzony, a mający w sobie cechy odrębności ducha żydowskiego” [8, s. 40-49]. Do grupy tej zalicza, poza przedmiotami użytku synagogalnego, również same synagogi. Architekturę żydowską opiera więc na obiektach wzniesionych na zlecenie gmin żydowskich lub będących częścią rytuału religijnego [164, s. 159]. Kluczowy, z punktu widzenia architektury judaizmu, jest drugi człon tego stwierdzenia, który pokazuje sztukę żydowską przez pryzmat kultury zakorzenionej w religii. Podobne stanowisko zajmuje David Dawidowicz, według którego domy modlitwy w Polsce posiadają szczególną wartość, przejawiającą się w poszukiwaniu indywidualizmu oraz tożsamości religijnej i kulturowej. Artyści żydowscy, którzy wzrastali w tradycji i religii, swoją twórczość opierali na ciaggłym poszukiwaniu wartości żydowskich jako środka do wyrażania „duszy żydowskiej” [24, s. 12]. Owo wyrażanie duszy żydowskiej przejawiało się w „zbarbaryzowanej” [160, s. 309] formie wytworów sztuki żydowskiej w diasporze. Nie można jednak wykluczyć, że sztuka żydowska ma swe źródło w formach artystycznych i starożytnej architekturze, która wywarła wpływ na tradycje i obyczaje narodu [24, s. 11]. Za przykład budownictwa żydowskiego David Dawidowicz uznaje synagogę Wysoką w Krakowie [24, s. 21]. Autor stwierdza jednak również, że to nie forma budynku była typowo żydowska, ale ze względu na zastosowaną dekorację było takie wnętrze [25, s. 28] $]^{5}$. Podobne zdanie wyraził Georg Loukomski, sugerując, że „prawdopodobnie jedynie dekoracja i imponujące inskrypcje mają indywidualne i charakterystyczne dla sztuki Żydowskiej cechy" [112, s. 22].

Encyklopedia judaica definiuje pojęcie judaizmu jako „religię, filozofię i drogę życia dla Żydów" [36, s. 511]. Żyd natomiast określany jest jako osoba, która wyznaje judaizm, a szerzej jako osoba, która wywodzi się z pokolenia Judy [36, s. 211]. Można zaryzykować stwierdzenie, iż kultura żydowska jest kulturą religijną, na co wskazuje Richard Krautheimer, pisząc 
o kulturze judaizmu. Przejawia się to szczególnie w komplementarności kultury i religii. Religia spełnia rolę kulturotwórczą, stanowiąc o tożsamości człowieka. Kultura natomiast pozwala przybliżyć się do objawienia. Dlatego też, upraszczając, można powiedzieć, iż architektura judaizmu jest pojęciem odnoszącym się do jednego z elementów kultury, jakim jest religia.

Kulturę judaizmu można rozpatrywać z różnych punktów widzenia. Zawsze jednak podstawowe znaczenie ma to, czy jest traktowana jako wytwór religii, czy społeczności żydowskiej. $Z$ jednej strony można ją bowiem rozumieć jako dzieło twórców wyznania mojżeszowego, z drugiej zaś jako zbiór budowli. Ignacy Schiper szczególną rolę w powstawaniu tych obiektów przypisuje żydowskim budowniczym [160, s. 308]. Wskazuje, jak się mylnie wydaje, że większość bożnic wznieśli budowniczowie wyznania mojżeszowego, a jedynie nieliczne synagogi - chrześcijanie [71, s. 119], [196, s. 34]. Gdyby jednak założyć realny wpływ żydowskich budowniczych na wznoszenie synagog ${ }^{6}$, to powstaje pewnego rodzaju luka związana z niezaklasyfikowaniem obiektów, które pełnią istotną rolę w religii i kulturze żydowskiej, a zostały zaprojektowane przez twórców niezwiązanych z gminą żydowską. Okazuje się zatem, że w kontekście architektury judaizmu i architektury żydowskiej granica ta jest niezwykle cienka.

Jak podaje Richard Krautheimer, należy zwrócić uwagę na inny aspekt obiektów związanych z kulturą i religią żydowską. Nie tylko „bezpośrednio na formalny charakter, [gdyż] jest to również miejsce dla niektórych działań, wyraz postawy właściciela do religijnych i społecznych problemów, które są związane bezpośrednio lub pośrednio z budynkiem" [91, s. 11]. Ważnym elementem jest skupienie się na dwóch sposobach wyrażania architektury: teurgicznym, który jest związany z praktykowaniem rytuału, oraz liturgicznym, który z rytuału wynika. Przez rytuał należy rozumieć w tym wypadku zbiór zachowań oraz czynności, które jednoczą daną społeczność oraz stanowią o jej tożsamości. W gruncie rzeczy jednak „odrębność religijna i rytualna i szczególna pozycja religii żydowskiej [...] były czynnikiem oddziałującym bardziej lub mniej wybitnie - w zależności od epoki i kraju - na bożnicę" [201, s. 186-187]. Architektura żydowska ma być zatem zdefiniowana jako „spełnienie potrzeb żydowskiej społeczności” [97, s. 43]. Żydzi samostanowili o własnej przestrzeni, w związku z czym nie wykształcili tradycyjnej formy architektonicznej. Bet ha-Kneset konstytuują: Aron ha-Kodesz, bima i orientacja. „Te trzy elementy istnieją od czasów Miszny i warunkują przestrzeń jako synagogę - świętą przestrzeń Judaizmu” [123, s. 43]. Bożnica oznaczała tym samym jedynie funkcję [71, s. 13], z której wypływała wielość form architektonicznych, ujęta w skończoną liczbę układów funkcjonalnych [71, s. 11]. Architektura służąca społeczności żydowskiej sprowadza się zatem do télos, stanowiąc „końcowe duchowe miejsce przeznaczenia” [97, s. 43].

Na uwagę zasługuje stanowisko jeszcze dwóch autorów: Georga Loukomskiego i Davida Dawidowicza. Ten pierwszy wyraził pogląd, że synagogi z bimą-podporą są typowo żydowskim motywem, w związku z czym należy pozwolić architekturze żydowskiej na zaistnienie w historii architektury [112, s. 33]. Ten drugi stwierdził jednoznacznie, że sztuka reli- 
gijna Żydów polskich jest nie tylko ważnym ogniwem historii sztuki żydowskiej, ale również jednym z najciekawszych etapów starożytnej kultury materialnej [24, s. 11]. Oznacza to, że sztuka żydowska jest elementem wzbogacającym sztukę polską czy europejską, a nie, jakby się wydawało, elementem z tej sztuki wypływającym.

\subsection{Synagogi w Polsce i Europie}

Zainteresowanie architekturą judaizmu można wprawdzie zauważyć już w końcu XVII wieku, jednak znaczne jego nasilenie przypada już na XVIII wiek ${ }^{7}$. Próby mające na celu syntezę tej tematyki podjęte zostały na początku XX wieku w publikacjach książkowych oraz czasopismach naukowych. Jedną z pierwszych prac, w której ta tematyka została potraktowana znacznie szerzej, była książka Alfreda Grottego Deutsche, bömische und polnische Synagogentypen vom XI bis Anfang des XIX fahrhundersts z 1915 roku. Autor nie tylko omawia - w bardzo obszernym wstępie - sposób kształtowania sali męskiej i zastosowanie zdobiących ją elementów architektonicznych, ale także przedstawia rozwój siedmiu typów synagog [54, s. 1], które dzieli ze względu na czas oraz miejsce powstania. Analizy Grottego dotyczą obiektów średniowiecznych, wzniesionych w XIV wieku na terenie Niemiec, Czech i Polski. Autor pisze między innymi o symbolicznych nawiązaniach w architekturze synagog do świątyni Salomona [54, s. 5-6]. Wszelkie kwestie dotyczące synagog w Koronie opiera na monograficznych pracach nie tylko Majera Bałabana, który skupia się na Żydach lwowskich i krakowskich, ale również Mathiasa Bershona i Zygmunta Glogera [48, s. 25], którzy omawiają architekturę drewnianą w Polsce, w tym również synagogi. Niewiele uwagi poświęca architekturze bożnic z bimą-podporą. Wskazuje na istnienie takiego trendu, głównie w wypadku synagog drewnianych, od których niejako wywodzi rozwiązania bimy w postaci baldachimu, a jako przykłady podaje synagogi w Przeworsku (1. połowa XVIII w.) i Rzeszowie (1. połowa XVII w. oraz XVIII w., a dokładnie lata 1701-1708). Prezentuje również plany i zdjęcia synagog w Żółkwi (1692), Lwowie (1567) oraz Rzeszowie ${ }^{8}$.

Synagogi średniowieczne stanowią również główny temat pracy Richarda Krautheimera z 1927 roku [91, s. 11]. Autor opisuje wpływ religii na sztukę w społeczności żydowskiej. Rozpoczynając rozdział dotyczący głównego zagadnienia publikacji, autor stwierdza, że antyk umarł i nie miał przełożenia na architekturę bożnic w średniowieczu [91, s. 71]. Należy zwrócić uwagę, że Krautheimer opisuje głównie architekturę bożnic aszkenazyjskich, przy czym szukając wzorów odnosi się do miniatur z manuskryptów hiszpańskich. Omawia wszystkie ważniejsze bożnice średniowiecza, głównie te zlokalizowane na terenie Niemiec (w: Spirze, Wormacji, Regensburgu, Bambergu, Mitlenbergu), a także w Pradze (bożnicę Staro-Nowa Szkoła i bożnicę Pinkasa) ${ }^{9}$.

Zakrojone na szeroką skalę badania dotyczące dziedzictwa Żydów w Polsce podjął prof. Majer Bałaban i prowadził je właściwie do momentu rozpoczęcia II wojny światowej. W bo- 
gatym zasobie publikacji tego autora związanych z kulturą i sztuką Żydów pojawiają się również prace dotyczące domów modlitwy, między innymi Bóżnice obronne na wschodnich kresach Rzeczypospolitej (1927) i Zabytki historyczne Żydów w Polsce (1929). W pierwszym opracowaniu, które jest wstępem do obszerniejszej publikacji z 1929 roku, Majer Bałaban pisze, iż w Polsce znane są dwa typy synagog. O przynależności do jednego z typów decyduje lokalizacja w obrębie murów miejskich lub poza nimi ${ }^{10}$.

Ta systematyzacja architektury bożniczej w Polsce była - jak do tej pory - najbardziej rozbudowana. Nie uwzględniała układów przestrzennych obiektów czy detali architektonicznych, posługiwała się natomiast binarnym rozróżnieniem obiektów architektury. W swojej drugiej, obszerniejszej publikacji Majer Bałaban podaje dokładniejszą typologię. Stara się opisać chronologię bożnic, jednak dane, które posiada, nie są wystarczające, aby przedstawić w pełni zagadnienie. Podobnie jest w wypadku typologii Bet ha-Kneset, choć jest ona obszerniejsza ${ }^{11}$. W swoich badaniach Majer Bałaban opierał się na pracach Adolfa Szyszko-Bohusza, który przeprowadził analizy kilku obiektów, w tym synagog w: Szydłowie, Zamościu czy Szczebrzeszynie.

Publikacja Adolfa Szyszko-Bohusza [172] została poprzedzona wstępem do architektury bożniczej między innymi średniowiecza i renesansu. Analiza autora wskazuje na pewne braki w materiale badawczym. Skupia się bowiem na czysto racjonalnych układach konstrukcyjnych oraz wpływach planów synagog na sposób przesklepiania wnętrza bożnicy w obiektach zarówno drewnianych, jak i murowanych.

Wszystkie wymienione wyżej opracowania stały się punktem wyjścia dla Szymona Zajczyka przy tworzeniu publikacji w latach 30. XX wieku [201] ${ }^{12}$.

Lata 20. i 30. XX wieku były czasem prężnej działalności Instytutu Architektury Polskiej Politechniki Warszawskiej, kierowanego przez Oskara Sosnowskiego. Na podstawie przeprowadzonych pomiarów przygotowano wówczas niezwykle bogaty zbiór rysunków inwentaryzacyjnych bożnic zlokalizowanych na obszarze Rzeczpospolitej, w tym dużej grupy bożnic drewnianych. Z tego okresu pochodzi bardzo ważny zbiór zdjęć wielu nieistniejących bożnic, wykonanych przez Szymona Zajczyka.

Zainteresowanie dziedzictwem żydowskim wzrosło po II wojnie światowej. W Polsce należy je wiązać przede wszystkim z dużymi stratami materii zabytkowej oraz próbami ratowania tego, co pozostało po zniszczeniach wojennych. Odnosiło się to szczególnie do synagog i cmentarzy żydowskich. W latach powojennych przeprowadzono bardzo dużo badań zarówno historycznych, jak i architektonicznych, które stały się podstawą wielu artykułów monograficznych dotyczących synagog [10]-[12], [122], [129], [131].

Już w końcu lat 40. XX wieku pojawiła się publikacja Georgea Loukomskiego [112, s. 33] zawierająca krótki opis rozwoju bożnic oraz około osiemdziesiąt zdjęć różnych synagog. Dla tego badacza bima-podpora jest niezwykłym rozwiązaniem, choć klasyfikuje je do bożnic dziewięciopolowych [112, s. 33-35].

Próbę oszacowania strat wojennych oraz analizy tematu podjęła w latach 50 . XX wieku Anna Kubiak. W swoim dwuczęściowym opracowaniu [101], [102] opublikowanym na 
łamach Biuletynu Żydowskiego Instytutu Historycznego omówiła zachowane zabytkowe, renesansowe oraz barokowe synagogi. Poza częścią ilustracyjną publikacja zawiera również część tekstową, w której autorka przedstawia pogląd dotyczący architektury bożnic w Polsce, jaki panował przez wieki ${ }^{13}$.

Najbardziej kompleksowym opracowaniem z lat 50. XX wieku, dotyczącym drewnianych bożnic zlokalizowanych na terenie Polski, była publikacja Marii i Kazimierza Piechotków [133]. Autorzy zebrali wszystkie dostępne materiały i na ich podstawie przedstawili szczegółowe rozwiązania architektoniczne i wystrój tego typu obiektów, a także uwarunkowania, w jakich powstawały. Powodem napisania tej pracy, podobnie jak wszystkich publikacji powojennych, były znaczne straty wojenne w tkance architektonicznej i próba zachowania pamięci o utraconych obiektach.

Synagogi zlokalizowane na terenie Polski były również przedmiotem badań autorów zagranicznych. Jedną z pierwszych prac, była publikacja Davida Dawidowicza [24, s. 11]. Autor ten - poza opisem dziedzictwa żydowskiego w Polsce - koncentruje się na przyczynach oraz skutkach zniszczeń wytworów kultury żydowskiej i obejmuje okres od XVI wieku do końca II wojny światowej ${ }^{14}$. Druga praca tego samego autora dotyczyła wystroju malarskiego bożnic znajdujących się w Polsce [25]. Należy jednak stwierdzić, że badacz ten nie poświęca zbyt wiele miejsca dekoracjom synagog murowanych, skupiając się głównie na bożnicach drewnianych.

Zdecydowanie bardziej dogłębne ujęcie tematu można znaleźć u Rachel Wischnitzer [194], która szczegółowo przedstawia kontekst historyczny powstawania domów zgromadzeń w Europie. Opisuje ich formy: od starożytnych bazylik do współczesnych obiektów powojennych z lat 50. i 60. XX wieku. Zwraca również uwagę na niezwykłe zakorzenienie w tradycji poszczególnych elementów synagogi, jak i samego domu modlitwy. Opisuje związki aranżacji synagogi ze słowami Pisma Świętego oraz ideałem, jaki stanowiła świątynia jerozolimska. Elementem, na podstawie którego można odnaleźć analogię w tych dwóch przypadkach, jest szafa na rodały i Arka Przymierza ${ }^{15}$.

Typologia obiektów w pracy Rachel Wischnitzer jest mniej lub bardziej rozbudowana, w zależności od części Europy, której dotyczy. Pewne schematy funkcjonalne wykształciły się według autorki w Polsce. W publikacji Alfreda Grottego można przeczytać, że obniżenie posadzki w synagodze było zabiegiem typowo polskim, a jego stosowanie w synagogach na obszarze Niemiec było związane z migracją [54, s. 15]. Rachel Wischnitzer stwierdza natomiast, że plan centralny (kwadratowy) został zaadaptowany i był wykorzystywany przy wznoszeniu domów zgromadzeń pod wpływem włoskiego renesansu panującego w polskiej architekturze. Pokłosiem procesów, o których mowa powyżej, było zastosowanie w lubelskiej synagodze Maharszala (1567) po raz pierwszy planu centralnego z bimą-podporą. Autorka zwraca również uwagę, że schemat sali męskiej otoczonej czterema podporami pojawia się w architekturze europejskiej, między innymi na Morawach [194, s. 149].

Kolejnym kompleksowym opracowaniem, bardzo szeroko traktującym o architekturze bożnic w Europie ze względu na obszar terytorialny, jak również czasowy, była publikacja 
Carol Herselle Krinsky [99] ${ }^{16}$. Autorka skrupulatnie opisuje przemiany w układach, planach, wyglądzie oraz lokalizacji bożnic, podając jako przykład synagogi z obszaru Polski, które szerzej omawia. Są nimi bożnice w: Lublinie, Wilnie, Warszawie, Wołpie, Łańcucie, Krakowie. Ciekawą częścia tej pracy jest analiza związku świątyni jerozolimskiej z synagogą. Jej konkluzja jest, jak się wydaje, niezwykłe uproszczona. Autorka stwierdza bowiem, iż relacje między obiektami przejawiają się bardziej w słowach niż w architekturze, co popiera argumentami o charakterze strukturalnym i formalnym [99, s. 8-14 $]^{17}$.

Na pierwszy rzut oka monograficznym opracowaniem była publikacja Thomasa Hubki [61]. Pomimo że autor skupia się głównie na architekturze synagogi w Gwoźdźcu (1640), wstęp i analiza pewnych tendencji, którą przeprowadza, są chyba najobszerniejsze w całej literaturze specjalistycznej z zakresu architektury bożniczej w Polsce. Badacz podaje wzorce $\mathrm{w}$ architekturze synagog oraz zasady, jakimi kierowano się przy ich wznoszeniu. Zwraca uwagę na związki między synagogą a świątynią jerozolimską, pisząc jednocześnie, że świątynia i miejsce święte były dla twórców synagog wzorcami [61, s. 144]. W jednym z rozdziałów autor omawia wpływ Sefer ha-Zohar na formę synagogi oraz tłumaczy odniesienia i wzorce wprowadzone do architektury synagog w XVII wieku ${ }^{18}$.

W ostatnich 25 latach ukazało się kilka ważnych prac naukowych dotyczących synagog. Pierwszą z nich, przedstawiającą bożnice w katalogowy sposób jest praca Eleonory Bergman i Jana Jagielskiego [14]. Autorzy podali w zasadzie wszystkie źródła oraz informacje dotyczące istniejących obiektów, opierając się na powstałych wcześniej publikacjach. Oczywiście również $\mathrm{w}$ tej publikacji nie udało się wyeliminować błędów odnoszących się czy do datowania, czy do ogólnego opisu poszczególnych budynków. Należy jednak zwrócić uwagę, iż w wypadku tak obszernej i przekrojowej pracy pewne nieścisłości mogą się pojawić. Niestety, publikacja ta nadal nie wyczerpała tematu. Forma katalogu, zasadna w przypadku tak wielu obiektów, ma wiele luk, które można i należałoby wypełnić. Odpowiedzią na te braki miała być praca Marii i Kazimierza Piechotków [134]. Autorzy - w oparciu o wcześniejsze publikacje zarówno zagraniczne, jak i polskie - opracowali najpełniejszą i najdokładniejszą typologię synagog wzniesionych na terenie Polski począwszy od średniowiecza a skończywszy na XIX wieku. Jednocześnie praca stanowi swego rodzaju katalog wszystkich bożnic, które kiedykolwiek istniały na obszarze Polski, z uwzględnieniem terenów nieznajdujących się obecnie w jej granicach. Rozważania dotyczące bożnic na terenie Rzeczpospolitej poprzedzone są obszernym wprowadzeniem w tematykę związaną z architekturą bożniczą, obejmującym kult świątynny, synagogi starożytne i europejskie z okresu średniowieczna. Godne podziwu wydaje się poszukiwanie wzorów zastosowanych rozwiązań w architekturze europejskiej i analogii między układami przestrzennymi synagog zlokalizowanych na terenie Polski i innych krajów.

Pod względem typologicznym synagogi powstałe w XVII i XVIII wieku można podzielić na: jednonawowe, dziewięciopolowe z bimą-podporą, a także z dziewięciopolowymi halami. Maria i Kazimierz Piechotkowie dokładnie opisują wszystkie obiekty charakterystyczne dla omawianego okresu i wyróżniają aż trzy typy bożnic. 
W ciągu ostatnich kilkunastu lat pojawiło się wiele publikacji naukowych dotyczących synagog w Polsce i Europie. W 2007 roku ukazała się praca Simona Paulusa dotycząca średniowiecznych bożnic [130]. Autor opisuje - podobnie jak Krautheimer - bożnice aszkenazyjskie. Zakres tej pracy jest jednak znacznie większy. Analiza poszczególnych obiektów lub miejsc, w których synagogi się znajdowały, została poprzedzona wprowadzeniem do architektury bożniczej z uwzględnieniem przepisów religijnych. Autor odnosi się również do przykładów bożnic w: Strzegomiu, Oleśnicy i Krakowie.

Niezwykle bogatym zbiorem traktującym o europejskiej architekturze Żydów była książka fewish Architecture in Europe [73]. Ten zbiór referatów autorów z różnych stron świata jest najszerszym podejściem do architektury żydowskiej, zarówno pod względem czasowym, jak i obszarowym. Poza informacjami o bożnicach w: Czechach, Hiszpanii, Francji, Niemczech, Rosji, Anglii, Maroku i basenie Morza Śródziemnego, a także na Słowacji i Węgrzech można odnaleźć również tekst poświęcony bożnicom w Polsce autorstwa Tobiasa Lameya $[106]^{19}$.

Tobias Lamey jest autorem jeszcze dwóch opracowań, w których opisuje architekturę bożnic murowanych. W pierwszym z nich, będącym pracą doktorską [108], na podstawie analizy materiału ikonograficznego, archiwalnego oraz źródeł pisanych sformułował wniosek, że synagoga w Przemyślu, w latach 1592-1594, czyli w okresie jej powstawania, nie posiadała bimy-podpory. Jej pojawienie się wiązał z przebudową synagogi w latach 40. XVII wieku [108, s. 128]. We wspomnianej pracy opisał również rozwój formy bimy-podpory w synagogach znajdujących się na terenie Polski. Analizując możliwe wzorce, doszedł do wniosku, że pierwotnie bima posiadała formę cyborium i nie wspierała sklepienia. Dopiero z czasem, w miarę rozwoju formy tego elementu doprowadzono do połączenia go z konstrukcją budynku. Podobne przykłady wolnostojących bim-cyboriów pojawiają się w synagogach w dwóch miejscowościach, tj. w Łęcznej (1655) i Opatowie (połowa XVII w.). Biorąc pod uwagę, że pierwsze bożnice z bimą-podpora zostały wzniesione znacznie wcześniej, trudno jest zgodzić się $\mathrm{z}$ tą tezą ${ }^{20}$. Lamey przeprowadził wnikliwe badania w celu znalezienia wzorów dla bimy-podpory zarówno w obrębie przykładów architektonicznych z różnych epok, jak i uwarunkowań religijnych, symbolicznych i mistycznych $^{21}$.

Badania nad bożnicami Europy Wschodniej prowadzi również od lat 90. XX wieku Centrum Sztuki Żydowskiej w Jerozolimie. Efektem podjętych działań było opracowanie inwentaryzacji ponad sześciuset bożnic, klojzów i beit midraszy z obszaru Białorusi, Ukrainy i Litwy. Obszerny materiał na temat obiektów zlokalizowanych na Litwie został zebrany w formie dwutomowego leksykonu [168], [169] poprzedzonego obszernym wstępem dotyczącym architektury bożniczej.

W ostatnich latach powstało również kilkanaście prac będących omówieniem synagog z obszaru całej Europy, w których podane zostały przykłady synagog z terenu Polski. Wśród tych, o których wspomnieć należy, znajdują się publikacje Ilii Rodova ${ }^{22}$ i Brachy Yaniv ${ }^{23}$. Ilia 
Rodov jest również autorem monografii opisującej XVI-wieczne rodały stanowiące element wystroju bożnic zlokalizowanych w Polsce [149].

Na szczególną uwagę zasługują publikacje Sergieya Kravtsova ${ }^{24}$. Ten badacz architektury bożnic dziewięciopolowych z obszaru dawnej Rzeczpospolitej stwierdza, że synagogi dziewięciopolowe są nawiązaniem do rekonstrukcji świątyni jerozolimskiej, wykonanej pod koniec XVI wieku przez dwóch jezuitów: Jana Baptysty Villalpanda i Hieronima Prada ${ }^{25}$. Ten interesujący trop zostanie przeanalizowany $\mathrm{w}$ dalszej części monografii.

Żródłem, które stanowiło podstawę przynajmniej kilku publikacji z zakresu architektury bożnic, jest Katalog Zabytków Sztuki w Polsce. Prowadząc badania synagog zlokalizowanych na ziemiach polskich, autor niniejszej pracy sięgnął również po inne opracowania, chociażby monograficzne, dotyczące polichromii czy konkretnych elementów w obrębie pojedynczych obiektów. Wszystkie są wymienione w bibliografii.

\section{Przypisy}

${ }^{1}$ Termin synagoga powstał w Aleksandrii, w wyniku kontaktu Żydów z kulturą grecką ok. połowy III w. p.n.e. i przejęcia przez Żydów języka greckiego jako języka codziennego. Vide: W. Rosenau, Jewish ceremonial institutions and customs, New York 1925, s. 13.

${ }^{2}$ Żydzi sefardyjscy (Sefardyjczycy) - ludność, która zamieszkiwała Półwysep Iberysjski do 1492 r. Po wygnaniu z tego terenu osiadlali się głównie we Włoszech, w Holandii i na Bałkanach, a w XVI w. niewielka grupa osiadła również w Polsce.

Żydzi Aszkenazyjscy (Aszkenazyjczycy) - ludność, która zamieszkiwała Europę Środkową, Wschodnią i częściowo Zachodnią. Obie grupy oprócz języka (Aszenazyjczycy - jidysz, Sefardyjczycy - ladino) różni również rytuał.

${ }^{3}$ Liczba ta dotyczy obiektów zarówno murowanych, jak i drewnianych.

${ }^{4}$ Jeżeli nie określono inaczej, cytaty z Biblii pochodzą z wydania: Pismo Święte Starego i Nowego Testamentu, Najnowszy przekład z języków oryginalnych, tłum. ksiąg W. Borowski i in., red. nauk. A. Jankowski i in., red. K. Dynarski, Poznań 2003.

${ }^{5}$ Panu Prof. Marcinowi Wodzińskiemu należą się serdeczne podziękowania za udostępnienie kopii tej książki.

${ }^{6}$ Niezależnie od tego, czy synagogi były wznoszone przez chrześcijańskich czy żydowskich rzemieślników, decydująca była opinia społeczności i aprobata rabina. Vide: B. Yaniv, Galami ec jehudim ba-mizrach eropa, „Zion: A Quarterly for Research in Jewish History” 2012, Vol. 77, No. 1, s. 62; B. Yaniv, Motiw szloszet ha-ktarim be-aronat ha-kodesz szel mizrach eropa, [w:] Kenishta: Studies of the Synagogue World, red. J. Tabory, t. 2, Ramat-Gan 2003, s. 74.

${ }^{7}$ Z tego okresu pochodzą liczne sztychy autorstwa: F. Smuglewicza, Z. Vogla, N. Ordy, W. Kielisińskiego oraz S. Putiatyckiego. Pierwsze badania dotyczące architektury bożniczej na terenie Polski i Europy obejmowały monografie poszczególnych obiektów i miały miejsce już pod koniec XIX w. 
${ }^{8} \mathrm{~W}$ przypadku tego ostatniego obiektu Alfred Grotte myli Synagogę Starą z Synagogą Nowomiejską, podpisując plany obiektów odwrotnie. Ten z pozoru błahy błąd pojawiał się w opracowaniach jeszcze do lat $90 . \mathrm{XX}$ w.

${ }^{9}$ O bożnicy Starej w Krakowie autor pisze - powołując się na Grottego - że zna ją tylko z literatury i ustawia w jednym szeregu z synagogą w Chełmie. Vide: R. Krautheimer, Mittelalterische Synagoge, Berlin 1927, s. 213.

${ }^{10}$ Synagogi intra muros musiały odpowiadać jedynie przepisom prawa dotyczącym odległości od najbliższego kościoła i wysokości, natomiast synagogi extra muros musiały spełniać warunki obronności, które rozumiano dwojako. Synagogi pierwszego typu wznoszone były z drewna, co umożliwiało ich bardzo szybką destrukcję, tym bardziej że stały zazwyczaj na przedpolu umocnień. Drugie rozwiązanie zakładało wybudowanie domu modlitwy jako obiektu warownego. Ze względów obronnych synagogi często były przykrywane sklepieniami drewnianymi lub miały drewniane wiązary dachowe, co powodowało, iż w wypadku ataku ulegały spaleniu. W związku z tym przy przebudowie zdejmowano blanki i stosowano dachy strome. Vide: M. Bałaban., Bóżnice obronne na wschodnich kresach Rzeczypospolitej, „Studia Historyczne”, Warszawa 1927, s. 94.

${ }^{11}$ Majer Bałaban zaznacza, że synagogi można podzielić na czerpiące z wpływów zachodnich (katolickich) oraz wschodnich (bizantyjskich). Te pierwsze zakładane były na planie podłużnym, te drugie na planie centralnym. Pewne różnice związane ze sposobem lokalizowania synagog zaznaczają się także w wyglądzie obiektów i ich cechach charakterystycznych. Oznacza to, że synagoga wolnostojąca lokowana w mieście wygląda inaczej niż synagoga miejska „wciśnięta” w podwórze. Innym typem według tego autora są synagogi lokowane poza miastem. Vide: M. Bałaban, Zabytki historyczne Żydów w Polsce, Warszawa 1929, s. 60, 63-64.

${ }^{12}$ Szymon Zajczyk rozróżnia dwie zasady kształtowania bożnic. Pierwsza z nich dotyczy elementów wnętrza, a więc Aron ha-Kodesz, a przede wszystkim - na co wskazuje autor - bimy, druga zaś rozdzielenia mężczyzn i kobiet. W Polsce bożnice powstawały w okresie baroku i renesansu. Nastąpiło wówczas zerwanie z planem sześciopolowym i podziałem wnętrza dwoma filarami podkreślającymi ustawioną między nimi bimę na rzecz planów centralnych, jednoprzestrzennych, założonych na kwadracie. Należy zaznaczyć, iż w tym sposobie rozumienia synagogi dziewięciopolowe z bimą-podporą powstały w okresie baroku z jednoprzestrzennych obiektów renesansowych, np. synagoga w Zamościu (1618). Dziewięciopolowe synagogi były wznoszone w końcu XVI lub na początku XVII w. i zależnie od sposobu rozwiązania bimy można rozróżnić takie, w których bimę umieszczano $\mathrm{w}$ centrum w przestrzeni halowej ze sklepieniem identycznym jak w pozostałych ośmiu polach, oraz takie, w których bima miała formę baldachimu z obniżonym sklepieniem, a niekiedy kaplicy.

${ }^{13}$ Idąc tropem wytyczonym przez Zygmunta Glogera, Kazimierza Mokłowskiego i innych badaczy, autorka wyraża pogląd, iż synagoga w swoim głównym zrębie i dekoracji jest przejawem rdzennie polskiej architektury i nie można stwierdzić w jej obrębie cech architektury żydowskiej. Na związki z kulturą żydowską wskazuje jedynie układ pomieszczeń, który wpływa na bryłę obiektu. Jak jednak twierdzi Zygmunt Gloger, nie był on czymś stałym i określonym, a w związku z tym nie można przyjąć go jako stałej i niezmiennej cechy będącej wyróżnikiem tej architektury. Vide: Z. Gloger., Budow- 
nictwo drzewne i wyroby z drzewa w dawnej Polsce, t. 1, Warszawa 1907, s. 39; K. Mokłowski, Sztuka ludowa w Polsce, Lwów 1903; Sz. Zajczyk, Architektura barokowych bożnic murowanych w Polsce, „Biuletyn Historji Sztuki i Kultury: kwartalnik wydawany przez Zakład Architektury Polskiej i Historji Sztuki Politechniki Warszawskiej” 1933, vol. 1, nr 4, s. 187.

${ }^{14}$ Dzięki pracy Davida Dawidowicza uzyskuje się przegląd synagog, począwszy od synagogi Starej w Krakowie a skończywszy na XIX-wiecznych domach modlitwy w centralnej Polsce. Ciekawym pomysłem autora jest zarys typologii synagog z okresu od XVI do XVIII w. Wyróżnia trzy podstawowe typy domów zgromadzeń charakterystyczne dla tego okresu: (1) synagogi renesansowe, w których problem centralnej przestrzeni został rozwiązany poprzez wykorzystanie planu kwadratu, co według autora jest efektem wpływów wschodnich z jednej oraz włoskich rozwiązań konstrukcyjnych z drugiej strony, (2) synagogi z czterema filarami, które były niejako zwieńczeniem wielowiekowych poszukiwań spójnej formy architektonicznej i wyróżnieniem nowego indywidualnego schematu, (3) tzw. barokowe bożnice o charakterze twierdz, a więc wspomniane przez Majera Bałabana synagogi obronne, które miały powstawać od 4. dekady XVII w. Jako przykłady autor podaje synagogi w Tarnopolu (2. połowa XVII w.), Brodach (1742) oraz - nie wiedzieć czemu - w Łańcucie (1761). Ostatni dom zgromadzeń nie posiadał przecież żadnych cech obronnych, może poza grubymi murami oraz wspólnym, wtórnym dachem obejmującym wszystkie elementy. Autor opisuje obiekty te jako surowe, wznoszone z gołego kamienia, pozbawione dachów (posiadające natomiast attykę), z salami męskimi w kształcie kwadratu, z potężnymi sklepieniami. Nieznany jest również powód, z jakiego autor nie uwzględnia w tym opisie synagog w Szydłowie (1534-1564) i Pińczowie (1594), o których mowa jest w rozdziale dotyczącym synagog renesansowych. Attyki, skarpy, bardzo grube mury oraz scalenie pod jednym dachem w zwartej bryle wszystkich funkcji idealnie odpowiadają wyglądowi tych obiektów, w przeciwieństwie do synagogi w Tarnopolu, w której babińce i przedsionki były niższe i przekryte osobnymi, pulpitowymi dachami. Vide: D. Dawidowicz, Batej kneset be-Polin we-churbanam, Jerozolima 1960, s. 31; M. Bałaban, Bóżnice obronne na wschodnich kresach Rzeczypospolitej, „Studia Historyczne”, Warszawa 1927, s. 94.

${ }^{15}$ Autorka podaje, że zarówno jeden, jak i drugi element był pierwotnie mobilny i dopiero z biegiem lat zyskał swoje stałe miejsce.

${ }^{16}$ Poza ogólnymi informacjami dotyczącymi zasad obowiązujących w architekturze synagog autorka zaznacza, iż jednym z elementów wpływających na wygląd domów modlitwy był układ wolności oraz ograniczeń, jakim podlegały gminy żydowskie. Bet ha-Kneset stanowiły szczególny przykład związku pomiędzy architekturą i społeczeństwem, przejawiającego się oddziaływaniem większości chrześcijańskiej na obraz mniejszości żydowskiej.

${ }^{17}$ Kwestia ta zostanie omówiona w dalszej części monografii.

${ }^{18}$ Ze względu na istnienie dwóch światów będących swoimi wzajemnymi odbiciami, a więc świata ziemskiego i świata niebiańskiego, synagoga ziemska jest kopią synagogi niebiańskiej i to niejako synagoga niebiańska wywiera wpływ na organizację planu synagogi ziemskiej.

${ }^{19}$ Tobias Lamey rozważa kwestię bim w synagogach wzniesionych na terenie Polski od średniowiecza do wytworzenia się wzoru bimy-podpory pod koniec XVI w. Typologia zastosowana przez 
tego badacza pokrywa się w znacznym stopniu z typologią zaproponowaną przez Szymona Zajczyka. Różnicą jest rozbudowanie tej typologii u Lameya o bimy-„,wieże” niepełniące funkcji konstrukcyjnej (Łęczna).

${ }^{20}$ Vide: podrozdz. 3.5 oraz podrozdz 3.3.3.

${ }^{21}$ Druga publikacja tego autora traktuje $\mathrm{w}$ dużej mierze o pozycji synagog polskich w XVI i XVII w. w kontekście architektury europejskiej, w tym architektury czeskiej, niemieckiej i holanderskiej. Biorąc pod uwagę zagęszczenie społeczności żydowskiej w Polsce w tym czasie oraz niezwykle silny rozwój form architektonicznych, autor stwierdza, iż Polska stanowiła ważne ogniwo w rozwoju architektury bożniczej w Europie. Vide: T. Lamey, Die Stellung des polnischen Steinsynagogenbaus in Europa im 16. und 17. Jahrhundert - Versuch einer Annäherung, „Aschkenaz - Zeitschrift für Geschichte und Kultur der Juden“" 2004, Nr. 14, s. 412-446.

${ }^{22} \mathrm{Z}$ ważniejszych prac tego autora należy wymienić: I. Rodov, The Eagle, its Twin Heads and Many Faces: Synagogue Chandeliers Surmounted by Double-Headed Eagles, „Studia Rosenthaiana” 2004, No. 37, s. 77-129; Idem, Dragons: A Symbol of Evil in European Synagogue Decoration?, „Ars Judaica” 2005, No. 1, s. 63-84; Idem, The King of the Kong of Kings: Images of Rulership in Late Medival and Early Modern Christian Art and Synagogue Design, [w:] Interaction between fudaism and Christianity in history, religion, art and literature, eds. M. Poorthuis et al., Leiden-Boston 2009, s. 457-476; Idem, Tower-Like Torah Arks, the Tower of Strenght and the Architecture of the Messianic Temple,,Journal of the Warburg and Courtauld Institutes" 2010, Vol. LXIII, s. 65-89; Idem, Winged Image of the Divine: A Comparative Note on Catholic, Orthodox, and Jewish Art in Early Modern Ukraine, , Judaica Ukrainica” 2014, No. 3, s. 105-127; Idem, With Eyes toward Zion:Visions of the Holy Land in Romanian Synagogues, "Quest Issues in Contemporary Jewish History; journal of Fondazione CDEC" 2006, No. 3, s. 138-173.

${ }^{23} \mathrm{Z}$ ważniejszych prac tej autorki należy wymienić: B. Yaniv, Galami ec jehudim ba-mizrach eropa, op. cit., s. 31-66; Idem, „Kise chawod marom”: al icuw aronot kodesz ba-mizrach eropa ma-mean ha-szmore asar, „Tarbiz: A Quarterly for Jewish Studiem” 2012, Vol. LXXX, No. 3, s. 427-461; Idem, Motiw szloszet ha-ktarim be-aronat ha-kodesz szel mizrach eropa, [w:] Kenishta: Studies of the Synagogue World, ed. J. Tabory, t. 2, Ramat-Gan 2003, s. 67-87.

${ }^{24}$ S.R. Kravtsov, O proiskhozhdenii deviatipolevykh kamennykh sinagog, [w:] Evreiskoie iskusstvo $v$ evropeiskom kontekste, ed. I. Rodov, Jerusalem-Moskwa 2002, s. 191-204; Idem, fuan Bautista Villalpando and Sacred Architecture in the Seventeenth Century, „Journal of the Society of Architectural Historians" 2005, Vol. 64, No. 3, s. 312-339.

${ }^{25}$ Vide: rozdz. 6. 


\section{RYS HISTORYCZNY}

\subsection{Zarys sytuacji Żydów w Rzeczpospolitej}

Począwszy od XVI wieku liczba Żydów mieszkających w Polski zwiększała się. O ile przed 1648 rokiem było ich ok. 250000 osób, o tyle do 1764 roku liczba ta wzrosła aż do 750000 osób, z których połowa żyła w miastach [155, s. 520]. Przyczyną tej zmiany była wędrówka Żydów z zachodniej do wschodniej części Europy [176, s. 29], która spowodowała, że $20 \%$ ludności tej narodowości osiedliło się na wschodnich rubieżach Polski [63, s. 48]. Ponieważ Żydzi ci stali się poddanymi króla, mieli stosować się do jego zarządzeń, przede wszystkim tych sankcjonujących ich funkcjonowanie w Rzeczpospolitej, ale także mogli korzystać z przywilejów, jakie zostały im nadane.

Szesnastowieczne prawodawstwo dotyczące ludności żydowskiej zostało stworzone w oparciu o statut kaliski wydany w 1264 roku przez Bolesława Pobożnego. Zapewniał on Żydom autonomię sądowniczą i stał się podstawą wielu przyznanych im później przywilejów ${ }^{26}$. Polityka władców wobec Żydów, zwłaszcza na początku XVI wieku, spowodowała wytworzenie się w obrębie tej grupy ludności autonomicznych struktur, w których duże znaczenie miał rabin [175, s. 334-336]. Był on swego rodzaju urzędnikiem, a równocześnie pełnił rolę poborcy podatkowego. Organizacja gminy i normy moralne, którymi kierowali się jej członkowie, wynikały wprawdzie z tradycji żydowskiej, jednak jej funkcjonowanie w ramach Rzeczpospolitej wymagało podstaw ustanowionych przez nie-Żydów [177, s. 6] $]^{27}$.

W 1539 roku król Zygmunt Stary zmienił status prawny Żydów. Właścicielom miast prywatnych zostały przydzielone obowiązki wobec Żydów, którzy zamieszkiwali na podległych im obszarach. Przekazano im również sprawowanie jurysdykcji nad obywatelami narodowości żydowskiej [175, s. 334], a także prawo do nadawania im przywilejów. Nie oznaczało to, że król nie ustanawiał odgórnych przepisów - miały one jednak drugorzędne znaczenie [49, s. 13].

W XVI wieku, choć sytuacja Żydów była stabilna, po Unii Lubelskiej (1569) wielu z nich emigrowało z miast królewskich do miast magnackich. W miastach Żydzi byli względnie tolerowani, choć zdarzały się ataki słowne ze strony kleru i mieszczan. Zamieszkiwali zwykle przydzielone im obszary, ponieważ zgodnie ze swoim statusem prawnym posiadali własne struktury administracyjne. Władze miasta i kahał działały więc równolegle i niezależnie od siebie [63, s. 112].

Duża liczba przywilejów nadanych gminom żydowskim oraz przepisy, które sankcjonowały prawny i społeczny status Żydów w Rzeczpospolitej, doprowadziły do wytworzenia 
rozbudowanego systemu zarządzania [51, s. 53]. Jego podstawę stanowiły gminy, natomiast kolejne szczeble w hierarchii zajmowały region i państwo reprezentowane przez Wielki Sąd Rabinacki, a od 1580 roku również przez Sejm Czterech Ziem (hebr. Waad Arba Aracot). Sejm Czterech Ziem był organem powołanym przede wszystkim w celu redystrybucji ustalonych przez Sejm Polski kwot podatku pogłównego, który ryczałtowo pobierany był od poszczególnych gmin. Zajmował się również regulowaniem kwestii społecznych i ekonomicznych, które dotyczyły polskich Żydów[174, s. 375]. W wyniku zmiany systemu fiskalnego i powstania oddzielnego trybunału sądowego dla Litwy w 1623 roku z Sejmu Czterech Ziem wyodrębnił się Sejm Żydów Litwy (hebr. Waad Medinat Lita). Od tego czasu organy te funkcjonowały niezależnie, a ich podstawowym zadaniem było reprezentowanie interesów wszystkich gmin żydowskich zlokalizowanych na obszarze Rzeczpospolitej [63, s. 50]. Waad jako centralny organ władzy samorządowej podejmował również decyzje dotyczące synagog.

Pod koniec XVI wieku zmieniła się rola rabina w gminie i sposób jego funkcjonowania. Pełniący tę funkcję - pierwotnie podlegli państwu i opłacani przez nie [175, s. 342-343] - stali się urzędnikami gminy żydowskiej. W związku z tym gmina miała dwóch przywódców: duchowego i świeckiego. Rabin był zatrudniany i zwalniany na polecenie zarządu gminy, a za wypełnianie swoich obowiązków otrzymywał wynagrodzenie [174, s. 373]. Jego zadaniem było zajmowanie się sprawami religijnymi, w tym rozwiązywaniem problemów w oparciu o halachę (wykładnię prawa żydowskiego) [177, s. 8]. Należał do sądu rabinackiego. Decyzje dotyczące spraw socjalnych i ekonomicznych podejmował przywódca świecki wraz z zarządem gminy. Przeniesienie Żydów pod jurysdykcję właścicieli miast spowodowało ingerowanie tych drugich w sprawy gminy [156, s. 219-243]. W XVII i XVIII wieku możni panowie chcieli wpływać na decyzje gminy dotyczące wyboru rabina czy inne kwestie. Nie było to takie trudne, gdyż często uzyskanie posady rabina wiązało się z wniesieniem opłaty do gminy. Praktyka ta spowodowała podjęcie przez Sejm Czterech Ziem decyzji o heremie (ekskomunice) każdego, kto zdecyduje się na zbycie zaszczytnej funkcji przywódcy duchowego tą drogą ${ }^{28}$.

Prawo państwowe nie zawierało szczególnych przepisów zakazujących wznoszenia obiektów przeznaczonych na Bet ha-Kneset. Konieczne było w zasadzie jedynie uzyskanie zgody właściciela miasta lub króla, co w większości przypadków nie stanowiło problemu [8, s. 54]. Wyrażenie zgody na budowę bożnicy zwykle wiązało się z przydzieleniem kahałowi poza materiałami budowlanymi również placu należącego do właściciela miasta. W osiedlaniu się ludności wyznania mojżeszowego w mieście na stałe upatrywano szansę na rozwój gospodarki i handlu, a co za tym idzie zwiększenie wpływów z podatków. Dla właścicieli miast stanowiło to bardzo często pokusę przyznawania ludności żydowskiej coraz większej liczby swobód. Królowie i możni panowie, fundując synagogę, wpływali na zewnętrzny wygląd domów modlitwy. W wydanym w 1624 roku zezwoleniu na budowę synagogi w Łucku Zygmunt III Waza nakazywał, aby posiadała strzelnice [194, s. 111-112]. Ulokowane w attykach, które stały się nieodłącznym elementem bożnic znajdujących się na terenie Polski, pełniły funkcję nie tylko przeciwpożarową, ale również militarną. Funkcja obronna była cha- 
rakterystyczna dla synagog lokowanych poza murami miasta. Ich powstawanie należy wiązać z przywilejem de non tolerandis judaeis, z którego pod wpływem ludności chrześcijańskiej i nacisków Kościoła rzymskokatolickiego korzystano stosunkowo często począwszy od XV wieku [24, s. 43]. Wprowadzenie tego przywileju wpływało na formę oraz funkcję obiektu, który miał z jednej strony spełniać ogólne wymogi bezpieczeństwa, zwłaszcza w XVII wieku, $\mathrm{z}$ drugiej zaś stanowić rodzaj bastionu ludności żydowskiej.

W 1638 roku Władysław IV wydał przywilej dotyczący wzniesienia synagogi przez Żydów chęcińskich [15, s. 132]. Dokument ten zawierał szczegółowe wymiary bożnicy, a jego zapisy zaczęły pojawiać się w wielu przywilejach nadanych innym gminom [49, s. 7]. Państwo właściwie nadal nie przeszkadzało w budowie synagog, ale dbało jedynie o to, by, jak pisze Majer Bałaban, „nie wyróżniały się ni wysokością, ni pięknym wyglądem od innych domów żydowskich" [8, s. 54].

Należy jednak zaznaczyć, że w XVII wieku szlachta wraz z władzami kościelnymi protestowała niekiedy przeciwko remontom i budowie synagog. W 1661 roku na sejmiku padło żądanie usunięcia osadnictwa żydowskiego z okolic kościoła oraz odwołania zgody na remont bożnicy. Równocześnie apelowano jednak, aby „ubodzy Żydzi” mieli zapewnioną ochronę dawnych praw [82, s. 72]. W 1689 roku szlachta województwa łęczyckiego protestowała przeciwko budowie bożnicy i nakazywała oddać ją ojcom pijarom.

Generalnie szlachta nie występowała jednak przeciwko religii mojżeszowej, a raczej starała się o usunięcie Żydów ze swojego terytorium. Liczba wzmianek informujących o takich zdarzeniach jest niewielka, co wskazuje jednak na akceptację prawa tej grupy ludności do pielęgnowania własnych tradycji religijnych.

Po wojnach, które nawiedziły Polskę w 2. połowie XVII wieku, miasta były wyludnione, a magnaci poszukiwali nowych źródeł dochodów oraz próbowali odbudować swoje posiadłości i założone przez siebie osiedla. Mimo że był to okres intensywnej reformy i wzrastającej nietolerancji religijnej, zezwalano Żydom na wznoszenie synagog i organizację cmentarzy. Zgody te wydawali nie tylko właściciele miast i starostowie, ale i władze kościelne [49, s. 17]. Żydzi stanowili w tej sytuacji koło ratunkowe, ponieważ byli w znacznie lepszej sytuacji ekonomicznej niż większość Polaków ${ }^{29}$.

Żydzi odgrywali niezwykle istotną rolę w gospodarce, ponieważ wpływali na dynamikę rozwoju miast. Ich działalność opierała się na obsłudze pieniędzy pożyczonych od szlachty lub produkcji i rozprowadzaniu spirytusu i piwa [50, s. 259]. W końcu XVII i na początku XVIII wieku stawali się zatem kupcami i arendarzami propinacji. Dzierżawili monopole również w dobrach kościelnych [63, s. 103]. Tak dobra pozycja tej grupy ludności nie podobała się mieszczanom. Dodatkowo, za osiedlenie się w mieście oraz za spełnianie swoich obowiązków wobec miasta - w tym obrony - Żydzi byli zwalniani z płacenia podatku i ceł od synagogi, łaźni, domu kantora, rabina czy woźnego [80, s. 219]. Trwające od średniowiecza wykluczenie Żydów z cechów rzemieślniczych skierowało ich działalność głównie w stronę handlu. W XVIII wieku szlachta zezwalała na trudnienie się rzemiosłem ludności wyznania mojżeszo- 
wego, ale na własny użytek, bez udziału w cechach chrześcijańskich i tym samym uiszczania stosownych opłat. W konsekwencji powstawały cechy żydowskie, co jeszcze bardziej pogarszało stosunki między chrześcijańskimi mieszczanami a Żydami.

Kościół katolicki nie zmienił swojego stosunku do Żydów. Kultywował wielowiekową tradycję czerpiącą ze starożytności [81, s. 350], [80, s. 216]. Jednym z istotnych problemów było zamieszkiwanie Żydów wśród ludności chrześcijańskiej. Poza Lwowem, Poznaniem i Lublinem Żydzi nie osiedlali się w wydzielonych dzielnicach, a kler upatrywał znacznych niebezpieczeństw w ich kontaktach z chrześcijanami ${ }^{30}$.

Już od początku XIII wieku, zgodnie z rozporządzeniem Kościoła katolickiego, w każdym mieście - małym czy dużym - Żydzi mogli mieć jedną synagogę. Zabraniano im zarówno wznoszenia nowych domów modlitwy w miejscach, w których dotąd ich nie było, jak i przebudowywania, rozbudowywania i odbudowywania tych już stniejących [110, s. 29]. Zezwalano im jedynie na naprawy i to tylko za wyraźną zgodą biskupa, ale od XVI wieku również tego rodzaju prace mogły być wykonywane bardzo rzadko. Żydzi obchodzili jednak te zakazy kościelne, korzystając z protekcji możnych panów, urzędników państwowych czy samorządowych oraz właścicieli dóbr i za ich aprobatą budując nowe synagogi [80, s. 222]. Stanowczo sprzeciwiali się temu biskupi polscy, dla których znaczna liczba Żydów i ciągle zwiększająca się liczba gmin oznaczała wznoszenie kolejnych synagog. Na synodach powstawały memoriały czy, jak je określa Majer Bałaban, „konstytucje o synagogach” [80, s. 217], w których dostojnicy kościoła kierowali do króla nawoływania o ograniczenie działalności żydowskiej. Na przykład, w trakcie synodu piotrkowskiego w 1542 roku wystosowano do króla memoriał z prośbą o całkowite zamknięcie napływu Żydów do Polski przez zabronienie osiedlania się w tych miejscowościach, w których dotąd ich nie było. Biskupi nawoływali również do burzenia nowo powstających synagog i zabronienia ich wnoszenia, a zezwalania jedynie na naprawę i konserwację tych już istniejących [189], [92, s.105]. Synod uchwalił również limity wysokości synagog i określił dopuszczalne miejsca ich lokalizacji, tj. z daleka od rynku, kościoła i ulic, którymi mogła przechodzić procesja [97, s. 44].

W 1550 roku papież przysłał do Polski legata Alojzego Lippomano, którego zadaniem była walka z reformacją. Ze względu na brak zdecydowanych działań ze strony Zygmunta Augusta przystąpił do walki przeciw Żydom i zainspirował działania, które doprowadziły do procesu w sprawie zbezczeszczenia hostii w Sochaczewie. Wywołało to ostrą reakcję króla, która jednak nie zapobiegła kolejnym procesom w sprawie mordów rytualnych [142, s. 51]. Efektem tych zdarzeń i bezsilności monarchy było wydanie drugiego przywileju kaliskiego, jak również przywilejów de non tolerandis Judaeis w wielu miastach. Drugi statut litewski ograniczył prawo Żydów do posiadania i noszenia drogich szat, kosztowności czy zatrudniania służby chrześcijańskiej. Wprowadzono również przymus noszenia znaku hańbiącego.

W 1589 roku na synodzie w Piotrkowie została wystosowana kolejna prośba do króla o wydanie zarządzenia potępiającego Żydów, jeśli w miastach królewskich, wbrew dawnym statutom i zwyczajom, mieliby kilka synagog, budowali nowe domy modlitwy albo rozbudo- 
wywali te istniejące ze szkodą i uszczerbkiem dla Polaków, tj. chrześcijan, i wbrew od dawna istniejącym prawom [121, s. 33].

Epoka oświecenia była dla kościoła katolickiego okresem istotnych zmian, które wynikały między innymi z wprowadzenia w życie postanowień soboru trydenckiego [81, s. 350]. W polskim kościele zaowocowała wyraźnym wzrostem liczby księży i umocnieniem się jego pozycji. Powstało wówczas najwięcej klasztorów i zakonów oraz kościołów, a wielokulturowa Polska stała się głównie katolicka. Ruch budowlany nie ominą jednak synagog. Przez cały XVII wiek biskupi trzymali się zasady, iż zgoda na budowę nowej synagogi zależy od decyzji sądu biskupiego, co potwierdzone zostało oficjalnie na synodzie krakowskim w 1711 roku. Zgodnie z postanowieniami innych synodów, na przykład synodu diecezjalnego lwowskiego w 1765 roku, burzone miały być synagogi zarówno nowe, jak i stare, które zostały odbudowane, przebudowane lub naprawione bez zgody biskupa. Na duszpasterzy lokalnych nałożono obowiązek czuwania nad tym, aby Żydzi nie powiększali liczby synagog. O każdej próbie złamania tego zakazu mieli natychmiast zawiadamiać biskupa, ten zaś niezwłocznie miał domagać się od miejscowego dziedzica cofnięcia pozwolenia na budowę czy przebudowę bożnicy. Oznaczało to, że wbrew przepisom wielu możnych panów wydawało pozwolenie na budowę synagogi bez uzyskania zgody kleru [63, s. 95]. Zgoda taka wiązała się z uiszczeniem odpowiedniej opłaty: w Łasku tamtejsi Żydzi mieli płacić na rzecz kolegiaty kontrybucję, a w Bobrowniku miejscowa gmina musiała co roku dostarczyć do kościoła jeden kamień (ok. 13 kg) łoju [49, s. 32]. Biskupi określali również warunku odbudowy synagog. Na przykład, biskup Jan Lipski (1690-1746) zezwolił na odbudowę synagogi w Kutowie, jednak nie mogła być ona murowana.

Liczne zakazy dotyczące budowy oraz restauracji istniejących synagog spowodowały wprowadzenie do prawa zasady ne fudaei novas synagogas extruere audeant, nec tantum veteres reficere audeant [8, s. 56]. Również królowie zaczęli zastrzegać w wydawanych zezwoleniach, iż bożnice mają być wznoszone zgodnie z uszanowaniem prawa kościelnego lub - jak w przypadku synagogi w Łucku - nie mogą przewyższać kościoła. Oczywiście nic nie stało na przeszkodzie, aby w danej miejscowości gmina żydowska posiadała budynek wyższy niż kościół, nie mógł być jednak wykorzystywany w celach związanych z rytuałem synagogalnym. Ten wymagał bowiem wybudowania niższego i mniejszego obiektu [54, s. 10].

Jednym z kluczowych problemów tamtego okresu były kontakty Żydów i chrześcijan. W związku ze skargami polskich dostojników kościoła papież Benedykt XIV wyraził sprzeciw wobec dzierżawy ziemi i monopoli, udzielania kredytów i pożyczek Żydom [63, s. 91]. Spowodowało to dalsze obostrzenia, jakie z inicjatywy kościoła zaczęły obowiązywać w kontaktach tych dwóch grup. Kwestie z tym związane były dyskutowane na wielu synodach, a najwięcej kontrowersji budziło zatrudnianie przez Żydów chrześcijan jako służących. Zgodnie z postanowieniem synodu w Chełmie w 1628 roku takie praktyki miały stanowić dla sądu podstawę do wytaczania Żydom procesów [50, s. 255].

Kontakty chrześcijan z Żydami w największym stopniu ograniczył synod diecezji łuckiej w 1728 roku. Stwierdzono wówczas, że chrześcijanie nie powinni służyć Żydom, spożywać 
z nimi posiłków ani dzielić domu, strzec żydowskich cmentarzy, zapalać i gasić świec w święta żydowskie, jeść macy, kąpać się z Żydami, odgrywać roli Hamana, a kobiety katolickie nie powinny być położnymi kobiet żydowskich ${ }^{31}$. W 1595 i 1607 roku, niejako w odpowiedzi na zakaz pracy chrześcijan u Żydów, oba Waady zadecydowały, że Żydówki trudniące się handlem nie powinny wchodzić do domów zamieszkałych przez chrześcijan bez towarzystwa żydowskiego mężczyzny[50, s. 252].

W XVIII wieku większość biskupów uważała, że Żydów należy tolerować, ale równocześnie odizolować od chrześcijan [81, s. 351]. Źródłem takiej postawy było panujące wówczas przekonanie, że Żydzi powinni być podlegli chrześcijanom [155, s. 522]. Liczba spraw sądowych wytoczonych Żydom za łamanie praw kościoła katolickiego była jednak stosunkowo niewielka. Powodem była polityka biskupów wobec Żydów, bardziej tolerancyjna niż przepisy zawarte w statutach. Zakazy wydawane przez kościół nie oznaczały jednak, że sam kler nie utrzymywał kontaktów z Żydami ${ }^{32}$.

Czas niewątpliwie trudny dla społeczności żydowskiej nastał w XVIII wieku. Kościół katolicki po udanej walce z prawosławiem i protestantyzmem postanowił położyć kres negatywnemu wpływowi Żydów na społeczność chrześcijańską. Sytuacja była niebezpieczna tym bardziej, że przyrost naturalny w społecznościach żydowskich był coraz wyższy, zwłaszcza w miastach szlacheckich. Już w 1584 roku papież Grzegorz XIII nakazał biskupom w Niemczech i Polsce prowadzenie działalności misyjnej wśród Żydów. W XVI i XVII wieku apel ten pozostał w Polsce właściwie bez echa. Wezwanie powtórzył papież Klemens XI w 1704 roku i stało się ono przyczynkiem do niezwykle aktywnej działalności misyjnej kościoła wobec Żydów w 1. połowie XVIII wieku [81, s. 354]. W diecezji łuckiej, w której biskupem był Franciszek Antoni Kobielski (1679-1755), zarządzono wygłoszenie w synagogach w ciągu roku czterech kazań, a sam biskup opublikował w 1741 roku zbiór listów pasterskich do Żydów [63, s. 96].

Z czasem wprowadzane były różne obostrzenia, które ograniczały prawa Żydów. Podjęto działania, które miały zmusić Żydów do dostosowania się do zakazu pracy w niedziele i święta (co dotyczyło również chrześcijan zatrudnianych przez nich jako służący), urządzania publicznych pogrzebów i wesel w okresie Wielkiego Postu, a także otwierania okien i chodzenia po ulicach w tym szczególnym dla katolików czasie. Te działania miały prawdopodobnie na celu uchronienie Żydów przed prześladowaniami [80, s. 222-223]. Uzasadnienie takie wydaje się tym bardziej prawdopodobne, że w XVIII wieku stosunkowo często zdarzały się oskarżenia o mordy rytualne i bezczeszczenie hostii, których mieli się dopuszczać Żydzi. Ostatecznie papież Klemens XIV uznał oskarżenia o mordy rytualne za bezpodstawne [63, s. 110]

Ze względów etnicznych, religijnych i kulturowych, a przede wszystkim ze względu na status prawny determinowany przepisami prawa państwowego i przepisami wydawanymi przez szlachtę [50, s. 282], Żydzi byli izolowani od społeczeństwa polskiego, a w konsekwencji wyłączani z polskiej kultury [50, s. 282]. Nie oznacza to jednak, że w ślad za tym zaczęli odcinać się od swoich polskich korzeni - przyznawali się do nich, ale istotne było dla nich nietracenie żydowskości [155, s. 528]. 
Różnice językowe oraz różna sytuacja ekonomiczna Żydów i chrześcijan doprowadziły, pomimo licznych podobieństw kulturowych, do segregacji Żydów i Polaków. Przyczynili się do niej również Żydzi, czego przykładem było wydanie przez starozakonnych zakazu używania piasku i wapna pozostałego po budowie kościoła do naprawy już istniejących synagog bądź wznoszenia nowych [71, s. 124].

\subsection{Kabała i ruchy mistyczne i mesjanistyczne - podstawy teoretyczne i zarys dziejów}

Każdego Żyda prowadzi przez życie halacha. Ta wykładnia Prawa Mojżeszowego stała się podstawą odpowiedzi na pytania dotyczące przykazań przekazanych przez Boga, a co za tym idzie zasad moralnych. Ten oficjalny zbiór praw i zakazów nie rozwiewał jednak wątpliwości, które powstawały w trakcie interpretacji samego tekstu Tory i poszukiwania w nim źródła, czyli Boga. Efektem związanych z tym niewystarczajacych starań w znalezieniu sensu przykazań [4, s. 295] i zrozumienia najwyższego sensu żydowskiej praktyki jest kabała - bo tak trzeba nazwać ten obszar. Wszelkie działania, zarówno teozoficzne, jak i ekstatyczne, miały na celu wyjaśnienie i zgłębienie tych „wskazówek” danych przez Boga ${ }^{33}$.

Słowo „kabała” pochodzi od hebrajskiego kabala [hebr. קבלה - otrzymywać, przyjmować]. „Oznacza [...] przyjmowanie lub dostąpienie światła nieskończoności” [126, s. 10] i służy zwykle do określania tajemnic mistyki żydowskiej. Kabała odnosi się przede wszystkim do rozbudowanej wizji relacji człowieka ze wszechświatem i opiera się na rozważaniach, często metafizycznych, które mają na celu odkrycie niezwykłej głębi obu wymenionych elementów. W całym procesie wykorzystywana jest duża liczba różnego rodzaju metod ${ }^{34}$.

Prądy o odmiennym niż rabiniczne rozumieniu treści zawartych w Torze powstały jeszcze w czasach starożytnych. Z tego okresu pochodzą Sefer fecira (Księga Stworzenia) i Sefer ha-Bahir (Księga Światta). Jednak powstanie współcześnie rozumianej kabały przypisuje się autorytetom żyjącym w XII i XIII wieku w Hiszpanii. W ramach tej mistycznej tradycji żydowskiej wyróżniano wówczas ruchy, które doprowadziły do powstania w jej obrębie na pewno dwóch, a w zasadzie nawet trzech prądów: (1) kabały teozoficznej, której przedstawicielem był Mojżesz ben Nachman [Nachmanides] (1194-1270), (2) kabały ekstatycznej, której przedstawicielem był Abraham Abulafia (1240-1291) [42, s. 143] i (3) kabały symbolicznej, której przedstawicielem był Mojżesz de Leon (1250-1305), twórca Sefer ha-Zohar (Księgi Bla$s k u)$. Obok tych wymienionych powstaje ruch chasydów aszkenzyjskich zapoczątkowany na terenie Niemiec przez Jude ben Samuela he-Chasida (1150-1217), autora dzieła Sefer Chasidim (Ksiegi Pobożnych).

„Kabalistyczna teozofia podkreśla transcendentalny charakter najważniejszych zagadnień konceptualnych stanowiących przedmiot jej zainteresowań. Jednocześnie główną drogą, która umożliwia przekroczenie przepaści miedzy człowiekiem a Bogiem, stanowił ka- 
balistyczny rytuał" [42, s. 271]. Obok ruchu teozoficznego niezbędne jest więc wystąpienie zjawisk ekstatycznych, które mają charakter rytuału.

Istotne w kabale, w początkach jej prężnego rozwoju w XIII wieku, były sefirot ${ }^{35}$. Jak podaje Moshe Idel, próbowano je wyjaśniać w różny sposób. Jedni przyjmowali, że sefirot stanowiły część boskiej natury i uczestniczyły w istocie bóstwa. Inni uważali, że znajdowały się blisko Boga, ale pozbawione były aspektu boskości, lub że były boskimi emanacjami wewnątrz rzeczywistości stworzenia, co wskazuje na ich immanencje [64, s. 255]. Ostatnia $\mathrm{z}$ interpretacji znaczenia sefirot stała się podstawą teorii panteistycznych w kabale.

W kabale zakłada się, że między rzeczywistościami zachodzi rezonans. Jest on efektem oddziaływania zmian, które następują w świecie dolnym, na świat górny i odwrotnie. Sefirot łączą się z konstytuowaniem się Boga i jednoczesnym jego tworzeniem przez ludzi. Tworzenie Boga przez ludzi dokonuje się poprzez modlitwy i wypełnianie micwot (przykazań, obowiązków) z zachowaniem w równowadze sefirot. Świat górny oddziałuje tym samym na dolny za pomocą narzędzia objawienia, jakim jest Tora [64, s. 349]. Tora jest zatem Bogiem i taki pogląd jest rozpowszechniany od lat 70. XIII wieku ${ }^{36}$.

Powyższy fragment wskazuje na treści symboliczne, które pojawiały się w pismach kabalistów. Z powstaniem księgi Zohar aspekt symboliczny nabiera największego znaczenia. To właśnie tutaj następuje utożsamienie sefiry Chased z Abrahamem, sefiry Gewura z Izaakiem, a sefiry Tiferet $\mathrm{z}$ Jakubem [42, s. 152]. Symboliczne znaczenie zastosowane w Zoharze stanowi swego rodzaju substytut dekoracji o znaczeniu symbolicznym, które są stosowane w kościołach chrześcijańskich.

Zainteresowanie mistyką żydowską powróciło w XVI wieku. Powodów tego należy upatrywać z pewnością w wypędzeniu Żydów z Hiszpanii w 1492 roku. Fakt ten wpłynął na społeczność żydowską nie tylko tamtego obszaru, ale również innych krajów. Wygnanie stało się bowiem początkiem epoki mesjańskiej [161, s. 274]. Był to czas, w którym okazało się, że kabała potrafiła „z ezoterycznej doktryny dla wybranych przekształcić się w ruch ludowy” [161, s. 274]. To przekształcenie wpłynęło z pewnością na uśpienie odłamu mesjanistycznego i zwrócenie się w kierunku rozważań dotyczących kosmogonii oraz odkupienia. Chciano odbudować łączność ludzkiego życia z Bogiem, co miało nastąpić w oparciu o: śmierć, powrót i odrodzenie [161, s. 277]. Silna grupa kabalistów wyrosła w Safedzie. Wśród nich znajdowali się: Josef Karo (14881575), Mojżesz Kordowero (1522-1570), Izaak Luria (1534-1572) i Chaim Vital (1542-1620) ${ }^{37}$.

W kabale ekstatycznej Mojżesza Kordowero pojawia się dewekut (przylgnięcie) rozumiane jako coś, co jest niezbędne każdemu człowiekowi do rozwoju mistycznego. Podstaw tej koncepcji należy szukać w Księdze Powtórzonego Prawa ${ }^{38}$ [42, s. 156]. Jej rozwinięcie jest traktowane jako swego rodzaju rekonstrukcja. Zakłada bowiem, że człowieka należy utożsamiać z połową koła, która wznosząc się, może połączyć się z drugą połową koła, czyli cząstką boską, „człowiekiem wyższym”. Osiągnięcie dewekut było możliwe dzięki muzyce i kontemplowaniu boskiego imienia, natomiast jego symbolem stały się dwie zestawione ze sobą hebrajskie litery jod: " [64, s. 125]. 
Idea dewekut została niezwykle rozbudowana w powstałym znacznie później chasydyzmie besztiańskim. W celu osiągnięcia stanów mistycznych stosowano kilka interesujących technik, między innymi: łkanie, wznoszenie się duszy, kombinowanie liter i wizualizację kolorów [64, s. 147] $]^{39}$, którym towarzyszyły: post, umartwienie się, przyjmowanie odpowiednich postaw, na przykład postawy Eliasza.

Izaak Luria spędził ostatnie lata życia w Safedzie. Nie pozostawił po sobie żadnego dzieła, w którym przedstawiłby swoją doktrynę. Została ona rozpowszechniona w formie spisanych przez jego uczniów wykładów. Luria był konserwatystą i uzasadnienie swoich teorii czerpał z dziedzictwa i klasyki kabalistycznej, do której należał z pewnością Zohar [161, s. 284]. Rozwinął również techniki ekstatyczne, w tym przede wszystkim wznoszenia się duszy, które dawało możliwość pozyskiwania wiedzy z niebiańskiej akademii będącej źródłem mistycznych objawień.

U podstaw kabały luriańskiej leżały trzy istotne koncepcje: cimcum (wycofanie) ${ }^{40}$, tikkun (naprawa) $^{41}$ i gilgul (wędrówka dusz) ${ }^{42}$. Kabała ta wywarła niezwykły wpływ na społeczność żydowską, a przejawem tego było przede wszystkim wprowadzeniem w obszar życia wspólnotowego zasad ascezy. „Człowiek powinien prowadzić mało interesów, przez cały tydzień winien powstrzymywać się od zbytku jadła i napojów, mało mówić i wiele milczeć, odprawiać posty po dwa dni i dwie noce razem, a zanim po poście przyjmie jadło, winien posypać głowę popiołem i wśród łez spożywać chleb powszedni” [7, s. 258]. Luria uznawał za równouprawnione wszystkie porządki modlitewne różnych grup żydowskich, jednak za sprawą jego kabały wprowadzono nowe elementy do liturgii i obrzędów. Obowiązkowa stała się trzecia uczta sobotnia (hebr. szalosz sudot). Dodano również wiele praktyk religijnych, na przykład: nabożeństwo o północy (hebr. tikkun chacot), w trakcie którego płacząc odmawiano treny o zburzeniu Jerozolimy i rozproszeniu Izraela, a następnie spowiadano się [7, s. 258], post pierworodnych w wigilię Pesach, nocne czuwanie przed świętami Szawuot oraz Hoszana Rabba ${ }^{43}$, które ze święta radosnego zostało przekształcone w święto pokutne. Kabała luriańska nie tylko zmieniła dziedziny życia żydowskiego, w tym sposób obchodzenia świąt i szabatu, ale także wpłynęła na intymne sfery życia Żydów czy podejście do umierania i życia pośmiertnego. Wprowadzono nowe modlitwy, w tym wiele modlitw jednostkowych, które do tej pory były rzadkością [7, s. 257]. Dobrym przykładem modlitwy zbiorowej może być hymn Lecha dodi [161, s. 315], który trafił do Polski być może jeszcze pod koniec XVI wieku [108, s. 363].

W czasie, kiedy tworzyła się kabała luriańska, autorytety rabiniczne w Polsce, czyli Mojrzesz Isserles i Salomon Luria (1510-1573), nie podchodziły zbyt przychylnie do studiowania kabały. Isserles negował wręcz korzystanie z tej wiedzy bez odpowiedniej znajomości halachy i Talmudu, a Salomon Luria nazywał ją tajemną. Choć z drugiej strony Luria nie odżegnywał się od wykorzystywania mądrości Zoharu w celu rozsądzania sporów halachicznych, za co był potępiany przez Isserlesa.

Podobna dyskusja trwała na gruncie praskim. Tradycyjnie przyjmowano studiowanie kabały po uzyskaniu biegłości w studiach talmudycznych lub też, zgodnie z wprowadzonym 
ograniczeniem, od czterdziestego roku życia. Rabi Jari Hajim Bacharach (1639-1702) zaznaczał, że każdy powinien zachować dystans względem kabały, ponieważ jej zagadnienia są zbyt wzniosłe [42, s. 112].

Treści kabalistyczne zaczęły być przekazywane w społecznościach żydowskich w modlitwie ${ }^{44}$. W XVII i XVIII wieku dzięki rozwojowi technik drukarskich, które umożliwiły rozpowszechnianie traktatów kabalistycznych, kabała stała się niezwykle popularna ${ }^{45}$. Ten przełom doprowadził też do krytycznego spojrzenia na interpretacje rabiniczne oraz dał możliwość własnego poszukiwania [155, s. 532]. Apogeum popularności koncepcji kabalistycznych przypada na 2. połowę XVII wieku. Teksty kabalistyczne wydawane były wówczas w formie tanich, a przez to łatwo dostępnych broszur. Wiele ksiąg kabalistycznych, między innymi prace kabały luriańskiej, było publikowanych w Pradze. Literaturę tego zakresu drukowano również w jidysz, dzięki czemu mogła ona trafić do jeszcze szerszej grupy - również do osób nieznających hebrajskiego ${ }^{46}$.

Rok 1648 miał być szczególny dla Żydów. Zgodnie z przepowiednią zapisaną w Sefer ha-Zohar miał być bowiem rokiem pojawienia się mesjasza [94, s. 312], na co wskazywali również Rabbi Szabataj Kohen i Sabatem Horowic [25 s. 26]. Zamiast mesjasza pojawiły się jednak wojska Bohdana Chmielnickiego. Potem nastał okres wojny z Rosją i Szwecją. Kiedy w latach 60. XVII wieku sytuacja powoli się stabilizowała, szukano winnych klęsk, które spadły na Polskę. Odpowiedzialnością obciążono innowierców, w tym Żydów, co doprowadziło do fali pogromów. W tak trudnej sytuacji Żydom pozostało oczekiwanie na mesjasza, a przyśpieszeniu jego przyjścia miały służyć tikkun (naprawie) i wynikające z niego działania religijne i duchowe.

W czasie wojen w Polsce o sobie jako o mesjaszu coraz odważniej zaczął mówić Sabbataj Cwi (1626-1676), mieszkający w Smyrnie położonej na wybrzeżu Turcji. Nie zdziałał jednak wiele w kwestii upowszechnienia swojego posłannictwa i nie zdołał porwać tłumów. Z pomocą przyszedł dopiero prorok Natan z Gazy (1644-1680) $)^{47}$, który w 1665 roku ogłosił, że Sabbataj Cwi (1626-1676) jest mesjaszem. Wieść ta wzbudziła niezwykły entuzjazm Żydów w niemal całej Europie [63, s. 163]. Do Polski dotarła jesienią tego samego roku i spowodowała udanie się do nowego mesjasza kilku delegacji.

Sabbataizm, pomimo szybkiego upadku, pomagał w szerzeniu kabały luriańskiej [155, s. 457]. Mesjasz lgnie do boskiej mocy, po to, aby przywrócić harmonię. Bycie mesjaszem o zmiennych stanach świadomości dawało Sabbatowi Cwi jeszcze większe możliwości. Odczuwanie na przemian stanów „oświecenia” i „upadku” podbudowywało wrażenie mesjanizmu. „Otóż kiedy podczas „rozbicia naczyń” iskry Bożego światła wyemanowanego przez En-Sof [...] właśnie spadły w dół, wraz z nimi upadła dusza Mesjasza zawarta w owym pierwszym boskim świetle. [...] Razem z tą najświętszą duszą mieszkają tam, w mroku otchłani, krepujące ją i próbujące uwieść „węże”. Tym „wężom” wydany jest na pastwę „święty wąż” - Mesjasz” [161 s. 327] $]^{48}$. „Sabbataizm zrodził się więc z odczucia wewnętrznej sprzeczności...” [161, s. 377]. W jego centrum znajdują się paradoksy, z których największym był Odkupiciel-Apostata. Właściwie istnienie jednostki opiera się zdaniem sabbataistów na stałym konflikcie 
z samym sobą, a więc Bóg i mesjasz nosili piętno tej „wewnętrznej sprzeczności i dezintegracji” [161, s. 356]. Ten paradoks unaocznia jeszcze lepiej Mircea Eliade. Każdy czyn nieczysty i zły wprowadza w łączność z duchem świętym, a kto czyni zło jest cnotliwy w oczach Boga. Zło należy więc zwalczać złem. Natan z Gazy przejmuje koncepcje oddziaływania na siebie rzeczywistości, ale z tą różnicą, że wskazuje na dążenie bóstwa do przywrócenia stworzenia do „pierwotnego stanu chaosu wewnątrz bóstwa” [64, s. 18].

Po upływie pół roku od momentu ogłoszenia się mesjaszem Sabbataj udał się do Konstantynopola, gdzie został pojmany przez Mustafa Paszę. W 1666 roku, aby uniknąć więzienia i męczeństwa, wyparł się judaizmu i przeszedł na islam. Apostazja Sabbataja i jego śmierć w 1676 roku nie wpłynęły istotnie na szerzenie się nowego ruchu. Za ogniska sabbataizmu można uznać Bałkany oraz Włochy. Na Litwie, po okresie rozkwitu, ruch ten praktycznie zniknął. Silnym punktem były również wschodnie rubieże Rzeczpospolitej, w tym Podole i Ukraina. Głównym powodem takiego stanu była utrata tych terenów na rzecz Turcji na mocy pokoju w Buczaczu w 1672 roku. Po powrocie utraconych ziem w 1699 roku wiele gmin na tym obszarze było przesiąkniętych naukami następcy Sabataja [7, s. 264].

Przez 100 lat, liczonych od momentu wystąpienia Sabataja Cwi, w Polsce panował względny spokój, choć zdarzały się incydenty z udziałem sabbataistów. Sytuacja zmieniła się wraz z pojawieniem się w 1755 roku Jakuba Franka, despotycznego mesjasza [161, s. 369], niejako następcy Sabataja Cwi. Jego podróż po Polsce trwała kilka lat, ku uciesze kryjących się przed światem sabbataistów. Skończyła się przejściem Jakuba Franka i jego zwolenników na chrześcijaństwo w 1759 roku.

Oba ruchy, czyli zarówno sabbataizm, jak i frankizm nie pozostawiły po sobie żadnych szczególnych wartości, które sprzyjałyby rozwojowi duchowemu.

W XVII i XVIII wieku kabała praktyczna stała się podstawą funkcjonowania baal szem [155, s. 550] (Mistrza Dobrego Imienia). Jego działalność wynikała z przekonania, że kabaliści mogą wpływać na tok spraw w sferach niebieskich. Baal szem znał tajemne imię Boga i potrafił się nim posługiwać dla osiągnięcia własnych celów [63, s. 183] ${ }^{49}$.

Wpływy kabały były bardzo rozległe i doprowadziły do rozwinięcia się ruchu chasydzkiego w latach 60. i 70. XVIII wieku [63, s. 163]. Najważniejszą postacią, która najprawdopodobniej zapoczątkowała ten ruch, był Izrael ben Elizer, znany jako Baal Szem Tow (Baszt) $(1698-1760)[44]^{50}$.

\section{Przypisy}

${ }^{26}$ To zagadnienie zostało opisane w pracach m.in.: J. Goldberg, Jewish Privileges in the Polish Commonwealth: Charters of Rights Granted to fewish Communities in Poland-Lithuania in the Sixteenth to Eighteenth Centuries, Jerozolima 1985; G. Hundert, Żydzi w Rzeczypospolitej Obojga Narodów w XVIII wieku. Genealogia nowoczesności, Warszawa 2007. 


\section{Rys historyczny}

${ }^{27}$ Jednym z istotnych działań świadczących o statusie ludności żydowskiej w Rzeczpospolitej było zatwierdzenie przez Zygmunta Starego przywilejów nadanych przez Witolda karaitom trockim i objęcie nimi wszystkich Żydów zamieszkałych na Litwie. Nadania te wraz z przywilejami dla gmin w: Grodnie, Pińsku, Ostrogu, Łucku i Tykocinie (zatwierdzone w latach 1507-1514) stały się podstawą całego prawodawstwa żydowskiego na Litwie i weszły w 1529 r. w skład statutu litewskiego. Niespotykanym dotychczas wydarzeniem, związanym z tym statutem, było nadanie Żydom prawa do posiadania ziemi na własność, co pierwotnie związane było z działalnością agrarną. Wskazywać to może, co potwierdza konstytucja sejmowa z 1629 r., że przez państwo Żydzi nie byli traktowani jako obcy. Vide: E. Ringelblum, Dzieje zewnętrzne Żydów w dawnej Rzeczypospolitej, [w:] Żydzi w Polsce odrodzonej: działalność społeczna, gospodarcza, oświatowa i kulturalna, red. I. Schiper, A. Tartakower, A. Hafftka, t. 1, Warszawa 1932, s. 49; J. Goldberg, Poles and Jews in the 17th and 18th Centuries: Rejection or Acceptance, „Jahrbücher für Geschichte Osteuropas: Neue Folge” 1973, Vol. 22, Nr. 2, s. 50.

${ }^{28}$ Stosowanie heremu przez Sejm Czterech Ziem było źle odbierane przez rabinów. Mechanizm ten należał bowiem do ich kompetencji jako przywódców religijnych. Sejm Czterech Ziem sięgał jednak po to narzędzie, np. w 1672 r. w sprawie związanej z sabbataistami. Vide: A. Teller, Rabbis Without a Function? The Polish Rabbinate and the Council of Four Lands in the Sixteenth to Eighteenth Centuries, [w:] Jewish religious leadership: image and reality, ed. J. Wertheimer, New York 2004, s. 384.

${ }^{29}$ Działo się tak, ponieważ dobytek Żydów był ruchomy i pomimo wojny udało im się zachować większość swojego bogactwa. Po wojnie bardzo szybko zaczęli zaludniać miasta, pomagając jednocześnie ludności chrześcijańskiej w odbudowie domów. Dzięki temu stawali się właścicielami odbudowywanych posiadłości, ale do czasu, aż chrześcijan było stać na spłacenie długu. Doprowadziło to do przesiedlenia się ludności żydowskiej po 1670 r. do centrów miast i skupienia się jej osadnictwa wokół rynku. Należy jednak zaznaczyć, że wraz ze wzrostem odległości od rynku osadnictwo stawało się rozproszone. Vide: A. Teller, The Schtetl as an Arena for Polish-Jewish Integration in the Eighteenth Century, „Polin: Studies in Polish Jewry” 2004, Vol. 17, s. 31-35; M. Rosman, Żydzi Pańscy. Stosunki magnacko-żydowskie w Rzeczpospolitej w XVIII wieku, Warszawa 2005, s. 67, 97-99.

${ }^{30} \mathrm{Na}$ synodzie we Wrocławiu w 1267 r. zalecono separację żydów i chrześcijan. Vide: G. Hundert, Żydzi w Rzeczypospolitej Obojga Narodów w XVIII wieku. Genealogia nowoczesności, Warszawa 2007, s. 89.

${ }^{31}$ Większość zakazów została zaczerpnięta z wydanego przez Jezuitów w Wilnie traktatu Sekret $\dot{z} y d o w s k i e j$ przewrotności wyjawiony i światu polskiemu w przestrodze wielce pożytecznej przekazany. Vide: J. Goldberg, Poles and Jews in the 17th and 18th Centuries.Rejection or Acceptance, „Jahrbücher für Geschichte Osteuropas: Neue Folge" 1973, Vol. 22, Nr. 2, s. 254.

32 Kanonik Krzepic pożyczył dużą sumę gminie w Działoszynie. Bernardyni z Leżajska zamawiali u żydowskich kupców materiały do swojej manufaktury. Zdarzało się również, że Żydzi mieszkali $\mathrm{w}$ tych samych domach co mieszczanie lub wynajmowali pokoje w domach państwowych urzędników lub duchownych. Byli dzierżawcami dóbr kościelnych i dopiero pod koniec XVIII w. zaniechano usilnych działań mających na celu usuwanie ich z zarządzanych majątków. Szlachta również nie przestrzegała przepisów prawa kanonicznego, jeśli zależały od nich jej prerogatywy lub sytuacja eko- 


\section{Rys historyczny}

nomiczna i gospodarcza. Vide: J. Goldberg, Poles and Jews in the 17th and 18th Centuries: Rejection or Acceptance, „Jahrbücher für Geschichte Osteuropas: Neue Folge” 1973, Vol. 22, Nr. 2, s. 256.

${ }^{33}$ Temat ten przewija się w pismach wprawdzie od XIII w., jednak jeszcze w XV w. Mojżesz z Kijowa pisze Szoszon ha-Sodot. Vide: M. Idel, Kabała Nowe perspektywy, Kraków 2006, s. 18.

${ }^{34}$ Widocznym tego przejawem jest tzw. kabała ekstatyczna, która w oparciu o różnego rodzaju techniki medytacyjne pozwala człowiekowi osiągnąć stan ekstazy oraz zbliżyć się do boskości, a w szczególnych przypadkach nawet połączyć się z nią.

35 Dziesięć sefirot to: Keter (korona), Chochma (mądrość), Bina (sąd), Gedula (majestat) [Chesed (łaska)], Gewura (srogość), Tiferet (piękno), Necach (zwycięstwo), Hod (chawała), Jesod (fundament), Malchut (królestwo).

${ }^{36}$ Zagadnienie to omówiono w rozdz. 8. Vide: M. Idel, Kabała. Nowe perspektywy, Kraków 2006, s. 352.

${ }^{37} \mathrm{~W}$ tym czasie poruszano się raczej w obszarze kabały ekstatycznej i praktycznej, choć nie odrzucano szkoły teurgiczno-teologicznej. Kabała ekstatyczna była zarezerwowana dla wąskiego grona wtajemniczonych, podczas gdy nurt teozoficzny był idealny dla treści, które miały dotrzeć do większego grona odbiorców. Vide: M. Idel, Kabała. Nowe perspektywy, Kraków 2006, s. 20.

38 „Bójcie się Pana, Boga swego, Jemu się oddajcie, służcie Mu i na Jego imię przysięgajcie” [137, Pwt 10,20]; „Jeśli pilnie strzec będziecie wszystkich tych poleceń, które ja wam dziś nakazuję pełnić, miłując Pana, waszego Boga, postępując według wszystkich Jego dróg i Jego się trzymając" [137, Pwt 11,22]; „Za Panem, Bogiem swoim, pójdziesz. Jego się będziesz bał, przestrzegając Jego poleceń. Jego głosu będziesz słuchał, Jemu będziesz służył i przylgniesz do Niego” [137, Pwt 13,5]; „miłując Pana, Boga swego, słuchając Jego głosu, lgnąc do Niego; bo tu jest twoje życie i długie trwanie twego pobytu na ziemi, którą Pan poprzysiągł dać przodkom twoim: Abrahamowi, Izaakowi i Jakubowi” [137, Pwt $13,20]$.

${ }^{39}$ Szczegółowy opis technik wizualicaji kolorów moża znaleźć w pracy: M. Idel, Visualization of Colors, I: David ben Yehudah he-H asid's Kabbalistic Diagram, „Ars Judaica” 2015, No. 11, s. 31-54.

${ }^{40}$ Przed kosmogonią Bóg był wszędzie i wypełniał sobą całą przestrzeń, musiał wycofać się (w głąb siebie), aby móc stworzyć świat. Oznacza to, jak pisze Gershom Scholem, że istnienie wszechświata stało się możliwe dopiero dzięki procesowi „kurczenia się Boga”. Vide: M. Eliade, Historia wierzeń i idei religijnych, t. 3, Warszawa 1995, s. 115.

${ }^{41}$ Koncepcja tikkun nie wnosiła nic nowego. Działania Żyda mają na celu „restytucję rozrzuconych iskier i świateł”. Zwieńczeniem tego procesu jest przyjście mesjasza. Dla Żyda istotne jest, że proces ten następuje na dwóch płaszczyznach: (1) zachowań religijnych, czyli poprzez Torę i wypełnianie micwot, oraz (2) duchowej, czyli poprzez modlitwę. Człowiek jest niezbędnym elementem tego procesu, który ma na celu „intronizację Boga w królestwie niebieskim”. Z jednej strony ten sposób rozumienia naprawy świata doprowadza w gruncie rzeczy do rozumienia odkupienia jako powrotu wszystkiego do swej pierwotnej jedności z Bogiem. Z drugiej oznacza jednak, że człowiek ma wpływ na procesy zachodzące w bóstwie. Vide: G. Scholem, Mistycyzm żydowski i jego główne kierunki, Warszawa 2007, s. 303; M. Eliade, Historia wierzeń i idei religijnych, t. 3, Warszawa 


\section{Rys historyczny}

1995, s. 116; M. Idel, Kabała. Nowe perspektywy, Kraków 2006, s. 300-301. Więcej informacji o rozbiciu naczyń w pracy: J. Bar-Lew, Kabała pieśn duszy, wprowadzenie do żydowskiego mistycyzmu, Kraków 2006.

42 Gilgul pojawiła się w doktrynach wcześniejszych kabalistów, jednak oznaczała karę za przewinienia, głównie natury seksualnej, w tym grzechu keri (polucji). U Lurii gilgul wyraża rzeczywistość wygnania. Każda dusza zachowuje swoją indywidualność, aż do chwili swej duchowej odnowy. Ta transmigracja dusz ma nie tylko podstawy w karze, ale również daje możliwość samodoskonalenia, które następuje poprzez wykonywanie kolejnych z 613 nakazów Tory (hebr. micwot). Pojęcia wędrówki dusz pojawia się po raz pierwszy w Zoharze. Vide: S. Flatto, The Kabbalistic Culture of EighteenthCentury Prague: Ezekiel Landau (the 'Noda Biyehudah') and his Contemporaries, Oxford-Portland 2010, s. 199.

${ }^{43}$ Siódmy dzień święta Sukkot.

${ }^{44}$ Najlepszym tego przykładem jest list cytowany przez Sharon Flatto. Pojawia się w nim problem „polskiego nusachu”, w którym na zakończenie Szabatu recytowany jest fragment „wszędzie znajdziesz Jego majestat (gedula)”, zamiast zapisanego w Talmudzie i w liturgii fom Kipur „wszędzie znajdziesz Jego siłe (gewura)". Vide: S. Flatto, The Kabbalistic Culture of Eighteenth-Century Prague: Ezekiel Landau (the 'Noda Biyehudah') and his Contemporaries, Oxford-Portland 2010, s. 126.

${ }^{45}$ W Polsce Zohar wydano po raz pierwszy w Lublinie w 1623 r. Vide: K. i M. Piechotkowie, Bramy Nieba: Bożnice murowane na ziemiach dawnej Rzeczypospolitej, Warszawa 1999, s. 67.

${ }^{46}$ Bardzo popularne w tym czasie były drukowane pisma Chaima Vitala, w tym Ecej Chaim (Drzewo Życia). Wkład w tę dziedzinę mieli również polscy kabaliśsi, m.in. Natan Spira (1585-1633) czy Izajasz Horowic (ok. 1565-1630). Horowic po wędrówce po Europie osiadł w Galilei, gdzie ukończył książkę Dwie tablice przymierza. Jego dzieło, w którym propagował kabałę luriańską, w krótkim czasie zdobyło popularność i było sprzedawane w całej Polsce. W XVII i XVIII w. działały w Polsce grupy chasidim, tj. kabistów, które opierały się na kabale luriańskiej i jej postulacie ascezy. Największe ośrodki powstały w: Brodach, Ostrogu, Wilnie, Opatowie, Brześciu Litewskim, Szułowie, Lwowie. Vide: M. Bałaban, Mistyka i ruchy mesjańskie wśród Żydów w dawnej Rzeczypospolitej, [w:] Żydzi w Polsce odrodzonej: działalność społeczna, gospodarcza, oświatowa i kulturalna, red. I. Schiper, A. Tartakower, A. Hafftka, t. 1, Warszawa 1932, s. 260; G. Hundert, Żydzi w Rzeczypospolitej Obojga Narodów w XVIII wieku. Genealogia nowoczesności, Warszawa 2007, s. 162.

${ }^{47}$ Sabataj Cwi cierpiał na psychozę maniakalno-depresyjną. Z prośbą o uzdrowienie udał się do Natana z Gazy. Ten - sądząc, że widzi Sabataja w stanie ekstazy - przekonał go, że naprawdę jest mesjaszem. Rola Natana jako proroka, nowego mesjasza, spowodowała, że stał się twórcą doktryny nowego ruchu. Vide: M. Eliade, Historia wierzeń i idei religijnych, t. 3, Warszawa 1995, s. 117; G. Scholem, Mistycyzm żydowski i jego główne kierunki, Warszawa 2007, s. 319.

${ }^{48}$ Scholem wskazuje, że słowo masziach [hebr. משיח - mesjasz] ma wartość równą słowu nachasz [hebr. נחש - wąż]. Wartość ta wynosi 358.

${ }^{49}$ Różne środki, np. magiczne amulety i zaklęcia, miały chronić przed demonami, m.in. przed dybukiem. Rozwój tych demonicznych teorii przypisuje się powstającej w tym czasie literaturze ka- 


\section{Rys historyczny}

balistycznej. W XVIII w. koncepcje kabalistyczne stały się częścią „gramatyki kultury Żydowskiej” i podstawowym punktem twórczości literackiej i religijnej. Jednym z przykładów takiego dzieła jest Kaw ha-jaszar (właściwa miara) autorstwa Hirsza z Kojdanowa. Z grzechów ludzkich rodzą się demony, upiory i złe duchy, które zapełniają świat. Żeby uchronić się przed demonami, należało przede wszystkim nie wychodzić w nocy z domu. Ważne jest również, aby w trakcie wchodzenia do domu i wychodzenia z niego nie przylgnęła do człowieka pokusa. Dlatego trzeba dotykać mezuzyi trzymać się prawej strony odrzwi. Najbardziej narażone na działania demonów były niemowlęta. Jako bezbronne padały ofiarami Machlat i Lilit, które do kołysek wsadzały w zamian gliniane i słomiane lalki. Majer Bałaban cytuje za Kaw ha-jaszar, że zgodnie z księgą Zohar te dwie „rozpustnice” stanęły z jednym dzieckiem przed Salomonem. Wartość gematryczna imienia Machlat to 478, a Lilit 480. Wartości te odpowiadają liczbie czartów, które towarzyszą każdej z nich. W sytuacji radości pokonana zostaje Machlat, w sytuacji żałoby i smutku Lilit. Biorąc pod uwagę nierówność: $478<480$, autor wysnuwa wniosek, że lepiej jest się smucić, gdyż odsuwa się od siebie więcej złych mocy. Vide: G. Hundert $\dot{Z} y$ dzi w Rzeczypospolitej Obojga Narodów w XVIII wieku. Genealogia nowoczesności, Warszawa 2007, s, 193, 201; M. Bałaban, Mistyka i ruchy mesjańskie wśród Żydów w dawnej Rzeczypospolitej, [w:] Żydzi w Polsce odrodzonej: działalność społeczna, gospodarcza, oświatowa i kulturalna, red. I. Schiper, A. Tartakower, A. Hafftka, t. 1, Warszawa 1932, s. 256, 265.

${ }^{50} \mathrm{O}$ chasydyzmie można przeczytać w pracach: M. Wodziński, Historical Atlas of Hasidism, Princeton 2018; Idem, Groby cadyków w Polsce: o chasydzkiej literaturze nagrobnej i jej kontekstach, Wrocław 1998; Idem. Oświecenie żydowskie w Królestwie Polskim wobec chasydyzmu: dzieje pewnej idei, Warszawa 2003; Idem, Wtadze Królestwa Polskiego wobec chasydyzmu: z dziejów stosunków politycznych, Wrocław 2008; Essential papers on hasidim, Orgins to present, red. G.D. Hundert, New York 1991; J. Doktór, Mesjańskie widzenie Beszta (przyczynek do dyskusji na temat stosunku Baal Szem Towa do sabbataizmu), „Biuletyn ŻIH” 2000, nr 4, s. 523-531; R. Šats Ufenhaymer, Hasidism as mysticism: quietistic elements in eighteen century hasidic thought, thum. J. Chipman, Princeton-Jerusalem 1993. 


\section{SYNAGOGA}

\subsection{Elementy synagogi - uwarunkowania religijne i kulturowe}

Synagoga nigdy nie pełniła roli świątyni. Była raczej miejscem zgromadzeń i studiowania pisma ${ }^{51}$. Można to wywnioskować chociażby z faktu, że pierwsze, jeszcze antyczne synagogi istniały już w III i II wieku p.n.e., a więc w czasie, kiedy w Jerozlimie funkcjonowała jeszcze Druga Świątynia [134, s. 21]. Wskazują na to również słowa psalmisty: „[...] i palili wszystkie zbory Pańskie w kraju” [137, Ps 74,8]. Forma rytuału związanego z modlitwą i odczytywaniem Tory oraz wykluczenie kultu ofiarnego w czasach po zburzeniu świątyni jerozolimskiej wskazują jednoznacznie na odmienny charakter bożnicy. Synagog nie wznoszono zatem w opozycji do świątyni, ale jako jej kontynuację i uzupełnienie, w konsekwencji czego w diasporze była traktowana jako substytut świętego miejsca [71, s. 35].

Bet ha-Kneset budowane były w duchu tradycji konstytuującej przebieg liturgii synagogalnej [61, s. 139]. Obowiązek organizacji miejsca modlitwy w oparciu o Talmud [110, s. 18] wprowadził już w XII wieku rabbi Mosze ben Majmon (Majmonides) w swoim dziele Miszne Tora: „Gdziekolwiek mieszka dziesięciu Żydów, konieczne jest stworzenie miejsca do ich gromadzenia się na modlitwę w czasie każdego nabożeństwa” [141, s. 119].

Liczba dziesięć jest w judaizmie bardzo istotna. Wskazuje na zgromadzenie, wspólnotę, synagogę i konstytuuje wzory zachowań w sferze publicznej. Równie ważna w religii mojżeszowej jest rodzina i dom, które stanowią sferę prywatną. Obie sfery cechują zachowania religijne i obie są nie tylko niemożliwe do oddzielenia w życiu każdego Żyda, ale czasem nawet wzajemnie się przenikają. Życie w domu pozostawia przestrzeń, którą wypełnia synagoga i zachowania publiczne, a te zostawiają miejsce dla domu i rodziny. W centrum tego rozróżnienia między sferą prywatną i publiczną stoi koncepcja minjanu, a więc zgromadzenia co najmniej dziesięciu dorosłych mężczyzn powyżej 13 roku życia. Taka ich liczba jest wymagana do odmawiania pewnych modlitw, szczególnie Kadiszu [28, s. 119].

Majmonides wyznaczył obowiązek wznoszenia budynku na cele gminy i określił jego funkcję: „To miejsce nazywa się Beit K’nesset. Mieszkańcy miasta mogą zmusić siebie nawzajem do budowy synagogi i zakupu zwojów zawierających Torę, Proroków i Święte Pisma” [141, Hlichot tefilla 11,1].

Synagogi były obiektami orientowanymi ${ }^{52}$, co oznacza, że na ścianie zwróconej w kierunku Jerozolimy umieszczano Aron ha-Kodesz. Okres średniowiecza i rozwój urbanistyczny miast zmienił podejście do tej kwestii. Brak możliwości sytuowania obiektów zgodnie z obo- 
wiązującymi zasadami spowodował, że zaczęto kierować je na wschód [107, s. 421]. Orientacja synagogi była tematem podejmowanym również w Biblii hebrajskiej Tanach ${ }^{53}$. Zgodnie z opiniami rabinów można było wykorzystać budynek nieorientowany, gdyż z punktu widzenia halachy „bardziej istotne jest serce modlącego się Żyda skierowane do Boga niż twarz skierowana w stronę Jeruzalem” [83, s. 245].

Równie ważne przy budowie synagogi było miejsce, w którym była wznoszona. Zgodnie z ogólnym założeniem miało być ono dobrze widoczne. Dlatego też domy modlitwy lokalizowano na rogach ulic, w pobliżu bram, a także wzdłuż strumieni wody lub w otwartym polu. Podejmowano również próby budowy synagog na wzniesieniach, co było nawiązaniem do stwierdzenia Raba, nauczyciela żyjącego w III wieku: „Każde miasto, którego dachy są wyższe niż synagogi, zostanie ostatecznie zniszczone, jak to się mówi, do wywyższenia domu Boga naszego i do naprawy jego ruiny" [173, Sabbath 11a,2].

Słowa te powtórzył Majmonides w Miszne Tora [141, Hlichot tefilla 11,2]. Nie stanowiły one jednak zasady, której rygorystycznie przestrzegano, zwłaszcza w sytuacji konfrontacji społeczności żydowskiej ze społecznością chrześcijańską. Synagogi lokowano najczęściej przy murach miejskich, we wnętrzach kwartałów lub przy rynku, ale po stronie przeciwnej niż kościół i jak najdalej od niego, „by Żydzi swemi szemraniami nie przeszkadzali katolickiej modlitwie” [8, s. 56]. Miejsce, w którym stawiano bożnicę, było również uzależnione od zezwolenia na budowę i przydzielenia przez właściciela miasta działki znajdującej się w jego posiadaniu. Generalną zasadą było wznoszenie bożnicy w kwartale żydowskim, w oddaleniu od centrum, tak by nie była zbyt dobrze widoczna [83, s. 243]. Należy jednak zwrócić uwagę, że pod w koniec XVII i w XVIII wieku dzielnice żydowskie często przesuwały się w okolice rynku, czego konsekwencją było wznoszenie bożnic w jego okolicy, w odpowiedniej relacji do światyni chrześcijańskiej.

Na decyzję o budowie lub remoncie synagogi oprócz tych wymienionych czynników wpływały jeszcze dwa inne. Jednym były finanse. Pieniędzy na budowę bożnicy nie wolno było pozyskiwać ze sprzedaży szat na rodały [194, s. 69]. Drugim było zezwolenie na wzniesienie nowego domu zgromadzeń. Jeżeli gmina nie posiadała go, nie mogła zburzyć starej bożnicy, aby zrobić miejsce na nową, zanim nie skonsultowała się z bet din i nie poprosiła go o zgodę [194, s.127]. Zasadę tę potwierdził w 1628 i 1644 roku Sejm Żydów Litwy, który nakazał budowę nowych synagog lub zastępowanie tych drewnianych murowanymi, ale pod warunkiem uzyskania wcześniej zgody na takie działania [25, s. 27].

Rolę synagogi mogło pełnić dowolne pomieszczenie posiadające okno, przez które wpadało światło słoneczne. Tradycję tę należy wywodzić z Księgi Daniela ${ }^{54}$ [1, s. 27]. Zgodnie z myślą zawartą w Sefer ha-Zohar okno zapewniało łączność między człowiekiem a Bogiem i przez nie modlitwy docierały do Najwyższego [61, s. 147]. Między innymi z tego powodu okna umieszczano na takiej wysokości, aby znajdowały się powyżej poziomów dachów budynków w mieście i dawały wgląd bezpośrednio w niebo [194, s. 114] ${ }^{55}$.

Światło było w synagodze niezwykle ważne. Zasady dotyczące liczby okien w sali modlitwy przynosi mistyka. Dwanaście okien, którymi starano się doświetlić Bet ha-Kne- 
set, miało odpowiadać dwunastu bramom niebiańskiej Jerozolimy, opisanym w Zoharze [61], [134], [194]: „Każde z plemion otrzymuje swoje boskie błogosławieństwo przez jedną z dwunastu bram niebieskiego Jeruzalem" $[159, \text { s. 231 }]^{56}$. Inna interpretacja wynikająca z Zoharu wskazuje na dwanaście niebiańskich okien, przez które modlitwy trafiają do Najwyższego.

Od początku XVII wieku w centralnych rozwiązaniach planów synagog widać dążenie, niejednokrotnie udane, do stosowania się do tej zasady. Rozwiązanie dziewięciopolowe dawało możliwość umieszczenia preferowanej liczby okien, czyli dwunastu, po trzy na każdej ścianie synagogi [1, s. 27]. Istniał również zwyczaj, aby światło znajdowało się powyżej bimy, ponieważ miało reprezentować wieczne światło, które spalało się w świątyni jerozolimskiej. Dziś symbolizuje również koncepcję, że światło Tory nigdy nie zgaśnie [4, s. 61]. Należy również zwrócić uwagę na ner tamid - lampkę wiszącą w obrębie Aron ha-Kodesz. Stanowi ona nawiązanie do menory znajdującej się w świątyni jerozolimskiej i ma symbolizować boską wszechmocność i wieczność.

Całość organizacji wnętrza synagogi podlega jednemu elementowi - Torze. Zasada ta dotyczy Aron ha-Kodesz, czyli szafy (skrzyni) na rodały, i bimy, czyli podestu, na którym czytane są zwoje Tory. To w świętej skrzyni przechowywana jest Tora - rodał zawierający najświętsze prawo. Uważa się, że zwój Tory jest święty i może uświęcić wszystko, z czym wejdzie w kontakt. Jego „ubiór” jest tego najlepszym dowodem, ale wskazuje również na symboliczne odniesienia do czasów świątynnych ${ }^{57}$.

Właściwe zasady co do kształtowania Aron ha-Kodesz i bimy, a więc na przykład jego wysokość, zostały sfomułowane dopiero około V wieku. W Miszne Tora Majmonides określa natomiast zasady, którymi należy się kierować przy ich lokalizacji i sposobie wykonania. Podaje on, że Aron ha-Kodesz powinien być skonstruowany jako element stały i umieszczony po stronie, w którą modlą się ludzie, a więc w kierunku Jerozolimy [141, Hilchot tefilla 11,2]. Bima natomiast powinna znajdować się w centrum obiektu, aby wszyscy zgromadzeni mogli dobrze słyszeć słowa Pisma odczytywane z podestu [141, Hilchot tefilla 11,3]. Faktem jest jednak, iż w pierwotnej, starożytnej formie skrzynia na rodały była wnoszona do synagogi w trakcie liturgii [194, s. 14].

Józef Karo, jeden z największych kodyfikatorów halachy (prawa religijnego) w XVI wieku, również starał się wyznaczyć takie miejsce we wnętrzu domu zgromadzeń, które byłoby najlepsze do umieszczenia bimy. Trzeba nadmienić, że Karo był Żydem sefardyjskim mieszkającym w Safed, a jego opinie nie były jednoznaczne. W swoim dziele Szulchan Aruch (Nakryty stót) napisał: „A bimę stawiamy w środku synagogi, tak by czytający Torę, stojący na niej, słyszany był przez wszystkich w synagodze” [79, Orech Chaim 150,1].

W komentarzu do Miszne Tory zatytulowanym Kesef Miszne Majmonides twierdził, że bimę można postawić w dowolnym miejscu w synagodze, lecz tak, by mogli ją widzieć wszyscy zgromadzeni. W związku z tym zaleceniem utarło się w gminach sefardyjskich, aby podest umieszczać na osi, naprzeciwko Aron ha-Kodesz po stronie zachodniej. Taka jego loka- 


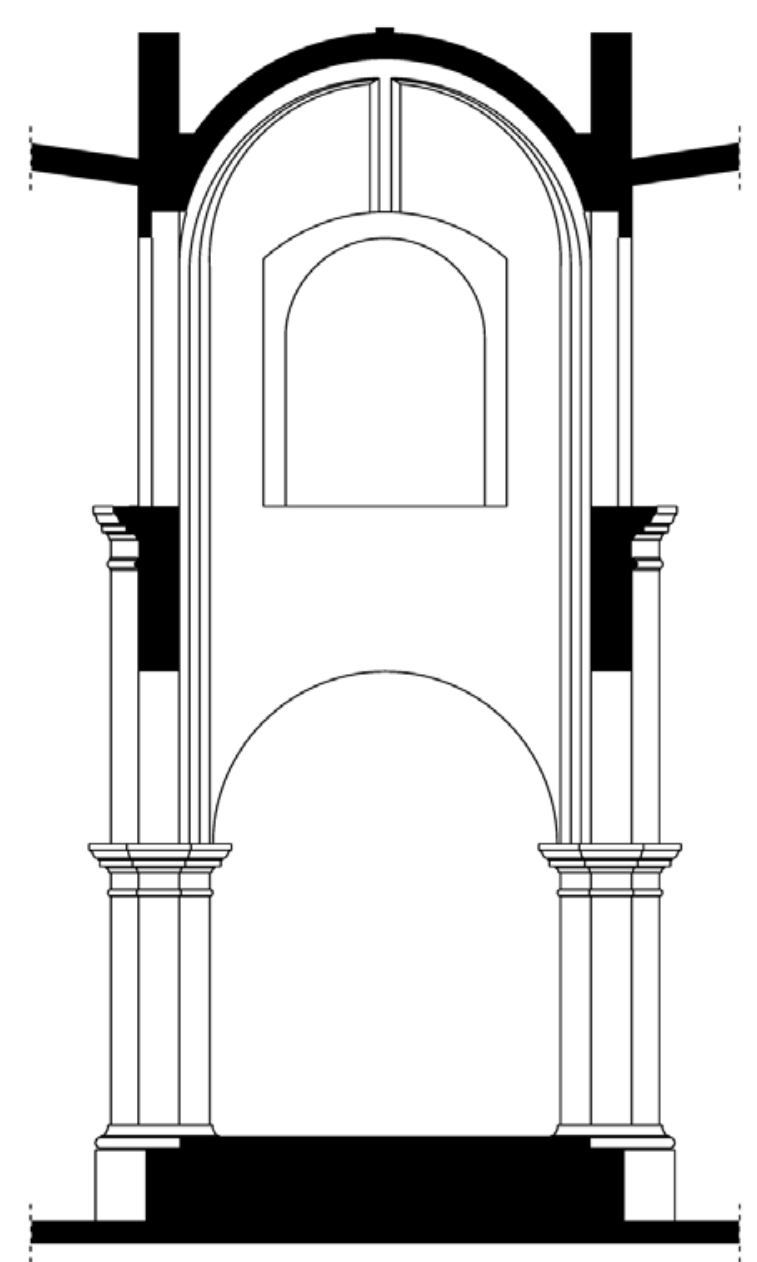

(a)

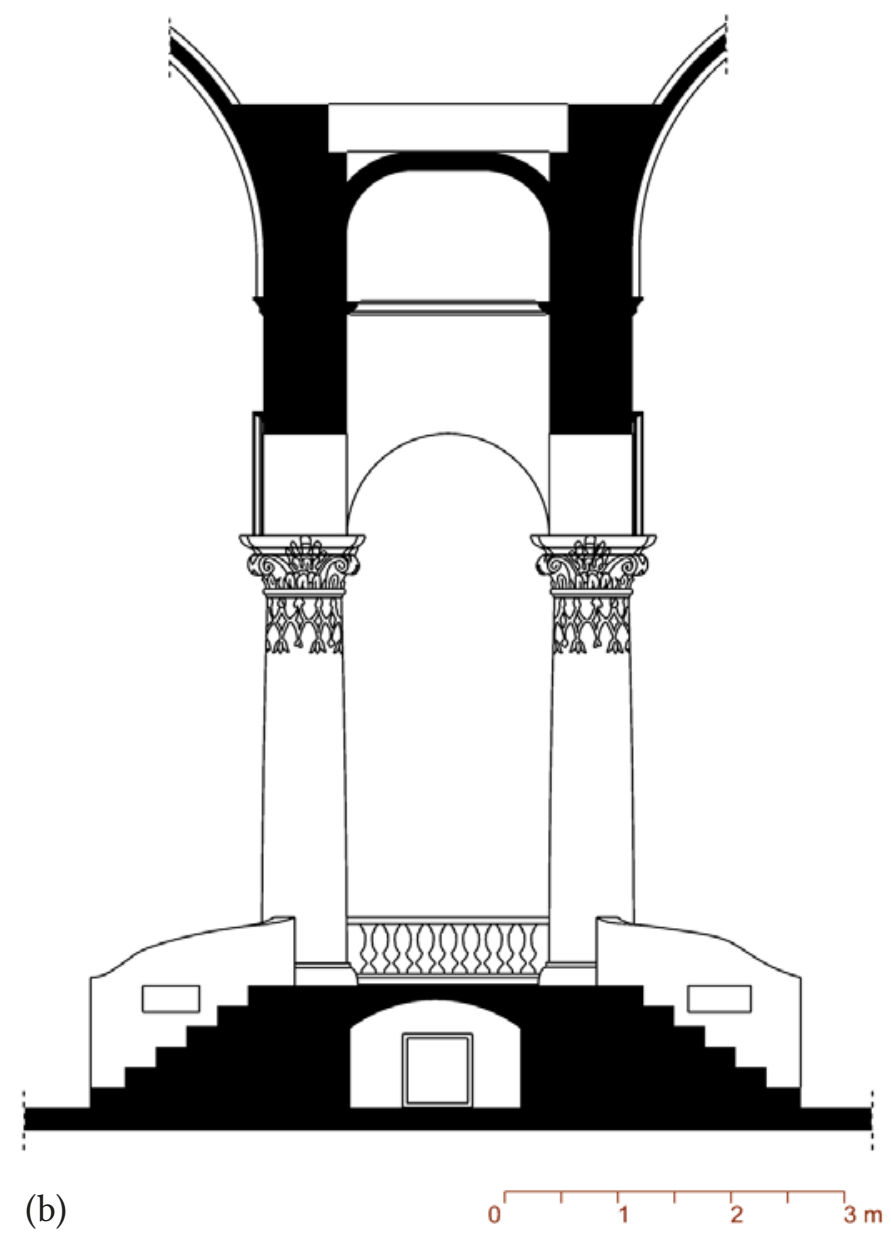

Il. 3.1. Przekroje bim w synagogach w Tykocinie (a) i Łańcucie (b) [21]

lizacja miała znaczenie użytkowe, gdyż umożliwiala czytającemu zwrócenie się twarzą do zgromadzonych, którzy stali przed bimą. Z tym poglądem nie zgadzał się Mojżesz Isserles, zwany Remu, krakowski autorytet talmudyczny Żydów aszkenazyjskich i zagorzały zwolennik sytuowania bimy w centrum.

Podest, którego prototypem był $a m u d^{58}$ i z którego odczytywano słowo Boga, mimo podległości szafie na rodały [71, s. 22] stał się w tym czasie niezwykle ważny. W XVII i XVIII wieku bima-podpora (il. 3.1) uzyskała niezwykłe znaczenie. Centralna bima flankowana czterema filarami pełniła bowiem funkcję symboliczną podobną do tej, jaką nadano iglicy kościoła gotyckiego. W procesie kształtowania idealnych wnętrz dziewięciopolowych, a więc zakładanych na kwadracie, horyzontalna przestrzeń audytorium (sali męskiej) została przeciwstawiona elementowi wertykalnemu w postaci bimy ${ }^{59}$, która niczym pień drzewa podtrzymywała w środku koronę sklepienia ${ }^{60}$.

Poza bimą, której forma świadczy o jej niezwykłej roli, równie ważnym, albo nawet ważniejszy element, był Aron ha-Kodesz ${ }^{61}$ (il. 3.2). Te szafy na rodały, które powstawały w oma- 

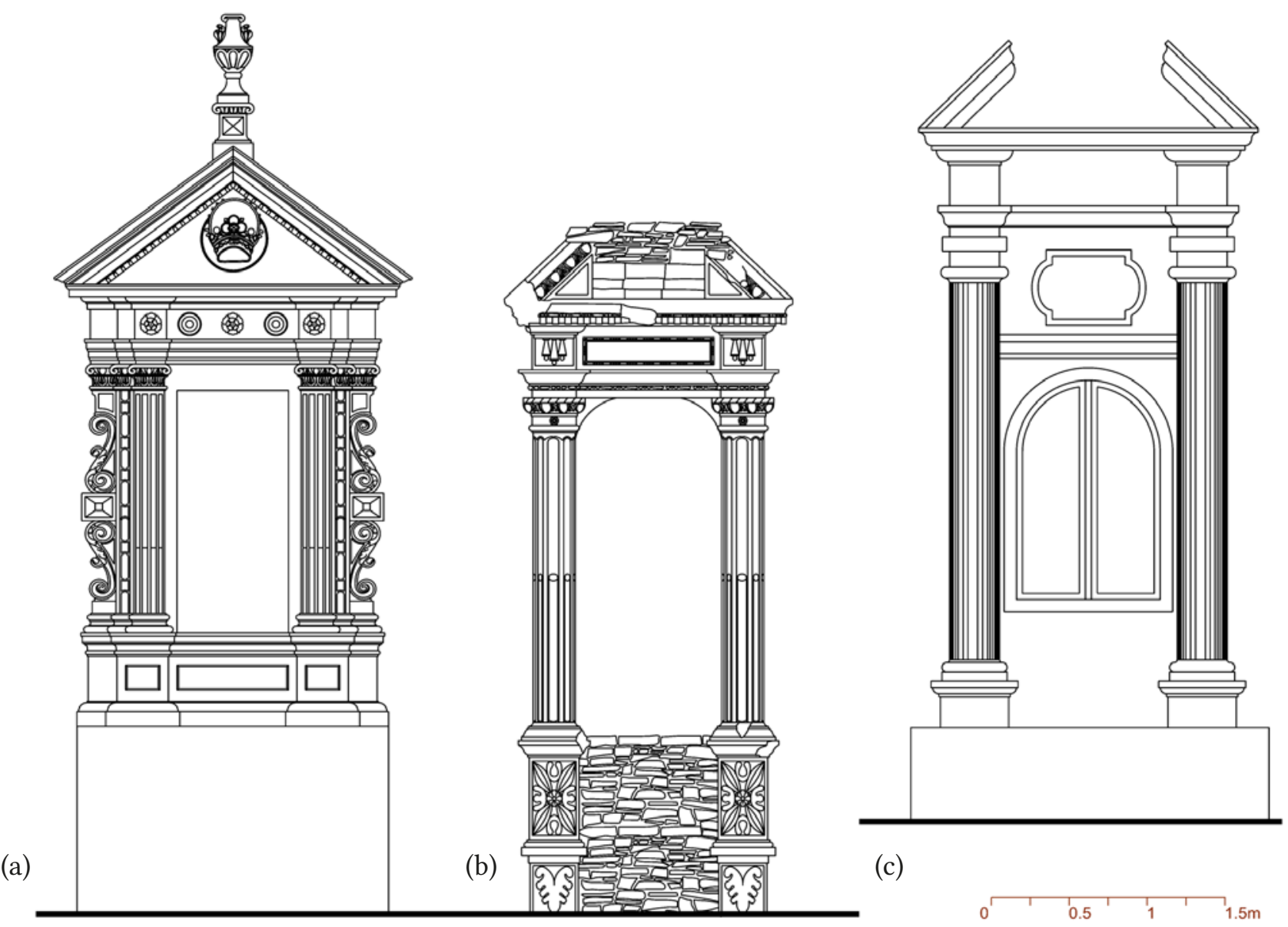

(c)

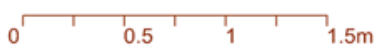

Il. 3.2. Aron ha-Kodesz w synagogach w: Pińczowie (a), Szczebrzeszynie (b) i Zamościu (c) [21]

wianym okresie, stawały się coraz bardziej okazałe. Uściślić trzeba jednak, że coraz większa była nie tyle wnęka (hebr. Aron ha-Kodesz), co dekoracyjne obramienie, które można byłoby porównać do retabulum.

Charakterystyczne dla sali męskiej jest obniżenie poziomu posadzki w stosunku do poziomu terenu, ale i poziomu przedsionka dobudowywanego do brył synagog w późniejszym czasie. Powód stosowania tego rozwiązania był często dyskutowany przez badaczy. Za pierwotną przyczynę uważano przepisy religijne zawarte w psalmie: „Z głębokości wołam do Ciebie Panie" [137, Ps 130]. Wskazują na to Majer Bałaban, Rachel Wischnitzer, Carol Krinsky [99, s. 21] czy William Rosenau [154, s. 25] $]^{62}$.

Innym istotnym przedmiotem dociekań jest kwestia przestrzeni dla kobiet $\mathrm{w}$ synagogach. Babiniec ${ }^{63}$ wywodzi się, jak wynika z Talmudu, z zewnętrznego „sądu” dla kobiet (hebr. ezrat naszim) w świątyni jerozolimskiej ${ }^{64}$. To rozdzielenie przestrzeni ze względu na płeć było odpowiedzią na fragment zamieszczony w pochodzącym z X wieku Seder Elyahu Rabba: „Mężczyzna nie powinien modlić się pośród kobiet, ponieważ ich obecność mogłaby go rozpraszać”.

W Polsce babińce wznoszono od XVI wieku w parterze jako aneksy dobudowywane od zachodu, południa i pólnocy lub na piętrze nad puliszami (przedsionkami) po stronie za- 
chodniej. Zdarzało się jednak, jak choćby w synagogach włoskich, że babiniec znajdował się pod salą męską, gdy ta była zlokalizowana na ostatniej kondygnacji budynku [99 s. 29]. Od połowy XVII wieku elementami synagog przeznaczonymi dla kobiet stały się we Włoszech galerie obiegające salę męską, a w Holandii empory nad nawami bocznymi. Niezależnie od zastosowanego rozwiązania obecność babińców wskazuje na coraz większy udział kobiet w publicznym rytualne [155, s. 557].

W XIV wieku w synagodze w Regensburgu, jak również Staro-Nowej Szkole w Pradze wzniesiono dodatkowe pomieszczenia służące celom gminy. Przełom XVI i XVII wieku przyniósł zmiany w sposobie sprawowania liturgii synagogalnej, co doprowadziło do powszechnego obudowywania synagog dodatkowymi pomieszczeniami. Przede wszystkim wynikało to z wyrugowania z wnętrz sal męskich funkcji innych niż kultowe. Dlatego też wznoszono aneksy, które miały pełnić rolę między innymi sali kahalnej czy bet midraszu (domu nauki).

\subsection{Układ przestrzenny sali męskiej do końca XVI wieku}

Żydzi nie wykształcili jednego uniwersalnego planu synagogi, który byłby powtarzany przez następne wieki. Istotą bożnicy miała być sieć zależności pomiędzy dwoma najistotniejszymi elementami: bimą i Aron ha-Kodesz ${ }^{65}$. Ostatecznie zaczęto więc wznosić domy modlitwy, w których zachowane były powiązania tych komponentów przy wykorzystaniu cech architektury typowej dla danego okresu i danego obszaru.

W okresie panowania Rzymian w Palestynie wznoszone były synagogi na planie prostokąta, z kolumnadami obiegającymi salę wewnątrz, najczęściej z trzech stron ${ }^{66}$. Przykładem są synagogi w: Irbid (III-IV w.), Tell Hum (III-IV w.) i Kafar Baram (III w.). Całość planu uzupełniano amfiteatralnie usytuowanymi miejscami siedzącymi [134, s. 22]. Skrzynia na rodały była elementem ruchomym a wnoszono ją do synagogi w trakcie liturgii [194, s. 14]. Tego typu działanie - poza „uświęceniem” przestrzeni, w której się modlono - przywodzi na myśl odniesienie do Arki Przymierza, ukryte zresztą pod określeniem Aron ha-Kodesz. Nie ma jednoznacznych informacji co do sposobu usytuowania bimy. Ponieważ w tych obiektach była wykonana w materiale nietrwałym, do naszych czasów nie pozostał po niej żaden ślad.

Kiedy Palestyna znalazła się pod panowaniem Bizancjum, zaczęto wznosić bożnice trójnawowe (Beth Alpha w 1. połowie VI w.) i - rzadziej - jednoprzestrzenne jak Eshtemoa z IV wieku. Salę męską poprzedzał dziedziniec - atrium. W ścianach skierowanych w stronę Jerozolimy sytuowane były absydy, które stanowiły miejsce na Aron ha-Kodesz. Wzorców planów z absydą należy poszukiwać we wczesnochrześcijańskiej architekturze kościołów z IV wieku [123, s. 45]. W synagogach tego okresu bimy zajmowały centrum planu. Posadzki zaś wyłożone były barwnymi mozaikami. W pochodzącej z IV wieku synagodze w Hamat Tiberias oraz we wzniesionych w VI wieku synagogach w Beth Alpha i Beth Shean Aron ha-Kodesz jest dwudrzwiowy, ujęty w dwie kolumny i zwieńczony trójkątnymi tympanonami lub półkolistą konchą. 
Układ bazylikowy jest kontynuowany w architekturze synagog w Hiszpanii, niejako pod wpływem architektury meczetów, w której zaczął być stosowany [123, s. 48]. Najlepszym przykładem takiego rozwiązania jest synagoga w Toledo, która od 1411 roku znana jest jako kościół Santa Maria la Blanca. W 1085 roku została wzniesiona na planie czworoboku o nierównoległych ścianach, w który wpisano cztery rzędy arkad o wykroju podkowy, wspartych na ośmiobocznych słupach i tworzących plan pięcionawowy.

Podobnym rozwiązaniem planu charakteryzowała się synagoga w Segowii. Była to bazylika trójnawowa, również o arkadach podkowiastych wspartych na słupach ośmiobocznych. Trudno jest oszacować datę jej powstania. Wiadomo natomiast, że w 1450 roku została zamieniona na kościół Bożego Ciała.

Migiel Ángel Espinosa-Villegas zwraca uwagę na trzy typy planów synagog, które wykształciły się w basenie morza śródziemnego. Pierwszym z nich jest omówiona powyżej bazylika, drugim są synagogi, które można by nazwać strukturami domowymi, a trzecim synagogi czteropodporowe [38, s. 82].

W przypadku struktur domowych społeczność Żydów sefardyjskich wykorzystała inne plany jak w przypadku dwóch synagog jednoprzestrzennych: jednej w Kordobie i drugiej, El Transito, w Toledo. Pierwsza z nich jest niewielką bożnicą wzniesioną w 1315 roku i - podobnie jak wcześniejsze obiekty - została zaadaptowana na inne cele. Nastąpiło to jednak dopiero po wypędzeniu Żydów z Hiszpanii w 1492 roku. W przeciwieństwie do synagog w Toledo i Segowii miała bimę lokowaną blisko zachodniej ściany. Synagoga El Transito została wzniesiona w 1357 roku, a jej fundatorem był Samuel Halewi (Samuel Abulafia). Składała się z jednej nawy $\mathrm{z}$ aneksami bocznymi, które stanowiły w większości prywatne pomieszczenia inwestora.

Interesujący jest sposób wykonania Aron-ha-Kodesz w synagogach hiszpańskich. Jak wynika z omówionych przykładów na ścianie zwróconej w kierunku Jerozolimy wznoszono pomieszczenie nazywane heichal (dosł. pałac) i dopiero w nim umieszczano skrzynię na rodały, określaną przez Żydów sefardyjskich jako tewa [197, s. 427].

Należy jeszcze wspomnieć o innym, nieco odosobnionym przypakładzie synagogi zlokalizowanej na Półwyspie Iberyjskim, a mianowicie o synagodze w Tomar (XV w.). Jako jedyna znana z tego okresu bożnica została wzniesiona na planie dziewięciopolowym ${ }^{67}$.

Średniowiecze wśród Żydów niemieckich przyniosło zupełnie nowe rozwiązania zarówno wnętrza synagogi, jak i szafy na rodały. Bożnice, które powstawały na obszarach zamieszkiwanych przez społeczność aszkenazyjską, były jedno- i dwunawowe. Synagogi jednonawowe były zakładane na planie prostokąa ${ }^{68}$.

Zdecydowaną większość stanowiły obiekty dwunawowe, zbudowane na planie sześciopolowym. Ich pierwowzorów należy poszukiwać w układach gotyckich wywodzących się z Niemiec i nawiązujących do dormitoriów i refektarzy [194]. Najstarszym znanym obiektem z tej grupy jest synagoga w Wormacji (1174-1175). Z późniejszego okresu pochodzi synagoga w Erfurcie (XIII w.) i synagoga Stara Szkoła w Pradze (XIII/XIV w.). Plan sześciopolowy podkreślał centralność oraz znaczenie bimy usytuowanej między dwoma filarami. Zastosowanie 
znalazły również inne plany - czteropolowy ze słupem po środku w synagodze w Egerze (1347-1375) czy ośmiopolowy w synagogach w Regensburgu (1267) ${ }^{69}$ i Budzie (1461, które ze względu na lokalizację bimy na środku bożnicy były jednak mniej korzystne.

Synagogi miały dwa rodzaje przekrycia: stropy drewniane lub sklepienia. Ten pierwszy mają synagogi w: Rufach (XIII w.), Erfurcie (XIV w.) i Spirze, natomiast ten drugi synagogi w: Miltenbergu, Bambergu, Mödling i Korneubergu.

W wielu domach modlitwy wznoszonych w tym okresie sale miały proporcje 3:2, a przykładem mogą być budowle we Frankfurcie, a także w Spirze czy Wormacji. W przypadku planu sześciopolowego drzwi do sali męskiej były zwykle umieszczone w ścianie północnej lub południowej i przesunięte w kierunku zachodnim, dzięki czemu zgodnie z obowiązującą zasadą Aron ha-Kodesz był widoczny bezpośrednio po wejściu do wnętrza [99, s. 45]. Pod względem formy szafa na rodały była wzorowana na motywie starożytnego edykułu. Nie stanowiła już osobnego pomieszczenia jak w synagogach hiszpańskich, ale była wnęką w ścianie wschodniej. Czasami wnęka ta zarysowywała się na zewnątrz budynku w formie absydy lub pogrubienia ściany.

W XV i XVI wieku, a więc po wygnaniu Żydów z Hiszpanii, zaczęto stosować także inne rozwiązanie wnętrz synagog - sefardyjski typ bipolarny. Pojawiał się on już w średniowiecznych synagogach przede wszystkim południowych Włoch, a także Półwyspu Iberyjskiego [107, s. 423]. Zastosowanie tego modelu nie oznaczało jednak końca synagog jednonawowych, które powstawały dalej, przede wszystkim na obszarze Czech i Polski. Oprócz tych wymienionych od XVI wieku wznoszone były również synagogi jednoprzestrzenne na planie kwadratu.

Rozwiązanie dwubiegunowe zakładało wykonanie prostokątnej, podłużnej, orientowanej sali, w której na obu krótszych bokach, naprzeciwko siebie umieszczano Aron ha-Kodesz i bimę. Miejsca siedzące sytuowano wzdłuż dłuższej ściany, równolegle po obu stronach osi sali męskiej.

Do dziś nie zachowała się żadna XV-wieczna synagoga, której układ byłby dwubiegunowy. Z XVI wieku pochodzą synagogi weneckie, na przykład: Scoula Grande Tedesca (1529), Scoula Canton (1531), Scoula Levantina (1538), Scoula Italiana (1575). Najbardziej znana jest jednak Scoula Spagnola (1584) w Wenecji, która popularność zawdzięcza wnętrzu zaprojektowanemu w 1655 roku przez Baltassara Loghene (1598-1682) [194, s. 60]. Jest założona na planie prostokąta, a wpisana we wewnątrze elipsa stanowi jednocześnie krawędzie dla balkonów przewidzianych jako babińce. Ten schemat stał się dominujący w wielu XVII-wiecznych synagogach [107, s. 424].

Podobne rozwiązanie wnętrza zostało zastosowane w aszkenazyjskiej synagodze Scoula Grande Tedesca. Wskazuje to na charakterystyczną dla Półwyspu Apenińskiego przewagę układu bipolarnego nad ściśle przestrzeganym przez Żydów aszkenazyjskich lokowaniem bimy w centrum. Rozwiązanie dwubiegunowe dominowało w kolejnych stuleciach ${ }^{70}$. Wszystkie synagogi weneckie lokowane były na ostatniej kondygnacji budynków mieszkalnych.

W 1592 roku w Livorno została wzniesiona synagoga, która swoim układem nawiązywała wprawdzie do planu bipolarnego, jednak znajdująca się w niej bima nie przylegała do ściany. 
Jest to jeden z pierwszych przykładów zastosowania układu halowo-emporowego w synagodze. Empory obiegały wnętrze sali męskiej z trzech stron i to aż na dwóch kondygnacjach ${ }^{71}$.

W synagogach podłużnych jednonawowych zakładano charakterystyczny dla synagog Żydów aszkenazyjskich podział wnętrza, w którym Aron ha-Kodesz lokowano w ścianie wschodniej, natomiast bimę w centrum planu. Jest to również okres, w którym przedsionki i babińce zaczynają stanowić z synagogami jedną bryłę.

Reprezentująca styl późnogotycki jednonawowa synagoga Pinkasa w Pradze została wzniesiona w 1535 roku, a jej fundatorem był Aaron Meshulam Horowitz. W latach 16071620 wykonano sklepienia przedsionka i babińca, które powstały na parterze budowli, jako jej integralne części, oraz dobudowano babiniec nad puliuszem. Do tej samej grupy, do której należy opisywana bożnica, można zakwalifikować również synagogi Krakowa. Warto dodać, że obiekty na planie jednonawowym powstawały przez cały XVII i XVIII wiek ${ }^{72}$.

Synagogą jednoprzestrzenną na planie zbliżonym do kwadratu była Synagoga Wysoka w Pradze (1568). W Polsce przełom XVI i XVII wieku obfitował również w wiele tego typu budowli.

Jedyną w swoim rodzaju - jak na miejsce i czas powstania - była praska synagoga ufundowana przez Mordechaja Maisela (1590-1592). Bożnica została wzniesiona na planie trójnawowym, ale ze względu na późniejsze przebudowy i wprowadzenie układu halowo-emporowego trudno jest określić, czy była pierwotnie bazyliką, czy halą.

W XVI wieku ponownie zaczynają być wznoszone synagogi czteropodporowe, które w zasadzie - można byłoby nazwać dziewięciopolowymi. Jest to również okres, w którym na ziemiach polskich powstają pierwsze synagogi z bimą-podporą. Odosobnionym przykładem synagogi na planie dziewięciopolowym, pochodzącym z tego okresu, a dokładnie z lat 70. XVI wieku, jest synagoga ha-Ari Aszkenazi w Safedzie.

Jak wynika z powyższego opisu, układ przestrzenny synagog zmieniał się. Część wzorców zapożyczano z architektury innych religii i kultur i adaptowano do potrzeb religijnych judaizmu. Znamienne wydaje się wykorzystanie starożytnego planu bazyliki w synagogach Półwyspu Iberyjskiego, planu dwunawowego charakterystycznego dla architektury klasztorów i kościołów. Plan jednonawowy, na którym budowano już w średniowieczu, stanowi podstawę synagog renesansowych. Trzeba zwrócić uwagę również na synagogi czteropodporowe, które w XIV i XVI wieku są jednak wyjątkami.

\subsection{Układ przestrzenny sali męskiej w synagogach w dawnej Polsce}

Istotną część synagog zlokalizowanych w Europie stanowiły te znajdujące się na terenie Polski. Ze względu na charakter niniejszej pracy wymagają one szerszego omówienia. Wzorce wskazane powyżej - zarówno sześciopolowe i jednonawowe z okresu średniowiecza, jak i jed- 
noprzestrzenne z XV wieku - były wykorzystywane w Polsce, ale w formie udoskonalonej. W końcu XV lub na początku XVI wieku wzniesiono ostatnią bożnicę sześciopolową o charakterze średniowiecznym na krakowskim Kazimierzu. Ostatnim i szczególnym - ze względu na czas budowy - przykładem zastosowania tego planu była synagoga w Chełmie (1660).

Synagogi wybudowane w Polsce od XVI wieku wyróżniają się ze względu na jakość wykonania oraz ich liczbę na tle obiektów, które od tamtego czasu powstawały na obszarze Europy. Ciekawa jest również pewnego rodzaju innowacyjność w podejściu do wcześniej wypracowanych wzorców oraz stopień ich oddziaływania zarówno w obrębie kraju, jak i poza nim. Nowe podejście do architektury bożniczej można prawdopodobnie zawdzięczać większej partycypacji artystów wyznania mojżeszowego [107, s. 416].

W XVI wieku popularne stały się rozwiązania jednonawowe i jednoprzestrzenne z centralnym wnętrzem założonym na planie kwadratu. Plan podłużny był stosowany przez cały XVII i XVIII wiek. W XIX wieku układ podłużny, w tym bazylikowy, prawie całkowicie wyparł plan centralny.

Synagogi XVII- i XVIII-wieczne pod względem architektonicznym są kontynuacją wypracowanych wcześniej modeli. Pojawiają się jednak również innowacyjne rozwiązania w postaci planu dziewięciopolowego czy nowocześniej potraktowanych bim. Rozwiązania bim-podpór były różne i na przestrzeni XVII wieku wypracowano właściwie wszystkie później pojawiające się typy tego elementu bożnicy. Należy zwrócić uwagę, że w ciągu niecałych trzydziestu lat od momentu wzniesienia prawdopodobnie pierwszej synagogi z bimą-podporą wypracowano nową formę planu dziewięciopolowego, w którym almemor był elementem niezależnym od konstrukcji budynku.

\subsubsection{Synagogi średniowieczne}

Architektura bożnic w Polsce w okresie od XII do początku XVI wieku pod względem układu przestrzennego nie odbiegała od tego, co proponowano na zachodzie Europy. Powstawały dwa wskazane wyżej typy Bet ha-Kneset: jednonawowe oraz sześciopolowe.

Plan jednonawowy zastosowano w synagodze w Strzegomiu (koniec XIV w.). Były to dwa przęsła sklepione krzyżowo-żebrowo ${ }^{73}$. Plan sześciopolowy został zaadaptowany przez Żydów czeskich [194, s. 55], choć synagogi dwunawowe pojawiały się na ziemiach polskich znacznie wcześniej, bo już w końcu XIII wieku ${ }^{74}$.

Plan sześciopolowy jest charakterystyczny dla dawnej synagogi w Oleśnicy ${ }^{75}$, wzniesionej razem z niewielkim przedsionkiem od strony północnej. W ścianie wschodniej umieszczono Aron ha-Kodesz, który od zewnątrz został ukryty w przyporze [134, s. 46].

W Polsce najbardziej znanym zachowanym przykładem planu sześciopolowego jest synagoga Stara (XV/XVI w.) na krakowskim Kazimierzu. Ze względu na pożar w 1557 roku, w wyniku kórego spłonęła cała budowla, trudno jest określić wygląd pierwotny wnętrza synagogi krakowskiej. Wiadomo jednak, że po stronie zachodniej wzniesiono wraz z salą męską 
przedsionek. W trakcie odbudowy, która trwała do 1570 roku i odbywała się pod okiem włoskiego muratora Mateo Gucci, zmieniono wysokość wnętrza i jego dekorację, zastosowano detal renesansowy oraz wykonano w nowym duchu szafę na rodały. Zmiany wprowadzone przez Gucciego spowodowały ujednolicenie wnętrza i prawdopodobnie zatarcie pierwotnego mocnego podziału na przęsła, jaki jest w Staro-Nowej Szkole w Pradze. Z tego samego okresu pochodzi z pewnością babiniec o szczytowo usytuowanych dachach. We wnętrzu bożnicy znajduje się bima na planie dwunastoboku ${ }^{76}$, pochodząca zapewne z końca XVI wieku [106, s. 110]. Podest został nadbudowany ażurową klatką z metalu.

\subsubsection{Synagogi jednoprzestrzenne}

Wiek XVI był okresem ekspansji ludności żydowskiej, przede wszystkim na ziemie Rusi [118, s. 326]. Silny rozwój demograficzny, ekonomiczny i kulturowy był powodem przemian społecznych oraz doprowadził do zmian w ukształtowaniu oraz funkcjonowaniu synagog. Najciekawsze przykłady architektury bożniczej pochodzą z XVI i XVII wieku, czyli z okresu rozwoju swoistego folkloru, który swoje źródło ma w kulturze żydowskicej [24, s. 20].

Przełom XVI i XVII wieku przyniósł zmiany kultowe i religijne związane z nasileniem ruchów mistycznych [118, s. 68]. Teorie i prace mistyków, które w tym czasie powstały, wywarły wpływ na formy domów modlitwy [194, s. 68]. Spowodowało to odmienny sposób traktowania sali męskiej, która powoli przestawała pełnić funkcje sali kahalnej, bet midraszu itp. Zaczęto też obudowywać synagogi dodatkowymi pomieszczeniami, które mogły przejąć funkcje opisane w podrozdziale 3.1. Bryła bożnicy była zwarta i poza salą męską składały się na nią przedsionek oraz empora dla kobiet.

W okresie tym zaczęły pojawiać się synagogi na planie centralnym - kwadracie. Ich genezy należy szukać w architekturze chrześcijańskich budowli z okresu renesansu ${ }^{77}$. Zwłaszcza na obszarze Małopolski sale synagog były jednak nadal prostokątne, co stanowi kontynuację planu jednonawowego. Obok synagog należących do gmin powstają również synagogi prywatne. Do tych drugich należą z pewnością zlokalizowane na krakowskim Kazimierzu bożnice: Remu (1553) $)^{78}$ ufundowana przez Israela ben Josefa, Poppera (1620) ufundowana przez kupca i bankiera Wolfa Poppera, Izaaka (1638-1644) ufundowana przez Izaaka Jakubowicza, a także synagoga Nachmanowicza (synagoga Złotej Róży) we Lwowie (1580-1582).

W latach 1534-1564 wzniesiono synagogę w Szydłowie. Obiekt ten powtarzał wprawdzie plan podłużny synagogi Remu, posiadał jednak inne proporcje. Sala założona została na planie prostokąta i była sklepiona niecką z lunetami. W późniejszym okresie dostawiono przy ścianie zachodniej przedsionek z babińcem, których również nie scalono z bryłą synagogi. Szafę na rodały w formie portalu usytuowano w ścianie wschodniej. Ośmioboczna bima wykonana z kamienia około 1550 roku [106, s. 109] znajdowała się w centrum planu i była otoczona kamienną balustradą, nad którą wykonano arkadowanie wsparte na narożnych słupkach balustrady. 
Synagoga Wysoka (1556-1563) była szczególnym przykładem synagogi wzniesionej na planie podłużnym. O jej wyjątkowości decydowało to, że została nadbudowana nad kamienicą na krakowskim Kazimierzu, a w celu zachowania orientacji za ważniejszą uznano oś poprzeczną. Szafa na rodały została umieszczona tym samym w centrum dłuższej ściany. Synagoga była sklepiona kolebą założoną prostopadle do osi wschód-zachód. Bima w formie wolnostojącego podestu otoczonego balustradą znajdowała się w centrum.

Oś poprzeczna była istotniejsza również w synagodze Poppera, założonej na planie podłużnym, na osi północ-południe. Ze względu na jej usytuowanie bezpośrednio przy murze miejskim i w podwórzu Aron ha-Kodesz wykonano jako wnękę w murze miejskim na osi poprzecznej. W późniejszym okresie do sali męskiej dobudowano od północy dodatkowe pomieszczenia.

W latach 1592-1594 powstała synagoga w Przemyślu. Obiekt ten pierwotnie był prostokątną salą przekrytą kolebą z lunetami, w której centrum była usytuowana wolnostojąca, ośmioboczna bima [108, s. 126]. Na ścianie wschodniej znajdowała się szafa na rodały.

Mury miejskie stały się problemem również w przypadku synagogi Kupa (1643-1647). Ze względu na fakt, iż ściana północna bożnicy przylegała do fortyfikacji, budowla uzyskała nieregularny kształt zbliżony do prostokąta. Podobnie jak w synagodze Wysokiej oś poprzeczna była osią wschód-zachód. Sala męska posiadała drewniane sklepienie pozorne z lunetami. W późniejszym okresie dobudowano od zachodu dodatkowe pomieszczenia z babińcem na piętrze.

Obiektem, który od początku łączył w sobie cechy architektoniczne zwartej bryły i prostokątnej sali męskiej, była synagoga Izaaka. Była ona kolejną bożnicą w Krakowie - po synagodze Starej i synagodze Remu - w której w pełni wykorzystyne zostały walory planu podłużnego. Jej podzielone na przęsła wnętrze przekryto bogato dekorowaną kolebą z lunetami. Aron ha-Kodesz usytuowano w ścianie wschodniej, a w centrum bimę założoną na planie dwunastoboku i pod względem formy podobną do bimy w synagodze Starej w Krakowie [108, s. 110]. Od zachodu do synagogi przylegał przedsionek zajmujący jedno z przęseł, nad którym wykonano babiniec. Synagoga Izaaka była pierwszą bożnicą, w której wnętrze sali męskiej zostało połączone z emporą dla kobiet. Wizualne oddzielenie tych dwóch stref zapewniały arkadowanie zwieńczone belkowaniem oraz zmiana koloru i dekoracji sklepienia.

Kolejnym krokiem w rozwoju architektury synagog była kwadratowa sala męska, zamknięta w zwartej bryle z przedsionkiem i babińcem. Obiekty o takim układzie przestrzennym wznoszono w ostatniej ćwierci XVI i na początku XVII wieku [201, s. 189] $]^{79}$. Przykładem może być synagoga Złotej Róży we Lwowie, która posiadała salę męską sklepioną żebrowym sklepieniem klasztornym z lunetami. Sala ta została założona jeszcze na planie prostokąta, jednak jej proporcje zbliżone są do kwadratu [99, s. 213]. W synagodze tej zastosowano - jak się wydaje po raz pierwszy - inne niż centralne usytuowanie bimy. Stanęła ona przed Aron ha-Kodesz, w środku odległości między schodami a ścianą zachodnią. Tym sposobem przesunięta została nieco w kierunku zachodnim.

Synagoga w Pińczowie (1594) podobnie jak synagoga Izaaka została wzniesiona jako zwarta bryła wraz z przedsionkiem i babińcem usytuowanymi od północy. Sala synagogi mia- 
ła prawie kwadratowe proporcje i była sklepiona kolebą z lunetami. Bima została usytuowana jak w synagodze Nachmanowicza. Wykonano ją z kamienia i nadano formę identyczną jak bimie w synagodze w Szydłowie [106, s. 109].

W 1638 roku wzniesiono synagogę w Chęcinach. Jej rzut był bardzo podobny do rzutu synagogi w Pińczowie - różnił się jedynie położeniem przedsionka i babińca, które znalazły się po stronie południowej. Sala męska pierwotnie była kryta drewnianym stropem, dopiero w 2. połowie XVII wieku założono sklepienie nieckowe z lunetami [134, s. 146].

Nieco inne rozwiązanie przyjęto w synagodze w Zamościu, wybudowanej około 1618 roku. Sala męska byłą wyższa niż babińce, które dostawiono od północy i południa, Została wzniesiona na planie kwadratu i przekryta sklepieniem żaglasto-lunetowym. W ścianie wschodniej znajdowała się wnęka na rodały. Lokalizacja bimy była powtórzeniem schematu przyjętego w synagodze Złotej Róży we Lwowie i w synagodze w Pińczowie. Miała kształt ośmiobocznego podium rozciągniętego wzdłuż osi północ-południe, otoczonego kutą z żelaza ozdobną balustradą, która w górnej części przechodziła w ażurowy baldachim. Podobnie rozplanowane wnętrze oraz ośmioboczna bima z balustradą z kutego żelaza były charakterystyczne dla pochodzącej z 1. ćwierci XVII wieku synagogi w Szczebrzeszynie ${ }^{80}$.

W XVI i XVII wieku następuje zdecydowane odejście od planów dwunawowych, które były jedną z cech architektury średniowiecznej, na rzecz planów podłużnych jednonawowych, a w dłuższej perspektywie planów centralnych jednoprzestrzennych. Działanie takie było podyktowane zapewne poszukiwaniem przez społeczność żydowską idealnego rozwiązania przestrzeni sali męskiej. Centralny plan, z którym borykało się wielu architektów XVI wieku, był traktowany jako ideał w sakralnej architekturze renesansu. Pomimo podstawy w traktacie Isserlesa ${ }^{81}$ trudno nie zwrócić uwagi na to, że plan kwadratu był silnie rozpowszechnionym wzorcem już od starożytności ${ }^{82}$. Być może dążenie Żydów do stosowania w rzucie kwadratu miało niezależne podłoże, jednak ze względu na zafascynowanie planem centralnym w renesansie oraz wpływ muratorów chrześcijańskich na architekturę bożnic trudno nie odnieść wrażenia, że Żydzi zaadaptowali to rozwiązanie.

Synagogi jednonawowe na planie prostokąta i centralne na planie kwadratu są ponownie wznoszone po 2. połowie XVII wieku. Z tego okresu pochodzą boźnice w: Lesku (1654), Goraju (3. ćwierć XVII w.), Tarnopolu (2. połowa XVII w.), Szarogrodzie (2. połowa XVII w.), Satanowie (2. połowa XVII w.), Husiatynie (1692), Sokalu (XVII/XVIII w.), Sandomierzu (1758), Nieświeżu (XVIII w.), Kazimierzu Dolnym (2. połowa XVIII w.), Janowcu (połowa XVIII w.), Nowym Korczynie (koniec XVIII w.).

\subsubsection{Synagogi z bimą-podporą}

Sztuka i architektura barokowa wywarły duży wpływ na formę bożnicy, czego najwyraźniejszym przejawem był dziewięciopolowy układ wnętrz Bet ha-Kneset ${ }^{83}$. Zbliżenie centralnych podpór do siebie spowodowało stworzenie bimy-podpory. Plan z bimą-podporą 
jest zatem rodzajem planu dziewięciopolowego, który ze względu na zmniejszenie pola centralnego w stosunku do pozostałych pól należy uznać za szczególny.

W Polsce układ dziewięciopolowy rozwinięto niezwykle szybko. Z czasem wyodrębniły się jego dwa typy, których największy rozkwit przypada właściwie na 1. połowę XVII wieku [118, s. 68]. Pierwszy z nich reprezentują omawiane synagogi z bimą-podporą. Drugi synagogi na planie dziewięciopolowym o równych polach, w których bima stanowi element wolnostojący i przybiera formę bimy altanowej. Bożnice odpowiadające pod względem formy zarówno jednemu, jak i drugiemu typowi wznoszono jeszcze przez niemalże cały XVIII wiek.

Powodów takiego kształtowania przestrzeni synagogi było kilka. Rozwój społeczności żydowskich wymagał wznoszenia obiektów o większej kubaturze, a w przypadku większych planów stosowania sklepień żaglastych (na przykład w Zamościu) czy koleb (na przykład w Pińczowie) było niemożliwe. Na takim sposobie kompozycji wnętrza domów modlitwy odcisnęła swoje piętno również symbolika i założenia kabały. Rozwój planu dziewięciopolowego z bimą-podporą był związany przede wszystkim z centralizacją przestrzeni sali męskiej przez coraz większe zbliżanie podpór sali w kierunku bimy. Takie działania powodowały stworzenie monumentalnych wnętrz, które wydawały się tym lżejsze, im bliżej siebie były umieszczone podpory i im mniejsza była bima. Ten sposób kształtowania bimy łączony był z fragmentem tekstu u Nehemiasza [137, Ne 8,4], a architektonicznie spełniał warunek centralnej kopuły, której synagoga nie mogła posiadać. Dodatkowo istotne wydaje się pokonanie planu sześciopolowego, który zaburzał relacje optyczne między bimą a Aron ha-Kodesz [193, s. 101].

Obiekty z bimą-podpora były nowoczesnym rozwiązaniem, również jak na ówcześnie stosowane układy konstrukcyjne. Jego nowatorski charakter wynikał przede wszystkim $\mathrm{z}$ faktu, iż siły poziome z przeciwległych sklepień równoważyły się na bimie ${ }^{84}$.

Badacze podają różne ramy czasowe powstawania budowli odpowiadających kompozycji syngogi z bimą-podporą. Według Adama Miłobędzkiego plan ze zsuniętymi słupami wykształcił się około 1620 roku. Szymon Zajczyk podaje, iż synagogi takie ${ }^{85}$ wznoszono od końca XVI do połowy XIX wieku [201, s. 190-191]. Maria i Kazimierz Piechotkowie przyjmują natomiast okres od 1. połowy XVII do końca XVIII wieku [133, s. 28]. Analizując jednak typ synagogi z bimą-podporą, autorzy ci podają, iż wykształcił się on już w połowie XVI wieku, a więc zanim wzniesiono synagogi w Zamościu i Szczebrzeszynie ${ }^{86}$.

Polska była niejako prekursorem formy synagogi z bimą otoczoną czterema słupami ${ }^{87}$, która spełniała wszelkie potrzeby wynikające $z$ religii, tradycji i kultury. Z pewnością była ona związana z nusachem (rytem liturgicznym) [13, s. 98], a plan dziewięciopolowy z bimą-podporą zapewniał relacje wnętrza ustanowione przez Rabbiego Isserlesa i odpowiadał wytworzonym kanonom liturgicznym [95, s. 191-192]. Na wykształcenie się tej formy synagogi wpłynęły być może zalecenia Isserlesa, a przed nim Majmonidesa [107, s. 444]. Było to rozwiązani typowo polskie, które nie ma zastosowania w architekturze innej religii czy innych kręgów kulturowych ${ }^{88}$. 


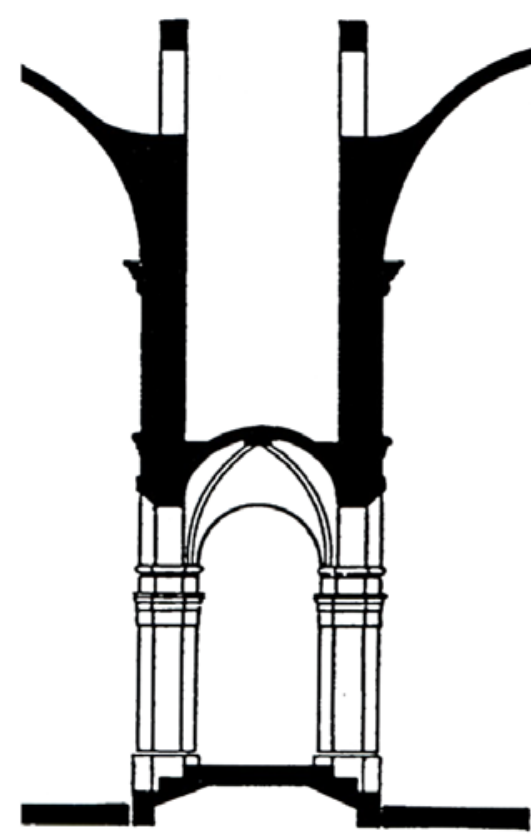

(a)

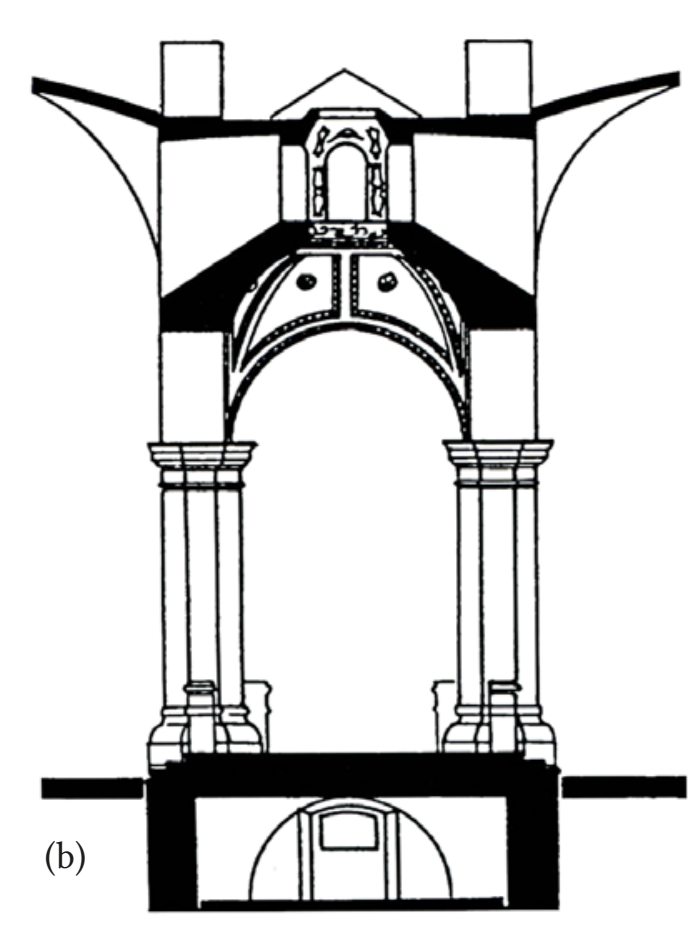

Typ 2

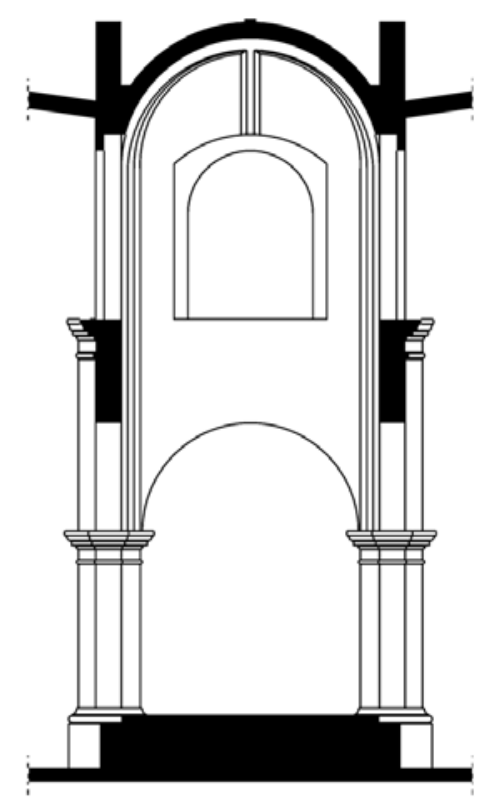

(c)

Typ 1

Podtyp Typu 2

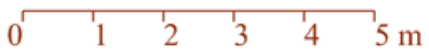

Il. 3.3. Typy bim w synagogach w: Łucku (a) i Pińsku (b) [25] oraz w Tykocienie (c) [21]

Bimy nie były jednolite pod względem formy. Można je podzielić na kilka typów i podtypów (il. 3.3), które wykształciły się w 1. połowie XVII wieku. Charakterystycznym elementem pierwszego typu było obniżenie sklepienia w centralnym polu, tj. nad bimą, które można zaobserwować w synagodze w Tarnowie (XVI/XVII w.), Łucku (1629) oraz w Synagodze Starej w Rzeszowie (początek XVII w.). Z tej formy bimy wywodzi się najbardziej rozbudowany typ drugi, tzw. bima kaplicowa [201, s. 191]. Charakteryzuje się on tym, że sklepienie nad bimą jest osadzone w połowie wysokości wnętrza synagogi, natomiast powyżej sklepienia znajduje się nadbudowana latarnia, do której prowadzą cztery otwory w ścianach nadstawy bimy. Przykładem takiego rozwiązania są synagogi w: Pińsku (1640), Słonimiu (1642) i Nowogródku (1648). Do tego typu Adam Miłobędzki zalicza również synagogę w Tykocinie (1642) [118, s. 289]. Jak pisze Szymon Zajczyk, jest ona jednak pewną formą typu drugiego [201, s. 192], ale nie może być kwalifikowana, w kontekście powyższej definicji, do synagog z bimą kaplicową.

O ile takie ukształtowanie pola centralnego powodowało zaciemnienie wnętrza bimy, o tyle oświetlenie sztucznym światłem dawało bardzo teatralny efekt, zwłaszcza wówczas, gdy światło sączyło się przez otwory w nadstawie. Podest w formie, jaką otrzymał, nabierał większego znaczenia. Nastąpił niejako powrót do przestrzennego podkreślenia go, podobnie 
jak to miało miejsce w obiektach sześciopolowych, w których był ujmowany z dwóch stron kolumnami czy filarami.

Tobias Lamey do przedstawionej typologii dodaje jeszcze jeden interesujący typ: bimę w formie baldachimu, która jednak nie pełni funkcji konstrukcyjnej [106, s. 110]. Autor ten podaje jako przykład synagogi w: Łęcznej (1655), Opatowie (połowa XVII w.), Zamościu, a także synagogę Nachmanowicza we Lwowie [106, s. 190 $]^{89}$. Zastosowanie w Łęcznej takiej formy almemor było podyktowane z pewnością jej przekryciem w formie stropu, co jest ewenementem na obszarze Polski.

W kontekście formy planów i bim-podpór pierwszym obiektem, który ze względu na swoją pierwotną formę wciąż budzi kontrowersje, jest synagoga Maharszala (1567). Wygląd jej wnętrza jest efektem przebudowy w XIX wieku. Synagoga została wybudowana na planie kwadratu, a w centrum ulokowano almemor otoczony czterema wiązkami kolumn. Gdyby przyjąć, że ta forma bimy została ukształtowana już w XVI lub - co bardziej prawdopodobne - w XVII wieku, możliwe stałoby się zrozumienie niezwykle symbolicznego znaczenia bimy. Układ dwunastu kolumn, po trzy na każdej podporze, miał odpowiadać dwunastu pokoleniom Izraela [95, s. 195]. Zastosowanie czterech podpór mogło być nawiązaniem do czterech strona świata oraz wyrazem znaczenia Sejmu Czterech Ziem, który mógł wpłynąć na rozprzestrzenienie się wzorca. Bardzo prawdopodobne jest jednak - na co wskazują Maria i Kazimierz Piechotkowie - że almemor w tej formie został wzniesiony dopiero po 1856 roku [134, s. 172-173]. W związku z tym doszukiwanie się nawiązania do Sejmu Czterech Ziem, który wówczas już nie funkcjonował, wydaje się niesłuszne. Nie oznacza to oczywiście, że wcześniej nie istniała jakaś forma bimy-podpory [108, s. 285 $]^{90}$. Porównując jednak sposób podparcia, który pojawia się w XVI i XVII wieku, należy przyjąć raczej formę wielobocznych filarów lub masywnych kolumn.

Podobne kolumny otaczały bimę synagogi w Tarnowie i Synagogi Starej w Rzeszowie. Na podstawie zdjęć archiwalnych można stwierdzić, że w Tarnowie zastosowano korynckie kapitele. Wnętrze bimy sklepione było konchą i obniżone względem sklepienia sali męskiej - miało więc cechy pierwszego typu bim. Cała bożnica była zbudowana na planie idealnego kwadratu $^{91}$. W synagodze rzeszowskiej w centrum znajdował się prawie kwadratowy almemor, otoczony czterema masywnymi kolumnami o doryckich kapitelach uzupełnionych czterema wolutami. Ze względy na wydłużenie bimy w kierunku wschód-zachód została ona delikatnie przesunięta w kierunku wschodnim.

Inny typ podpór bimy zastosowano w Łucku. Były to ośmioboczne filary, na których wsparto nadstawę bimy. Almemor synagogi łuckiej jest najlepszym przykładem pierwszego typu bim, których sklepienie znajdowało się w połowie wysokości sali męskiej. Sklepienie żaglaste przekrywające bimę uzupełniono przekątniowymi żebrami i zwornikiem. Synagoga została założona na rzucie prostokąta, a bimę przesunięto delikatnie w kierunku zachodnim, więc nie znajdowała się idealnie w centrum planu.

Ośmioboczne filary charakterystyczne są również dla domów modlitwy w: Pińsku (1640), Słonimiu (1642), Tykocinie (1642), Nowogródku (1648). We wszystkich wymienionych 
synagogach bimy zostały usytuowane w centrum planu i są do siebie podobne, przy czym bimy w: Pińsku, Słonimiu i Nowogródku reprezentują drugi typ, a bima w Tykocinie podtyp drugiego typu. Sale męskie różniły się natomiast kształtem planu, na którym zostały założone: w Pińsku i Słonimiu był to prostokąt, w Tykocinie i Nowogródku kwadrat.

W latach 40. XVII wieku przebudowane zostało wnętrze synagogi w Przemyślu (15921594). Po przebudowie bożnica była połączeniem planu podłużnego i centralnego za sprawą kwadratowej bimy-podpory. Almemor był flankowany czterema okrągłymi kolumnami zwieńczonymi korynckimi kapitelami. Patrząc na perforacje nadstawy, można przypuszczać, że był to - podobnie jak w synagodze w Tykocinie - podtyp typu drugiego.

W synagodze w Orli (2. ćwierć XVII w.) pierwotnie była bima-podpora. Wnętrze budowli było założone na prawie idealnym kwadracie. W wyniku przebudowy bima nie tylko została nieco przesunięta w kierunku wschodnim, ale również otrzymała nieco inną formę niż pierwotna, która pozostaje nieznana. Pozostałości fundamentów podpór wewnętrznych nie pozwalają stwierdzić ich formy.

Jak już zaznaczono powyżej, szczególnym przykładem synagogi z bimą w formie podpory była bożnica w Łęcznej (il. 3.4). Bima założona na planie kwadratu została usytuowana przed Aron ha-Kodesz, w środku odległości między schodami a ścianą zachodnią. Wyjątkowość tej synagogi spowodowana jest formą bimy, odbiegającą nieco od form bim omówionych do tej pory - ma charakter wielokondygnacyjny, czego konsekwencją jest zmultiplikowanie prześwitów w nadstawie ${ }^{92}$.

Wolnostojąca bima znajdowała się również w synagodze w Opatowie (połowa XVI w.) [108, s. 293]. Choć nie ma informacji o wyglądzie samej bimy, to wiadomo, że dom modlitwy tworzyła jednoprzestrzenna sala na planie prostokąta o proporcjach 2:3. Sala była orientowana i została przekryta sklepieniem krzyżowo-kolebowym z luneta-

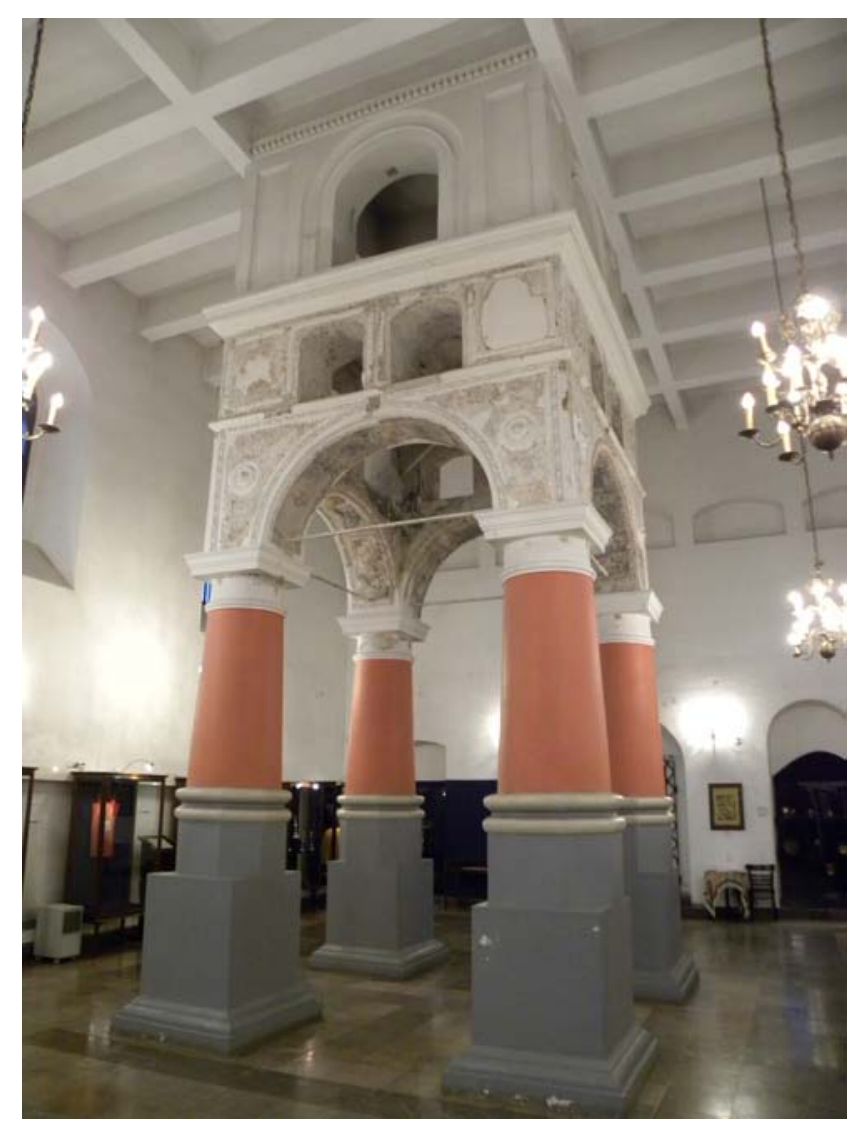

Il. 3.4. Bima w synagodze w Łęcznej [21] mi. Synagoga w Bychowie Nowym (4. ćwierć XVII w.) została założona na planie zbliżonym w proporcjach do kwadratu, a synagoga w Żmigrodzie Nowym (XVII/XVIII w.) na planie prostokąta. W obu obiektach w środku planu usytuowano bimę-podporę wspartą na czterech kwadratowych słupach o ściętych narożnikach. Bimy w synagogach w Bychowie i Łęcznej były identyczne pod względem kompozycyjnym. 
W obu obiektach nad arkadą znajdowały się w każdej ze ścian dwa otwory, a na wyższej kondygnacji jeden większy otwór, który w przypadku bimy w Bychowie został umieszczony w lunecie sklepienia.

Proporcje planu sali męskiej 2:3 uzyskano w synagodze w Przeworsku (XVII/XVIII w.). Jest to jedna z sal, w których kwadratowa bima znalazła w centrum. Nadstawę bimy wsparto na ośmiobocznych filarach o nieproporcjonalnych głowicach składających się z gęsto ułożonych, profilowanych wsporników.

Na planie kwadratu oparte były sale synagog w Lubomlu (XVII/XVIII w.) i Różanej Grodzieńskiej (połowa XVIII w.). W centrum pierwszej z wymienionych bożnic usytuowano bimę flankowaną czterema filarami, które w strefie podestu miały kształt kwadratu z cofniętymi, zaokrąglonymi narożnikami, natomiast powyżej niej były ośmioboczne. W centrum drugiej znajdował się, podobny do bimy w Słonimiu, trzykondygnacyjny almemor wsparty na ośmiobocznych filarach.

Na prawie kwadratowym planie została zniesiona synagoga w Dukli (1758). Bima otrzymała - wyjątkowo - miejsce w jego centrum, gdyż miała plan prostokąta wydłużonego na osi poprzecznej wnętrza. Nadstawę wsparto na ośmiobocznych filarach. Brak materiału ikonograficznego nie pozwala określić jednoznacznie ukształtowania sklepienia bimy. Należy założyć, że było ono obniżone w stosunku do sklepienia sali męskiej.

Najbardziej rozpoznawalnym przykładem synagogi z bimą-podporą jest bożnica w Łańcucie (1761). Sala główna została założona na planie zbliżonym do kwadratu. Bima natomiast miała plan idealnego kwadratu. Na podeście ustawiono cztery kolumny z wkomponowanymi w głowice palmetami, a całość sklepiono spłaszczoną kopułką. Almemor został usytuowany idealnie w centrum planu sali męskiej.

Ośmioboczne filary zastosowano po raz kolejny w synagodze w Maciejowie (przed 1781) i Przysusze (3. ćwierwiecze XIII w.). W Maciejowie w centrum kwadratowej sali znalazł miejsce kwadratowy almemor podobny do bimy synagogi tykocińskiej. W Przysusze sala synagogi była prostokątem o proporcjach 4:3. W centrum usytuowano na planie kwadratu bimę-podporę przekrytą kopułą obniżoną w stosunku do sklepienia sali. Głowice ośmiobocznych filarów miały rozbudowaną i nieproporcjonalną formę. Pod koniec XVIII wieku wzniesiono synagogę w Rymanowie. Był to obiekt założony na planie podłużnym, z usytuowaną prawdopodobnie w centrum bimą-podporą. Wskazuje na to poziom zbliżenia do siebie filarów i ich spięcie łukami poniżej poziomu sklepienia. Pierwotne sklepienie nie zachowało się. Nadstawa bimy wsparta została na czterech kwadratowych filarach i sklepiona była żaglaście.

W XVII i XVIII wieku repertuar form bim-podpór, jak również sposobów ich sytuowania był niezwykle bogaty, co świadczy o nietrzymaniu się kurczowo - wynikającej z logiki planu - centralnej lokalizacji.

Obiekty na planie dziewięciopolowym z bimą-podporą istnieją dziś w Niemczech, Czechach i na Węgrzech [84, s. 120], co jest efektem migracji ludności żydowskiej po najeździe wojsk Bohdana Chmielnickiego w latach 1648-1657. Żydzi poza minhagami (zwyczajami) 
propagowali wiedzę i wzorce, chętnie zresztą wykorzystywane przez mieszkańców tych terenów, na które zawędrowali [194, s. 148]. Bima-podpora przypominająca pod względem formy bimę w Synagodze Nowomiejskiej w Rzeszowie ${ }^{93}$ pojawia się w 1689 roku w synagodze w Nikolsburgu [85, s. 132]. Z początku XIX wieku pochodzi przebudowa osiemnastowiecznej synagogi w Hotzenplotz. Bima-podpora pojawiła się także w synagodze w Marmaros Sziget zlokalizowanej obecnie na terenie Rumunii, a dawniej Wegier. Podobne rozwiązanie znajdziemy również w zbudowanej na początku XVII wieku synagodze w Fürth w Bawarii.

\subsubsection{Synagogi dziewięciopolowe}

Analizując literaturę przedmiotu dotyczącą XVII- i XVIII-wiecznej architektury bożniczej, można zauważyć, że w odniesieniu do planu z wolnostojącą bimą usytuowaną między czterema filarami i bimą-podporą niemalże wszyscy autorzy ${ }^{94}$ zamiennie stosują również określenie „synagogi dziewięciopolowe”. Oba zjawiska architektoniczne są traktowane całościowo, dlatego datowania, które zostały przedstawione powyżej w odniesieniu do synagog z bimą-podporą, były tożsame dla synagog dziewięciopolowych ${ }^{95}$.

Pewne zamieszanie wprowadziła z pewnością publikacja Szymona Zajczyka - jedna z pierwszych dotyczących bożnic barokowych. Autor ten wyróżnia kilka typów bożnic dziewięciopolowych, przy czym zalicza do nich również synagogi z różnymi typami bim-podpór. W opisie typologii pojawia się stwierdzenie: „w pierwszej połowie XVII w. spotykamy pierwszą odmianę dziewięciopolówki (niezłączone wolnostojące słupy)” [201, s. 192]. Jest to dość mylące, choć w dalszej części tekstu autor tłumaczy, że był to typ późniejszy niż synagogi z bimą-podpora.

W tym „pierwszym” typie słupy stanowiły ramy dla wolnostojącej bimy i razem z nią tworzyły zmonumentalizowaną formę, zachowując przy tym w centralnym polu wysokość sklepienia sali męskiej. Podstawą wyróżnienia tego typu staje się zatem przede wszystkim halowy charakter wnętrza. Trudno jest zatem stwierdzić, że synagogi tego typu opierają się głównie na podziale na w zasadzie równe pola [94, s. 318]. Szczególnie widoczne jest to w przypadku synagog o innym podziale pól ${ }^{96}$.

Uszczegóławiając datowanie zaproponowane przez Szymona Zajczyka, trzeba przytoczyć opinię Sergiey'a Kravtsova, który wskazuje, że pierwsze synagogi typu dziewięciopolowego powstały dopiero po 1620 roku. Autor jako prekursorską pod tym względem podaje Synagogę Przedmiejską we Lwowie (1624-1632) i synagogę w Ostrogu (1627) [95, s. 200] oraz będącą następstwem wzniesienia tych dwóch synagogę w Wilnie (1633) [97, s. 46-47]. Autor stwierdza jednocześnie, że plan dziewięciopolowy nie był efektem długotrwałego procesu, ale autorskim działaniem Jakuba Medliniego ${ }^{97}$, zainspirowanym rekonstrukcją świątyni jerozolimskiej [94, s. 320].

Synagoga Przedmiejska we Lwowie (1624-1632) wzniesiona została na prawie kwadratowym planie. Jej wnętrze zostało wsparte na czerech ośmiobocznych filarach zwieńczo- 
nych doryckimi głowicami [134, s. 217] ${ }^{98}$. Wysokość sklepień wszystkich pól była identyczna, a pola zostały oddzielone od siebie gurtami. Bima stanowiła wolnostojący mebel i znajdowała się w centrum planu. Podział sali na pola nie był jednak symetryczny. Centralne pasy sklepień miały mniejszą szerokość niż pasy skrajne.

Synagoga w Ostrogu (1627) ${ }^{99}$ została wzniesiona na planie zbliżonym do kwadratu jako dziewięciopolowa hala. Podział pól sklepień nie był jednak symetryczny. Centralne pasy sklepień były szersze od pasów skrajnych. W centrum znalazły się ośmioboczne filary, podtrzymujące pola sklepień wspartych na gurtach. Filary te zwieńczone zostały doryckimi kapitelami. W centrum planu ustawiono wolnostojącą bimę.

Obiektem halowym w typie dziewięciopolowym, o polu centralnym wspartym na czterech kolumnach doryckich była Wielka Synagoga w Wilnie (1633). Sklepienie sali założono $\mathrm{w}$ formie przecinających się koleb. Kolumny zostały lekko przesunięte w kierunku centrum planu. Bima wypełniała całe centralne pole i, jak podają Maria i Kazimierz Piechotkowie, była to forma wielobocznej „kaplicy” o kwadratowej podstawie, prawdopodobnie autorstwa Jana Krzysztofa Glaubitza (1700-1767) [97, s. 225].

Synagoga w Tarnogrodzie, która została wzniesiona po 1686 roku, była szczególna: jej centralne pole zajmowało prawie 30 procent całej powierzchni budynku i było znacznie większe niż pozostałe pola. Synagoga, podobie jak pole centralne, miała proporcje idealnego kwadratu. Całość została przekryta sklepieniem żaglastym, które oparto na kwadratowych słupach ze ściętymi narożnikami.

Idealny podział na równe pola uzyskano w synagogach w Leszniowie (1677) i Żółkwi (1692). Plany obu synagog są prawie idealnymi kwadratami. Słupy w synagodze w Leszniowie miały przekrój kwadratu i zwieńczone zostały pseudotoskańskimi kapitelami. W Żółkwi zastosowano słupy o przekroju okrągłym.

Plan trapezowy miała sala męska Synagogi Nowomiejskiej w Rzeszowie (1700-1708). Jednak również tutaj słupy zostały usytuowane bliżej jego centrum i w porównaniu do omówionych przykładów stanowią nowe rozwiązanie. Wzniesiono je bowiem na planie kwadratu i pokryto boniowaniem. Sklepienie pola centralnego zostało tylko nieznacznie obniżone w stosunku do sklepienia sali męskiej.

Salą na planie kwadratu była synagoga w Brodach (1742), również tutaj idealnie podzielona na równe pola. Słupy miały plan kwadratu o ściętych, zaokrąglonych i nieco cofniętych do wnętrza narożnikach. Całość została przekryta sklepieniami krzyżowymi na gurtach.

W planach synagog w Bobowej (1750-1756) i we Włodawie (1764) postanowiono wykonać pole środkowe jako nieco większe od pozostałych. Sale męskie o proporcjach planu zbliżonych do kwadratu zostały podzielone czterema słupami. Na przecięciu gurtów oddzielających od siebie pola sklepienia usytuowano w bożnicy w Bobowej cztery słupy o planie kwadratu i z zaokrąglonymi narożnikami ${ }^{100}$, natomiast we Włodawie wysokie kolumny ${ }^{101}$.

Nieco inne rozplanowanie zastosowano w synagodze w Druji (1765-1766). Sala męska została wzniesiona na planie zbliżonym do kwadratu. W centrum usytuowano lekko zbliżone 
w jego kierunku cztery kwadratowe filary. Na nich umieszczono dodatkowo pilastry i półkolumny z entasis i jonizującymi kapitelami, postawionymi na konsolach.

W synagogach w: Nowym Sączu (1769-1774), Stawiskach (połowa XVIII w.) i Wyszogrodzie (XVIII/XIX w.) celem nadrzędnym budowniczych było wytworzenie centralnego, kwadratowego pola. W Nowym Sączu sala męska miała plan prostokąta wydłużonego na osi północ-południe, podczas gdy w Wyszogrodzie i Stawiskach prawie kwadratu. W Stawiskach wnętrze podzielono na równe pola. W Nowym Sączu i Wyszogrodzie, aby pole centralne było kwadratem, pozostałe pola uzyskały proporcje prostokątów. Centralne pola we wszystkich obiektach wsparto na kwadratowych słupach z nałożonymi nań pilastrami.

Wnętrze synagogi w Orli - pierwotnie z bimą-podporą - zostało przebudowane na przełomie XVIII i XIX wieku. Wówczas to wstawiono nowe kolumny o doryckich kapitelach, zwiększając $\mathrm{w}$ ten sposób szerokość centralnego pola. W efekcie uzyskano podział sali na dziewięć równych kwadratów.

Synagogi na planie dziewięciopolowym miały różnie ukształtowane wnętrze. Generalną zasadą, którą starano się realizować w tatmtym czasie, był podział sklepienia podtrzymywanego za pomocą słupów na dziewięć równych pól. Przykładem mogą być synagogi w: Leszniowie (1677), Żółkwi (1692), Brodach (1742), Włodawie (1764), Stawiskach (połowa XVIII w.).

Zdarzało się jednak, że centralne pasy sklepień były stosunkowo szerokie, jak w synagogach w: Ostrogu (1627), Tarnogrodzie (po 1686), Bobowej (1750-1756), Druji (1765-1766), Nowym Sączu (1769-1774), Wyszogrodzie (XVIII/XIX w.), Orli (XVIII-XIX w.). Stosowano również podział, w którym zmniejszano szerokość centralnego pola, jak w synagogach we Lwowie (1624-1632), a także w Wielkiej Synagodze w Wilnie (1633) czy w Synagodze Nowomiejskiej w Rzeszowie (1700-1708).

W Synagodze Przedmiejskiej we Lwowie (1624-1632) i w synagodze w Ostrogu (1627) pojawiły się ośmioboczne filary z doryckimi kapitelami. Patrząc na podobieństwo form obu bożnic można wysnuć wniosek, iż zostały one wzniesione przez tego samego mistrza [94, s. 320].

Rzadkim zjawiskiem architektonicznym były kolumny, które pojawiły się tylko w trzech obiektach, zlokalizowanych w: Żółkwi (1692), Włodawie (1764), Orli (XVIII-XIX w.). Najbardziej rozbudowaną grupę stanowią obiekty o podporach kwadratowych lub będących modyfikacjami kwadratu uzyskanymi w wyniku ścięcia, zaokrąglenia i nałożenia pilastrów i półkolumn. Są to synagogi w: Leszniowie (1677), Tarnogrodzie (po 1686), Brodach (1742), Synagoga Nowomiejska w Rzeszowie (1700-1708), Bobowej (1750-1756), Druji (1765-1766), Nowym Sączu (1769-1774), Stawiskach (połowa XVIII w.), a także Wyszogródzie (XVIII/XIX w.).

Wiele bożnic, w tym również tych dziewięciopolowych, było inspirowanych XVIIi XVIII-wiecznymi synagogami znajdującymi się na terenie Polski [76, s. 231] Na rozpowszechnienie tego wzorca wpłynęła migracja ludności żydowskiej z Polski.

Projektantem wielu synagog w Europie Zachodniej opartych na planie dziewięciopolowym był Elias Bouwman. Jego autorstwa były bożnice w: Altonie (1682-1684), Grote Sjo- 
el (1670-1671), czyli Wielka Synagoga należąca do Żydów aszkenazyjskich i zlokalizowana w Amsterdamie [94, s. 327], a także Esnoga (1674-1675), czyli synagoga należąca do Żydów portugalskich osiadłych w Amsterdamie (1674-1675). Z początku XIX wieku pochodzi również holenderska synagoga w Leeuwarden (1800). W przeciwieństwie jednak do synagog w Polsce, w synagogach w Holandii podkreślano osiowość obiektu [107, s. 433] poprzez zastosowanie pilastrów przyściennych tylko na dwóch z czterech ścian. Ważnym zabiegiem było również zaznaczenie orientacji za pomocą architrawu łączącego wszystkie kolumny i pilastry.

\subsection{Wzory bimy-podpory}

Bima, niezależnie od formy, była tym miejscem, bez którego synagoga w zasadzie nie mogłaby pełnić swojej funkcji. Stąd bowiem do wiernych płynęło słowo boże. Dzięki bimie mógł być realizowany fundamentalny aspekt liturgii synagogalnej, czyli przekazywanie słowa, na którym jest oparta. Uzyskanie optymalnych warunków dla rozchodzącego się dźwięku było więc niezwykle istotne i zapewne $\mathrm{z}$ tego względu modyfikowano rozwiązania podestu.

Forma bimy wspierającej sklepienie sali męskiej przy jednoczesnym usytuowaniu jej w centrum jest niezwykle ciekawym i nietypowym rozwiązaniem, ponieważ bardzo rzadko stosowane było w architekturze innych religii i kultur. Wydaje się jednak, że można znaleźć punkty odniesienia dla takiej formy w przypadku obiektów, które powstały znacznie wcześniej ${ }^{102}$.

Faktycznie ważnym aspektem bimy-podpory jest taka jej konstrukcja, która powoduje, że jest ona „ustrojem” niezależnym statycznie. Poszukując odpowiednich rozwiązań, należy więc odnieść się do elementów, które pełnią podobną funkcję w innych obiektach.

Pierwszym wzorem, z którego prawdopodobnie czerpano, były cyboria (il. 3.5). Forma ta składała się z czterech kolumn lub słupów podtrzymujących zadaszenie, często w postaci kopuły, i była wznoszona już od IV wieku. Sytuowano je w kościołach nad ołtarzem, a w późniejszym okresie nad tabernakulum, co miało przywodzić na myśl tron Chrystusa [178, s. 88]. Umieszczano je również nad basenami chrzcielnymi, a w dalszej perspektywie nad relikwiarzami i grobami męczenników, natomiast począwszy od VI wieku nad amboną, z której głoszono słowo Boga. Chrześcijańskie cyborium miało zwrócić uwagę na obiekt czci bądź chronić go w sposób dosłowny lub symboliczny. Kościół rozumiał cztery filary jako czterech ewangelistów, a sklepienie, które często były malowane, jako firmament. Takie analogie wypływały z transcendentalnego charakteru Boga, który niejako staje się obecny pod sklepieniem cyborium. Cyborium stanowiło zatem instrument doktryny chrześcijańskiej ${ }^{103}$.

Między XI a XIII wiekiem cyboria były już w świątyniach w całej Europie ${ }^{104}$. Szczególnie bogate pod względem formy i dekoracji wzorce dla rozwiązań baldachimów pochodziły z okresu renesansu. Zwłaszcza sztuka rzymska obfituje w przykłady. Jedno z najwcześniejszych renesansowych cyboriów znajduje się w kościele Matki Bożej Większej w Spello $(1515)^{105}$. 

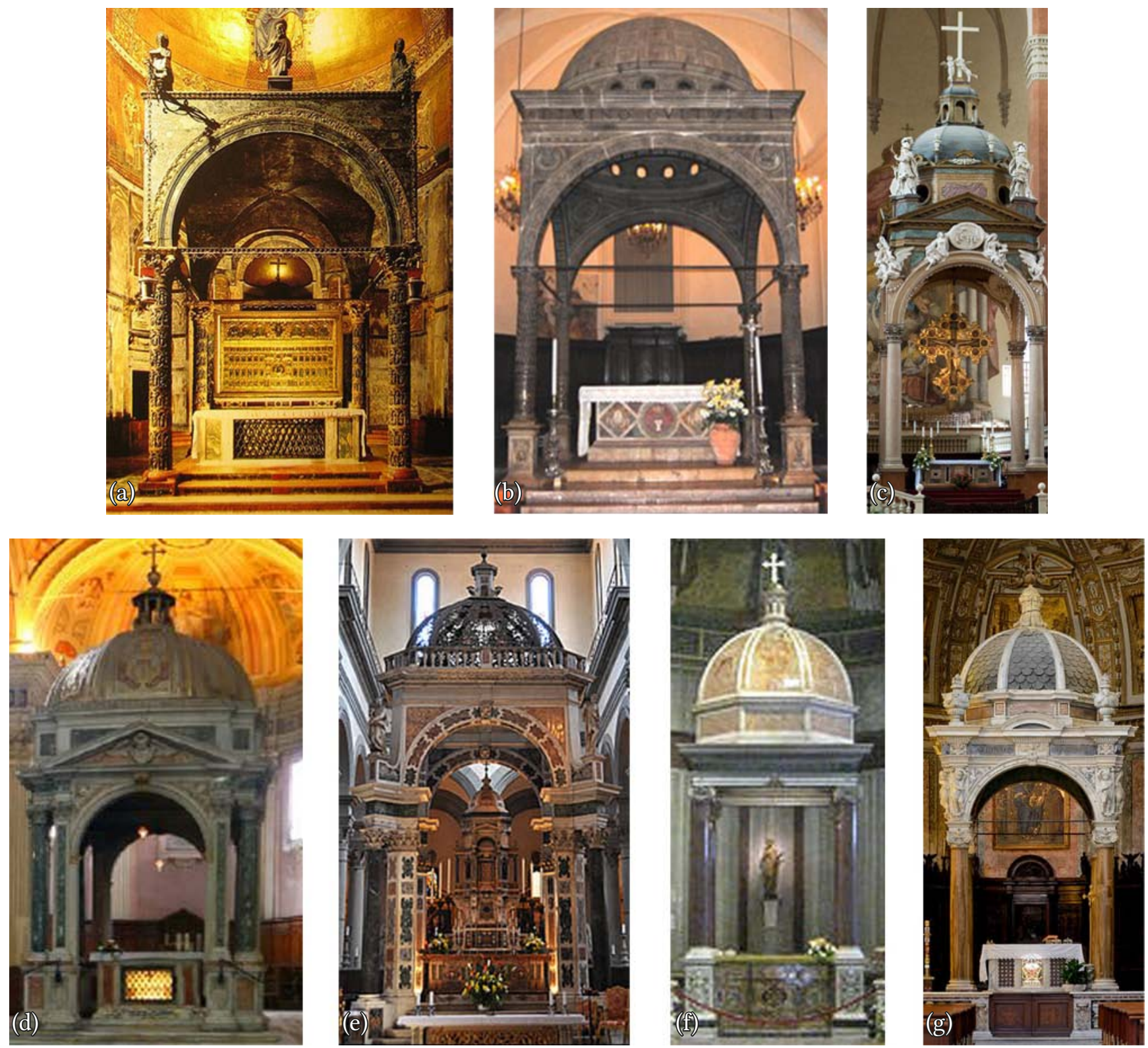

Il. 3.5. Przykłady form cyboriów w bazylice św. Marka w Wenecji (a) [21] oraz w kościołach: Matki Bożej Większej w Spello (b) [34], św. Petroniusza w Boloni (c) [16], św. Aleksego w Rzymie (d) [11], św. Ducha we Florencji (e) [15], św. Agnieszki (f) [14] i św. Chryzogona w Rzymie (g) [13]

Niezależnie od powiązania z konstrukcją, można znaleźć wiele form bim, które łączyłyby się z elementami wykorzystanymi w cyboriach (il. 3.5) ${ }^{106}$. W pierwszym etapie wznoszenia bim-podpór najpierw stosowano kolumny, potem ośmioboczne filary. Kolumny występują zarówno w cyboriach, jak i w synagogach do lat 20. XVII wieku. Ośmioboczne filary są w cyborium w kościele św. Ducha we Florencji i synagogach, które powstały w okresie od lat 20. XVII wieku. Ścięcie powyżej kolumn i filarów w cyborium kościoła Św. Ducha było elementem charakterystycznym dla nadstawy bimy w synagogach w Łucku i Lublinie, w którym bima została wzniesiona w 1856 roku. 

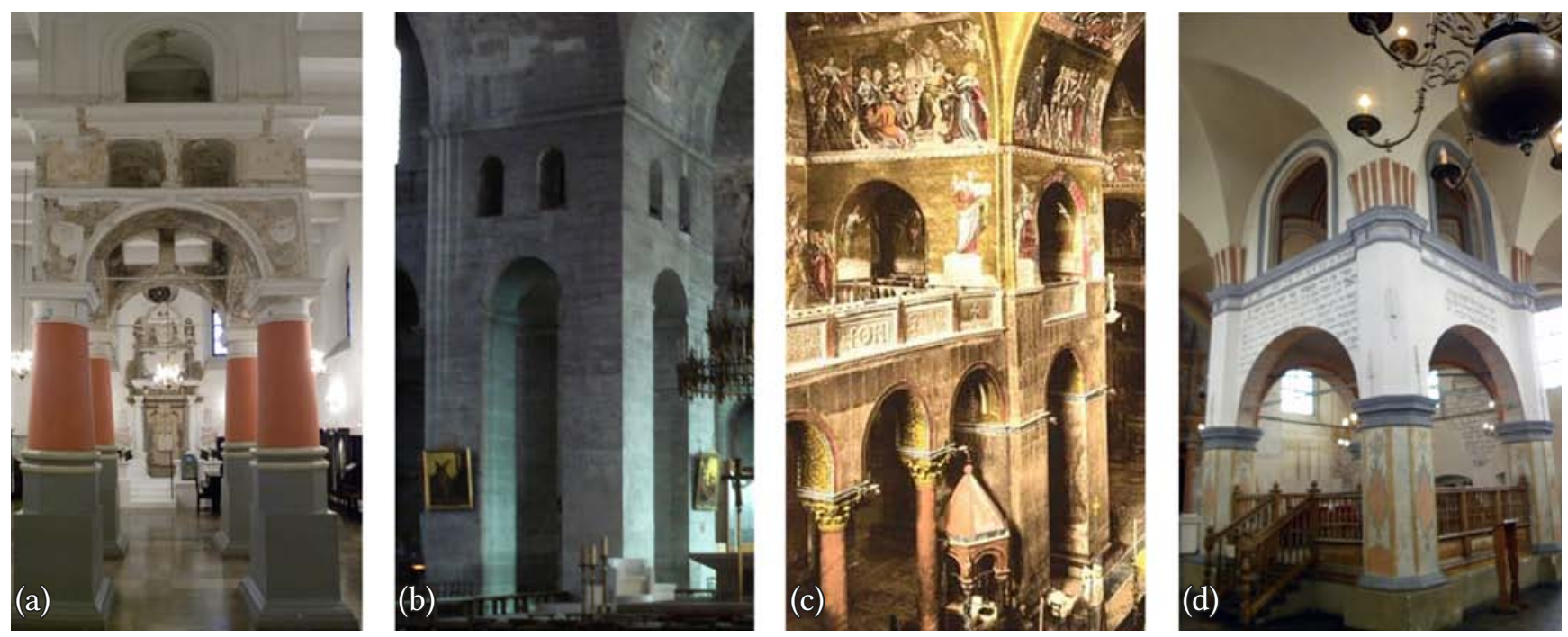

Il. 3.6. Filary i bimy w kościołach i synagogach: bima w synagodze w Łęcznej (a) [21], filar w kościele św. Fronta w Périgueux (b) [12], filar w katedrze św. Marka w Wenecji (c) [33] i bima w synagodze w Tykocinie (d) [21]

Schodkowe ukształtowanie filara uzyskane poprzez nałożenie pilastra w synagodze w Bychowie Nowym (4. ćwierć XVII w.) może odpowiadać wielopłaszczyznowym kompozycjom w kościołach św. Aleksego i św. Chryzogona w Rzymie.

Cyborium w kościele Matki Bożej Większej w Sapello jest najbardziej podobne do bimy w Synagodze Starej w Rzeszowie i w synagodze w Przemyślu [108, s. 328].

W Polsce do XVII wieku cyboria nie były bardzo rozpowszechnione. Konstrukcja tego rodzaju stanęła w XI wieku w kościele św. Wojciecha w Krakowie i w XII wieku w kościele Matki Bożej w Kotłowie [108, s. 313]. Ta z pewnością najbardziej znana została wykonana w latach 1626-1629 w Katedrze Wawelskiej nad konfesją św. Stanisława przez Jana Trevano. Zważywszy, że pierwsze synagogi z bimą-podporą powstały na przełomie XV i XVI wieku, trudno byłoby uznać polskie cyborium za wzorzec bimy-podpory. Nie wyklucza to jednak kształtowania cyborium w polskiej architekturze sakralnej pod wpływem wzorca włoskiego, tym bardziej, że w okresie renesansu na dworze polskim pojawiło się wielu artystów włoskich, co oznaczało możliwość wymiany myśli.

Problemem wydaje się sposób wsparcia sklepienia na bimie, które nie ma żadnego pokrycia w konstrukcji cyborium. Nie ulega jednak wątpliwości, że kompozycja bim z gzymsem ograniczającym od góry cały układ jest podobna do kompozycji cyborium ${ }^{107}$.

Innym rozwiązaniem wzorowanym na architekturze bizantyjskiej są filary kościołów krzyżowo-kopułowych (il. 3.6). W dwóch kościołach zastosowano na skrzyżowaniu naw niezwykle rozbudowane struktury filarowe. Jednym przykładem jest wzniesiona w XI wieku bazylika św. Marka w Wenecji, drugim zaś katedra św. Fronta w Périgueux (XII w.). W VI wieku powstał kościół Hagia Sophia, który różni się nieco kompozycją filarów, głównie ze względu na ich wtopienie w nawę okrężną. 

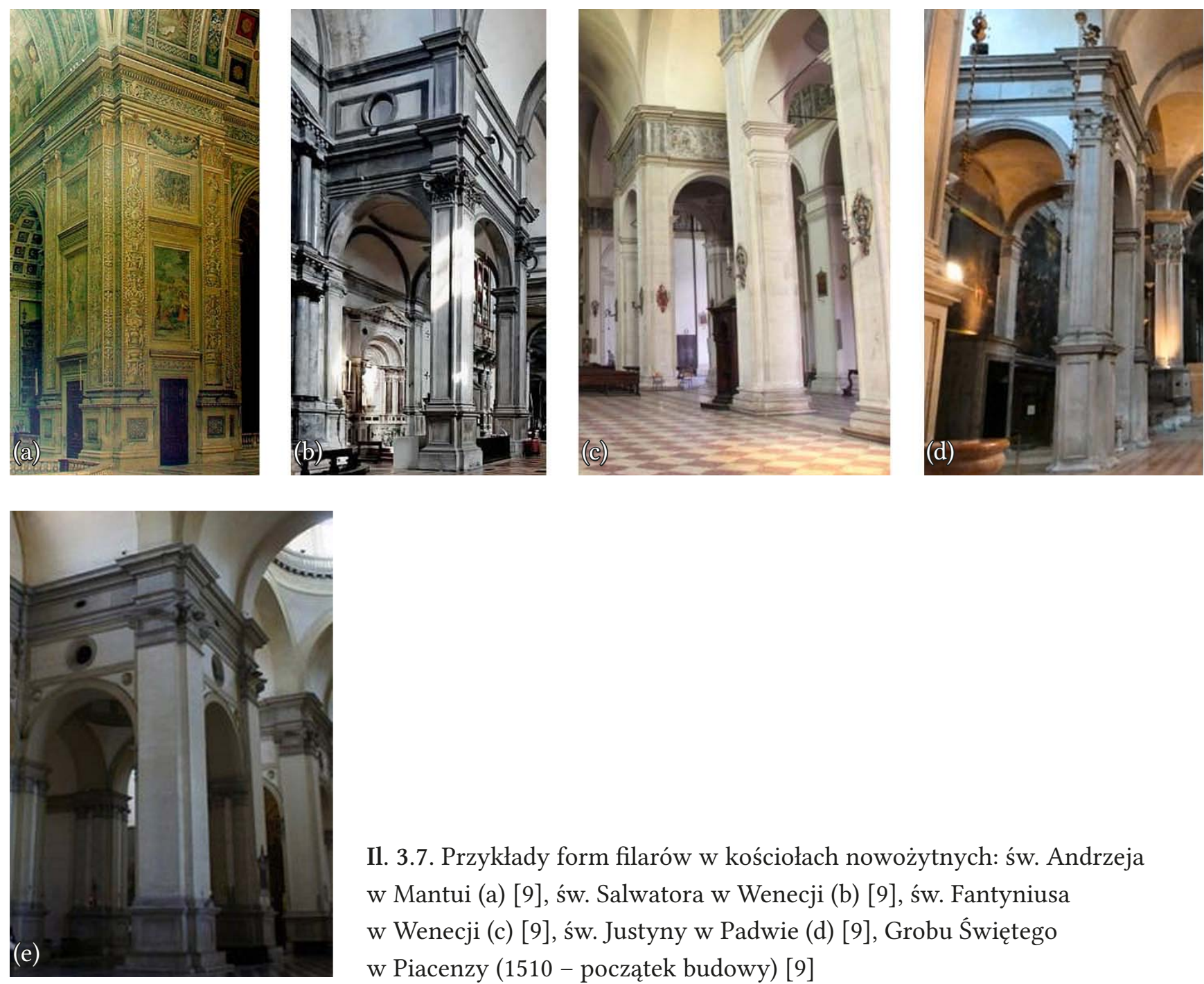

Il. 3.7. Przykłady form filarów w kościołach nowożytnych: św. Andrzeja w Mantui (a) [9], św. Salwatora w Wenecji (b) [9], św. Fantyniusa w Wenecji (c) [9], św. Justyny w Padwie (d) [9], Grobu Świętego w Piacenzy (1510 - początek budowy) [9]

Oprócz różnic w proporcjach bim-podpór i czteropodporowych filarów uwagę zwraca także kilka podobieństw. Filary w tych obiektach są niezależne i dopiero wspólnie stanowią wsparcie sklepienia. Nie ulega wątpliwości, że perforacje filarów w formie korytarzy mają na celu przede wszystkim odciążenie ich konstrukcji. Ze względów kompozycyjnych istotny wydaje się układ otworów. Dla bim w synagogach w Łęcznej i Słonimiu charakterystyczny jest układ dwóch otworów powyżej arkady, podobnie jak dla filarów w kościele św. Fronta. W synagodze w Tykocinie jest jeden otwór. Również dwukondygnacyjnym rozwiązaniem jest filar w bazylice św. Marka w Wenecji. Aspekt funkcjonalny górnych prześwitów w obu przypadkach jest zupełnie inny. Patrząc na zastosowane formy, trudno nie dostrzec pewnych podobieństwa. W obu kościołach słupy zostały odcięte od łuku za pomocą opasek, podobnie jak słupy i kolumny bim. Jedną z cech jest również zwieńczenie filaru gzymsem i oddzielenie w ten sposób strefy sklepienia. W przypadku bim zasada kompozycji jest podobna, jednak ze względu na wysokości sklepień górne prześwity pojawiają się w lunetach. 

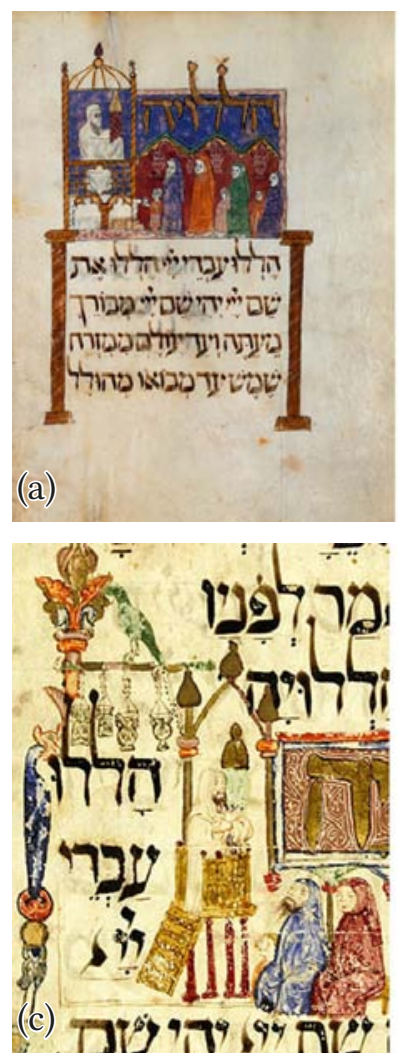
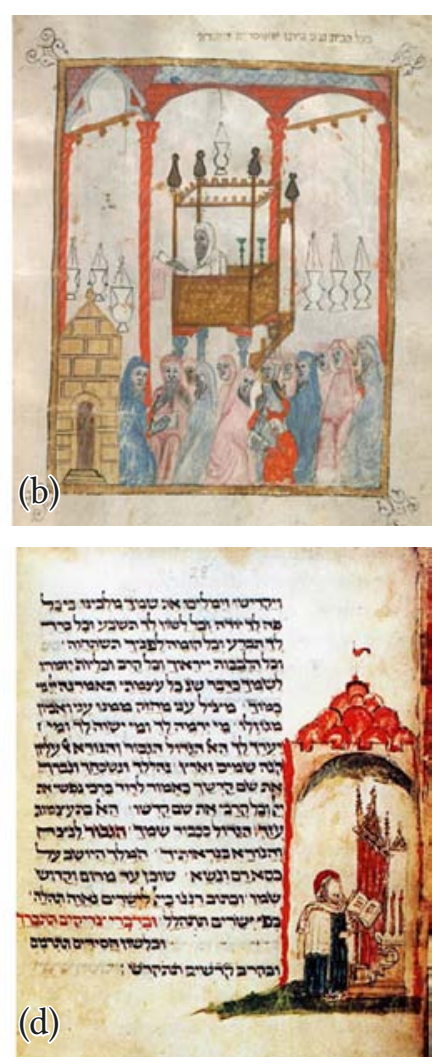

Il. 3.8. Wzory bim i Aron ha-Kodesz zaczerpnięte z hagad. Hagady: barcelońska (a) [5], Sister Hagada (b) [8], z Katalonii (c) [7] i Florsheim (d) [6]

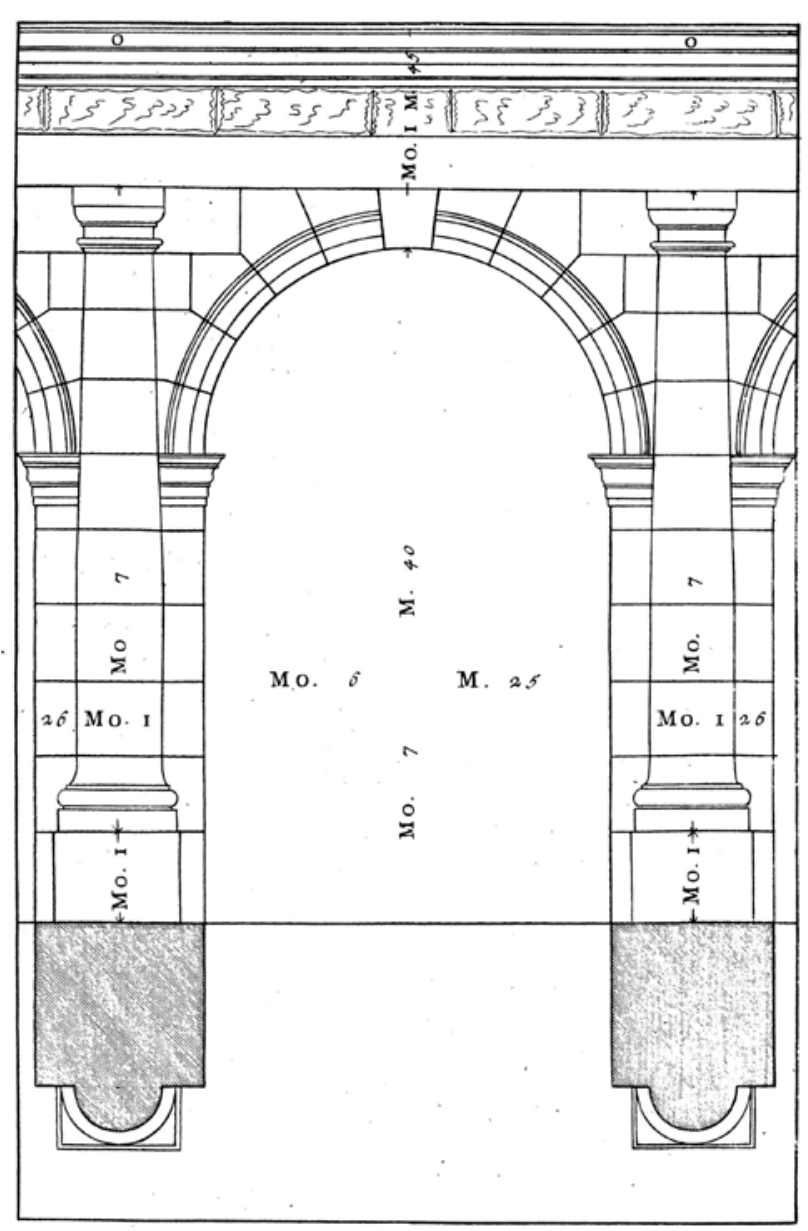

Il. 3.9. Porządek toskański [24]

Pewną formą rozwoju tych rozwiązań, która bardziej odpowiada formalnie elementom zastosowanym w bimach, są filary słupowe (il. 3.7) w kościele św. Salwatora w Wenecji (1507-1534), a także filary Grobu Świętego w Piacenzy (początek budowy w 1510), grobu św. Fantyniusa w Wenecji (1549-1564) czy św. Justyny w Padwie (konsekracja w 1606) [108, s. 325-329]. Przy tej okazji należy jeszcze wskazać filary w kościele św. Andrzeja w Mantui (1472-1732), zaprojektowane przez Albertiego. Za interesującą należy uznać ich formę, która jest jest jeszcze bardziej zbliżona do formy bimy-podpory. Zastosowanie elementów dekoracyjnych oraz opilastrowanych filarów sprawia, że znacznie różnią się od kolumn i ośmiobocznych form stosowanych w początkowym okresie wznoszenia bim-podpór. Raczej właśnie ta forma mogła być wzorem w przypadku słupów, które po raz pierwszy pojawiły się w synagodze w Bychowie Nowym (4. ćwierć XVII w.). Sam fakt zwiększenia ażurowości konstrukcji w stosunku do filarów w bazylice św. Marka w Wenecji zbliża ją do rozwiązań stosowanych w synagogach. Ciekawy jest również fakt, iż w kościele św. Fantyniusa w Wenecji struktury filarowe nie wspierają kopuł, ale sklepienia krzyżowe na lekko zarysowanych gurtach. Takie rozwiązanie było charakterystyczne dla bożnic powstających od lat 40 . XVII wieku. 

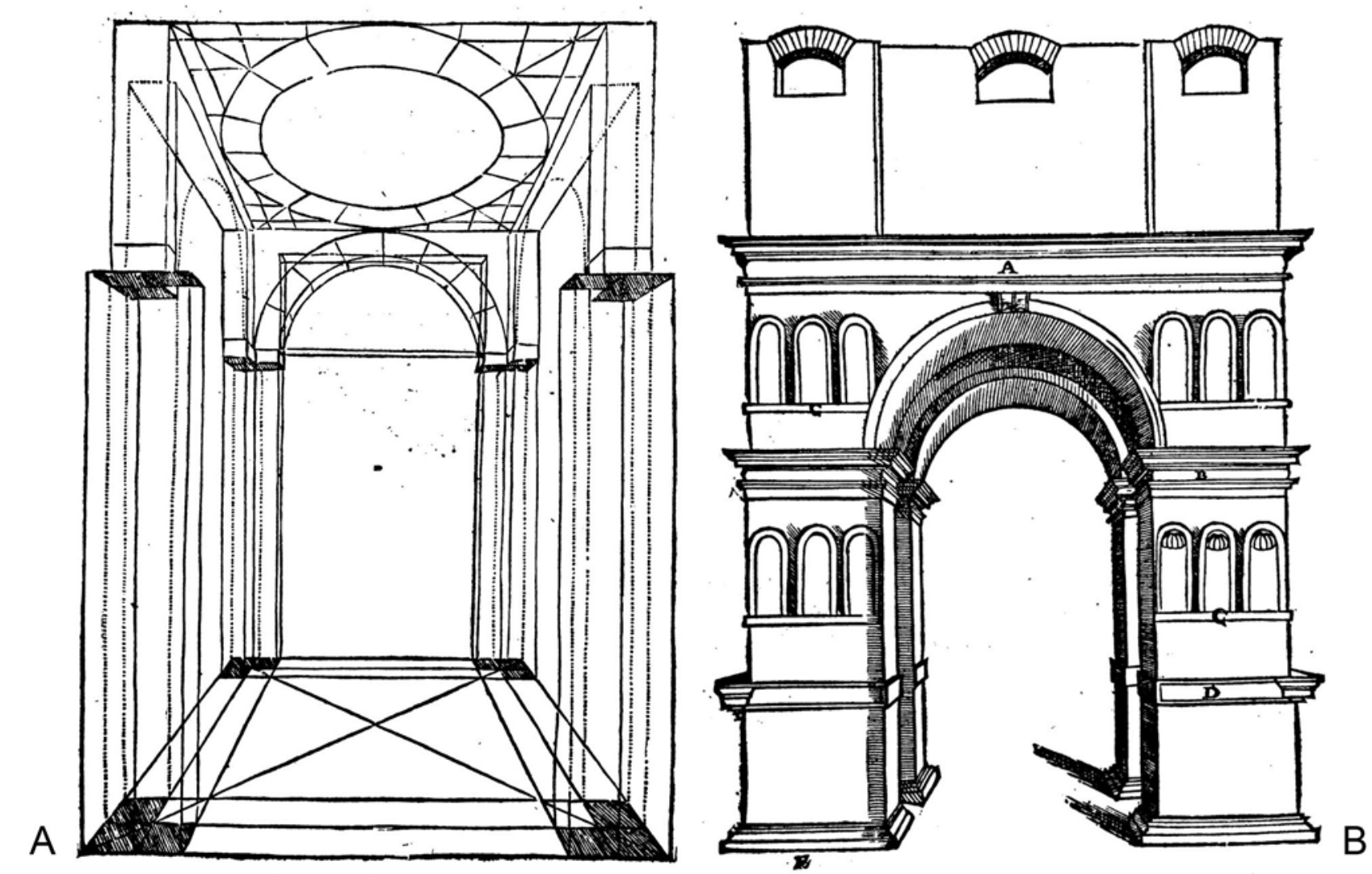

Il. 3.10. Rysunki budowli przypominających pod względem formy bimę [27]

Ciekawym rozwiązaniem, które może również stanowić wzór dla wcześniej opisanych struktur filarowych, są wielkie, puste filary w kościele św. Andrzeja w Mantui, zaprojektowane przez Albertiego. Oparcie koleb na filarze w dwóch kierunkach przywodzi na myśl sposób przesklepiania wnętrz synagog z centralną bimą-podporą.

W polskiej architekturze rozwiązanie zastosowane przez Albertiego zostało, jak się wydaje, zmodyfikowane. Pod wpływem architektury kościoła Il Gesu, w którym artykulację ścian uzyskano w wyniku zdwojenia i znacznego zbliżenia pilastrów. Układ zdwojonych pilastrów pojawił się na filarach w bazylikach, powstałych w grupie kościołów karmelickich. Filary te, o odmiennym charakterze od opisanych powyżej, znajdowały się między kaplicami. Posiadały przejścia tworzące amfiladę, a otwory miały zwykle formę arkady. Poprzez zbliżenie pilastrów nie uzyskano jednak formy otwartej $\mathrm{z}$ trzech stron jak w kościołach włoskich ${ }^{108}$.

Pisząc o wzorcach czerpanych z architektury włoskiej, należy zwrócić uwagę również na traktaty architektoniczne, wśród których tym podstawowym jest $O$ architekturze ksiag dziesięć autorstwa Witruwiusza. Traktat ten powstał jeszcze w czasach przed naszą erą, a odnalezienie go w 1415 roku w bibliotece klasztoru Sankt Gallen zwiększyło wiedzę na temat architektury starożytnego Rzymu i Grecji. Co oczywiste, renesans czerpał z tych klasycznych wzorów, a autorzy renesansowych traktatów architektonicznych 
opierali się na dziele Witruwiusza, pisząc chociażby o klasycznych porządkach architektonicznych.

Wszystkie traktaty architektoniczne powstałe od XV do XVII wieku odnoszą się do formy stosowanej w elewacji teatru rzymskiego. Arkadowanie oddzielone kolumną lub pilastrem wykorzystywano w architekturze pałacowej w postaci loggi i krużganków. Motyw ten pojawił się między innymi ${ }^{109} \mathrm{w}$ traktacie Andrea Palladia (1508-1580) I Quattro Libri dell'Architettura (1570) (il. 3.9). W Polsce po raz pierwszy został użyty w loggi poznańskiego ratusza (1552-1560) [88, s. 93]. Można pokusić się o stwierdzenie, że bimy-podpory powtarzały układ zastosowany w motywie ściany teatru rzymskiego ${ }^{110}$ [108, s. 171].

W traktatach architektonicznych uwagę przykuwają dwa rysunki wykonane przez Serlia (il. 3.10a i b). Rysunek pierwszy (il. 3.10a) został umieszczony w księdze dotyczącej perspektywy. Autor przedstawił w perspektywie jednozbiegowej centralną budowlę składającą się z czterech arkad wspartych na kwadratowych słupkach. Dodatkowo na suficie zaznaczył okrąg, który mógłby służyć do wykreślenia kopuły. Na kolejnych rysunkach w tej części traktatu są przedstawione gzymsy i bazy oraz arkady wsparte na filarach. Wykreślony został także sposób wykonania przesklepienie takiej formy.

Drugi rysunek (il. 3.10b) pochodzi z księgi dotyczącej architektury starożytnej. Z rzutu obiektu wynika, że jest on symetryczny i ma cztery arkady, po jednej na każdej ze ścian. Arkady wsparte są na czterech zwieńczonych gzymsem filarach, powyżej których dodatkowo została umieszczona nadbudowa o trzech otworach. Gdyby nie proporcje obiektu, można byłoby stwierdzić, że był on wzorem bim-podpór. Brakuje również pewnej informacji o sposobie zwieńczenia nadbudowy oraz tego, czy stanowiła ona wsparcie innego elementu.

Widać jednak, że takie formy wolnostojących zgrupowań filarów połączonych arkadowaniem pojawiają się $\mathrm{w}$ traktatach architektonicznych i nie są - jak w do tej pory omówionych przykładach - powiązane ze ścianą, ale stanowią element samodzielny, dodatkowo nadbudowany.

Wzorem bimy-podpory mogą być formy almemor i Aron ha-Kodesz, jakie można zobaczyć w hiszpańskich manuskryptach (il. 3.8), a przede wszystkim na obrazach przedstawionych w hagadach ${ }^{111}$ [194, s. 37], [99, s. 43]. Zdarzało się, tak jak w hagadzie

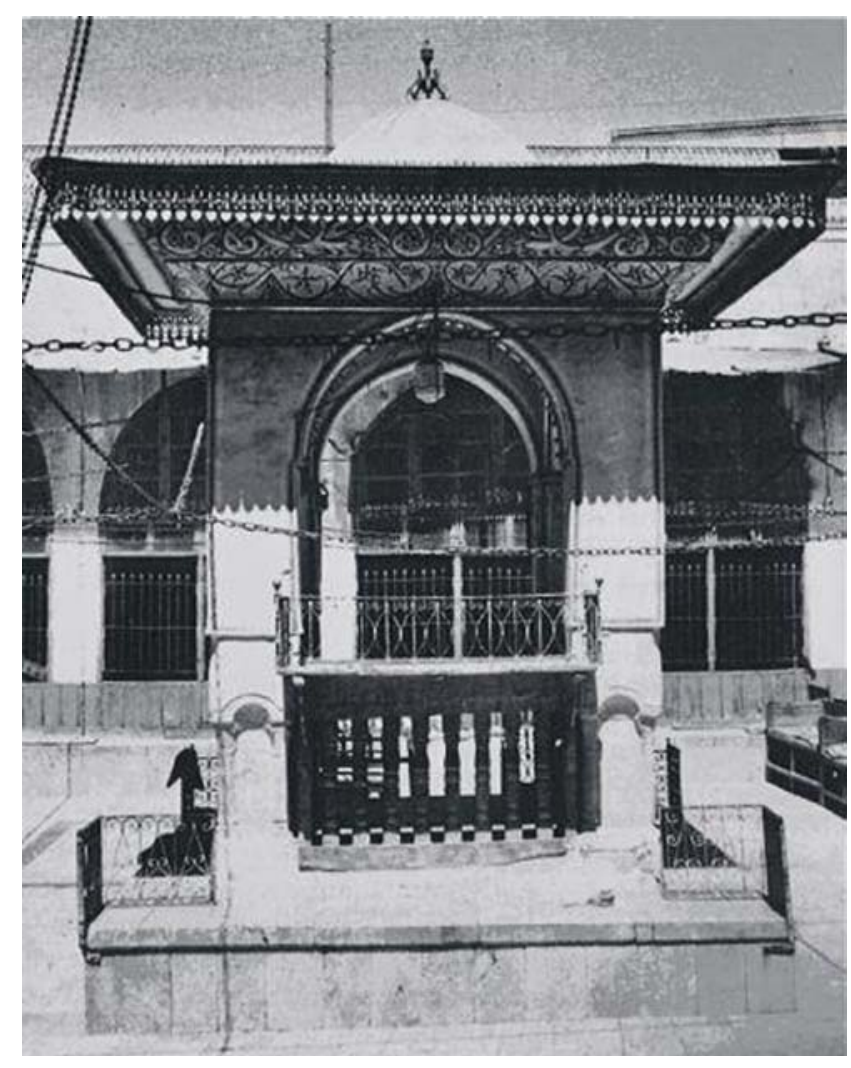

Il. 3.11. Bima w Aleppo [1] 
z Florsheim, że Aron ha-Kodesz był przedstawiany w formie baldachimu ${ }^{112}$. Zarówno jedne, jak i drugie wzorce mogły wpłynąć na rozwój tego typu rozwiązań.

Pewnym tego przejawem jest bima na dziedzińcu synagogi w Aleppo (il. 3.11) [108, s. 309]. Trudno jest określić czas jej powstania, jednak ze względu na przybycie dużej liczby Żydów sefardyjskich w XVI wieku należy przyjąć, że nastąpiło to właśnie w tamtym czasie. Bima posiada formę cyborium i znajduje się na środku dziedzińca synagogi. Miała osłaniać osobę czytającą w trakcie liturgii Torę przed słońcem, a rodały przed wiatrem i deszczem. Na podstawie źródeł pisanych można przypuszczać, że podobną konstrukcję, lecz w formie drewnianej, wzniesiono w X wieku w Babilonii.

Dawid Dawidowicz wskazywał w swojej publikacji na związek bimy-podpory z chupa [24, s.36] (czyli baldachimem, pod którym zawierany jest związek małżeński). Takie skojarzenie jednoznacznie narzuca formę oderwaną od konstrukcji budynku ${ }^{113}$. W odniesieniu zarówno do cyboriów, jak i zaprezentowanych przykładów z hagad i Aleppo takie rozumienie tej korelacji można uznać za poprawne. W synagogach znajdujących się na terenie Polski bimy wolnostojące są rzadkością ${ }^{114}$.

Tobias Lamey zwraca uwagę również na związek bimy z wczesnochrześcijańskimi rotundami w Dijon (1002-1018) [171, s. 121-122] i Citroux (1029-1047) oraz Tomarze (od 1160) i Sergovi (1208). Polskimi odpowiednikami rotund miałyby być, zdaniem tego autora, kaplica na Ostrowie Lednickim (1031) i kaplica św. Wawrzyńca w Legnicy (lata 30. XVII w.) [108, s. 332-333]. Poza podobieństwami pod względem konstrukcyjnym form tych w zasadzie nic nie łączy. Uwzględniając jednak sposób, w jaki przenoszono idee pewnych rozwiązań w zakresie osadnictwa [90], można próbować doszukać się związku między obiektami ${ }^{115}$.

Wydaje się, że pomimo wagi, jaką w XVII wieku przykładano do wrażenia estetycznego, bimy-podpory nie tylko były ładnym meblem, ale też miały swoje znaczenie, które być może było związane z chupa. Choć nie ma przekonujących argumentów, które świadczyłyby, że rozwinięcie się modelu wolnostojącego baldachimu w synagogach zlokalizowanych w Polsce nastąpiło za sprawą społeczności sefardyjskich, nie można wykluczyć, że wzór ten mógł przeniknąć właśnie z tych kręgów kulturowych. Wszak wśród społeczności żydowskich kwitły kontakty zagraniczne.

Jak wskazano powyżej, źródeł takiej formy bimy może być wiele. Najbliższe pod względem rozwiązań formalnych i konstrukcyjnych są jednak formy pojawiające się w kościołach o proweniencji bizantyjskiej, na przykład w bazylice św. Marka w Wenecji, a w ślad za nimi w kościołach o strukturach filarowych, które w mocno przetworzonej formie rozprzestrzeniają się pod wpływem architektury kościołów karmelitów bosych, również w XVII-wiecznej Polsce. Podobnie dużego wpływu na architekturę bożnic można doszukiwać się w traktatach architektonicznych. Wzorce zawarte w publikacji Serlia mogły posłużyć do stworzenia bimy-podpory. We wszystkich przeanalizowanych przypadkach należy wziąć pod uwagę, że prawdopodobnie większość murowanych XVII- i XVIII-wiecznych bożnic została wzniesiona przez muratorów chrześcijańskich, ale przy współudziale artystów żydowskich. 
Chcąc zrozumieć znaczenie bimy-podpory, trzeba jednak nawiązać do znaczenia cyborium. Z pewnością bima-podpora miała podkreślać istnienie istotnego elementu przestrzeni i kierować na niego uwagę. W trakcie liturgii takim elementem był zwój Tory, której słowa rozbrzmiewały z bimy.

\subsection{Geneza układów dziewięciopolowych}

Plan dziewięciopolowy jest szczególnym rodzajem planu centralnego. Stosowany był już w architekturze wczesnochrześcijańskiej ${ }^{116}$, przede wszystkim jako podstawa martyrionów, mauzoleów i baptysteriów. Znanym przykładem budowli wzniesionej na planie dziewięciopolowym jest baptysterium przy katedrze w Petrze (V-VI w.). Pomiędzy czterema filarami, nad którymi rozpostarto sklepienie, umieszczono basen chrzcielny.

Kolejnym przykładem bardzo częstego wykorzystywania plan dziewięciopolowego jest architektura islamu. Działo się tak z pewnością dlatego, że stanowił odtworzenie podstawowej części zbiorowego planu meczetu. Uzyskiwano go, multiplikując pole przed mihrabem [125, s. 190]. Wczesnoislamski typ tego rozwiązania opierał się jeszcze na układzie bazylikowym z podkreśleniem osi podłużnej za pomocą pilastrów przyściennych, jak na przykład w wielkim meczecie w Wasit (86-705) [125, s. 202]. Powodem zastosowania tego typu rozwiązania był z pewnością sposób zadaszenia kwadratowego planu oraz uzyskanie odpowiedniej widoczności mihrabu bezpośrednio z wejścia.

Plan dziewięciopolowy był wyraźnie widoczny w architekturze karolińskiej (VIII-IX w.), przy czym plan kwinkunksa uzupełniono o sklepienia i kopułę w centralnym polu. W takiej formie stanowił podstawę kaplic pałacowych. Jedną z nich jest wzniesione w 806 roku karolińskie oratorium Germigny-des-Prés.

Od czasów karolińskich na planie dziewięciopolowym oparte były również strefy wejściowe kościołów. Przykładem mogą być hale znajdujące się w parterach westwerków w kościele opactwa benedyktynów w Corvey nad Wezerą (873-885), a także w kościele św. Philiberta w Tournous (XI w.). Podobne rozwiązanie zastosowano w narteksie/paradyzu znajdującym się w parterze westwerku w Saint-Benoi sur Loire (1. połowa XII w.) [171, s. 129].

Kaplice pałacowe były jednak niewątpliwie tym rodzajem budowli, które najdłużej, bo jeszcze w XII wieku, były wznoszone na planie dziewięciopolowym. Potwierdzeniem tego są kaplice dwupoziomowe w Egerze (Chebie) i Norymberdze.

W tym samym czasie, co w architekturze chrześcijańskiej, plan dziewięciopolowy był nadal wykorzystywany w architekturze meczetów. Na Półwyspie Iberyjskim można wskazać tylko dwie budowle w Toledo: Bāb al-Mardum (X/XI w.) i Las Tornerías (XI-XII w.). W przypadku pierwszej w centrum znajdowały się cztery kolumny, a arkady krzyżowały się. Każde pole zwieńczone było kopułą z przecinających się łuków, przy czym pole centralne było nieco wyższe. Funkcja drugiego obiektu nie jest do końca pewna ze względu na nie- 
prawidłową orientację. Na podstawie planu i form można przypuszczać, że pełniło funkcję meczetu ${ }^{117}$.

Plan dziewięciopolowy stał się podstawą wielu założeń również architektury monastycznej. Tym pierwszym było, jak się wydaje, parlatorium klasztoru benedyktyńskiego w Cluny (1080) [113, s. 23-25]. Po nim, na takiej formie planu wzniesiono pomieszczenia w niemalże wszystkich zakonach konwentualnych, w kapitularzu klasztoru w Fonteney (XII w.), założonego przez Bernarda z Clairvaux, jak również w klasztorach w Altenbergu (1235) czy Byland (1160-1165). W Polsce wzorzec został wykorzystany jako podstawa pomieszczeń w klasztorach cysterskich, między innymi kapitularzy ${ }^{118}$ klasztorów w Wąchocku (2-3. ćwierci XIII w.) i Jędrzejowie (XII w.) [103, s. 233].

Przykłady dziewięciopolowych hal można znaleźć również w architekturze kościołów katolickich i cerkwi. W Polsce na szczególną uwagę zasługuje bazylikowy kościół św. Andrzeja w Krakowie (1079-1098) oraz halowy kościół św. Janów w Toruniu, który przebudowano na przełomie XIII i XIV wieku, dodając dziewięciopolową nawę główną do istniejącego prezbiterium. Na przełomie XIV i XV wieku wzniesiono również kościół Wniebowzięcia Najświętszej Marii Panny we Lwowie, którego część nawowa podzielona była na dziewięć pól.

W przypadku cerkwi plan dziewięciopolowy był idealnym rozwiązaniem, zwłaszcza w odniesieniu do kwinkunksa, na planie którego lokowano pięć kopuł. Dziewięciopolowe rozplanowanie wykorzystano między innymi w pochodzącej z początku XIII w. cerkwi św. Pantelejmona [62, s. 34], a także w cerkwiach w Ostrogu (1521) i Synkowiczach (1. połowa XVI w.) [108, s. 319].

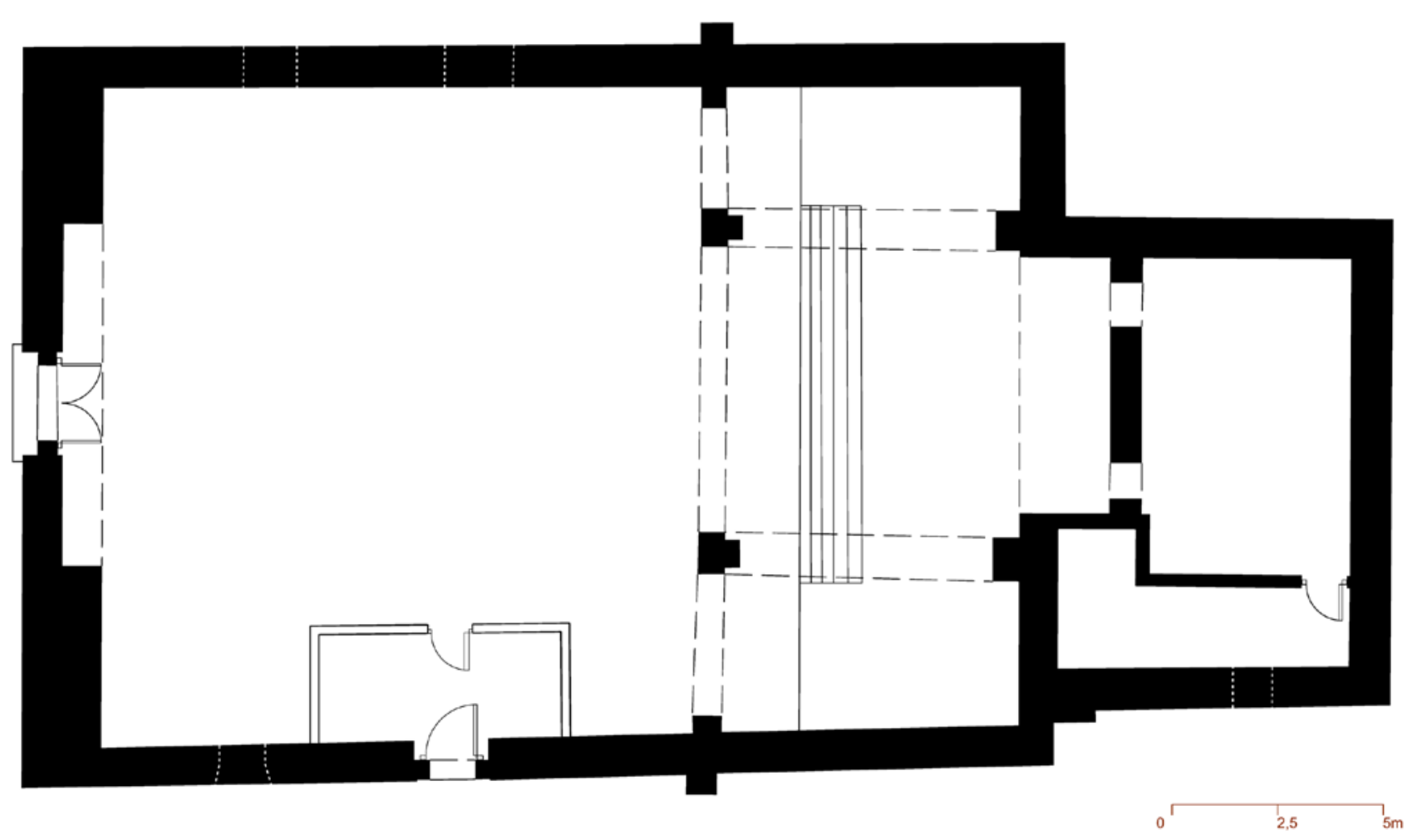

Il. 3.12. Kościół św. Potra w Bembibre (dawna synagoga), plan przyziemia [3] 


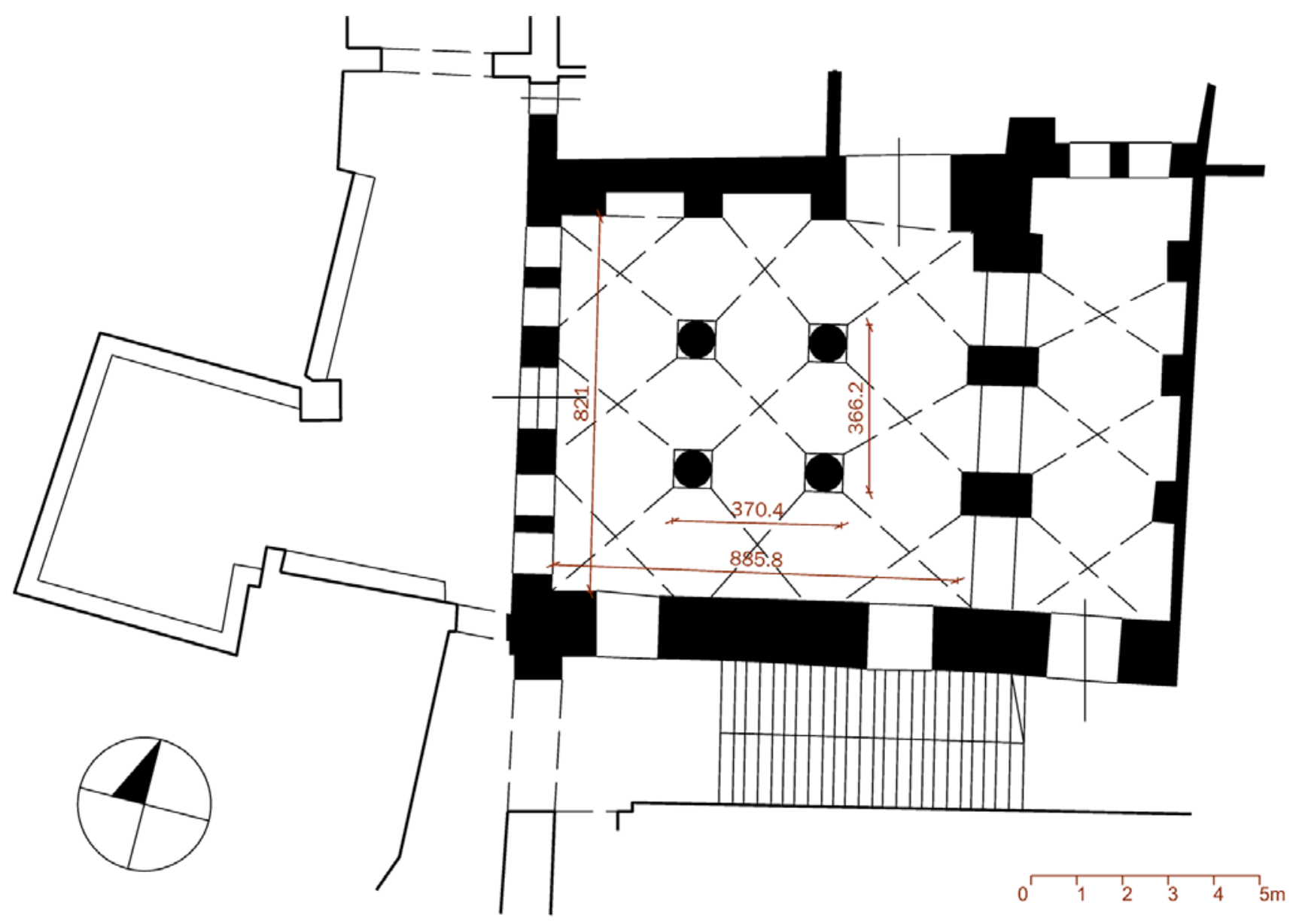

Il. 3.13. Plan synagogi ha-Ari Aszkenazi w Safedzie [4]

W architekturze synagog plan dziewięciopolowy, zwany również czteropodporowym [38, s. 82], pojawia się w XII wieku w zachodniej części Półwyspu Iberyjskiego. Pierwszym przykładem jest synagoga w miejscowości Bembibre (1191) [52, s. 14] (il. 3.12). Obiekt został w późniejszym czasie przebudowany i zaadaptowany na kościół na planie podłużnym, z czterema filarami dzielącymi wnętrze. Filary zostały jednak przesunięte w kierunku wschodnim i częściowo stopione ze ścianą. Drugim przykładem jest synagoga w Tomar (1460). Przypuszcza się, iż była wzorowana na krypcie kolegiaty w Ourém w Portugalii [194, s. 43].

Podobne rozplanowanie uzyskała wzniesiona w latach 70 . XVI wieku synagoga ha-Ari Aszkenazi w Safedzie (il. 3.13). Pierwotnie była to bożnica sefardyjska, jednak później zmieniła gospodarza. Została poświęcona Izaakowi Lurii (1534-1572), którego ojciec pochodzący z rodziny aszkenazyjskiej najpierw mieszkał na terenie Niemiec lub Polski, a następnie wyemigrował do Jerozolimy. Sklepienie obiektu w tym przypadku również zostało wsparte na czterech kolumnach, jednak wszystkie pola są w zasadzie identycznymi kwadratami.

W XVI wieku o planie dziewięciopolowym pisał w swoim traktacie Leon Battista Alberti [2, s. 210]. Również w tym czasie plan ten stał się podstawą do zaprojektowania bazyliki św. Piotra $^{119}$ - symbolu katolicyzmu. 
Jak wynika z przedstawionego przeglądu, wzorzec dziewięciopolowy był wykorzystywany od starożytności w architekturze różnych kręgów kulturowych. Zgodnie z jego założeniami zostało wzniesionych wiele obiektów w: Bizancjum, Armenii, Syrii i Europie.

\subsection{Podsumowanie}

Bet ha-Kneset stanowi centralne miejsce kultu w diasporze. Początku domów zgromadzeń można szukać już w okresie niewoli babilońskiej. Należy zaznaczyć jednak, że synagoga, poprzez odmienną formę rytuału opartego przede wszystkim na liturgii słowa, nie może być traktowana jak świątynia. Wszelkie odniesienia do wyposażenia bożnicy, w tym do stroju Tory, mają jedynie charakter symboliczny i odzwierciedlają nostalgię za czasami świątynnymi.

Społeczność żydowska nie wykształciła jednej typowej formy synagogi. Pomimo braku homogeniczności układu wnętrz bożnic, opierano kompozycję na orientacji i lokalizacji Aron ha-Kodesz i bimy. Na sposób usytuowania tych dwóch elementów wpłynęła tradycja oparta na przepisach halachicznych, a wykształcenie się dwóch głównych typów układów wynikało z nieco odmiennej kodyfikacji w obrębie społeczności sefardyjskiej i aszkenazyjskiej. Z tego powodu w bożnicach o rycie hiszpańskim bima była lokowana naprzeciw szafy na rodały, podczas gdy wśród żydów niemieckich bimę sytuowano w centrum bożnicy.

W początkowym okresie udział kobiet w liturgii synagogalnej był znikomy. Ich aktywność religijna koncentrowała się bowiem na domu. Symbolem większego zaangażowania kobiet w życie synagogi było powstanie w XIII wieku w Wormacji pierwszych babińców. W XIV wieku w Regensburgu w Staro-Nowej Szkole zaczęto rozdzielać funkcje, jakie pełniła synagoga. Skutkiem tego było dobudowywanie do sal męskich przedsionków, które miały służyć świeckim celom gminy. Obudowywanie sal synagog dodatkowymi pomieszczeniami rozwinęło się na szeroką skalę w XVI wieku.

W układzie wnętrz sal męskich zastanawia zrywanie z wcześniej wypracowanymi wzorcami na rzecz zupełnie nowych. Pomimo prób powrotu do tego, z czego czerpano wcześniej, w danym okresie trzymano się danego układu przestrzennego. I tak w starożytności obowiązywały dwa typy układów: plan wzorowany na bazylice rzymskiej o amfiteatralnym układzie siedzeń, z ruchomą skrzynią na rodały (Irbid, Tell Hum, Kafar Baram) i plan trójnawowej bazyliki (Beth Alpha), rzadziej jednoprzestrzennej sali (Eshtemoa) poprzedzonej atrium. W przypadku zastosowania któregoś z dwóch wymienionych planów zapewniano wnękę na rodały $\mathrm{w}$ formie absydy w ścianie skierowanej w stronę Jerozolimy.

Pewne typy rozwiązań stosowanych w starożytności zostały przyjęte w okresie średniowiecza na Półwyspie Iberyjskim. Przede wszystkim należy wspomnieć o trzech układach wnętrz: bazylikowym (w Santa Maria la Blanca w Toledo w Sergowii), ustroju domowym (w El Transito w Toledo w Cordobie) oraz dziewięciopolowym (w synagodze w Tomarze). Żydzi w Niemczech wykształcili dwa odmienne rozwiązania: jednoprzestrzenne na planie prosto- 
kąta (w synagogach w: Spirze, Frankfurcie, Erfurcie, Miltenbergu, Wiedniu, Strzegomiu) lub dwunawowe, zwykle zakładane na sześciu polach (w synagodze w Wormacji, w Starej Szkole, a także w bożnicach w: Pradze, Egerze, Oleśnicy, w synagodze Starej w Krakowie).

W XV wieku pod wpływem społeczności sefardyjskiej - głównie na obszarze Włoch - powstały rozwiązania dwubiegunowe (Scoula Grande Tedesca, Scoula Canton, Scoula Levantina, Scoula Italiana, Scoula Spagnola). W XVI wieku obok tego modelu w dalszym ciągu budowane były, przede wszystkim na obszarze Czech i Polski, synagogi jednonawowe (w Przemyślu, Szydłowie, a także synagogi Remu i Wysoka w Krakowie oraz Pinkasa w Pradze). W tym czasie wznoszone były również bożnice bazylikowe (Maisela w Pradze) i jednoprzestrzenne na planie kwadratu (w Pińczowie oraz we Lwowie synagoga Nachmanowicza).

Wiek XVII i XVIII był okresem popularności głównie czterech planów i w konsekwencji wznoszenia: bożnic jednonawowych (Kupa, Izaaka, Poppera w Krakowie), jednoprzestrzennych na planie kwadratu (w: Chęcinach, Zamościu, Szczebrzeszynie, Tomaszowie Lubelskim), z bimą-podporą (w Tarnowie, Synagoga Stara w Rzeszowie, a także w: Łucku, Pińsku, Słonimie, Tykocinie, Nowogródku, Przeworsku, Dukli, Przysusze) i dziewięciopolowych (we Lwowie, w Ostrogu, Wilnie, Synagoga Nowowmiejska w Rzeszowie, w Bobowej, Żółkwi, Brodach, Włodawie).

Synagoga z bimą-podporą stanowi swoisty schemat architektoniczny, w obrębie którego można wyróżnić kilka typów rozwiązań bim. Charakterystyczne dla tego zastosowanego w synagogach w Tarnowie, Łucku i w Synagodze Starej w Rzeszowie było obniżenie sklepienia nad bimą. Z tego rozwiązania wywodzi się kolejny typ bimy, bima kaplicowa, w której sklepienie osadzano w połowie wysokości wnętrza synagogi. Powyżej głównego sklepienia nadbudowywano natomiast latarnię (w synagogach w: Pińsku, Słonimie, Nowogródku). Kolejnym typem bimy jest baldachim, który nie pełni funkcji konstrukcyjnej (w synagogach w Łęcznej i Opatowie).

W XVII i XVIII wieku stosowano niezwykle bogaty repertuar form bim-podpór. Również sposób ich usytuowania był różny. Ze względu na kompozycję planu większość bim była lokowana centralnie, jednak w kilku przypadkach nastąpiło odejście od tej zasady (w synagogach w Łęcznej i Orli).

Geneza synagog z bimą-podporą oraz bożnic dziewięciopolowych jest bardzo trudna do ustalenia. Szukając ich wzorów, badacze wskazywali na różne źródła. Forma ta miała być, ich zdaniem, efektem zestawienia z sobą modułów jednonawowych hal [108, s. 164] czy rozwoju planu jednoprzestrzennego, nawiązaniem do wzorów bizantyjskich [8], [108], [118] lub z północnej Italii [153, s .83] bądź do architektury Tempietta Bramantego [104, s. 85]. Trzeba jednak zwrócić uwagę, że trudno jest znaleźć w obszarze architektury innych religii czy kultur podobne ukształtowanie wnętrza.

Jednoznaczne ustalenie źródła, które stanowiło wzorzec formy konstrukcyjnej bimy, jest dosyć trudne. Najbardziej prawdopodobne wydają się kościoły o proweniencji bizantyjskiej (bazylika św. Marka w Wenecji), a w dalszej kolejności kościoły o strukturach filarowych (św. Salwatora w Wenecji, Grobu Świętego w Piacenzy, św. Fantyna w Wenecji, św. Justyny 
w Padwie, św. Andrzeja w Mantui), których forma, choć mocno przetworzona, zyskuje popularność dzięki karmelitom bosym i ich budowlom sakralnym. W Polsce przykładem tego typu realizacji są wzniesione w XVII wieku kościoły w: Wilnie, Warszawie, Komarnie i Węgrowie.

Podobnie duży wpływ na architekturę bożnic mogły mieć traktaty architektoniczne. Wzorce zawarte w traktacie Sebastiana Serlia mogły stanowić fundament, na którym opierało się tworzenie bimy-podpory. Podobnym do bim-podpór rozwiązaniem kompozycyjnym były cyboria. Razem z bimą z Aleppo i rysunkami z hagad mogły być one pierwowzorem bimy konstrukcyjnej. Analiza ostatnich wymienionych wzorców nie rozwiewa wątpliwości dotyczących wsparcia sklepienia na konstrukcji bimy, ponieważ takie rozwiązanie nie zostało $\mathrm{w}$ nich zastosowane. $\mathrm{Z}$ pewnością bima-podpora i cyborium miały podkreślić to, co $\mathrm{w}$ tym miejscu było najistotniejsze, a mianowicie Torę, której słowa rozbrzmiewały z podestu.

Od lat 20. XVII wieku powstawały na terenie Rzeczypospolitej bożnice dziewięciopolowe. Pomimo że słupy stanowiły w nich ramy dla wolnostojącej bimy i razem z nią tworzyły zmonumentalizowaną formę, w centralnym polu zachowana była wysokość sklepienia sali męskiej. Stosowano trzy podstawowe kompozycje wnętrza: podział na równe pola (w synagogach w: Leszniowie, Żółkwi, Brodach, Włodawie, Stawiskach), poszerzenie centralnych pasów sklepień sali męskiej (w synagogach w: Ostrogu, Tarnogrodzie, Bobowej, Druji) lub zmniejszenie centralnego pola (w synagogach we Lwowie, w Wilnie oraz w Synagodze Nowomiejskiej w Rzeszowie).

Poszukując wzorów planu dziewięciopolowego, badacze stwierdzali, że jest on efektem rozwoju planu z bimą-podporą [192, s. 128] lub autorskim działaniem Jakuba Medliniego, opartym na rekonstrukcji świątyni jerozolimskiej wykonanej przez dwóch jezuitów: Jana Baptystę Villalpanda i Hieronima Prada [94, s. 320]. Nie można wprawdzie wykluczyć wpływu chrześcijańskiej rekonstrukcji na wytworzenie się dziewięciopolowego układu wnętrza w synagogach w Polsce, trudno jednak nie zauważyć częstego stosowania tego planu począwszy od starożytności w różnych częściach świata i kręgach kulturowych, w tym również jako podstawy synagog w XIV i XVI wieku. Zakorzenienie planu dziewięciopolowego również na obszarze Rzeczpospolitej może świadczyć o wykorzystaniu istniejącego wzorca dziewięciopolowego po przeprowadzeniu modyfikacji synagogi z bimą-podporą. Przypuszczenie to wydaje się o tyle zasadne, że modyfikacja ta z pewnością rozwiązywała problem akustyki we wnętrzu bożnicy. Bima-podpora poprzez zbliżenie słupów wytwarzała zdecydowanie większą martwą strefę. Rozsunięcie słupów w planie dziewięciopolowym skutkowało zmniejszeniem tych obszarów powierzchni w synagodze, do których nie dociera dźwięk.

Forma planu i układ wnętrza zmieniał się na przestrzeni wieków. Część wzorców zapożyczano z architektury innych religii i kultur i adaptowano je do potrzeb religijnych judaizmu. Przykładem może być wykorzystanie planu starożytnej bazyliki w synagogach Półwyspu Iberyjskiego czy planu dwunawowego, charakterystycznego dla architektury klasztorów i kościołów, w architekturze bożnic niemieckich. Plany jednonawowe, które pojawiają się już w średniowieczu, stanowią podstawę synagog renesansowych. Trzeba jednak w tym miejscu 
zwrócić uwagę również na synagogi czteropodporowe, które pojawiają się jako ewenementy w XIV i XVI wieku.

W XVI i XVII wieku następuje zdecydowane odejście od planów średniowiecznych dwunawowych na rzecz planów podłużnych jednonawowych, a w dłuższej perspektywie planów centralnych jednoprzestrzennych. Działania takie było podyktowane zapewne poszukiwaniem przez społeczność żydowską idealnego rozwiązania przestrzeni sali męskiej. Pomimo solidnych podstaw w traktacie Isserlesa trudno nie zwrócić uwagi na to, że plan kwadratu był bardzo rozpowszechnionym wzorcem już od starożytności. Być może działania Żydów w odniesieniu do zastosowania w rzucie kwadratu miały niezależne podłoże, jednak z uwagi na zafascynowanie planem centralnym w renesansie oraz na wpływ muratorów chrześcijańskich na architekturę bożnic, trudno nie odnieść wrażenia, że Żydzi przystosowali to rozwiązanie do swoich potrzeb. Kolejnym krokiem w architekturze bożniczej było wytworzenie monumentalnych wnętrz, tak z bimą-podpora, jak i dziewięciopolowych. Osiągnięcie idealnej formy bożnicy dziewięciopolowej w latach 20. XVII wieku nie spowodowało odejścia od planów podłużnych, centralnych czy dwunawowych. Wskazuje to na zakorzenienie pewnych układów przestrzennych w świadomości społecznej i wykorzystywanie ich niezależnie od trendów panujących w danej epoce.

\section{Przypisy}

${ }^{51}$ Halacha definiuje synagogę jako budynek, w którym mężczyźni żydowscy mogą się zbierać na modlitwę. Vide: V. Levin, Synagogues in Lithuania: A Historical Overview, [w:] Synagogues in Lithuania: a catalogue. A-M, eds. A. Cohen-Mushlin et al., Wilno 2010, s. 18.

52 Jak wskazuje za Talmudem William Rosenau, w czasie istnienia świątyni jerozolimskiej Żydzi kierowali się w trakcie modlitwy na zachód w akcie protestu przeciwko wyznawcom Słońca, którzy mieli w zwyczaju dziękować mu za danie im poranka. Kiedy w czasie rozproszenia Żydów po 70 r. n.e. ustał kult Słońca, wyznawcy judaizmu żyjący na zachód od Jerozolimy odwrócili się na znak żałoby i nadziei w kierunku wschodnim, a ci mieszkający na wschód od Jerozolimy w kierunku zachodnim. W. Rosenau, Jewish ceremonial institutions and customs, New York 1925, s. 18.

53 „I [one] modlić się będą do Ciebie w stronę swojego kraju, który dałeś ich ojcom, miastu, któreś wybrał i domowi, który zbudowałem dla Twego imienia" [137, 1 Krl 8,48].

54 „Miał on w swoim górnym pokoju okna skierowane ku Jerozolimie. Trzy razy dziennie padał na kolana, modląc się i uwielbiając Boga, tak samo jak to czynił przedtem” [137, Dn 6,11].

${ }^{55} \mathrm{Na}$ lokowanie okien wysoko, w odniesieniu do idealnego kościoła chrześcijańskiego, zwrócił uwagę Leon Battista Alberti. Modlący się mieli widzieć jedynie niebo i nie mieć kontaktu ze światem zewnętrznym. W przypadku synagog należy również zwrócić uwagę na względy bezpieczeństwa, które z pewnością odgrywały istotną rolę. Vide: A.F. Janson, H.W. Janson, History of Art: The Western Tradition, Upper Saddle River 2003, s. 423. 


\section{Synagoga}

${ }^{56}$ Autor powołuje się na księgę Zohar 1, 251b.

57 Tora jest ozdobiona wieloma elementami. Jednym z nich jest tas (tarcza), która jest odpowiednikiem napierśnika arcykapłana, noszonego w czasie nadzorowania kultu w starożytnej świątyni w Jerozolimie. Zwój nawinięty jest na drewniane uchwyty Ecej Chaim (drzewo życia). Tora ubrana jest w meil (płaszcz) oraz ozdobiona rimmonim (granatami) lub zwieńczona Keter Tora (koroną Tory). Ten element wiąże się z fragmentem traktatu talmudycznego Pirkej Awot, wedle którego „są trzy korony: korona Tory, korona kapłaństwa i korona królewska; jednakże korona dobrego imienia przewyższa je wszystkie". Na koronie umieszczone są dzwonki reprezentujące dzwonki noszone na szacie przez arcykapłana. Zwój Tory jest najważniejszy w synagodze. Pozostaje w arce za drzwiami i zasłoną ( $p a-$ rochet) symbolizującą zasłonę oddzielającą Kodesz ha-Kodaszim od sanktuarium w świątyni. Nad parochetem wisi lambrekin (kaporet) oznaczający pierwotnie wieko arki. Te symboliczne odniesienia są zawarte w Talmudzie.

${ }^{58}$ Pulpit dla kantora, z którego odczytuje się część modlitw.

${ }^{59}$ Określenie stosowane przez Żydów aszkenazyjskich. Odpowiednikiem sefardyjskimi była tewa.

${ }^{60}$ Symboliczne znaczenie bimy-podpory zostało omówione w rozdz. 4.

${ }^{61}$ Nazwa Aron ha-Kodesz, określająca wnękę na rodały, w społecznościach Żydów aszkenazyjskich wywodzi się z Drugiej Księgi Królewskiej i utożsamiana jest z Arkę Przymierza. U Żydów sefardyjskich ten sam element określany jest mianem heikhal, oznaczającym miejsce święte. Określenie to pojawia się m.in. w opisie świątyni Salomona [137, $1 \mathrm{Krl}$ 6,17]. Miszna natomiast nazywa wnękę na rodały tewa. Słowo to oznacza Arkę Noego. Vide: R. Wischnitzer R., The Architecture of the European Synagogue, Philadelphia 1964, s. 15; C.H. Krinsky, Synagogues of Europe: Architecture, History, Meaning, Cambridge 1985, s. 25.

${ }^{62}$ Bałaban zaznacza, że przepisowi zawartemu w słowach psalmisty odpowiadało niewielkie obniżenie miejsca dla kantora, natomiast obniżenie poziomu posadzki audytorium było związane z przepisami kościelnymi, które zakazywały budowania synagogi wyższej od kościoła. Zatem w celu osiągnięcia odpowiedniej wysokości sali męskiej trzeba było obniżyć poziom posadzki. Wydaje się jednak, iż ważny był również proces narastania terenu wokół obiektów. Analizując ten charakterystyczny zabieg w kształtowaniu posadzki z punktu widzenia miejsca występowania, Alfred Grotte uznał, że był charakterystyczny jedynie dla synagog polskich i niemieckich wzniesionych w XVIII w. przez emigrantów z Polski. Była to jednak tendencja funkcjonująca na obszarze niemalże całej Europy, chętnie wykorzystywana w celu obejścia przepisów prawa i uzyskania tym sposobem odpowiedniej wysokości sali modlitw. Praktyka ta stała jednak w sprzeczności z przepisami zawartymi w talmudycznym traktacie Sabat, dotyczącymi lokowania obiektu na wzgórzu. Vide: M. Bałaban, Zabytki historyczne Żydów w Polsce, Warszawa 1929, s. 71; R. Wischnitzer, The Architecture of the European Synagogue, Philadelphia 1964, s. 50; A. Grotte, Deutsche, böhmische und polnische Synagogentypen vom XI. bis Anfang des XIX. Fahrhunderts, Berlin 1915, s. 15; C.H. Krinsky, Synagogues of Europe: Architecture, History, Meaning, Cambridge 1985, s. 22.

${ }^{63}$ William Rosenau tłumaczy, iż według Israela Abrahamsa dawniej modlitwa kobiet była prowadzona przez kobietę kantora. Wnioskuje tak na podstawie pochodzącego z XIII w. nagrobka, na którym 


\section{Synagoga}

widnieje epitafium poświęcone kobiecie pełniącej funkcję kantora. Maria i Kazimierz Piechotkowie podają, iż pierwsze babińce powstały w XIII w., czego przykładem ma być najstarszy tego typu aneks dostawiony w latach 1212-1213 do budynku synagogi w Wormacji. W synagodze w Regensburgu babiniec pojawia się przed XIV w., w synagodze w Spiże w XIV w. Aneksy dla kobiet w synagogach w Wormacji, jak i Spiże były salami czteropolowymi, wspartymi na centralnym słupie. Maria i Kazimierz Piechotkowie podają 1235 r. jako czas dostawienia aneksu do synagogi w Wormacji. Vide: K. i M. Piechotkowie, Bramy Nieba: Bożnice murowane na ziemiach dawnej Rzeczypospolitej, Warszawa 1999, s. 2, 35; S. Paulus, Die Architektur der Synagoge im Mittelalter: Überlieferung und Bestand, Petersburg 2007, s. 90, 107.

${ }^{64} \mathrm{Na}$ aspekt symboliki światyni zakorzenionej w planie i układzie funkcjionalnym synagogi zwraca uwagę Israel Abrahams w pracy: I. Abrahams, Jewish Life in the Middle Ages, London-New York 1896, s. 26, 30. Vide: W. Rosenau, Jewish ceremonial institutions and customs, New York 1925, s. 22; R. Wischnitzer, The Architecture of the European Synagogue, Philadelphia 1964, s. 39; C.H. Krinsky, Synagogues of Europe: Architecture, History, Meaning, 1996, s. 28; K. i M. Piechotkowie, Bramy Nieba: Bożnice murowane na ziemiach dawnej Rzeczypospolitej, Warszawa 1999, s. 20; V. Levin, Synagogues in Lithuania: A Historical Overview, [w:] Synagogues in Lithuania: a catalogue. A-M, eds. A. Cohen-Mushlin et al., Wilno 2010, s. 36-37.

${ }^{65}$ Vide: rozdz. 7.

${ }^{66}$ Bazalel Narkiss przypuszcza, że Żydzi wybrali układ z wewnętrzną kolumnadą, aby odróżnić synagogę od pogańskiej (rzymskiej) świątyni, którą kolumnada obiegała na zewnątrz. Wzorców dla synagogi tego okresu poszukiwano w architekturze świeckiej. Wykorzystano zatem wzorzec rzymskiej bazyliki, gdyż była ona pozbawiona konotacji religijnych. Vide: B. Narkiss, Sacred Spades: Inerrelations Between Jewish, Christian, and Moslem Architecture, [w:] Jewish Architecture in Europe, eds. A. Cohen-Mushlin, H.H. Thies, Petersburg 2010, s. 31.

${ }^{67}$ Dokładniejsze omówienie synagogi w Tomar znajduje się w kolejnych rozdziałach niniejszej monografii.

${ }^{68}$ Synagogi wzniesione według tych zasad są w: Spirze (XI w.), Frankfurcie (XII w.), Erfurcie (XIII w.), Miltenbergu (XIII w.), Wiedniu (1250) Bambergu (XIII-XIV w.), Mödling (koniec XIII w.), Sapron I (1300-1325), Sapron II (1350-1370), Korneubergu (XIV w.). Prawdopodobnie również synagoga w Wormacji (1084) miała pierwotnie formę jednonawowej sali. Synagoga w Wiedniu została przebudowana na sześciopolową przed 1296 r. Vide: S. Paulus, Die Architektur der Synagoge im Mittelalter, Petersburg 2007, s. 381.

${ }^{69} \mathrm{~W}$ pierwszej fazie (XI/XII w.) synagoga była jednonawowa. Vide: S. Paulus, Die Architektur der Synagoge im Mittelalter, Petersburg 2007, s. 175, 179.

${ }^{70}$ W XVIII w. wzór ten został przeniesiony również do Prowansji. Vide: R. Wischnitzer, The Architecture of the European Synagogue. Philadelphia 1964, s. 69-73.

${ }^{71}$ W latach 1689-1694 wzniesiono synagogę Klausa w Pradze, która również posiadała emporę.

${ }^{72}$ W 1669 r. wzniesiono synagogę Tylną w Třebíč. Vide: T. Lamey, Die Stellung des polnischen Steinsynagogenbaus in Europa im 16. und 17. Fahrhundert - Versuch einer Annäherung, „Aschkenaz Zeitschrift für Geschichte und Kultur der Juden” 2004, Nr. 14, s. 426. 


\section{Synagoga}

${ }^{73}$ Trudno jest określić, jaka była organizacja wnętrza, gdyż w 1454 r. Żydzi zostali wypędzeni ze Strzegomia, a synagoga zmieniła funkcję na kościół filialny św. Barbary. Od wschodu dobudowano wówczas prezbiterium, dlatego też nie zachowały się pozostałości szafy na rodały. Vide: K. i M. Piechotkowie, Bramy Nieba: Bożnice murowane na ziemiach dawnej Rzeczypospolitej, Warszawa 1999, s. 43.

${ }^{74} \mathrm{Na}$ tym planie wzniesiono w XIII w. kapitularz klasztoru cystersów w Koprzywnicy oraz w XIV w. kościoły w: Stopnicy, Niepołomicach, Szydłowie i Wiślicy.

${ }^{75}$ W XVI w. był to arsenał, od XVII w. kościół św. Salwatora.

${ }^{76}$ We wcześniejszym okresie były bimy kwadratowe lub na planie sześcioboku (synagogi w Wiedniu (sprzed 1296) oraz Sapron I i II).

77 Tobias Lamey zwraca jednak uwagę, iż kwadratowy plan synagogi może wynikać z opisu znajdującego się w dziele Mojżesza Isserlesa Mappa (obrus). Geometryczna rekonstrukcja planu faktycznie wskazuje, że źródła takiego rozwiązania mogły być zupełnie niezależne od renesansowych wzorców architektury chrześcijańskiej. Vide: T. Lamey, Zur Genese der „Stütz-Bimah” im frühneuzeitlichen polnischen Synagogenbau am Beispiel der Synagoge in Przemyśl, Braunschweig 2010, mps Biblioteka Uniwersytetu w Braunschweig, s. 227.

${ }^{78}$ Synagoga Remu (1553) pierwotnie zbudowana została jako sala męska o proporcji prostokąta 2:1. Sala kahalna, przedsionek i babińce wzniesiono prawdopodobnie później jako drewniane i dopiero w XIX w. zostały zamienione na murowane. Wnętrze sklepione było kolebą, w ścianie wschodniej umieszczono szafę na rodały, a w centrum znajdowała się bima.

${ }^{79}$ Adam Miłobędzki podaje pierwszą połowę XVII w. Vide: A Miłobędzki, Architektura polska XVII wieku, Warszawa 1980. Za swego rodzaju pierwowzór tego rozwiązania Ignacy Schiper przyjmuje synagogę we Lwowie ufundowaną przez Izaaka Nachmanowicza. Vide: L. Schiper, Sztuka plastyczna u Żydów dawnej Rzeczypospolitej, [w:] Żydzi w Polsce odrodzonej: działalność społeczna, gospodarcza, oświatowa i kulturalna, t. 1, red. I. Schiper, A. Tartakower, A. Hafftka, Warszawa 1932, s. 314.

${ }^{80}$ Podobny sposób rozplanowania wnętrza uzyskała również synagoga w Tomaszowie Lubelskim ( 2. ćwierć XVIII w.).

${ }^{81}$ Vide. podrozdz. 3.1.

82 Tobias Lamey opisuje w swojej pracy doktorskiej rozprzestrzenianie się planu kwadratu od starożytnego Rzymu oraz przemiany w układach funkcjonalnych kościołów i światyń. Vide: T. Lamey, Zur Genese der „Stütz-Bimah”..., s. 268-279.

${ }^{83}$ Zdaniem Adama Miłobędzkiego oznacza to znacznie wcześniejsze wpływy baroku na architekturę synagog niż na architekturę kościołów. Vide: A. Miłobędzki, Architektura polska XVII wieku, Warszawa 1980, s. 27.

${ }^{84} \mathrm{Z}$ tego powodu Tobias Lamey przedstawił genezę tego rozwiązania jako efekt zestawienia z sobą modułów jednonawowych hal. Cztery hale usytuowane prostopadle i w pewnej odległości od siebie dały możliwość wytworzenia centralnej podpory. Vide: T. Lamey, Zur Genese der „Stütz-Bimah"..., s. 164.

${ }^{85}$ Zarówno Adam Miłobędzki, jak i Szymon Zajczyk nazywają opisywane przez siebie synagogi dziewięciopolowymi. Dopiero dalsza analiza ich tekstów ujawnia, że chodzi o typ z bimą-podporą. 


\section{Synagoga}

${ }^{86}$ Również sposób oraz miejsce zaistnienia takiego rozwiązania budzą mniejsze lub większe kontrowersje. Adam Miłobędzki podaje, że plan ten wykształcił się na południowo-wschodnich rubieżach Rzeczpospolitej. Analogią do takiego rozwiązania wnętrza były świątynie chrześcijańskie, związane bardziej z architekturą cerkiewną niż z późnogotycką halą. Na podobny związek wskazuje Majer Bałaban, który typ synagog na planie kwadratu wywodzi z wzorców bizantyjskich. Carol Krinsky zwraca jednak uwagę, iż przez skupienie czterech filarów w centrum synagogi nie są podobne do centralnych kościołów prawosławnych ani rzymskokatolickich i nie naśladują obiektów należących do żadnej innej religii. Podkreślają to bardziej dobitnie Maria i Kazimierz Piechotkowie, przyjmując taki plan za oryginalne rozwiązanie odpowiadające potrzebom judaizmu. Sergiey Kravtsov pisze, że synagogi „,czteropodporowe” były najbardziej popularnym rozwiązaniem w XVII w., a jednym z pierwszych przykładów była synagoga w Przemyślu (1592-1594). Vide: A. Miłobędzki, Architektura polska XVII wieku, Warszawa 1980, s. 287; M. Bałaban, Zabytki historyczne Żydów w Polsce, Warszawa 1929, s. 60; C.H. Krinsky, Synagogues of Europe: Architecture, History, Meaning, Cambridge 1985, s. 51; S.R. Kravtsov, Synagogue Architecture in Lithuania, [w:] Synagogues in Lithuania: a catalogue. A-M, eds. A. Cohen-Mushlin et al., Wilno 2010, s. 45.

${ }^{87}$ Ciekawy jest wniosek Helen Rosenau, iż synagogi z bimą-podporą nawiązują do wzorca popularnego w północnej Italii. Autorka nie wskazała jednak przykładów. Innym włoskim wzorcem bimy-podpory miało być Tempietto Bramantego. Vide: H. Rosenau, The Synagogue and Protestant Church Architecture, „Journal of the Warburg and Courtauld Institutes” 1940/1941, Vol. 4, No. 1/2, s. 83; H. Kunzl, Jüdische Kunst: von der biblischen Zeit bis zur Gegenwart, München 1992, s. 85.

${ }^{88}$ Plan dziewięciopolowy z bimą-podporą może być efektem przemian planu jednoprzestrzennego, a - jak wskazuje Adam Miłobędzki - początkowe formy tego rozwiązania opierały się na podziale na równe pola. Stoi to nieco w sprzeczności z teorią Marii i Kazimierza Piechotków, którzy twierdzą, że obiekty te rozwijały się równolegle, a ich początku należy szukać w synagogach Lublina - w synagodze Maharszala (1567) - czy Brześcia Litewskiego (1568). Podobną teorię wysunęła - zapewne na podstawie opracowania Davida Dawidowicza - Rachel Wischnitzer, uznając za początek synagog z bimą-podporą synagogę Maharszala (1567) w Lublinie. Jak podaje Majer Bałaban, forma tej synagogi zmieniła się diametralnie. Szymon Zajczyk podkreśla wyraźnie, że bożnice te wykształciły się na obrzeżach Małopolski zachodniej i tam należy szukać początków tego rozwiązania, które związane było z renesansowymi dążeniami do stworzenia idealnego planu centralnego. Wiadomo jednak, że plan ten rozpowszechniony był we wschodniej części kraju, na pograniczu Małopolski i Rusi Czerwonej. W centrum i dzielnicach zachodnich przeważały nadal plany podłużne. Można przyznać rację Davidowi Dawidowiczowi, który wskazuje na niezwykle istotny krok, jaki w umocnieniu się polskiego wzorca bożnicy murowanej stanowiły bożnice z bimą-podporą. Być może rozwój tego wzorca został zapoczątkowany w kabalistycznym opisie pałaców niebiańskich, gdzie pojawia się opis kanału w formie czteropodporowego, wydrążonego słupa łączącego pałace. Vide: A. Miłobędzki, Architektura polska XVII wieku, Warszawa 1980, s. 42; D. Dawidowicz, Batej kneset be-Polin we-churbanam, Jerozolima 1960, s. 31; Sz. Zajczyk, Architektura barokowych bożnic murowanych w Polsce, „Biuletyn Historji Sztuki i Kultury: kwartalnik wydawany przez Zakład Architektury Polskiej i Historji Sztuki Politechniki Warszawskiej” 1933, vol. 1, no. 4, s. 189. 


\section{Synagoga}

${ }^{89}$ Obecnie żadne badania nie potwierdzają zastosowania bimy w formie cyborium w synagodze Nachmanowicza.

${ }^{90}$ Tobias Lamey wskazuje, że forma bimy-podpory powstała już w XVI w.

${ }^{91}$ Wymiary potwierdzone in situ na podstawie negatywów murów.

92 Jeżeli jednak wziąć pod uwagę różnice w warsztacie budowlanym, należy przyznać rację Tobiasowi Lameyowi, że ostatnia kondygnacja bimy została prawdopodobnie nadbudowana później. Podobnie zmieniono wielokrotnie wygląd baz kolumn. Vide: T. Lamey, Zur Genese der „Stütz-Bimah”..., s. 293.

${ }^{93}$ Zdaniem Rachel Wischnitzer przypomina Synagogę Starą w Rzeszowie. Autorka myli jednak te dwa obiekty. Vide: R. Wischnitzer, The Architecture of the European Synagogue, Philadelphia 1964, s. 149.

${ }^{94} \mathrm{~W}$ ten sposób dziewięciopolowość analizują: A. Grotte, Sz. Zajczyk, M. Bałaban, A. Miłobędzki. R. Wischnitzer. Inne podejście można reprezentują: M. i K. Piechotkowie oraz S.R. Kravtsova i T. Lameya. Choć w przypadku S.R. Kravtsova wątpliwości budzi stosowanie pojęcia czteropodporowy.

${ }^{95}$ Wskazują na to: Sz. Zajczyk, K. i M. Piechotkowie, A. Miłobędzki.

${ }^{96}$ Tarnogród (po 1686), Rzeszów (Synagoga Nowomiejska) (1700-1708), Bobowa (1750-1756), Staszów (4. ćwierć XVIII w), Strzyżów (4. ćwierć XVIII w.). W dwóch ostatnich synagogach i w Synagodze Nowomiejskiej słupy były bardzo blisko siebie, jednak wysokość sklepień i usytuowanie wolnostojącej bimy zadecydowały o ich dziewięciopolowym charakterze.

${ }^{97}$ Był on prawdopodobnie autorem synagog we Lwowie i w Ostrogu.

${ }^{98}$ Sergiey Kravtsov zwraca uwage na wpływy korynckie w kompozycji kapiteli. Vide: S.R. Kravtsov, Juan Bautista Villalpando and Sacred Architecture in the Seventeenth Century, ,Journal of the Society of Architectural Historians" 2005, Vol. 64, No. 3, s. 319.

${ }^{99}$ Maria i Kazimierz Piechotkowie datują synagogę na lata 30./40. XVII w., natomiast zdaniem Sergieya Kravtsova prawdopodobne są lata 20. XVII w.

${ }^{100} \mathrm{~W}$ Bobowej na każdej ze ścian słupa usytuowano dodatkowe pilastry. Centrum zaplanowano jako nieco wyższe i przekryte sklepieniem klasztornym, podkreślonym niewielkimi żebrami i osadzonym na niewielkim gzymsie. Pozostałe pola przesklepione zostały sklepieniami żaglastymi.

${ }^{101}$ We Włodawie wszystkie pola, włącznie z centralnym, przesklepiono krzyżowo.

${ }^{102}$ Taką próbę podjął wprawdzie w swojej pracy doktorskiej Tobias Lamey, jednak wydaje się zasadne przytoczenie i rozszerzenie jego analiz. Vide: T. Lamey, Zur Genese der „Stütz-Bimah”..., s. 227-346.

${ }^{103}$ Najstarszy przykład istniał w bazylice na Lateranie w IV w. W okresie od V do X w. powstało wiele cyboriów sytuowanych w sposób przedstawiony w tekście, m.in. w bazylice Ursiana w Rawennie (V w.), Bir al-Knissia i Douimes (V-VI w.) w Kartaginie, św. Klemensa na Lateranie (VI w.), Sant Apollinare in Classe (IX), św. Mikołaja w Myrze (IX w.).

${ }^{104} \mathrm{Z}$ około 1100 r. pochodziło cyborium w katedrze w Spirze. W XIII w. powstają cyboria w kościele św. Pawła za Murami i św. Cecylii w Trastevere, a także w katedrach w: Neples, Hamersleben, Münzenberg. Również z tego okresu pochodzi baldachim w bazylice Eufrazjusza w Poreču. W XIV i XV w. cyboria wzniesiono w kościele św. Jana na Lateranie i katedrze w Erfurcie. Vide: T. Lamey, Zur Genese der „Stütz-Bimha“..., s. 89. 


\section{Synagoga}

${ }^{105}$ W 1547 r. Vignola wzniósł cyborium w kościele św. Petroniusza w Bolonii. Inne cyboria znajdują się w kościołach: św. Ducha we Florencji (1600), św. Aleksego (1600) i św. Agnieszki za Murami w Rzymie (ok. 1620), św. Chryzogona (1627) w Rzymie. W 1623 i 1631 r. powstaje również baldachim w katedrze św. Piotra w Rzymie projektu Gianlorenzo Berniniego.

${ }^{106}$ Tobias Lamey wskazuje na związki formalne między cyboriami w kościołach: Matki Bożej Większej, św. Ducha, Aleksego i Chryzogona a bimami w synagogach na terenie Polski. Autor analizę tę opiera na założeniu, że bima była pierwotnie elementem niezwiązanym z konstrukcją budynku. Vide: T. Lamey, Zur Genese der „Stütz-Bimah”..., s. 326.

107 Tobias Lamey wskazuje, iż zaadaptowanie cyborium na potrzeby synagogi pozbawia go transcendentalnego charakteru, przez co bima staje się jedynie formą „ornamentu przestrzennego”. Vide: T. Lamey, Zur Genese der „Stütz-Bimah”..., s. 223, 335.

${ }^{108}$ Tobias Lamey stwierdził [sic], że po raz pierwszy to rozwiązanie pojawia się pod koniec XVII w. w kościele misjonarzy w Warszawie. Motyw ten, tak popularny w architekturze karmelitów w Polsce, został wykorzystany w kościele tego zakonu w Wilnie (1634-1653), a więc prawie w tym samym czasie, w którym najprężniej rozwijały się bimy-podpory, a także w kościołach powstałych w Warszawie (1661-1672). Pojawia się również w kościele parafialnym w Komarnie (po 1656). Forma ta była popularna do końca XVII w. Dwoma ostatnimi obiektami o mocno zredukowanych wnętrzach filarów były kościoły: kapucynów w Warszawie (1683-1686) i reformatorów w Węgrowie (1693-1715). Vide: T. Lamey, Zur Genese der „Stütz-Bimah”..., s. 330; A. Miłobędzki, Architektura polska XVII wieku, Warszawa 1980, s. 181.

${ }^{109}$ Wskazane rozwiązanie przedstawiają traktaty: Leona Battisty Albertigo (1404-1472) De Re Aedificatoria (1452), Sebastiano Serlia (1475-1554) Di Architettura (od 1537), Giacomo Barozzi da Vignoli (1507-1573) Regola delli cinque ordini dell' architettura (1562), Andrea Palladia (1508-1580) I Quattro Libri dell'Architettura (1570), Vincenzo Scamozziego (1548-1616) L'Idea della Architettura Universale (1625).

${ }^{110}$ Vide: prace Tobiasa Lamey'a.

${ }^{111}$ Carol Krinsky, na podstawie sztychu zamieszczonego w manuskrypcie hagady siostrzanej [99, s. 49], wysnuła wniosek, iż ten typ bimy wspartej na czterech słupach i przykłady jego zastosowania w bożnicach mogą pochodzić nawet z XIV w. W hagadzie barcelońskiej i siostrzanej są formy wsparte na czterech słupach, wyciągniętych ponad głowę postaci na nich stojącej. Są one przedstawione w jednym przypadku en face, w drugim izometrycznie. Bima w hagadzie z Katalonii nie posiada wprawdzie wyciągniętych słupów, jednak również jej nadstawa wsparta jest na czterech filarach. Baldachim, który się nad nią znajduje, jest formą zupełnie niezależną. Vide: C.H. Krinsky, Synagogues of Europe: Architecture, History, Meaning, Cambridge 1985, s. 49.

${ }^{112}$ Szczegółowy opis przedstawień szaf na rodały w manusktyptach: I. Rodov, Tower-Like Torah Arks, the Tower of Strenght and the Architecture of the Messianic Temple, „Journal of the Warburg and Courtauld Institutes" 2010, Vol. LXIII, s. 65-89.

${ }^{113}$ Szczegółowe rozwinięcie tej symboliki w podrozdz. 4.3.

${ }^{114}$ Istnieją dwa udokumentowane przykłady. Tobias Lamey zwraca uwagę na rozwój synagog od takiej wolnostojącej formy. Miała ona trafić do Polski i zostać tutaj rozpowszechniona przez Ży- 


\section{Synagoga}

dów sefardyjskich, których skupiska były w Zamościu i Lwowie (synagoga Złotej Róży). W wypadku Zamościa autor opiera swoją teorię na bimie w formie cyborium ze szkicu prof. Wiktora Zina i zdjęciu wykonanym po odsłonięciu fundamentów bimy w trakcie badań archeologicznych, na którym widać fragmenty murów ściany wschodniej, ośmiobocznej w zarysie bimy, usytuowanych na fundamentach. Fragmenty te były elementami, które stanowiły prawdopodobnie dalszą część podstawy owej bimy. Można je uznać za słupki ze względu na znajdujący się między nimi otwór. Oznacza to, że przypuszczalnie w tym miejscu umieszczono, zamurowaną później, genizę. Materiał ceglany odkryty w synagodze jest jednorodny, co musiałoby oznaczać, że przyjęta dla bimy forma cyborium powstała na narysie wydłużonego ośmioboku i została później powtórzona. Nic nie wskazuje, że przestrzeń między słupkami została uzupełniona w trakcie wznoszenia bimy, po $1788 \mathrm{r}$. Jak stwierdza Tobias Lamey, żadne z dotychczas przeprowadzonych badań nie wykazały, iż w synagodze Złotej Róży była bima w formie cyborium. Vide: T. Lamey, Zur Genese der „Stütz-Bimah”..., s. 289, 310; R. Pomarański, Zamość - Stare miasto. Synagoga. Sprawozdanie z nadzoru archeologicznego, Zamość 2010, mps WUOK w Lublinie, delegatura w Zamościu, sygn. 5391, s. 6.

${ }^{115}$ Przykładem takim niech będzie wzorowanie oratorium Germigny-des-Prés na kaplicy w Akwizgranie. Teodulf potwierdził takie konotacje w liście. Dla lepszego zrozumienia sposobu przenoszenia idei można dodać, że kaplica Teodulfa była dziewięciopolowym kwadratem, natomiast akwizgrański wzór miał narys szesnastoboku, z wewnętrznym układem słupów na planie ośmioboku. Vide: N. Pevsner, Historia architektury europejskiej, Warszawa 1976, s. 45-46.

116 Początku planu dziewięciopolowego można doszukiwać się już w starożytności. Prawdopodobnie po raz pierwszy został zastosowany m.in. w świątyni w Tel Lachisz (XIV w. p.n.e.), w której największa była sala dziewięciopolowa. Sanktuaria świątyni Ramzesa II w Karnaku i Ramzesa III w Medinet Tabu (XIII-XII w. p.n.e.) były założone również na takim planie. W architekturze pre-helleńskiej można odnaleźć podobne rozwiązanie, np. megaron w Tirynsie (XI-XII w. p.n.e.). Forma planu dziewięciopolowego była często stosowana w państwie Achaemidów (VI-IV w. p.n.e), na obszarach Suzy i Persepolis, w architekturze zarówno rezydencjalnej, jak i tej o charakterze sakralnym. Należą do niej świątynie w Kūh-i Khajeh i Oxus at Takht-i Sangīn datowane na II-III w. p.n.e. Przykładem z terenu Gruzji jest świątynia Dedopolis Mindori z II-I w. p.n.e. Z II w. n.e. pochodzi sala świątyni Bard-i Naishanda w Chuzestanie, a z okresu 50-150 r. świątynia z Surkh Kotal w Afganistanie. Późniejsze pałace Nippur i Aszur wyposażone były w pokoje o proporcji prostokąta, które wewnątrz miały cztery kolumny dzielące je na niemal równe pola. Można by przytoczyć wiele innych przykładów zastosowania tego rozwiązania na obszarze Bliskiego Wschodu. Ważne jest jednak, że ten wzorzec został ostatecznie zmodyfikowany poprzez zwiększenie centralnego pola i wytworzenie kwinkunksa. Szczególnie widoczne było to w obrębie architektury bizantyjskiej, m.in. w monastyrze św. Gajene (630) w Armenii. Vide: P. Amiet, Art of the Ancient Near East, New York 1980, s. 476; E. Stern, Excavations at Tel Mevorakh: The Bronze Age, Jerusalem 1984, s. 472; S.E. Lakovidis, Late Helladic Citadels on Mainland Greece, Leiden 1983, s. 195; B. O'kane, The Nine-Bay Plan in Islamic Architecture: Its Origin, Development and Meaning, [w:] Studies in Honor of Arthur Upham Pope, red. A. Daneshvari, Costa Mesa 2006, s. 196, 200. 


\section{Synagoga}

117 Architektura cystern przy meczetach w X i XI w. była również wzorowana na planie dziewięciopolowym. Najwcześniejszym przykładem z obszaru obecnej Hiszpanii jest cysterna pod dziedzińcem wielkiego meczetu w Kordobie (X w.). Jej pola sklepione były krzyżowo i podzielone gurtami. Podobne rozwiązania zastosowano w cysternach w Granadzie i Maladze (IX/X w.). Vide: B. O'kane, The Nine-Bay Plan in Islamic Architecture: Its Origin, Development and Meaning, [w:] Studies in Honor of Arthur Upham Pope, ed. A. Daneshvari, Costa Mesa 2006, s. 196, 200.

${ }^{118}$ Należy wspomnieć również o wykorzystaniu planu dziewięciopolowego przy zakładaniu krypt. Podobnie jak w przypadku cystern, plan ten był niezwykle popularny głównie ze względu na sposób przesklepiania wnętrz o układzie halowym. W Polsce rozwiązanie takie zastosowano w krypcie pod wschodnim chórem katedry Hermanowskiej na Wawelu (konsekracja 1142) oraz w Wiślicy (poł. XII w.).

${ }^{119}$ Papież Juliusz II (1443-1513) zlecił to zadanie Donato Bramantemu (1444-1514). Bazylika została założona na planie kwadratu podzielonym na dziewięć pól, dzięki czemu uzyskano plan krzyża greckiego. Na skrzyżowaniu naw miała znajdować się kopuła. Koncepcję planu zaproponowaną przez Bramantego docenił Michał Anioł Buonarrotti (1475-1564), który kontynuował budowę od 1546 r.. Wprowadził do planu zmiany, które uczytelniły dziewięciopolowy układ i jednocześnie podkreśliły krzyż grecki. 


\section{SYMBOLIKA \\ DEKORACJI I WYSTROJU \\ XVI- I XVII-WIECZNYCH SYNAGOG \\ ZACHOWANYCH NA OBSZARZE WSPÓŁCZESNEJ POLSKI}

Architektura judaizmu opiera się na prostej formie architektonicznej oraz dekoracji, która „wraz z grą światła i cienia uzyskuje manifestacje tak dobrze znanego w historii Żydów kontrastu" [153, s. 84]. Światło w synagodze staje się szczególnie ważne, zwłaszcza od połowy XVI wieku. Pod wpływem traktatów kabalistycznych zaczyna się bowiem zauważać jego związek z emanacjami Boga, czyli sefirot. Światło naturalne rozumiane jest jako światło boskie [145, s. 124].

Rozwój sztuk plastycznych w społecznościach żydowskich był ograniczony. Powodu należy szukać przede wszystkim w zawartym w dekalogu, a dokładnie w drugim przykazaniu, zakazie: „Nie będziesz czynił żadnej rzeźby ani żadnego obrazu tego, co jest na niebie wysoko, ani tego, co jest na ziemi nisko, ani tego, co jest w wodach pod ziemią!" [137, Wj 20,4]. Zapis ten dotyczył nie tylko przedstawiania ludzi, ale również zwierząt, roślin i ciał niebieskich. Stanowił asumpt do toczącej się od średniowiecza dysputy co do zasadności stosowania dekoracji we wnętrzu synagogi [99, s. 56]. Zgodnie z Talmudem [173, Berachot 5b] pomiędzy modlącym się a ścianą nie powinno się znajdować nic [114, s. 174], co jest nawiązaniem do fragmentu księgi Izajasza ${ }^{120}$. Ściana natomiast nie stanowi bariery, ponieważ „nawet przegrody zrobione z żelaza nie oddzielą ludu Izraela od jego Ojca w niebie" [173, Sota 38b]. Jedną z wykładni halachicznych dotyczących stosowania dekoracji w synagodze podaje Majmonides, który stwierdza, że rozwiązaniem nie jest zakaz, ale to, co jest bardziej pożądane. Zakaz umieszczony w Talmudzie nie dotyczy, jego zdaniem, ubioru szafy na rodały, ale raczej elementów wyposażenia domu, natomiast sposobem na rozproszenie uwagi spowodowane patrzeniem na obraz jest odwrócenie od niego wzroku [114, s. 175]. Ważny jest zatem cel wizerunku. Odnosi się to przede wszystkim do malowideł ściennych i obrazów, które są rodzajem dekoracji, czyli przedmiotami artystycznymi. Malarstwo synagogalne czy parochet są natomiast elementami rytuału, dlatego zakaz ten nie może być do nich stosowany [25, s. 9]. Dekoracje roślinne, zwierzęce czy przedstawiające postacie ludzkie miały być odczytywane nie jako odzwierciedlenie elementów otaczającego świata, ale jako treści metaforyczne [135, s. 71]. Tematyka dekoracji, zwłaszcza przedstawień biblijnych, była społeczności żydowskiej dobrze znana, przez co nie przyciągała uwagi modlących się. Mimo to istniały pewne ob- 
ostrzenia co do treści, które wolno było przedstawiać, oraz elementów dekoracyjnych, które mogły znajdować się w synagodze ${ }^{121}$.

W kwestiach dotyczących wystroju synagog rabini reagowali dopiero w sytuacji, gdy członkowie gminy protestowali przeciwko obrazom. Stanowczo sprzeciwiali się przedstawianiu idoli, jak również umieszczaniu w synagogach symboli kultu innowierców. Prostesty poza samą tematyką dekoracji - często dotyczyły również osobistej darowizny dla synagogi, gdyż uważano, że może ona podważyć znaczenie wspólnoty [149, s. XXIV].

\subsection{Dekoracje wnętrz synagogi i ich symbolika}

Malowidła w synagogach starożytnych nie podlegały, jak się wydaje, obostrzeniom związanym z przytoczonym wyżej drugim przykazaniem. Są bogate i przedstawiają sceny z Pisma Świętego, w których dominują motywy figuratywne, geometryczne i roślinne. Najlepszym przykładem jest synagoga w Dura Europos (244-245) [112, s. 17]. Zanik dekoracji figuratywnych w synagogach nastepuje właściwie dopiero w VI i VII wieku, pod wpływem ikonoklastyki żydowskiej [25, s. 25]. Wyeliminowanie tematyki biblijnej było podyktowane głównie wykorzystywaniem jej przez religię chrześcijańską [99, s. 45]. Od średniowiecza do XVII wieku dekoracje wnętrz bożnic opierały się głównie na inskrypcjach [186, s. 74]. Świat zwierząt i roślin ${ }^{122}$ również nie stanowił ich motywu przewodniego ${ }^{123}$. Pojawiał się głównie na ilustracjach w hebrajskich manuskryptach [25, s. 23].

Różnorodność ornamentów i motywów już w starożytności była ogromna. W Dura Europos przestawiano owoce (pomarańcze, granaty), zwierzęta (żółwie, delfiny) oraz znaki zodiaku [25, s. 24]. Podobnie w synagogach wznoszonych w kolejnych wiekach w poszczególnych krajach opierano się na rodzimej faunie i florze. Elementy ozdobne, które pojawiały się w synagogach wznoszonych w kolejnych wiekach, pochodziły w dużej mierze z tego powstałego jeszcze w starożytności kanonu. Wykorzystywano motywy ustalone przed wiekami, gdyż były istotne nie tylko ze względów estetycznych, ale również ideowych i moralizatorskich. Zwracano uwagę na sposób ich rozmieszczenia w obrębie sali męskiej. Należało wybierać taki, który nie utrudniałby zgromadzonym Żydom skupienia w trakcie modlitwy ${ }^{124}$.

Od XVII wieku w synagogach zaczęły pojawać się przedstawienia figuratywne, co potwierdził rabin Krakowa Menachem Mendele Krochmal [25, s. 13]. Od XV wieku funkcjonował ruch żydowskich „ikonoklastów”. Prowadził działania, których celem było usuwanie, na polecenie rabinów, głów z malowideł ściennych (w synagogach w: Żydaczowie, Tykocinie i Kobryniu) [135, s. 71]. W okresie tym najbardziej popularnym motywem były nadal inskrypcje, które pokrywały, poza ścianami, również bimy (w synagogach w: Tykocinie, Łańcucie, Łęcznej). Były to zarówno teksty liturgiczne, sentencje z Biblii i Talmudu, modlitwa za panującego, jak i informacje ogólne, fundacyjne, jorcajtowe czy różnego rodzaju upomnienia [186, s. 90-95] 
Wspomnieć należy o stosowanym, zwłaszcza w XVII wieku, jednolitym podziale i kompozycji ścian [201, s. 191]. Wykształca się wówczas horyzontalny trójpodział ${ }^{125}$ ściany. Dolna część stanowiła cokół. Centralną część komponowano w formie arkadowania lub pasa dekoracji ramowych. W górnej natomiast znajdowały się okna. Pas arkadowania narzucał ramy dla tekstów modlitw, które umieszczano na ścianach ${ }^{126}$. W strefie okien wykonywano dekorację malarską i sztukatorską, która stanowiła kontynuację ornamentu sklepienia (w synagogach w: Zamościu, Szczebrzeszynie, Łańcucie, Orlej).

Szczególnym przykładem układu kompozycyjnego jest synagoga w Pińczowie. Jednorodny charakter wnętrza uzyskano poprzez podział ścian za pomocą identycznych nisz. Dekoracja ścian synagogi jest jednak zróżnicowana i wskazuje na brak całościowego zamysłu kompozycyjnego. Różnorodnej wielkości tablice z inskrypcjami nie tworzą jednorodnego układu. Inaczej jest w przypadku dekoracji przedsionka, gdzie wśród obramień w formie kobiercy, dostosowanych kształtem do architektury wnętrza, zostało namalowanych wiele zwierząt. Nieco podobne rozwiązanie zastosowano w synagodze tykocińskiej, z tą różnicą, że w synagodze pińczowskiej jest większa różnorodność fauny [186, s. 78], [188, s. 94].

Wnętrza synagog XVII- i XVIII-wiecznych charakteryzują się niezwykłym bogactwem form. To właśnie one dominują nad zewnętrzem [201, s. 192] pozbawionym dekoracyjnych i reprezentacyjnych fasad. Jedynymi elementami o cechach dekoracyjności były attyki, które stosowano niezwykle często do początku XVIII wieku [97, s. 52]. Motyw ślepej arkady, który pojawiał się w tej strefie na elewacji, przenoszono - jak wskazano powyżej - do wnętrza [201, s. 191] i wykorzystano do tworzenia horyzontalnych dekoracji ścian ${ }^{127}$. Wprowadzenie go w tej formie może być nawiązaniem do motywu stosowanego w architekturze rzymskiego teatru, rozpowszechnionej pod wpływem traktatów: Vignoli, Palladia, Scamozziego, a przede wszystkim Serlia.

Charakterystycznym elementem w architekturze bożnic zarówno drewnianych, jak i murowanych, zwłaszcza w XVIII wieku, były alkierze. Ich wzorcem poza architekturą rodzimą, jak wskazywał Kazimierz Mokłowski [120, s. 437-438], mogła być rekonstrukcja świątyni Heroda opisana w Misznie [93, s. 96].

W strefie cokołu umieszczano zwykle okienka do babińców. W synagogach w Łańcucie i Dukli są również małe nisze, które miałyby pełnić funkcję półek ${ }^{128}$ [185, s. 250]. Strefa cokołowa była zwykle monochromatyczna, choć w synagodze w Łańcucie została podzielone na dwa pasy. Pas górny uzyskał iluzjonistyczną artykulację w postaci namalowanych pilastrów.

Pas arkadowania wykorzystywano na inskrypcje. W bożnicach, w których brak było podziałów architektonicznych, teksty modlitw umieszczano dość dowolnie i oprawiano w malowane, ozdobne ramy. Obramienia tekstów na ścianach zdobione były różnorodnymi ornamentami geometrycznymi i roślinnymi. Dekoracja wykonywana była w oparciu o motywy kandelabrowe, a w zwieńczeniach stosowano kwiatony. Wprowadzano również iluzjonistyczne podziały architektoniczne [186, s. 76]. Ciekawym motywem były koliste bordiury, które stanowiły ramy dla tekstu (w synagogach w Pińczowie i Tykocinie oraz w synagodze Izaaka w Krakowie). 
Formy dekoracji obramień znacznie różniły się od siebie w zależności od miejsca i czasu powstania. Jak wskazuje Andrzej Trzciński, panele z modlitwami nawiązywały pod względem formy do stronic z ksiąg. Jednak o ile polichromia synagogi Izaaka w Krakowie bardziej odpowiadała stronom z renesansowych traktatów, o tyle dekoracja obramień tekstów synagogi w Tykocinie kojarzyła się ze stronicami hebrajskich manuskryptów [60, s. 230]. W gruncie rzeczy wszystkie formy stanowiły odwołanie do bram lub inaczej: do arkad lub edykułu.

Inskrypcje, zwłaszcza teksty modlitw, sytuowano na ścianach przede wszystkim ze względów utylitarnych [25, s. 18]. Sposób ich rozmieszczenia nie był jednoznacznie regulowany. Brano pod uwagę kierunek, w którym zwracano się w trakcie wypowiadania danej modlitwy. Lokalizacji przyświecały jednak przede wszystkim preferencje danej społeczności. Na przykład modlitwę na przywitanie szabatu (Lecha dodi) umieszczono w synagogach w Chorodowie czy Wyszogrodzie, w kierunku, w którym obracano się w trakcie jej odmawiania, a więc blisko wejścia na ścianie zachodniej [61, s. 91]. Ta sama modlitwa w synagodze w Tykocinie znalazła swoje miejsce w południowej części ściany wschodniej. Przy zmianie dekoracji górę brało przyzwyczajenie gminy, dlatego najczęściej teksty odświeżano i pozostawiano w swojej formie w tych samych miejscach ${ }^{129}$.

W XVII i XVIII wieku korzystano już swobodnie ze wszelkiego rodzaju motywów dekoracyjnych [99, s. 56]. Dotyczy to nie tylko synagog murowanych, ale i drewnianych, w których ornament był niekiedy jeszcze bardziej bogaty. Jak można sądzić, zarówno w jednych, jak i w drugich obiektach stosowano te same motywy oraz zasady lokalizowania dekoracji. Przedstawiane były zwierzęta, a nawet sceny rodzajowe. Bracha Yaniv [199] wskazuje, że źródłem dla palety przedstawień zwierząt w synagogach, zwłaszcza motywów umieszczanych w obrębie Aron ha-Kodesz, było Perek Szira ${ }^{130}$. Poza motywami zwierzęcymi na ścianach synagog znajdują się tablice ze świętymi tekstami, wyobrażenia naczyń i sprzętów służących kultowi świątynnemu. W szczególny sposób eksponowano tablice przykazań, menory i stoły na chleby pokładne [134, s. 67]. Przedmioty te były zarezerwowane jedynie dla kultu świątynnego, a ich przedstawienie w synagodze może wskazywać na dążenie do sakralizacji przestrzeni bożnicy. Jednym z działań w XVII i XVIII wieku było także polichromowanie dekoracji sztukatorskich, w tym opraw Aron ha-Kodesz oraz dekoracji bim.

Rozmieszczenie części dekoracji podlegało pewnym zasadom. Tablice przykazań zawsze lokalizowano na ścianie wschodniej, na lub nad Aron ha-Kodesz. Podobnie sytuowano dłonie w geście błogosławieństwa. Menora była zwykle po południowej stronie ściany wschodniej (w synagodze Izaaka) lub na ścianie południowej (w synagodze w Szczebrzeszynie). Stół na chleby pokładne znajdował się po stronie przeciwnej do menory, w północnej części ściany wschodniej (w bożnicy Kupa) lub na ścianie północnej (w synagodze w Szczebrzeszynie). W synagodze w Łańcucie menora i stół na chleby pokładne umieszczone są symetrycznie, po południowej stronie nadstawy bimy [186, s. 83]. Symbole Lewitów (dzban i misę) nie były przypisane do konkretnego miejsca. W synagodze w Zamościu znajdują się na spływie sklepienia na wschodniej ścianie, nad szafą na rodały, a w Szczebrzeszynie nad wejściem, na ścianie zachodniej. 
Równie bogato dekorowaną strefą w XVII i XVIII-wiecznych synagogach były sklepienia. Dekoracje, na przykład w synagodze włodawskiej i łańcuckiej, wykonywano w formie polichromowanej sztukaterii, nadając każdemu przedstawieniu znaczenie symboliczne. W formy ornamentu kalisko-lubelskiego, charakterystycznego dla synagog Zamościa i Szczebrzeszyna, ubrano typowe dla judaizmu motywy: stoły na chleby pokładane, menorę, Keter Tora.

Motyw korony, której forma i symbolika były rozwijane, pojawia się właściwie tylko w obrębie Aron ha-Kodesz. Pierwotnie korona miała być nawiązaniem do zer zahaw (złotego wieńca) [146, s. 462], wieńczącego Arkę Przymierza [137, Wj 25,11, 37,2]. W wyniku przekształcenia wieńca w oparciu o komentarze Rasziego (1040-1105) zaczęto stosować koronę jako atrybut zer zahaw. Efektem szeregu zmian symboliki tego motywu było przypisanie mu znaczenia korony Tory (Keter Tora).

Pierwszą synagogą, w której zastosowano koronę z odpowiednią inskrypcją jako symbol Keter Tora, jest synagoga w Norymberdze (1451) [146, s. 463 $]^{131}$. W tej formie korona pojawia się na szafie na rodały powszechnie do połowy XVIII wieku. Działanie to jest podyktowane wspomnianym już fragmentem traktatu Pirkej Awot (Sentencje Ojców): „są trzy korony: korona Tory, korona kapłaństwa i korona królewska; jednakże korona dobrego imienia przewyższa je wszystkie" (por. rozdz. 3). Keter Tora była powszechnie stosowanym symbolem wieńczącym arkę lub znajdującym się w jej górnej części. Zwykle flankowano ją za pomocą gryfów ${ }^{132}$, lwów lub orłów. Wszystkie te zwierzęta w obrębie szafy na rodały miały symbolizować cheruby, co jest odniesieniem do czterech istot pojawiających się w wizji Ezechiela [99, s. 3]. Cheruby symbolizowane były również za pomocą skrzydeł umieszczanych na Aron ha-Kodesz jak w synagodze w Łucku. Skrzydlata korona miała przywodzić na myśl - podobnie jak złoty wieniec - Arkę Przymierza [198, s. 73].

W XVII i XVIII wieku cztery korony opisane w Sentencjach Ojcó $w^{133}$ zostały przedstawione dwukrotnie. Oba przypadki dotyczą dwóch szaf na rodały, wzniesionych jedna po drugiej w synagodze w Wormacji.

Już w XVII wieku korony z traktatu Pirkej Awot zaczęto sytuować hierarchicznie ${ }^{134}$. Jednak dopiero od połowy XVIII wieku popularne stało się przedstawianie trzech koron, umieszczonych jedna nad drugą. Zmianie uległa również ich symbolika. Korona na najniższym poziomie, tuż nad drzwiami do szafy, znajdowała się zwykle nad dłońmi kapłana w geście błogosławieństwa i symbolizowała koronę kapłaństwa. Keter Tora była umieszczana zaś powyżej, nad tablicami przykazań. Na samej górze lokalizowano koronę królewską, wieńczącą postać dwugłowego orła [198, s. 82].

Orzeł, niezależnie od miejsca, które otrzymał w synagodze, symbolizował królestwo niebieskie [198, s. 77]. Dwugłowy orzeł rozumiany jako opieka Boga nad ludem Izraela [134, s. 314] był powszechny w synagogach Europy Wschodniej. Pochodził natomiast z Bizancjum i w średniowieczu został przejęty jako symbol władcy Świętego Cesarstwa Rzymskiego, a później rosyjskiego cara [198, s. 77]. W XVIII-wiecznych synagogach symbolizował Boga, a umieszczany w obrębie Aron ha-Kodesz wskazywał na odniesienia do tronu Boga 
[200, s. 283]. Dwie głowy były odzwierciedleniem dwoistego charakteru Boga: z jednej strony jego miłosierdzia, z drugiej zaś sprawiedliwości [151, s. 120]. Przedstawienie Najwyższego pod postacią orła było niezgodne z drugim przykazaniem. Nie później niż na początku XVIII wieku dwugłowy orzeł trzymający w szponach zwierzęta, zwykle zające ${ }^{135}$, był rozumiany jako symbol Boga, który pomści nieszczęścia narodu Żydowskiego [112, s. 455]. Inną interpretację tego przedstawienia proponuje Ilia Rodov. Autor wskazuje, że motyw ten symbolizował boską opiekę nad pojedynczym człowiekiem przedstawianym pod postacią zająca [151, s. 119].

Od XVI wieku dwugłowego orła umieszczano na drzwiach Aron ha-Kodesz. Dopiero wytworzenie wielokondygnacyjnych szaf na rodały doprowadziło do przesunięcia tego symbolu ku górze, na zwieńczenie.

Najwcześniej, bo w XV wieku, motyw dwugłowego orła zaczął być stosowany w synagogach zlokalizowanych na terenie Niemiec i przede wszystkim jako forma wieńcząca żyrandole [145, s. 92]. Związanie symbolu Boga ze światłem odpowiadało fragmentowi zawartemu u Izajasza ${ }^{136}$.

W malarstwie synagogalnym dwugłowy orzeł pojawia się po raz pierwszy na malowidle w przedsionku synagogi w Pińczowie (1695-1696). Do grupy bożnic, w której obecne było to przedstawienie, należą synagogi drewniane w: Zabłudowie (1712), Chodorowie (1714), Smotryczu (1746) [145, s. 87].

Na ikonografię stosowaną w synagogach w XVII i XVIII wieku z pewnością miały wpływ wojny, które zdziesiątkowały społeczność żydowską. Jej powolna odbudowa w duchu ruchów mistycznych, mesjanizmu i chasydyzmu decydowała nie tylko o obyczajach, ale również wystroju bożnic. Działo się tak za sprawą tekstów kabalistycznych, w których przedstawiano wzorce, w tym motywy eschatologiczne [197, s. 436]. Były to głównie wicie roślinne, fantastyczne stworzenia i zwierzęta, w tym przede wszystkim alegorie cnót związane z traktatem Pirkej Awot: „Bądź wytrzymały jak tygrys, a lekki jak orzeł, rączy jak jeleń, a silny jak lew, abyś mógł wypełnić wolę Ojca twego w niebiosach” [136, Pirkej Awot 5,20]. Wyłącznie w XVII wieku pojawiają się również inne zwierzęta: wieloryb, bawół [197, s. 437], lisy, zające, wiewiórki, bocian z wężem w dziobie [187, s. 94], lwy, wielbłądy, strusie [61, s. 96] czy wspomniane orły [60, s. 217], co związane jest z późnośredniowieczną tradycją artystyczną żydów aszkenazyjskich $^{137}$. W dekoracjach występują także stworzenia fantastyczne: jednorożec, gryf, smok. Zaczęto sięgać również po motywy przedstawiające stworzenia eschatologiczne: Lewiatana, Behemota czy Ziza, które można wiązać tak z „żydowskimi, jak i chrześcijańskimi średniowiecznymi i późnośredniowiecznymi manuskryptami i sztuką dekoracyjną" [60, s. 219]. Na przykład smok pojawiający się w synagogach był, podobnie jak w chrześcijaństwie, symbolem wiary w zniszczenie zła boską mocą [144, s. 84]. Był tym samym nawiązaniem do słów psalmu: „Będziesz stąpał po wężach i żmijach, a lwa i smoka będziesz mógł podeptać” [137, Ps 91,13].

Zwierzęta przedstawiane w bożnicach miały symboliczne znaczenie. Wyobrażały, jak już wspomniano wcześniej, między innymi cztery cnoty. Znaczenie przedstawień zwierząt w synagogach drewnianych wyjaśnił Max Grunwald ${ }^{138}$. Z przygotowanego przez badacza 
zestawienia wynika, że sowa symbolizowała mądrość, bocian pobożność, wiewiórka niewinność, słoń cierpliwość, królik zmysł domowy, natomiast niedźwiedzie wspinające się na drzewo po miód słodycz płynącą ze studiowania Tory [135, s. 72].

Lwy [147] ${ }^{139}$ były częstym motywem flankującym szafę na rodały lub tablice przyka$z^{2}{ }^{140}$. Stanowią swego rodzaju nawiązanie do pałacu Salomona [61, s. 56]. Lew był również symbolem Judy i Izraela [135, s. 72]. Motyw przedstawiający lwa pojawił się już na mozaice w synagodze w Beth-Alpha, a jego pierwowzoru można szukać we wcześniejszych rzeźbiarskich przedstawieniach w Kfar Nachum. Pary lwów, podobnie jak ptaków, jeleni lub innych zwierząt, były „typowym motywem żydowskiej heraldyki” [25, s. 22]. Bestie oraz drapieżne zwierzęta i ptaki, chwytające swoje ofiary, miały zwracać uwagę na uciemiężenie ludu Izraela [144, s. 63]. Za szczególnie wymowny uważany był motyw przedstawiający bociana (symbol pobożności) łapiącego węża (symbol szatana).

Dekoracje bożnic są efektem czerpania przez Żydów również z chrześcijańskich wzorców, do których należały na przykład wspomniane wyżej motywy zwierzęce: jednorożec i słoń, i za ich pomocą starali się przestawiać własne „legendy i historie” [60, s. 218]. Tomas Hubka przypuszczał, że dla żydowskich społeczności żyjących z dala od wpływów kontrreformacji i symboliki barokowej wprowadzanej przez kościół katolicki przedstawienia animalistyczne były narzędziem do przekształcenia żydowskiej komunikacji i symboliki.

Elementami dekoracyjnymi, które również pojawiały się w synagogach, były instrumenty muzyczne, na przykład: szofar, harfa, cytra, bębny, flet, cymbały [137, Ps 150,3-5]. Zwykle umieszczano je na ścianie wschodniej (w synagodze w Łańcucie) lub w jej sąsiedztwie. Dekorowano nimi również sklepienia (w synagodze Kupa w Krakowie) [186, s. 83]. Innym motywem wystroju malarskiego synagog były kotary, najczęściej lokalizowane na Aron ha-Kodesz. Być może miały one symbolizować zasłony składające się na Przybytek wzniesiony przez Mojżesza.

Jednym z najstarszych motywów dekoracyjnych były znaki zodiaku. Można było ich poszukiwać już w synagogach starożytnych (Beth Alpha, Hammat-Tiberias, Naaran), w których otrzymywały zwykle formę okręgu z umieszczoną w środku - pod wpływem kultury greckiej - postacią Heliosa [18, s. 179]. Na terenie Rzeczpospolitej znaki zodiaku pojawiają się od początku XVII wieku, ale najpierw w synagogach drewnianych, a dopiero z czasem również w murowanych. Zwykle umieszczano je na sklepieniach (prawdopodobnie w synagodze w Pińczowie [187, s. 101], Synagodze Przedmiejskiej we Lwowie [94, s. 320], a także w synagodze Remu w Krakowie) lub na ścianach, tak aby tworzyły fryz. Występowały również w innych konfiguracjach (w synagogach w Łańcucie i Kraśniku, a także w synagodze Kupa w Krakowie) [187, s. 82]. Jedno z najbardziej znanych i - niestety - nieistniejących przedstawień o tematyce związanej ze znakami zodiaku znajdowało się w synagodze w Chodorowie. Dekoracja ta nawiązywała do opisanego starożytnego motywu okręgu, jednak w centrum umieszczono dwugłowego orła zamiast Heliosa.

Wśród motywów zdobiących bożnice nie zabrakło również tych przedstawiających sceny biblijne. Najbardziej znane znajdują się w synagodze w Łańcucie. Większość z nich nie 
powstała w omawianym okresie, ale znacznie później - dopiero w XX w. Jak podaje Andrzej Trzciński, najstarszy motyw pochodzi z 2. połowy XVIII w. i jest zatytułowany „Nad rzekami Babilonu”. Podobnie jak datowany na 1760 rok motyw znajdujący się w synagodze w Przedborzu [152, s. 142] został zainspirowany treścią Psalmu 137. Dawid Dawidowicz podaje, że malowidła zdobiące synagogi Izaaka i Wysoką w Krakowie oraz Nachmanowicza we Lwowie w XVII wieku również stanowią nawiązanie do tematyki biblijnej. W synagodze Izaaka pojawiły się: zwierzęta w Arce Noego, jaskinia Machpela oraz motyw inspirowany wspomnianym już wersetem: „Nad rzekami Babilonu” [137, Ps 137,1]. W synagodze Wysokiej można podziwiać Hebron z jaskinią Machpela. Natomiast w synagodze Nachmanowicza, po obu stronach Aron ha-Kodesz przedstawiono odgrodzony balustradą ogród, w którym znajduje się wór skórzany z kwiatami, a całość uzupełnia podpis: „Jeruzalem, jeśli zapomnę o tobie, niech uschnie moja prawica!" [137, Ps 137,5].

Jerozolima jako temat przewodni motywów lokalizowanych zwykle na ścianie zachodniej stała się w XVIII wieku istotna. Działo się tak ze względu na midraszowe przedstawienia Ziemi Świętej jako centrum wszechświata. Pojawiały się więc porównania do tęczówki oka, pępka czy kamienia węgielnego [152, s. 139]. Sam fakt wykorzystywania tego tematu na ścianie zachodniej miał swoje korzenie w kabalistycznym odczytywaniu Jerozolimy jako synonimu najniższej z sefirot - sefiry Malchut. Związek sefiry Malchut z zachodem pojawia się w Pardes Rimonim (Sadzie granatów) autorstwa Mojżesza Cordovero [152, s. 140].

\subsection{Bima-podpora - wystrój i symbolika}

Pod koniec XVI wieku miejscem w synagodze, na którym głównie skupiała się uwaga, było centrum sali męskiej. Tutaj pojawił się bowiem nowy element - bima-podpora - któremu starano się nadać odpowiedni wyraz artystyczny.

W XVII wieku bimy były flankowane kolumnami. Z XVIII wieku pochodzi tylko jeden przykład bimy kolumnowej - bima w bożnicy w Łańcucie. W tego rodzaju bimach zwieńczane były kapitelami korynckimi (w synagogach w Przemyślu i Tarnowie) lub jońskimi (w synagodze Starej w Rzeszowie), na których lokowano bezpośrednio impost (w synagodze w Łęcznej). W latach 20. XVII wieku popularne stają się ośmioboczne filary podtrzymujące bimę-podporę (w synagogach w: Łucku, Pińsku, Słonimie, Tykocinie, Nowogródku, Przeworsku, Dukli, Przysusze). Od 4. ćwierci XVII wieku zaczęto stosować filary kwadratowe o różnym profilowaniu. Ścięte narożniki pojawiły się w bożnicach w Bychowie Nowym i Żmigrodzie Nowym. W Lubomlu zostały zaokrąglone, a w Rymanowie zastosowano najczystszą formę kwadratu.

Dekoracje bim z omawianego okresu zwykle opierały się na układzie elementów architektonicznych, które uzupełniano polichromiami przedstawiającymi motywy roślinne, zwierzęce, geometryczne i inskrypcje, a dopiero w XX wieku motywami nawiązującymi do Biblii. 


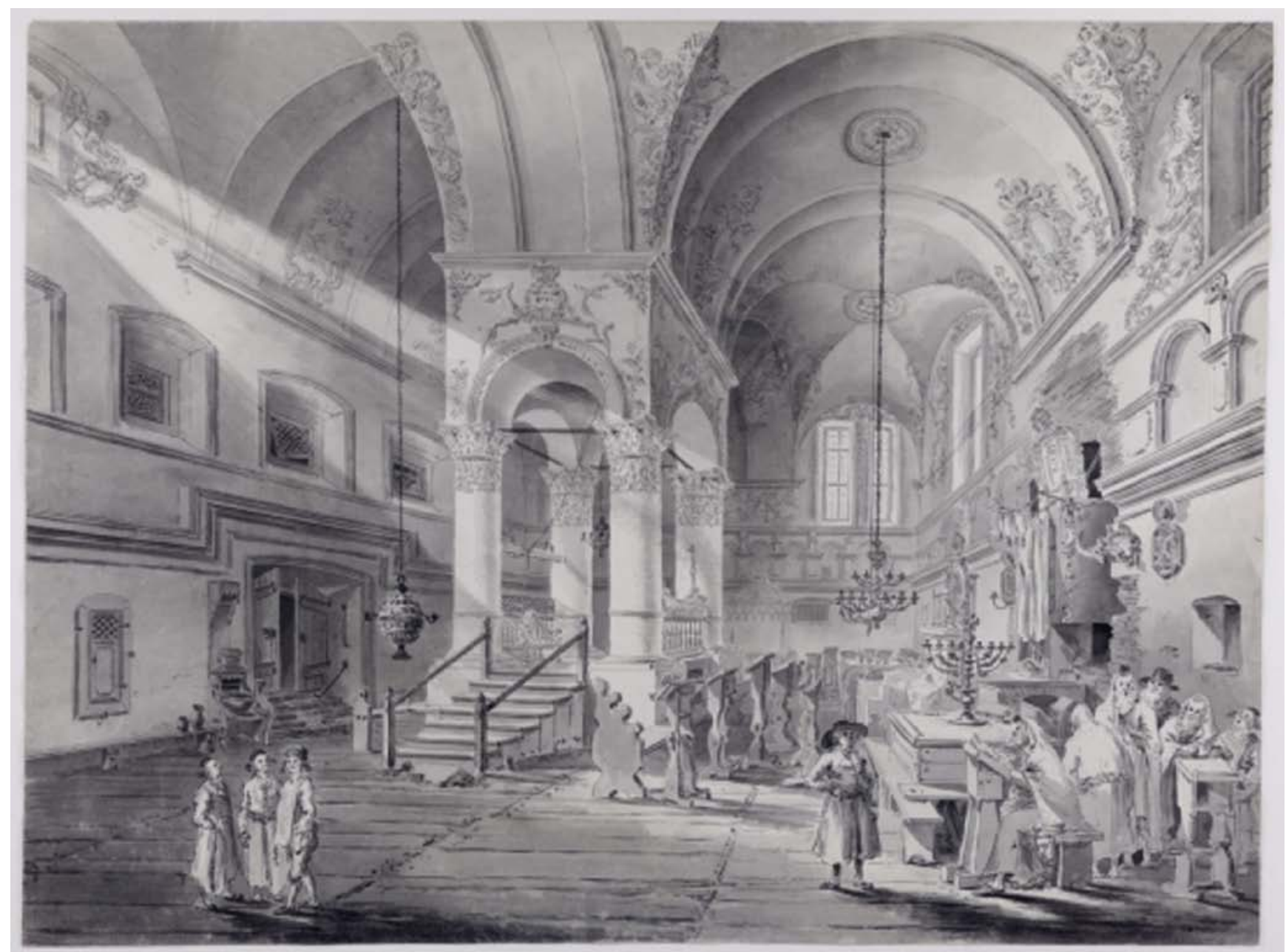

Il. 4.1. Wnętrze synagogi w Łańcucie [31]

W synagodze w Przemyślu w XVIII wieku wykonano dekoracje bimy w formie wici roślinnej, sklepienie sali pokryto wstęgowo-cęgową bordiurą, a kolumny marmoryzacją. Rozwiązania z tego samego okresu zdobiły również kolumny bimy w synagodze Starej w Rzeszowie. Nadstawa była bogato dekorowana wiciami roślinnymi, natomiast między gzymsami wykonano fryz z motywem meandra. Podobny fryz, jednak w technice sztukatorskiej, zastosowano na bimie $\mathrm{w}$ synagodze $\mathrm{w}$ Łucku. $\mathrm{W}$ obiekcie pojawiły się motywy roślinne, $\mathrm{w}$ tym także dekoracje kandelabrowe.

Za pomocą motywu kandelabrowego udekorowano również słupy synagogi w Słonimiu. Wnętrze czaszy bimy zostało ozdobione sztukatorsko wicią roślinną. Wśród plątaniny dekoracji można wyróżnić kilka dobrze widocznych motywów fleur-de-lis.

W Tarnowie pendentywy w sklepieniu bimy wypełniały sztukaterie przedstawiające hiacynty. W Łęcznej na sklepieniu wykonano geometryczną dekorację w typie kalisko-lubelskim, a arkady podzielono na prostokątne pola i w każdym umieszczono sztukatorską rozetę.

Dekoracja bimy w Łańcucie pierwotnie była dość skromna. Ówczesne wnętrze bożnicy można zobaczyć na jedynej dziś istniejącej rycinie z 1797 roku, wykonanej przez Zygmunta 

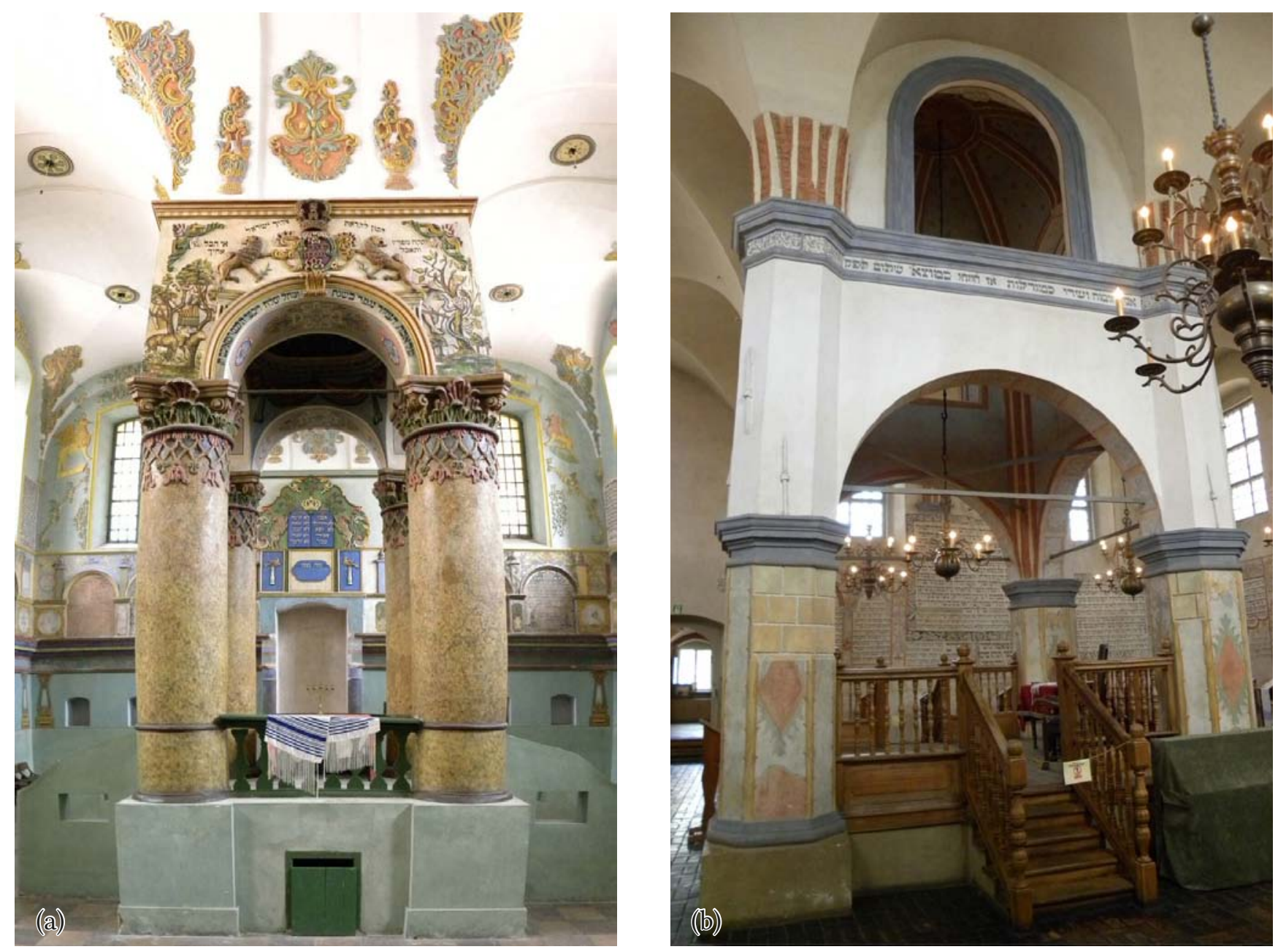

Il. 4.2. Zachodnia ściana bimy w Łańcucie (a) i południowa ściana bimy w Tykocinie (b) [21]

Vogla (il. 4.1). Na czterech ścianach nadstawy umieszczone były ornamenty roślinne. Prawdopodobnie w centrum każdej ze ścian znajdowały się pary zwierząt trzymające ukoronowaną plakietę, której krawędzie zdobiła wić roślinna. Wewnątrz kartusza widoczna jest inskrypcja. W XX wieku dekoracje bimy zastąpiono motywami biblijnymi, wykonanymi w technice stiuku (il. 4.2a). W centrum każdej ściany nadstawy pojawiły się również dekoracje podobne do tych pierwotnych.

Na bimie w Tykocinie (il. 4.2b) wykonano podobnie powściągliwą dekorację, a odzwierciedleniem etapów jej powstawania są ornamenty widoczne na filarach. Część najstarsza, jak się wydaje XVII-wieczna, przedstawia iluzjonistyczne boniowanie. Część późniejsza, prawdopodobnie XVIII-wieczna, została oparta na geometrycznym podziale z podkreśleniem krawędzi słupa opaską, stylizowaną na formę trzciny lub pień palmy daktylowej. Na czterech ścianach każdego słupa znajdują się owoce, wiszące na rozciągniętej między pniami szarfie. Sklepienie bimy zostało pomalowano na kolor niebieski i ozdobione gwiazdami.

Dekoracja nadstawy jest nad wyraz skromna. Zastosowano monochromatyczny układ dwóch odcieni błękitu, przy czym ciemniejszy posłużył do podkreślenia gzymsów. W górnym 
pasie usytuowano fryz, na który składają się głównie inskrypcje. Umieszczone na bimie, wyrażają szeroko pojęte odniesienia do wieży i baszty: „Jego król to wieża pomocy” [129, s. 105], „Imię Pana jest mocną wieżą” [137, Prz 18,10]. Wskazują na to również fragmenty Pieśni nad Pieśniami Salomona: „Szyja twoja jak wieża Dawida” [137, Pnp 4,4] czy „Murem jestem ja, a piersi me są basztami” [137, Pnp 8,10].

Na podobną symbolikę za Rachel Wischnitzer wskazują Maria i Kazimierz Piechotkowie [134, s. 76]. Słowa Pieśni Salomona utożsamiane są z migdal etz ${ }^{141}$ [194, s. 29], a więc z podestem, z którego Ezdrasz odczytywał słowa Tory [99, s. 21].

Symbolizm tego elementu był niezwykle rozbudowany. Najważniejsze jest odniesienie do mistyki Merkawy, a więc tronu Boga opisywanego w wizji Ezechiela [134, s. 76]. Jest to ciekawe porównanie, mające swoje korzenie w wyobrażeniu nieba składającego się z 7 pałaców (komnat) niebiańskich. Ostatni z pałaców jest pomieszczeniem, w którym znajduje się tron z siedzącym na nim Bogiem. Zastanawiające jest, skąd takie ujęcie symboliczne tego elementu, zwłaszcza w kontekście tego, że „św. Hieronim w jednym ze swoich listów mówi o żydowskiej tradycji zakazującej studiowania początku i końca Księgi Ezechiela przed ukończeniem trzydziestego roku życia" [161, s. 55]. Symbolika ta staje się jednak zrozumiała, jeżeli uwzględni się w kontekście znaczenie tronu Boga i przesłanie, jakie niesie. Wgłębienie się w wizję Merkawy nie ma na celu poznania istoty Boga, ale raczej obserwowanie Boga siedzącego na tronie. „Świat Tronu [...] jest „pleroma” („pełnią”), świetlistym światem boskości ze wszystkimi jej potęgami, eonami i zwierzchnościami” [161, s. 57]. Wydaje się, że podobnie jest w przypadku bimy: stanowi kanał, którym Szechina przenika do wnętrza synagogi. W Zoharze pojawia się informacja o czterech filarach zlokalizowanych w centrum i łączących poszczególne pałace niebiańskie. Forma ta opisana została przez Rabbiego Szymona: „każda para filarów określała jedną ze stron świata i stanowiła kanał, przez który sączyło się światło nieskończoności” [126, s. 50] i którym modlitwy oraz duchy wędrowały do Boga [61, s. 149].

Rozwijając dalej symbolikę bimy odnoszącą się do tronu Boga, należy zwrócić uwagę na Sefer fecira pełną równie tajemniczych opisów świata, jego stwarzania za pomocą sefirot i liter alfabetu hebrajskiego. W tekście uwagę przykuwają przede wszystkim stworzenia zamieszkujące świat Merkawy. Gershom Scholem przypuszcza, iż istnieje związek, narzucony przez autora Księgi Stworzenia, między opisanymi przez Ezechiela chajot (czterema istotami podtrzymującymi Merkawę) a sefirot [161, s. 91]. Podążając tym tokiem rozumowania, przyjmowaną liczbę chajot można byłoby wyjaśnić jako nawiązanie do na przykład czterech pór roku czy czterech okresów w życiu człowieka, którymi są dzieciństwo, młodość, dojrzałość, starość. Czwórka może wyrażać fazowość, proces, następstwo, dzieli też przestrzeń na cztery strony świata, a ruch i materię na cztery żywioły [190, s. 22]. Nasuwa się więc skojarzenie czterech filarów bimy z czterema Istotami Żywymi Wozu Tronowego Wszechmogącego, czyli chajot [61, s. 145], będącymi cherubinami.

Odpowiedzi na pytanie dotyczące symboliki bimy należałoby szukać również w księdze Zohar. Pojawia się tam motyw tronu, który pełni zupełnie inną funkcję: ma moc niemal 
stwórczą [78, s. 19-20]. W opowieści o kamieniu węgielnym można przeczytać, że stwarzając świat, Święty, oby był Błogosławiony, wyjął drogi kamień spod tronu i rzucił go w otchłań. Tym sposobem czubek kamienia stał się centrum świata (łac. axis mundi), a świat powstał i trzyma się wokół niego. W kontekście tej opowieści centrum świata stanowiła góra Synaj, bo to ona okazuje się owym kamieniem węgielnym. Jednak gdyby chcieć wiązać bimę z symbolem tronu Boga, wówczas należałoby powiedzieć, że po zburzeniu świątyni każda gmina posiadałaby swoje małe axis mundi w postaci bimy stanowiącej centrum sali męskiej.

Tobias Lamey neguje koncepcję przedstawiania bimy jako wydrążonego słupa będącego kanałem, którym modlitwy docierają do Boga [108, s. 374]. Zakorzenienie bimy w formie baldachimu ma według niego swoje początki w chupie [24, s. 36]. Twierdzenie takie pojawia się już wcześniej u Dawida Dawidowicza, jednak w przeciwieństwie do tego autora Tobias Lamey przedstawia argumenty na poparcie swojej koncepcji.

Chupa jest formą baldachimu składającego się z fragmentu materiału wspartego na czterech słupkach. Stoi pod nim młoda para, której jest udzielany ślub. Forma ta ma swoje uzasadnienie religijne, jednak nie w odniesieniu do bimy w synagodze [108, s. 352]. Zasadniczą kwestią jest określenie powodu stosowania baldachimu nad bimą. Pomocna w tym względzie ma być napisana w 1540 roku w Safedzie pieśn Lecha dodi, śpiewana na powitanie szabatu (kabbalat szabat): „Przyjdź, mój ukochany naprzeciw Oblubienicy - powitajmy Szabat” [119, s. 15]. W myśl refrenu tej pieśni Oblubienica (Szabat) spotyka się z ukochanym (ludem Izraela). Szabat jest utożsamiany z żeńskim aspektem Boga - Szechina [108, s. 352]. Podstawą jest rozumienie sacrum i profanum w kontekście obecności Szechiny w trakcie szabatu [42, s. 188]. Generalną zasadą było rozróżnianie między męskim a żeńskim aspektem Boga. Tetragram był związany z sefirą Tiferet, czyli aspektem męskim, i Elohejnu z sefirą Malchut, czyli aspektem żeńskim [64, s. 402].

Interpretacja bimy w nawiązaniu do Lecha dodi nastręcza jednak kilku problemów. Podstawowym jest fakt, że pieśń ta dotarła do Polski w 2. dekadzie XVII wieku, co oznacza, że w przypadku synagog w Łucku czy Rzeszowie czas na wytworzenie się odpowiedniego wzorca był zbyt krótki. Ponadto Tobias Lamey zwraca uwagę, że obie miejscowości były raczej podrzędne, chociażby ze względu na fakt nieposiadania jesziwy [108, s. 353] (wyższej szkoły talmudycznej).

Ze względu na podstawy rozumienia szabatu jako królowej [173, Szabat 119a] lub panny młodej [173, Baba Kama 32b] nie można wykluczyć, że Polscy rabini w XVI wieku wypracowali podobną symbolikę lub że samo Lecha dodi trafiło do Polski jeszcze przed końcem XVI wieku.

W rozważaniach na temat symboliki chupy i jej źródeł nie można nie uwzględnić zupełnie innego źródła wiążącego oblubienicę z Torą, a nasuwającego się w kontekście kompozycji wnętrza sali modlitw. We fragmencie Zoharu przedstawione zostało mistyczne znaczenie wersetu: „Mojżesz wszedł w środek obłoku i wstąpił na górę” [137, Wj 24,18]. Według tej interpretacji Mojżesz przyodziany w tęczę [137, Rdz 9,13] wstępuje, by otrzymać Torę utoż- 
samianą z dziewicą. Jak podaje Moshe Idel, „wkracza on [Mojżesz] w obłok - ewidentnie symbol żeńskości - podobnie jak kochanek musi wejść do pałacu, aby stać się mistycznym mężem Tory" [64, s. 408]. We fragmencie tym widoczne są silne aluzje seksualne. Podobnie jest w Zoharze, gdzie Mojżesz określany jest jako małżonek Szechiny [64, s. 409].

Wydaje się, że symbolika bimy-podpory jako chupy w odniesieniu do interpretacji przedstawionej w Zoharze, która wiąże szabat z oblubienicą, nie deprecjonuje znaczenia bimy-podpory jako zoharycznego symbolu łącznika pałaców niebiańskich. Wspólnym elementem obu tych przedstawień jest Szechina, która pojawia się pod czaszą bimy. Drogi jej przybycia są prawdopodobnie w obu przypadkach inne, jednak cel zostaje ukryty w uświęceniu przestrzeni bożnicy poprzez obecność Szechiny w trakcie szabatu [42, s. 188].

\subsection{Aron ha-Kodesz - analiza dekoracji i form z okresu XVI-XVIII wieku}

W wystroju synagogi najważniejszą rolę odgrywała szafa na rodały. Jej forma nawiązywała do bramy, przez którą modlitwy trafiają przed tron Boga [150], [198]. Otrzymywała formy i wystrój charakterystyczny dla danej epoki. Szafa na rodały była uświęcona obecnością Tory i przywodziła na myśl Arkę Przymierza. Podobnie jak w Arce Przymierza w świątyni przechowywane były kamienne tablice z zapisanymi Dziesięcioma Przykazaniami, tak w arce w synagodze umieszczano rodały [149, s. 90].

Przez długi czas czerpanie z dorobku starożystnego przy wznoszeniu synagog było niemożliwe, ponieważ architekturę Rzymu postrzegano jako sztukę narodu, który zniszczył Jerozolimę i dał początek chrześcijaństwu. Powrót do wzorców starożytnych stał się możliwy dopiero w XVI wieku. Wnękę, zwykle o wykroju półkolistym, ujmowano w pary kolumn, które miały symbolizować Jachim i Boaz. Właściwie każda z kolumn przy szafie na rodały mogła być rozumiana w ten sposób [148, s. 202]. Całość zwieńczano naczółkami z tympanonami o różnych formach. Rozpropagowanie wzorców takich rozwiązań w XVI i XVII wieku, podobnie jak rozbudowanych struktur nawiązujących do retabuli ołtarzowych w XVIII wieku, było możliwe dzięki wydawanej w tamtym czasie literaturze [196, s. 50-53] ${ }^{142}$. Stanowiła ona inspiracje przy tworzeniu nadstaw ołtarzy i Aron-ha-Kodesz.

W Polsce forma edykułu dla szafy na rodały pojawiła się w XV wieku [149, s. 81] za sprawą włoskich Żydów, dzięki którym doszło do legitymizacji i adaptacji modeli rzymskich w architekturze bożniczej [197, s. XIX]. Obiektem, który oddziaływał szczególnie na formy Aron ha-Kodesz, była szafa bożnicy Starej w Krakowie [143]. Formy XVI-wiecznych Aron ha-Kodesz w synagogach w Polsce mają początek prawdopodobnie w synagodze Remu w Krakowie, a także w synagogach Starej i Wysokiej w Krakowie czy w synagogach w Szydłowie i Pińczowie. W synagogach Starej i Remu, a także w synagodze w Szydłowie pojawia się inskrypcja: „dzięki mnie królowie panują” [137, Prz 8,15], wzorowana prawdopodobnie na 
inskrypcji w bożnicy Pinkasa w Pradze. Nietypowym rozwiązaniem jest zwieńczenie szafy na rodały trójkątnym (zamkniętym) naczółkiem. Po raz pierwszy ten rodzaj naczółka pojawił się najpierw w synagodze Nachmanowicza we Lwowie, a następnie w bożnicy w Pińczowie. Stosowany jest jeszcze w 1 . połowie XVII wieku [149, s. 172].

W 2. połowie XVIII wieku widoczne jest znaczne zwiększenie rozmiarów szaf na rodały przy jednoczesnym zachowaniu ich proporcji w stosunku do wielkości sal męskich. Charakteryzują się one bogactwem ikonograficznym, niezwykłą plastycznością i tektoniką. Bracha Yaniv zwraca uwagę, że swoje formy zawdzięczają żydowskim artystom [197, s. 428] ${ }^{143}$.

Maria i Kazimierz Piechotkowie podkreślają, iż forma szafy na rodały, a właściwie jej podwyższenie w stosunku do audytorium, ma również swoje symboliczne znaczenie. Należy go upatrywać w tronie Salomona ${ }^{144}[134$, s. 68].

Na podest prowadziły schody złożone z sześciu stopni, zwykle zabezpieczone poręczami. Zdarzało się, że przed schodami instalowana była dwuskrzydłowa bramka [199, s. 14-20]. Liczba stopni nie była kwestią przypadku, ale prawdopodobnie zalecaniem zawartym w Zoharze [83, s. 253]. Podobną liczbę stopni zaczęto przyjmować również przy kształtowaniu bim, choć zasadniczo powinny być umiejscowione niżej niż szafa na rodały ${ }^{145}$. Wyniesienie powyżej poziomu sali męskiej nie wynikało z żadnych aspektów funkcjonalnych, tak jak to miało miejsce w przypadku bimy. Chodziło przede wszystkim o podkreślenie istoty szafy na rodały i wytworzenie pewnego centralnego punktu [197, s. 431].

W tamtym czasie konstrukcja szafy na rodały nie oparła się wpływowi mistycyzmu i chasydyzmu, w których niezwykle istotne było odpowiednie jej zwieńczenie, zwłaszcza wtedy, gdy była rozumiana jako Arka Przymierza, a synagoga jako „mała świątynia” [197, s. 438 $]^{146}$. Ewolucja tego poglądu spowodowała zrównanie istoty Arki Przymierza i tronu Boga znanego z Wizji Ezechiela i Księi feremiasza. Symbolika ta jest widoczna na początku XVII wieku, a fizycznym jej przejawem jest dekoracja drzwi szafy na rodały w Szydłowie. Również Mojżesz Isserles zwraca uwagę na symbolikę tronu chwały [197, s. 446]. Tron chwały utożsamiony został z tronem salomonowym, którego symbolikę przywołano wyżej, i to utożsamienie stanowi wytłumaczenie liczby stopni przed szafą na rodały. Również z literatury zawierającej opisy tronu chwały wynika półkoliste zamknięcie wnęki na rodały. Te elementy wraz z symbolem orła nad Aron ha-Kodesz jednoznacznie przywodzą na myśl Boga siedzącego na tronie.

Z pewnością trudno jest mówić o udziale Żydów przy wznoszeniu synagog murowanych. Te powstałe w okresie od XVI do XVIII wieku w większości były dziełem chrześcijan. Inaczej było w przypadku synagog drewnianych, zwłaszcza tych XVIII-wiecznych, które zostały nie tylko wzniesione, ale również wyposażone przez żydowskich rzemieślników, w tym stolarzy, snycerzy i złotników [25, s. 22], [197, s. 428]. Podobnie z pewnością było z dekoracją synagog, gdyż to żydowscy artyści byli odpowiedzialni w połowie XVII i XVIII wieku za obrazy i teksty hebrajskie w synagogach [196, s. 34], co zadecydowało o niezależności ideowej tej sztuki [25, s. 54]. 


\subsection{Kolory i ich znaczenie symboliczne}

Kolor w tradycji żydowskiej odgrywał ważna rolę. Pierwszą wzmianką na temat koloru jest opis tęczy, którą Bóg umieścił na niebie jako znak przymierza i obietnicy zachowania życia po potopie [137, $\operatorname{Rdz} 9,13-17]$.

Język hebrajski zastosowany w Biblii nie zawierał słowa, które opisywałoby właściwość światła powszechnie określaną mianem koloru [180, s. 174]. Dlatego w celu porównania dwóch obiektów pod względem barwy stosowano słowo ajin (hebr. עין - oko) [137, Kpł 13,55; Lb 11,7; Prz 23,81; Ez 1,4. 7. 16. 27; 8,2; 10,9; Dn 10,6], lub mar'e (hebr. מראה - wygląd)[ Ez 11,3]. Pojawiały się również wyrażenia, które miały na celu określenie natężenia koloru, czyli jednocześnie jego odcieni ${ }^{147}$. W niektórych miejscach Biblii pojawiają się jednak określenia kilku kolorów, które posiadają swoje jednoznaczne nazwy: lawan (hebr. לבן - biały ${ }^{148}$ ), adom (hebr. אדום - czerwony ${ }^{149}$ ) i jerek (hebr. ירק - zielony ${ }^{150}$ ). Odcienie kolorów podstawowych opisywano za pomocą stopnia jasności i ciemności. W odniesieniu do pozostałych posługiwano się nazwami obiektów, od których pochodziły.

Słowo lawan występuje między innymi w opisach koloru kozy [137, Rdz 9,13-17], zębów, manny [137, Wj 16,31], odzieży [137, Koh 9,8]. Stosowane były również określenia odnoszące się do odcieni bieli: mlecznobiały [137, Rdz 49,12], biel nasion kolendry [137, Wj 16,31], śnieżnobiały [137, Lb 10,10; 2 Krl 5,27; Ps 68,15; Iz 1,18], blada biel [137, Kpł 13,39]. Słowo szachor (hebr. שחור) [137, Kpł 13,31. 37], które oznacza ciemność, reprezentuje natomiast czerń.

Określenie koloru czerwonego (adom) związane jest prawdopodobnie ze słowem oznaczającym krew (dam) [137, $2 \mathrm{Krl}$ 3,22; Iz 63,3], a pojawia sie w opisie jałówki [137, Lb 19,2]. Służyło ono ponadto do określania karnacji [137, Rdz 25,25; 1 Sm 16,12], plam i owrzodzeń na ciele trędowatego [137, Kpł 13,19. 24. 42], a także barwnika skóry [137, Wj 25,5].

Słowo jarok określa kolor między zielenią, żółcią i błękitem, charakterystyczny dla roślinności zarówno tej w rozkwicie [137, Hi 39,8; 2 Krl 19,26; Iz 37,27], jak i więdnącej [137, Pwt. 28,22].

W Biblii pojawiają się również nazwy dwóch pigmentów: szkarłatu i purpury. W trakcie urządzania Przybytku wykorzystano natomiast zasłony w kolorze techelet ${ }^{151}$ (hebr. תכלת niebieska purpura), aregaman ${ }^{152}$ (hebr. ארגמן - czerwona purpura) i szani (hebr. שני - szkarłat) [137, Wj 26,1].

Poszczególne kolory miały określone znaczenie. Kolor czarny lub ciemny miał przywodzić na myśl nieszczęście [137, 2 Sm 19,24; Zach 6,6]. Kolor biały oznaczał czystość [137, Iz 1,18; Ps 2,9] i radość [180, s. 178]. Kolory czerwony symbolizował rozlew krwi lub grzech [137, Iz 1,15. 18; 63,1]. Czerwona purpura wiązana może być z władzą królewską i wynikającą z niej chwałą [137, Sdz 8,26; Est 8,15; Dn 5,7]. Niebieska purpura wykorzystywana była, aby barwić cicit [137, Lb 15,38], a uzyskany kolor miał przywodzić na myśl wysoką godność członków ludu Izraela [180, s. 178]. Takie skojarzenie staje się tym bardziej zrozumiałe, że kolor ten opisywał niebo, które z kolei miało kojarzyć się z Królestwem Niebieskim [137, Rdz 
24,7; Ps 9,4]. W tym kolorze była również szata zewnętrzna arcykapłana, nakładana na białą szatę wewnętrzną [137, Wj 28,31].

Kolor pojawia się również jako istotny element w mistycyzmie żydowskim. W XIII wieku stał się podstawą kilku manuskryptów kabalistycznych, w których powtarzającym się elementem był diagram składający się z dziesięciu koncentrycznie ułożonych sfer ${ }^{153}$. Każda ze sfer odpowiadała jednej sefirze i była połączona z odpowiednim kolorem oraz wokalizacją Tetragramu [65]. Począwszy od zewnątrznej krawędzi okręgu w kierunku jego wnętrza kolory ułożone były w kolejności: Keter (korona) biała jak śnieg [64, s. 43], Chochma (mądrość) błękitna jak niebo, Bina (sąd) zielona jak tęcza, Gedula (majestat)/Chesed (łaska) w kolorze czystego srebra, Gewura (srogość) czerwona jak ogień, Tiferet (piękno) w kolorze bieli dążącej do czerwieni, Necach (zwycięstwo) w kolorze bieli dążącej do błękitu, Hod (chwała) w kolorze zieleni dążącej do czerwieni, fesod (fundament) w kolorze błękitu dążącego do czerni, Malchut (królestwo) w odcieniu czerni [64, s. 34]. Aby uzyskać dostęp do danej emanacji, należało wyobrazić sobie odpowiadący jej kolor lub przywdziać szaty w tym kolorze [180, s. 178]. I tak biały oznaczał pokój, miłosierdzie i litość, czarny utajenie przymiotów, czerwony okrucieństwo i sprawiedliwość. Ciekawe były również połączenia dokonywane dla uzyskania innego koloru, na przykład: kolor żółty składał się z czerwieni i bieli ${ }^{154}$, zielony z czerwieni, bieli (żółci) i błękitu, natomiast czerwona purpura była mieszanką wszystkich barw [180, s. 178].

Dekorację bożnic charakteryzowała niezwykła bogata paleta motywów, ale stosunkowo ograniczona paleta kolorów. Trudno jest jednak znaleźć informacje dotyczące kolorystyki wnętrz bożnic zarówno drewnianych, jak i murowanych z kilku powodów. Większość bożnic drewnianych została zniszczona w trakcie wojny, podobnie zresztą stało się z wnętrzami bożnic murowanych. Poza tym na etapie remontów prowadzonych po wojnie w celu restytucji synagog nie przeprowadzano zbyt dokładnych badań kolorystyki wnętrz. Zachowało się wprawdzie kilka przykładów dekoracji bożnic z XVII i XVIII wieku, trzeba jednak pamiętać, że część z nich jest efektem XIX- i XX-wiecznych przebudów.

Jeszcze w końcu XIX wieku badaczy zainteresowały polichromie bożnic drewnianych. Ich badania trwały około pięćdziesięciu lat, a więc do wybuchu II wojny światowej. Prace powstałe przed wojną lub zaraz po jej zakończeniu wskazują przede wszystkim na zastosowane motywy i ich symboliczne znaczenie [135, s. 65]. Jednym z najobszerniejszych opracowań była z pewnością publikacja Holzsynagogen in Polen [20], która poza opisem tematyki przedstawień zawiera również omówienie kolorystyki stosowanej w bożnicach ${ }^{155}$. Jako podkład służyły farby w kolorze białym lub ultramaryna [25, s. 61 $]^{156}$, a pigmenty były zawsze pochodzenia organicznego. Elelmenty dekoracyjne malowano zawsze w taki sposób, aby podkreślić ich kontury lub stworzyć duży kontrast między tłem a przedstawianym na nim motywie. Teksty modlitw pisano zwykle czarną farbą na białym tle, choć w synagodze w Tykocinie, na ścianie wschodniej przy Aron ha-Kodesz znajduje się malowany sepią, pochodzący z 1691 roku fragment modlitwy na święto Simchat Tora (Radość Tory). Polichromia w podobnym kolorze, a także inskrypcja w kolorze błękitnym zdobią wnętrze synagogi w Tarnogrodzie [111, s. 1]. 
Jedne z najstarszych polichromii znajdują się w synagodze Izaaka na krakowskim Kazimierzu. Choć zachowane są w bardzo złym stanie, można stwierdzić, jaki jest ich kolor i sposób malowania. Dekoracje wykonywano w formie konturowej. Bordiury, zwykle w kolorze czerwonym lub żółtym, wypełniało rozbielone, niebieskie tło, na które nanoszono inskrypcje w kolorze czarnym. Zachowały się również blado zielone lub blado niebieskie fragmenty, jednak są one bardzo rozmyte i ledwo widoczne. W podobnej kolorystyce utrzymane są zachowane fragmentarycznie XVII-wieczne dekoracje w synagodze Kupa i synagodze Wysokiej na krakowskim Kazimierzu.

W synagodze w Tykocinie zachowały się malatury z lat 20. XVII wieku. Ostatnie inskrypcje pochodzą natomiast z XIX wieku. Dekorację w bożnicy wykonano na bazie pobiały wapiennej, farbami temperowymi, klejowymi oraz w technice sgraffita [166, s. 3]. Zaliczana do najstarszych, bo pochodząca z 1691 roku, inskrypcja na ścianie wschodniej utrzymana jest w barwach sepii i ochry. Obramienia innych tablic wykonanych w XVIII wieku, utrzymanych zwykle w kolorze czerwonego ugru palonego lub captur mortuum wypełniano dekoracją w kolorach: ciemnej, stonowanej zieleni, żółci, błękitu. Tło bordiury stanowił rozbielony niebieski lub rozbielony szary. Na bimie zachował się biało-niebieski pas fryzu. Wnętrze sklepienia pomalowano na kolor błękitny oraz wykonano dekorację w postaci gwiazd. Aron ha-Kodesz posiada polichromię w kolorach: błękitu i błękitu pruskiego, żółci i pomarańczu, czerwieni i ciemnego brązu. Dekoracja ta pochodzi prawdopodobnie z 2. połowy XVIII wieku.

W przedsionku synagogi w Pińczowie zachowała się niezwykle bogata polichromia z XVIII wieku, z bladoniebieskim tłem i podziałami zaznaczonymi farbą w kolorach: sieny, czerwieni i żółci. Dekoracje zaczerpnięte ze świata flory i fauny utrzymane były w kolorach: bieli, żółci, czerwieni, zieleni i błękitu. Dekoracja w podobnej kolorystyce została wykonana w sali kahalnej.

Rekonstrukcji kolorystyki została poddana także część sztukaterii w synagodze w Zamościu. Dekoracja ta w większości została pomalowana na kolor czerwony, który dodatkowo uzupełniono warstwami malarskimi w kolorach: błękitu, zieleni i ugru.

W synagodze w Szczebrzeszynie zachowały się relikty warstw malarskich Aron ha-Kodesz. Do tej pory na belkowaniu można znaleźć takie kolory, jak: czerwień, czerń, ugier. Trudno jednak określić, z jakiego okresu pochodzą te relikty.

Wygląd dekoracji w synagodze w Lesku można próbować wyobrazić sobie na podstawie resztek polichromii ${ }^{157}$, które przetrwały II wojnę światową. Pilastry w pasie arkadowania miały kolor błękitny, natomiast wnęki utrzymane były w tonacji ciepłego brązu. Dodatkowo z opisu odkrywek [115, s. 2-3] wynika, że opaska półokrągłego otworu Aron ha-Kodesz miała kolor brązowy, podobnie jak otwory przebite później od strony północnej. Klucze w architrawach arkadowania miały kolor szary, a zwieńczenia pilastrów kremowy.

W bożnicy w Tarnogrodzie stwierdzono obecność inskrypcji w kolorach błękitnym i sepii. Obok tych dekoracji zachowała się szafa na rodały o dość bogatej kolorystyce. Bazy 
kolumn pomalowano na kolor szarozielony, profilowanie na zielono-brązowy, a trzony na kolor niebieski, podobnie jak fragment ściany za kolumną. W głowicach kolumn pojawiają się dwa kolory: zieleń i brąz. Impost posiadał dekorację kwiatową w kolorze zielono-brązowym na niebieskim tle. W zwieńczeniu Aron ha-Kodesz usytuowano dekorację malarską, na którą składały się zielono-brązowe gryfy, żółta Korona Tory i beżowo-biało-zielone dłonie w geście błogosławieństwa. Między gryfami umieszczono szaroniebieską wić roślinną [111, s. 8].

W ostatnich latach prowadzone były prace rekonstrukcyjne i konserwatorskie przy jednym z najstarszych, bo pochodzących z przełomu XVI i XVII wieku, malowideł w synagodze Remu na krakowskim Kazimierzu. Odsłonięto XIX-wieczne dekoracje sklepienia. Ich tło w kolorze kremowym zostało pokryte dekoracjami geometrycznymi i roślinnymi w kolorach: czerwonym, błękitnym i zielonym oraz ozdobione pozłacanymi elementami. Dodatkowo odkryto również pas ze znakami zodiaku pochodzący z XIX wieku.

W synagodze Starej na krakowskim Kazimierzu dekoracja właściwie się nie zachowała. Jedyną pozostałością jest fragment modlitwy El melech joszew al kise rachamim w tak zwanej sali śpiewaków. Ta dekoracja malarska przedstawiająca modlitwę jest zbiorem nawarstwień od XVII wieku [186, s. 71]. Choć patrząc na formę obramienia dekoracji w kolorze czarnym, która jest elementem najbardziej widocznym, można przypuszczać, że powstała w XIX wieku, podobnie jak identyczne formy w synagodze w Tykocinie.

Istnieją również fragmentaryczne opisy kolorystyki dekoracji bożnic drewnianych. $\mathrm{Na}$ ścianie zachodniej synagogi w Mohylewie (XVIII w.) znajdowały się dwa pawie w kolorze niebieskim, dwa wielkie lwy w kolorze oliwkowo-zielonym oraz dwie tarcze: jedna w kolorze ciemnozielonym, ozdobiona motywami roślinnymi i druga w kolorze biało-niebieskim [25, s. 46]. We wnętrzu synagogi dominował błękit, a uzupełniały go dwie barwy: bursztynowo-brązowa i biało-czerwona [25, s. 46]. W Chodorowie ornament roślinny został umieszczony na niebieskim i czerwonym tle [20, s. 51]. Podobna kolorystyka występowała w Jabłonowie.

Pewną kompilację wszystkich wymienionych do tej pory barw stanowiła kolorystyka dekoracji bożnicy w Gwoźdźcu. Teksty modlitw w kolorze czarnym umieszczono w medalionach i polach w kolorze białym. Tło dekoracji ze świata fauny i flory stanowiły dwa kolory: błękitny i jasnozielony. Czerwień i żółć wykorzystano do zaznaczenia podziału ramowego. Kolory te pojawiały się w wypełniających pola, niezwykle bogatych dekoracjach.

\subsection{Podsumowanie}

Pomimo drugiego przykazania Dekalogu Żydzi rozwinęli sztukę dekorowania bożnic. Bogactwo form dekoracyjnych i motywów figuratywnych charakteryzowało przede wszystkim synagogi starożytne. W okresie średniowiecza stosowane w nadmiarze ornamenty ustąpiły miejsca inskrypcjom, których pojawienie się w synagodze spowodowane było przede wszystkim kwestiami utylitarnymi. W XVI wieku nastąpił powrót do motywów nawiązu- 
jących do świata fauny i flory, co umożliwiło znaczne rozbudowanie formy i zwiększenie ilości elementów dekoracyjnych. Sprzeciwy rabinów i autorytetów halachiczych nie spowolniły działań na polu sztuki. Doprowadziły jedynie do określenia pewnych zasad co do sposobu rozmieszczania dekoracji oraz ograniczyły nieznacznie paletę motywów, która mimo to w XVIII wieku rozrosła się jeszcze bardziej.

Wiek XVII był czasem, w którym wykształciła się jednorodna kompozycja dekoracji ścian bożnic, oparta na horyzontalnym trójpodziale. Poza motywami ze świata przyrody centralną pozycję nadal zajmowały teksty liturgiczne, które malowano na ścianach. Sposób ich rozmieszczenia uwzględniał zwykle kierunek, w którym obracano się w trakcie ich odmawiania.

Formy dekoracyjne i bogactwo motywów stosowanych w salach męskich spowodowały zdecydowany wzrost znaczenia tych wnętrz w stosunku do elewacji bożnicy. Wśród najpopularniejszych przedstawień znajdowały się zwierzęta, wzorowane prawdopodobnie na zwierzętach z Perek Szira [199, s. 14-20]. Ściany dekorowano również elementami kojarzonymi ze świątynią: tablicami przykazań, sprzętami liturgicznymi, stołami na chleby pokładne, menorą i instrumentami muzycznymi. Nie mogły one być jednak rozmieszczane dowolnie, ale według szczegółowych zasad. Do istotnych motywów symbolicznych należały również korony, na przykład Keter Tora, oraz orły, wśród których zdarzały się również orły dwugłowe.

Na ikonografię XVII- i XVIII-wiecznych synagog mogły mieć wpływ ruchy mistyczne, mesjanizm i chasydyzm, czego uzasadnieniem byłoby pojawienie się w niej alegorii cnót, stworzeń fantastycznych i eschatologicznych. W 2. połowie XVIII wieku do dekoracji zostały ponownie wprowadzone znaki zodiaku. Coraz więcej miejsca poświęcano tematyce biblijnej oraz Ziemi Świętej, której obrazy, zgodne zwykle z Pardes Rimmonim, umieszczane były na zachodniej ścianie synagogi.

Poza ścianami dekorowano również szafy na rodały i bimy. W XVII wieku bimom towarzyszyły kolumny, które zwieńczano różnymi formami kapiteli. Od lat 20. XVII wieku bardziej popularne stały się ośmioboczne filary podtrzymujące bimę-podporę, a od 4. ćwierci XVII wieku zaczęto stosować filary kwadratowe o różnym profilowaniu. Architektoniczne formy bim uzupełniano polichromiami z motywami roślinnymi, zwierzęcymi, geometrycznymi i inskrypcjami, a w XX wieku również przedstawieniami tematów biblijnych.

Bimę rozumiano jako symbol wieży i baszty, który łączono z migdal etz. Symbolika tego elementu sali męskiej jest jednak niejednoznaczna. Przede wszystkim można go szukać w opisie Merkawy w wizji Ezechiela. Na podstawie mistyki rydwanu i w oparciu o opis sefirot w Sefer fecira cztery słupy bimy mogą zostać utożsamione z czterema cherubami lub z opisem kanału czy pustego słupa w Zoharze. Warto podkreślić, że zoharyczna wizja może przywodzić na myśl również symbol bimy jako axis mundi. Symboliczne znaczenie bimy ma również chupa. Ta metafora uzyskuje uzasadnienie w pieśni Lecha dodi. Zgodnie z takim rozumieniem bima stanowi baldachim, pod którym lud Izraela bierze za żonę Szabat (Szechinę). W obu symbolach bimy centralne miejsce zajmuje Szechina, która w trakcie liturgii w synagodze ma pojawić się pod czaszą bimy. 
Najważniejszym elementem sali męskiej jest z pewnością Aron ha-Kodesz symbolizujący bramę, przez którą modlitwy miały przechodzić do Boga. Forma i wystrój szaf na rodały były ściśle związane z epoką, w której powstawały. Nazewnictwo i pełniona rola mogą świadczyć o porównaniu ich z Arką Przymierza. Tę z kolei, w związku z zastosowaniem sześciu stopni przed Aron ha-Kodesz, zaczęto porównywać z tronem Salomona, a pod wpływem mistycyzmu również z tronem Boga.

W Polsce forma edykułu w kompozycji szaf na rodały została zaczerpnięta w XV wieku przez włoskich Żydów, dzięki którym doszło do legitymizacji i adaptacji modeli rzymskich w architekturze bożniczej. Obiektem, który oddziaływał na formę Aron ha-Kodesz w innych synagogach, była szafa bożnicy Starej w Krakowie.

W 2. połowie XVIII wieku szafy na rodały ulegaja zmianie: widoczne jest znaczne zwiększenie ich rozmiarów. Charakterystyczne staje się dla nich bogactwo ikonograficzne, niezwykła plastyczność i tektonika.

Wpływ Żydów na proces powstawania synagog jest trudny do ustalenia. Pewne jest, że bożnice murowane, pochodzące z XVI, XVII i XVIII wieku są dziełem budowniczych i artystów chrześcijańskich. Te drewniane, zwłaszcza XVIII-wieczne, zostały wzniesione i ozdobione w większości przez Żydów, co może dowodzić przynajmniej częściowej niezależności ideowej architektury i sztuki synagog [25, s. 54].

Jak wynika z analizy, kolorystyka zastosowana w bożnicach zlokalizowanych na terenie Polski nie została zaczerpnięta z tradycji biblijnej. Podobna jest jedynie paleta barw, oparta na czerwieni, żółci, zieleni i błękicie [135, s. 74], a więc na naturalnych kolorach uzyskiwanych z barwników pochodzenia roślinnego. Pojawiał się również kolor biały i czarny. W okresie XVI i XVII wieku dość popularne były także kolory ziemi: brąz, ugier i sjena. Wybierane były jednak zwykle jako kolory tła. Dopiero XVIII wiek przyniósł zmianę, w efekcie której ich miejsce zajęły: rozbielony błękit, róż i zieleń. W tym względzie dekoracje bożnic wpisują się w pewien trend.

W dekoracjach malarskich architektury synagogalnej XVI i XVII wieku widać pewien dysonans. W malaturach ich twórcy operują bardzo ograniczoną paletą barw, składającą się wyłącznie z tych wymienionych. Właściwie poza błękitem i żółcią, które połączone dają zieleń, nie mieszano innych kolorów podstawowych. Malarze bożnic wykorzystywali cztery główne barwy, a poszerzenie ich palety następowało poprzez rozbielenie. Rzadkością jest stosowanie koloru pomarańczowego (żółtego w połączniu z czerwonym), a kolor fioletowy (niebieski w połączeniu z czerwonym) właściwie się nie pojawia. Zastanawiające jest natomiast użycie dużej ilości czerwieni, która na przykład w kościele katolickim oznacza dostojność i królewskość i z tego powodu była kolorem stosowanym zwykle w przedstawieniach Chrystusa. W synagogach często stanowiła podstawę przy malowaniu podziałów ramowych.

Barwa niebieska w synagogach była zwykle używana w przedstawieniach nieba lub wodnego świata. Kolorem tym pokrywano również sklepienia, ponieważ miały kojarzyć się 
z niebem. W XVIII wieku niebieski pojawiał się często również w dekoracji szaf na rodały, co może przywodzić na myśl związek tego elementu z bramą nieba [150, s. 65].

Trudno jest stwierdzić, czy kolory wymieniane w Biblii lub traktatach kabalistycznych faktycznie miały wpływ na kolorystykę bożnic. Paleta barw stosowanych w tych budynkach jest dość ograniczona i może kojarzyć się z Tanachem. Opis kolorów części sefirot można byłoby rozumieć jako rozbielanie barw podstawowych. Jeżeli jednak sposób ich mieszania przedstawiony w kabale byłby obowiązujący, to sefira Tiferet miałaby kolor żółty. Oczywiste wydaje się natomiast, że stosowane barwy uzyskiwane były z łatwo dostępnych pigmentów naturalnych. Typowo żydowski był natomiast sposób wykorzystania kolorów z tych otrzymanych w polichromiach bożnic murowanych w XVII i XVIII wieku.

\section{Przypisy}

120 „Wtedy Ezechiasz odwrócił się do ściany i modlił się do Pana” [137, Iz 38,2].

${ }^{121} \mathrm{~W}$ dziele Eliakima Ben Josefa z Mainz jest mowa o umieszczeniu w synagodze w Kolonii witraża z wizerunkami lwa i smoka, pomimo że można podać powody, dla których stosowanie w bożnicach tego rodzaju elementów powinno być zabronione. Przede wszystkim w żadnym halachicznym źródle nie są wymieniane jako dopuszczalne w bożnicach. Smok - podobnie jak słońce i księżyc - był rozumiany jako idol. Zastosowanie witrażu dawałoby mylne wrażenie, że modlitwa wznoszona jest do obrazu na szkle, a nie do Boga. Ponadto kolorowe światło witrażu wpływałoby na osiągniecie kawana. Vide: V.B. Mann, Spiritual and Jewish ceremonial Art, Jewish Spirituality and Divine Law, eds. A. Mintz, L.H. Schiffman, New Jersey 2005, s. 220.

${ }^{122}$ Jak wskazuje Vivian Mann, pierwsze elementy ozdobne z wizerunkami ptaków i gałęzi z liśćmi pojawiły się w synagodze Pinkasa w Pradze, w trakcie przebudowy w XVI w. Vide: V.B. Mann, Spiritual and Jewish ceremonial Art, [w:] Jewish Spirituality and Divine Law, eds. A. Mintz, L.H. Schiffman, New Jersey 2005, s. 221.

${ }^{123}$ Zdarzało się jednak, że wizerunki lwów i smoków były umieszczane. W synagogach w Kolonii (1000) i Rouen (1096-1116), a także w synagodze Starej w Krakowie (XV/XVI w.). Vide: I. Rodov, Dragons: A Symbol of Evil in European Synagogue Decoration?, „Ars Judaica” 2005, No. 1, s. 63-64, 81.

${ }^{124}$ Rabin Abraham Abele Gombiner zakazywał umieszczania lub malowania obrazów na ścianach na linii wzroku, ale dopuszczał je powyżej wysokości, do której głową sięgają wierni. Poznański rabin Akiba Eiger w 2. połowie XVII w. zezwalał jedynie na malowanie obrazów ze świata roślin. Vide: K. i M. Piechotkowie, Bramy Nieba: Bożnice murowane na ziemiach dawnej Rzeczypospolitej, Warszawa 1999, s. 313.

125 Trójpodział ścian prawdopodobnie został zaczerpnięty z dekoracji synagog drewnianych, których udokumentowanymi przykładami są synagogi w: Chorodowie, Jabłonowie czy Gwoźdźcu. Nie można jednak nie zauważyć, że horyzontalny układ trzech pasów był rozwiązaniem, którego należałoby szukać najpierw w sztuce wczesnochrześcijańskiej (np. w bazylikach Santa Maria Maggiore 
w Rzymie (432-440) oraz Sant'Apollinare Nuovo w Rawennie (504)), skąd prawdopodobnie został zaczerpnięty do architektury sakralnej włoskiego renesansu. Przykładem tej ostatniej mogą być zakrystie (w San Lorenzo (1419-1440)) i kaplice (Sykstyna (1475-1483)). Vide: A. Trzciński, Zachowane wystroje malarskie bożnic w Polsce, „Studia Judaica” 2010, vol. 4, nr 1-2(7-8), s.7, 75; T. Lamey, Zur Genese der „Stütz-Bimah“im frühneuzeitlichen polnischen Synagogenbauam Beispiel der Synagoge in Przemýsl, Braunschweig 2010, mps Biblioteka Uniwersytetu w Braunschweig, s. 171.

${ }^{126}$ Przykłady dekoracji z XVII w. znajdowały się w synagogach w: Zamościu, Szczebrzeszynie, Łucku oraz w Synagodze Starej w Rzeszowie. W XVIII w. ten układ kompozycyjny pojawia się w synagogach w: Rymanowie, Dukli, Łańcucie, Żółkwi i Przeworsku.

${ }^{127}$ Jak podaje Adam Miłobędzki, próba podkreślenia własnego oblicza kulturowego przejawiała się przede wszystkim w dekoracjach attyk, fryzów, portali, które wykazywały wpływy ormiańskie i aszkenzyjskie. Vide: A. Miłobędzki, Architektura polska XVII wieku, Warszawa 1980, s. 337.

${ }^{128}$ Bardziej prawdopodobne wydaje się jednak, że tę funkcję pełniła nisza w ścianie zachodniej, podczas gdy wspomniane otwory w ścianach miały na celu poprawienie akustyki wnętrza. Było to istotne, gdyż martwe pole dźwięku generowanego na bimie-podporze miało dość dużą powierzchnię.

${ }^{129}$ Również dla ułatwienia społeczności czytania tekstów modlitw ze ścian, stosowano w bożnicach murowanych tzw. czcionkę amsterdamską. Żydzi w wielu gminach byli z nią obeznani za sprawą hebrajskich modlitewników, drukowanych z wykorzystaniem tego typu liternictwa. W tekstach umieszczanych na ścianach w synagogach drewnianych stosowano głównie czcionkę STAM, która miała charakter bardziej odświętny ze względu na używanie jej w przepisywanym tekście Tory. Vide: D. Dawidowicz, Cijuri-kir be-wate-keneset be-Polin, Jerozolima 1968, s. 20.

${ }^{130}$ Perek Szira (co dosłownie można przetłumaczyć jako rozdział pieśni) jest starożytnym i tajemniczym tekstem nieznanego autora, choć ze względu na niektóre komentarze przypisywany jest Królowi Dawidowi. Jest to lista osiemdziesięciu czterech elementów wchodzących w skład świata przyrody, w tym nieba i ziemi, roślin, ptaków, zwierząt i owadów. Elementom tym przypisano odpowiednie wersety z Biblii. W Perek Szira jest mowa o tym, że wszystko w świecie przyrody może nas czegoś nauczyć. Po raz pierwszy w Polsce tekst ten pojawia się w modlitewniku wydanym w Krakowie w 1651 r. Vide: B. Yaniv, Praising the Lord: Discovering a Song of Ascents on Carved Torah Arks in Eastern Europe, „Ars Judaica” 2006, No. 2, s. 14-20.

131 Jednym z najstarszych zachowanych przykładów są szafy z dwóch synagog: Scòla Catalana w Rzymie (1523) i Scòla Grande w Mantui (1543).

${ }^{132}$ Motyw ten pojawił się na Aron ha-Kodesz w synagodze Wysokiej w Krakowie i synagodze Maharszala, jak również w synagogach w: Tarnogrodzie, Włodawie, Bobowej, Nieświeżu, Sapieżynie, Orli.

133 Szafy na rodały powstały w Wormacji, w trakcie przebudowy synagogi w latach 1623-1624 i w $1704 \mathrm{r}$.

${ }^{134}$ Pierwszą na ziemiach polskich synagogą z takim usytowaniem koron była synagoga w Zamościu (1618). 


\section{Symbolika dekoracji i wystroju synagog XVI- i XVII-wiecznych...}

135 Znane są dwa przedstawienia: jedno w synagodze w Chodowie i drugie w Smotryczu. Szeroki opis tego zjawiska można znaleźć w pracy: B. Yaniv, The Hidden Message of the Hares in the Talons of the Eagle, „AJS Review” 2012, Vol. 36, No. 2, s. 281-294.

136 „Już słońca mieć nie będziesz w dzień jako światła, ani jasność księżyca nie zaświeci tobie, lecz Pan będzie ci wieczną światłością i Bóg twój - twoją ozdobą. Twe słońce nie zajdzie już więcej i księżyc twój się nie zaćmi, bo Pan będzie ci światłością wieczną i skończą się dni twej żałoby” [137, Iz 60, 19-20]. I. Rodov wskazuje również na fragment Księgi Przystów [137, Prz 6,23]: „bo lampą jest nakaz, a światłem Prawo".

${ }^{137}$ W XVIII w. następuje zanik tych przedstawien.

${ }^{138}$ M. Grunwald, Anhang. Zur Ikonographie der Malerei in unseren Holzsynagogen, [w:] A. Breier, M. Eisler, M Grunwald, Holzsynagogen in Polen, Wien 1934.

${ }^{139}$ Ciekawy opis symboliki lwów w synagogach we Włoszech i Hiszpanii przedstawia Ilia Rodov. Wskazuje na związek lwów w pozycji stojącej pojawiających się na dekoracjach synagog z wzorem znajdującym się na herbie papieskim Pawła II - Pietro Barbo (1417-1471).

${ }^{140}$ Taka dekoracja pojawiła się w synagogach w: Bobowej, Łańcucie, Słonimiu i Lubomlu.

141 „Pierwszego dnia miesiąca siódmego przyniósł kapłan Ezdrasz Prawo przed zgromadzenie, w którym uczestniczyli przede wszystkim mężczyźni, lecz także kobiety oraz wszyscy inni, którzy byli zdolni słuchać. I czytał z tej księgi, zwrócony do placu znajdującego się przed Bramą Wodną, od rana aż do południa przed mężczyznami, kobietami i tymi, którzy rozumieli; a uszy całego ludu były zwrócone ku Księdze Prawa. Pisarz Ezdrasz stanął na drewnianym podwyższeniu, które zrobiono w tym celu" [137, Ne 8,2-4].

${ }^{142}$ Bracha Yaniv podaje kilka wzorników, z których korzystano przy wykonywaniu ołtarzy i szaf na rodały, m. in. Architectura von den Fünf Sälen sambt Ihren Ornamenten und Zierden Gabriela Kramera z $1600 \mathrm{r}$.

${ }^{143}$ Bracha Yaniv podaje, że do XVII w. za wygląd szaf na rodały odpowiadali chrześcijańscy rzemieślnicy. Vide: B. Yaniv, Galami ec jehudim ba-mizrach eropa, „Zion: A Quarterly for Research in Jewish History” 2012, Vol. 77, No. 1, s. 31.

144 „[...] król sporządził wielki tron z kości słoniowej, który wyłożył szczerym złotem. Tron miał sześć stopni i podnóżek ze złota oraz poręcze po obu stronach siedzenia, a przy poręczach stały dwa lwy" [137, 2 Krn 9,17-18].

145 Alfred Grotte wspomina o 3-9 stopniach, które prowadziły do „świętej szafy” [54, s. 18]. Analizę swoją opierał jednak na budowlach pochodzących z różnych okresów z obszaru Niemiec oraz Czech, wyłączając synagogi z obszaru Polski, zatem jego teoria nie wyklucza wyników analiz uzyskanych przez Marę i Kazimierza Piechotków.

${ }^{146}$ Bracha Yaniv również zwraca uwagę na wpływ kabały i chasydyzmu na motywy dekoracyjne szafy, jak i na dekoracje ścian synagog. Vide: B. Yaniv, Galami ec jehudim ba-mizrach eropa, „Zion: A Quarterly for Research in Jewish History" 2012, Vol. 77, No. 1, s. 31-66.

${ }^{147}$ Szczegółowy opis tych określeń i ich znaczenie, jak również omówienie ich występowania w literaturze rabinicznej można znaleźć w pracy: The Jewish Encyclopedia, t. 4, ed. I. Singer, New York 1903. 


\section{Symbolika dekoracji i wystroju synagog XVI- i XVII-wiecznych...}

${ }^{148}$ Kolor biały pojawia się w Tanachu 46 razy. Liczbę fraz w tym i kolejnych przypisach podano za: A. Even-Shoshan, A New concordance of the Bible: thesaurus of the language of the Bible: Hebrew and Aramaic roots, words, proper names, phrases, and synonyms, Jerozolima 1985.

149 Kolor czerwony pojawia się w Tanachu 47 razy.

${ }^{150}$ Słowo to występuje w tej formie w Biblii dziesięciokrotnie. Na kolor zielony wykorzystywano częściej określenie desze [hebr. דשא - trawa]. W Biblii występuje 16 razy.

${ }^{151}$ Słowo tłumaczono jako niebieski. Pojawia się w Tanachu 49 razy.

${ }^{152}$ Słowo tłumaczono jako fiolet. Pojawia się w Tanachu 38 razy.

${ }^{153}$ Szersze omówienie tego schematu w rozdz. 7.

154 Żółty jest jednym z kolorów podstawowych i nie powstaje w wyniku zmieszania ze sobą barw.

${ }^{155}$ Jak podają Maria i Kazimierz Piechotkowie, przekazy dotyczące barw zastosowanych w bożnicach są dość ubogie i odnoszą się głównie do zaledwie kilku fragmentów w różnych obiektach. Najbogatszą ikonografię posiadała synagoga w Gwoźdźcu, a kolorystyka tych dekoracji, które pochodziły sprzed 1914 r., została opisana przez Thomasa Hubkę. Dalsze badania dały możliwość wykonania fizycznej rekonstrukcji kolorystyki wnętrz tej synagogi, którą można zobaczyć w Muzeum Żydów Polskich w Warszawie. Vide: K. i M. Piechotkowie, Polichromie polskich bożnic drewnianych, „Polska Sztuka Ludowa - Konteksty” 1989, vol. 43, nr 1-2, s. 65; T.C. Hubka, Resplendent Synagogue: Architecture and Worship in an Eighteenth-century Polish Community, Hanover, London 2003, s. 107-114.

${ }^{156} \mathrm{~W}$ tamtym czasie był to bardzo drogi barwnik, dlatego stosowanie tego koloru jako podkładu wydaje się mało prawdopodobne. Vide: G.K. Loukomski, Jewish art in European synagogues: from the Middle Ages to the eighteenth century, London 1947, s. 39.

${ }^{157}$ Dokumentacja z badań jest jednak dość uboga, a autorka, stwierdzając, że polichromia posiada niskie walory artystyczne, nie podjęła się przedstawienia pełnej stratygrafii i ewentualnego datowania. Podobnie zresztą w próbkach nie podaje informacji, które odnosiłyby się do rodzaju zastosowanych zapraw i pozwoliły na bardziej wiarygodne odtworzenie pierwotnej kolorystyki. Dekoracja prawdopodobnie nie była monochromatyczna, jak pisze autorka, tym bardziej, że w dokumentacji zamieszcza zdjęcie prezentujące motywy roślinne na pilastrze arkadowania. Vide: H. Mankowska-Zawadzka, Sprawozdanie z przebiegu badań konserwatorskich zabytkowej synagogi w Lesku, mps WUOK w Przemyślu, delegatura w Krośnie. 


\section{PROPORCJE ARCHITEKTONICZNE XVII- I XVIII-WIECZNYCH SYNAGOG ZACHOWANYCH NA OBSZARZE WSPÓŁCZESNEJ POLSKI}

\subsection{Zakres badań}

Jednym z elementów analizy metrologicznej ${ }^{158}$ synagog z XVII i XVIII wieku było określenie proporcji oraz zależności geometrycznych występujących w ich planach. Większość sal męskich w bożnicach zlokalizowanych na obszarze Polski była wznoszona na planie kwadratu. Tyczy się to zarówno bożnic jednoprzestrzennych, jak i bożnic z bimą-podporą i dziewięciopolowych.

$\mathrm{W}$ analizie przeprowadzonej $\mathrm{w}$ niniejszej monografii uwzględnione zostały przede wszystkim wymiary zewnętrzne, w tym długość i szerokość obiektów - w ich pierwotnej formie - oraz wysokość do okapu. Badania wnętrza dotyczyły również długości i szerokości sali męskiej oraz wysokości w najwyższym punkcie sklepienia. W synagogach z bimą-podporą i dziewięciopolowych wymiary almemor i centralnego pola poddano podobnej analizie. Sprawdzano przede wszystkim stosunek długości do szerokości oraz stosunek ich wartości do odpowiadającej im wartości wysokości.

Kolejnym aspektem poddanym analizie było zastosowanie przy kształtowaniu wnętrza sali męskiej zasady boskiej proporcji (łac. divino proportio). Zasada ta była rozpowszechniona w architekturze od starożytności, jednak - jak pokazują badania traktatów architektonicznych - zwykle nie była traktowana jako wytyczna przy wznoszeniu obiektów. Poza pokazaniem ogólnego wzoru, według którego należy dokonać idealnie geometrycznego złotego podziału, istotne jest również przedstawienie, na podstawie różnych dzieł, sposobu rozpowszechniania tej niepisanej zasady w architekturze. Ma to na celu stwierdzenie, czy jako podstawa kompozycji wnętrz synagog wynikała z przejęcia ogólnych zasad idealnej proporcji z architektury innych kultur, czy była zakorzeniona w jakiś sposób w tradycji żydowskiej. 
Tabela 5.1. Proporcje wymiarów analizowanych synagog

\begin{tabular}{|c|c|c|c|c|c|c|c|c|c|c|c|c|c|c|c|}
\hline Lokalizacja & 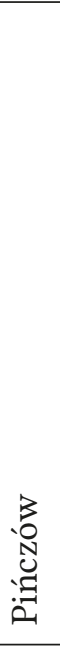 & 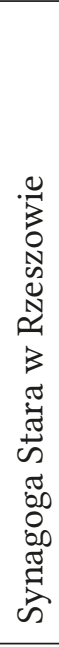 & 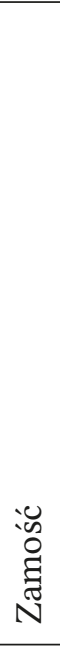 & 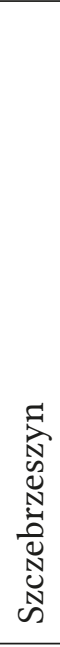 & 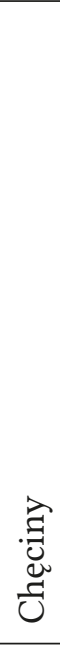 & 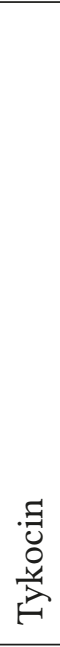 & $\frac{\pi}{\tilde{O}}$ & 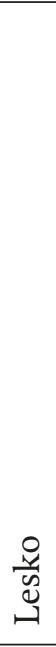 & 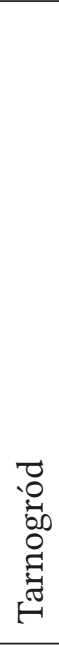 & 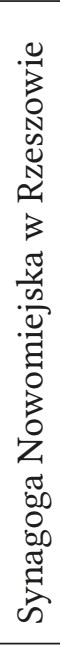 & $\frac{\frac{\pi}{3}}{3}$ & $\begin{array}{l}\pi \\
3 \\
0 \\
0 \\
0 \\
\infty\end{array}$ & 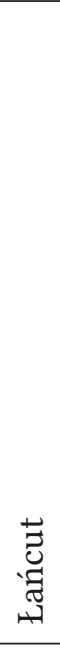 & $\frac{\pi}{3}$ & 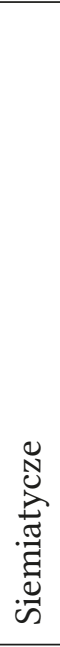 \\
\hline $\begin{array}{l}\text { Długość do szerokości } \\
\text { synagogi }\end{array}$ & $\ddot{\ddot{n}}$ & $\stackrel{ت}{\rightrightarrows}$ & $\begin{array}{l}\stackrel{+}{0} \\
\stackrel{-}{\longrightarrow}\end{array}$ & $\begin{array}{l}\stackrel{H}{-} \\
\stackrel{\because}{-}\end{array}$ & $\hat{\operatorname{n}}$ & $\ddot{\ddot{r}}$ & 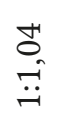 & 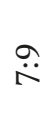 & $\ddot{\ddot{H}}$ & $\stackrel{m}{\sim}$ & 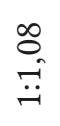 & $\vec{i}$ & $\stackrel{\substack{n \\
\hdashline \\
\hdashline}}{\rightarrow}$ & $\stackrel{n}{\stackrel{2}{\rightarrow}}$ & $\stackrel{\hat{N}}{\stackrel{-}{ت}}$ \\
\hline $\begin{array}{l}\text { Długość do wysokości } \\
\text { do okapu }\end{array}$ & $\begin{array}{l}\stackrel{\mathscr{O}}{O} \\
\stackrel{\vec{H}}{\sim}\end{array}$ & $\stackrel{m}{\sim}$ & $\begin{array}{l}\hat{\sigma} \\
\stackrel{+}{+} \\
\end{array}$ & $\stackrel{\vec{\infty}}{\stackrel{\sim}{\sim}}$ & $\begin{array}{l}\ddot{H} \\
\stackrel{\vec{H}}{-}\end{array}$ & $\stackrel{\sim}{\stackrel{\sim}{-}}$ & $\begin{array}{l}\vec{\sigma} \\
\vec{\sim}\end{array}$ & $\stackrel{\substack{n \\
-\pi}}{\rightarrow-}$ & 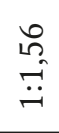 & $\underset{\ddot{n}}{\stackrel{\sim}{*}}$ & 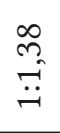 & $\begin{array}{l}\stackrel{n}{m} \\
\stackrel{\sim}{\sim}\end{array}$ & 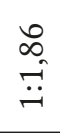 & $\stackrel{\stackrel{n}{n}}{\stackrel{\sim}{\sim}}$ & 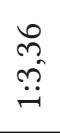 \\
\hline $\begin{array}{l}\text { Szerokość do } \\
\text { wysokości do okapu }\end{array}$ & $\ddot{i n}$ & $\stackrel{n}{m}$ & $\underset{\ddot{G}}{\ddot{\sim}}$ & 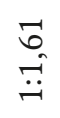 & 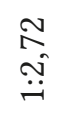 & $\stackrel{\sim}{\sim}$ & 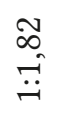 & $\underset{\mathfrak{N}}{\stackrel{\sim}{-}}$ & 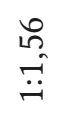 & 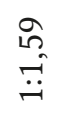 & $\stackrel{\leftrightarrow}{\ddot{r}}$ & $\underset{\stackrel{\leftrightarrow}{\sim}}{\stackrel{\sim}{\sim}}$ & 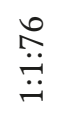 & 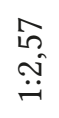 & $\begin{array}{l}\stackrel{\leftrightarrow}{b} \\
\stackrel{\sim}{\oplus}\end{array}$ \\
\hline $\begin{array}{l}\text { Długość sali męskiej do } \\
\text { szerokości sali męskiej }\end{array}$ & $\begin{array}{l}\stackrel{2}{O} \\
\stackrel{-}{\longrightarrow}\end{array}$ & $\begin{array}{l}\stackrel{0}{m} \\
\stackrel{-}{-}\end{array}$ & $\begin{array}{l}\hat{O} \\
\stackrel{-}{\rightarrow}\end{array}$ & $\stackrel{\infty}{\stackrel{\infty}{\rightleftarrows}}$ & 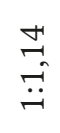 & $\ddot{\ddot{H}}$ & 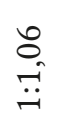 & $\stackrel{\stackrel{n}{m}}{\stackrel{\sim}{*}}$ & $\overrightarrow{-}$ & 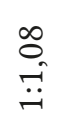 & $\underset{ت}{\stackrel{H}{ت}}$ & $\ddot{\vec{H}}$ & $\stackrel{-}{\rightarrow}$ & 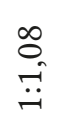 & 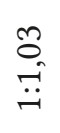 \\
\hline $\begin{array}{l}\text { Długość sali męskiej do } \\
\text { wysokości sali męskiej }\end{array}$ & 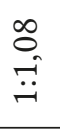 & $\stackrel{m}{\stackrel{m}{\leftrightarrows}}$ & 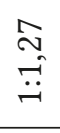 & $\ddot{n}$ & $\underset{\vec{\sigma}}{\vec{i}}$ & $\stackrel{\infty}{\rightarrow}$ & $\begin{array}{l}\vec{b} \\
\stackrel{-}{+} \\
\end{array}$ & $\stackrel{\circ}{\stackrel{\ddot{r}}{ }}$ & $\underset{\stackrel{F}{\rightleftarrows}}{\stackrel{\leftrightarrow}{\rightleftarrows}}$ & $\stackrel{\hat{m}}{\stackrel{\sim}{\rightarrow}}$ & 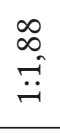 & $\begin{array}{l}\stackrel{\Re}{0} \\
\stackrel{n}{H} \\
\end{array}$ & $\underset{\mathscr{Z}}{\stackrel{\sharp}{\rightarrow}}$ & $\stackrel{\infty}{\stackrel{\infty}{ت}}$ & $\stackrel{\sim}{\stackrel{\sim}{ت}}$ \\
\hline $\begin{array}{l}\text { Szerokość sali męskiej } \\
\text { do wysokości sali } \\
\text { męskiej }\end{array}$ & $\begin{array}{l}\stackrel{+}{\leftrightarrows} \\
\stackrel{-}{\rightleftarrows}\end{array}$ & $\stackrel{\rightleftarrows}{\stackrel{\leftrightarrows}{\leftrightarrows}}$ & $\stackrel{\infty}{\stackrel{\infty}{\sim}}$ & $\stackrel{\infty}{\stackrel{\sim}{\sim}}$ & $\stackrel{\text { f }}{\stackrel{\leftrightarrow}{\rightleftarrows}}$ & $\stackrel{\stackrel{\leftrightarrows}{\leftrightarrows}}{\stackrel{\leftarrow}{ت}}$ & 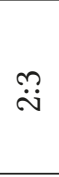 & 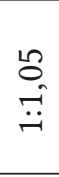 & $\stackrel{\text { F }}{\stackrel{\sim}{\rightleftarrows}}$ & $\begin{array}{l}\stackrel{\circ}{N} \\
\stackrel{\leftrightarrow}{\sim}\end{array}$ & $\begin{array}{l}\stackrel{10}{b} \\
\stackrel{-\pi}{-1}\end{array}$ & $\stackrel{\vec{\infty}}{\vec{\pi}}$ & $\stackrel{g}{\ddot{r}}$ & $\stackrel{a}{\dot{n}}$ & 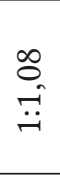 \\
\hline $\begin{array}{l}\text { Długość bimy/ } \\
\text { pola centralnego do } \\
\text { szerokości bimy/pola } \\
\text { centralnego }\end{array}$ & 1 & $\stackrel{\infty}{\stackrel{\infty}{\sim}}$ & 1 & 1 & 1 & $\ddot{-}$ & $\stackrel{\infty}{\overrightarrow{-}}$ & 1 & $\ddot{ت}$ & $\begin{array}{l}\widetilde{O} \\
\stackrel{-}{-}\end{array}$ & $\begin{array}{l}\vec{H} \\
\vec{ت}\end{array}$ & $\stackrel{m}{\stackrel{\sim}{-}}$ & $\ddot{\ddot{H}}$ & $\begin{array}{l}0 \\
\stackrel{-}{-}\end{array}$ & 1 \\
\hline $\begin{array}{l}\text { Długość bimy/ } \\
\text { pola centralnego do } \\
\text { wysokości bimy/pola } \\
\text { centralnego }\end{array}$ & 1 & $\stackrel{\varphi}{\ddot{*}}$ & 1 & 1 & 1 & $\begin{array}{l}\stackrel{\sim}{7} \\
\stackrel{\sim}{\sim}\end{array}$ & $\begin{array}{l}\stackrel{ }{\not} \\
\stackrel{\sim}{r}\end{array}$ & 1 & $\ddot{m}$ & $\begin{array}{l}\stackrel{0}{\sim} \\
\stackrel{\sim}{\sim}\end{array}$ & 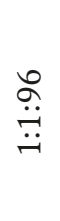 & $\begin{array}{l}\infty \\
\stackrel{\leftrightarrow}{-}\end{array}$ & $\underset{\vec{*}}{\vec{F}}$ & & 1 \\
\hline $\begin{array}{l}\text { Szerokość bimy/ } \\
\text { pola centralnego do } \\
\text { wysokości bimy/pola } \\
\text { centralnego }\end{array}$ & 1 & $\begin{array}{l}\stackrel{f}{+} \\
\stackrel{\leftrightarrow}{-}\end{array}$ & 1 & 1 & 1 & $\begin{array}{l}\stackrel{\sim}{\sim} \\
\stackrel{\sim}{\sim}\end{array}$ & $\stackrel{m}{i}$ & 1 & $\ddot{m}$ & $\begin{array}{l}\stackrel{\circ}{-} \\
\stackrel{\leftrightarrow}{\sim} \\
\end{array}$ & $\begin{array}{l}\stackrel{N}{\ddot{\oplus}} \\
\stackrel{\leftrightarrow}{ت}\end{array}$ & $\begin{array}{l}0 \\
\stackrel{-}{-}\end{array}$ & $\underset{\ddot{*}}{ت}$ & 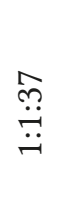 & 1 \\
\hline
\end{tabular}


Tabela 5.2. Proporcje powtarzające się w wymiarach synagog

\begin{tabular}{|c|c|}
\hline Proporcja & Lokalizacja synagogi \\
\hline $1: 1,04$ & Zamość, Orla \\
\hline $1: 1,05$ & Pińczów, Lesko, Łańcut \\
\hline $1: 1,08$ & Pińczów, Synagoga Nowomiejska w Rzeszowie, Bobowa, Włodawa, Siemiatycze \\
\hline $1: 1,1$ & Dukla Łańcut \\
\hline $1: 1,14$ & Pińczów, Synagoga Stara w Rzeszowie, Szczebrzeszyn, Chęciny, Bobowa \\
\hline $1: 1,18$ & Synagoga Stara w Rzeszowie, Zamość, Szczebrzeszyn, Włodawa \\
\hline $1: 1,27$ & Zamość, Siemiatycze \\
\hline $7: 9$ & Lesko, Bobowa, Łańcut, Włodawa \\
\hline $1: 1,3$ & Synagoga Stara w Rzeszowie, Dukla \\
\hline $1: 1,35$ & Synagoga Stara w Rzeszowie, Lesko \\
\hline $1: 1,37$ & Synagoga Nowomiejska w Rzeszowie, Włodawa \\
\hline $5: 7$ & Pińczów, Szczebrzeszyn, Chęciny \\
\hline $7: 10$ & Orla, Lesko \\
\hline $1: 1,47$ & Synagoga Stara w Rzeszowie, Chęciny, Tarnogród \\
\hline $2: 3$ & Synagoga Stara w Rzeszowie, Synagoga Nowomiejska w Rzeszowie \\
\hline $1: 1,59$ & Synagoga Nowomiejska w Rzeszowie, Włodawa \\
\hline $1: 1,61$ & Zamość, Szczebrzeszyn, Orla \\
\hline $1: 1,81$ & Szczebrzeszyn, Dukla \\
\hline $1: 1,86$ & Tykocin, Łańcut \\
\hline $1: 2,35$ & Dukla, Włodawa \\
\hline
\end{tabular}

\subsection{Proporcje sal męskich}

Z analizy przedstawionej w formie tabeli (tab. 5.1) wynika, że w przypadku poszczególnych wymiarów wszystkich badanych synagog następująco kształtują się:

1) proporcje poziomych wymiarów zewnętrznych 1:1 - Tykocin, Tarnogród, 1:1,04 - Zamość, Orla, 1:1,05 - Łańcut, 1:1,08 - Bobowa, 1:1,10 - Dukla, 1:1,11 - Synagoga Stara w Rzeszowie, 1:1,14 - Szczebrzeszyn, 1:1,15 - Włodawa, 1:1,27 - Siemiatycze, 7:9 - Lesko, 3:4 - Pińczów, 5:7 - Chęciny, 2:3 - Synagoga Nowomiejska w Rzeszowie;

2) proporcje długości do szerokości sal męskich: 1:1 - Tykocin i Tarnogród (sala kwadratowa), 1:1,03 - Siemiatycze, 1:1,04 - Orla, 1:1,05 - Pińczów, 1:1,07 - Zamość, 1:1,08 - Synagoga Nowomiejska w Rzeszowie, Włodawa, 1:1,1 - Dukla, Łańcut, 1:1,13 - Synagoga Stara w Rzeszowie, 1:1,14 - Chęciny, 1:1,18 - Szczebrzeszyn, 1:1,35 - Lesko; 
3) proporcje bim i pól centralnych: 1:1 - Tykocin, Tarnogród, Łańcut, 1:1,02 - Synagoga Nowomiejska w Rzeszowie, 1:1,04 - Orla, 1:1,14 - Bobowa, 1:1,16 - Włodawa, 1:1,18 - Synagoga Stara w Rzeszowie, 1:1,3 - Dukla.

Proporcje uzyskane w trakcie analizy (tab. 5.2) powtarzają się zarówno w planach synagog, jak również w wynikach badania stosunku wymiarów planu poziomego do poszczególnych wysokości.

\subsection{Zasada złotego cięcia}

Złoty podział (łac. sectio aurea), inaczej nazywany złotą lub boską proporcją, oznacza podział odcinka na dwie części: dłuższą i krótszą, ale w taki sposób, aby stosunek długości dłuższej do krótszej był taki sam, jak całego odcinka do części dłuższej. Opisując to językiem matematyki, trzeba by powiedzieć, że długość dłuższej części ma być średnią geometryczną długości krótszej części i całego odcinka. Algebraicznie można byłoby to wyrazić w następujący sposób:

$$
\frac{a+b}{a}=\frac{a}{b}=\varphi
$$

Proporcja jest jednym z podstawowych zagadnień teorii architektury. W źródłach pochodzących sprzed XVI wieku próżno jednak poszukiwać informacji na temat złotego podziału. Warto jednak prześledzić, jak kształtowało się podejście do proporcji w traktatach architektonicznych.

W traktatach starożytnych złoty podział na pewno nie stanowił istotnego tematu. Jednak analiza architektury starożytnych świątyń wykazuje, że przywiązywano wagę do odpowiedniego kształtowania tych obiektów. W traktacie $O$ architekturze ksiag dziesięć jego autor, Marek Pollio Witruwiusz, poza praktyczną stroną budowania omawia również kwestię estetyki. Wszystkie aspekty kształtowania obiektów zamknięte zostają w witruwiańskiej triadzie: firmitas (trwałość), utilitas (użyteczność), venustas (piękno).

Witruwiusz pisze, że pracując nad dziełem architektonicznym jego twórca musi znać geometrię i arytmetykę [195, I, 4]. Wszystkie plany świątyń opracowane są na podstawie relacji geometrycznych ich poszczególnych części składowych [195, IV, 4,1] (proporcji kolumn i interkolumnia). Swoje rozważania Witruwiusz przenosi również na ciało człowieka, pisząc, że: „żadna budowla nie może mieć właściwego układu bez symetrii i dobrych proporcji, które powinny być oparte ściśle na proporcjach ciała dobrze zbudowanego człowieka” [195, III, 1,1]. W pracy $O$ architekturze ksiag dziesięć można więc przeczytać o znaczeniu układu symetrii, proporcji obiektu i poszczególnych składowych, chociaż pojęcie złotej proporcji nie jest jeszcze używane [46, s. 10], czy o stosowaniu stosunku geometrycznego, a nie arytmetycznego w kompozycji obiektu [47, s. 65]. Trudno więc nie nawiązać do tego kanonicznego dzieła, będącego podstawą wielu nowożytnych traktatów architektonicznych. 
Wiedza dotycząca budowania rozwijała się również w średniowieczu. Powstawały wówczas dzieła opisujące techniki i materiały budowlane oraz zasady wznoszenia i kształtowania budynków. Wciąż jednak były to informacje ogólnie dotyczące estetyki, a nie boskiej proporcji.

Traktaty renesansowe przyniosły wprawdzie pewne novum, jednak wielu autorów nadal odnosi się w swoich pracach do proporcji ludzkiego ciała. Należą do nich Alberti i jego rozprawa De pictura (1435) oraz Filarete i jego Trattato di Architettura (1460-1464). Swoistym apogeum w tym względzie są traktaty Francesco di Giorgio Martiniego ze Sieny (1439-1501) Trattati di Architettura civile e militare (1482) i Das Skizzenbuch, w których poza planami również proporcje elewacji, w tym belkowania, zostają oparte na proporcjach ludzkiego ciała [47, s. 65], co wskazuje na traktowanie architektury w sposób antropometryczny.

W XVI wieku zostają wprowadzone również nowe zasady dotyczące estetyki architektury. Alberti, pisząc o idealnej architekturze, podaje jej trzy aspekty: liczby (łac. numerus), proporcje (łac. finitio), rozmieszczenia (łac. collocatio). Odpowiedni ich dobór został uznany za warunek cocinnitas (zgodności części przedmiotu lub całości) [69, s. 24].

Inną kwestią było nawiązywanie do proporcji harmonicznych. Ten rodzaj proporcji, mającej swoje źródła w teorii Pitagorasa, był również promowany przez Albertiego jako jedno z istotnych rozwiązań [46, s. 10].

Niezależnie od stosowanych systemów proporcji w wymienionych traktatach autorzy nie nawiązują w jakikolwiek sposób do złotego podziału.

Pierwszym traktatem w pełni poświęconym temu zagadnieniu było składające się z czerech części dzieło Luki Paciolego ${ }^{159}$ (1445-1517) Divina proportione (1509). W pierwszej części autor wyraża pogląd, iż boską proporcję można scharakteryzować za pomocą pięciu atrybutów Boga. Cztery z nich to: jedność i niepowtarzalność, trójosobowość, niemożność zdefiniowania względem ludzkich proporcji, niezmienność. Piątym jest przejęta od Platona boska esencja [46, s. 11]. Znamiona traktatu architektonicznego ma dopiero część druga, w której określone są „normy i metody dochodzenia do pożądanego efektu w architekturze” [127, I, cap. LXXI]. Pacioli nie skupia się na zastosowaniu złotego podziału. Zwraca natomiast uwagę na wykorzystanie prostych form (kwadratu czy koła) i zasad witruwiańskich. Zaleca proste proporcje liczb całkowitych, np.: 1:2, 1:3, 3:4, 2:3. Wskazuje więc, że praktyka i teoria nie idą $\mathrm{w}$ parze i $\mathrm{w}$ odniesieniu do architektury złoty podział nie odgrywa żadnej roli [46, s. 14].

W swoim traktacie Luca Pacioli wyjaśnia sposób wykreślania złotego podziału oraz złotego prostokąta (il. 5.1). Większe zainteresowanie może jednak wzbudzić za-

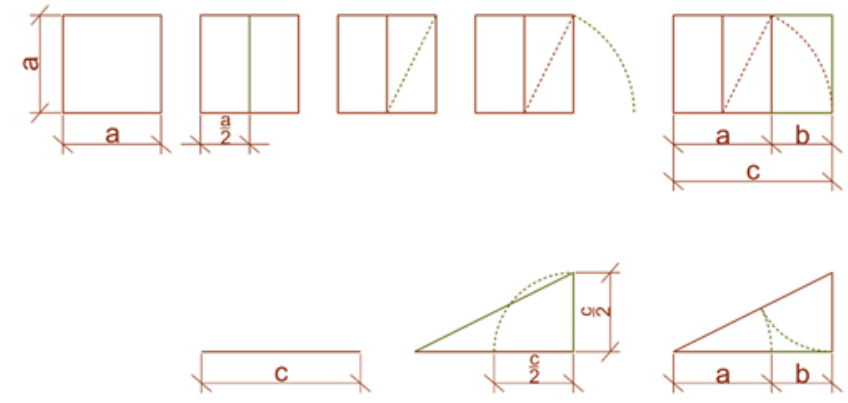

Il. 5.1. Schematy geometryczne wyznaczenia złotego prostokąta i złotej proporcji odcinka [21] 
proponowany przez niego sposób wykreślenia pięciokąta foremnego (il. 5.2). Autor dochodzi do wniosku, że pięciokątem rządzi zasada złotej proporcji i jest ona kluczem do skonstruowania idealnego pięciokąta [47, s. 55-56].

Pięciokąt foremny można skonstruować z dwóch trójkątów: ABC i ABF, których boki pozostają $\mathrm{w}$ złotym stosunku. W pięciokącie foremnym widoczne są następujące zależności:

$$
\begin{aligned}
& \frac{C A}{B A}=\frac{B A}{A F}=\varphi \\
& B A^{2}=C A \times F A \\
& C F^{2}=C A \times F A \\
& B A=C B=C F
\end{aligned}
$$

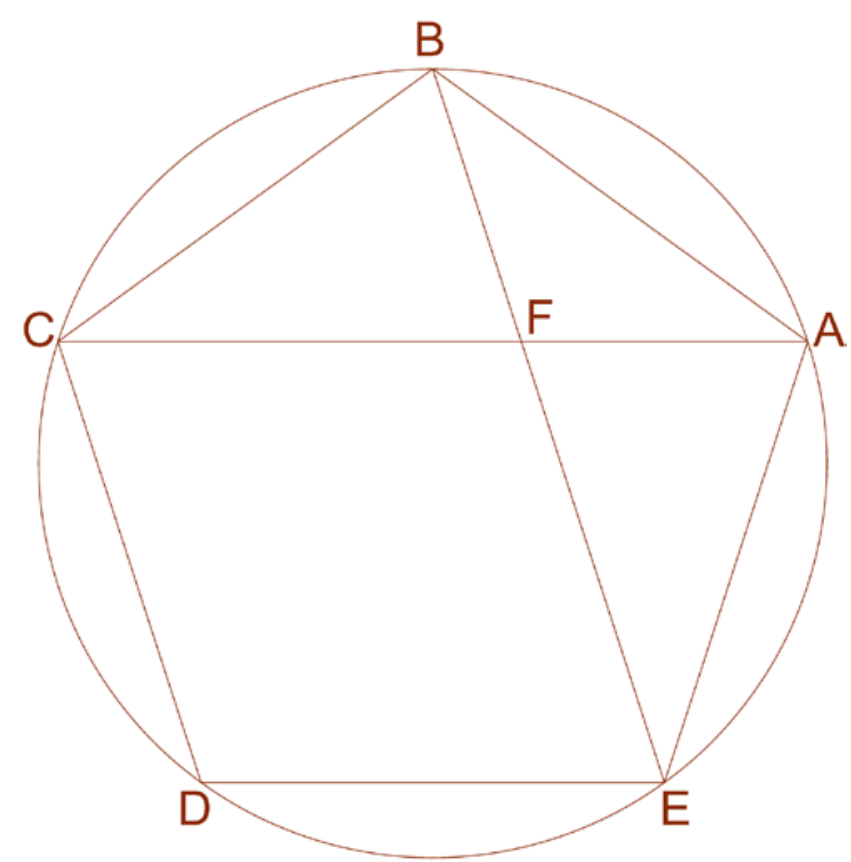

Il. 5.2. Schemat konstrukcji pięciokąta formenego wg Luki Paciolego [21]

Oznaczają one, że do narysowania pięciokąta foremnego o boku długości CF wystarczy znaleźć odcinek AC będący z nim w złotej proporcji i na podstawie tego odcinka i odcinka CF wykreślić pięć boków pięciokąta [128, s. 339] ${ }^{160}$.

Praca Paciolego prawdopodobnie wpłynęła ${ }^{161}$ na Leonarda da Vinci (1452-1519) i Albrechta Dürera (1471-1528). Żaden z nich nie zwraca jednak uwagi na kwestie techniczne związane z wyznaczeniem złotej proporcji. Leonardo da Vinci korzysta z przybliżeń do pięciokąta foremnego, Albrecht Dürer natomiast ze schematu Paciolego, nie zastanawiając sie, że sposób wykreślenie figury wynika ze złotej proporcji [46, s. 16]. W swoim traktacie Underweysung der messung, mit den zirckel un richtscheyt, in Linien ebnen unnd gantzen corporen Dürer pokazuje sposób wykreślenia pięciokąta, korzystając z metody geometrycznej [33, II, 15]. Pomimo, jak się wydaje, znajomości zagadnienia w jego traktacie architektonicznym: Etliche underricht zu befestigung der Stett, Schloß und lecken (1527) złoty podział nie ma żadnego przełożenia na architekturę.

Wyznaczenie dwóch złotych prostokątów (il. 5.3) pozostających względem siebie w złotej proporcji okazało się możliwe także za pomocą półokręgu. Schemat postępowania przedstawił w traktacie Architettu-

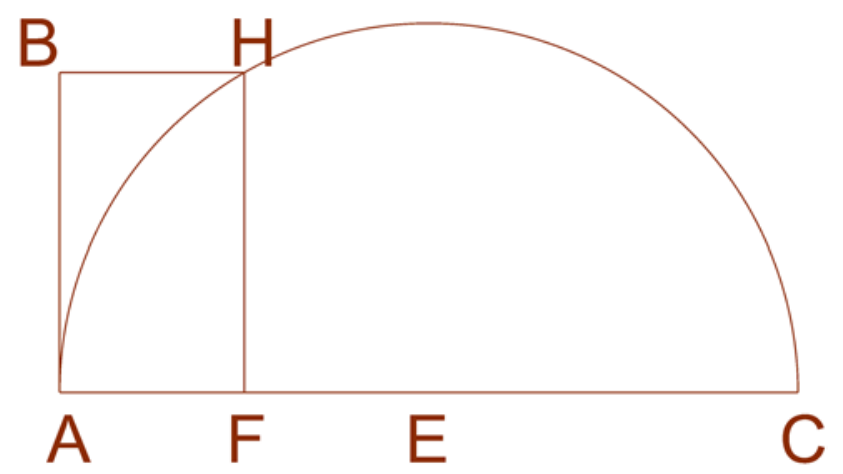

Il. 5.3. Schemat konstrukcji złotych prostokątów wg Guarino Guariniego [21] 
ra civile (1737) Guarino Guarini (1624-1683). Zgodnie z jego założeniem należy narysować najpierw odcinek o długości AC, a następnie z jego środka, którym jest punktu E, łuk o promieniu długości AE. Punkt F znajdujący się w połowie odcinka AE należy połączyć prostopadłym odcinkiem z punktem przecięcia na łuku (punkt H). Odcinki AF i FH stanowią boki prostokąta, które powinny pozostać w stosunku 1:1,618. Odcinki FH i FC stają się bokami drugiego prostokąta zachowującego - w mniemaniu Guariniego - taką samą proporcję [55, s. 54]. Prawda jest jednak inna: proporcja boków, które wyznaczył Guarini, wynosi 1:1,7320 $[58$, s. 226].

Brak informacji w traktatach architektonicznych o złotym podziale nie oznaczał wcale braku stosowania takiego rozwiązania i fascynacji nim. Pierwotnie przedstawiano go wyłącznie geometrycznie, co spowodowane było prawdopodobnie niewymiernością wartości liczbowej, która go opisuje, a która została sprowadzona do wartości dziesiętnej dopiero pod koniec XVI wieku. Pierwszą definicję podał Euklides [39, VI, def. 3.] w IV wieku p.n.e. Ze złotą liczbą łączy się nierozerwalnie ciąg Fibonacciego, w którym stosunek kolejnych wartości ciągu asymptotycznie zbliża się do wartości złotego podziału.

Znaczenie proporcji ludzkiego ciała opisywane w wielu traktatach jako podstawowe narzędzie proporcji narzucało stosowanie złotego podziału. Analizę taka przeprowadził dopiero w XIX wieku Adolf Zeising (18101876) [46, s. 18]. Faktem jest jednak, że już w starożytnych obiektach można odnaleźć zasadę złotego podziału. Przykładem jest elewacja greckiego Partenonu (447-432 r. p.n.e.) [58, s.13], plan Rzymskiego Panteonu (118-128 r.) [47, s. 109] czy piramida Cheopsa (2560 r. p.n.e) skonstruowana z wykorzystaniem złotego trójkąta, fasada katedry Notre Dame (1163-1346), katedra w Mediolanie (od 1386 r.) (il. 5.4) czy Round Tower (XIV w.) w zamku w Windsorze.

Zasadę złotej proporcji z pewnością stosowali również artyści tworzący $\mathrm{w}$ dobie renesanu. Zgodnie z nią Leonardo da Vinci we fresku Ostatnia Wieczerza (1495-1498) umieścił po lewej stronie postać Judasza, a Michał Anioł we fresku Stworzenie Adama postacie Boga i Adama. Stosunkowo często boska proporcja zaczęła być wykorzystywa-

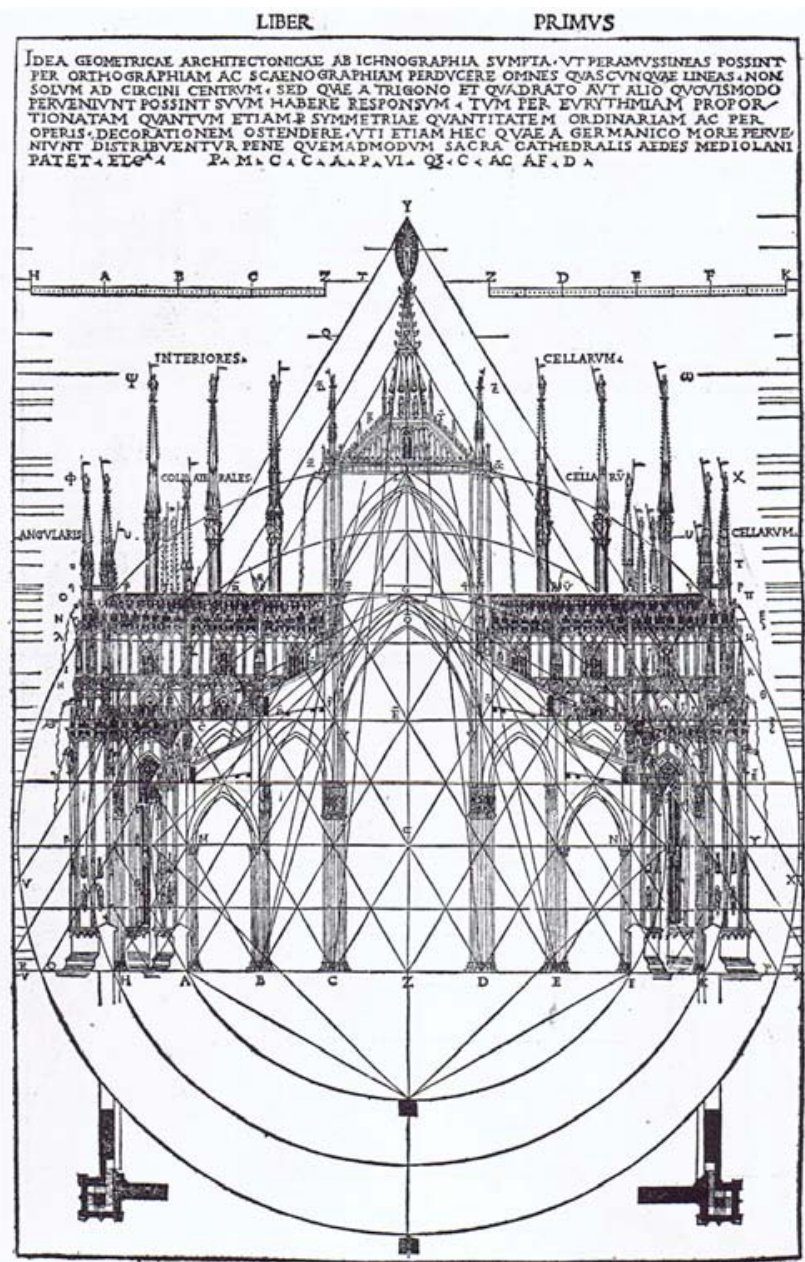

Il. 5.4. Przekrój przez katedrę w Mediolanie [1] 
na w architekturze renesansu, a także baroku. Przykładem może być kaplica Pazzich (ok. 1430) Filippo Brunelleschiego (1377-1446), w której konstrukcja zarówno wnętrza, jak i fasady opiera się na zasadzie złotego podziału. Dziełem doskonałym było rozplanowane w podobny sposób Tempietto (1502-1510) Donato Bramantego (1444-1514). Fasada bazyliki św. Piotra (1608-1612) - mierząc od podstaw baz do gzymsu nad kolumnami - zawiera dwa złote prostokąty. Powód, dla którego Carlo Maderna (1556-1629), zastosował takie proporcje jest trudny do określenia tym bardziej, że proporcja fasady, mierząc od podstawy schodów, wynosi 5:9 [47, s. 109].

W Polsce złotych proporcji należy szukać w architekturze powstałej pod kierunkiem włoskich artystów, którzy gościli na dworze Zygmunta Starego. Przykładem może być brama prowadząca na zamek Piastów Śląskich w Brzegu (1550-1560) [202, s. 27]. Fasada brama jako kompozycja niesymetryczna została podzielona zgodnie z zasadą złotej proporcji, czyli jednej z najidealniejszych proporcji nierówności. Złoty stosunek można zresztą stwierdzić nie tylko w przypadku szerokości i wysokości bramy, ale i każdego jej piętra. Co ciekawe, modułem pomiaru całości kompozycji stała się figura Jerzego II, której trzykrotna wysokość jest równa wysokości kondygnacji. Pięciokrotna wysokość postaci Jerzego II stanowi szerokość fasady, a ośmiokrotna jej wysokość [202, s. 30]. Tym sposobem uzyskano kolejny stosunek, w tym przypadku 5:8, oparty na ciągu Fibonacciego. Złota proporcja stała się również podstawą rozplanowania Kaplicy Zygmuntowskiej na Wawelu.

Wraz z nastaniem kontrreformacji zależność ta stała się podstawą rozmierzania planów kościołów jezuickich w Polsce, ale i innych zakonów kontrreformacyjnych ${ }^{162}$.

Próbując znaleźć złoty podział w architekturze bożniczej, należy zwrócić uwagę na wartości liczbowe zawarte w Torze. W kilku przypadkach ich proporcje znajdują się bardzo blisko złotego podziału i na dodatek stanowią kolejne wartości ciągu Fibonacciego. Należy wspomnieć chociażby o opisie Arki Przymierza [137, Wj 25,10] czy ołtarza w przybytku wzniesionym przez Mojżesza [137, Wj 27,1]. Wynik stosunku wartości tam podanych, czyli 3:5 $=1,666$, jest bardzo bliski liczbie 1,618. Podobnie opisy wymiarów Arki Noego [137, Rdz 6,15] i podestu, na którym klęczał Salomon [137, 2 Krn 6,13], przedstawiają tę zależność. W Księdze Ezechiela tym stosunkiem opisano wymiary przedsionka świątynnego [137, Ez 40,49]. W Pierwszej Księdze Królewskiej natomiast proporcja ta pojawia się w opisie pałacu Salomona [137, 1 Krl 7,2. 6]. Również w kilku miejscach Tanachu występują wartości, których stosunek wyrażony został w proporcji 5:3 [137, Rdz 31,41; 2 Krl 5,5; Ne 5,18; 2 Sm 10,6].

\subsection{Złote proporcje sal męskich synagog}

Pierwszym domem zgromadzeń wzniesionym z zachowaniem boskiej proporcji jest XV-wieczna synagoga w Tomar (il. 5.5), w której filary zostały usytuowane po zewnętrznej 
5. Proporcje architektoniczne XVII- i XVIII-wiecznych synagog...

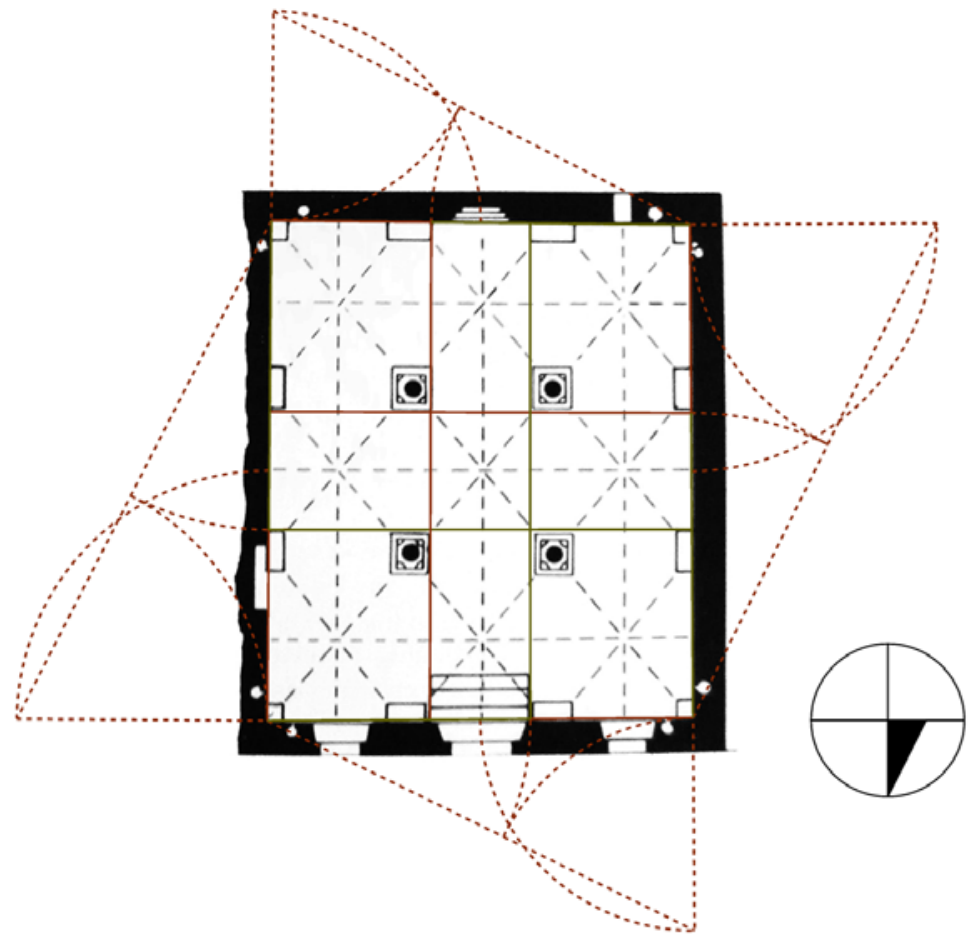

Il. 5.5. Schemat złotego podziału w synagodze w Tomar. Na podstawie: [20]

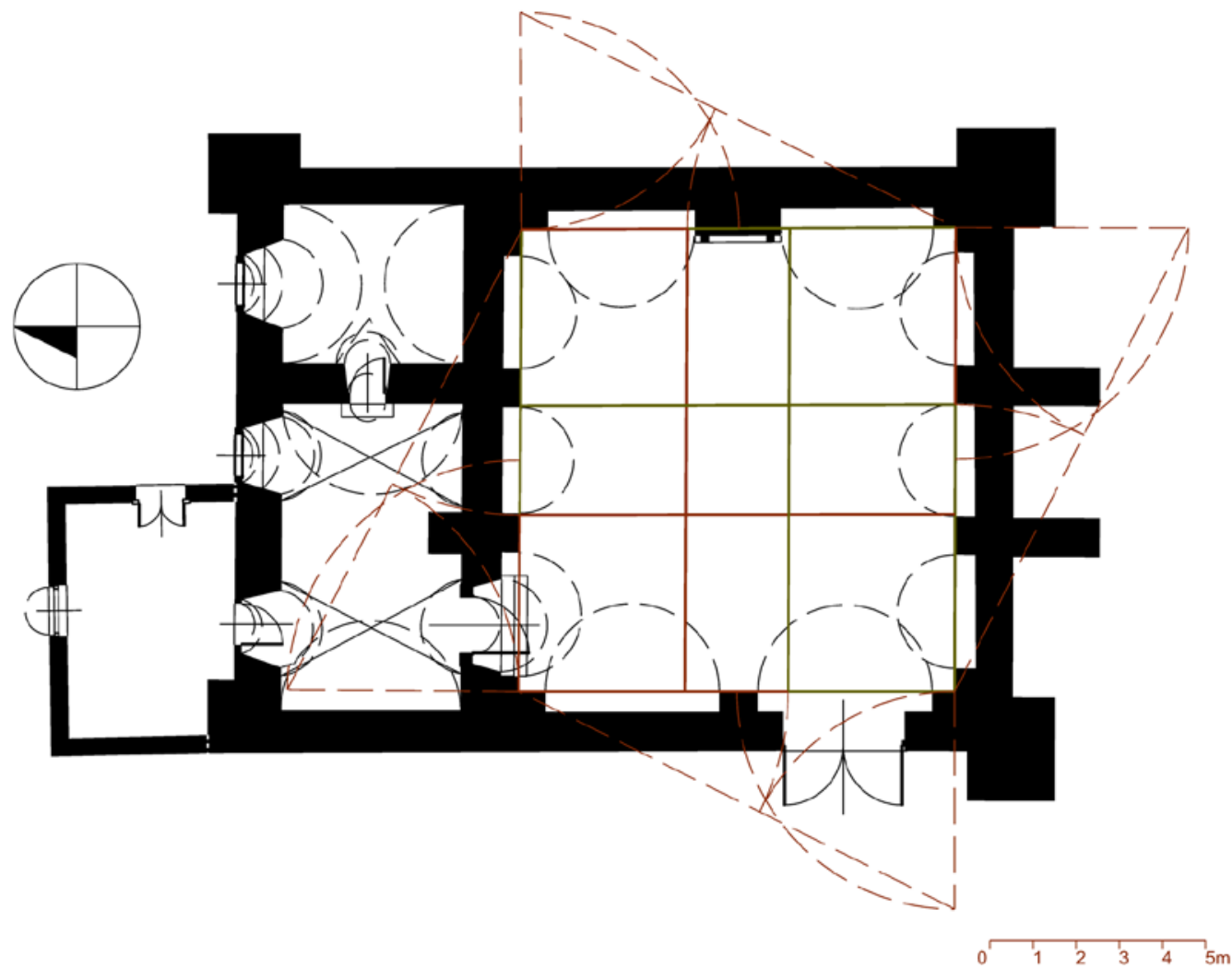

Il. 5.6. Schemat złotego podziału ścian sali męskiej w synagodze w Pińczowie [21] 
stronie linii wyznaczających złoty podział sali. Określają one tym samym odległości między gurtami sklepienia. Wydaje się, że zastosowanie złotego podziału w przypadku tej synagogi może raczej wynikać z poczucia estetyki i wyczucia idealnej proporcji, niż być zamierzonym i w pełni przemyślanym działaniem.

Złoty podział jest elementem charakterystycznym dla synagog polskich z bimą-podporą oraz dla synagog jednoprzestrzennych i dziewięciopolowych. Jednym z najwcześniejszych przykładów jest bożnica w Pińczowie (il. 5.6), której kompozycja planu jest dokładnie przemyślana. Ten obiekt, o pewnych cechach warowności, został zaplanowany z wykorzystaniem złotego cięcia w sposób inny niż synagoga w Tomar. Z przeprowadzonej analizy sali męskiej wynika, że wnęki centralne w ścianach północnej i południowej wpisują się niemal idealnie w proporcje złotego podziału tych ścian, a wymiary kolejnych wnęk są identyczne z wymiarami wnęki centralnej, będącej pokłosiem tego zabiegu.

\subsubsection{Złote proporcje sal męskich synagog z bimą-podporą}

Złota proporcja jest widoczna szczególnie w synagogach dziewięciopolowych z bimą-podporą, w których zastosowano ją w celu wyznaczenia wymiarów i lokalizacji słupów bimy (il. 5.7-5.9). Cała procedura polegała na podzieleniu - za pomocą złotego cięcia - czworoboku, na którym zakładane było wnętrze synagogi. W miejscach, w których przecinały się linie podziału ścian, były lokowane słupy bimy. Metoda ta została stwierdzona w większości analizowanych obiektów. Nawet jeżeli bima była sytuowana w innym miejscu, rozstaw słupów wynikał ze złotego podziału sali męskiej. W Synagodze Starej w Rzeszowie słupy bimy zostały umiejscowione właśnie $\mathrm{w}$ ten sposób, jednak nie centralnie w punktach przecięcia. Sama bima jest nieco rozciągnięta na osi wschód-zachód i przesunięta względem centrum planu w kierunku wschodnim.

Bima w synagodze w Tykocinie jest umieszczona w centrum obiektu i pod względem proporcji stanowi nawiązanie do kwadratu powstałego w wyniku podziału ścian zgodnie ze złotym cięciem. Słupy po raz kolejny nie zostały jednak usytuowane centralnie w punktach przecięcia, ale przesunięte o około $20 \mathrm{~cm}$ po przekątnej bimy na zewnątrz wyznaczonego pola. Podobne rozwiązanie zastosowano w synagogach w Pińsku (1640) i Rymanowie (koniec XVIII w.).

W synagodze w Orli zamysł ten został zatarty ze względu na przebudowę oraz zmianę rozstawu słupów. Relikty, które zostały odkryte w trakcie badań archeologicznych, dają podstawę, by stwierdzić, iż schemat, o którym tutaj mowa, został zachowany, z jednoczesnym lekkim przesunięciem bimy w kierunku wschodnim, podobnie jak w Synagodze Starej w Rzeszowie.

W synagodze w Dukli jest realizowany opisywany schemat, jednak w nieco przetworzonej formie. O ile bowiem gurty sklepienia oraz słupy „ślizgają się” po liniach złotego podziału ściany wschodniej i zachodniej i są wysunięte na zewnątrz w kierunku północnym i połu- 

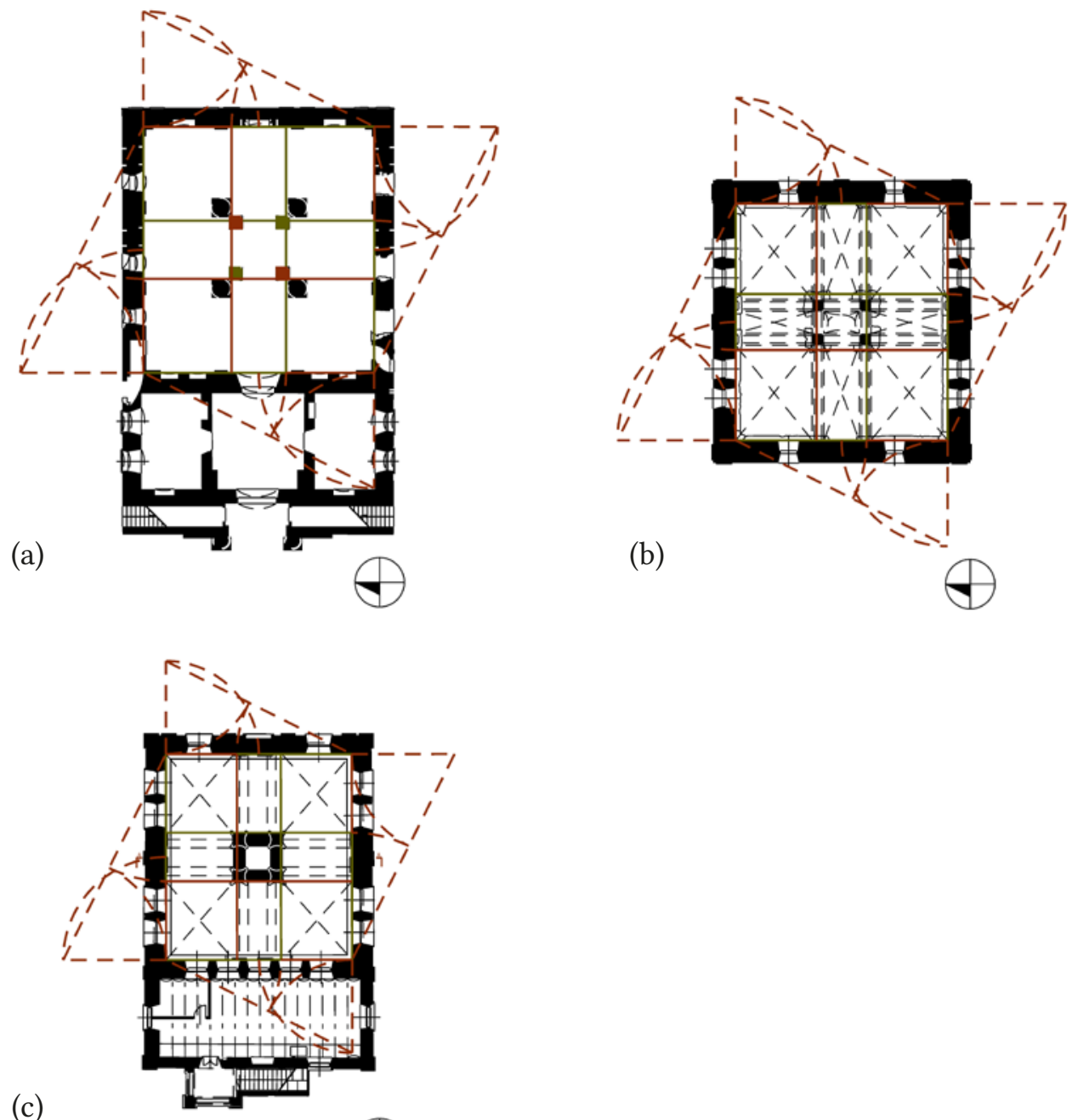

(c)

$\odot$

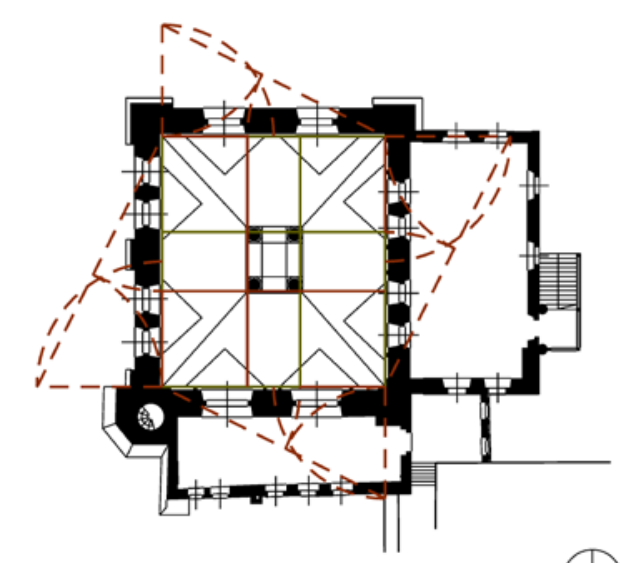

(d)
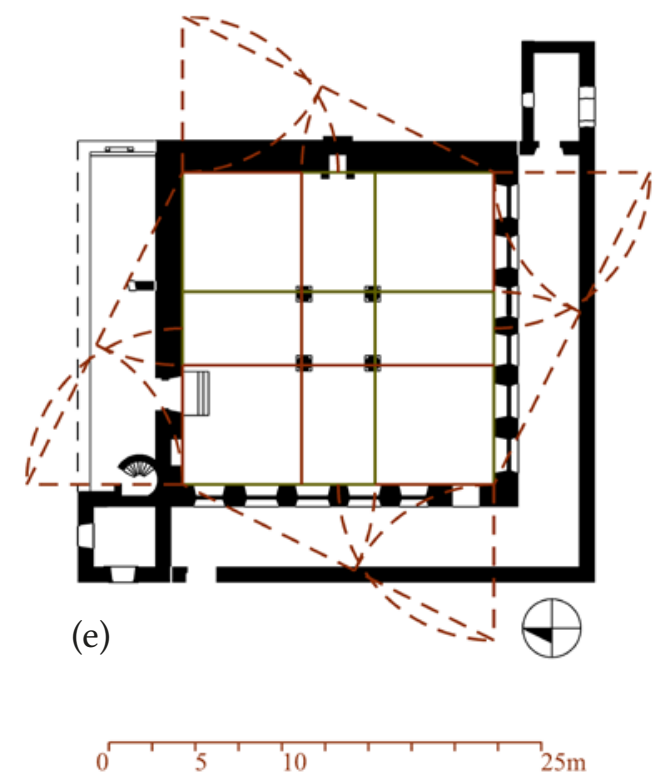

Il. 5.7. Schematy złotego podziału w synagogach w: Orli (2. ćw. XVII w.) (a), Dukli (1758) (b), Łańcucie (1761) (c), Synagodze Starej w Rzeszowie (pocz. XVII w.) (d) i Tykocinie (1642) (e) [21] 


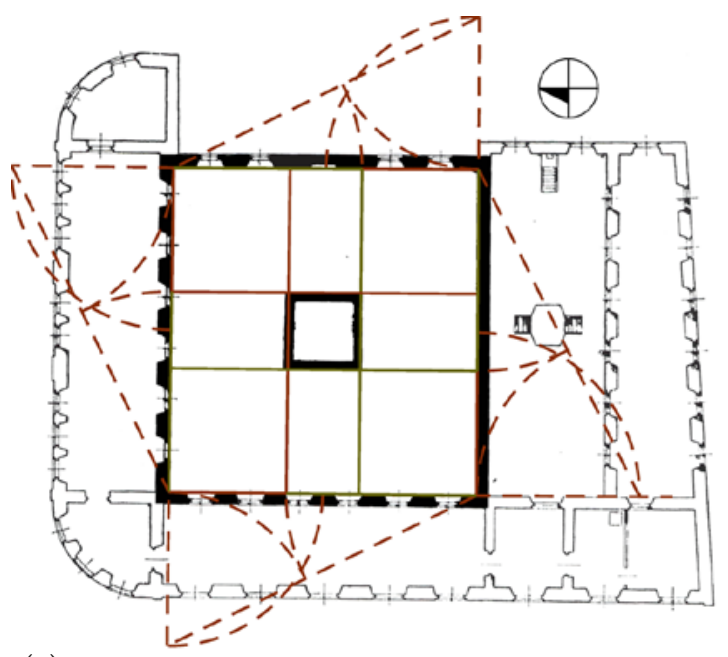

(a)

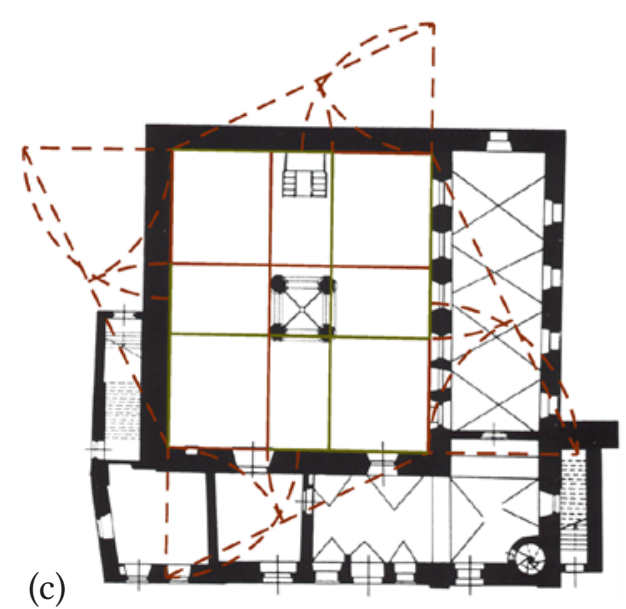

$\theta$

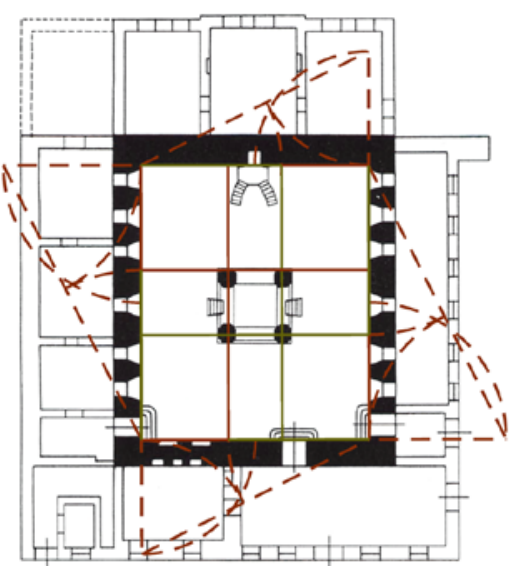

(e)

$\oplus$ (b)

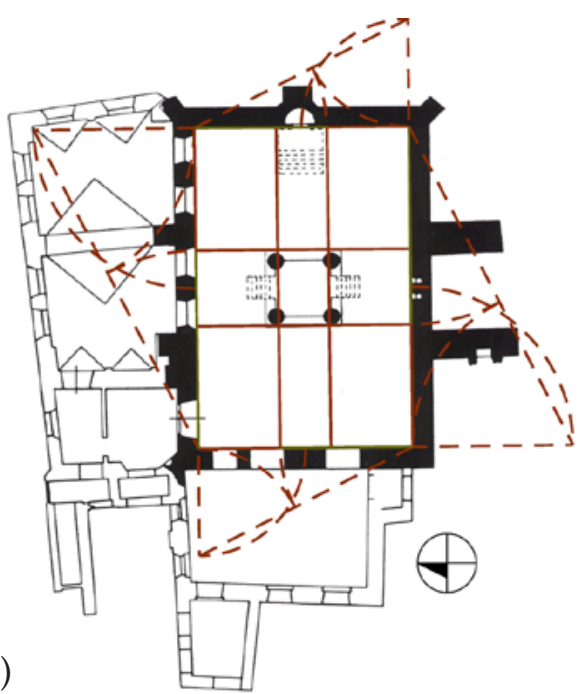

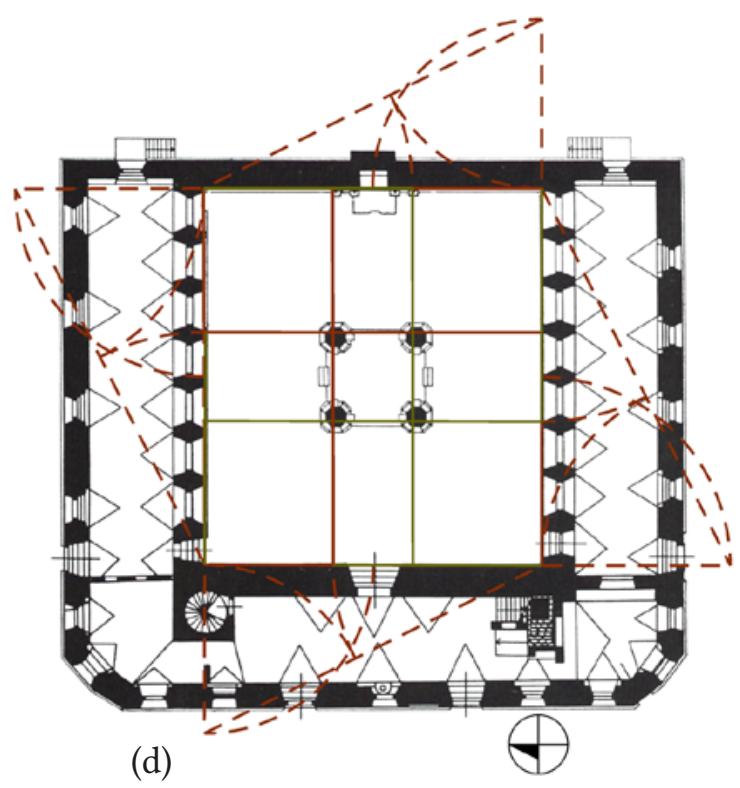

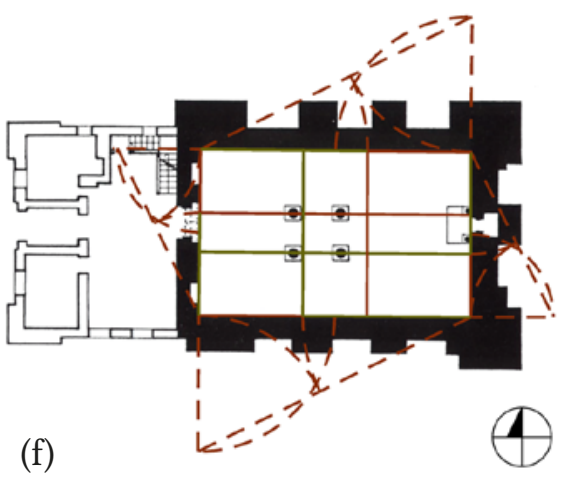

pierwotna forma obiektu wg M. i K. Piechotków póżniejsze dobudowy

Il. 5.8. Schematy złotego podziału w synagogach z bimą-podporą. Synagoga Maharszala w Lublinie (stan w 1920) (a) oraz synagogi w: Przemyślu (1592-1594) (b), Łucku (1629) (c), Pińsku (1640) (d), Słonimiu (1642) (e), Łęcznej (1655) (f). Na podstawie: [25] 

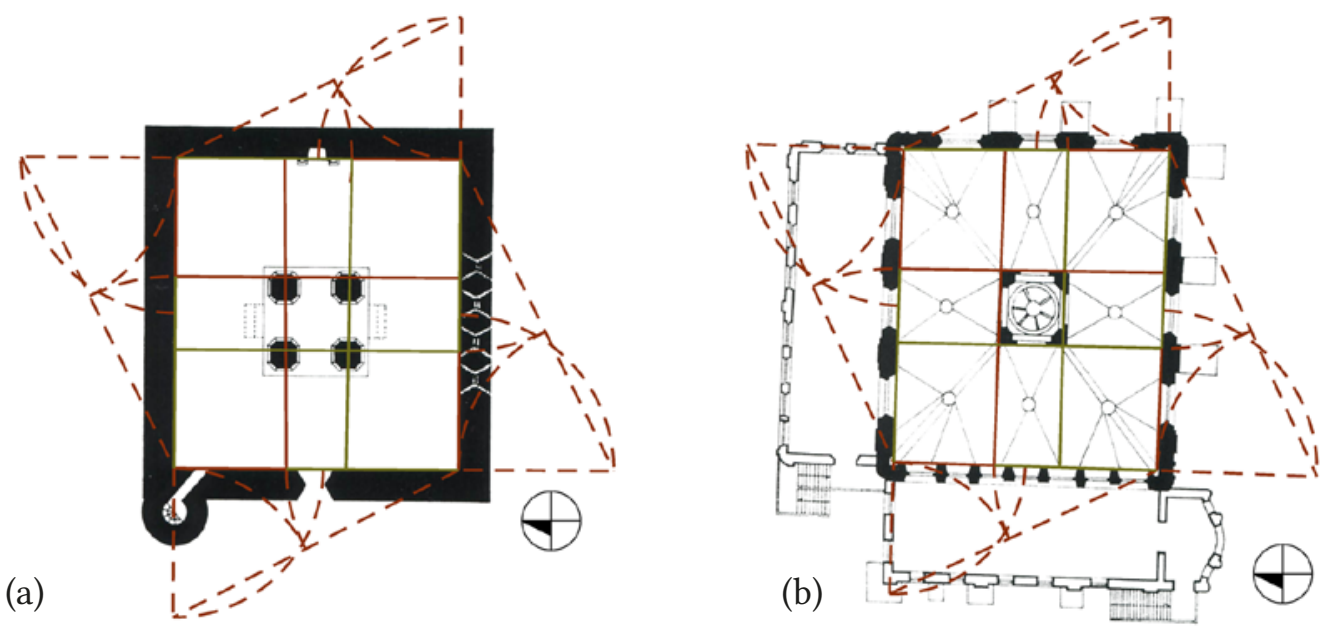

(c)

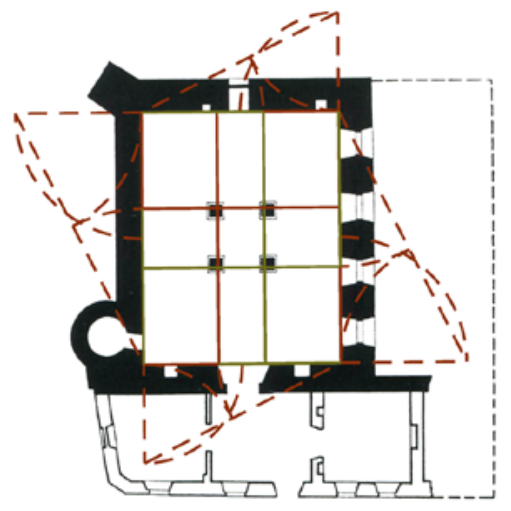

pierwotna forma obiektu wg M. i K. Piechotków póżniejsze dobudowy

Il. 5.9. Schematy złotego podziału w synagogach z bimą-podporą w: Bychowie Nowym (4. ćwierć XVII w.) (a), Przeworsku (XVII/XVIII w.) (b), Rymanowie (koniec XVIII w.) (c). Na podstawie: [25]

dniowym, o tyle w przypadku osi północ-południe bima została wciśnięta między osie powstałe na skutek podziału wnętrza. Wynika to natomiast z faktu, że do prawie kwadratowej sali wstawiono bimę prostokątną, usytuowaną poprzecznie do osi wschód-zachód.

Jednym z lepszych przykładów realizacji złotego podziału jest synagoga w Łańcucie. Na osi północ-południe bima krawędziami nadstawy wpisuje się złoty podział, ale niemal idealnie, ponieważ jest lekko przesunięta w kierunku zachodnim. Na osi wschód-zachód „wylewa” się natomiast poza granice wyznaczone złotym cięciem. Jej lokalizacja względem wyznaczonego schematu jest prawie bliska doskonałości.

Bimy idealnie wpisane w linie złotego podziału znajdowały się w synagodze Maharszala w Lublinie (1567) i w synagodze w Przeworsku (XVII/XVIII w.). W tym drugim obiekcie, pomimo romboidalnego kształtu sali męskiej, bima została dostosowana do kształtu wnętrza - jej krawędzie były równoległe do krawędzi ścian, a tym samym stanowiła w rzucie również romb. 
Lokalizacja bim w kilku synagogach wydaje się przypadkowa i niezależna od złotego podziału sali. W synagogach w: Łucku (1629), Łęcznej (1655), Bychowie (IV ćw. XVII w.) oraz w Wielkiej Synagodze w Kalwarii na Litwie (1759-1802) bima została lekko przesunięta w kierunku zachodnim (jedynie w synagodze w Kalwarii w kierunku południowo-zachodnim), co było popularne w przypadku sal z wolnostojącymi podestami. Dawało to możliwość sytuowania jej w środku odległości między początkiem schodów do Aron ha-Kodesz a ścianą zachodnią. We wszystkich wymienionych budowlach albo wymiary bimy wpisują się idealnie między linie wyznaczające złoty podział sali (jak w synagodze Łuck) albo środki słupów są wyznaczane przecięciami linii (jak w synagogach w Bychowie i Łęcznej).

Twórcy synagogi w Przemyślu (1592-1594) wykazali się zupełnie innym podejściem do złotej proporcji. Na osi wschód-zachód linie podziału obejmują w całości podest bimy, natomiast na osi północ-południe znajdują się idealnie w centrum słupów. Podobnie jest w synagodze w Słonimiu (1642), przy czym bima została tam lekko rozciągnięta w kierunku zachodnim. Zasada złotego podziału pozwala więc wyjaśnić, z czego wynika zbliżenie słupów i wytworzenie centralnego pola o takich właśnie proporcjach. Jej proste i wyraźne zastosowanie w planie budynku jest unikalne dla architektury bożniczej. Wraz z obniżeniem sklepienia $\mathrm{w}$ centralnym polu i połączeniem podestu z konstrukcją konstytuuje rozwiązanie, jakim jest synagoga z bimą-podporą. We wszystkich przeanalizowanych obiektach dostosowano proporcje planu bim do proporcji złotego podziału planu sali męskiej.

\subsubsection{Złote proporcje sal męskich $\mathrm{w}$ synagogach dziewięciopolowych}

Wydaje się, że w synagogach dziewięciopolowych starano się dziedziczyć163 ${ }^{163}$ rozwiązanie związane z proporcją złotego cięcia (rys. 5.10).

W zlokalizowanych w Ostrogu i Lwowie pierwszych obiektach dziewięciopolowych wykorzystano podział na względnie równe pola. Ten typ kompozycji wnętrza utrzymywał się przez cały XVIII wiek. Obok tego nurtu powstał również drugi, w którym usytuowanie słupów powodowało zmniejszenie centralnego pola w stosunku do pozostałych pól. Wykorzystywano do tego celu zasadę złotego podziału, tak charakterystyczną dla bożnic z bimą-podpora.

Już w synagodze w Wilnie usytuowano słupy idealnie na przecięciu się osi złotego podziału sali męskiej. Co ciekawe, jest to jedyny przykład bożnicy dziewięciopolowej z tak idealnie rozplanowaną salą.

W innych obiektach wykorzystywano dwa układy. Przykładem jednego są Synagoga Nowomiejska w Rzeszowie (1700-1708) i synagoga w Druji (2. połowa XVIII w.). W pierwszym obiekcie podział ścian północnej i południowej wyznaczył centrum gurtów sklepiennych oraz słupów bimy. W osi wschód-zachód słupy bimy zostały wysunięte na zewnątrz, powiększając nieco przestrzeń centralnego pola. W bożnicy w Druji podział ściany wschodniej i zachodniej wyznaczył względnie centrum gurtów sklepiennych oraz słupów bimy. 
W osi północ-południe zastosowano układ identyczny jak w Synagodze Nowomiejskiej w osi wschód-zachód. Słupy bimy zostały wysunięte na zewnątrz, powiększając nieco przestrzeń centralnego pola.

Proces przesuwania złotego podziału z centrum słupów i gurtów na wewnętrzną krawędź gurtu w centralnym pasie sklepienia doprowadził do wytworzenia takiego systemu lokowania słupów, jak w synagodze w Tomar.

W Polsce poszerzenie centralnych pasów sklepiennych i lokowanie słupów na zewnątrz linii wyznaczających złote proporcje sali męskiej było charakterystyczne dla 4. ćwierci XVIII wieku. Przykładem takich działań są synagogi w Staszowie i Strzyżowie.

Z powyższych przykładów wynika, że w kilku bożnicach dziewięciopolowych zastosowano również zasadę złotego podziału. Sposób jej wykorzystania jest jednak odmienny: o ile w pierwszej fazie wznoszenia bożnic dziewięciopolowych można zauważyć dążenie do sytuowania słupów idealnie na przecięciach linii złotego podziału, o tyle pod koniec XVIII wieku zaczęto rozsuwać słupy poza centralny obszar wyznaczony tymi liniami, powiększając tym samym wymiary pola centralnego.

\subsection{Podsumowanie}

Synagogi powstające w XVII i XVIII wieku można podzielić na trzy grupy: jednoprzestrzenne, z bimą-podporą i dziewięciopolowe. Charakterystyczne dla ich twórców było dążenie do wzniesienia obiektu założonego na kwadracie. Oprócz synagog z wymienionych grup, począwszy od XVI wieku wznoszone były bożnice jednonawowe na planie prostokąta.

Największą grupę bożnic - w swojej pierwotnej formie opierających się zwykle na sali męskiej - tworzyły te na planie kwadratu lub na planie zbliżonym do kwadratu, jak na przykład w: Tykocinie, Tarnogrodzie, Zamościu, Orli, Łańcucie, Bobowej, Dukli, Rzeszowie (Synagoga Stara), Szczebrzeszynie i Włodawie. Inne obiekty wznoszono na planie prostokąta o proporcjach: 3:4 (w Pińczowie), 5:7 (w Chęcinach), 2:3 (Synagoga Nowomiejska w Rzeszowie) i zbliżonych do 5:6 (w Siemiatyczach i Lesku).

Niezależnie od proporcji bożnicy planowano salę męską na kwadracie lub z zachowaniem proporcji zbliżonej do kwadratu (synagogi w: Tykocinie i Tarnogrodzie, Siemiatyczach, Orli, Pińczowie, Zamościu, Włodawie, Dukli, Łańcucie, Chęcinach, Szczebrzeszynie, a także Synagoga Nowomiejska i Synagoga Stara w Rzeszowie) albo w nawiązaniu do proporcji całego budynku, jak w przypadku bożnicy w Lesku.

Większość bim-podpór i pól centralnych w bożnicach dziewięciopolowych również była na planie kwadratu. Właściwie jedynym szczególnym przypadkiem jest poprzecznie usytuowana, prostokątna bima w synagodze w Dukli.

Sposób ukształtowania wnętrz synagog z bimą-podporą, jak również części bożnic dziewięciopolowych oparty został na zasadzie złotego podziału. Bożnice w Polsce są ewe- 

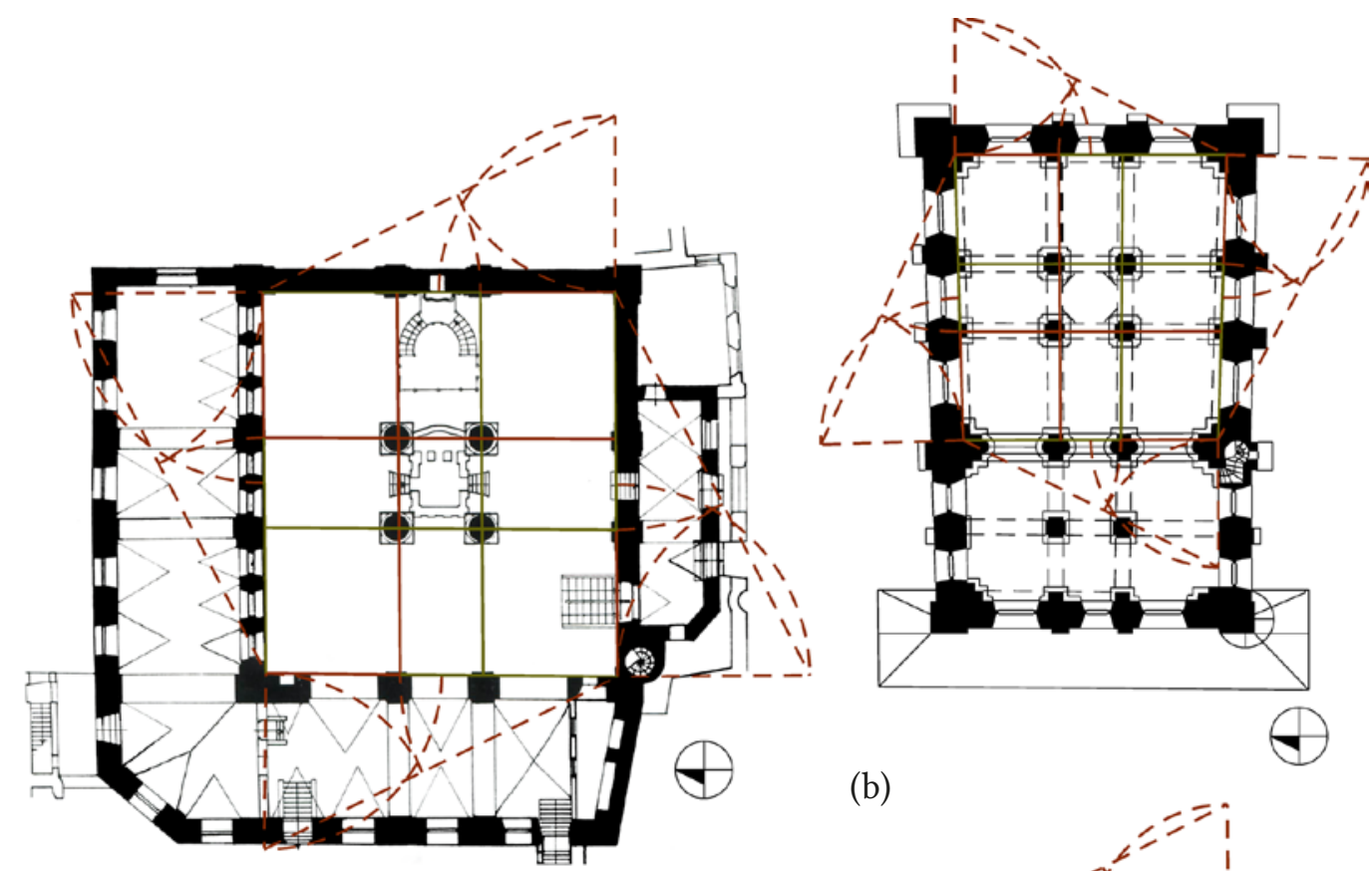

(a)

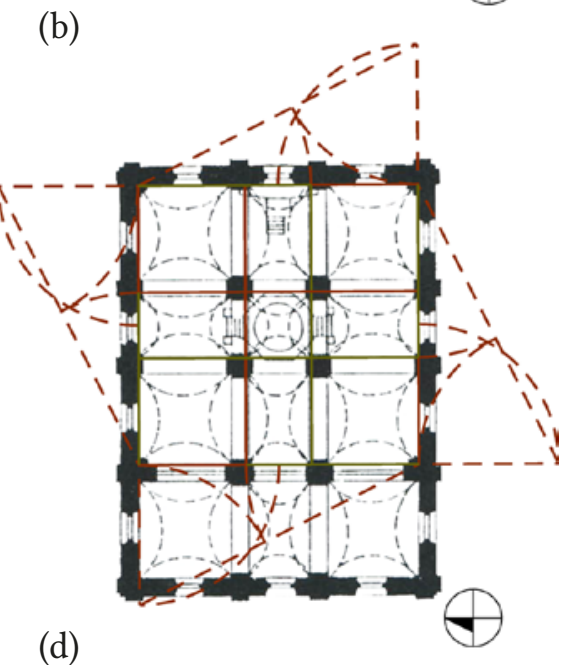

(c)
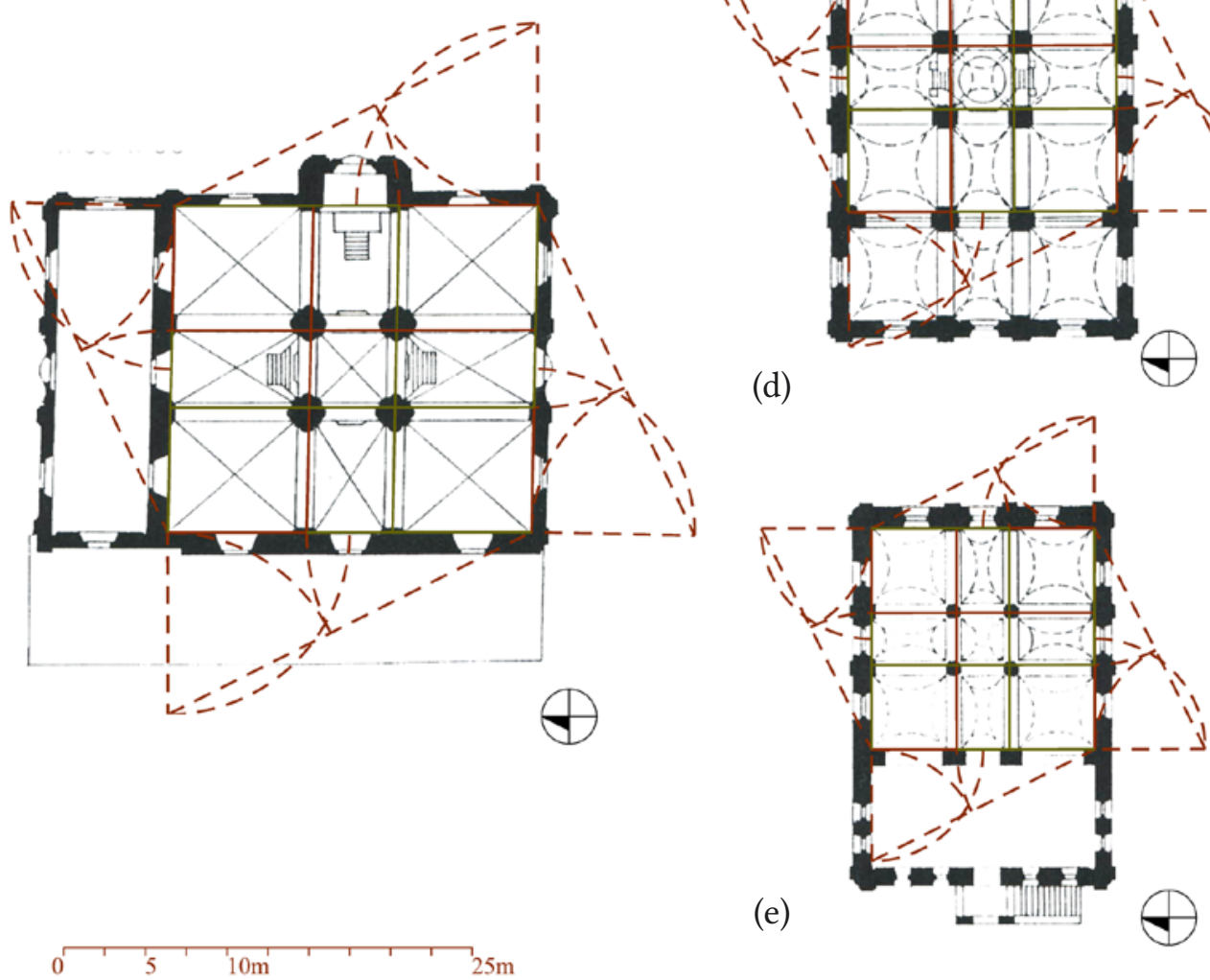

Il. 5.10. Schematy złotego podziału zastosowanego w synagogach dziewięciopolowych:

w Wielkiej Synagodze w Wilnie (1633) (a), w Synagodze Nowomiejskiej w Rzeszowie (1700-1708) (b) oraz w synagogach w: Druji (2. połowa XVIII w.) (c), Staszowie (4. ćwierć XIII w.) (d), Strzyżowie (4. ćwierć XVIII w.) (e). Na podstawie: [25] 
nementem w tej dziedzinie. Trudno jest znaleźć typ obiektu, który choć wznoszony w różnych miejscach na przestrzeni dwustu lat, nie zmieniałby swojej formy i za każdym razem powtarzałby zasadę złotego podziału. Idea zachowania idealnej proporcji przyświecała budowniczym już od wieków, nie pojawiała się jednak w traktatach architektonicznych jako wytyczna projektowa. Po raz pierwszy została nazwana i bardzo dokładnie omówiona w pochodzącej z 1507 roku pracy Luki Paciolego. Dzieło to prawdopodobnie nie było jednak zbyt popularne i dopiero powstały w latach 30. XVIII wieku traktat Guarino Guariniego mógł przyczynić się do rozpropagowania tej zależności, choć, jak wykazano powyżej, zaproponowana konstrukcja była błędna i nie uzyskiwano w związku z jej zastosowaniem złotej proporcji.

Mało prawdopodobne wydaje się również, aby społeczność żydowska dopuściła do zastosowania boskiej proporcji w kontekście symboliki przypisywanej jej przez Paciolego zwłaszcza w odniesieniu do trójosobowego Boga. Oznacza to, że znaleziono inną symbolikę dla złotej zasady, podobnie jak dla wykorzystania formy cyborium. Można również przypuszczać, że koncepcja złotej proporcji rozwijała się w kulturze żydowskiej niezależnie od innych kultur.

Uzasadnieniem słuszności tej drugiej teorii mogłaby być XV-wieczna synagoga w Tomar. Zastosowanie w tym obiekcie boskiej proporcji mogło być związane z wpływem społeczności muzułmańskiej, która stanowiła znaczną cześć ludności ówczesnego Półwyspu Iberyjskiego, oraz znała i wykorzystywała tę zasadę chociażby przy rozplanowywaniu meczetów [19] ${ }^{164}$. Nie ulega jednak wątpliwości, że Tanach zawiera wymiary i wartości, których proporcje znajdują się bardzo blisko złotego podziału.

Wartości zbliżone do złotej proporcji występują również w stosunkach wymiarów analizowanych bożnic. Podobnie jak w przypadku Arki Przymierza, ołtarza czy pałacu Salomona wiążą się one ze stosunkieim wysokości do jednego z wymiarów rzutu. I tak w bożnicach w Zamościu i Szczebrzeszynie złota zasada dotyczy zewnętrznych wymiarów synagogi, natomiast w Chęcinach, Orli i Dukli wnętrza sali męskiej. Zastosowanie proporcji, które odnoszą się do Arki Przymierza, ołtarza oraz przedsionka świątyni w wizji Ezechiela, może przywodzić na myśl próbę uświęcenia bożnicy, podobnie jak w przypadku zastosowania w wystroju sprzętów świątynnych.

Z wzorca złotego podziału czerpali również twórcy synagog dziewięciopolowych. Forma i realizacja schematu przyjętego w synagogach z bimą-podporą zostają w bożnicach dziewięciopolowych przetransponowane na pole centralne o powiększonych wymiarach, ale przy zachowaniu boskiej proporcji sali męskiej.

Kierowanie się przy wznoszeniu bożnic zasadą złotej proporcji było z pewnością efektem wpływu architektury renesansu. Analizując formę z tego okresu zlokalizowanych na terenie Polski, można stwierdzić, że była ona przestrzegana w architekturze fundowanej przez możnych panów. O wpływie architektury renesansu na architekturę bożnic może świadczyć identyczne zastosowanie idealnego podziału w kompozycji ściany Kaplicy Zygmuntowskiej 
i sali męskiej synagogi w Pińczowie. Od czasu działalności kontrreformacji staje się on w ogóle podstawą kształtowania planów kościołów.

Uwagę zwraca również fakt, że zasada złotej proporcji była uwzględniana w tych samych obiektach co złoty podział kwadratu, który jednoznacznie określił usytuowanie centralnej bimy-podpory. Wskazuje to jednoznacznie, że proporcje synagog w XVII i XVIII wieku oraz sposób kształtowania przestrzeni sali męskiej w oparciu o zasadę złotej proporcji są swoiste dla bożnic znajdujących się obszarze Polski.

\section{Przypisy}

158 Vide: podrozdz. 8.1.1.

${ }^{159}$ Luca Pacioli był franciszkaninem, który znaczną cześć swojego życia spędził na dworze Ludwika Sforzy.

${ }^{160}$ Inne traktaty architektoniczne milczą na temat złotej zasady. U Vignioli, Serlia, Palladia, Scamozziego nie znajdzie się tej zależności. Autorzy ci nadal wolą korzystać z całkowitych proporcji, a jedyną niewymierną liczbą, która występuje, jest $\sqrt{ } 2$.

${ }^{161}$ Luca Pacioli, Leonardo da Vinci i Donato Bramante spotkali się prawdopodobnie na dworze Sforzy. Albrecht Dürer mógł spotkać Paciolego w trakcie swojej wizyty we Włoszech w latach 1506-1507.

162 Vide: podrozdz. 6.2.5.2.

${ }^{163}$ Tym samym twierdzenie Rachel Wischnitzer o dziedziczności form z synagog z bimą-podporą w synagogach dziewięciopolowych wydaje się prawdziwe. Vide: S.R. Kravtsov, O proiskhozhdenii deviatipolevykh kamennykh sinagog, [w:] Evreiskoie iskusstvo v evropeiskom kontekste, ed. I. Rodov, Jerusalem-Moskwa 2002, s. 200; R. Wischnitzer, Symbole und Gestalten der jüdischen Kunst : mit 6 Farbigen Tafeln und 81 Abbildungen, Berlin 1935, s. 128.

${ }^{164}$ Wielki meczet w Kairouanie z VII w. był rozplanowany z wykorzystaniem złotej proporcji. 


\section{ODDZIAŁYWANIE ŚWIACTYNI JEROZOLIMSKIEJ NA ARCHITEKTURĘ BOŻNICZĄ}

\subsection{Związki między świątynią jerozolimską ${ }^{165}$ a synagogą}

Świątynia jerozlimska jest głównym motywem inspiracji w sztuce żydowskiej. Stanowi bowiem źródło symboli i form oraz - odpowiadając na pytanie Dominique Jarrassé [72, s. 68 $]^{166}$ - stała się fundamentem architektury żydowskiej [110, s. 18]. W wielu opracowaniach z zakresu literatury przedmiotu badacze wskazują na związki synagogi ze świątynią jerozolimską ${ }^{167}$. Początkiem rozumienia synagogi jako kontynuacji świątyni jest określanie jej jako małej świątyni. Informacja o tym zawarta jest w Talmudzie [99, s. 106], który za Ksiegga Ezechiela przypomina: „[...] wprawdzie wygnałem ich pomiędzy narody i rozproszyłem po krajach, jednak przez krótki czas będę dla nich świątynią w tych krajach, do których przybyli” [137, Ez 11,16]. Fragment ten był interpretowany w sposób, który sugerował ciągłość świątyni w bożnicy [194, s. 28]. Takie rozumienie synagogi znalazło odzwierciedlenie w inskrypcji fundacyjnej synagogi w Kordobie, a także w traktacie rabina Judy Ben Elizera Minza z XV wieku [99, s. 7]. Konsekwencją doszukiwania się analogii między oboma obiektami było przetransponowanie struktury domu zgromadzeń na poszczególne elementy przestrzeni wzgórza świątynnego. Stwierdzono tym samym, że synagoga na ogół przedstawia trzyczęściowy wzór świątyni w Jerozolimie. Jedną z osób, które zwróciły uwagę na symbolikę poszczególnych elementów i przestrzeni w bożnicach, był Kenneth Atkinson [4, s. 61-62]. Pierwsza część synagogi, audytorium (sala męska), odpowiada w starożytnej świątyni zewnętrznemu sądowi, gdzie wszyscy Żydzi mogli się modlić. Bima reprezentuje starożytne sanktuarium świątynne, w którym odbywały się rzeczywiste ceremonie kultu. Było ono otwarte tylko dla kapłanów, znajdował się w nim ołtarz ofiarny i zawsze rozświetlony siedmioramienny świecznik. Alfred Grotte rozszerza tę przestrzeń również o podest znajdujący się przed szafą na rodały, wskazując na ceremonialny charakter tej przestrzeni, związany z otwarciem arki i zamknięciem jej wrót po odczytaniu parszy [54, s. 6] (czyli porcji tekstu Tory przypadającej na jeden tydzień). Aron ha-Kodesz, który zawiera zwoje Tory, odpowiada Kodesz ha-Kodaszim ${ }^{168}$, czyli pokojowi najgłębiej umieszczonemu w świątyni, do którego mógł wejść tylko najwyższy kapłan i tylko raz w roku - w święto fom Kipur. Ten pokój był pusty i reprezentował obecność Boga [4, s. 61]. 
Związki między świątynią jerozolimską a synagogą zauważają również inni badacze ${ }^{169}$, choć niewątpliwie bardziej zaznaczają różnice istniejące w strukturze obu obiektów oraz w sposobie ich traktowania. Należy zwrócić uwagę, że o ile świątynia służyła wszystkim Żydom, o tyle synagoga funkcjonuje w obrębie mniejszej grupy - gminy. Bet ha-Kneset charakteryzuje się jeszcze kilkoma odmiennymi cechami. Dopuszcza pewne zachowania nieakceptowane w świątyni oraz możliwość adaptacji obiektu i jego sekularyzację [194, s. 11-13]. Można wprawdzie przyjmować symboliczne rozumienie synagogi i odniesienia do najświętszego miejsca judaizmu, należy jednak podkreślić, że oba obiekty nie są sobie w żaden sposób równe. Symbolika ta oznacza jedynie, iż synagoga jest miejscem, w którym Żydzi, również poprzez rozkład modlitw, zachowują pamięć o posłudze świątynnej. Budynek synagogi i przestrzeń, którą wykształca, mają prowadzić do jednego punktu istotnego w historii Żydów - wzgórza świątynnego [97, s. 43]. Niewłaściwe jest zatem rozumienie świątyni jerozlimskiej i synagogi jako tożsamych bytów, gdyż w synagodze nie ma elementu sakralnego, wyrażanego przez stałą obecność Boga. Świątynia stanowiła najwyższą formę ludzkiej ekspresji i była syntezą ludzkiej relacji ze światem, kosmosem i Bogiem [71, s. 9]. Synagoga nie może zatem imitować świątyni, czego wyrazem jest chociażby wygląd świeczników, które posiadają osiem, a nie siedem ramion jak świątynna menora. Jedynym elementem świętym w synagodze jest zwój. Jego obecność wraz z minjanem nadaje wnętrzu sakralny charakter [71, s. 11].

Wpływu wzorca świątyni jerozolimskiej na architekturę synagogalną z pewnością można szukać w rekonstrukcjach i wizjach tego najświętszego miejsca judaizmu, które powstawały już od III wieku ${ }^{170}$. Tworzono je nie tylko w obrębie społeczności żydowskiej, ale również w kręgach chrześcijańskich ${ }^{171}$.

Stylizowanie synagogi na świątynię - ze względu na wyraz architektoniczny, ale i aspekt symboliczny - było szczególnie widoczne w XIX wieku. Wzmożenie się ruchu propagującego podejście do synagogi jak do świątyni było ściśle związane z rozwijającym się wówczas judaizmem postępowym. Synagogi nazywano Tempel, co budzi jednoznaczne konotacje. Sposób patrzenia na to zagadnienie w tamtym czasie najlepiej obrazują słowa Zadoc Kahna, który uważał, że świątynia jest tam, gdzie są Żydzi [72, s. 67]. Zresztą za materialny wyraz wzorca świątyni przyjęto obiekt architektoniczny. Działo się tak za sprawą powstających wówczas rekonstrukcji świątyni jerozolimskiej, na których wzorowano się w trakcie wznoszenia bożnic [96].

\section{2. Świątynia jerozolimska - analiza wzorca}

Prawdopodobnie pierwszy ikonograficzny wizerunek namiotu spotkania można zobaczyć w synagodze w Dura Europos (244-245). Funkcjonujący wówczas język obrazu umożliwił jego wykreowanie jako grecko-rzymską świątynię [123, s. 41]. Graficzne przedstawienia Jeruzalem pojawiły się na ścianach wielu XVIII-wiecznych synagog ${ }^{172}$. Znalazły się one rów- 
nież u Majmonidesa ${ }^{173}$ [191] oraz w wielu różnych dziełach, w których ten symbol miał swoje wizualne manifestacje [74], [124], [140], [158].

Początek najświętszego miejsca judaizmu odnajdujemy w przybytku, którego opis zawarto w Księdze Wyjścia [137, Wj 25-31]. Przybytek miał po dziesięć łokci wysokości i szerokości oraz trzydzieści łokci długości. Uzyskano więc proporcję trzech kwadratów (1:3), z których jeden stanowił Najświętsze ze Świętych świątyni [137, Wj 26,16-29]. Dziedziniec świątynny został oparty na proporcji dwóch kwadratów (1:2). Jego ściany miały sto i pięćdziesiąt łokci długości oraz pięć łokci wyskości [137, Wj 27,18]. Ołtarz na ofiarę całopalną miał być prostopadłościanem o podstawie kwadratu. Bok podstawy to pięć łokci, a wysokość to trzy łokcie. Proporcja długości boku kwadratu do jego wysokości wynosiła 3:5. Arka Przymierza miała dwa i pół łokcia długości, po półtorej łokcia szerokości i wysokości [137, Wj 25,10]. Oznacza to, że uzyskano ponownie proporcję 3:5. Stół na chleby pokładne mierzył dwa łokcie długości i jeden łokieć szerokości oraz półtora łokcia wysokości [137, Wj 25,23]. W planie prostokąt ten posiadał proporcje dwóch kwadratów (1:2). Stosunek wysokości do długości stołu to 3:4, a do szerokości 2:3. Ostatnim z elementów, którego wymiary zostały podane, był ołtarz kadzielny. Jego długość i szerokość miały wynosić jeden łokieć, a wysokość miała być równa dwóm łokciom [137, Wj 30,1].

O świątyni i posługach, które miały być w niej sprawowane, można przeczytać również w Pierwszej Księdze Kronik [137, 1 Krn 21-23, 28-29] oraz Drugiej Księdze Samuela [137, 2 Sm 6-8, 24]. Wynika z nich, że Dawid przekazał plany świątyni swojemu synowi Salomonowi [137, 1 Krn 28,11-12; 2 Sm 7,12-13]. Nie ma jednak mowy o jej wymiarach. Opis świątyni Salomona pojawia się natomiast w Pierwszej Księdze Królewskiej [137, 1 Krl 5-8] i Drugiej Księdze Kronik [137, 2 Krn 2-6]. W pierwszej z wymienionych jest napisane: „Dom, który Salomon zbudował dla Pana, miał sześćdziesiąt łokci długości, dwadzieścia szerokości i trzydzieści wysokości. Sień zaś przed główną budowlą świątyni miała dwadzieścia łokci długości, stosownie do szerokości świątyni, i dziesięć łokci szerokości, w kierunku długości świątyni [137, 1 Krl 6,2-3]”. Stosunki boków, jakie uzyskano, wynosiły: 1:2, 1:3 i 2:3. Dookoła świątyni biegły pomieszczenia rozlokowane na trzech kondygnacjach: najniższej o szerokości pięciu, środkowej o szerokości sześciu i najwyższej o szerokości siedmiu łokci [137, $1 \mathrm{Krl} 6,6]$, [43, 7.3.2]. Sanktuarium miało czterdzieści łokci długości [137, $1 \mathrm{Krl}$ 6,17], [43, 7.3.3]. Kodesz ha-Kodaszim natomiast było sześcianem o boku równym dwudziestu łokciom [137, 1 Krl 6,20]. Przed świątynią znajdowały się dwie kolumny, z których każda miała osiemnaście łokci wysokości i dwanaście łokci obwodu. Każda z głowic kolumn miała wysokość pięciu łokci [137, 1 Krl 7,15-16 $]^{174}$. Stosunek obwodu do wysokości kolumny wynosił więc 2:3. Jeżeli jednak przyjmie się, że proporcja kolumny liczona jest do wysokości z kapitelem, wówczas będzie to 1:1,92. Stosunek wysokości kolumny i kapitelu do średnicy kolumny wynoszącej 3,82 łokcia to 1:6. W Drugiej Księdze Kronik podane jest jednak, że kolumny miały trzydzieści pięć łokci wysokości [137, 2 Krn 3,15], co razem z głowicą daje czterdzieści łokci i proporcję do obwodu 3:10.

Zbiornik wody na dziedzińcu świątynnym miał dziesięć łokci średnicy i pięć łokci wysokości oraz obwód równy trzydziestu łokciom [137, 1 Krl 7,23]. Proporcja średnicy do obwodu 
wynosiła 1:3, wysokości do średnicy 1:2, a obwodu do wysokości 1:6. Na dziedzińcu znajdował się również ołtarz w kształcie sześcianu, którego bok miał dwadzieścia łokci długości [137, 2 Krn 4,1]. Józef Flawiusz pisał jednak, że ołtarz ten był prostopadłościanem, a jego wysokość wynosiła tylko dziesięć łokci [43, 3.3.7].

W Drugiej Księdze Kronik opisane jest podwyższenie, na którym klęczał Salomon. Podest ten w podstawie miał kwadrat o boku, którego długość wynosiła pięć łokci, a wysokość trzy łokcie. Stosunek wysokości do boku podwyższenia był równy 3:5 $5^{175}$.

Historia świątyni Salomona kończy się wraz z jej zniszczeniem przez wojska Nabuchodonozora [137, 2 Krl 24-25; 2 Krn 36,19] około 586 roku p.n.e. Odbudowa nastąpiła około 520 roku p.n.e., jednak zanim do niej przystąpiono prorok Ezechiel przedstawił wizję nowej świątyni [137, Ez 40-48.]. Opis zawarty w Księdze Ezechiela jest niezwykle drobiazgowy. Podane są w nim dokładne wymiary w zasadzie wszystkich części budowli. Cztery przedsionki odpowiadające czterem stronom świata miały pięćdziesiąt łokci długości i dwadzieścia pięć łokci szerokości [137, Ez 40,13-15. 21. 25. 29.]. Zachowywały więc proporcję 1:2. Wnętrze przedsionka południowego miało proporcję 1:5, gdyż jego długość była równa dwudziestu pięciu, a szerokość pięciu łokciom [137, Ez 40,30]. Próg miał szerokość jednego pręta. Wewnątrz znajdowały się kwadratowe wnęki o boku długości jednego pręta, oddzielone filarem o długości pięciu łokci - stosunek obu długości wynosił więc 5:6. Przedsionek bramy miał szerokość ośmiu łokci i długość jednego pręta. Oznacza to, że stosunek boków wynosił 3:4. Wnęki w bramie były kwadratami o wymiarach boków równych trzem łokciom każdy. Przed wnękami znajdowały się kwadratowe przegrody, a długość każdego z ich boków była równa jednemu łokciowi. Jako że szerokość przejścia przez bramę miała dziesięć łokci, a jej głębokość trzynaście, to stosunek jednego wymiaru do drugiego wynosił 10:13.

Dziedzińce - zarówno zewnętrzny, jak i wewnętrzny - miały plan kwadratu i boki o długości stu łokci każdy. Na dziedzińcu wewnętrznym znajdowały się cztery stoły na chleby pokładne. Każdy z nich był długi na półtora łokcia i wysoki na jeden łokieć, co dawało stosunek 2:3. Północny dziedziniec zewnętrzny otoczony był galerią o szerokości dziesięciu łokci. Stojący przy nim budynek miał sto łokci długości i pięćdziesiąt łokci szerokości. W narożnikach dziedzińca zewnętrznego znajdowały się mniejsze place w kształcie kwadratu o długości boku równej czterdziestu łokciom. Dziedziniec po stronie wschodniej przed świątynią również był kwadratem, a długość boku wynosiła pięćset łokci.

W przedsionku świątyni były filary o podstawie kwadratu, którego bok miał pięć łokci długości. Szerokość bramy wynosiła czternaście łokci, a jej boki miały trzy łokcie głębokości. Stosunek szerokości do długości przedsionka to 3:5, a proporcja obu wymiarów to 3:14. Centralna część świątyni była wsparta na filarach o podstawie kwadratu o długości boków odpowiadającej w sumie sześciu łokciom. Szerokość sanktuarium wynosiła czterdzieści łokci, a długość dwadzieścia łokci. Po raz kolejny pojawiła się proporcja dwóch kwadratów. Najświętsze ze Świętych było na planie kwadratu o boku dwudziestu łokci. Proporcja trzech kwadratów w planie została więc zachowana. 
Budowla, która znajdowała się na zachodzie, miała siedemdziesiąt łokci szerokości i dziewięćdziesiąt długości, co dawało stosunek 7:9. Sumaryczny wymiar świątyni wzdłuż ogrodzeń wynosił zatem sto na sto łokci.

Podstawa ołtarza była wysoka i szeroka na jeden łokieć, a łączna długość obramienia była równa jednej piędźi. Wysokość ołtarza od postawy do dolnego odstępu miała tylko o jeden łokieć więcej niż podstawa, natomiast szerokośc była taka sama, czyli jeden łokieć. Od małego odstępu do większego odmierzono cztery łokcie i szerokość jednego łokcia, w związku z czym uzyskano proporcje: 1:1, 1:2 i 1:4. Palenisko dla ofiar było kwadratem, którego boki miały dwanaście łokci długości i cztery łokcie wysokości - ich stosunek wynosił więc 1:3. Górny uskok miał czternaście łokci długości i czternaście szerokości. Jego wysokość wynosiła pół łokcia, a podstawa, na której się znajdował, miała wysokość jednego łokcia.

Całe wzgórze świątynne zamyka się w kwadracie o boku czterech tysięcy pięciuset prętów.

Kolejne dane o świątyni Salomona pochodzą z opisów jej odbudowy zamieszczonych w Księdze Ezdrasza [137, Ezd 1, 3, 5-6]. Świątynia miała wymiary: trzydzieści łokci wysokości, sześćdziesiąt długości i dwadzieścia szerokości, co oznacza zachowanie proporcji: 1:2, 1:3, 5:7. Bardziej lakoniczne informacje można odnaleźć w pochodzącym z II wieku Liście Arysteasza. Wynika z niego, że świątynia miała więcej niż siedemdziesiąt łokci długości, szerokości i wysokości, odpowiadających strukturze budowli [181, s. 84]. Podobnie w Pierwszej Księdze Machabejskiej pojawia się informacja, że nowy ołtarz wzniesiono na wzór poprzedniego [137, 1 Mch 4,47]. Trudno jest jednak określić na podstawie tych informacji, jakie proporcje miały poszczególne elementy, tym bardziej że nie ma pełnego opisu świątyni po jej odbudowie.

W talmudycznym traktacie Middot [173] występuje opis świątyni jerozolimskiej wzniesionej przez Heroda około 20 roku p.n.e. (druga świątynia). Na wzgórze świątynne prowadziło pięć bram. Dwie znajdowały się na południu, natomiast na wschodnie, zachodzie i północy po jednej. Na dziedziniec świątynny prowadziło ich aż siedem: trzy po stronie północnej i południowej i jedna po wschodniej. Traktat podaje, że wzgórze świątynne mierzyło pięćset na pięćset łokci, a zatem było kwadratem. Na jego szczycie znajdowała się okratowana balustrada o wysokości równej czterdziestu palcom (czyli trzydziestu calom). Wewnątrz usytuowano szeroki na dziesięć łokci szaniec, na który prowadziło dwanaście stopni o wysokości połowy łokcia każdy i podstopnice o szerokości połowy łokcia. Wszystkie wejścia i bramy były na dwadzieścia łokci wysokie i na dziesięć łokci szerokie, co dawało stosunek 1:2. Dziedziniec kobiet miał sto osiemdziesiąt siedem łokci długości i sto trzydzieści pięć łokci szerokości. W jego czterech rogach znajdowały się kwadratowe, niezadaszone komnaty, których ściany miały czterdzieści łokci długości. Proporcja boków dziedzińca kobiet wynosiła 3:4. Piętnaście stopni wyżej znajdował się dziedziniec Izraelitów, którego wymiary i proporcje były identyczne jak dziedzińca kapłanów: sto trzydzieści pięć łokci długości i jedenaście łokci szerokości. Jak opowiadał rabin Elizer Ben Jakub, na dziedziniec kapłanów prowadziła droga składająca się kolejno ze stopnia o wysokości jednego łokcia, znajdującej się na nim platformy i dalej trzech kolejnych stopni o wysokości połowy łokcia. Zatem dziedziniec kapłanów był wy- 
niesiony o dwa i pół łokcia ponad pozostałe dziedzińce. Dziedziniec świątynny miał wymiary równe wymiarom dziedzińca kobiet.

Ołtarz mierzył trzydzieści dwa łokcie długości i trzydzieści dwa łokcie szerokości ${ }^{176}$. Miejsce dla szofaru (rogu baraniego) miało jeden łokieć z każdej strony, podobnie jak przestrzeń, w której stał kapłan. Pozostała przestrzeń o proporcjach kwadratu, którego każdy bok miał dwadzieścia cztery łokcie długości, przeznaczona była na ołtarz ogniowy.

Wejście do sanktuarium było wysokie na dwadzieścia i szerokie na dziesięć łokci, a zatem miało proporcje dwóch kwadratów. Powierzchnia sanktuarium wynosiła sto łokci kwadratowych, a jego wysokość sto łokci. Od wschodu do zachodu sanktuarium

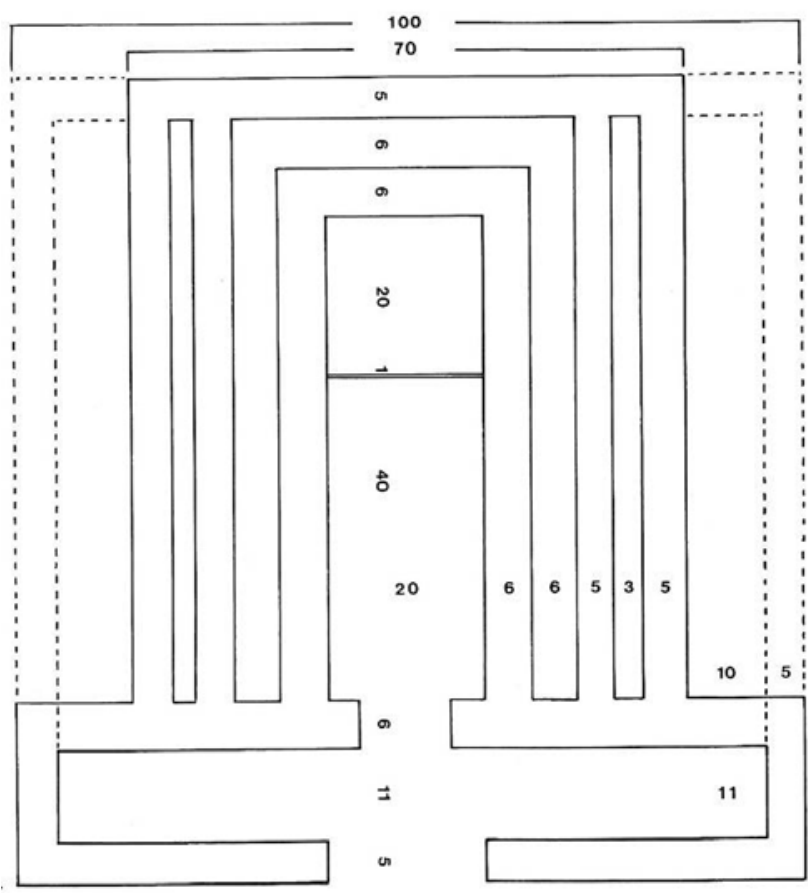

Il. 6.1. Rekonstrukcja świątyni Heroda autorstwa Rachel Wischnitzer [32] miało sto łokci długości. W Miszne Tora Majmonides podawał dokładne długości wszystkich elementów składowych świątyni (il. 6.1). Od zachodu zewnętrzna ściana świątyni miała pięć łokci, przestrzeń pomiędzy ściana zewnętrzną i wewnętrzną sześć łokci, natomiast grubość ściany wewnętrznej wynosiła sześć łokci [191, s. 17]. Proporcje wymiarów to 1:1 i 5:6. Kodesz ha-Kodaszim o długości dwudziestu łokci od sanktuarium o długości czterdziestu łokci oddzielała ściana o grubości jednego łokcia. Przedsionek był oddzielony od sanktuarium ścianą o grubości sześciu łokci i miał jedenaście łokci szerokości. Ściana zachodnia była grubości pięciu łokci. Proporcje strefy przedsionka to 1:1,83 i 5:11. Mierzone z północny na południe sanktuarium miało siedemdziesiąt łokci długości [173, Middot 4,7]. W wymienionej szerokości poza sanktuarium o szerokości dwudziestu łokci znajdowały się również pomieszczenia rozmieszczone na trzech piętrach [191, s. 17]. Szerokość poszczególnych części, w kierunku od sanktuarium, wynosiła tyle, ile grubość znajdującej się tutaj ściany, czyli sześć łokci. Przestrzeń między ścianą wewnętrzną a środkową miała sześć łokci. Grubość ściany środkowej i zewnętrznej wynosiła pięć łokci, a przestrzeń pomiędzy ścianami trzy łokcie. Proporcje opisanych wymiarów to: 1:1, 5:11, 3:5, 1:2. Proporcje boków prostokąta $(70 \times 100)$, na którym zostało założone sanktuarium, to 7:10. Najświętsze ze Świętych miało proporcje dwóch kwadratów, czyli 1:2.

U Majmonidesa (XII w.) pojawia się również opis dziedzińca, który miał mieć sto łokci i raczej zamykał całą świątynie w kwadracie, niż stanowił przestrzeń przed wejściem. Skutkiem tego był przedsionek wysunięty po obu stronach na piętnaście łokci i dopełniający szerokość do kwadratu o boku stu łokci. Należy to wiązać z traktatem Middot, który opisuje 
świątynię jako kwadrat [173, Middot 4,6]. Można przypuszczać, że zamknięcie planu świątyni w kwadracie było inspirowane meczetami Kairu, skąd pochodził Majmonides [191, s. 17].

Zestawiając przytoczone stosunki liczbowe, można zauważyć pewną ciągłość proporcji w różnych etapach funkcjonowania świątyni, ale również zanikanie i powracanie do wcześniejszych proporcji (tab. 6.1).

Tabela 6.1. Proporcje powtarzające się w różnych etapach funkcjonowania świątyni

\begin{tabular}{|c|c|c|c|c|c|}
\hline Proporcja & $\begin{array}{c}\text { Przybytek } \\
\text { Mojżeszowy }\end{array}$ & $\begin{array}{c}\text { Swiątynia } \\
\text { Salomona }\end{array}$ & $\begin{array}{c}\text { Wizja } \\
\text { Ezechiela }\end{array}$ & $\begin{array}{c}\text { Odbudowa } \\
\text { świątyni } \\
\text { Salomona }\end{array}$ & $\begin{array}{c}\text { Świątynia } \\
\text { Heroda }\end{array}$ \\
\hline $1: 1$ & & & & & \\
\hline $3: 4$ & & & & & \\
\hline $5: 6$ & & & & & \\
\hline $3: 3 \approx 1,618$ & & & & & \\
\hline
\end{tabular}

W opisie świątyni Salomona podane są proporcje, które nie pojawiły się nigdzie indziej: 1:1,92, 3:10, 1:6. Podobnie jest w wizji Ezechiela: 7:9, 1:3, 3:14, 1:5 czy świątyni Heroda: 7:10, $1: 1,83$.

\subsection{Rekonstrukcja świątyni jerozolimskiej według Villalpanda i Prada}

W latach 1594-1605 [139] powstała jedna z najbardziej znanych i rozpowszechnionych rekonstrukcji świątyni jerozolimskiej. Była wzorowana na wizji Ezechiela, a jej autorami byli Jan Baptysta Villalpando (1552-1608) oraz Hieronim Prado (1546-1595), którzy nie tylko wykonali graficzną rekonstrukcją świątyni, ale również skomentowali obszernie obiekty przedstawione w wizji Ezechiela [41]. Villalpando i Prado opracowali rekonstrukcje obozu Izraelitów wokół przybytku (il. 6.2) i wzgórza świątynnego (rys. 6.3). Obie zostały oparte na zasadzie planu dziewięciopolowego. W przypadku pierwszej autorzy umieścili w zewnętrznym obrysie kwadraty reprezentujące dwanaście pokoleń Izraela, skorelowane ze znakami zodiaku. Po stronie zachodniej zostali umieszczeni: Manasses (Bliźnięta) i Benjamin (Strzelec), po wschodniej: Zabulon (Koziorożec) i Issachar (Rak), na północy: Aszer (Waga) i Naftali (Panna), a na południu: Gad (Baran) i Symeona (Ryby). W czterech narożnikach znaleźli się: Efraim (Byk), Dan (Skorpion), Juda (Lew), Ruben (Wodnik). Wewnątrz, wokół centralnego pola - niczym cztery filary - zostali ulokowani trzej synowie Lewiego: Hekat (Powietrze), Gerszon (Ziemia) i Merari (Woda) oraz Mojżesza z Aaronem (Ogień), co oznacza, że każdej 
z wymienionych postaci przypisano jeden z żywiołów. Na osi znalazła się świątynia, zajmując dwa pola. W pozostałych siedmiu polach autorzy umieścili planety. W zachodnim wierszu były to Mars i Wenus, w centralnym znaleźli się Jowisz i Merkury, a we wschodnim Saturn, Księżyc i Słońce.

Schemat ten nasuwa skojarzenie z rzymskim castrum. Z silnie zaznaczonym, centralnie usytuowanym cardo i prostopadłym do niego decumanus, na którego osi znalazła miejsce świątynia. Między drogami i placami umieszczono dwanaście obozów plemion Izraela. Takie porównanie nie jest bezzasadnie w kontekście fragmentu Księgi Liczb: „Synowie izraelscy będą stawać obozem, każdy przy swoim sztandarze, przy znakach swoich rodów. Stawać będą osobno wokoło Namiotu Zgromadzenia" [17, Lb 2,2]. W Wulgacie pojawia się $\mathrm{w}$ tym fragmencie słowo castrametabuntur, a w innym [17, Lb 2,34] castrametati, które oznacza założyć (rozmierzyć) obóz [58, s. 113].

Zarówno w planie castrum, jak i rekonstruowanej świątyni można odnaleźć symetrię wzoru (ang. wallpaper symetry) [58, s. 110]. Oznacza to, że istnieje możliwość przetransponowania jednego z pól modułów siatki na kolejny. Nie ulega jednak wątpliwości, że schemat ten zawiera układ dziewięciu identycznych kwadratów. Co ciekawe, sam Jan Baptysta Villalpando pokazuje - poprzez wpisanie w plan plemion Izraela i synów Lewiego - że plan dziewięciopolowy daje w gruncie rzeczy szesnaście kwadratów [58, s. 115].

Nie inaczej jest w przypadku planu rekonstruowanej świątyni. Plan został jednak otoczony dodatkowo dwoma murami: ze-
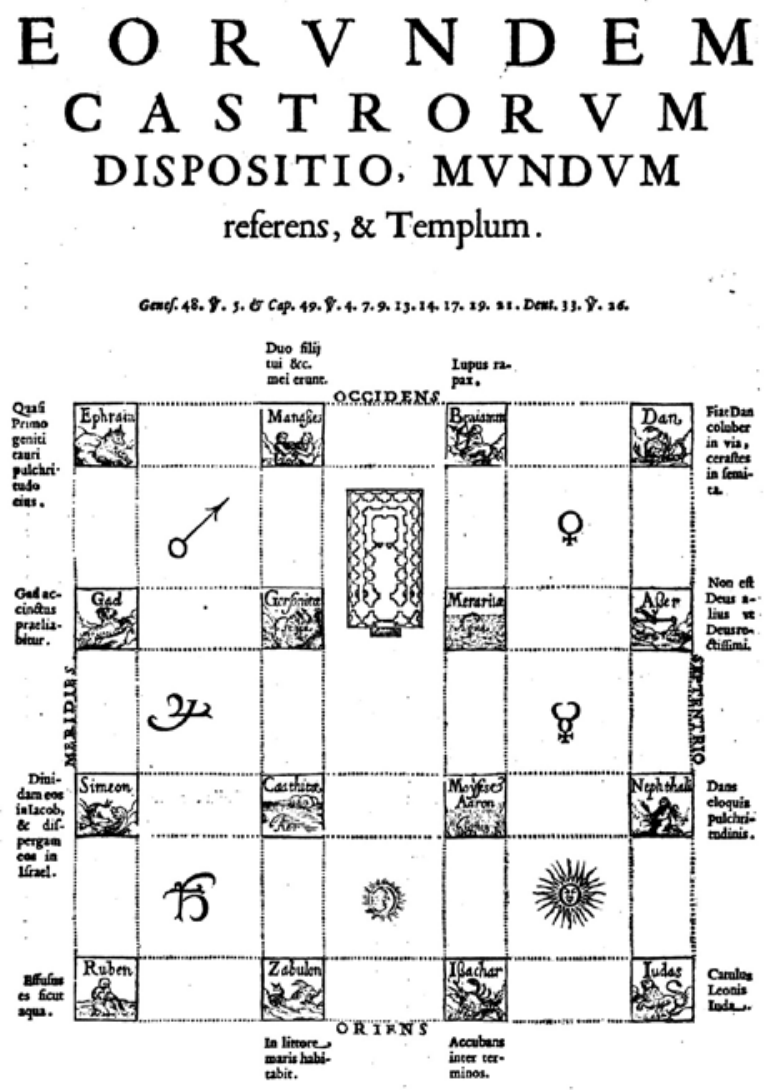

Il. 6.2. Plan obozu Izraelitów przygotowany z uwzględnieniem położenia względem stron świata i symboliki świątyni jerozolimskiej [30]

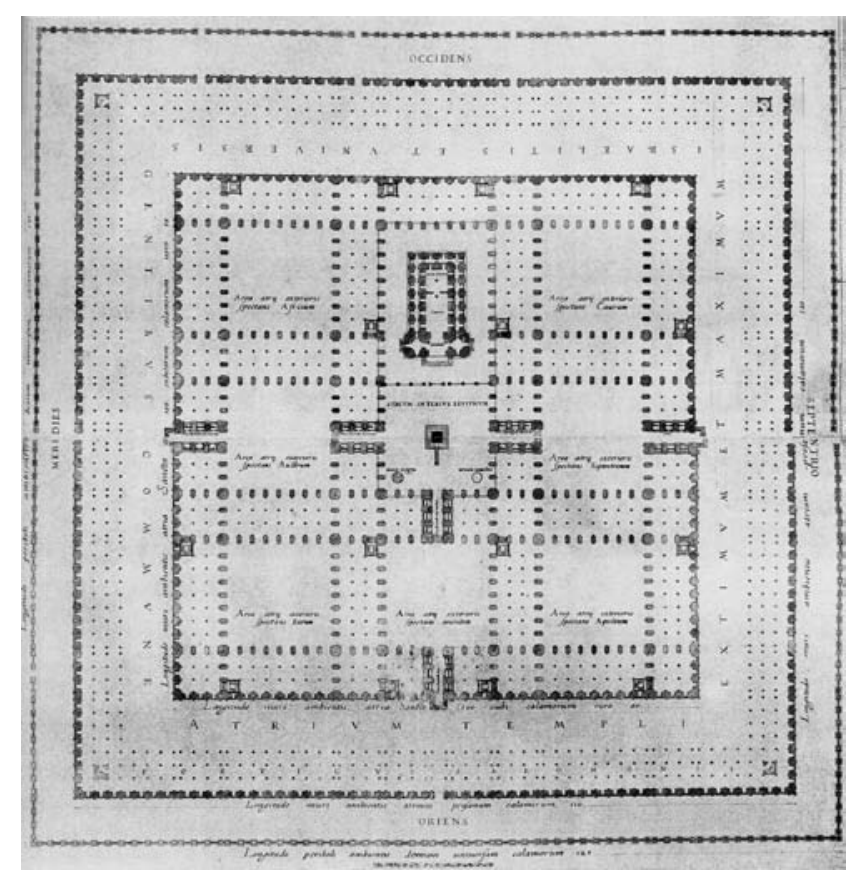

Il. 6.3. Rekonstrukcja świątyni jerozolimskiej [30] 
wnętrznym o długości stu dwudziestu pięciu modułów i wewnętrznym o długości stu modułów, o proporcji 1:1,13. Między drugim murem a murem Atria Sancta znajdował się najbardziej zewnętrzny i największy dziedziniec świątyni, przeznaczony dla Izraelitów i pogan. Mur Atria Sancta miał pięćset łokci długości, co zostaje przypisane wartości osiemdziesięciu modułów. Proporcja między nim a poprzednim murem wynosi więc 8:11. Za murem rozciąga się plan identyczny do przedstawionego dla obozu Izraelitów. W siedmiu polach dookoła świątyni znajdował się dziedziniec zewnętrzny, otoczony i podzielony krużgankami.

Z analizy planu wynika, że każdy z kwadratów składających się na rzut ma długość boku równą trzydziestu dwóm modułom. Do uzyskania długości odpowiadającej osiemdziesięciu modułom potrzeba więc jeszcze czterdziestu ośmiu modułów. Stosunek dłuższego odcinka do boku kwadratu, który stanowi długość dziedzińca wewnętrznego, to 3:5. Poszczególne części dziedzińca pokrywają się kolejno ze sobą, a elementem wspólnym jest krużganek o szerokości ośmiu modułów. Proporcja długości boku (32) do szerokości krużganka to 1:4. Ze stosunku dłuższego odcinka $(32-8=24)$ do boku kwadratu wynika proporcja 3:4. Na szerokość centralnego pola, po odliczeniu wszystkich krużganków, składa się szesnaście modułów. W centralnym polu znalazł się założony na planie kwadratu dziedziniec dla Lewitów. Całe pole wraz z przestrzenią, na której stoi świątynia, ma długość czterdziestu modułów, co oznacza, że znów uzyskano proporcję odcinków 3:5.

Jan Baptysta Villalpando również wykorzystuje wielokrotnie moduł kwadratu. Wspólny dla Przybytku Mojżeszowego, wizji Ezechiela, Świątyni Heroda i rekonstrukcji Villalpanda jest stosunek 3:4. Wartością łączącą wizję Ezechiela i rekonstrukcję jezuity jest stosunek 1:4. W swojej rekonstrukcji Villalpando stosuje także proporcje, których nie ma w żadnym z opisów, a mianowicie: 1:1,13 i 8:11.

Należy zaznaczyć, że u Villalpanda jedną z kluczowych jest proporcja 3:5 = 1:1,66, która zbliża się do wartości proporcji uzyskiwanej przy zastosowaniu złotego cięcia: 1:1,618. Proporcja ta pojawia się w opisie Arki Przymierza, ołtarza w Przybytku Mojżeszowym, podeście w świątyni Salomona czy przedsionku świątyni w wizji Ezechiela.

\subsubsection{Porządek salomonowy}

Porządkiem architektonicznym charakterystycznym dla XVII-wiecznej architektury był między innymi porządek salomonowy. Poszukiwanie wzorców biblijnej starożytności było niezwykle popularne w renesansie. W malarstwie i rysunku, między innymi Rafaela czy Francisco de Holanda, pojawiły się zakorzenione w średniowieczu wzorce spiralnych kolumn, które miały stać się elementem świątyni jerozolimskiej [89, s. 225]. Efektem poszukiwania jej idealnego wyglądu były prace teoretyków architektury, których podstawę stanowiła propozycja Sebastiana Serlia (il. 6.4) [157]. Porządek ten - jako że łączył w sobie dwa zaliczane do klasycznych porządki witruwiańskie - stanowił pewnego rodzaju wariację. Powstał w wyniku zestawienia kolumn o korynckim kapitelu oraz doryckiego fryzu tryglifowo-metopowego. 


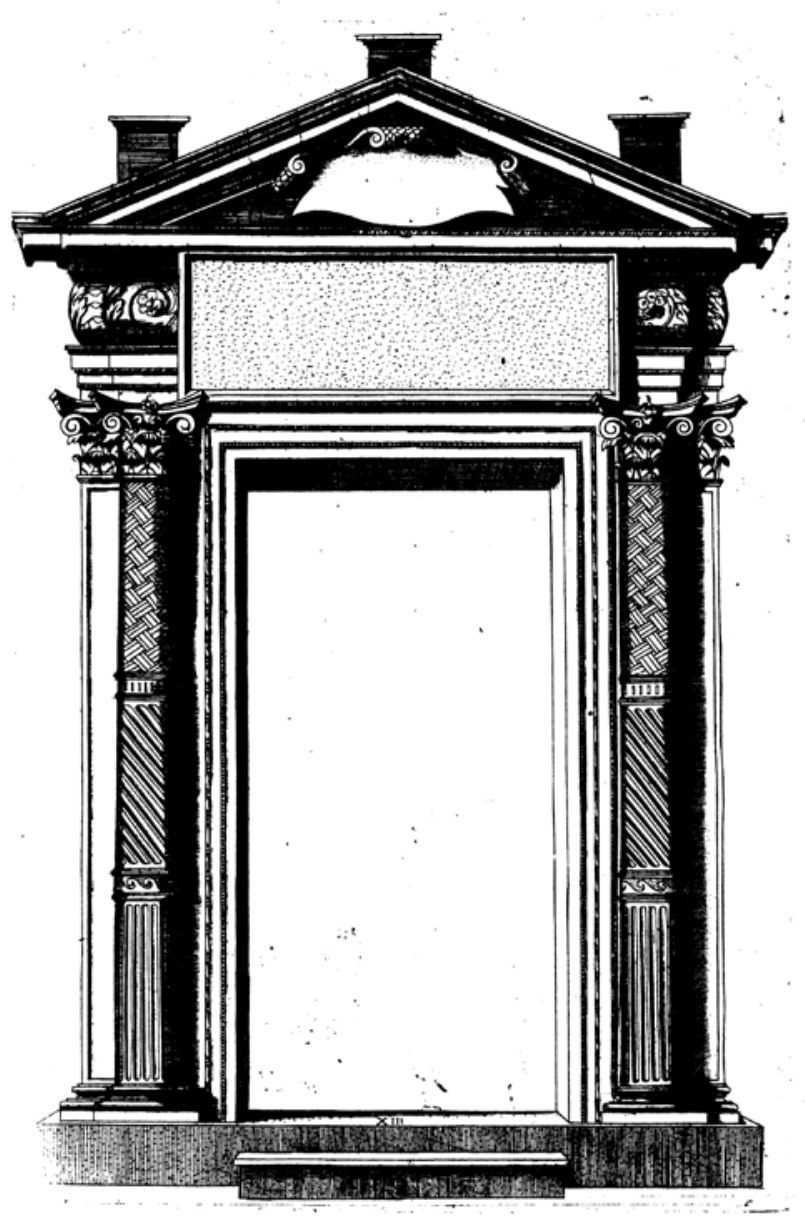

Il. 6.4. Porządek świątyni Salomona przedstawiony w traktacie Sebastiana Serlia [29]

\section{Il. 6.5. Porządek światyni Salomona} przedstawiony w traktacie Villalpanda i Prada [30]

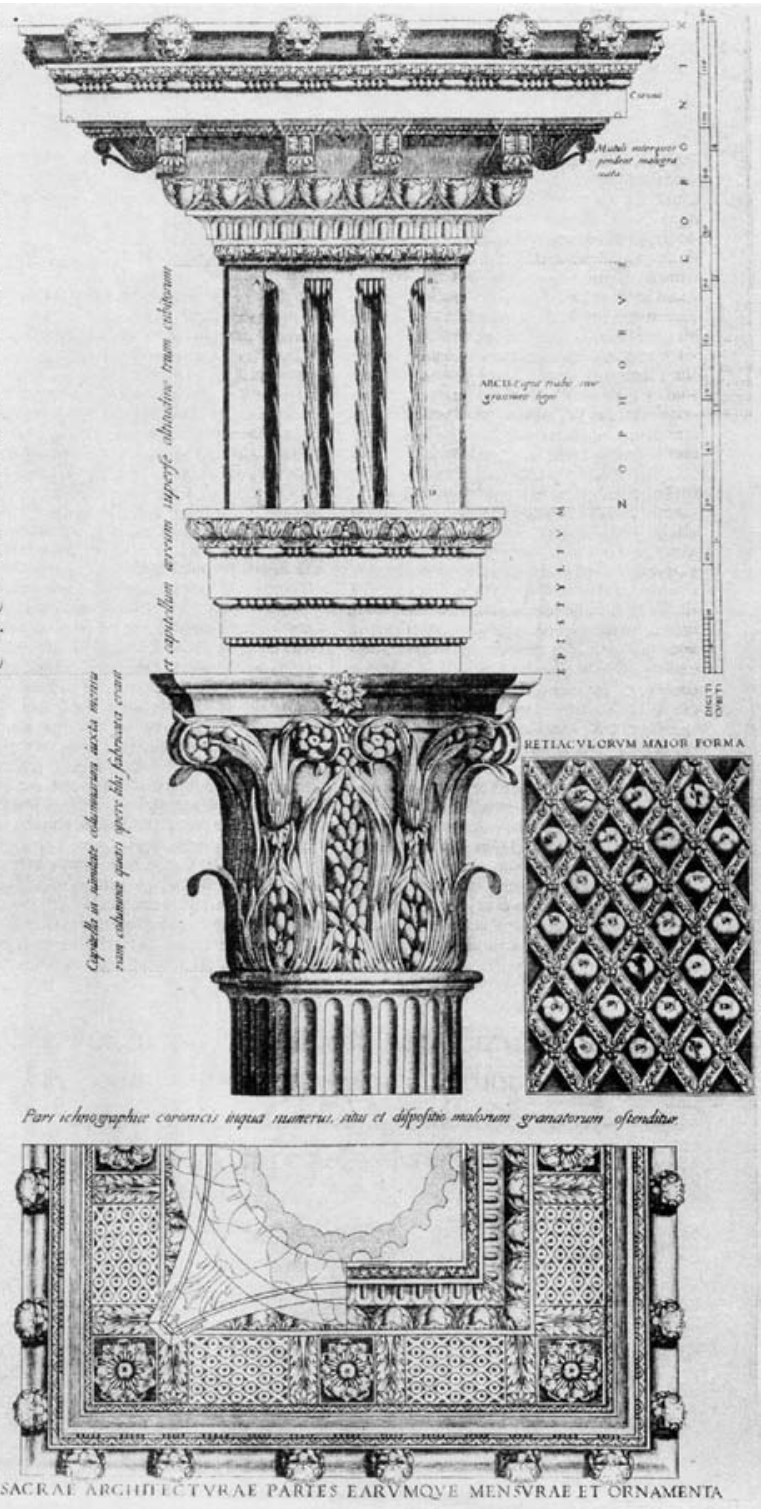

Szczególnie rozbudowaną wersją tego rozwiązania jest rekonstrukcja świątyni Salomona zaproponowana przez Villalpanda i Prada (il. 6.5). Kapitel w formach korynckich usytuowany na kanelowanej kolumnie posiadał, jak głosi napis na rysunku, formę liliii ${ }^{177}$. W dekoracji nie zostały jednak wykorzystane liście akantu. Zamiast nich pojawiły się liście palmy [94, s. 315] i daktyli. Na wyprofilowanym abakusie umieszczono w centrum kwiat lilii. Powyżej znajdował się architraw podzielony na trzy fasciae, z których każda została poprzedzona astragalem. Pomiędzy architrawem a fryzem zamiast guttae i reguli znalazł się profilowany gzyms przekryty teniq występującą w tym miejscu w porządku doryckim. Fryz został wprawdzie zaprojektowany $\mathrm{w}$ formie tryglifów i metop, jednak żłobkowanie płyt wypełniono liśćmi palmy. Powyżej nie ma wprawdzie mutulusu, ale rozpoczyna się bogato rozbudowany gzyms, który można byłoby uznać za zdwojony, tym bardziej że jego górna cześć została wsparta na konsolach. Wśród detalu tej strefy odnaleźć można kimation joński i astragal. Wszystko zostało ujęte w formy wici roślinnej. 
W traktacie z końca XVII wieku Augustin-Charles d'Aviler [26] pisze: „Villalpando traktuje, jako bajkę historię Kallimacha ${ }^{178}$ i zapewnia, że koryncki kapitel wywodzi swój początek w świątyni Salomona, oraz że liście były palmowe. Jest również przekonany o tym, że porządek koryncki jest arcydziełem architektury. d'Aviler podaje symboliczne znaczenie kompozycji zastosowanej przez Villalpanda. Wskazuje, że brak jest odniesień do Pierwszej Księgi Królewskiej, w której pojawia się opis lilii i granatów, które zdobiły kolumny” [137, $1 \mathrm{Krl}$ 7,17-20].

W swoim schemacie Jan Baptysta Villalpando uwzględnia owoce granatu, choć faktycznie nie pojawiają się one na kapitelu. „Dispositio malorum granatorum” przedstawia spodnią stronę belkowania. Matryce z dwudziestoma czterema granatami w każdej zostają usytuowane między konsolami. Faktem jest jednak, że sumaryczna liczba owoców granatu (192) różni się o osiem od wartości podanej w opisie świątyni Salomona (200) [137, 1 Krl 7,20].

Podobną dekorację w formie granatu zaproponował Diego de Sagredo (1490-1528) w opisie porządku hiszpańskiego (balaskowego) w Medidas del Romano (1526). Forma kapiteli wzorowana na dekoracji kojarzącej się z owocem granatu wywodzona jest przez autora od łacińskiego określenia związanego z kwiatami granatu [29]. Z jednej strony trudno doszukać się powiązań ze schematem zaproponowanym przez Villalpanda, z drugiej tradycja salomonowa wpłynęła na wytworzenie się w XVIII wieku stylu barroco florido, będącego szczególną formą architektury dworu Burbonów w Kastylii [31, s. 52].

Forma zaproponowana przez Villalpanda i Prada jest opisana również w traktacie $\mathrm{Pa}$ rallele de l'architecture antique (1650) Fréarta de Chambray'ego (1606-1676). Autor pisze, że połączenie miękkiego, żeńskiego kapitelu korynckiego z jędrnym, męskim doryckim belkowaniem jest najdoskonalszą formą ${ }^{179}[27$, s. 70].

Porządek salomonowy został przedefiniowany w 1660 roku w Tratado de la pintura sabia autorstwa benedyktyna Juana Ricci $(1600-1681)^{180}$, który pod tym pojęciem rozumiał spiralne kolumny, podobne do tych użytych w zaprojektowanym przez Berniniego baldachimie z bazyliki św. Piotra i wykorzystane w przedstawieniach świątyni w malarstwie Rafaela i Francisco de Holanda.

Jak podaje Adam Miłobędzki, „typowe dla budowli środowiska lubelskiego zestawienie korynckich pilastrów z doryckim belkowaniem w ówczesnej teorii sztuki było znamieniem porządku świątyni Salomona, z którą kontrreformacyjny światopogląd wiązał legendarnie początki architektury" [118, s. 149].

W Polsce istnieje wiele obiektów, w których starano się stosować porządek salomonowy. Rozwiązanie to zastosowano w portalach: zamku w Legnicy [23, s.179-180], ratusza krakowskiego (ob. Colegium Maius) (po 1593) [89, s. 230], kościoła jezuitów w Kaliszu (1592-1597), kaplicy Firlejów w Bejscach (1594-1600). W XVII wieku pojawiło się w fasadzie kościoła jezuitów w Lublinie (1617) [118, s. 149] i kościoła wizytek w Krakowie (1692-1695) [89, s. 232] oraz w prezbiterium i nawie kościoła parafialnego w Radzyniu Podlaskim (1641). Osiemnastowiecznym przykładem wprowadzenia tego układu jest fasada kościoła Karmelitów Bosych 
w Berdyczowie (1739-1754, fasada 1780) [89, s. 236]. W projekcie Jana de Witte występowały kapitele jońskie i układ w wielkim porządku, jednak ostatecznie wykonano porządek salomonowy.

W bożnicach zlokalizowanych na terenie Polski w okresie XVI-XVIII wieku nie odnajdzie się pełnego układu porządku salomonowego, składającego się z kapitela, architrawu i gzymsu. Jedynym punktem, w którym występuje zbieżność, są kapitele korynckie oparte na formach liści palmy względnie lilii.

Kapitele korynckie stosowano w synagogach z bimą-podporą. Znajdowały się w synagodze w Tarnowie i Przemyślu, gdzie w dekoracji kapiteli nie ma liści palmy ani lilii. Wygląd kapiteli w pierwszej z wymienionych budowli trudno jest jednoznacznie określić, gdyż jedynym istniejącym materiałem ikonograficznym jest szkic z 1941 roku. W synagodze w Przemyślu zastosowano w dekoracji liście akantu. Kapitele z tego obiektu przypominają niezwykłe formy, które można znaleźć w traktatach: Serlia, Vignioli, Palladia, Scamozziego [108, s. 101].

W dwóch synagogach dziewięciopolowych: synagodze w Ostrogu i Wielkiej Synagodze Przedmiejskiej we Lwowie są podobne kapitele. W obu obiektach filary zostały zwieńczone doryckimi echinusami. Sergiey Kravtsov zwraca uwagę, że pod nimi znajdowały się liście akantu z wplecionymi gałązkami oliwnymi, co zbliża kapitele bardziej do wzorców korynckich [95, s. 198]. Jednocześnie taka forma miała odpowiadać kapitelowi zaproponowanemu przez Serlia [94, s. 320], który formę tę opisuje jako kapitel kompozytowy (rys. 6.6).
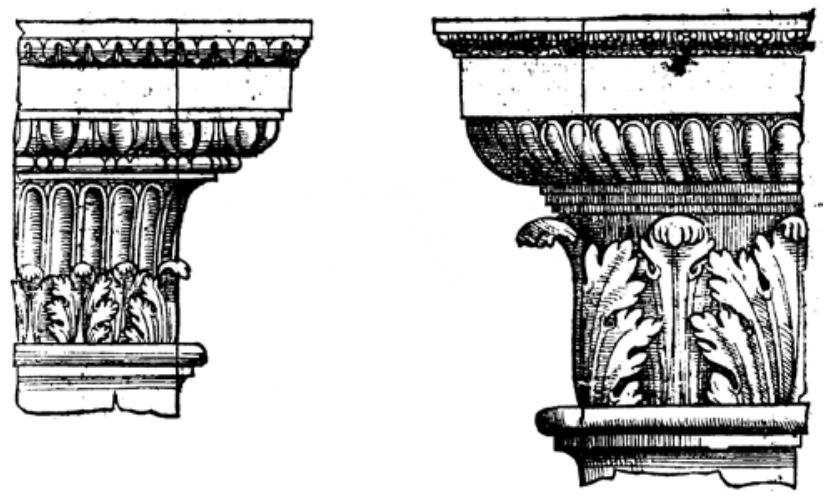

Il. 6.6. Kapitel kompozytowy przedstawiony w traktacie Serlia [28]

Formę koryncyzujących kapiteli zastosowano również w synagodze w Łańcucie. Ich zaburzone proporcje oraz zbarbaryzowane formy wzorowane były prawdopodobnie na liściach akantu.

Formy kapiteli korynckich pojawiają się zatem nie wcześniej niż pod koniec XVI wieku w synagodze w Tarnowie ${ }^{181}$. Forma kapiteli zarówno w tej synagodze, jak i w synagogach w Ostrogu czy we Lwowie nawiązywała bardziej do traktatu Serlia niż do rozwiązania zaproponowanego przez Villalpanda i Prada. Obecność dekoracji klasycznej opartej na liściach akantu wskazuje na brak związku z rozwiązaniem zaproponowanym przez obu jezuitów. Tym bardziej że w bożnicach nie można znaleźć form kompletnego porządku salomonowego.

Forma ta, jak widać na nielicznych przykładach, pojawia się jeszcze przed wydaniem In Ezechielem i jej powstanie należy być może wiązać z działalnością Komasków ${ }^{182}$, którzy często, w dość luźny sposób zestawiali ze sobą różne porządki i elementy. Ten trop wymagałby jednak oddzielnego opracowania. 


\subsubsection{Liście palmy}

Wzór palmy stał się inspiracją dla twórców kapiteli palmowych w starożytnym Egipcie (perystyl Górnej Świątyni przy piramidzie Sahure (2496-2483 p.n.e.), świątynia Horusa w Edfu (257-237 p.n.e.) [163, s. 33]. Dekoracje wykazujące podobieństwo do naturalnych liści palmy pojawiają się po raz pierwszy w Asyrii, gdzie przyjmują formę palmety - co prawda znanej jako ornament od czasów egipskich, jednak tym razem o innym wzorze roślinnym [56, s. 42$]^{183}$.

Palmeta składająca się z liści palmy stała się popularnym motywem między X a VI wiekiem p.n.e. w Persji, Fryzji i Lidii. Przewijała się w architekturze Grecji [30], [117] i Rzymu, również $\mathrm{w}$ formie antefiksu. W sztuce rzymskiej była widoczna tendencja do zastępowania liści palmy liśćmi akantu. W kolejnych wiekach palmety pojawiają się w architekturze kościołów i synagog.

Symbolika palmy została z pewnością zaadaptowana przez chrześcijaństwo [116, s. 266], czego przykładem było lektorium w bazylice św. Piotra w Rzymie z VIII wieku. Znajdowało się na nim arkadowanie wsparte na spiralnych kolumnach. Wewnątrz arkad umieszczono palmy.

Augustin-Charles d'Aviler zwraca uwagę, że zastosowanie palmy, czyli rośliny charakterystycznej dla Palestyny, w kompozycji Jana Baptysty Villalpanda jest pewną paralelą z opisem świątyni Salomona [26, s. 298]. Na kapitelach pojawiają się też formy w kształcie rogów baranich, co ma symbolizować ofiarę religii mojżeszowej.

Według d'Avilera formy te były odpowiednie dla architektury martyriów. Przede wszystkim z powodu symboliki palmy, która oznaczała zwycięstwo i zaufanie, czyli cechy reprezentowane przez bohaterów chrześcijaństwa przelewających krew za wiarę [26, s. 298]. Podobną symbolikę podaje Fréart de Chambray - posuwa się tylko o krok dalej, zastępując daktyle liśćmi palmy [27, s. 70].

W okresie renesansu liście palmy i palmety stały się popularnym, choć nie jedynym, istotnym motywem dekoracyjnym w architekturze synagogalnej. Oprócz nich dużego znaczenia nabrał kapitel koryncki, stosowany we włoskich szafach na rodały [148, s. 248-257]. W okresie nowożytnym palmety pojawiły się na kapitelach Aron ha-Kodesz w synagodze Remu i Starej Synago-

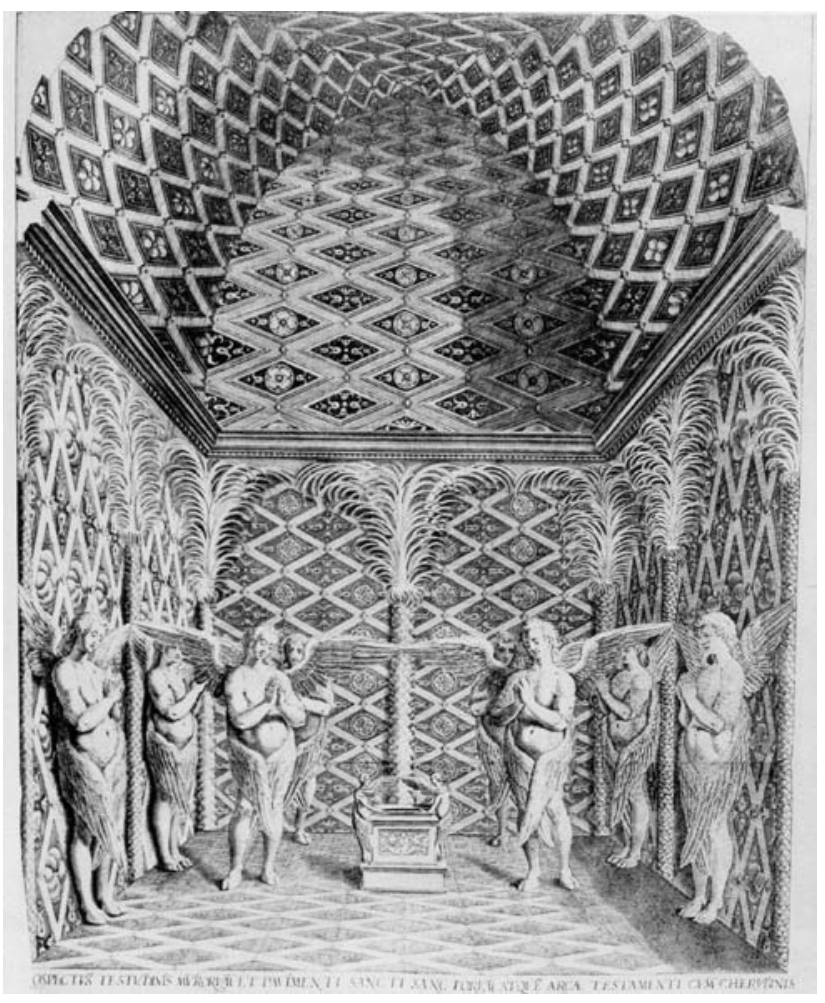

Il. 6.7. Wnętrze Najświętszego ze Świętych w świątyni [30] 


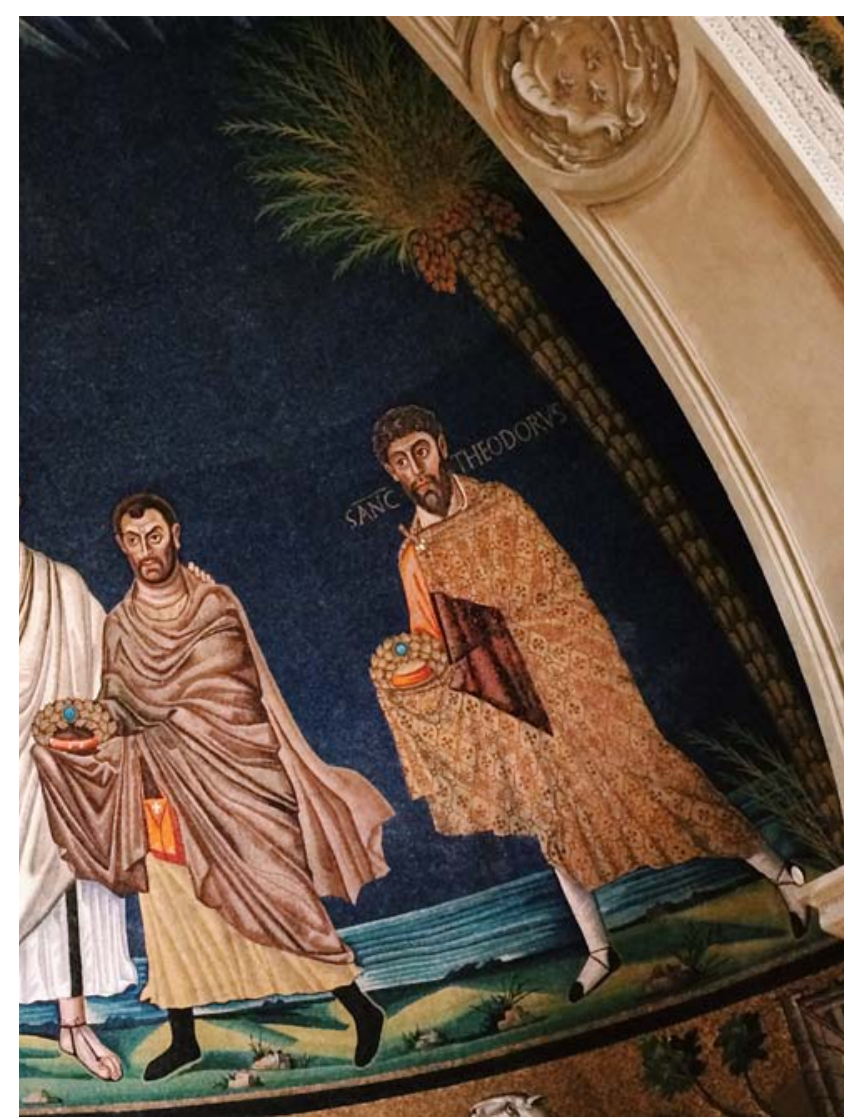

Il. 6.8. Mozaika w absydzie kościoła św. Kosmy i Damiana w Rzymie, przedstawiająca paruzję $(526-530)$ [10]

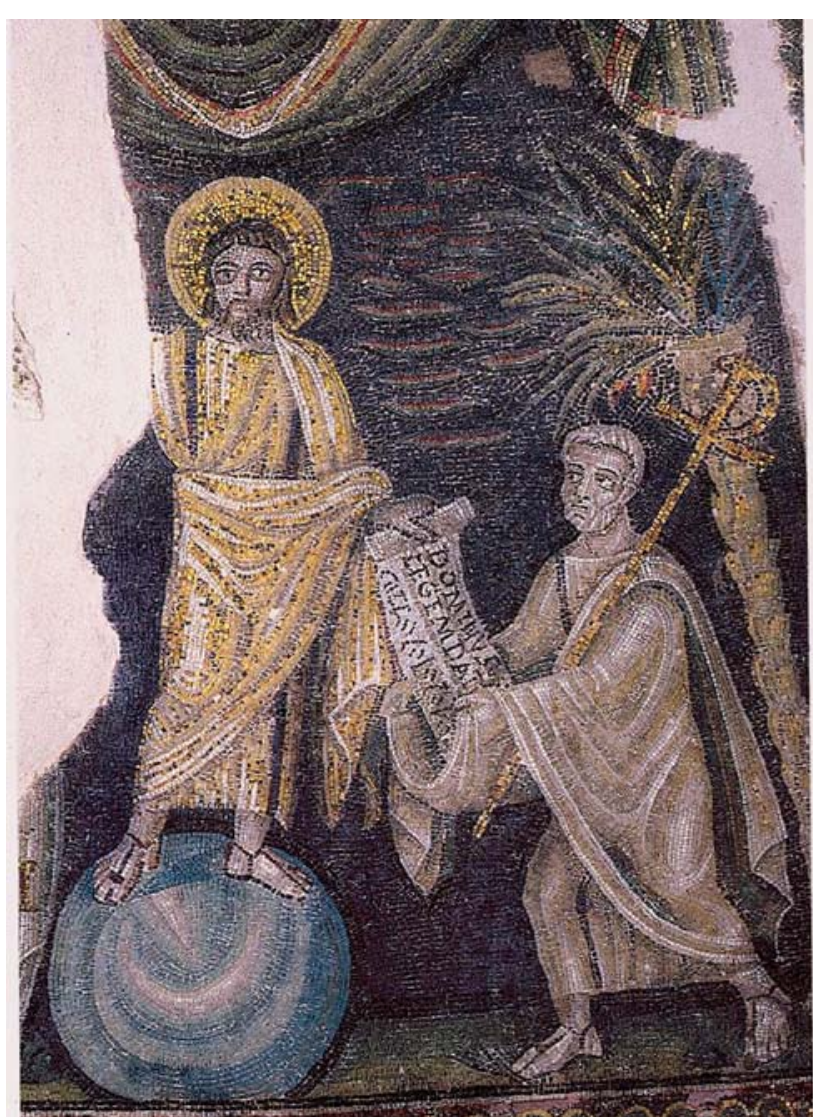

Il. 6.9. Mozaika w baptysterium San Giovanni in Fronte w Naples, przedstawiająca przekazanie prawa (III-IV w.) [18]

dze w Krakowie [148, s. 197]. Pilastry dekorowane liśćmi palmy występują również w synagodze w Szydłowie [148, s. 384].

Jak już wspomniano powyżej, Jan Baptysta Villalpando i Hieronim Prado wkomponowywali w porządek salomonowy liście palmy. Ten motyw dekoracyjny jest charakterystyczny i pojawia się dość często w opisie świątyni jerozolimskiej w wizji Ezechiela [137, Ez 40,16. 22. 26. 31. 34. 37; 41,18-20. 25-26], jak również w opisie świątyni w Pierwszej Księdze Królewskiej [137, $1 \mathrm{Krl}$ 6,29. 32. 35. 36]. Należy zaznaczyć, że Ezechiel precyzuje położenie liści palmy: nie tylko znajdowały się na kolumnach, ale wręcz wypełniały wnętrze świątyni ${ }^{184}$.

Obaj autorzy In Ezechielem nie ograniczyli się jednak do opisu. Ich dziełem jest również rekonstrukcja wystroju (il. 6.7), wykonana - za wyjątkiem szczegółów - zgodnie z tą przedstawioną u Ezechiela. W pomieszczeniu znajdują się Arka Przymierza i cherubiny, które jej strzegą. Arka ma zaburzone proporcje, przez co nie ma wymiarów biblijnych, a cherubiny bardziej przypominają ludzi niż opisywane istoty o czterech twarzach. Jak bowiem podaje Ezechiel, każde ze stworzeń miało cztery oblicza i cztery skrzydła [137, Ez 1,6], nogi podobne do nóg cielęcia [Ez 1,7], a ręce człowiecze; oblicze miały: z przodu człowieka, z prawej strony lwa, z lewej wołu, a z tyłu orła [137, Ez 1,10; 10,14]. Zgadza się właściwie wszystko poza twarzami. 
Palmy w rekonstrukcji Kodesz ha-Kodaszim przywodzą na myśl podobne mozaiki w kościołach wczesnochrześcijańskich. Ich duże i rozłożyste liście znajdują się między innymi na mozaice przedstawiającej Dobrego Pasterza w mauzoleum Galii Placydii w Rawennie (1. połowa $\mathrm{V}$ w.). Formy niezwykle podobnych do tych zastosowanych przez Villalpanda palm, ale o nieco mniejszych liściach, przedstawia mozaika paruzji w bazylice św. Kosmy i Damiana w Rzymie (526-530) (il. 6.8). Podobne, choć znacznie wcześniejsze przedstawienie palmy, z liśćmi bardziej przypominającymi formy z rekonstrukcji znajduje się w baptysterium San Giovanni in Fronte w Naples (III-IV w.) (il. 6.9), [116, s. 229]. Również z tego okresu (IV w.) pochodzą motywy palm w kościele Sant'Apollinare Nuovo w Rawennie, wkomponowane w dwie mozaiki: jedną przedstawiającą procesję męczenników oraz drugą przedstawiającą Trzech Króli.

Liść palmy jest zakorzeniony w religii żydowskiej i ściśle powiązany ze świętem Sukkot. W trakcie święta, za pomocą lulawu ${ }^{185}$ (bukietu złożonego z liści palmy, mirtu, wierzby) oraz etrogu (rodzaju cytrusa) składających się na świąteczny bukiet, potrząsa się na cztery strony świata oraz w górę i w dół, co ma przypominać o wszechobecności Boga. Lulaw jest również symbolem ofiary pierwocin, którą składano w święto Sukkot, oraz przypomnieniem płodów utraconej Ziemi Obiecanej [135, s. 71]. Gałązka palmy w lulawie oznacza ofiarę Izaaka [77, s. 75].

W architekturze synagog palmeta pojawia się jako symbol mesjańskiego odkupienia [148, s. 56]. W okresie V-VI wieku w synagodze w Susji, a w VI wieku na mozaice w bożnicy w Maon palma flankowana jest dwoma ptakami, co nasuwa skojarzenie z Drzewem Życia [148, s. 58]. Z okresu średniowiecza pochodzą palmety na kolumnach w synagodze w Wormacji (1174-1175), podobnie zresztą jak XI-wieczne wizerunki całych palm na ościeżach.

Palmy jako motyw dekoracyjny w synagogach mogły legitymizować związek z sanktuarium [148, s. 55]. Podobnie jak w starożytnej sztuce żydowskiej również w tej późniejszej palma oznacza Ziemię Świętą i odkupienie. To tak ważne w judaizmie drzewo przywodziły na myśl również palmety stosowane w dekoracji architektonicznej synagog. Kombinacje palmy o siedmiu gałęziach i wolut przypominających zwoje Tory tworzyły złożony symbol Tory jako Drzewa Życia [148, s. 433].

Z palmą przedstawianą w formie drzewa $\mathrm{z}$ siedmiomami ramionami wiąże się jej symboliczne odniesienie do menory [148, s. 61]. Należy jednak pamiętać, że wzór ten został zaadaptowany prawdopodobnie w oparciu o ornament przedstawiający asyryjskie Święte Drzewo [56, s. 60]. Na obszarze Polski przykładem może być obelisk znajdujący się na zwieńczeniu szafy na rodały w bożnicy w Szydłowie [149, s. 183].

W XVII i XVIII wieku w bożnicach stosowano palmety oraz motyw liści palmy jako elementy dekoracyjne. Z 1621 roku pochodzi fragment detalu kamieniarskiego Starej Synagogi w Krakowie ${ }^{186}$ wykonanego z piaskowca i przedstawiającego wazon. W centrum jego górnej części usytuowano palmetę złożoną z liści palmy. Na skarbonie w Pińczowie wykonano dekorację w formie zwiniętych liści palmowych. W synagodze w Żółkwi palmety zdobią słupy, 
a w Łańcucie stanowią zwieńczenie co drugiego pilastra między wnękami z tekstami modlitw. Liście palmy były fragmentem dekoracji nieistniejącego już Aron ha-Kodesz we Włodawie.

Motyw ten był wykorzystywany również w polichromiach. Przykładem mogą być nieistniejące XVIII-wieczne dekoracje w Synagodze Starej w Rzeszowie, na które składają się oprócz zwiniętych liści akantu także palmety i liście palmy. Nie należy również zapominać o przedstawieniach Ziemi Świętej i motywach biblijnych, w których również pojawiały się palmy.

W bożnicach trudno jest znaleźć formy rozłożystych palm zaproponowane w rekonstrukcji Villalpanda i Prada, które mogły być wzorowane na wczesnochrześcijańskich mozaikach. Są raczej pojedyncze liście lub palmety, które stanowią nawiązanie do klasycznych wzorców architektonicznych. Liście palmy są elementem pojawiającym się w wizji Ezechiela i zgodnie z nią uzyskują swoje bardzo konkretne usytuowanie.

Ograniczenie w zastosowaniu palmy w bożnicy mogło wynikać ze sposobu pojmowania synagogi i sanktuarium świątynnego oraz z zakazu nawiązywania synagogi pod względem struktury do świątyni. Można jednak próbować rozumieć każdy ze słupów jako formę palmy. Taką symbolikę można z pewnością zastosować na bimie-podporze stojącej w centrum bożnicy i podtrzymującej koronę sklepienia sali męskiej. Jest to jednak symbolika, która nie może mieć zakorzenienia w rekonstrukcji świątyni jerozolimskiej.

\subsubsection{Przypory}

Charakterystycznym elementem, który pojawia się w świątyni rekonstruowanej przez Jana Baptystę Villalpanda, są przypory. Rysując elewację świątyni, autor umieszcza ją na prawie czterokrotnie wyższej podbudowie, stanowiącej wzgórze świątynne. Do murów, które otrzymały formę arkadowania, zostają dostawione przypory (il. 6.10) w dosyć interesującym kształcie spływu.

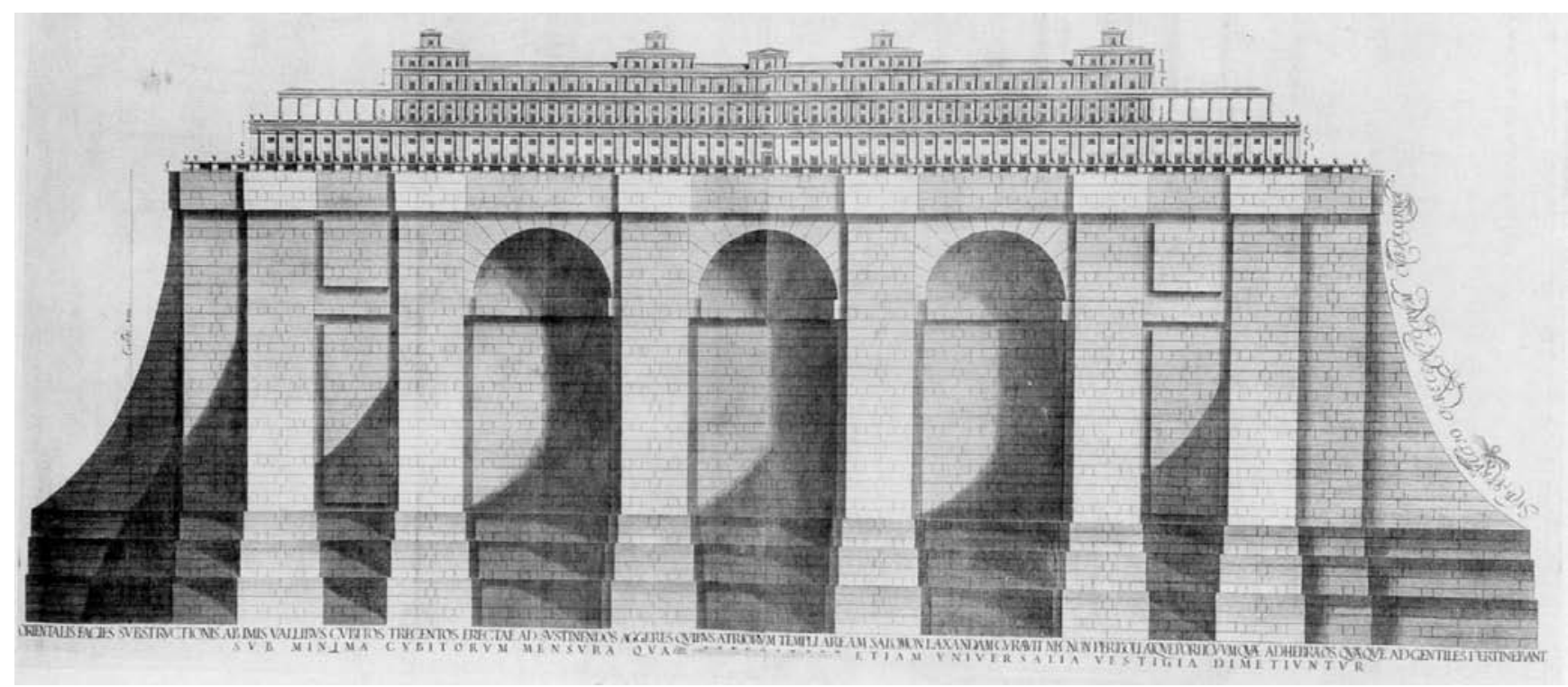

Il. 6.10. Elewacja wzgórza świątynnego [30] 
W architekturze przypory pełniły przede wszystkim istotną rolę konstrukcyjną. Miały przenosić sily rozporowe ze sklepień na grunt, w związku z czym z boku zwykle rozszerzały się schodkowo lub pochyło ku dołowi. Rozwój tej szczególnej formy architektonicznej nastąpił w okresie gotyku, podobnie jak systemu przyporowego opartego na wielu stopniach łęków i filarów.

Trudno jest znaleźć w architekturze starożytnej czy średniowiecznej rozwiązania takie jak te zastosowane w rekonstrukcji Villalpanda ${ }^{187}$. Co prawda na planie Poznania autorstwa Georga Brauna z 1641 roku, w zewnętrznym murze z XV wieku widoczne są przypory o podobnej formie, czyli z zakrzywioną płaszczyzną górną. Braun zaznaczył je wszystkie, dlatego wydaje się niemożliwe, aby fałszował ewentualnie istniejące formy o płaskiej płaszczyźnie, zmieniając ją na zakrzywioną. Podobnych form w fortyfikacjach europejskich jednak nie ma, co utrudnia szukanie wśród włoskich przykładów wzorców, z których mógłby skorzystać

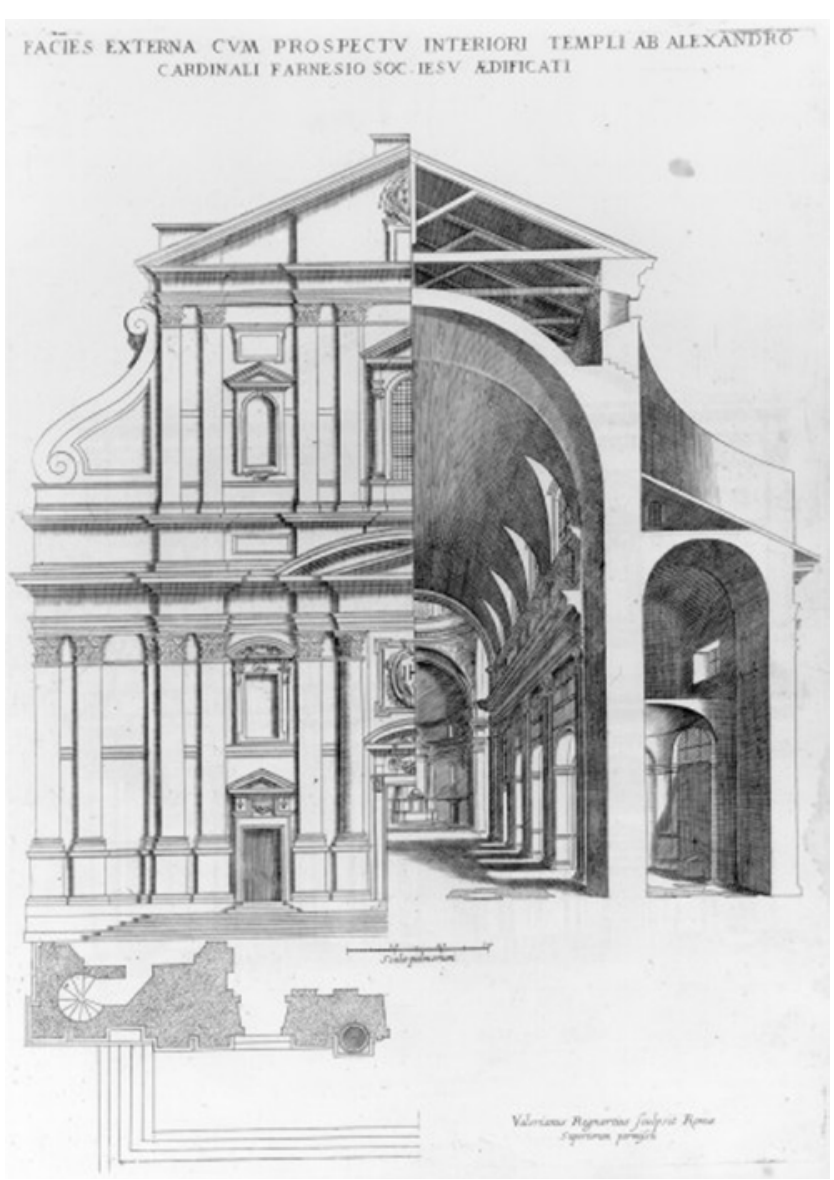

Il. 6.11. Przekrój i elewacja kościoła Il Gesu w Rzymie zaprojektowana przez Giacomo della Portę [26]

Villalpando. Należy więc stwierdzić, że forma przypory z zakrzywioną górną płaszczyzną (w formie spływu) nie była oryginalnym rozwiązaniem zaproponowanym przez Villalpanda.

Rozwiązanie w formie spływu pojawiło się już wcześniej. Giacomo Barozzi da Vignola zastosował je w kościele Il Gesu w Rzymie (1568-1584) (il. 6.11) oraz w niezrealizowanym projekcie fasady tego kościoła. Przypory miały sprowadzić obciążenia z górnych części ścian nawy głównej poprzez nawę boczną na grunt. Prawdopodobnie dalszy rozwój tej formy doprowadził do wykorzystania wolut w miejscu ściętych po łuku przypór jak w kościołach Santa Maria della Salute (1631-1687) Baltazara Longheny oraz St. Andrea al Quirinale (1658-1670) Gianlorenzo Berniniego.

Przypory w formie spływów były więc wzorowane na projekcie Vignioli i stosowane nie tylko w kościołach jezuickich, na przykład św. Ignacego Loyoli w Rzymie (1626-1650), ale również innych, na przykład Sant'Andrea della Valle (1590-1650), San Marcello al Corso (ukończonym w latach 1592-1594) czy w katedrze w Noto (1776).

Oprócz przypór w formie spływów elementem charakterystycznym architektury fasad kościołów jezuickich w Polsce były spływy w fasadzie kształtowane w formie łuku, które zako- 


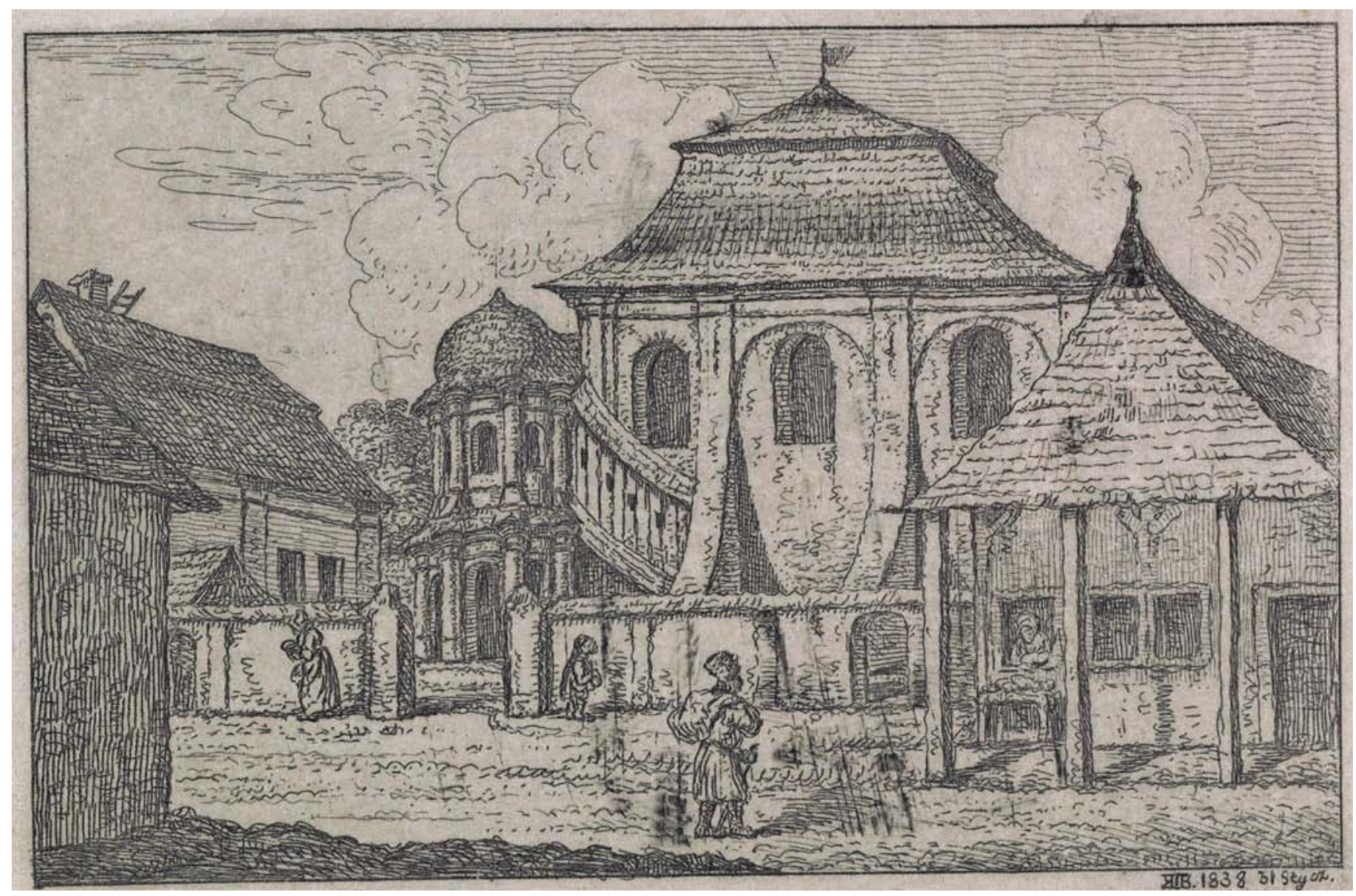

Il. 6.12. Synagoga w Przeworsku - widok od strony południowej [19]

rzeniły się pod wpływem niezrealizowanego projektu fasady kościoła Il Gesu. W stosowali je Giuseppe Brizio w kościele Bożego Ciała w Jarosławiu (1591-1594) czy Jan Maria Bernardoni w kolegiacie w Nieświerzu (1584-1593) i kościele św. Piotra i Pawła w Krakowie (1597-1619). W przypadku kościoła krakowskiego znamienne jest wykorzystanie poza spływem w szczycie również przypór o wykroju łuku, usytuowanych wzdłuż nawy głównej.

Formy przypór zaproponowane przez Villalpanda rozprzestrzeniały się, czego przykładem jest zastosowanie podobnej konstrukcji w rekonstrukcji świątyni przedstawionej przez Juana de Lebkowitza w traktacie Architectura civil recta, y obliqua (1678) [41, s. 386]. Również na fali teorii o tak zwanych nowych dzieciach Izraela [94, s. 327], rekonstrukcja Villalpanda trafiła na podatny grunt architektury kościołów protestanckich. Motyw spływających przypór pojawił się więc w dwóch kościołach autorstwa Jacoba van Campena: Ronswoulde (1639-1641) w Hooge Zwaluwe oraz Nieuwe Kerk (1646-1649) w Amsterdamie. Daniel Stalpaert zastosował podobne formy przypór w Oosterkerk w Amsterdamie (1669-1671), natomiast Elias Bouwman w dwóch synagogach: Grote Sjoel (1670-1671) [41, s. 386] i Esnodze (1674-1675) w Amsterdamie.

W architekturze bożnic zlokalizowanych na terenie Polski przypory ze spływami w formie łuku zostały wprowadzone tylko raz. Budowlą, w której się pojawiły, była synagoga w Przeworsku, widoczna na sztychu Kajetana Wincentego Kielisińskiego z 1838 roku (il. 6.12) [41, s. 323]. 


\subsubsection{Układ dziewięciopolowy u Villalpanda i Prada a plany XVII- i XVIII-wiecznych synagog zlokalizowanych na obszarze Polski}

Pierwsze bożnice na terenie Rzeczpospolitej, wzniesione na planie dziewięciopolowym znajdowały się najprawdopodobniej w Ostrogu i we Lwowie ${ }^{188}$.

Za wpływem In Ezechielem na architekturę bożnic od lat 20. XVII wieku miałoby przemawiać kilka argumentów. Tym najważniejszym byłaby działalność autora wymienionych bożnic, Jakuba Medliniego. Miał on przetransponować teoretyczną rekonstrukcję Villalpanda na architkturę synagog. Kolejnym byłoby przeniknięcie jezuickiego wzoru do społeczności żydowskiej za sprawą rekonstrukcji przygotowanej przez Jakuba Leona w oparciu o rekonstrukcję Villalpanda i Prada. Na jezuickiej rekonstrukcji wzorowano się zresztą znacznie częściej w pracach teoretycznych $[89, \text { s. 228 }]^{189}$. Nie bez znaczenia byłoby również to, że wzorzec ten miał się rozprzestrzeniać pod wpływem architektury jezuickiej. I wreszcie, w bibliotece lwowskiego kolegium jezuickiego [89, s. 228-230] znajdowała się kopia In Ezechielem, która miała stać się źródłem inspiracji bożnicy w Ostrogu i Lwowie [95, s. 199-200]. Uzasadniony wydaje się więc wniosek, że Lwów mógł stać się centrum nowego typu synagogi.

Uwzględniając jednak przeanalizowane wzorce takiego rozwiązania, należy stwierdzić, że plan dziewięciopolowy z podziałem na równe pola był powszechny od czasów starożytnych i pojawił się również $\mathrm{w}$ architekturze powstającej na obszarze Korony ${ }^{190}$. Jeżeli faktycznie wzorem bożnic była wyłącznie rekonstrukcja Villalpanda, to w dłuższej perspektywie oznaczałoby to nienajlepsze przyjęcie tego wzoru. Był poddawany modyfikacjom, jak się wydaje, pod wpływem synagog z bimą-podporą, które, jak do tej pory, były właściwie jedynym oryginalnym rozwiązaniem wynikającym z judaizmu. Widoczne jest to już w Wielkiej Synagodze w Wilnie (1633), gdzie filary zostały do siebie zbliżone, ale przy zachowaniu wolnostojącej bimy i tej samej wysokości sklepienia we wszystkich polach.

W planach bożnic dziewięciopolowych trudno dostrzec jednakowy sposób rozwiązywania każdego z nich, wzorowany na rzeczonej rekonstrukcji. Wynika to z wprowadzania dużej liczby modyfikacji w rozlokowaniu podpór, które w wielu przypadkach nie korespondują z równym podziałem na dziewięć pól. Nie ulega wątpliwości, że plan z bimą-podporą wpłynął na zaburzenie układu podpór we wnętrzu. Chcąc być dokładnym, należy stwierdzić jednoznacznie, że plan z bimą podporą jest szczególnym typem planu dziewięciopolowego, w którym centralne pole jest najmniejsze. Zarówno rozpowszechnienie się planu dziewięciopolowego w Europie, jak i pojawienie się wzorców w architekturze bożnic (w Tomarze i w Safedzie) może świadczyć o tym, że podstawą sposobu rozplanowania bożnic dziewięciopolowych były archetypy częściowo zakorzenione w świadomości społeczności żydowskie. W przypadku bożnic w Ostrogu i we Lwowie nie można wykluczyć - przez wzgląd na postać architekta i księgozbiór biblioteki kolegium - inspirowania się jezuicką rekonstrukcją, choć z punktu widzenia chrześcijańskiego artysty bardziej oczywistą sugestią był z pewnością plan dziewięciopolowy bazyliki św. Piotra. 


\subsubsection{Złote proporcje u Villalpanda i Prada a XVII- i XVIII-wieczna architektura polska}

W książce Georga L. Hersey’a można przeczytać, że świątynia jerozolimska stała się apogeum starożytnej żydowskiej myśli architektonicznej, a sposób jej rozmierzenia opierał się na centralizacji, bilateralności i podobieństwie [58, s. 114]. Autor ten odnosi się przede wszystkim do analizy geometrycznej rekonstrukcji świątyni opartej na wizji Ezechiela. W przypadku świątyni jerozolimskiej można zauważyć, że nadrzędna przy kształtowaniu planu była zasada złotego podziału. Rozmieszczenie poszczególnych elementów, jak i ich wielkość wynikały z podziału kolejnych, koncentrycznie usytuowanych kwadratów. Również plan został opracowany w oparciu o siatkę kwadratów. W rekonstrukcji świątyni przedstawionej przez Villalpanda zauważalne są te zależności, które kryją się w przybliżonej wartości proporcji 3:5. Na podstawie analizy geometrycznej planu można wskazać elementy architektoniczne, których lokalizacja wynika ze złotej proporcji.

Najbardziej zewnętrzny mur świątyni został założony na kwadracie o długości boku równej stu dwudziestu pięciu modułom. Dzieląc ten fragment zgodnie z zasadą złotego podziału, uzyskuje się dwie wartości: czterdzieści osiem i siedemdziesiąt siedem modułów. Obie wyznaczają wewnętrzne krawędzie kolumnad krużganków obiegających dziedziniec kapłański (il. 6.13).

Mur środkowy również został założony na kwadracie, ale o długości boku odpowiadającej stu dziesięciu modułom. Odcinki, które powstały po podziale, miały odpowiednio czterdzieści dwa i sześćdziesiąt osiem modułów. Zasada złotego podziału wyznacza w tym przypadku osie pierwszego rzędu kolumn wewnątrz krużganków (il. 6.14).

Zastosowanie złotego podziału w przypadku kolumnad obiegających mur środkowy określa szerokości słupów i filarów krużganków dzielących dziedziniec świątynny (łac. atria sancta). Wewnetrzny mur ograniczający Atria Sancta został

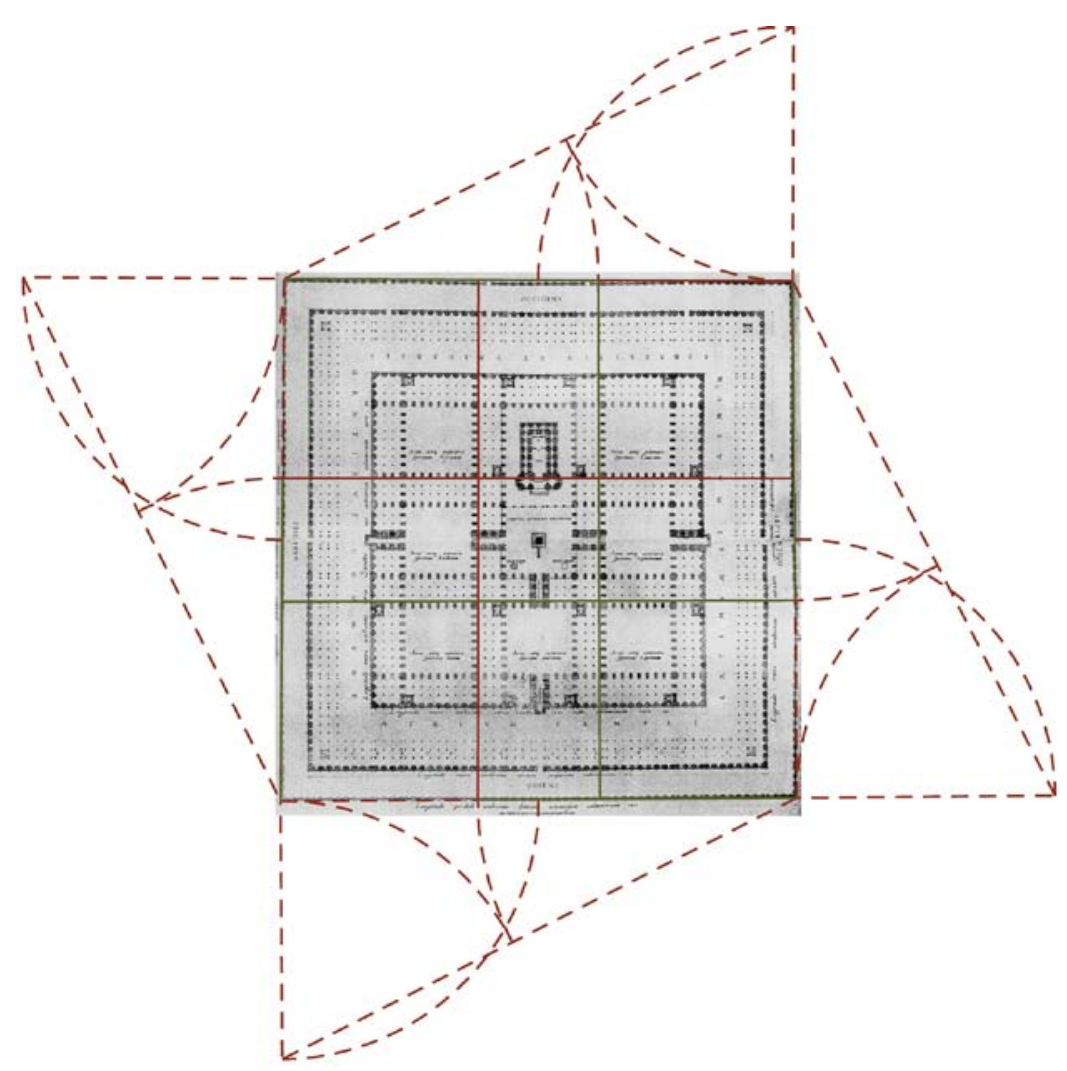

Il. 6.13. Złoty podział zewnętrznego muru świątyni rekonstruowanej przez Villalpanda i Prada [53] 
rozmierzony za pomocą osiemdziesięciu modułów. Zastosowanie złotej proporcji pozwala uzyskać dwa odcinki o długości czterdziestu dziewięciu i trzydziestu jeden modułów, zaś podział odcinka w tym stosunku drugą z wewnętrznych krawędzi krużganka okalającego dziedziniec kapłański (il. 6.17).

Wewnętrznej krawędzi krużganka obiegającego mur Atria Sancta przypisano długość sześćdziesięciu sześciu modułów. Zastosowanie złotej proporcji wprowadza podział tego odcinka na dwie części o długości dwudziestu pięciu i czterdziestu jeden modułów. Wynikiem tych dwóch ostatnich podziałów będzie grubość filarów krużganka. Podział muru Atria Sancta wyznacza osta-

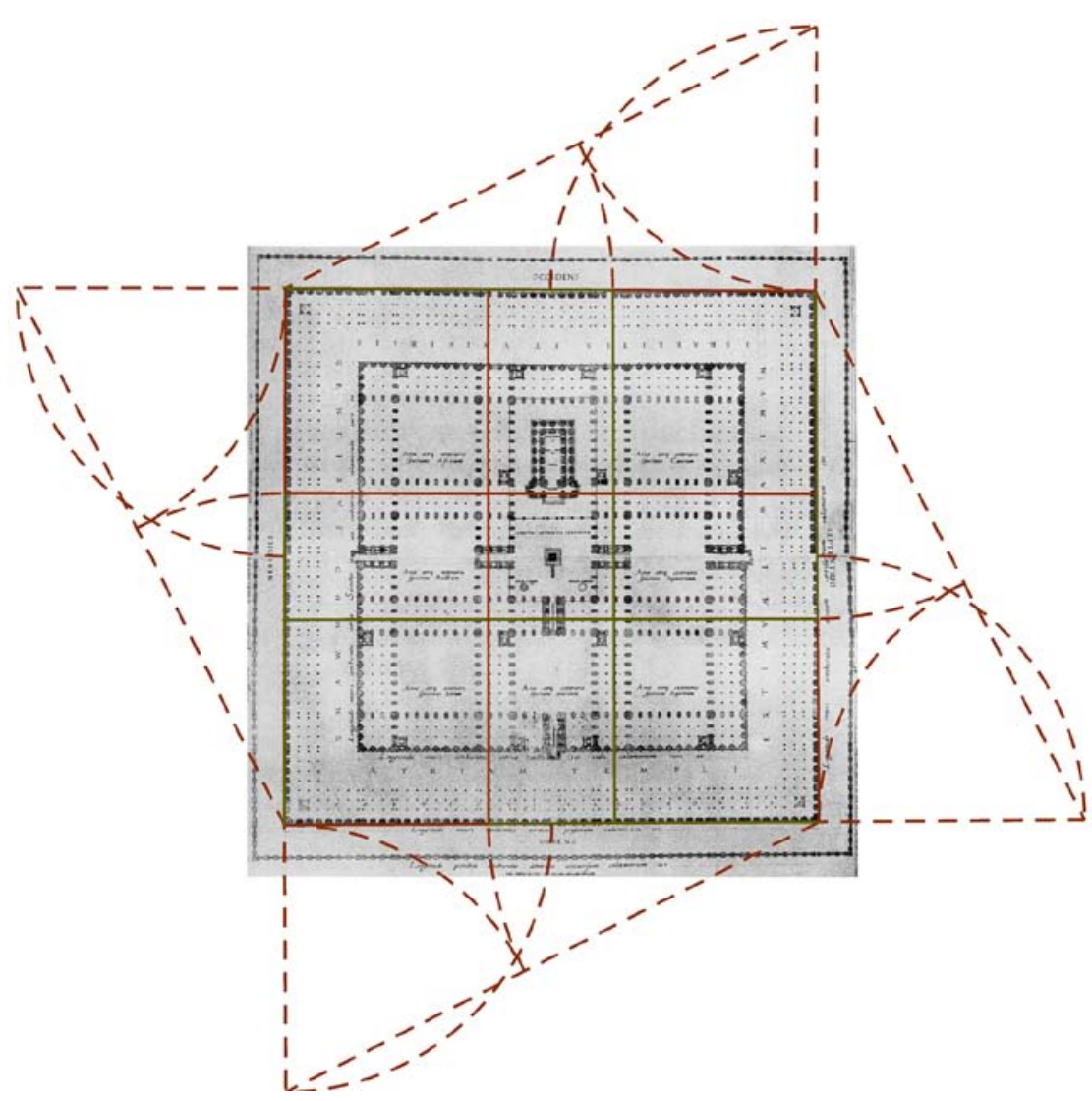

Il. 6.14. Złoty podział muru środkowego świątyni rekonstruowanej przez Villalpanda i Prada [21]

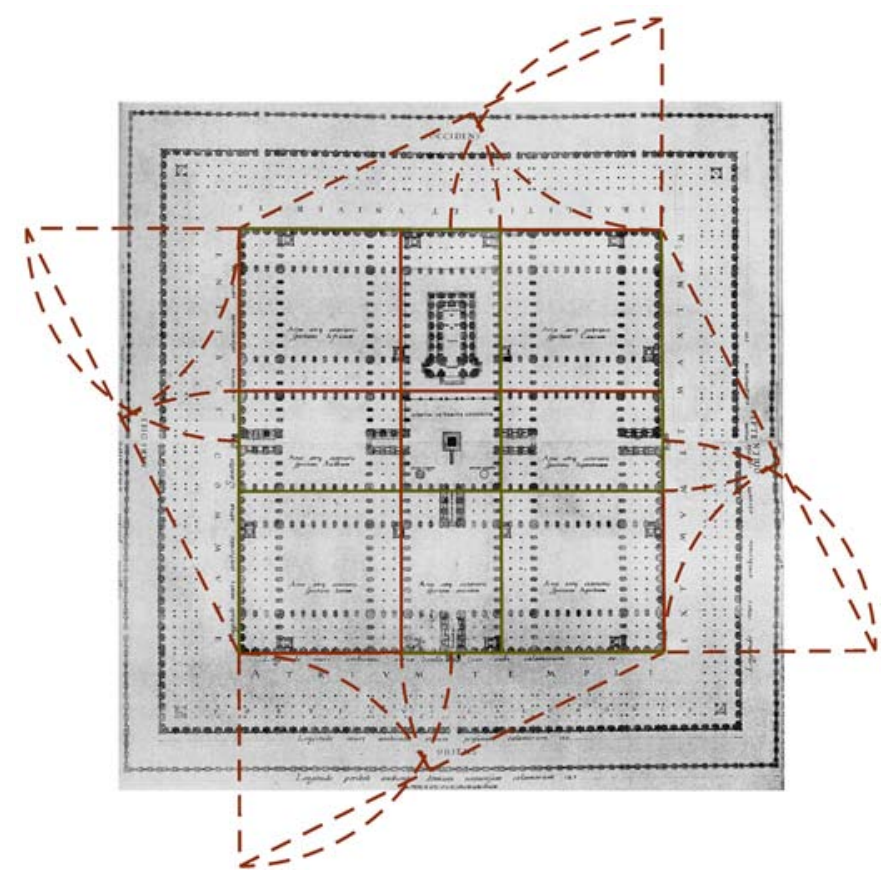

Il. 6.15. Złoty podział muru Atria Sancta świątynirekonstruowanej przez Villalpanda i Prada [21]

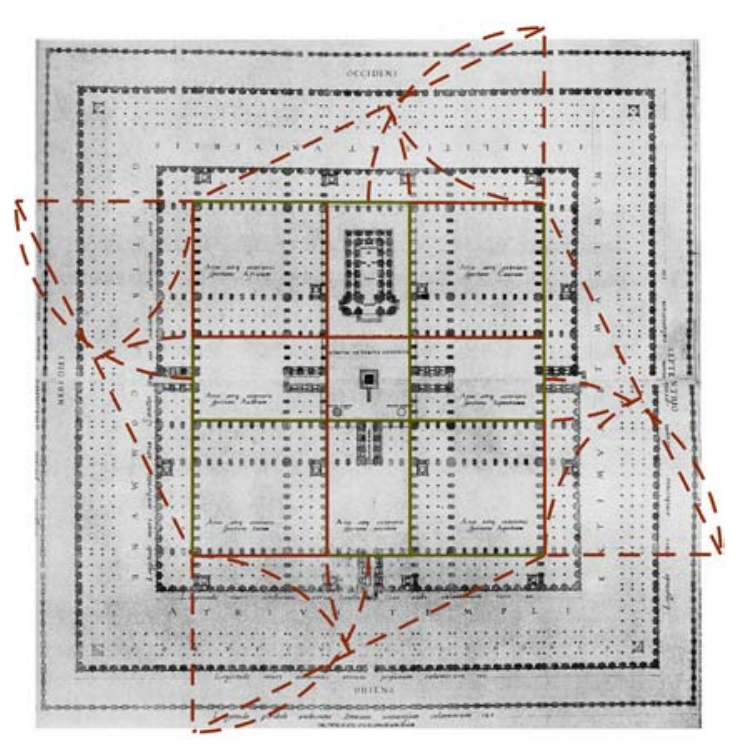

Il. 6.16. Złoty podział wewnętrznej krawędzi krużganka obiegającego mur Atria Sancta w światyni rekonstruowanej przez Villalpanda i Prada [21] 


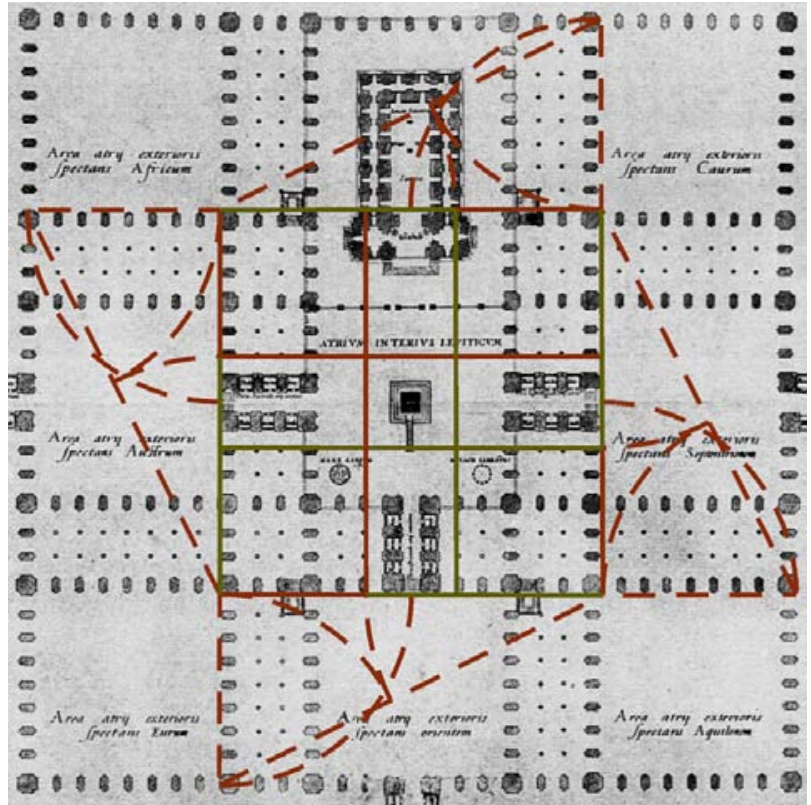

Il. 6.17. Złoty podział dziedzińca

kapłańskiego wraz z krużgankami w świątyni rekonstruowanej przez Villalpanda i Prada [21]

teczny wymiar każdego z dziewięciu kwadratowych dziedzińców, ograniczonych ze wszystkich stron krużgankami (il. 6.16).

Dziedziniec kapłański jest otoczony krużgankami z trzech stron. Założono go również na planie kwadratu o długości boku równej trzydziestu trzem modułom. Długości odcinków wynikające ze złotego podziału ściany atrium kapłańskiego wynoszą trzynaście i dwadzieścia modułów. Wartości te określają osie zewnętrznych ścian świątyni oraz wyznaczają symetryczny układ, w którym znajdują się trzy przedsionki (il. 6.17).

Wewnętrzna krawędź krużganka ma dziewiętnaście modułów długości. Stosunek wartości pozostających w złotym podziale w przypadku tego odcinka wynosi dwanaście i siedem modułów. Liczby te wyznaczają osie ścian wewnętrznych świątyni oraz szerokość przedsionków prowadzących na dziedziniec (il. 6.18).

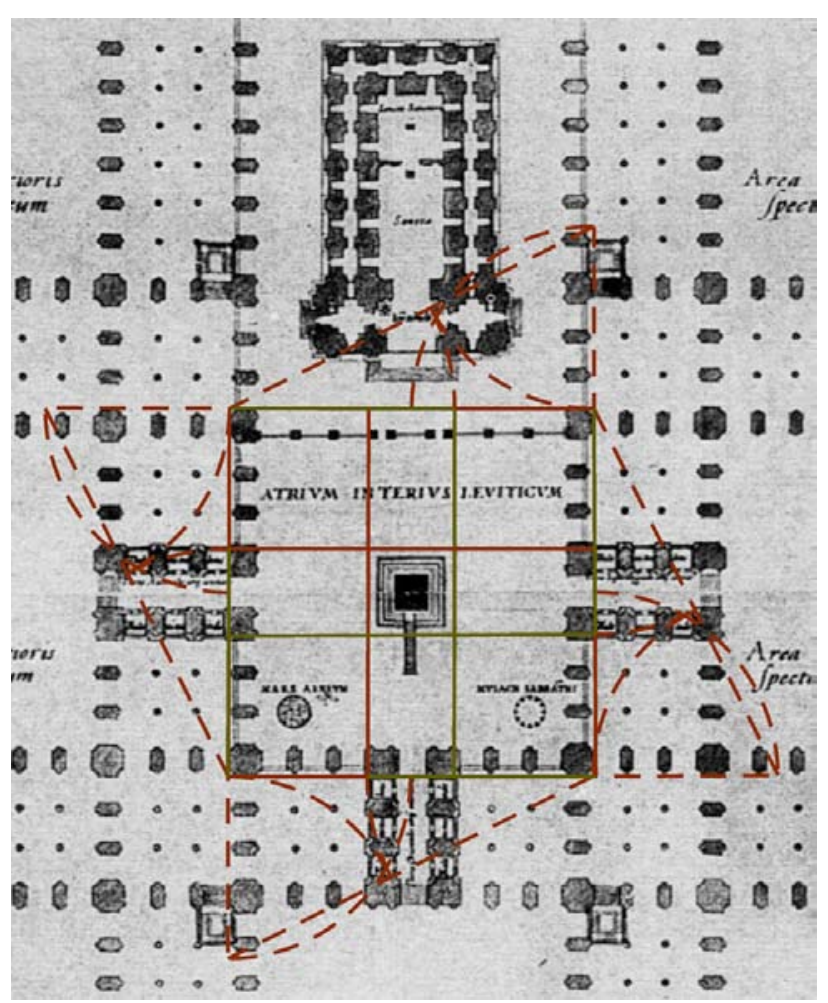

Il. 6.18. Złoty podział wewnętrznej krawędzi krużganka dziedzińca kapłańskiego w świątyni rekonstruowanej przez Villalpanda i Prada [21]

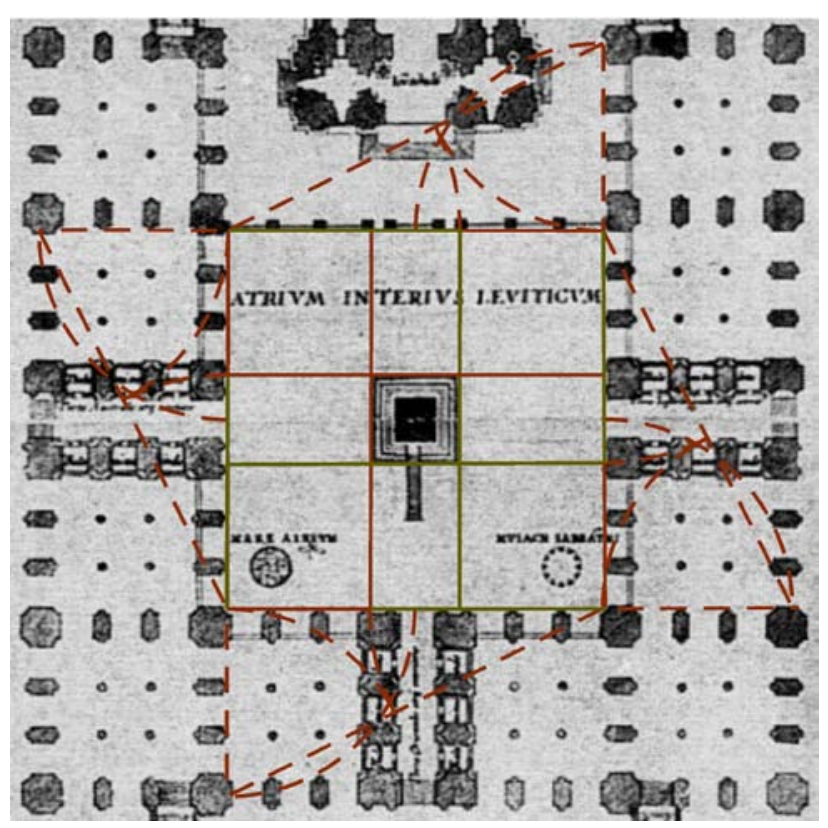

Il. 6.19. Złoty podział dziedzińca kapłańskiego świątyni rekonstruowanej przez Villalpanda i Prada [21] 
Plac ograniczony krużgankami, a stanowiący dziedziniec kapłański został założony na planie kwadratu o boku długości szesnastu modułów. Podział tej odległości w złotym stosunku daje dwa odcinki o długości sześciu i dziesięciu modułów. Wartości te wyznaczają dokładne usytuowanie i wymiary ołtarza znajdującego się w centrum dziedzińca (il. 6.19).

Złoty podział staje się więc podstawową zasadą kształtowania planu świątyni rekonstruowanej przez Villalpanda, a kolejne podziały planu wynikają bezpośrednio z wcześniejszych kwadratów. Wyjściowe do konstrukcji planu są zasadniczo dwa pierwsze zewnętrzne mury. $\mathrm{Z}$ ich podziału wynika szerokość między słupami krużganków, co pozwala na ustalenie odległości między kolejnymi koncentrycznymi kwadratami. Rzut świątyni, który jezuita zastosował poza planem dziewięciopolowym, pokazuje również układ centralny i koncentryczny, który jest charakterystyczny dla architektury synagog dziewięciopolowych i z bimą-podporą.

\subsubsection{Synagogi}

W konstrukcji planu XVII- i XVIII-wiecznych synagog widoczne jest zastosowanie boskiej proporcji ${ }^{191}$. Szczególnie dotyczy to bożnic z bimą-podporą, w których architekturze zasada ta nie była efektem wpływu rekonstrukcji jezuitów. Pierwsze bożnice o takiej formie oraz na planie z użyciem złotej proporcji powstają już w końcu XVI lub na początku XVII wieku. Nawet gdyby podważyć zasadność uznania synagogi Maharszala za pierwszą XVI-wieczną bożnicę z bimą-podporą, to przykładem pierwszego tego typu obiektu nadal pozostanie synagoga w Tarnowie (XVI/XVII w.) (il. 6.20). Na uwagę zasługują również inne starsze przykłady budowli, które pod wzglę-

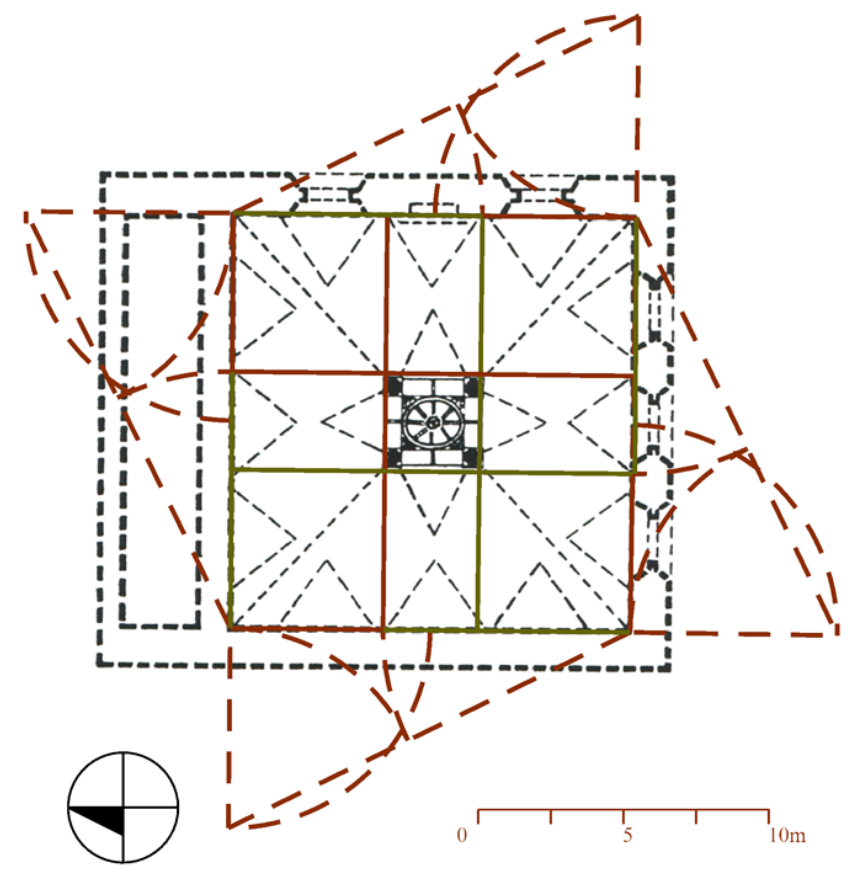

Il. 6.20. Złoty podział rekonstrukcji synagogi w Tarnowie przygotowanej przez M. i K. Piechotków [21]

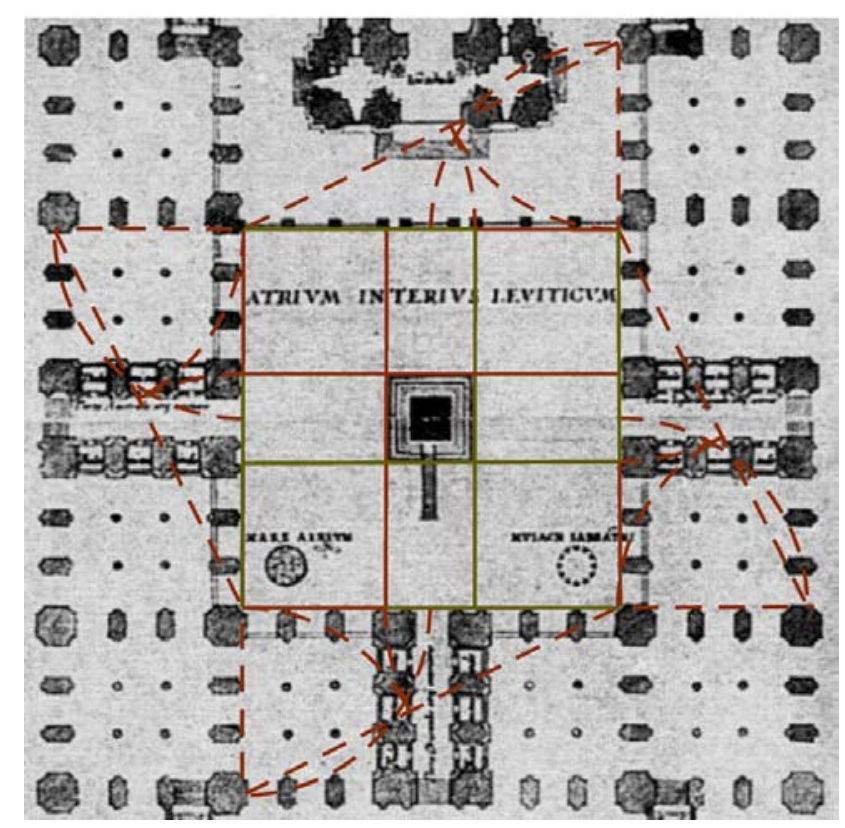

Il. 6.21. Złoty podział dziedzińca świątynnego $\mathrm{z}$ usytuowanym $\mathrm{w}$ centrum ołtarzem [21] 
dem kompozycyjnym odpowiadają zasadzie złotego podziału. Z pewnością należą do nich synagogi w Pińczowie czy w Tomar.

Dziedziniec świątynny narysowany przez Villalpanda i Prada jest powtórzeniem schematu planu bożnicy z bimą-podporą, przy czym almemor został zastąpiony ołtarzem (il. 6.21). Nie wskazuje to w żadnym razie na czerpanie z wzorców bożnic z obszaru Polski czy rekonstrukcji w synagogach z bimą-podporą, ale raczej na zastosowanie identycznej zasady kompozycyjnej, która w gruncie rzeczy opierała się na prostym działaniu związanym z podziałem kwadratu za pomocą złotej proporcji.

W przypadku dwóch pierwszych bożnic dziewięciopolowych (we Lwowie i w Ostrogu), które miałyby być wzorowane na rekonstrukcji świątyni przygotowanej przez Villalpanda i Prada, trudno odnaleźć złoty podział. Wynika z tego, że Jakub Medlini nie zgłębiał zasad rządzących planem i w związku z tym zastosował formę bez przeniesienia wszystkich idei, które nią rządziły. Być może wskazuje to jednak na czerpanie przez tego autora z powszechnych $\mathrm{w}$ architekturze, innych wzorców planu dziewieciopolowego.

Lokowanie bimy-podpory zgodnie z zasadą złotej proporcji wpłynęło prawdopodobnie na sposób planowania wnętrz bożnic dziewięciopolowych, w których słupy były zbliżone do siebie. Można je uznać za rozwiązanie pośrednie między bożnicą z bima-podporą a idealnym planem dziewięciopolowym o równych polach. Pierwszym bardzo wczesnym przykładem jego zastosowania była Wielka Synagogą w Wilnie. W planie tego obiektu uwzględniono sposób lokowania słupów w oparciu o zasadę boskiej proporcji. Co ciekawe, jest to jeden z najlepszych przykładów, w którym słupy znajdują się idealnie w centrum linii wyznaczających złoty podział sali męskiej. Można wprawdzie próbować wiązać takie rozwiązanie z rekonstrukcją przedstawioną przez Villalpanda i Prada. Zarówno plan dziewięciopolowy, jak i kompozycja oparta na złotej proporcji pojawia się w architekturze bazyliki św. Piotra w Rzymie i innych obiektów architektury chrześcijańskiej, również tych w Polsce. Trudno zatem nie wiązać takiego rozwiązania wnętrza z rodzimymi wzorcami, zwłaszcza że boska proporcja funkcjonuje również w architekturze bożniczej.

Opieranie się przez twórców architektury synagogalnej na zasadzie złotej proporcji mogło być skutkiem zakorzenienia tego wzorca w kulturze żydowskiej. Stosowanie tej zasady w synagogach ${ }^{192}$, które wzniesiono zanim powstała rekonstrukcja świątyni, wskazuje zdecydowanie na inne źródło niż rekonstrukcja przygotowana przez Villalpanda i Prada.

\subsubsection{Kościoły katolickie (ze szczególnym uwzględnieniem kościołów zgromadzeń kontrreformacyjnych)}

Wzór świątyni jerozolimskiej przedstawionej przez Villalpanda i Prada został rozpowszechniony prawdopodobnie przez jezuitów i karmelitów [89, s. 228]. Jego oddziaływanie na architekturę nie budzi wątpliwości [58, s. 114], a dowodami tego wpływu mają być pałacowo-klasztorne założenie Escorial [41, s. 367] czy architektura klasztorów karmelickich [21, 


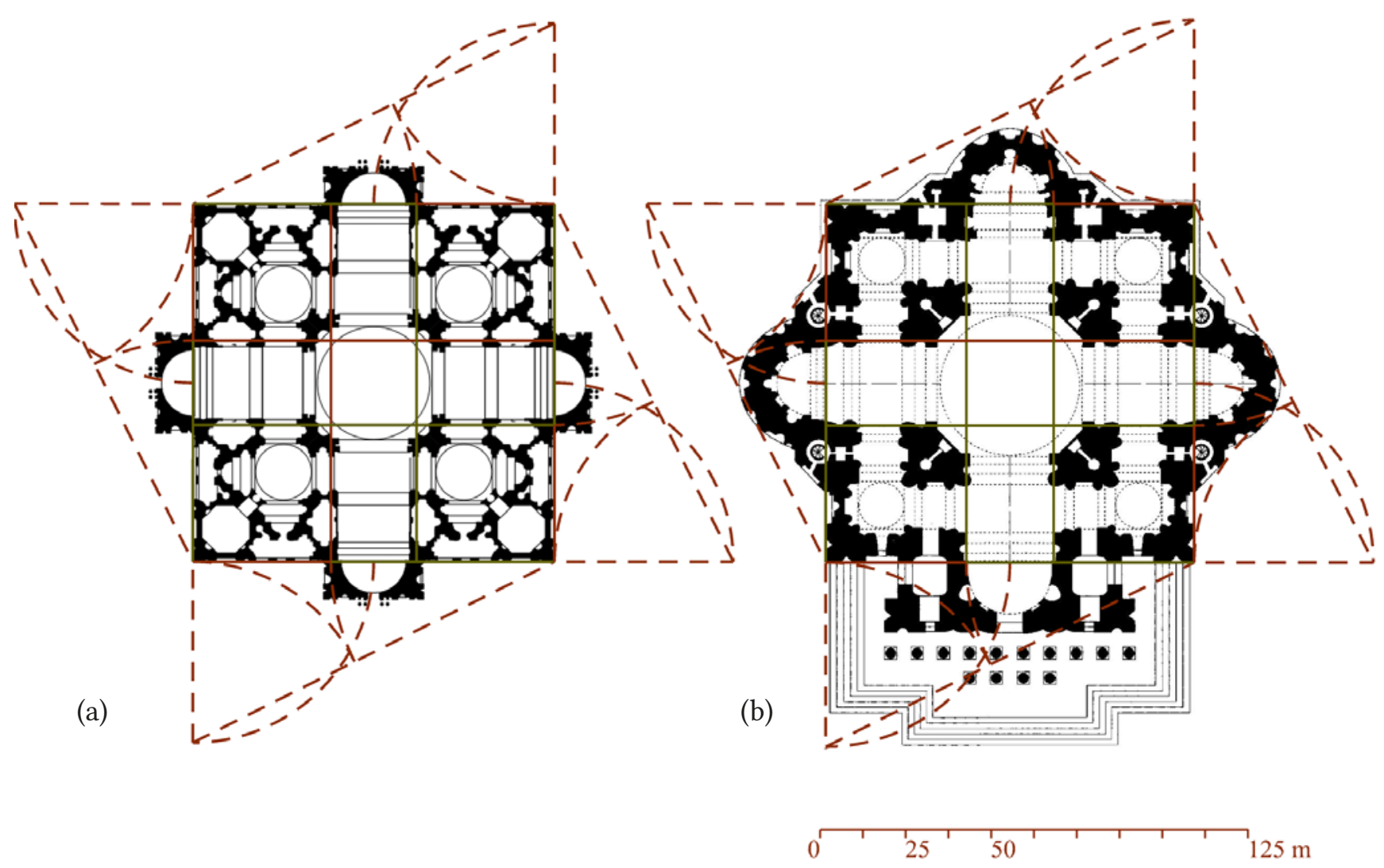

Il. 6.22. Złoty podział w projektach bazyliki św. Piotra w Rzymie autorstwa Bramantego (1506) (a) i Buonarrottiego (1547) (b) [21]

s. 176-178]. Jednak kompozycja Escorialu i klasztoru karmelitów w Czernej ${ }^{193}$ nie nawiązuje do zasady boskiej proporcji.

Złota proporcja była niekiedy stosowana w architekturze sakralnej. Za szczególnie interesujące można uznać jej wykorzystanie w konstrukcji planu.

Przede wszystkim należy zwrócić uwagę na kształtowanie rzutów obiektów powstałych jeszcze przed wydaniem In Ezechielem.

Kierowanie się przez twórcę zasadą złotego podziału jest widoczne w konstrukcji planu bazyliki św. Piotra w Rzymie (il. 6.22). Historia powstawania tego symbolu katolicyzmu jest rozbudowana, a została napisana przez wielu ważnych artystów XVI wieku. Należy jednak skupić się na jej fragmencie, a mianowicie na dwóch powiązanych ze sobą planach bazyliki. W obu zastosowano złotą proporcję, jednak linie złotego podziału zostały odmiennie zakomponowane. Oba rzuty są centralne i posiadają formę dziewięciopolową. Charakterystycznym elementem jest jednak podkreślenie planu krzyża, który zaciera dziewięciopolowy charakter.

Pierwszym projektem poddanym analizie jest plan sporządzony przez Bramantego i przyjęty w 1506 roku za podstawę do rozpoczęcia budowy bazyliki. Cechą zaprojektowanej konstrukcji była filigranowość. W centrum każdej ze ścian usytuowano ryzality, w których 
ukryto absydy. Linie podziału wyznaczają osie ścian absyd, a we wnętrzu ślizgają się po ścianach nawy głównej.

Drugi projekt, autorstwa Michała Anioła, został sporządzony na dalszym etapie budowy bazyliki. Znaczne uproszczenie rzutu spowodowało zmianę masywności konstrukcji, a złoty podział został niemalże idealnie wpisany w kompozycję planu. Linie podziału wyznaczają szerokość nawy bazyliki św. Piotra.

W czasie, kiedy w Rzymie powstawał symbol chrześcijaństwa, w Krakowie trwały prace przy budowie Kaplicy Zygmuntowskiej (1519-1533). Mauzoleum wzniesione przy katedrze wawelskiej zostało zaprojektowane przez Bartolommeo Berrecciego (1480-1537). Ten florencki architekt i rzeźbiarz również posłużył się w kompozycji planu boską proporcją. Zgodnie z tą zasadą wyznaczył podziały ścian oraz szerokości nisz (il. 6.23), a także zaprojektował ośmioboczny tambur pod kopułą.

Złote proporcje pojawiały się $\mathrm{w}$ architekturze sakralnej renesansu jeszcze zanim Villalpando i Prado zastosowali je w swojej wizji świątyni jerozolimskiej. Obaj autorzy In Ezechielem byli jezuitami. Zakładając zatem, że ich pomysł oddziaływał na architekturę, dowodów należałoby poszukać u źródła,

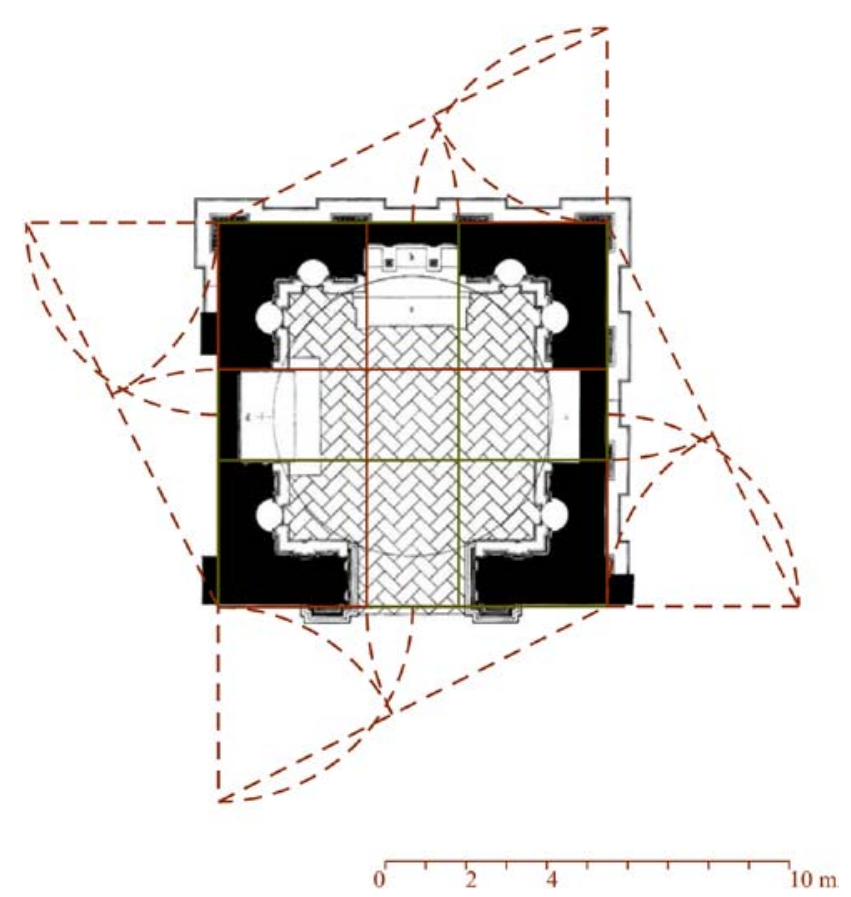

Il. 6.23. Złoty podział w planie Kaplicy Zygmuntowskiej [21] a więc w fundacjach jezuickich. Jeżeli to Towarzystwo Jezusowe przyczyniło się do upowszechnienia planu dziewięciopolowego i określonego wzorca świątyni, należy założyć, że w obrębie samego klasztoru musiały powstawać obiekty odpowiadające opisanym zasadom planu, w tym przede wszystkim zasadzie złotej proporcji.

Reformacja wywołała reakcję kościoła katolickiego i to nie tylko w postaci powołania zakonów, które miały z nią walczyć. Kontrreformacja przejawiała się również w sztuce i architekturze. Teatralizacja, przepych oraz opracowanie nowych form architektonicznych, które najlepiej odpowiadałyby ówczesnym nastrojom, były celem samym w sobie. Najlepszym tego przykładem było wzniesienie kościoła Il Gesu, macierzystego kościoła zakonu jezuitów. Budowla ta stała się wzorem dla twórców nie tylko wielu kościołów jezuickich w całej Europie, ale również innych zakonów. W Polsce wzór ten był wielokrotnie przetwarzany. Zmiany w strukturze planu mogły być podyktowane zastosowaniem zasady złotego podziału, której brak w planie kościoła Il Gesu.

W polskich kościołach jezuickich skracano nawę główną, a rzędy kaplic zastępowano nawami bocznymi. Skrócenie nawy głównej doprowadzało bardzo często do ograniczenia głów- 


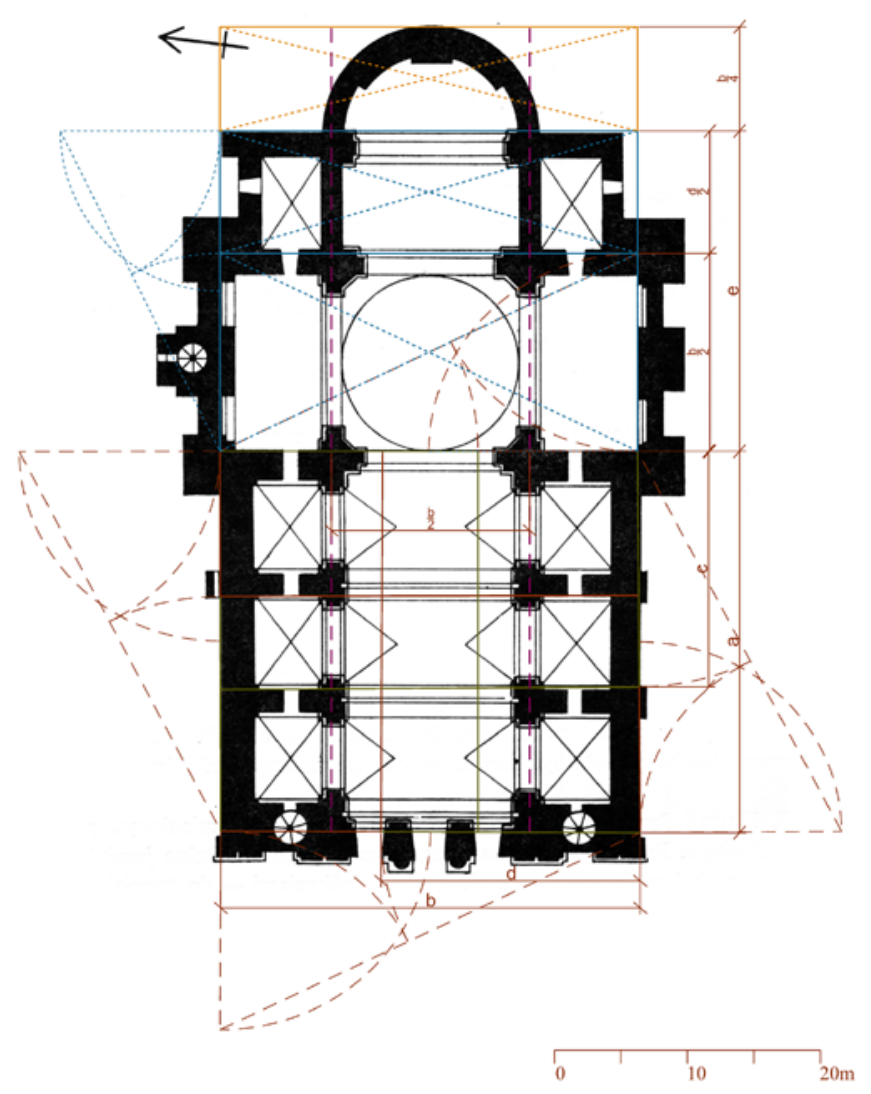

Il. 6.24. Schematy złotego podziału kolegiaty w Nieświeżu [21]

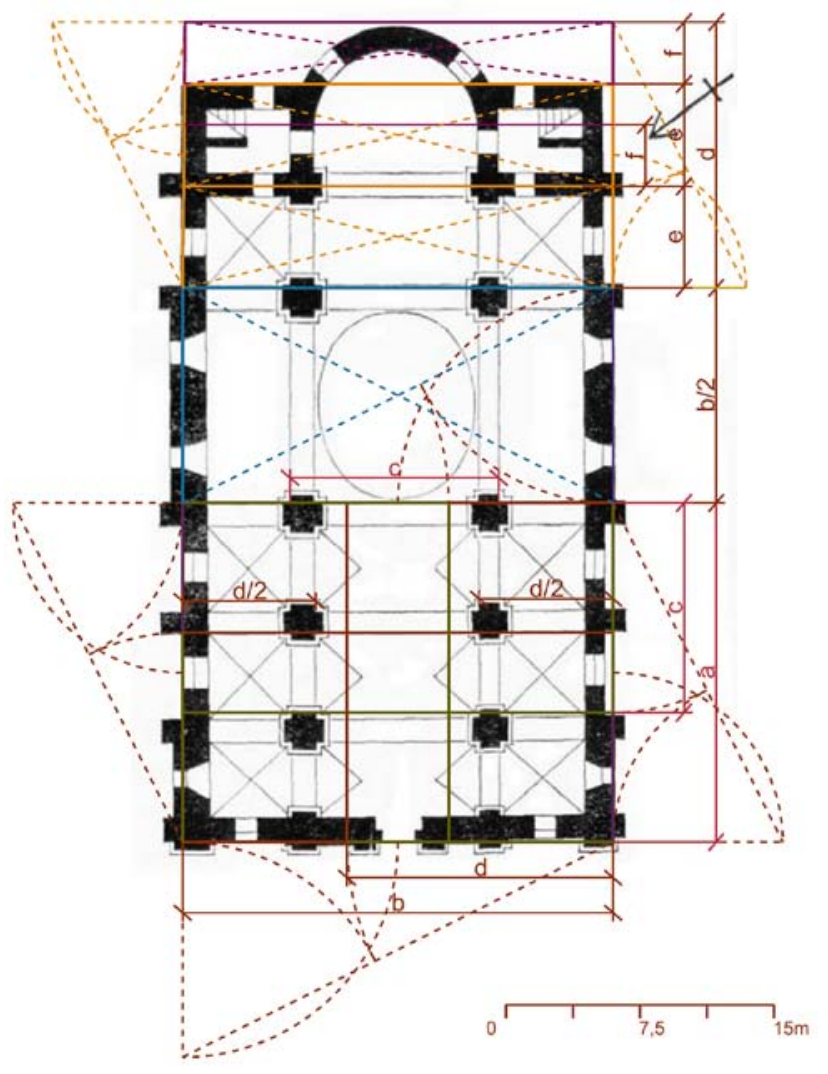

Il. 6.25. Schematy złotego podziału kościoła św. Piotra i Pawła [21]

nej części korpusu (przed transeptem) do dziewięciu pól (trzy nawy po trzy przęsła). Stopień wpływu zasady złotego cięcia na architekturę zakonów kontrreformacyjnych pozwoli ustalić analiza kilku jej przykładów.

Wykorzystanie boskiej proporcji w kościołach jest dosyć skomplikowane i właściwie nie ma jednego sposobu rozmierzenia całej budowli. Podstawowym zadaniem było rozplanowanie trójprzęsłowego korpusu. W wyniku tego działania uzyskiwano idealną szerokość przęsła, którą następnie powielano. W schemacie tym zwraca uwagę to, iż korpus nie był kwadratem. Zwykle jego szerokość była większa od długości. Dlatego też w trakcie działań z wykorzystaniem złotej proporcji uzyskiwano cztery, a nie dwa odcinki wynikające z podziału. Zależność tę można prześledzić na przykładzie pierwszego jezuickiego kościoła wybudowanego na ziemiach polskich.

Kolegiata w Nieświeżu (1584-1593) została zaprojektowana przez Jana Marię Bernardoniego (il. 6.24). Jeżeli przyjmie się, że długość trzech przęseł nawy wynosi (a) a szerokość kościoła (b), to po podziale odcinka (a) uzyska się odcinek (c) i (a - c), a po podziale odcinka (b) odcinek (d) i $(b-d)$. Odcinek (c) stanowi w tym przypadku szerokość nawy głównej, a odcinek $(\mathrm{d} / 2)$ jest szerokością naw bocznych. Długość transeptu równa jest (b/2), a więc nie wynika z zasady złotego podziału. Dwa ostatnie przęsła kościoła wraz z absydą mają długość 

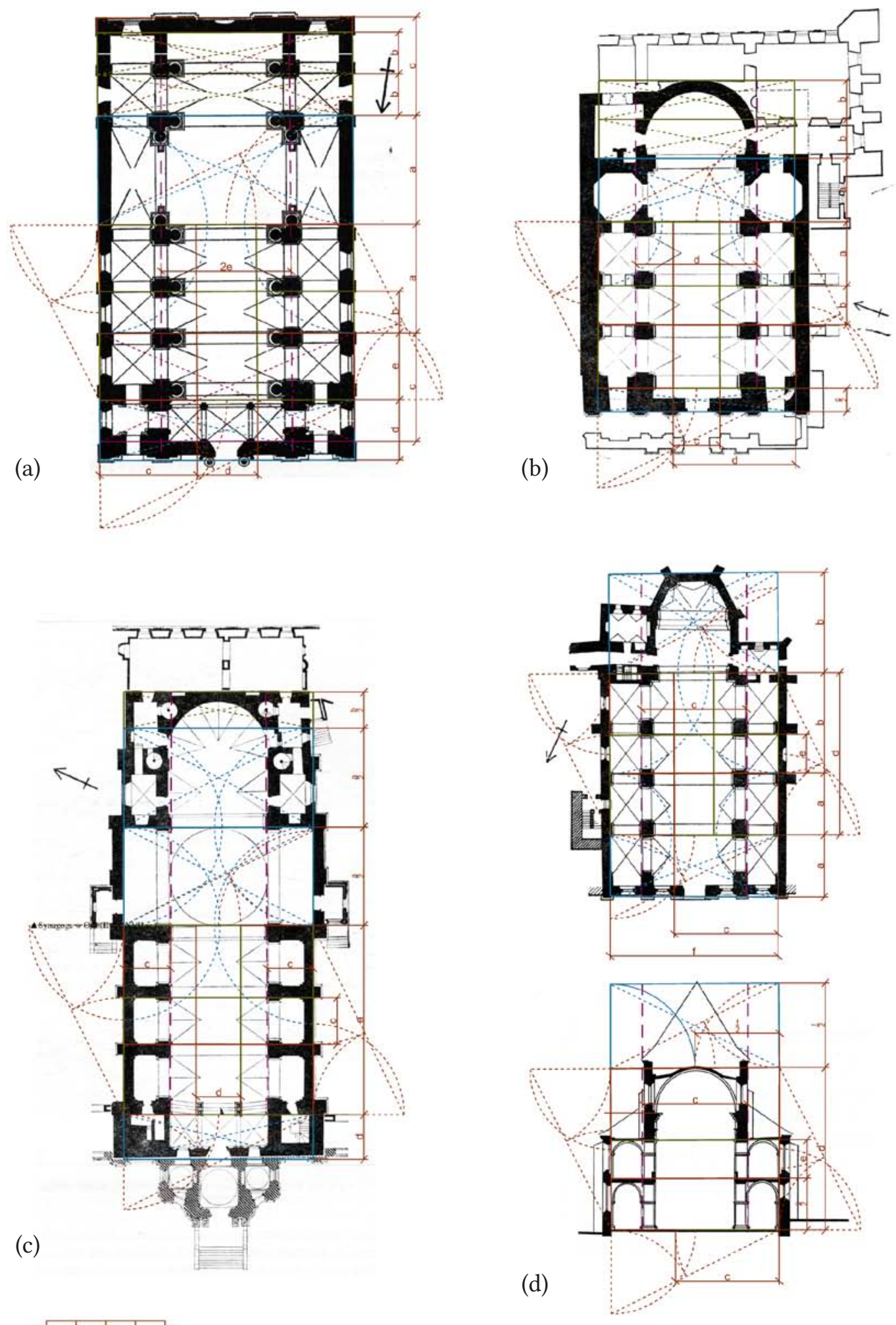

Il. 6.26. Schematy złotego podziału w kościołach jezuickich w: Poznaniu (1649-1701, autorzy obiektu: Tomasz Poncino, Bartłomiej Nataniel Wąsowski, Jan Catenazzi) (a), Lublinie(1586-1604, autor obiektu: Jan Maria Bernardoni) (b), Wilnie (1604-1616, autor obiektu: Jan Frankiewicz) (c), Kaliszu (1578-1595, autor obiektu: Jan Maria Bernardoni) (d) [22] 

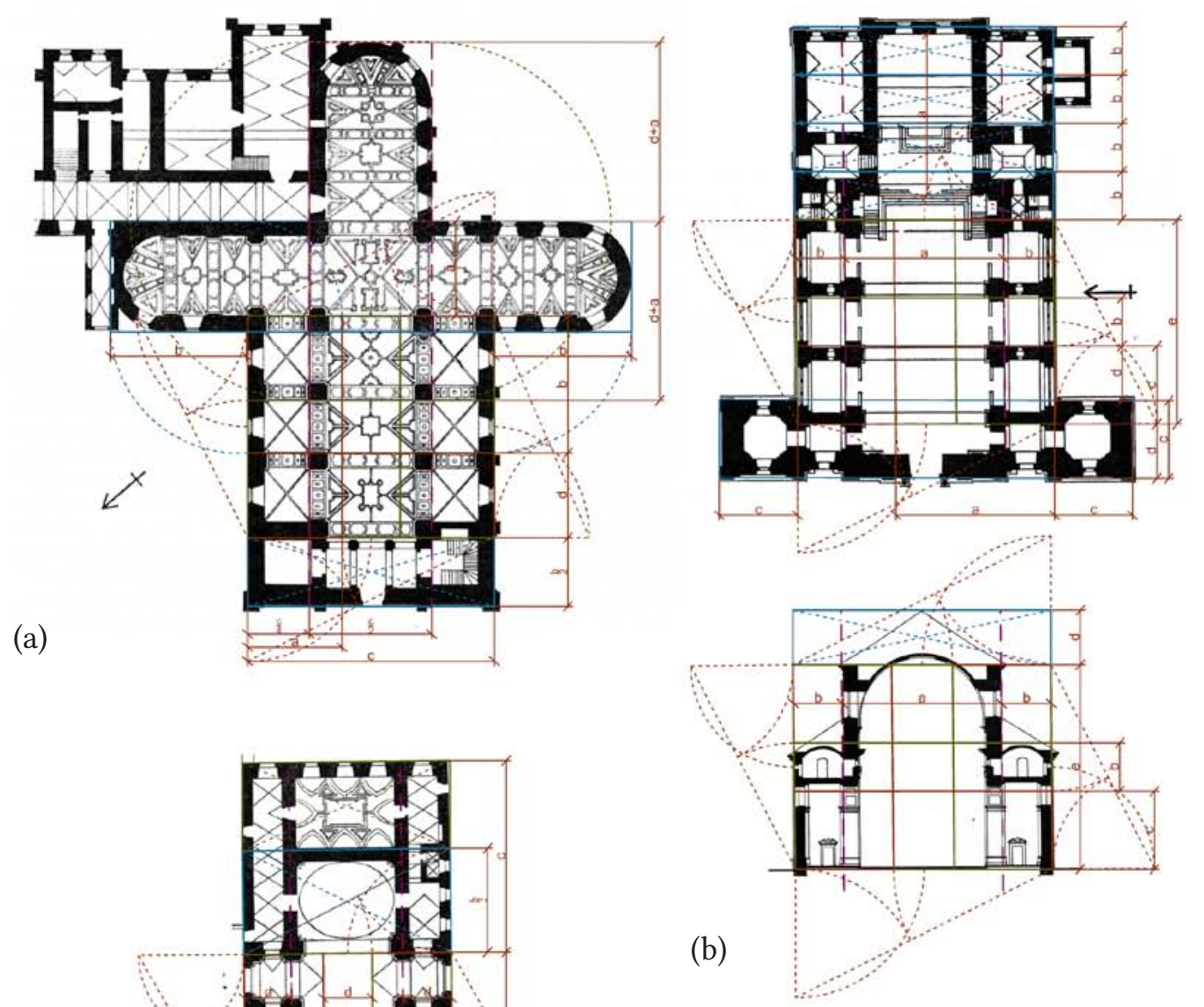

(c)
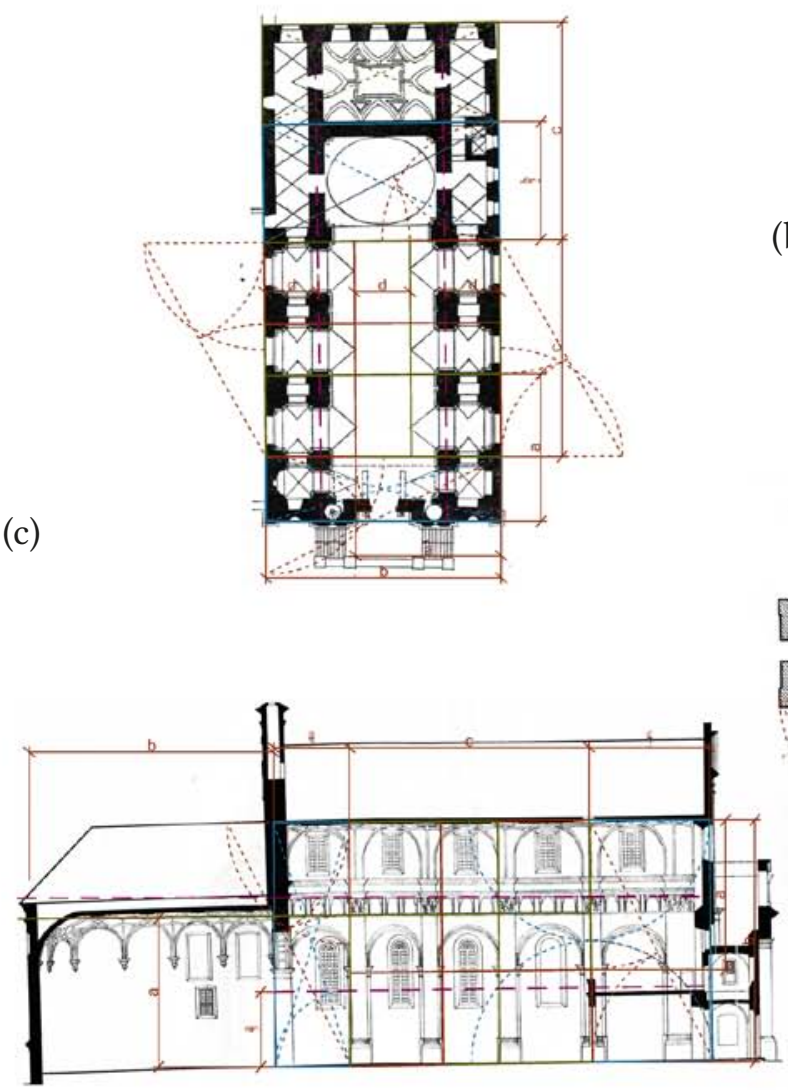

(d)

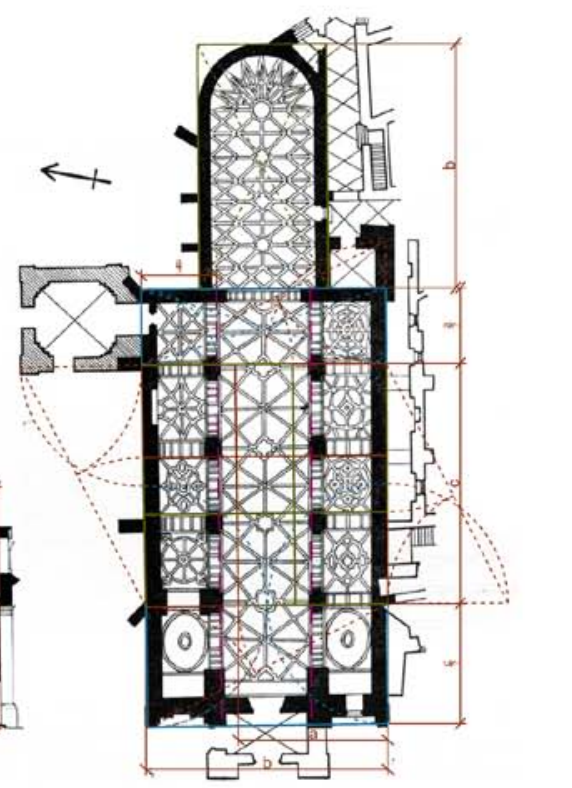

Il. 6.27. Schematy złotego podziału w kościołach: dominikanów w Gidle (1632-1644, autor obiektu: Jan Buszt) (a), kamedułów na Bielanach (Kraków) (1609-1617) (b), karmelitów bosych w Wilnie (1632-1644, autor obiektu: Constante Tencalla) (c), bernardynów w Lublinie (1603-1608, autor obiektu: Jakub Balin (?)) (d) [22] 
odcinka (d). Jeżeli odcinek (d) zostanie podzielony zgodnie z zasadą złotego podziału, to wynikiem tego będzie odcinek (e) i (d - e). Każde z dwóch przęseł kościoła za transeptem ma długość (e). Absyda zamyka się natomiast w odcinku o długości (f). Odcinek (f) jest równy różnicy odcinka $(\mathrm{d}-\mathrm{e})$ i odcinka $(\mathrm{e}): \mathrm{d}-2 \mathrm{e}=\mathrm{f}$. Należy przy tym pamiętać, że odcinki (e) i (f) pozostają w złotym stosunku. Już w tym przypadku widoczne jest zdecydowane wykorzystanie złotego podziału, jednak w dość zawiłej i skomplikowanej strukturze.

Drugim obiektem zupełnie odmiennym pod względem zastosowania złotej proporcji jest kościół św. Piotra i Pawła w Krakowie (il. 6.23), w którym złoty podział nawy głównej nie jest podstawą rozmierzenia całości planu - ten ma bowiem proporcje dwóch kwadratów (czyli $\mathrm{a} \approx \mathrm{b}$ ). Rozmierzenie rzutu opiera się na szerokości korpusu (b). W wyniku złotego podziału tego odcinka uzyskuje się odcinki (d) i (b - d). Szerokość nawy głównej, jak i transeptu określona jest jako odcinek o długości (b/2). Długość przęsła prezbiterium jest równa odcinkowi (d/2). Odcinki (d/2) i (b/2) pozostają w złotym podziale, tak jak odcinki (b) i (d). Absyda mieści się w odcinku o długości (b/4).

Przedstawione przykłady obrazują dwa zupełnie odmienne podejścia do sposobu rozmierzenia kościołów. Te opisane poniżej dotyczą pierwszego z systemów, który w największym stopniu opiera się na zasadzie boskiej proporcji. Rozmierzenie kolejnych z omówionych kościołów następowało podobnie w oparciu o trójprzęsłową nawę główną (il. 6.24-6.25). Złoty podział wyznaczał szerokość centralnego przęsła w osiach ścian. Dłuższy z wymiarów powstałych w wyniku złotego podziału którejś ze ścian trójprzęsłowego korpusu stanowił szerokość nawy głównej (w kościołach według projektu Jana Marii Bernardoniego w Lublinie (1586-1604) i Kaliszu (1587-1595) oraz w kościele kamedułów na Bielanach (1609-1617)). Zdarzało się również, że mniejsza wartość lub połowa większej wartości uzyskanej w wyniku złotej proporcji stanowiła szerokość naw bocznych (w kościele jezuitów według projektu Jana Frankiewicza w Wilnie (1604-1616) czy w kościele bernardynów według projektu Jakuba Balina (?) w Lublinie (1603-1608)). Stwierdzono również, że szerokość nawy głównej była połową całkowitej szerokości (w kościele dominikanów według projektu Jana Buszta w Gidle (1632-1644) i karmelitów bosych według projektu Constante Tencalla w Wilnie (1632-1644)) oraz wielokrotnością krótszego odcinka złotej proporcji (w kościele jezuitów według projektu Tomasza Poncino, Bartłomieja Nataniela Wąsowskiego i Jana Catonazzego w Poznaniu (1649-1701)).

Kolejne długości i szerokości opierały się na wielokrotności odcinków powstałych w wyniku złotego podziału trójprzęsłowego korpusu. Generalną zasadą było korzystanie przy rozmierzaniu przekrojów z proporcji uzyskanych w planie.

Zasada złotej proporcji nie przyświecała natomiast twórcom kościołów parafialnych w: Pińczowie (1615-1619), Gołębiu (1628-1636), Tarłowie (1645-1655), Lesznie (1685-1696), Rokitnie (1693-1708). Konstrukcja planu kościoła podłużnego nie dawała możliwości wykorzystania złotego podziału w czystej formie, jak to się działo w synagogach z bimą-podporą. Co prawda przeniknięcie zasad złotego cięcia, jak i wzorców rekonstrukcji Villalpanda i Prada 
można przypisywać architektom włoskim działającym na obszarze Rzeczpospolitej, którzy odpowiedzialni byli zarówno za wznoszenie kościołów, jak i synagog [95, s. 199], [94, s. 322]. Ze schematów wykorzystywanych w kościołach zakonów kontrreformacyjnych wynika jednak, że poziom skomplikowania systemu rozmierzania na podstawie boskiej proporcji ma się nijak do czystego systemu zastosowanego w planie rekonstruowanej świątyni. Pod względem wykorzystania skomplikowanego systemu przoduje architektura Jana Marii Bernardoniego, o którego udziale przy projektowaniu którejkolwiek z bożnic wzniesionych w granicach Rzeczypospolitej nie ma wzmianki w dokumentach czy literaturze.

Wydaje się, że sposób kompozycji w oparciu o złotą proporcję, pomimo wspólnego źródła, był różny w zależności od tego, którego obiektu dotyczył i stanowił tym samym indywidualną cechę pracy każdego architekta. Szczegółowe określenie zasad związanych z rozmierzaniem planów kościołów doby kontrreformacji oraz wpływu na nie takich zjawisk, jak rekonstrukcja Villalpanda i Prada, jest jednak obszernym zagadnieniem i wymagałoby odrębnego opracowania ze szczegółowym uwzględnieniem nauk Akademii Świętego Łukasza. W niniejszej monografii istotna jest powszechność istnienia złotej proporcji w kościołach o proweniencji jezuickiej w Polsce. Należy zaznaczyć również, że ten sposób kompozycji wykształca się przed rozpowszechnieniem rekonstrukcji świątyni autorstawa Villalpanda.

\subsection{Podsumowanie}

Archetyp świątyni odgrywa w kulturze żydowskiej dużą rolę, a jego wpływ na architekturę bożniczą można rozważać na różnych poziomach. Przede wszystkim widoczny jest aspekt symboliczny, w przypadku którego synagoga w diasporze stanowi swego rodzaju kontynuację i substytut kultu świątynnego, ale w odmiennej formie. Ten paradoks kontynuacji i zastępstwa spowodował, że świątynia stała się centralnym tematem sztuki judaizmu na różnych jej płaszczyznach.

Nostalgia i żal po zburzeniu świątyni jerozolimskiej - najświętszego miejsca judaizmuspowodował ciągłe powracanie do koncepcji świątyni, przede wszystkim w symbolicznym rozumieniu elementów składających się na przestrzeń synagogi. Jak wynika z powyższych analiz, próbowano również na podstawie zachowanych opisów rekonstruować formę przybytku świątynnego.

Tanach przedstawia kilka opisów świątyni. Pierwsze miejsce kultu zostało wzniesione przez Mojżesza i było przybytkiem ruchomym, który Izraelici przenosili ze sobą w trakcie wędrówki. Pierwszą stałą świątynię wzniósł Salomon, a druga powstała za czasów Heroda. W Biblii pojawia się jeszcze jeden opis świątyni - znajduje się w Księdze Ezechiela i stanowi, podobnie jak cała księga, nieskończone źródło analiz. Charakterystycznym i stałym elementem wszystkich opisów jest sanktuarium, którego forma i wymiary pozostają właściwie nie- 
zmienne. Jego plan zawsze składa się z trzech kwadratów, z których ostatni jest przeznaczony na Najświętsze ze Świętych.

Świątynia jerozolimska, jak wynika ze wszystkich analiz i opisów tego przybytku, fascynowała zarówno Żydów, jak i chrześcijan. Już w talmudycznym traktacie Middot [173] analizie poddana została forma drugiej świątyni, a Majmonides w XII wieku wykonał jej graficzną rekonstrukcję. Świątynia opisana w wizji Ezechiela stanowiła ważny punkt w rozważaniach chrześcijańskich uczonych, zwłaszcza w epoce renesansu. Najprostszym tego przejawem było poszukiwanie idealnego porządku architektonicznego, z którego korzystano przy budowie świątyni. Wydaje się również, że dla kościoła katolickiego opis w Księdze Ezechiela był istotny, zwłaszcza w połączeniu z apokaliptyczną wizją Nowego Jeruzalem zawartą w Apokalipsie św. Jana [137, Ap 21, 9-19]. Niezależnie jednak od źródeł tego zainteresowania renesansowi artyści przystąpili do zrekonstruowania świątyni przedstawionej przez Ezechiela.

W końcu XVI wieku dwóch jezuitów, Jan Baptysta Villalpando i Hieronim Prado, opracowało schemat świątyni, który przez dwieście lat oddziaływał nie tylko na innych teoretyków architektury, ale, jak się wydaje, również na jej twórców. W przedstawionej przez nich rekonstrukcji świątyni upatrywano wzorów, które mogłyby stanowić inspirację w przypadku innych obiektów wznoszonych w całej Europie. Faktem jest, że koncentryczny, stworzony zgodnie z zasadami złotej proporcji dziewięciopolowy plan mógł fascynować. Autorzy rekonstrukcji skupiają się na zawarciu w swojej pracy opisanego w Księdze Ezechiela wystroju świątyni, w tym często przywoływany w niej motyw palmy. Zostaje przez nich wykorzystany porządek, który - jak uważano - odpowiadał temu zastosowanemu w świątyni. Villalpando i Prado opierają się prawdopodobnie również na schematach wypracowanych przy wznoszeniu kościołów jezuickich, na przykład na motywie przypory o wklęsłej płaszczyźnie.

Należy zaznaczyć, że jedną z kluczowych proporcji zastosowanych w planie zaproponowanym przez Villalpanda i Prada, jest proporcja 3:5 = 1:1,66, która zbliża się do wartości proporcji uzyskiwanej przy zastosowaniu złotego ciecia: 1:1,618. Proporcja ta pojawia się w opisie Arki Przymierza, ołtarza w Przybytku Mojżeszowym, podeście w świątyni Salomona czy przedsionku świątyni w wizji Ezechiela. Proporcje, które stosują obaj autorzy, przedstawiają również inne wartości, jednak kluczowe dla zrozumienia zaproponowanej rekonstrukcji wydaje się poza planem dziewięciopolowym również boska proporcja.

Niniejszy rozdział stanowi próbę zdefiniowania wzorca świątyni jerozolimskiej oraz określenia, na ile wpłynął on na kształt innych XVII- i XVIII-wiecznych obiektów chrześcijańskiej architektury sakralnej i architektury synagogalnej. Związku z rekonstrukcją Villalpanda i Prada upatrywano w hiszpańskim Escorialu i klasztorze karmelitów w Czernej. Sergiey Kravtsov wywodzi również plan dziewięciopolowy bożnic zlokalizowanych na terenie Polski z jezuickiego planu. Jest jednak kilka szczegółów, które w tym przypadku mogą wskazywać na inne źródła tego rozwiązania. Po pierwsze: stwierdzona powszechność planu dziewięciopolowego od czasów starożytnych, jak również wzorce takiego rozwiązania w architekturze polskiej. Po drugie: zakorzeniony w starożytności podział planu na równe pola, sprawiający 
wrażenie archaicznego w odniesieniu do planu z bimą-podporą. Po trzecie: brak realnych związków w bożnicach wzniesionych na obszarze Polski z formami porządku salomonowego, zaproponowanego przez jezuitów. Formy kapiteli korynckich w synagogach w Ostrogu i Lwowie związane są ze schematami zawartymi w traktacie Serlia. Po czwarte: zakorzenienie symboliki palmy w judaizmie, związane z jej wykorzystywaniem w dekoracjach obiektów starożytnych, średniowiecznych i XVI-wiecznych. Motyw ten nie pojawia się zresztą istotnie częściej w synagogach z XVII i XVIII wieku. Po piąte: brak rozpowszechnienia w innych obiektach na terenie Polski charakterystycznych przypór związanych z architekturą jezuicką. Jedynym znanym ikonograficznym przedstawieniem jest bożnica w Przeworsku. Po szóste: brak zastosowania złotej proporcji w pierwszych bożnicach dziewięciopolowych. Ta zasada rekonstruowanego planu była kluczowa dla zrozumienia idei rozwiązania. Pojawia się za to w innych synagogach na planie dziewięciopolowym, co można wiązać raczej z rozwojem planu dziewięciopolowego pod wpływem bożnic z bimą-podporą. Jak jednak wykazano, w Polsce boska proporcja była powszechnie stosowana w kościołach zakonów kontrreformacyjnych, w związku z czym jeżeli jezuici rzeczywiście przyczyniliby się do rozpowszechnienia wzorca zaproponowanego przez Villalpanda i Prada, wówczas zasady złotego podziału należałoby szukać także poza planem dziewięciopolowym.

Z przeprowadzonej analizy wynika, że w architekturze większy wpływ miały detale zaproponowane przez Villalpanda, w tym upowszechnienie porządku salomonowego i szczególnego rodzaju przypór, niż rekonstrukcja jego autorstwa. Ostatecznie mogła ona natomiast wpłynąć na rozpropagowanie planu dziewięciopolowego oraz ornamentów i detali w architekturze Niderlandów w XVII wieku.

\section{Przypisy}

${ }^{165}$ O świątyni jerozolimskiej, porządku Salomonowym i ich recepcji w architekturze przeczytasz również w: M. Michalski, Templum Hierosolymitanum - święta architektura i porządek salomonowy, „Architectus” 2019, vol. 60, nr 4, s. 23-36.

166 Autor zastanawia się, czy świątynia była elementem stanowiącym fundament żydowskiej architektury.

167 O związkach między światynią jerozolimską a synagogą piszą m.in:. K. Atkinson, fudaism, Philadelphia 2004, s. 61-62; R. Wischnitzer, The Architecture of the European Synagogue, Philadelphia 1964, s. 28; C.H. Krinsky, Synagogues of Europe: Architecture, History, Meaning, Cambridge 1985, s. 7; T.C. Hubka, Resplendent Synagogue: Architecture and Worship in an Eighteenth-century Polish Community, Hanover, London 2003, s. 34; S.R. Kravtsov, O proiskhozhdenii deviatipolevykh kamennykh sinagog, [w:] Evreiskoie iskusstvo v evropeiskom kontekste, ed. I. Rodov, Jerusalem-Moskwa 2002, s. 191204; Idem, Fuan Bautista Villalpando and Sacred Architecture in the Seventeenth Century, ,Journal of the Society of Architectural Historians" 2005, Vol. 64, No. 3, s. 312-339; Idem, Reconstruction of the Temple 


\section{Oddziaływanie świątyni jerozolimskiej na architekturę bożniczą}

by Charles Chipiez and its applications in architecture, [w:] „Ars Judaica” 2004, No. 4, s. 25-42; Idem, Synagogues in Eastern Galicia, [w:] Treasures of Jewish Galicia: Judaica from the Museum of Ethnography and Crafts in Lviv, Ukraine, ed. S. Harel-Hoshen, Tel Aviv 1996, s. 38.

${ }^{168}$ Najświętsze ze Świętych świątyni (łac. Sanctus Sancti).

${ }^{169}$ Chodzi o opinię: R. Wischnitzer, C.H. Krinsky czy T.C. Hubki.

${ }^{170}$ W III w. pojawia sie przedstawienie świątyni na ścianach synagogi w Dura Europos. W XII w. Majmonides prezentuje rekonstrukcję świątyni.

${ }^{171}$ Jak wskazuje Sergiey Kravtsov, począwszy od lat 20. XVII w. jednym z wzorców najbardziej rozpowszechnionych i mających największy wpływ na architekturę synagog była bazująca na wizji Ezechiela rekonstrukcja świątyni autorstwa dwóch jezuitów: Jana Baptysty Villalpanda (1552-1608) oraz Hieronima Prada (1546-1595), opublikowana w latach 1594-1605. Zaproponowana przez nich wizja świątyni przyczyniła się do spopularyzowania w XVII i XVIII w. planu dziewięciopolowego. Za rozpowszechnienie tego wzorca odpowiadać mieli Jezuici poprzez swoje działania budowlane [95, s. 199]. Vide: S.R. Kravtsov, O proiskhozhdenii deviatipolevykh kamennykh sinagog, [w:] Evreiskoie iskusstvo v evropeiskom kontekste, red. I. Rodov, Jerusalem-Moskwa 2002, s. 199; H. Pradus, J.B. Villalpandus, In Ezechielem explanationes et apparatus urbis ac templi Hierosolimitani. Commentarii et emag-inibus illustratus opus..., t. 2, Rzym 1596-1604.

172 Łańcut, Bobowa, Kraśnik, Kraków (synagoga Kupa), Lwów (synagoga Nachmanowicza).

${ }^{173}$ Majmonides pisze o wymiarach świątyni Heroda w Miszne Tora w księdze Awodah (nabożeństwo).

${ }^{174}$ Vide: 2 Krl 25,17 [137] - zgodnie z zawartą w tym fragmencie informacją głowice miały po trzy łokcie. Oznacza to stosunek wysokości do obwodu 1:1,75, a wysokości do średnicy 1:5,5.

175 Józef Flawiusz pisał, że świątynia miała wysokość po sam dach i długość równą sześćdziesięciu łokciom oraz szerokość dwudziestu łokci. Cała świątynia wraz z podbudową w formie palowania miała sto dwadzieścia łokci wysokości. Przedsionek miał dwadzieścia łokci długości i szerokość dwunastu łokci. Jego proporcje to ponownie 3:5. Vide: J. Flawiusz, The Antiquities of the Jews, tt. W. Whiston, London-New York 1900, 3.2.2.

176 „Wznosił się na jeden łokieć i rozciągał na jeden łokieć: tak uformowano podstawę; pozostało więc trzydzieści łokci na trzydzieści łokci. Wznosił się na pięć łokci i rozciągał na jeden łokieć; tak uformowano obwód; pozostało więc dwadzieścia osiem łokci na dwadzieścia osiem łokci” [173, Middot $3,1]$.

177 Fragment napisu głosi: „quasi opere lilii fabricata”.

${ }^{178}$ Był greckim rzeźbiarzem działającym w V w. p.n.e. Jest możliwe, że Witruwiusz przypisywał mu stworzenie porządku korynckiego.

${ }^{179} \mathrm{~W}$ polskich opracowaniach teoretycznych wzór identyczny jak ten przedstawiony w In Ezechielem pojawia się po raz pierwszy w $1678 \mathrm{r}$. w Callitectonicorum seu de pulchro architecturae sacrae et civilis autorstwa jezuity Bartłomieja Nataniela Wąsowskiego. Autor tego podręcznika do nauczania w szkołach jezuickich czerpie wzór z traktatu Villalpanda i Prada, choć nazwiska tych twórców nie pojawiają się. Vide: Kowalczyk J., Porządek salomonowy w polskiej architekturze nowożytnej [w:] Claret 


\section{Oddziaływanie świątyni jerozolimskiej na architekturę bożniczą}

Opus. Studia z dziejów sztuki dedykowane Mieczysławowi Zlatowi, red. L. Kalinowski, S. Mossakowski, Z. Ostrowska-Kębłowska, Wrocław 1998, s. 228.

${ }^{180}$ Traktat wydano dopiero w $1930 \mathrm{r}$. Do tego czasu był tylko w formie manuskryptu.

${ }^{181}$ Motyw ten pojawia się również w dekoracjach szaf na rodały. Po raz pierwszy prawdopodobnie w synagodze Wysokiej w Krakowie.

${ }^{182}$ Z włoskiego maestri lub magistri „comacini”- mistrzowie z okolic Como. Byli to rzemieślnicy, budowniczowie i artyści pochodzący z terenów otaczających jezioro Como, leżące na pograniczu Ticino (Szwajcaria) i Lombardii (Włochy).

${ }^{183} \mathrm{~W}$ Egipcie palmety były wzorowane na lotosie, rzadziej papirusie.

184, „[... [ nad wejściem do części najbardziej wewnętrznej i na zewnątrz oraz na ścianach wokoło, wewnątrz i na zewnątrz, były wyobrażenia cherubów i palm, a mianowicie po jednej palmie pomiędzy dwoma cherubami; każdy cherub miał dwie twarze, jedną twarz ludzką, zwróconą w stronę palmy po jednej stronie, i twarz lwa, zwróconą w stronę palmy po drugiej stronie: tak było zrobione na całej świątyni dokoła. Od ziemi aż ponad wejście były umieszczone cheruby oraz palmy [...]" [137, Ez 41,17-20].

${ }^{185}$ Lulaw jest określeniem oznaczającym również palmę daktylową.

186 Obecnie element ten jest przechowywany w Muzeum Historycznym Miasta Krakowa Oddział Stara Synagoga.

187 Serdecznie dziękuję Panu Prof. Ernestowi Niemczykowi za uwagę, że spływy przypór w rekonstrukcji świątyni w wersji Villalpanda są zapewne zapożyczeniem z warownej formy stosowanej w Palestynie w zamkach krzyżowców. Formy te, tzw. Talud, stabilizowały mur, czyniąc go odpornym zarówno na wstrząsy sejsmiczne, jak i na działania oblężnicze oraz pozwalając obrońcom miotać pociski rykoszetem na oblegających.

188 Sergiey Kravtsov stwierdza, że forma planu dziewięciopolowego została zastosowana w oparciu o rekonstrukcję świątyni wykonaną w końcu XVI w. przez Villalpanda i Prada [94], [95], [97]. Nawiązanie widoczne jest przede wszystkim w planie (dziewięć pól) oraz porządku korynckiej kolumny. Trudno nie zauważyć, że podstawą zarówno jezuickiej rekonstrukcji, jak i wybudowanych bożnic we Lwowie i Ostrogu jest plan dziewięciopolowy o niemalże równych, kwadratowych polach.

189 Sergiey Kravtsow podaje, że było to co najmniej dwadzieścia opracowań.

190 Vide: podrozdz. 3.5 .

${ }^{191}$ Szczegółowy opis tego zagadnienia znajduje się w podrozdz. 5.3.

192 Synagogi w: Tomar, Pińczowie, Przemyślu.

193 Tłumaczenie planu dziewięciopolowego jako rozbitego na pięć pól w planie kościoła i cztery dziedzińce wydaje się daleko idącą nadinterpretacją. 


\section{PLAN KONCENTRYCZNY W ARCHITEKTURZE SYNAGOG}

\subsection{Plan centralny a plan koncentryczny}

Analizując architekturę synagog z bimą-podporą, jak również tych jednoprzestrzennych, z centralnie usytuowaną bimą, należy zwrócić uwagę na konstrukcję planu, która wskazuje - w mniejszym lub większym stopniu - na jego koncentryczny charakter. Szczególnie jest to widoczne w synagogach z bimą-podporą, w których poszczególne strefy usytuowane wokół jednego punktu są od siebie wyraźnie oddzielone.

Zdaniem Tobiasa Lamey'a początku planu centralnego można poszukiwać w nauce Mojżesza Isserlesa [108, s. 265]. Może to oznaczać, że konstrukcja planu koncentrycznego jest również $\mathrm{w}$ jakiś sposób ugruntowana w religii i kulturze żydowskiej. Jednym z elementów tego rozdziału jest określenie, czy układ skoncentrowany na punkcie jest charakterystyczny dla tradycji żydowskiej oraz w jaki sposób ta tradycja może przekładać się na konstrukcję planu XVII- i XVIII-wiecznych bożnic.

Sposób organizacji sali męskiej synagogi został już omówiony ${ }^{194}$. Jednak zastanawiając się nad źródłem form centralnych lub koncentrycznych, należy przywołać regulacje, które ustanowił Majmonides w Miszne Tora. Po raz pierwszy w przepisach halachicznych pojawiła się wzmianka o lokalizowaniu bimy w centrum, a powodem wyboru takiego miejsca było dążenie do uzyskania przez wszystkich zebranych w synagodze w trakcie nabożenstwa identycznego dostępu do artykułowanego z bimy słowa bożego ${ }^{195}$.

Tobias Lamey zwraca uwagę, że w talmudycznym traktacie Brachot $27 a, 31 b$ jest mowa o tym, że ilość miejsca dostępna dla modlących się powinna być taka, aby każdy miał takie same warunki [108, s. 26]. Zalecenie to można rozumieć podobnie, jak zalecenie Majmonidesa w odniesieniu do słuchania słów Tory.

W 1571 roku Mojżesz Isserles w swoim komentarzu do Szulchan Aruch Josefa Karo pisał również o usytuowaniu bimy w centrum, powtarzając zresztą argumentację użytą przez Majmonidesa. W żadnym z przytoczonych fragmentów nie określa się szczegółowo formy ani kształtu sali męskiej, choć z form, które umożliwiłyby stworzenie identycznych warunków dla wszystkich modlących się w tym samym czasie, na myśl przychodzą dwie: okrąg i - jak można przypuszczać - wpisany w niego kwadrat. 


\subsection{Układ koncentryczny w myśli żydowskiej}

Kwadratowy, a zarazem centralny i koncentryczny plan przywodzi na myśl fragment Księgi Sprawiedliwych: „Bóg, dobry Król, słuchaj Izraelu, Pan Bóg nasz, jest jedynym Panem - cztery imiona, odpowiadające czterem stronom synagogi, gdzie nie usiądziesz, a każdemu przekazuje się tak, jakby naprzeciw niego była Szechina” [57, s. 512]. Cztery imiona Boga odpowiadające czterem ścianom synagogi wskazują na układ w kształcie kwadratu. W centrum układu na bimie obecnać jest Szechina. Każdy Żyd będący w synagodze $\mathrm{w}$ trakcie liturgii zwraca się w kierunku centrum układu, gdyż niezależnie od miejsca, w którym się znajduje, zawsze ma przed sobą Szechinę [108, s. 264] ${ }^{196}$.

Autor Księgi Sprawiedliwych zwraca tym samym uwage na plan dośrodkowy. W przypadku takiego rozumienia przestrzeni synagogi na myśl przychodzi bima-podpora ${ }^{197}$, na której - zgodnie ze znaczeniem przypisywanym jej na podstawie Zoharu czy Lecha dodi - następują zaślubiny ludu

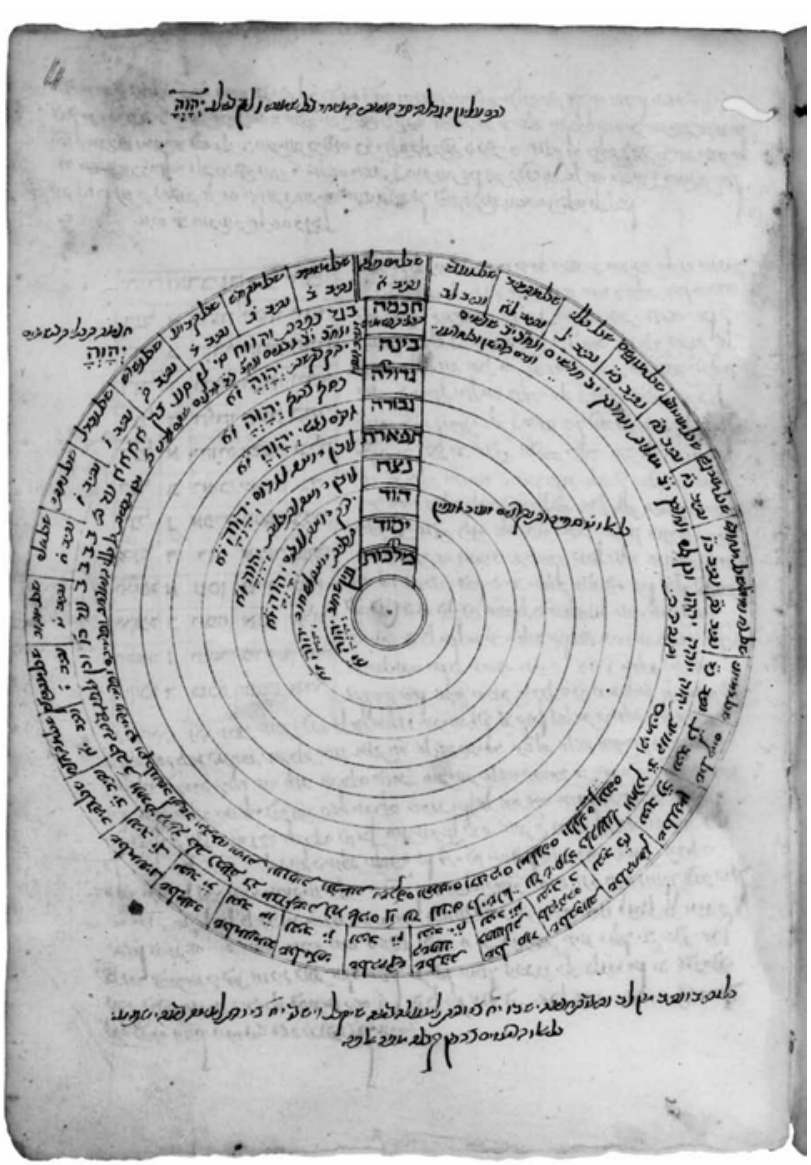

Il. 7.1. Schemat kabalistyczny Jehuda he-Chasid (?). Fragment traktatu kabalistycznego z XIII lub XIV w. [23] Izraela z Szechiną.

Inny opis koncentrycznego układu pojawia się przy opisie techniki mistycznej, której źródła należy poszukiwać w specyficznym rozumieniu terminu kawwana. Technika ta polegała na wizualizacji kolorów i opierała się na traktowaniu słów modlitwy jako nadnaturalnych symboli boskiej mocy. Przekładało się to na kontemplowanie niebiańskich mocy i wpływanie na nie [64, s. 197], wznoszenie się świata myśli na poziom świata sefirot. Wizualizowanie w trakcie modlitwy kolorów, które odpowiadały poszczególnym sefirom [64, s. 199], było uzasadnione zakazem wizualizowania emanacji boskiego światła [65], podobnie jak wyobrażania i przedstawiania Boga [64, s. 199].

$\mathrm{W}$ pismach kabalistów pojawia się opis wizualizacji liter tetragramu w formie okręgu [66, s. 48] w połączeniu z barwą odpowiadającą danej sefirze. Ta wizualizacja uzyskała swoją fizyczną manifestację po raz pierwszy u rabina Dawida ben Jehudy he-Chasida (XIIIXIV w.) (il. 7.1). W kilku manuskryptach przedstawiono diagram składający się z dziesięciu koncentrycznie ułożonych sfer, z których każda odpowiadała danej sefirze i połączona była 
z odpowiednim kolorem oraz wokalizacją Tetragramu [65, s. 203]. W schemacie Dawida ben Jehudy he-Chasida wokalizacja jest identyczna w każdym przypadku, jednak w zewnętrznym kręgu (sferze) pojawiają się trzydzieści dwie mistyczne ścieżki stworzenia (intelekty), a w kolejnym elementy świata rzeczywistego ${ }^{198}$. To działanie mistyczne miało na celu połączenie się z atrybutami Boga. Jak pokazuje Moshe Idel, wyobraźnia ${ }^{199}$ posiadała moc tworzenia bytów wznoszących się do boskiego świata Merkawy. Zatem „proces wizualizacji obejmuje nie tylko boskie imiona, kolory lub okręgi, ale również antropomorficzną konfigurację kolorów, która symbolizuje aspekt królestwa Bożego" [66, s. 45-46].

Symbolicznie układ koncentryczny zostaje wpisany w opowieść rabina Samuela Małego [173, Derech Erec Zuta 9] (II w.). Wydaje się, że w tym przypadku można mówić z całą pewnością o kosmogramie. Autor opisuje związki między światem a świątynią, posługując się metaforą wiążącą świat z częściami ciała człowieka. W opowieści tej świat zostaje porównany do oka: białko jest oceanem, tęczówka ziemią, źrenica Jerozolimą. Obraz powstający w źrenicy jest świątynią [18, s. 71].

Koncepcja koncentryczności opiera się przede wszystkim na rozdzieleniu usytuowanych współśrodkowo elementów i wytworzeniu między nimi pewnej granicy. W pismach uczniów Izaaka Lurii i rabina Pragi Ezechiela Landaua (1713-1793) pojawia się określenie „prywatna posiadłość” [42, s. 187], oznaczające jednak byt abstrakcyjny. Wymiary owej posiadłości zostają określone za pomocą Tetragramu i szem mem heh. Tetragram ma wartość dwadzieścia sześć. Szem mem heh inaczej określone jest imieniem czterdzieści pięć i oznacza wartość liter tetragramu zapisanych w postaci fonetycznej (יוד הא ואו הא). Stosunek wartości dwadzieścia sześć i czterdzieści pięć wynosi 1:1,730. Odpowiada więc wartości stosunku boków złotych prostokątów, które opisywał Guarino Guarini ${ }^{200}$.

Generalnie przestrzenie: prywatna i publiczna - w oparciu o podobieństwo do świata sefirot - rozumiane są jako sacrum i profanum [42, s. 188]. Można powiedzieć, że uświęcenie przestrzeni następuje poprzez obecność Szechiny bądź że przestrzeń profanum jest obszarem opanowanym w tym czasie przez kelipot (skorupy).

\subsection{Teoria a praktyka - układ wnętrza synagog}

Przy konstruowaniu planów synagog w XVII i XVIII wieku próbowano bazować na planie centralnym, z którym borykali się architekci wczesnego renesansu, tworząc świątynie chrześcijańskie. W przypadku Bet ha-Kneset plan ten okazał się możliwy do zrealizowania ze względu na przebieg rytuału. Trudno byłoby wywodzić formy bożnic z architektury renesansowych obiektów centralnych czy nawet budowli wczesnochrześcijańskich, szczególnie pod względem skupienia filarów w kierunku centrum, które nie naśladuje rozwiązań obiektów należących do żadnej innej religii. Formy centralne, jako symbol nieba, w przypadku kościołów nie były praktyczne ze względu na organizację liturgii i ołtarza [194, s. 110]. Zyskały 
jednak ogromną popularność w kongregacjach synagogalnych, stając się jednocześnie celem budowlanym [99, s. 51].

O centralnym charakterze sal modlitw świadczą przede wszystkim trzy osie symetrii. Porównując bryły bożnic, trudno nie zauważyć, że symetryczny układ został zatarty w wyniku powiększenia w późniejszym okresie kubatury tych obiektów o babińce i przedsionek pełniący funkcję szkoły żydowskiej. Zasadą było dążenie do scentralizowania sali męskiej Bet ha-Kneset, a więc wytworzenia symetrycznego rzutu. Podkreślenie tej formy zostaje zmaterializowane w postaci planu kwadratu, który ma odpowiadać czterem imionom Boga.

Idealnie kwadratowe plany są charakterystyczne dla dwóch przeanalizowanych bożnic, zlokalizowanych w Tykocinie i Tarnogrodzie. Nie oznacza to jednak, że konstrukcja planów innych synagog odbiegała od tego założenia. Problemem było raczej dokładne rozmierzenie, choć przy porównaniu długości boków wymiary bożnic oscylują w okolicach stosunku 1:1.

W synagogach z bimą-podporą, w centrum kwadratowej sali sytuowano zwykle kwadratową bimę. W ten sposób tworzono konstrukcję z koncentrycznie rozmieszczonych kwadratów. W przestrzeni tej zostaje podkreślona również oś wschód-zachód, na której zostają umieszczone dwa ważne elementy: Aron ha-Kodesz oraz bima (il. 7.2). Wynika to z pewnej fascynacji formą kwadratu, która ujawnia się nie tylko w planie, ale również w całej bryle budynku (jak w synagodze w Tykocinie).

Kwadrat jako figura geometryczna jest swego rodzaju ideałem - archetypem znanym i rozpowszechnianym od starożytności. W zbiorowej świadomości stanowi manifestację stabilności i skończoności. Korzystanie $\mathrm{z}$ tej figury jest związane w dużej mierze z jej symbolicznym charakterem. Kwadrat utożsamia się z czterema stronami świata czy czterema powtarzalnymi cyklami czasu [86, s. 95]. W judaizmie jest to dość czytelny symbol wszechobecności Boga [77, s. 75]. Ta figura geometryczna, której matematycznym obrazem jest cyfra cztery (czworobok), może być utożsamiana również ze świętym Tetragramem [37, s. 106]. Ciekawy może się wydawać również związek czwórki z rajem, czyli Pardes. Słowo to jest akronimem nazw czterech poziomów: peszat, remez, deresz $i \operatorname{sod}^{201}$, na których można analizować Torę. Konstruowanie planu obiektu jako kwadratu ma na celu uporządkowanie fragmentu

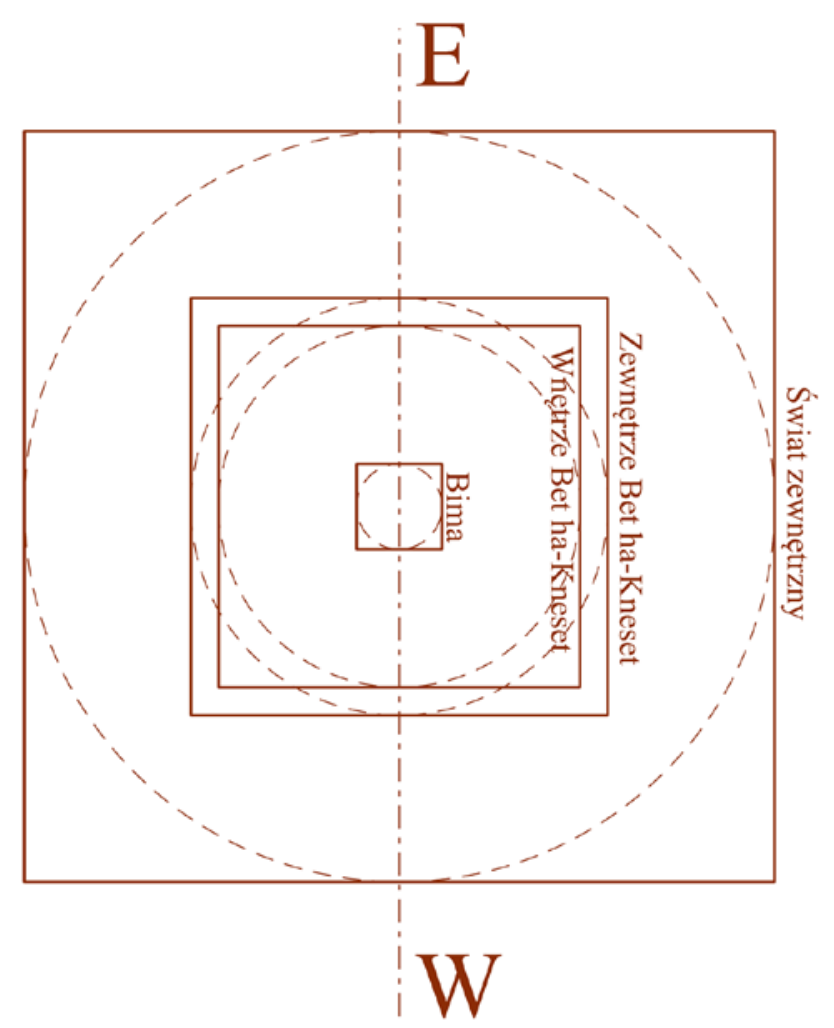

Il. 7.2. Transpozycja koncentrycznego układu okręgów na układ kwadratów z podkreśleniem osi wschód-zachód [21] 
przestrzeni wyjętej z „chaosu”, a także nadanie jej konkretnych cech oraz zasad, jakimi ma się ona rządzić. Jest to paralelne do stwierdzenia Landaua o sposobie konstytuowania sacrum i profanum w oparciu o zewnętrze, w którym królują kelipot.

Koncepcja uporządkowania fragmentu przestrzeni opiera się na centrum - miejscu, które musi być zdefiniowane w sposób kompletny i niepodważalny. W centrum sali męskiej, która staje się jednocześnie niejako centrum świata, lokalizowana jest axis mundi łącząca ze sobą górę i dół, a więc ten i tamten świat. To zespolenie dwóch biegunów oraz wymiana między nimi następuje na drodze aktu rytualnego. Układ horyzontalny wraz z osią wertykalną wyznacza i ustanawia wyobrażeniową strukturę świata, nazywaną wzorcem przestrzeni symbolicznej, którego „ujawnienie się w czasoprzestrzeni społecznej wymaga dokonania aktu rytualnego" [87, s. 61]. Opisany proces kształtowania się tej przestrzeni można odnieść do innego pojęcia - uniwersalnego kompleksu znakowego Toporowa [87, s. 60].

Ten proces kształtowania się sali męskiej, a więc miejsca, w którym odbywa się rytuał, symbolizuje strukturę. W centrum znajduje się byt abstrakcyjny - Drzewo Świata. Sala męska staje się zatem wyobrażeniową strukturą, która łączy płaszczyznę horyzontalną, a więc teraźniejszość, ze znajdującą się w centrum osią pionową, odnoszącą się do przyszłości i przeszłości lub do świata ponadziemskiego i podziemnego [87, s. 60].

Emanacje boskiego światła (sefirot), które stanowią objawienie woli Bożej [9, s. 94] i zostają zgrupowane w formie abstraktu, tj. mistycznego drzewa, kształtują i charakteryzują budowę Wszechświata oraz przymioty Boga. To właśnie sprawia, iż synagoga - a konkretnie bima - stanowi punkt centralny, przez który przebiega oś kosmiczna. Scenografia zostaje ukształtowana w taki sposób, by zawrzeć cały Wszechświat w małej przestrzeni, jaką jest Bet ha-Kneset. Obniżenie poziomu posadzki, które jest rozumiane w prosty sposób jako sfera tu i teraz, utożsamione ze słowami psalmu: „z głębokości wołam do Ciebie Panie” [137, Ps 130] może symbolizować świat chtoniczny. Wynika to z gradacji wertykalnej pewnych stref przestrzeni sali męskiej. Zgromadzenie w trakcie rytuału zrzeka się swego tu na rzecz bimy, której płaszczyzna stanowi obszar świata ziemskiego, a przecięcie z axis mundi, które symbolizuje, stanowi o miejscu najwyższej religijnej doniosłości. To stąd, za pomocą liter, którymi posłużył się Bóg, stwarzając świat [78, s. 5-12], Haszem przemawia do swego ludu. Najwyższym punktem jest Aron ha-Kodesz stanowiący nieco przewrotnie korzeń „drzewa”. Ten abstrakcyjny obraz należy rozumieć jako drzewo usytuowane do góry korzeniami, tkwiącymi w sefirze Keter, a siły witalne czerpiące z sefiry Chochma, czyli Bożej Mądrości [78, s. LXXXII]. Wzrost ilana rawerwa (Drzewa Światła) następuje tym samym z góry do dołu. Co ciekawe, człowiek w Biblii określany jest jako Drzewo Polne [137, Pwt 20,19].

Elementy przestrzeni sali męskiej nie koncentrują się na axis mundi, ale pozostają z nią w relacji. Wykształcają pewne metaforyczne osie, które łączą je z centrum. W procesie aktu rytualnego, odbywającego się w centrum wszechświata, w przestrzeni sali modlitw intensyfikuje swoje działanie Szechina, która może być utożsamiana z sefirą Malchut [9, s. 12]. Jest to zgodnie z przytoczoną symboliką bimy jako chupy czy wydrążonego zoharycznego słupa. 
Obecność Boga, która jest wszędzie i zawsze, jest tym, co umożliwia bezpośredni kontakt Najwyższego z ludem. „Dlatego też, by połączyć Emanującego, który pragnie komunikować się ze Swoimi Stworzeniami, powołane jest do istnienia jedno działanie, jedna sefira, jeden błysk, jedno światło" [78, s. LXXXII].

Nawiązując do przeprowadzonej powyżej analizy, przestrzeń sali męskiej synagogi można rozumieć jako kli [hebr. כלי - naczynie]. Jest to przestrzeńn ${ }^{202}$ wyposażona w zdolność epifanii i pośredniczenia między rzeczywistościami oraz transferu między nimi. Daje zatem możliwość połączenia ich jakości [87, s. 66]. Z punktu widzenia antropologii naczyniem jest organ mowy, który umożliwia pozorne zmaterializowanie świata myśli; stoi on na granicy rzeczywistości myśli i rzeczywistości działania. Paralelą dla organu mowy w przypadku Bet ha-Kneset jest bima, z tą różnicą, że sfera myśli zapisana jest na zwoju. Myśl materializuje się z bimy za pomocą ust (ole) mężczyzny otrzymującego alije ${ }^{203}$ lub lektora (baal kojre). „Dla myślenia judaistycznego system języka wydaje się reprezentować surrealistyczną, pozasubiektywną, potężną i aktywną istotę, której status jest równy Bogu [...]. Pismo jest przede wszystkim prawodawstwem, czymś ojcowskim i autorytarnym, jest pojmowane jako model, względem którego to, co rzeczywiste, musi się dostosować i przez co to, co rzeczywiste, jest formowane" [170, s. 135], [100, s. 100].

Akt rytualny jest więc w gruncie rzeczy aktem lingwistycznym, którego istotą jest połączenie za pomocą „naczynia” różnych rzeczywistości. Spojrzenie w ten sposób na przestrzeń rytualną koncentruje się przede wszystkim na axis mundi, której realnym przedstawieniem jest podest. Ta oś stanowi metaforyczne połączenie z istotą Boga. Wokół bimy rozprzestrzenia się audytorium, które chłonie moc Bożą w trakcie aktu rytualnego. Kolejnym elementem jest wyraźna krawędź w postaci ściany, która stanowi metaforę granicy między sacrum a profanum, a właściwie wydziela, o czym była mowa wcześniej, fragment świata z chaosu.

\subsection{Podsumowanie}

Wzór zaproponowany przez rabina Dawida ben Jehudę he-Chasida nie był bardzo popularny, ale przeniknął prawdopodobnie do kabały luriańskiej i w niezwykle podobnej formie pojawił się w Sefer Ec Chaim napisanej przez Chaima Vitala [66, s. 51]. Koncepcja koncentryczności i okręgu pojawia się również w wielu późniejszych pismach kabalistycznych [66, s. 53]. Dlatego zasadne wydaje się przypuszczenie o celowym wykorzystaniu schematu koncentrycznego planu z podkreśloną architektonicznie formą bimy-podpory.

Koncepcja czterech ścian bożnicy w odniesieniu do czterech imion Boga oraz struktura wyobrażeniowa sacrum i profanum dają możliwość powiązania XVII-wiecznej bożnicy z wzorcem przestrzeni symbolicznej, który ujawnia się w wielu kulturach od czasów prehistorycznych. Wydaje się, że takie rozumienie sali męskiej - jak w przytoczonym opisie opartym na mistycyzmie żydowskim - nie odbiega od uniwersalnych wzorców. 
Przestrzeń rytualna stanowi szczególny fragment przestrzeni, który pozostaje suwerenny względem otaczającego świata - chaosu. Z tego wynikają liczne zasady kształtujące przestrzeń sali męskiej oraz wyobrażeniowe osie wiążące poszczególne elementy tej struktury. Uwzględniając podobne wzorce układów centralnych i koncentrycznych zawarte w Księdze Sprawiedliwych, pismach Mojżesza Isserlesa czy schemacie Jehudy he-Chasida, można uznać zakorzenienie tej koncepcji w tradycji. Początkiem tej tradycji jest z pewnością zalecenie związane z lokalizowaniem bimy w centrum, jednak dopiero w wyniku wykształcenia centralnego planu bożnicy można mówić o uzyskaniu idealnego, koncentrycznego archetypu.

\section{Przypisy}

${ }^{194}$ Vide: podrozdz. 3.1.

${ }^{195}$ Szczegółowy opis układu funkcjonalnego oraz opis wytycznych zawartych w prawie halachicznym i traktarach rabinackich znajdują się w rozdz. 3.

${ }^{196} \mathrm{Na}$ takie rozumienie tego fragmentu wskazuje Tobias Lamey, jednak bardziej w kontekście planu centralnego niż układu koncentrycznego, który z niego wynika.

197 Vide: podrozdz. 4.2 .

${ }^{198}$ Jak wskazuje Moshe Idel schemat ten nie jest tylko kosmogramem. Być może na tę formę miały wpływ hinduistyczne mandale. Vide: M. Idel, Visualization of Colors, I: David ben Yehudah he-H asid's Kabbalistic Diagram, „Ars Judaica” 2015, nr 11, s. 42.

${ }^{199}$ Moshe Idel zwraca uwagę, że wyobrażenie nie zawsze było rozumiane pozytywnie, zwłaszcza że wyobraźnia daje możliwość przedstawienia elementów nieistniejących.

${ }^{200}$ Vide: podrozdz. 5.2.

${ }^{201}$ Peszat - sens dosłowny, remez - sens aluzyjny, deresz - sens pożądany, sod - sens ukryty.

202 Jechiel Bar-Lew definiuje naczynie jako rzeczywistość.

${ }^{203}$ Wezwanie do wejścia na bimę i odczytywania Tory często ogranicza się jedynie do wygłoszenia błogosławieństwa przed czytaniem świętej księgi i po jego zakończeniu. 


\section{GEMATRIA W XVII- I XVIII-WIECZNYCH SYNAGOGACH ZLOKALIZOWANYCH NA OBSZARZE ADMINISTRACYJNYM WSPÓŁCZESNEJ POLSKI}

\subsection{Mistyka liter}

Elementem konstytuującym judaizm jest święta księga - Tora - oraz słowo Najwyższego. Bóg stwarza świat za pomocą słowa jesz me-ajin (ex nihilo). Mówa o tym jest w Księdze Rodzaju²04.

Sefer fecira zaczyna się od słów: „Trzydziestoma dwiema cudownymi ścieżkami mądrości Bóg wyrył i stworzył swój świat przez trzy: przez liczbę, słowo i pismo. Dziesięć sefirot nicości oraz dwadzieścia dwa podstawowe znaki [...]” [126, s. 269]. Ten zbiór trzydziestu dwóch elementów zostaje przedstawiony również przez późniejszych kabalistów jako liczba intelektów [66, s. 33]. Należy również zwrócić uwagę, że według Sefer ha-Bahir (Księgi Świattości) litery Tory zawierają w sobie boskie formy [64, s. 33]

Koncepcja stwórczego słowa, które Haszem daje ludowi Izraela, zostaje jeszcze bardziej rozwinięta w Sefer ha-Zohar (Księdze Blasku). Pojawia się tam koncepcja kosmogonii za pomocą pojedynczych liter Tory, które w kolejności od ostatniej do pierwszej podchodzą do tronu Boga. Druga litera alfabetu - bet (ב) - zostaje przez Boga wykorzystana do rozpoczęcia dzieła stworzenia [78, s. 33].

W Księdze Blasku przedstawiona jest stwórcza moc nie tylko tej jednej, ale wszystkich liter alfabetu hebrajskiego. Skoro bowiem słowo wypowiedziane przez Boga ma moc powoływania nowych bytów, to również tworzące je litery muszą być obdarzone tą wyjątkową zdolnością. Posiadają więc niezwykłą siłę i energię, która doprowadziła do tego, że stały się narzędziami stworzenia, pojemnikami boskiego światła [67, s. 170], a język hebrajski leszon ha-kodesz, czyli językiem świętym [126, s. 270].

Podążając za słowami Talmudu [173, Berachot 31a], należy wysnuć wniosek, że „Bóg wyartykułował świat językiem zrozumiałym dla człowieka, a akt stworzenia można nazwać aktem lingwistycznym, lecz bardzo szczególnej natury. Bóg jawi się zatem jako wszechmocny i podporządkowujący sobie wszystko inne, a jego potęga mieści się w słowie. Oznacza to, że „wszystko pochodzi od liter i wszystko można do nich sprowadzić”[18, s. 63]. 
Proces tworzenia teorii stwórczej mocy liter trwał przez wieki i był ściśle związany z ruchami kabalistycznymi, które odżyły w Europie w XIII wieku. System gematryczny, chociaż ma związek z bardziej prozaicznymi aspektami życia i jest znacznie starszy, stał się podstawą doszukiwania się drugiego, prawdziwego i ukrytego - w rozumieniu ówczesnych - znaczenia słów Tory, która w terminologii teozoficznej ujawniona w przeszłości jest tożsama $\mathrm{z}$ sefira Bina, a ujawniona w przyszłości związana jest z sefirą Chochma [67, s. 175].

W celu poznania znaczenia Tory wykorzystywano cztery podstawowe metody analizy tekstu, które wiodą od znaczenia dosłownego do najgłębiej ukrytego. Metody te można przypisać czterem hierarchicznym światom, z których najniższy - asija (świat, w którym żyjemy) - odpowiadałby paszat (rozumieniu tekstu wprost) [161, s. 301]. Jednak tym, co jest naprawdę ważne, nie jest semantyka. Tekst sam w sobie jest kompletny, nie można z niego usunąć ani nie można do niego dodać żadnego znaku. Jest również ograniczony białymi polami. Te wplecione między czarne literu tekstu można również kontemplować, rozumiejąc je jako białe znaki [67, s. 169]. Tekst pod względem formy jest więc z jednej strony hermetyczny, ale z drugiej nieskończenie otwarty, ponieważ można go interpretować, szukać nieznanego, ukrytego w nim szyfru i analizować go [67, s. 170].

Kosmogonia kabalistyczna wykształciła koncepcję troistości wszechświata, czyli jego podziału na światy: niższy, pośredni i wyższy. Jest to najprostszy podział, w którym w celu zapewnienia łączności między wymienionymi światami niezbędne jest wykorzystanie trzech elementów mających swoje miejsce dokładnie w środku, w świecie pośrednim. Należą do nich rozpatrywane już sefer (księgi) [126, s.106] ${ }^{205}$, sefar (liczby, matematyka i geometria) oraz sefirot (dziesięć emanacji boskiego światła). Dzięki tym elementom światy wyższy i niższy mogą konaktować się ze sobą. Gematria jest zatem, jak pisze Franz Dornseiff [32, s. 150], szczególną odmianą mistyki liter, polegającą na przetwarzaniu poszczególnych liter w wyrazach w liczby. Metoda ta zakłada rozumienie liter jako znaków graficznych liczb. Pierwotnie była stosowana do oznaczania numerów ksiąg i pism w starożytnej Grecji, skąd została przyjęta do alfabetu hebrajskiego. Efektem tego jest możliwość przetransponowania każdego słowa wyrażonego w języku hebrajskim na wartość liczbową. Można więc powiedzieć, że niemalże każda wartość liczbowa posiada swój odpowiednik lingwistyczny lub kilka odpowiedników. Również Szechina (Obecność Boga) zawiera się w dynamice języka, w związku z nieskończoną liczbą kombinacji liter alfabetu. Litery oznaczają napływ Elohim do tego świata, stanowiąc kanał, którym to następuje [67, s. 186]. Chodzi przede wszystkim o usuwanie przeszkód w przepływie tej siły, co dokonuje się za pomocą liter alfabetu, w tym przede wszystkim liter boskiego imienia. Już psalmista zwraca uwagę na niezwykłą moc świętego Tetragramu, pisząc: „Ci wozami, a ci rumakami, a my imieniem Pana Boga Naszego chlubimy się” [137, Ps. 20,8]. Długotrwałe powtarzanie liter i imienia Boga było techniką mistyczną popularną nie tylko w judaizmie [64, s. 186].

Mistyka liter pozwala na poznanie ukrytego znaczenia słów Pisma i tym samym tłumaczenie świata. Jednocześnie język uzyskuje swego rodzaju moc stwórczą. Człowiek dostaje za- 
tem siłę tworzenia, zarówno w sferze języka, jak i materii. Tym samym staje się artystą [137, Pnp 7,2]. Sztuka - w tym architektura - jest metafizyką stawania się [126, s. 249]. Jeżeli zatem świat stworzony został za pomocą alfabetu, a szerzej słowa, należy odszukać realne znaczenie elementów, które go tworzą. Akcesoria wykorzystywane do obrzędów wykonywane były w taki sposób, aby zawierały w sobie boskie imiona, a w szczególności Tetragram. Z czteroliterowym imieniem Boga należy kojarzyć głównie talit, a dokładnie frędzle (cicit) znajdujące się na czterech rogach szala modlitewnego - sposób ich wiązania powoduje, że układając się, tworzą imię Boga. Na filakteriach, podobnie jak w mezuzie, pojawia się imię Szaddaj. Wszak „najważniejszym instrumentem, jakim człowiek dysponuje, jest wielkie imię” [64, s. 108]. Moshe Idel stwierdza, że stanowiło ono substytut praktyki ofiarniczej oraz że teurgiczny obrzęd związany z ofiarą został przełożony na litery wielkiego imienia.

Ta symbolika, będąca wyrazem nostalgii za czasami świątynnymi, daje szerokie pole do szukania w kabale wytłumaczenia sposobu kształtowania przestrzeni rytualnej. Jest to bardzo trudne zadanie, przede wszystkim ze względu na niejednoznaczność tekstów kabalistycznych. Ponadto poza kilkoma badaczami wymienionymi we wcześniejszych rozdziałach nikt do tej pory nie zajmował się taką analizą, a wszelkie stwierdzenia w tym względzie można uznać za daleko idące i właściwie niepoparte naukowo. Wydaje się jednak, iż wskazane byłoby podjęcie próby poszukania pewnych uniwersalnych cech oraz źródła, z którego być może czerpano. Próbę zdefiniowania tego należałoby wykonać w oparciu o pewną analizę strukturalistyczną oraz kabalistyczną, przy czym rozdzielenie ich w kontekście tego, o czym tutaj mowa, wydaje się niemożliwe. Istotne jest jednak znalezienie - w oparciu o analizy naukowe - wzorców, których można doszukać się również w mistyce żydowskiej, a nie tłumaczenie mistyki językiem nauki.

\subsection{Metoda badań}

Badania mające dać odpowiedź na pytanie, czy gematria była brana pod uwagę w momencie wznoszenia domów modlitwy w Polsce, można podzielić na dwie fazy. Pierwsza dotyczyła określenia, jakie wartości wymiarów zastosowano w trakcie wznoszenia bożnic. Druga miała umożliwić odnalezienie wartości lingwistycznych, tożsamych z wartościami liczbowymi. Poniżej przedstawiono wszystkie etapy badań oraz metody przyjęte w każdej z analiz.

\subsubsection{Analiza metrologiczna}

Analiza metrologiczna wybranych bożnic była pierwszym etapem przeprowadzonych badań. Na podstawie zebranych materiałów oraz pomiarów własnych starano się określić miary, w jakich zostały wzniesione analizowane synagogi. Pomiary in situ okazały się niezbędne, gdyż w wielu publikacjach pojawiają się bardzo przybliżone wartości. A zarówno 
inwentaryzacje przedwojenne, jak i powojenne wykazywały znaczne rozbieżności w przypadku poszczególnych wymiarów.

W badaniach uwzględniono dwa typy wymiarów. Pierwszy typ to wymiary przekroju poziomego, a więc długość całkowita obiektu na osiach wschód-zachód oraz północ-południe, długość i szerokość w świetle ścian sali męskiej oraz wymiary poziome pola centralnego w obiektach dziewięciopolowych i z bimą-podporą. Drugi typ to wymiary wertykalne, a więc wysokość sali męskiej w najwyższym punkcie sklepienia, wysokość obiektu do okapu oraz wysokość pola centralnego w synagogach dziewięciopolowych i z bimą-podporą. Bożnice były często przebudowywane i rozbudowywane, zwłaszcza w obrębie dachów, gdyż te ulegały zniszczeniu i ich formy zmieniały się najczęściej na przestrzeni lat. Dlatego też nie analizowano wysokości obiektów do kalenicy. W kilku przypadkach nie podano wysokości bimy lub wysokości do okapu obiektu, gdyż materiały, które istnieją, nie dają możliwości odtworzenia form tych elementów ${ }^{206}$.

\subsubsection{Miary uwzględnione w analizie metrologicznej}

Punktem wyjścia do analizy metrologicznej jest określenie miar obiektów uzyskanych w trakcie inwentaryzacji architektonicznych i porównanie ich z miarami, które obowiązywały na terenie Polski w okresie budowy. Jest to oczywiście trudne zadanie, gdyż w różnych okresach i różnych miejscach miary te odpowiadały różnym wartościom określającym miarę metryczną. Miary łokci próbowano ujednolicić na terenie całego kraju na podstawie różnych rozporządzeń wydawanych już od XVI wieku [165, s. 6]. Wiadomo jednak, że nie wszędzie stosowano się do nich, a niekiedy wprowadzano je z opóźnieniem. W XVII i XVIII wieku zgodnie z polskim prawem - obowiązywały dwie główne miary długości: łokieć krakowski $(58,6 \mathrm{~cm})$ do 1764 i łokieć warszawski $(59,55 \mathrm{~cm})$ od 1764 roku.

W 1507 roku miarę łokcia krakowskiego ujednolicono z łokciem poznańskim, natomiast w 1565 - miarę łokcia krakowskiego z łokciem warszawskim. Proces ten wiązał się z wprowadzeniem łokcia koronnego, który miał funkcjonować na obszarze całego kraju i odpowiadać łokciowi krakowskiemu. W 1569 roku zrównano również długość łokcia podlaskiego z łokciem warszawskim, a w gruncie rzeczy z krakowskim [165, s. 6]. Spowodowało to, że od lat 70. XVI wieku zgodnie z polskim prawem funkcjonowała jedna podstawowa miara: łokieć koronny równy $58,6 \mathrm{~cm}$. Stan ten utrzymywał się do 1764 roku, kiedy to Komisja Skarbowa Koronna wprowadziła unifikację łokcia koronnego na terenie całego kraju, ustalając jego długość na 2640 dziesiątych części linii paryskiej [165, s. 13], a więc 59,55 cm.

\subsubsection{Materiał do badań}

Najbardziej efektywna i dająca największą pewność, iż konkretne miary długości zostały zastosowane przy budowie synagog, byłaby analiza materiału źródłowego, na przykład 
odpowiednich zezwoleń władz lub właścicieli prywatnych - tak świeckich, jak i duchownych. Niekiedy zapisy kwestionujące wymiary bożnic pojawiają się również w dokumentach, w których kościół sprzeciwia się ich wznoszeniu ${ }^{207}$ [15, s. 129]. Innym źródłem pośrednich informacji w tej kwestii mogłyby być wydatki gmin w pinkasach oraz dokumenty dotyczące budowy synagogi. W księgach kahalnych z założenia miały być umieszczane informacje o ważnych wydarzeniach $\mathrm{w}$ gminie $[109,18]^{208}$. Wiadomo jednak, że takie dokumenty w wielu przypadkach nie istniały lub nie przetrwały do naszych czasów. W zezwoleniach na budowę bożnic często nie określano konkretnych wymiarów obiektów, podając jedynie ich usytuowanie oraz warunki, jakie powinny spełniać, na przykład być niższe od kościoła ${ }^{209}$. Sytuacja miała się inaczej wówczas, kiedy określano maksymalne wymiary, jakich nie należy przekroczyć, w tym wysokość i wymiary rzutu. Praktyka pokazuje jednak, że Żydzi często nie przestrzegali tych wytycznych, zwiększając albo zmniejszając zatwierdzone wymiary. Najlepszym przykładem takiego obiektu jest synagoga w Chęcinach, która jest nieco mniejsza, niż wskazywałyby podane w przywileju wymiary wnętrza [12, s. 63-64 $]^{210}$. Trudno jest jednak określić, dlaczego kahał nie wykorzystał w całości darowanej mu w przywileju powierzchni.

Informacje zawarte w rozporządzeniach i innych wymienionych dokumentach, jeżeli takowe istnieją, nie mogą więc być podstawą badań metrologicznych. W przypadku wymiarów są to jedynie dość orientacyjne wartości, które często nie były urzeczywistniane przy budowie domów modlitwy. Niezbędne jest więc opieranie się w analizach na stanie istniejącym obiektów, wynikach inwentaryzacji i na planach budowy.

W wielu publikacjach dotyczących architektury bożniczej, zlokalizowanej czy to w Polsce, czy w Europie, podawane są wymiary planów. Z ich analizy wynika jednak, że między wartościami deklarowanymi a wartościami rzeczywistymi istnieją rozbieżności. Wynika to zapewne z faktu, że wielu badaczy podawało wymiary przybliżone. Próba odczytania wartości z planów zamieszczonych w wyżej wymienionych publikacjach jest niemożliwa ze względu na ich wielkość, a tym samym na błąd, który generuje podziałka liniowa. Z tego względu użycie materiałów i inwentaryzacji wykonanych pod przewodnictwem Oskara Sosnowskiego, a znajdujących się w Zakładzie Architektury Polskiej Wydziału Architektury Politechniki Warszawskiej, jest utrudnione. Podstawą szczegółowych badań gematrycznych muszą być plany i materiały niebudzące wątpliwości z punktu widzenia analizy metrologicznej. Dokładniejszym materiałem, choć nie idealnym, są pomiary powojenne. W przypadku inwentaryzacji przedi powojennych można założyć, iż błąd pomiarowy wynosi $1 \mathrm{~cm}$.

Punktem wyjścia analizy było stworzenie zestawienia wymiarów metrycznych pozyskanych z inwentaryzacji zarówno przedwojennych, jak i tych wykonanych zaraz po wojnie. Ponieważ różnice w długości i szerokości sal męskich, które pojawiały się w badanych dokumentach ze wspomnianych okresów, sięgały czasem nawet 2-3 metrów na całym wymiarze, zdecydowano się na wykonanie pomiarów własnych ${ }^{211}$.

Analizie metrologicznej poddane zostały przede wszystkim podstawowe miary planów oraz przekroi synagog. Celem było ustalenie, czy faktycznie obiekty te były wzniesione 
zgodnie z miarami długości, o których mowa powyżej, a więc czy ich wymiary podane zostały w łokciach krakowskich przed 1764 rokiem oraz łokciach warszawskich po tej dacie. W badaniach metrologicznych starano się brać pod uwagę pierwotną formę obiektu, która niejednokrotnie ograniczała się do sali męskiej, a dopiero z czasem była powiększana o kolejne pomieszczenia ${ }^{212}$. Zdarzało się też, że w planach budowlanych przewidywano wzniesienie wraz z salą męską babińca lub przedsionka, a czasem obu pomieszczeń ${ }^{213}$. Często jednak stwierdzenie pierwotnej formy obiektu jest niemożliwe. O przemianach, jakie były dokonywane w obrębie synagog, można dowiedzieć się z badań i dokumentów. Przykładami są bożnice w Orli i Tykocinie, w których w wyniku przebudowy w znaczącym stopniu zmienił się układ wnętrza sali męskiej oraz jej wysokość. Zmiany dokonywane były zwykle po pożarach bożnic i miały na celu odbudowę zniszczonych obiektów oraz - co zdarzało się częściej odtworzenie sklepień. O ile w przypadku synagogi w Tykocinie wiązało się to $\mathrm{z}$ obniżeniem sklepienia i założeniem nowego dachu, o tyle w synagodze w Orli poza założeniem nowego sklepienia zmieniono zupełnie rozstaw słupów wyznaczających pole centralne. Ze względu na zmiany dokonane w tym obiekcie analizą metrologiczną objęta została jego najstarsza forma.

W celu ujednolicenia wymiarów pozyskanych z inwentaryzacji i pomiarów własnych konieczne stało się przyjęcie kilku założeń. Pierwszym i najważniejszym było ustalenie jednej wartości wszystkich wielkości. Ponieważ na przestrzeni wieków synagogi i inne obiekty ulegały deformacjom w wyniku m.in. zniszczeń, pożarów, osiadania, a dokładność ich tyczenia nie była w tamtym czasie zbyt duża, długości przeciwległych ścian i przeciwległych krawędzi bim zwykle nie są sobie równe. Podobnie często pomiędzy ścianami w narożniku nie ma zachowanego kąta prostego. $Z$ tego powodu w celu określenia jednego wymiaru konieczne było pobranie kilku wartości w każdym badanym kierunku oraz określenie wartości średniej poszczególnych długości, szerokości i wysokości. Nie należy jednak utożsamiać wartości średniej ze średnią arytmetyczną ${ }^{214}$. Takie założenie byłoby bowiem błędne, gdyż przy dużych rozbieżnościach wymiarów otrzymana liczba byłaby niezwiązana z wymiarami ścian. Wartością wyjściową była więc w takim przypadku długość ścian. Poszczególne wysokości każdej synagogi określano względem kilku stałych punktów odniesienia. Wysokość na zewnątrz mierzono do okapu od poziomu wejścia, który był pewny, bo niezależny od narastania terenu ${ }^{215}$. Jako wysokość wnętrza przyjmowano odległość od poziomu posadzki sali męskiej do najwyższego punktu sklepienia. W przypadku bimy były - w zależności od obiektu - najczęściej dwa punkty odniesienia: poziom posadzki sali męskiej lub poziom podestu. W obu przypadkach mierzono wysokość do najwyższego punktu sklepienia nad polem centralnym.

Wynikiem tych działań było stworzenie dla poszczególnych obiektów zestawienia wymiarów w systemie metrycznym. Zebrany materiał posłużył do przeliczenia wartości metrycznych na miary, które obowiązywały w Polsce w XVII i XVII wieku, a więc na łokcie lub ich części, czyli stopy i ćwierci. W zależności od tego, czy obiekty powstały przed 
1764 rokiem, czy później, przyjmowano charakterystyczne dla danego okresu wartości łokci. W przypadku obu długości łokcia (krakowskiej i warszawskiej) stosowano dwa rodzaje podziałów: podział prosty, zgodnie z którym jeden łokieć był równy dwóm stopom lub czterem ćwierciom [165, s. 22], oraz podział geometryczny, zgodnie z którym łokieć był dzielony na 24 cale, a te na 10 ziaren itd. [165, s. 22]. W niniejszej analizie podstawę stanowiły obie metody podziału łokcia, przy czym w celach badawczych przyjęto, że najmniejszą, dopuszczalną wartością, która mogła pojawić się w wymiarze, jest jedna ćwierć $(14,79 \mathrm{~cm}$ - ćwierć krakowska, 14,8875 cm - ćwierć warszawska). W kilku przypadkach w przeliczonej mierze zostały uwzględnione wartości cala $(2,44 \mathrm{~cm}$ - cal krakowski, $2,48 \mathrm{~cm}$ - cal warszawski).

\subsubsection{Błędy pomiarowe i przeliczeniowe}

Należy zwrócić uwagę na błąd, który może wystąpić przy przeliczeniu pobranych wymiarów w stosunku do miar krakowskich i warszawskich. Może być spowodowany kilkoma czynnikami. Należą do nich między innymi przemiany, które zachodziły we wnętrzach oraz na zewnątrz Bet ha-Kneset, a wynikały przede wszystkim z przebudów, dostawiania dodatkowych pomieszczeń do sal męskich, w tym przedsionków (pulisz) czy babińców (w kondygnacji zarówno parteru, przy ścianach północnej i południowej, jak i piętra, nad przedsionkami i salami kahalnymi). Ze zmianami wymiarów związane były również przemurowania ścian sal męskich, czego najlepszym przykładem jest synagoga w $\mathrm{Orli}^{216}$. W wielu obiektach przeprowadzone zostały szczególnie zintensyfikowane działania, przede wszystkim w obrębie okienek babińców, które najczęściej były przebijane lub otrzymywały inne wykroje i wymiary. Należy również zwrócić uwagę na błąd przy pomiarze inwentaryzacyjnym oraz na fakt, iż wymiary, zwłaszcza powojenne, dotyczą również obiektów, w których zaprawa tynkarska została zniszczona, lub takich, w których na przeciwległych ścianach tynk już w dużej części nie istniał. Dodatkowo, jak w synagodze w Tarnogrodzie ${ }^{217}$, następował proces odchylania się ścian do zewnątrz, co również powodowało zmiany w wymiarze rzutu obiektu.

Wszelkie wysokości również są obarczone zarówno błędem pomiarowym, jak i błędem wynikającym z przeliczenia miar metrycznych na miary długości, które były przyjęte w dawnej Polsce. Uwarunkowania są podobne. Najistotniejszym z nich były wymiany sklepień po pożarach, co wiązało się, jak w przypadku synagogi w Tykocinie, z obniżeniem wysokości sali męskiej. Kolejnym, związanym zwłaszcza z dokumentacją powojenną, jest trudność w określeniu poziomu posadzki sali męskiej, a w konsekwencji poziomu odniesienia dla wysokości obiektu do okapu. Teren w obrębie synagog narastał, zwykle nie był płaski, w związku z czym w zależności od miejsca przekroju wyglądał zupełnie inaczej. Szczególnie zauważalne było to w latach 50. XX wieku, po zawaleniu się sklepień i murów wielu bożnic i zagruzowaniu posadzek. To samo tyczyło się obszarów przy murach, na zewnątrz budowli. Poza tym po II wojnie 
światowej, w czasie, gdy synagogi były niewłaściwie użytkowane lub w ogóle nie funkcjonowały, materiał posadzki, który był dobrej jakości, wykorzystywano w innych obiektach. Inwentaryzacje przed- i powojenne wykazują również błędy w wynikach pomiarów wysokości sklepień ${ }^{218}$. W celach badawczych przyjęto więc, iż maksymalna różnica przy przeliczeniu miary metrycznej powinna wynosić nie więcej niż $1 \mathrm{cal}$, a więc 2,44 cm w przypadku łokcia krakowskiego oraz 2,48 cm w przypadku łokcia warszawskiego.

\subsubsection{Analiza gematryczna}

Na podstawie wartości uzyskanych w trakcie analizy metrologicznej przeprowadzono badania mające na celu uzyskania lingwistycznej reprezentacji dla otrzymanych wartości liczbowych.

Już na etapie określenia wartości miar, jakie stosowano przy wznoszeniu obiektów, dla układu metrycznego, w którym wykonano inwentaryzacje obiektów, można zauważyć, że pewne wartości liczbowe powtarzają się. W kontekście analizy gematrycznej oraz znaczenia abkstraktu, jakim jest liczba, jest to dość ciekawa zależność. Na pierwszy rzut oka nie widać związków łączących poszczególne wymiary bożnic w Polsce z mistyką liter, a ich poszukiwanie może wydawać się niedorzeczne. Istnieje jednak podstawa ku temu, aby spróbować znaleźć uniwersalną odpowiedź, która mogłaby wytłumaczyć przemiany, jakie dokonywały się w obrębie domów modlitwy, a szczególnie w obrębie sali męskiej.

Gematria stanowi szczególną odmianę mistyki liter, polegającą na przetwarzaniu liter wyrazów w liczby. Zakłada więc rozumienie liter w wyrazie jako znaków graficznych liczb. Ta zależność osadzona zostaje w języku hebrajskim w szczególny sposób. Zgodnie z nauką kabały „kosmos jest kodem imienia Boga i Tory” [53, s. 6]. W przypadku języka hebrajskiego, który jest nie tylko elementem poznawczym, ale również zjawiskiem o stwórczej mocy, sens ezoteryczny uzyskuje kulminację w imieniu Boga [161, s. 30].

Badania przeprowadzone w związku z tą częścią pracy należy określić raczej jako odwrotnie gematryczne niż jako stricte gematryczne. Każdej wartości liczbowej uzyskanej w wyniku analizy metrologicznej przyporządkowany został bowiem poprawny pod względem lingwistycznym odpowiednik. Nie jest on więc ciągiem liter przypadkowym, ale posiadającym wartość fonetyczną oraz znaczenie. Zsumowanie odpowiadającej każdej z nich wartości liczbowej jest równe wartości poszukiwanych wymiarów. Dlatego można mówić o odwróceniu gematrycznie poprawnej metody postępowania przejawiającej się w alfabetyczno-matematycznym zapisie, który pozwala od razu określić, iż konkretny werset posiada określoną wartość. Sytuacja jest skomplikowana tym bardziej, że jednej wartości liczbowej może odpowiadać nieskończona liczba semantycznie i fonetycznie poprawnych związków wyrazowych. Natomiast jedno słowo czy jeden wyraz, a więc poprawny ciąg znaków, będą posiadały zawsze jedną i niezmienną wartość, wynikającą z zastosowania danej metody gematrycznej. 
Analiza tego zagadnienia przeprowadzona została zgodnie z trzema metodami gematrii, które miały umożliwić poszukiwanie nie wartości słowa, ale sensu i znaczenia liczby. Wszystkie metody zostały przyjęte jako uproszczone w odniesieniu do sofitów (formy spółgłosek na końcu wyrazów). Oznacza to, że wartości liczbowe dla poszczególnych głosek, które występują w odmiennej formie w środku i na końcu wyrazu, zostały ujednolicone z formą podstawową we wszystkich wykorzystanych i opisanych poniżej metodach gematrii:

1) Metoda absolutna (mispar hechrachi) - wprowadza podział 22 liter alfabetu na trzy części. Pierwszych 9 liter posiada wartości od 1 (alef) [ $\aleph$ do 9 (tet) [ט]. Kolejnych 9 liter odpowiada wartościom od 10 (jod) [`] do 90 (cadi) [ษ]. Pozostałe cztery litery to wartości setek. Oznacza to, że litera kuf [ק] posiada wartość liczbową 100, a ostatnia litera alfabetu taw [ת] 400. W metodzie tej sofity: kaf [7], mem [ם], nun [१], pei [ๆ], cadi [Ү] uzyskały wartości odpowiednio: 20, 40, 50, 80, 90 (tab. 8.1).

Tabela 8.1. Wartości liczbowe 22 liter alfabetu hebrajskiego stosowane w metodzie mispar hechrachi

\begin{tabular}{|c|c|c|c|c|c|c|c|c|c|c|c|c|c|c|c|c|c|c|c|c|c|}
\hline$ת$ & $w$ & $ר$ & P & $y / Y$ & ף/פ & $y$ & 0 & $3 / 9$ & ם/מ & 3 & ד/כ & , & 0 & $\pi$ & $i$ & I & ה & 7 & $\lambda$ & $ב$ & א \\
\hline 400 & 300 & 200 & 100 & 90 & 80 & 70 & 60 & 50 & 40 & 30 & 20 & 10 & 9 & 8 & 7 & 6 & 5 & 4 & 3 & 2 & 1 \\
\hline
\end{tabular}

Źródło: opr. własne.

2) Metoda uproszczona (mispar siduri) - opiera się na wartościach liczbowych od 1 (alef) [ ] do 22 (taw) [ת] przypisanych 22 literom alfabetu hebrajskiego (tab. 8.2)

Tabela 8.2. Wartości liczbowe 22 liter alfabetu hebrajskiego stosowane w metodzie mispar siduri

\begin{tabular}{|c|c|c|c|c|c|c|c|c|c|c|c|c|c|c|c|c|c|c|c|c|c|}
\hline$\Omega$ & $ש$ & 7 & $P$ & $צ / \gamma$ & ף/ף & $y$ & 0 & $3 / 7$ & ם/מ & 3 & ד/כ & , & 0 & $\pi$ & $i$ & 1 & ה & 7 & $\lambda$ & $ב$ & א \\
\hline 22 & 21 & 20 & 19 & 18 & 17 & 16 & 15 & 14 & 13 & 12 & 11 & 10 & 9 & 8 & 7 & 6 & 5 & 4 & 3 & 2 & 1 \\
\hline
\end{tabular}

Źródło: opr. własne.

3) Metoda redukcyjna (mispar katan) - podobnie jak mispar hechrachi zakłada, że wartości liczbowe pierwszych 9 liter alfabetu hebrajskiego - od alef $[\boldsymbol{\aleph}]$ do tet [ט] - są cyframi od 1 do 9. Kolejnych 9 liter - od jod ['] do cadi [ $३$ ] - również ma wartości od 1 do 9. Pozostałe cztery litery od kuf[p] do taw [ת] - należy przyporządkować wartościom od 1 do 4 . Następuje zatem redukcja wartości liczbowych liter, przyjętych w metodzie mispar hechrachi o wszystkie zera (tab. 8.3).

Tabela 8.3. Wartości liczbowe 22 liter alfabetu hebrajskiego stosowane w metodzie mispar katan

\begin{tabular}{|c|c|c|c|c|c|c|c|c|c|c|c|c|c|c|c|c|c|c|c|c|c|}
\hline$\Omega$ & $ש$ & ר & $P$ & $\mathrm{~s} / \mathrm{Y}$ & ף/פ & ע & 0 & $3 / \uparrow$ & ם/מ & ל & J/ד & , & 0 & $\pi$ & $T$ & 1 & ה & 7 & $\lambda$ & ב & א \\
\hline 4 & 3 & 2 & 1 & 9 & 8 & 7 & 6 & 5 & 4 & 3 & 2 & 1 & 9 & 8 & 7 & 6 & 5 & 4 & 3 & 2 & 1 \\
\hline
\end{tabular}

Źródło: opr. własne. 


\subsubsection{Analiza metrologiczna}

Ze względu na swoją powtarzalność w rożnych Bet ha-Kneset wymiary poszczególnych obiektów wykazują kilka zależności. Da się to zauważyć, zestawiając odpowiadające sobie wielkości (tab. 8.4), ale również poszczególne wartości, odpowiadające różnym wymiarom synagog (tab. 8.5).

Wartość 11 stóp łączy szerokość bimy na osi północ-południe w Synagodze Starej w Rzeszowie i długość bimy na osi wschód-zachód w synagodze w Dukli.

Synagoga w Tarnogrodzie posiada pole centralne założone na kwadracie o wymiarach $15 \times 15$ łokci. Wartość ta odpowiada wysokości do okapu synagogi w Łańcucie.

Wysokość sali męskiej w synagodze w Pińczowie, jak również wysokość do okapu synagogi w Szczebrzeszynie osiągają wartość 16 łokci.

Szerokość sali męskiej na osi północ-południe w synagodze w Chęcinach oraz wysokość do okapu synagogi w Orli wynosi 17 łokci.

Centralne pole bożnicy w Tarnogrodzie ma wysokość równą wysokości do okapu synagogi w Lesku i wynosi 20 łokci.

Synagoga Nowomiejska w Rzeszowie ma do okapu 21 łokci wysokości. Taka wysokość jest charakterystyczna również dla sali męskiej tej synagogi. Identyczna jest także długość sali męskiej na osi wschód-zachód w synagodze w Zamościu oraz szerokość sali męskiej w synagodze w Bobowej.

Długość 23 łokci to wymiar na osi wschód-zachód synagogi w Pińczowie i sali męskiej w synagodze w Szczebrzeszynie, a miara 23 stóp łączy wysokość sali męskiej w synagodze w Chęcinach z długością pola centralnego na osi wschód-zachód w bożnicy w Orli.

Szerokość na osi północ-południe synagogi w Zamościu i Bobowej to 25 łokci, podobnie jak szerokość na osi północ-południe w synagodze w Zamościu i długość wnętrza sali męskiej w Synagodze Starej w Rzeszowie.

Wysokość do okapu synagogi w Chęcinach i Siemiatyczach, ale również szerokość centralnego pola na osi północ-południe w synagodze we Włodawie to 25 stóp,.

Łatwo zauważyć, iż długość synagogi w Orli i Dukli na osi wschód-zachód jest identyczna i wynosi 33 łokcie, podobnie jak szerokość sali męskiej na osi północ południe w synagodze w Siemiatyczach.

Wartość 33 stóp opisuje wysokość sali męskiej w synagogach w: Zamościu, Szczebrzeszynie, Tykocinie (il. 8.1) i Łańcucie. W niej wyrażona zostaje również wysokość pola centralnego w synagogach w Orli i Łańcucie.

Wysokości sal męskich synagog w Dukli i Siemiatyczach są identyczne i wynoszą 27 stóp.

Sala męska synagogi w Tarnogrodzie (rys. 8.2) założona została na kwadracie o wymiarach $28 \times 28$ łokci. Miara ta jest tożsama z długością na osi wschód-zachód w synagodze w Łańcucie. 


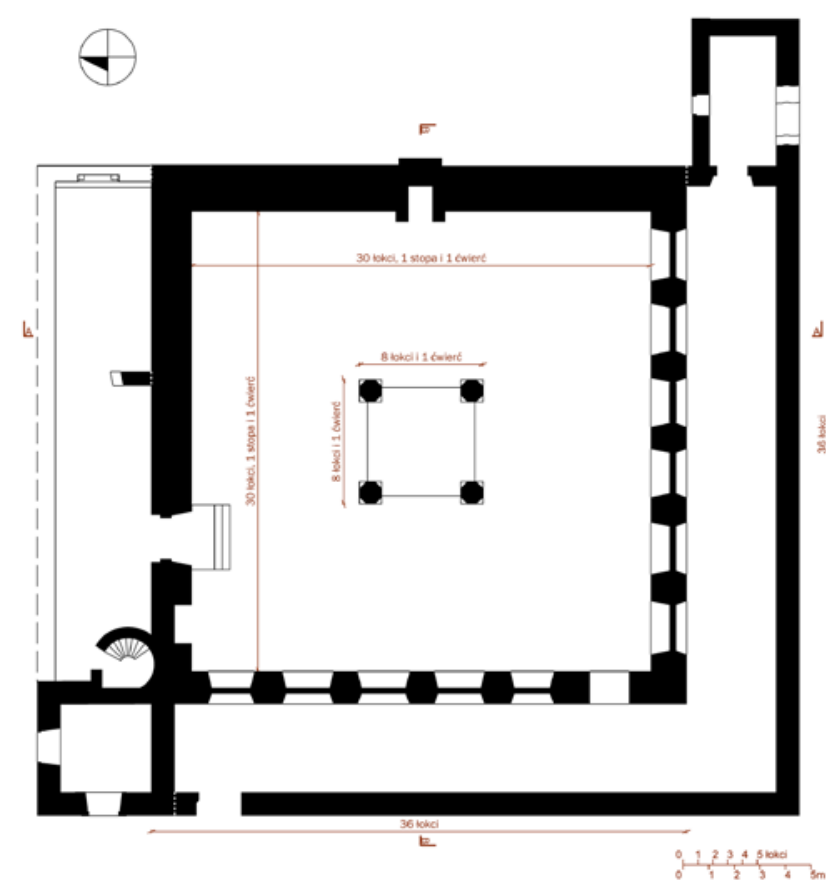

Il. 8.1. Plan synagogi w Tykocinie [21]

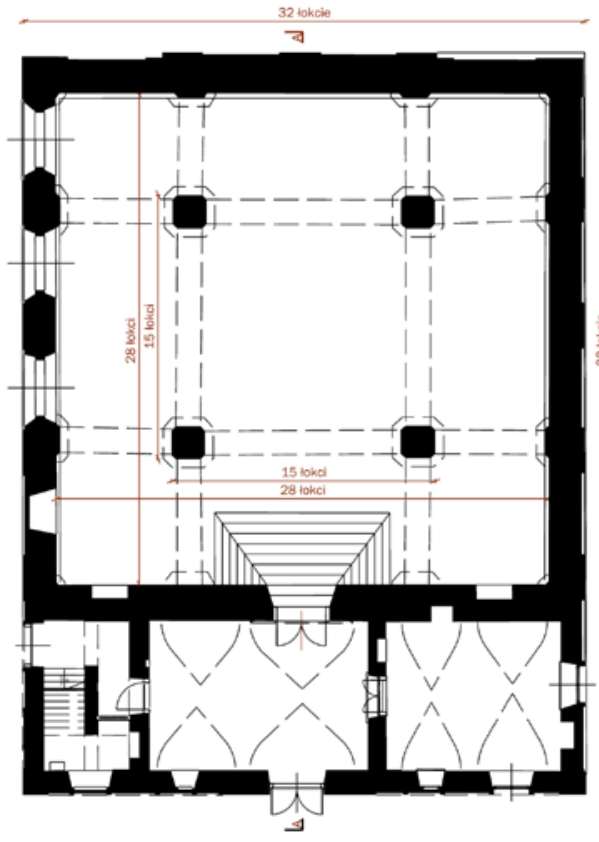

Il. 8.2. Plan synagogi w Tarnogrodzie [21]

Tabela 8.4. Zestawienie wymiarów analizowanych synagog, wyrażonych w miarach stosowanych w dawnej Polsce

\begin{tabular}{|c|c|c|c|c|c|c|c|c|c|c|}
\hline \multirow{3}{*}{\begin{tabular}{l}
\multicolumn{1}{c}{ Parametr } \\
Średnia długość sali na osi \\
E-W
\end{tabular}} & \multicolumn{10}{|c|}{ Synagogi w: } \\
\hline & \multicolumn{2}{|c|}{ Pińczowie } & \multicolumn{2}{|c|}{$\begin{array}{c}\text { Synagoga } \\
\text { Stara } \\
\text { w Rzeszowie }\end{array}$} & \multicolumn{2}{|c|}{ Zamościu } & \multicolumn{2}{|c|}{$\begin{array}{l}\text { Szczebrze- } \\
\text { szynie }\end{array}$} & \multicolumn{2}{|c|}{ Chęcinach } \\
\hline & 23 & łokci & 61 & stóp & 26 & łokci & 29 & łokci & 97 & ćwierci \\
\hline $\begin{array}{l}\text { Średnia szerokość sali na osi } \\
\text { N-S }\end{array}$ & 123 & ćwierci & 55 & stóp & 25 & łokci & 51 & stóp & 34 & łokcie \\
\hline $\begin{array}{l}\text { Średnia wysokość sali do } \\
\text { okapu }\end{array}$ & 87 & ćwierci & 81 & ćwierci & 31 & stóp & 16 & łokci & 25 & stóp \\
\hline $\begin{array}{l}\text { Średnia długość wnętrza sali } \\
\text { na osi E-W }\end{array}$ & 69 & ćwierci & 25 & łokci & 21 & łokci & 23 & łokci & 39 & stóp \\
\hline $\begin{array}{l}\text { Średnia szerokość wnętrza } \\
\text { sali na osi N-S }\end{array}$ & 73 & ćwierci & 22 & łokcie & 39 & stóp & 39 & stóp & 17 & stóp \\
\hline $\begin{array}{l}\text { Średnia wysokość wnętrza } \\
\text { sali }\end{array}$ & 16 & łokci & 77 & ćwierci & 33 & stopy & 33 & stopy & 23 & stopy \\
\hline $\begin{array}{l}\text { Średnia długość pola } \\
\text { centralnego na osi E-W }\end{array}$ & - & - & 13 & stóp & - & - & - & - & - & - \\
\hline $\begin{array}{l}\text { Średnia szerokość pola } \\
\text { centralnego na osi N-S }\end{array}$ & - & - & 11 & stóp & - & - & - & - & - & - \\
\hline $\begin{array}{l}\text { Średnia wysokość pola } \\
\text { centralnego }\end{array}$ & - & - & 65 & ćwierci & - & - & - & - & - & - \\
\hline
\end{tabular}




\begin{tabular}{|c|c|c|c|c|c|c|c|c|c|c|}
\hline \multirow[b]{2}{*}{$\begin{array}{l}\text { Średnia długość sali na osi } \\
\text { E-W }\end{array}$} & \multicolumn{2}{|c|}{ Tykocinie } & \multicolumn{2}{|c|}{ Orli } & \multicolumn{2}{|c|}{ Lesku } & \multicolumn{2}{|c|}{$\begin{array}{l}\text { Tarno- } \\
\text { grodzie }\end{array}$} & \multicolumn{2}{|c|}{$\begin{array}{c}\text { Synagoga } \\
\text { Nowo- } \\
\text { miejska } \\
\text { w Rzeszowie }\end{array}$} \\
\hline & 36 & łokci & 33 & łokcie & 63 & stopy & 32 & łokcie & 101 & stóp \\
\hline $\begin{array}{l}\text { Średnia szerokość sali na osi } \\
\text { N-S }\end{array}$ & 36 & łokci & 63 & stóp & 49 & stóp & 32 & łokcie & 67 & stóp \\
\hline $\begin{array}{l}\text { Średnia wysokość sali do } \\
\text { okapu }\end{array}$ & 18 & łokci & 17 & łokci & 20 & łokci & 41 & stóp & 21 & łokci \\
\hline $\begin{array}{l}\text { Średnia długość wnętrza sali } \\
\text { na osi E-W }\end{array}$ & 123 & ćwierci & 57 & stóp & 53 & stóp & 28 & łokci & 115 & ćwierci \\
\hline $\begin{array}{l}\text { Średnia szerokość wnętrza } \\
\text { sali na osi N-S }\end{array}$ & 123 & ćwierci & 107 & ćwierci & 39 & stóp & 28 & łokci & 53 & stopa \\
\hline $\begin{array}{l}\text { Średnia wysokość wnętrza } \\
\text { sali }\end{array}$ & 33 & stopy & 35 & stóp & 37 & stóp & 19 & łokci & 21 & łokieć \\
\hline $\begin{array}{l}\text { Średnia długość pola } \\
\text { centralnego na osi E-W }\end{array}$ & 33 & ćwierci & 23 & stopy & - & - & 15 & łokci & 37 & ćwierć \\
\hline $\begin{array}{l}\text { Średnia szerokość pola } \\
\text { centralnego na osi N-S }\end{array}$ & 33 & ćwierci & 11 & łokci & - & - & 15 & łokci & 9 & łokieć \\
\hline \multirow[t]{2}{*}{$\begin{array}{l}\text { Średnia wysokość pola } \\
\text { centralnego }\end{array}$} & 35 & stóp & 33 & stopy & - & - & 20 & łokci & 39 & stopa \\
\hline & \multicolumn{2}{|c|}{ Bobowej } & \multicolumn{2}{|c|}{ Dukli } & \multicolumn{2}{|c|}{ Lańcucie } & \multicolumn{2}{|c|}{ Włodawie } & \multicolumn{2}{|c|}{$\begin{array}{l}\text { Siemia- } \\
\text { tyczach }\end{array}$} \\
\hline $\begin{array}{l}\text { Średnia długość sali na osi } \\
\text { E-W }\end{array}$ & 27 & łokci & 33 & łokcie & 28 & łokci & 43 & łokcie & 43 & łokcie \\
\hline $\begin{array}{l}\text { Średnia szerokość sali na osi } \\
\text { N-S }\end{array}$ & 25 & łokci & 30 & łokci & 53 & stopy & 99 & stóp & 33 & łokcie \\
\hline $\begin{array}{l}\text { Średnia wysokość sali do } \\
\text { okapu }\end{array}$ & 39 & ćwierci & 14 & łokci & 15 & łokci & 77 & ćwierci & 25 & stóp \\
\hline $\begin{array}{l}\text { Średnia długość wnętrza sali } \\
\text { na osi E-W }\end{array}$ & 24 & łokcie & 55 & stóp & 47 & stóp & 123 & ćwierci & 121 & ćwierci \\
\hline $\begin{array}{l}\text { Średnia szerokość wnętrza } \\
\text { sali na osi N-S }\end{array}$ & 21 & łokci & 49 & stóp & 85 & ćwierci & 57 & stóp & 117 & ćwierci \\
\hline $\begin{array}{l}\text { Średnia wysokość wnętrza } \\
\text { sali }\end{array}$ & 51 & ćwierci & 27 & stóp & 33 & stopy & 73 & ćwierci & 27 & stóp \\
\hline $\begin{array}{l}\text { Średnia długość pola } \\
\text { centralnego na osi E-W }\end{array}$ & 7 & łokci & 11 & stóp & 6 & łokci & 29 & stóp & - & - \\
\hline $\begin{array}{l}\text { Średnia szerokość pola } \\
\text { centralnego na osi N-S }\end{array}$ & 8 & łokci & 29 & ćwierci & 6 & łokci & 25 & stóp & - & - \\
\hline $\begin{array}{l}\text { Średnia wysokość pola } \\
\text { centralnego }\end{array}$ & 55 & ćwierci & - & - & 33 & stopy & 73 & ćwierci & - & - \\
\hline
\end{tabular}

* Kolorem zaznaczone są wymiary powtarzające się w odpowiadających sobie wielkościach.

Źródło: opr. własne. 
Tabela 8.5. Zestawienie wymiarów analizowanych synagog, wyrażonych w miarach funkcjonujących w dawnej Polsce

\begin{tabular}{|c|c|c|c|c|c|c|c|c|c|c|}
\hline \multirow{3}{*}{\begin{tabular}{|l|}
\multicolumn{1}{|c}{ Parametr } \\
$\begin{array}{l}\text { Średnia długość sali na osi } \\
\text { E-W }\end{array}$ \\
\end{tabular}} & \multicolumn{10}{|c|}{ Synagogi w } \\
\hline & \multicolumn{2}{|c|}{ Pińczowie } & \multicolumn{2}{|c|}{\begin{tabular}{|c|} 
Synagoga \\
Stara \\
w Rzeszowie
\end{tabular}} & \multicolumn{2}{|c|}{ Zamościu } & \multicolumn{2}{|c|}{$\begin{array}{l}\text { Szczebrze- } \\
\text { szynie }\end{array}$} & \multicolumn{2}{|c|}{ Chęcinach } \\
\hline & 23 & łokcie & 61 & stóp & 26 & łokci & 29 & łokci & 97 & ćwierci \\
\hline $\begin{array}{l}\text { Średnia szerokość sali na osi } \\
\text { N-S }\end{array}$ & 123 & ćwierci & 55 & stóp & 25 & łokci & 51 & stóp & 34 & łokcie \\
\hline $\begin{array}{l}\text { Średnia wysokość sali do } \\
\text { okapu }\end{array}$ & 87 & ćwierci & 81 & ćwierci & 31 & stóp & 16 & łokci & 25 & stóp \\
\hline $\begin{array}{l}\text { Średnia długość wnętrza sali } \\
\text { na osi E-W }\end{array}$ & 69 & ćwierci & 25 & łokci & 21 & łokci & 23 & łokcie & 39 & stóp \\
\hline $\begin{array}{l}\text { Średnia szerokość wnętrza } \\
\text { sali na osi N-S }\end{array}$ & 73 & ćwierci & 22 & łokcie & 39 & stóp & 39 & stóp & 17 & łokci \\
\hline $\begin{array}{l}\text { Średnia wysokość wnętrza } \\
\text { sali }\end{array}$ & 16 & łokci & 77 & ćwierci & 33 & stopy & 33 & stopy & 23 & stopy \\
\hline $\begin{array}{l}\text { Średnia długość pola } \\
\text { centralnego na osi E-W }\end{array}$ & - & - & 13 & stóp & - & - & - & - & - & - \\
\hline $\begin{array}{l}\text { Średnia szerokość pola } \\
\text { centralnego na osi N-S }\end{array}$ & - & - & 11 & stóp & - & - & - & - & - & - \\
\hline \multirow[t]{2}{*}{$\begin{array}{l}\text { Średnia wysokość pola } \\
\text { centralnego }\end{array}$} & - & - & 65 & ćwierci & - & - & - & - & - & - \\
\hline & \multicolumn{2}{|c|}{ Tykocinie } & \multicolumn{2}{|c|}{ Orli } & \multicolumn{2}{|c|}{ Lesku } & \multicolumn{2}{|c|}{$\begin{array}{l}\text { Tarno- } \\
\text { grodzie }\end{array}$} & \multicolumn{2}{|c|}{$\begin{array}{c}\text { Synagoga } \\
\text { Nowo- } \\
\text { miejska } \\
\text { w Rzeszowie } \\
\end{array}$} \\
\hline $\begin{array}{l}\text { Średnia długość sali na osi } \\
\text { E-W }\end{array}$ & 36 & łokci & 33 & łokcie & 63 & stopy & 32 & łokcie & 101 & stóp \\
\hline $\begin{array}{l}\text { Średnia szerokość sali na osi } \\
\text { N-S }\end{array}$ & 36 & łokci & 63 & stopy & 49 & stóp & 32 & łokcie & 67 & stóp \\
\hline $\begin{array}{l}\text { Średnia wysokość sali do } \\
\text { okapu }\end{array}$ & 18 & łokci & 17 & łokci & 20 & łokci & 41 & stóp & 21 & łokci \\
\hline $\begin{array}{l}\text { Średnia długość wnętrza sali } \\
\text { na osi E-W }\end{array}$ & 123 & ćwierci & 57 & stóp & 53 & stopy & 28 & łokci & 115 & ćwierci \\
\hline $\begin{array}{l}\text { Średnia szerokość wnętrza } \\
\text { sali na osi N-S }\end{array}$ & 123 & ćwierci & 107 & ćwierci & 39 & stóp & 28 & łokci & 53 & stopy \\
\hline $\begin{array}{l}\text { Średnia wysokość wnętrza } \\
\text { sali }\end{array}$ & 33 & stopy & 35 & stóp & 37 & stóp & 19 & łokci & 21 & łokci \\
\hline $\begin{array}{l}\text { Średnia długość pola } \\
\text { centralnego na osi E-W }\end{array}$ & 33 & ćwierci & 23 & stopy & - & - & 15 & łokci & 37 & ćwierć \\
\hline $\begin{array}{l}\text { Średnia szerokość pola } \\
\text { centralnego na osi N-S }\end{array}$ & 33 & ćwierci & 11 & łokci & - & - & 15 & łokci & 9 & łokieć \\
\hline $\begin{array}{l}\text { Średnia wysokość pola } \\
\text { centralnego }\end{array}$ & 35 & stóp & 33 & stopy & - & - & 20 & łokci & 39 & stóp \\
\hline
\end{tabular}




\begin{tabular}{|l|c|c|c|c|c|c|c|c|c|c|}
\hline \multicolumn{2}{|c|}{} & \multicolumn{2}{|c|}{ Bobowej } & \multicolumn{2}{|c|}{ Dukli } & \multicolumn{2}{c|}{ Lańcucie } & \multicolumn{2}{c|}{ Włodawie } & \multicolumn{2}{c|}{$\begin{array}{l}\text { Siemia- } \\
\text { tyczach }\end{array}$} \\
\hline $\begin{array}{l}\text { Średnia długość sali na osi } \\
\text { E-W }\end{array}$ & 27 & łokci & 33 & łokcie & 28 & łokci & 43 & łokcie & 43 & łokcie \\
\hline $\begin{array}{l}\text { Średnia szerokość sali na osi } \\
\text { N-S }\end{array}$ & 25 & łokci & 30 & łokci & 53 & stopy & 99 & stóp & 33 & łokcie \\
\hline $\begin{array}{l}\text { Średnia wysokość sali do } \\
\text { okapu }\end{array}$ & 39 & ćwierci & 14 & łokci & 15 & łokci & 77 & ćwierci & 25 & stóp \\
\hline $\begin{array}{l}\text { Średnia długość wnętrza sali } \\
\text { na osi E-W }\end{array}$ & 24 & łokcie & 55 & stóp & 47 & stóp & 123 & ćwierci & 121 & ćwierci \\
\hline $\begin{array}{l}\text { Średnia szerokość wnętrza } \\
\text { sali na osi N-S }\end{array}$ & 21 & łokci & 49 & stóp & 85 & ćwierci & 57 & stóp & 117 & ćwierci \\
\hline $\begin{array}{l}\text { Średnia wysokość wnętrza } \\
\text { sali }\end{array}$ & 51 & ćwierci & 27 & stóp & 33 & stopy & 73 & ćwierci & 27 & stóp \\
\hline $\begin{array}{l}\text { Średnia długość pola } \\
\text { centralnego na osi E-W }\end{array}$ & 7 & łokci & 11 & stóp & 6 & łokci & 29 & stóp & - & - \\
\hline $\begin{array}{l}\text { Średnia szerokość pola } \\
\text { centralnego na osi N-S }\end{array}$ & 8 & łokci & 29 & ćwierci & 6 & łokci & 25 & stóp & - & - \\
\hline $\begin{array}{l}\text { Średnia wysokość pola } \\
\text { centralnego }\end{array}$ & 55 & ćwierci & - & - & 33 & stopy & 73 & ćwierci & - & - \\
\hline
\end{tabular}

* Kolorem zaznaczone są wymiary powtarzające się.

Źródło: opr. własne.

Bima bożnicy w Tykocinie podobnie jak sala męska synagogi w Orli są wysokie na 35 stóp.

Miarą powtarzającą się aż w pięciu synagogach jest 39 stóp.. Opisuje ona szerokość sali męskiej w bożnicach w: Zamościu, Szczebrzeszynie i Lesku (tab. 8.4), a także wysokość bimy w Synagodze Nowomiejskiej w Rzeszowie oraz długość sali męskiej na osi wschód-zachód w synagodze w Chęcinach (tab. 8.5).

Synagogi we Włodawie i w Siemiatyczach mają taką samą długość na osi wschód-zachód, równą 43 łokciom.

Wymiarem łączącym synagogi w Lesku i w Dukli jest 49 stóp. W obu przypadkach odnosi się on do szerokości na osi północ-południe, jednak w pierwszym obiekcie opisuje synagogę, w drugim wnętrze sali męskiej.

W przypadku synagog dzisiejszego Podkarpacia wspólne są 53 stopy. Tyle wynosi bowiem długość sali męskiej na osi wschód-zachód synagogi w Lesku. W synagodze w Łańcucie i w Synagodze Nowomiejskiej w Rzeszowie jest to wymiar na osi północ-południe, przy czym w pierwszej z bożnic opisuje szerokość synagogi, w drugiej szerokość sali męskiej.

Szerokość na osi północ-południe Synagogi Starej w Rzeszowie i długość na osi wschódzachód synagogi w Dukli wynosi 55 stóp. 
Do zewnętrznych wymiarów dwóch synagog: do szerokości na osi północ-południe synagogi w Orli oraz do długości na osi wschód-zachód w Lesku odnosi się natomiast miara 63 stóp.

Wspólna dla szerokości sali męskiej synagogi w Pińczowie oraz wysokości sali męskiej synagogi we Włodawie jest wartość 73 ćwierci, natomiast dla wysokości sali męskiej Synagogi Starej w Rzeszowie oraz wysokości do okapu synagogi we Włodawie wartość 77 ćwierci.

Ostatnią znamienną wartością są 123 ćwierci, będące długością i szerokością sali męskiej synagogi w Tykocinie, a także szerokością na osi północ-południe synagogi w Pińczowie i długością sali męskiej synagogi we Włodawie.

Na podstawie wyników otrzymanych po przeliczeniu miar stwierdzono, że prawie wszystkie synagogi ${ }^{219}$, które powstały przed 1764 rokiem, zostały rozmierzone w łokciu krakowskim. Synagoga siemiatycka została wytyczona w oparciu o miarę łokcia warszawskiego. Oznacza to, że ze względu na wymiar łokcia mogła powstać po 1764 roku, a nie w $1755^{220}$.

W przypadku dwóch budowli wartości łokcia warszawskiego zostały zastosowane w sposób szczególny. Pierwszą z nich jest synagoga w Łańcucie, której powstanie datuje się na 1761 rok, czyli rok wydania przywileju. Maksymalny błąd w przeliczeniu wymiarów tej synagogi wynosi mniej niż $1 \mathrm{cal}(2,25 \mathrm{~cm})$ i tyczy się wyłącznie wysokości bimy. Jeżeli chodzi o pozostałe wymiary, to maksymalna różnica wynosi $0,94 \mathrm{~cm} \mathrm{w}$ przypadku długości wnętrza na osi północ-południe. Ponieważ wymiary obiektu odpowiadają mierze wprowadzonej zgodnie z prawem trzy lata później niż przywilej na budowę synagogi, można interpretować to dwojako. Założyć, że już w momencie budowy obiektu około 1761 roku w Łańcucie obowiązywała miara warszawska albo że, co jest bardziej prawdopodobne, budowa obiektu była realizowana po 1764 roku.

Drugą budowlą jest synagoga w Orli, której wszystkie elementy zostały rozmierzone w miarach łokcia krakowskiego. Pole centralne, sklepienie oraz nadbudowę ścian zewnętrznych wykonano natomiast w 4. ćwierci XVIII wieku, co wymusiło zastosowanie łokcia warszawskiego. Dla wielkości, w których wykorzystano miarę łokcia krakowskiego, a więc długości i szerokości zewnętrznych murów synagogi, maksymalna i minimalna różnica w wymiarze wynosiła 0,5 i $0,1 \mathrm{~cm}$. Ze względu na liczne przebudowy wnętrza, które wiązały się z wielokrotnym przebijaniem otworów okiennych, pogrubianiem ścian, wymianą tynków, rozbieżność, która pojawia się w wymiarze, wynosi od 1,4 do 1,7 cm. Największa różnica jest w wysokościach pola centralnego i wynosi od 4,8 do 7,4 cm (od 2 do 3 cali).

Przeprowadzona analiza metrologiczna zezwala więc na umiejscowienie w czasie pewnych przemian w strukturze obiektów.

Analizując ogólne wyniki uzyskane w trakcie badań metrologicznych, należy zwrócić uwagę, iż różnice wynikłe przy przeliczaniu mieszczą się w przedziale od 0,01 do 6,4 cm. Przedział ten jest bardzo szeroki i różnice wynoszą prawie 3 cale, a więc wybiegają znacznie poza 
dopuszczalną wartość 1 cala. Należy jednak zaznaczyć, że jest tak tylko w czterech ze 116 analizowanych wartości, a więc w pojedynczych przypadkach. Dla wszystkich wymiarów rozbieżności nie przekraczają $0,5 \%$ danej wartości.

\subsubsection{Analiza porównawcza}

W celu potwierdzenia rozkładu zewnętrznych i wewnętrznych wymiarów synagog przeprowadzono analizę porównawczą w oparciu o dwa źródła: synagogi znajdujące się obecnie na terenie Ukrainy i Białorusi oraz kościoły katolickie wzniesione w Polsce w XVII i XVIII wieku.

Pierwszy etap badań miał na celu określenie układu wymiarów innych bożnic oraz części, które są wspólne z bożnicami z obszaru obecnej Polski. W trakcie badań metrologicznych poza przeanalizowanymi już obiektami wytypowano piętnaście innych powstałych w XVII i XVIII wieku, które obecnie znajdują się na obszarze Białorusi (w: Pińsku, Izabelinie, Stolinie) i Ukrainy (w: Łucku, Ostrogu, Lwowie, Husiatynie, Żółkwi, Samborze, Szepietówce, Sokalu, Zbarażu, Grzymałowie, Czortkowie, Dubnie). Działanie to miało na celu określenie, czy wymiary charakterystyczne dla bożnic z tego okresu, zlokalizowanych na terenie Polski mają pokrycie w innych obiektach, które znajdowały się dawniej na obszarze Rzeczpospolitej.

Zestawienie miar długości we wskazanych wyżej obiektach zostało wykonane w oparciu o dokładne inwentaryzacje znajdujące się w archiwum Centrum Sztuki Żydowskiej przy Uniwersytecie w Jerozolimie ${ }^{221}$ oraz materiały inwentaryzacyjne Zakładu Architektury Polskiej Politechniki Warszawskiej. W analizie Synagogi Przedmiejskiej we Lwowie wykorzystana została inwentaryzacja zawarta w pracy Alfreda Grottego [54, s. 38]. W tej części pracy uwzględnione zostały przede wszystkim obiekty istniejące. W wyniku działań wojennych zniszczone zostały jedynie Synagoga Przedmiejska we Lwowie oraz synagoga w Pińsku.

Drugi etap miał dać odpowiedź na pytanie, czy układ wymiarów kościołów jest tożsamy z układami wymiarów bożnic zlokalizowanych na terenie Polski. Pobrany materiał metrologiczny dotyczył trzydziestu trzech kościołów ${ }^{222}$, wśród których znalazły się kościoły zakonów kontrreformacyjnych i parafialne. W sumie analizie poddanych zostało 188 wymiarów, w tym wymiary planu poziomego oraz wysokości. Materiał do badań stanowiły inwentaryzacje obiektów zamieszczone w pracy Adama Miłobędzkiego [118].

Przeliczenie miar metrycznych na miary stosowane w Polsce w XVII i XVIII wieku przeprowadzone zostało zgodnie z opisaną powyżej metodą.

\subsubsection{Synagogi na Ukrainie i Białorusi}

Wymiary zostały ponownie przeliczone w oparciu o miary łokcia krakowskiego i warszawskiego, z dokładnością do jednego centymetra, dla 95\% procent wymiarów. W pozo- 
stałych przypadkach błąd wynosił maksymalnie 2 cale i nie przekraczał 0,5\% wymiaru (tab. 8.6).

W materiale porównawczym najczęściej pojawiają się wymiary o wartościach 25 łokci (w odniesieniu do synagog w: Łucku (dwukrotnie), Pińsku, Czortkowie) i 79 ćwierci (w odniesieniu do synagog w: Łucku, Ostrogu (dwukrotnie), Pińsku). Wartość 79 ćwierci opisuje we wszystkich obiektach wysokość sali męskiej. Pozostałe wartości miar występowały:

- trzykrotnie: 15 łokci (w synagodze na Blichu w Samborze oraz w synagogach w Szepietówce i Sokalu), 20 łokci (w Synagodze Przedmiejskiej we Lwowie (dwukrotnie) oraz w synagodze w Husiatynie), 22 łokcie (w synagogach w: Pińsku, Zbarażu, Czortkowie), 53 ćwierci (w synagogach w Szepietówce (dwukrotnie) i Stolinie), 36 stóp (w synagogach w: Pińsku, Czortkowie, Stolinie), 61 ćwierci (w synagogach w: Żółkwi, Czortkowie, Dubnie), 63 stopy (w synagogach w Ostrogu (dwukrotnie) i Grzymałowie). Wymiar 15 łokci (w synagodze na Blichu w Samborze oraz w synagogach w Szepietówce i Sokalu) odpowiada wysokości bożnic do okapu, podobnie jak wartość 25 łokci opisująca ten sam parametr w odniesieniu do synagog w Łucku i Pińsku. Wartość 53 ćwierci odpowiada natomiast wysokości sali męskiej w bożnicach w Szepietówce i Stolinie;

- dwukrotnie: 13 stóp (w synagodze w Łucku (dwukrotnie)), 14 łokci (w synagogach w Sokalu i Stolinie), 17 łokci (w synagogach w Ostrogu i Czortkowie), 21 łokci (w synagogach w Zbarażu i Izabelinie), 24 łokcie (w synagogach w Szepietówce i Sokalu), 27 stóp (w synagodze w Ostrogu i w Synagodze Przedmiejskiej we Lwowie) ${ }^{223}, 34$ łokcie (w synagodze w Żółkwi (dwukrotnie)), 36 łokci (w synagogach w Szepietówce i Dubnie), 41 łokci (w synagogach w Łucku i Żółkwi), 45 stóp (w synagogach w Husiatyni i Sokalu), 53 stopy (w synagogach w Husiatyni i Grzymałowie), 55 ćwierci (w synagodze w Samborze (dwukrotnie)) i 57 stóp (w synagogach w Sokalu i Czortkowie), 57 ćwierci (w synagogach w Żółkwi i Dubnie), 59 ćwierci (w synagogach w Ostrogu i Sokalu) ${ }^{224}, 63$ ćwierci (w synagodze w Żółkwi (dwukrotnie)), 67 ćwierci (w synagogach w Samborze i Grzymałowie), 97 ćwierci (w synagogach w Izabelinie i Zbarażu), 99 ćwierci (w synagodze w Dubnie (dwukrotnie), 109 (w synagodze w Stolinie (dwukrotnie));

- jednokrotnie: 13 łokci (w synagodze w Pińsku), 17 stóp (w synagodze w Łucku), 21 stóp (w synagodze w Stolinie), 25 stóp (w Synagodze Przedmiejskiej we Lwowie), 25 ćwierci (w synagodze w Szepietówce), 27 ćwierci (w synagodze w Zbarażu), 55 stóp (w synagodze w Zbarażu), 67 stóp (w synagodze w Samborze). Szczególne w tej grupie są wartości: 33 łokcie (w Synagodze Przedmiejskej we Lwowie) oraz 33 ćwierci (w synagodze w Izabelinie). Są one niezwykle częste w przypadku obiektów z obszaru Polski. Natomiast na Ukrainie i Białorusi zostały stwierdzone tylko w dwóch obiektach, podobnie jak 39 stóp i 39 ćwierci, a mianowicie po jednym razie w synagogach odpowiednio w Izabelinie i w Pińsku.

Wśród pozostałych wartości są takie, które występują jednokrotnie, oraz bardzo niewielka liczba takich, które pojawiły się dopiero w trakcie analizy materiału porównawczego. 
Tabela 8.6. Zestawienie wymiarów synagog na Białorusi i Ukrainie, wyrażonych w miarach stosowanych w Rzeczpospolitej w XVII i XVIII wieku

\begin{tabular}{|c|c|c|c|c|c|c|c|c|c|c|}
\hline \multirow{3}{*}{\begin{tabular}{|l|}
\multicolumn{1}{|c|}{ Parametr } \\
$\begin{array}{l}\text { Średnia długość sali na osi } \\
\text { E-W }\end{array}$ \\
\end{tabular}} & \multicolumn{10}{|c|}{ Synagogi w: } \\
\hline & \multicolumn{2}{|c|}{ Lucku } & \multicolumn{2}{|c|}{ Ostrogu } & \multicolumn{2}{|c|}{\begin{tabular}{|} 
Synagoga \\
Przed- \\
miejska we \\
Lwowie
\end{tabular}} & \multicolumn{2}{|c|}{ Pińsku } & \multicolumn{2}{|c|}{ Husiatynie } \\
\hline & 41 & łokci & 93 & stopy & 77 & stóp & 107 & stóp & 26 & łokci \\
\hline $\begin{array}{l}\text { Średnia szerokość sali na osi } \\
\text { N-S }\end{array}$ & 89 & stóp & 69 & stóp & 85 & stóp & 60 & łokci & 53 & stopy \\
\hline $\begin{array}{l}\text { Średnia wysokość sali do } \\
\text { okapu }\end{array}$ & 25 & łokci & 17 & łokci & - & - & 25 & łokci & 47 & ćwierci \\
\hline $\begin{array}{l}\text { Średnia długość wnętrza sali } \\
\text { na osi E-W }\end{array}$ & 25 & łokci & 63 & stóp & 33 & łokci & 22 & łokcie & 45 & stóp \\
\hline $\begin{array}{l}\text { Średnia szerokość wnętrza } \\
\text { sali na osi N-S }\end{array}$ & 29 & łokci & 63 & stóp & 137 & ćwierci & 36 & stóp & 20 & łokci \\
\hline Średnia wysokość wnętrza sali & 79 & ćwierci & 79 & ćwierci & 20 & łokci & 79 & ćwierci & 69 & ćwierci \\
\hline $\begin{array}{l}\text { Średnia długość pola } \\
\text { centralnegona osi E-W }\end{array}$ & 13 & stóp & 59 & ćwierci & 25 & stóp & 19 & stóp & - & - \\
\hline $\begin{array}{l}\text { Średnia szerokość pola } \\
\text { centralnegona osi N-S }\end{array}$ & 13 & stóp & 27 & stóp & 27 & stóp & 39 & ćwierci & - & - \\
\hline \multirow[t]{2}{*}{$\begin{array}{l}\text { Średnia wysokość pola } \\
\text { centralnego }\end{array}$} & 17 & stóp & 79 & ćwierci & 20 & łokci & 13 & łokci & - & - \\
\hline & \multicolumn{2}{|c|}{ Żółkwi } & \multicolumn{2}{|c|}{$\begin{array}{c}\text { Synagoga } \\
\text { na Blichu } \\
\text { w Samborze }\end{array}$} & \multicolumn{2}{|c|}{$\begin{array}{l}\text { Szepie- } \\
\text { tówce }\end{array}$} & \multicolumn{2}{|c|}{ Sokalu } & \multicolumn{2}{|c|}{ Zbarażu } \\
\hline $\begin{array}{l}\text { Średnia długość sali na osi } \\
\text { E-W }\end{array}$ & 40 & łokci & 207 & ćwierci & 36 & łokci & 24 & łokcie & 28 & łokci \\
\hline $\begin{array}{l}\text { Średnia szerokość sali na osi } \\
\mathrm{N}-\mathrm{S}\end{array}$ & 41 & łok & 67 & stóp & 24 & łokcie & 57 & stóp & 55 & stóp \\
\hline $\begin{array}{l}\text { Średnia wysokość sali do } \\
\text { okapu }\end{array}$ & 34 & łokcie & 15 & łokci & 15 & łokci & 15 & łokci & 43 & stopy \\
\hline $\begin{array}{l}\text { Średnia długość wnętrza sali } \\
\text { na osi E-W }\end{array}$ & 34 & łokcie & 71 & stóp & 38 & stóp & 37 & stóp & 97 & ćwierci \\
\hline $\begin{array}{l}\text { Średnia szerokość wnętrza } \\
\text { sali na osi N-S }\end{array}$ & 35 & łokci & 30 & łokci & 35 & stóp & 45 & stóp & 21 & łokci \\
\hline Średnia wysokość wnętrza sali & 63 & ćwierci & 55 & ćwierci & 53 & ćwierci & 14 & łokci & 77 & ćwierci \\
\hline $\begin{array}{l}\text { Średnia długość pola } \\
\text { centralnegona osi E-W }\end{array}$ & 57 & ćwierci & 67 & ćwierci & 7 & łokci & - & - & 27 & ćwierci \\
\hline $\begin{array}{l}\text { Średnia szerokość pola } \\
\text { centralnegona osi N-S }\end{array}$ & 61 & ćwierci & 49 & ćwierci & 25 & ćwierci & - & - & 9 & łokci \\
\hline $\begin{array}{l}\text { Średnia wysokość pola } \\
\text { centralnego }\end{array}$ & 63 & ćwierci & 55 & ćwierci & 53 & ćwierci & - & - & 22 & łokcie \\
\hline
\end{tabular}




\begin{tabular}{|l|c|c|c|c|c|c|c|c|c|c|}
\hline & \multicolumn{2}{|c|}{$\begin{array}{c}\text { Grzyma- } \\
\text { lowie }\end{array}$} & \multicolumn{2}{l|}{ Czortkowie } & \multicolumn{2}{|c|}{ Izabelinie } & \multicolumn{2}{|c|}{ Stolinie } & \multicolumn{2}{c|}{$\begin{array}{c}\text { Dubnie } \\
\text { Wielkim }\end{array}$} \\
\hline $\begin{array}{l}\text { Średnia długość sali na osi } \\
\text { E-W }\end{array}$ & 63 & stóp & 57 & stóp & 39 & stóp & 109 & ćwierci & 36 & łokci \\
\hline $\begin{array}{l}\text { Średnia szerokość sali na osi } \\
\text { N-S }\end{array}$ & 115 & ćwierci & 25 & łokci & 97 & ćwierci & 109 & ćwierci & 141 & ćwierci \\
\hline $\begin{array}{l}\text { Średnia wysokość sali do } \\
\text { okapu }\end{array}$ & 75 & ćwierci & 61 & ćwierci & - & - & 14 & łokci & 91 & ćwierci \\
\hline $\begin{array}{l}\text { Średnia długość wnętrza sali } \\
\text { na osi E-W }\end{array}$ & 53 & stopy & 22 & łokcie & 21 & łokci & 95 & ćwierci & 32 & łokcie \\
\hline $\begin{array}{l}\text { Średnia szerokość wnętrza } \\
\text { sali na osi N-S }\end{array}$ & 23 & łokcie & 36 & stóp & 33 & ćwierci & - & - & 131 & ćwierci \\
\hline $\begin{array}{l}\text { Średnia wysokość wnętrza } \\
\text { sali }\end{array}$ & 67 & ćwierci & 17 & łokci & - & - & 53 & ćwierci & 99 & ćwierci \\
\hline $\begin{array}{l}\text { Średnia długość pola } \\
\text { centralnegona osi E-W }\end{array}$ & - & - & - & - & - & - & 59 & ćwierci & 57 & ćwierci \\
\hline $\begin{array}{l}\text { Średnia szerokość pola } \\
\text { centralnegona osi N-S }\end{array}$ & - & - & - & - & - & - & 21 & stóp & 61 & ćwierci \\
\hline $\begin{array}{l}\text { Średnia wysokość pola } \\
\text { centralnego }\end{array}$ & - & - & - & - & - & - & 36 & stóp & 99 & ćwierci \\
\hline
\end{tabular}

Źródło: opr. własne.

\subsubsection{Kościoły polskie z XVII i XVIII wieku}

W trakcie analizy wymiarów kościołów powstałych w Polsce w XVII i XVIII wieku stwierdzono, że w 29,3\% pokrywają się z wymiarami w analizowanych bożnicach. Trudno jest na tej podstawie poszukiwać związków z ogólnym ruchem budowlanym, którego najprężniejszą gałęzią była z pewnością architektura sakralna.

Przeliczenie wymiarów zostało dokonane w oparciu o miary łokcia krakowskiego z dokładnością do dwóch centymetrów dla $87 \%$ procent wymiarów. W pozostałych przypadkach błąd wynosił maksymalnie dwa cale i nie przekraczał 0,5\% wymiaru (tab. 8.7).

Jedną z najczęściej pojawiających się wartości było 19 łokci (w kościołach: św. Piotra i Pawła w Krakowie (dwukrotnie), bernardynów w Rzeszowie (dwukrotnie), kanoników regularnych w Wągłczewie, a także w kolegiacie św. Anny w Krakowie i kościele paulinów w Warszawie). Pozostałe wartości miar występowały:

- pięciokrotnie: 18 łokci (w kościołach: bernardynów w Sierakowie, kanoników regularnych w Wągłczewie, parafialnym w Kodeniu, dominikanów w Gidle, parafialnym w Tarłowie), 35 łokci (w kościołach: jezuitów w Kalisz, bernardynów w Lublinie, kamedułów na Bielanach w Krakowie, dominikanów w Gidle, karmelitów w Warszawie), 36 łokci (w kościołach: jezuitów w Kaliszu, św. Piotra i Pawła na Antokolu w Wilnie, parafialnym w Lesznie oraz w kolegiacie św. Anny w Krakowie); 
- czterokrotnie: 41 stóp (w kolegiatach w Nieświerzu (dwukrotnie) i na Mirowie w Pińczowie oraz w kościele parafialnym w Grodzisku), 41 łokci (w kościołach: jezuitów w Wilnie (dwukrotnie), szpitalnym w Końskowoli i dominikanów w Gidle), 75 stóp (w kościołach: kamedułów na Bielanach w Krakowie, parafialnym w Kodeniu, bernardynów i paulinów w Warszawie);

- trzykrotnie: 15 łokci (w kościołach kanoników regularnych w Wągłczewie i karmelitanek we Lwowie (dwukrotnie), 16 łokci (w: kościele bernardynów w Sierakowie, kolegiacie św. Anny w Krakowie, kościele paulinów w Warszawie), 17 łokci (w kościołach bernardynów w Sierakowie oraz parafialnych w Grodzisku i Tarłowie), 21 łokci (w kościołach jezuitów i bernardynów w Wilnie oraz w kościele parafialnym w Grodzisku), 22 łokcie (w kościołach św. Piotra i Pawła w Krakowie oraz bernardynów w Lublinie i Rzeszowie), 27 łokci (w kościołach: jezuitów w Wilnie, parafialnym w Tarłowie i kapucynów w Warszawie), 40 łokci (w kościołach jezuitów w Kaliszu i parafialnym w Grodzisku oraz w kolegiacie św. Anny w Krakowie), 60 łokci (w kościołach parafialnych w Czemiernikach i Gołębiu oraz w kościele paulinów w Warszawie), 65 łokci (w kościołach: św. Piotra i Pawła w Krakowie, bernardynów w Rzeszowie i kamedułów w Rytwianach), 70 łokci (w kościołach: jezuitów w Kaliszu, kamedułów na Bielanach w Krakowie i parafialnym w Rokitnie), 81 stóp (w kościołach parafialnym w Kodeniu (dwukrotnie) i św. Piotra i Pawła na Antokolu w Wilnie), 85 stóp (w kościołach jezuitów i parafialny w Lublinie oraz parafialnym w Rokitnie), 191 stóp (w kościołach jezuitów w Poznaniu oraz bernardynów i karmelitów w Warszawie);

- dwukrotnie: 13 łokci (w kościołach bernardynów w Sierakowie i dominikanów w Gidle), 23 stopy (w kościołach szpitalnym w Końskowoli i karmelitanek we Lwowie), 25 łokci (w kościołach bernardynek w Wilnie i parafialnym w Grodzisku), 29 stóp (w kościołach św. Piotra i Pawła w Krakowie i bernardynów w Rzeszowie), 31 łokci (w kościołach bernardynów w Lublinie i kapucynów w Warszawie.), 38 łokci (w kościołach parafialnym w Czemiernikach i bernardynów w Sierakowie), 42 łokcie (w kościołach parafialnym w Kodeniu i karmelitów w Warszawie), 46 łokci (w kościele jezuitów w Wilnie i kolegiacie św. Anny w Krakowie), 52 łokcie (w kolegiacie św. Anny w Krakowie i kościele paulinów w Warszawie), 53 łokcie (w kościołach karmelitów i bernardynów w Wilnie), 59 stóp (w kościołach karmelitów w Wilnie i paulinów w Warszawie), 71 stóp (w kościołach bernardynów w Lublinie i kanoników regularnych w Wągłczewie), 76 łokci (w kościołach bernardynów w Sierakowie i parafialnym w Tarłowie), 83 łokcie (w kościele dominikanów w Gidle i karmelitów w Warszawie), 97 stóp (w kościołach parafialnych w Kodeniu i Tarłowie), 119 stóp (w kościołach bernardynów w Sierakowie i parafialnym w Gołębiu), 141 stóp (w kościele św. Piotra i Pawła w Krakowie i bernardynów w Rzeszowie), 147 stóp (w kościele parafialnym w Grodzisku i Tarłowie), 183 ćwierci (w kościołach św. Piotra i Pawła w Krakowie i bernardynów w Rzeszowie), 187 stóp (w kościele bernardynów w Lublinie i dominikanów w Gidle), 203 ćwierci (w kościołach św. Piotra i Pawła w Krakowie i bernardynów w Rzeszowie). 
Tabela 8.7. Zestawienie wymiarów w miarach stosowanych w dawnej Polsce w XVIIi XVIII-wiecznych kościołach

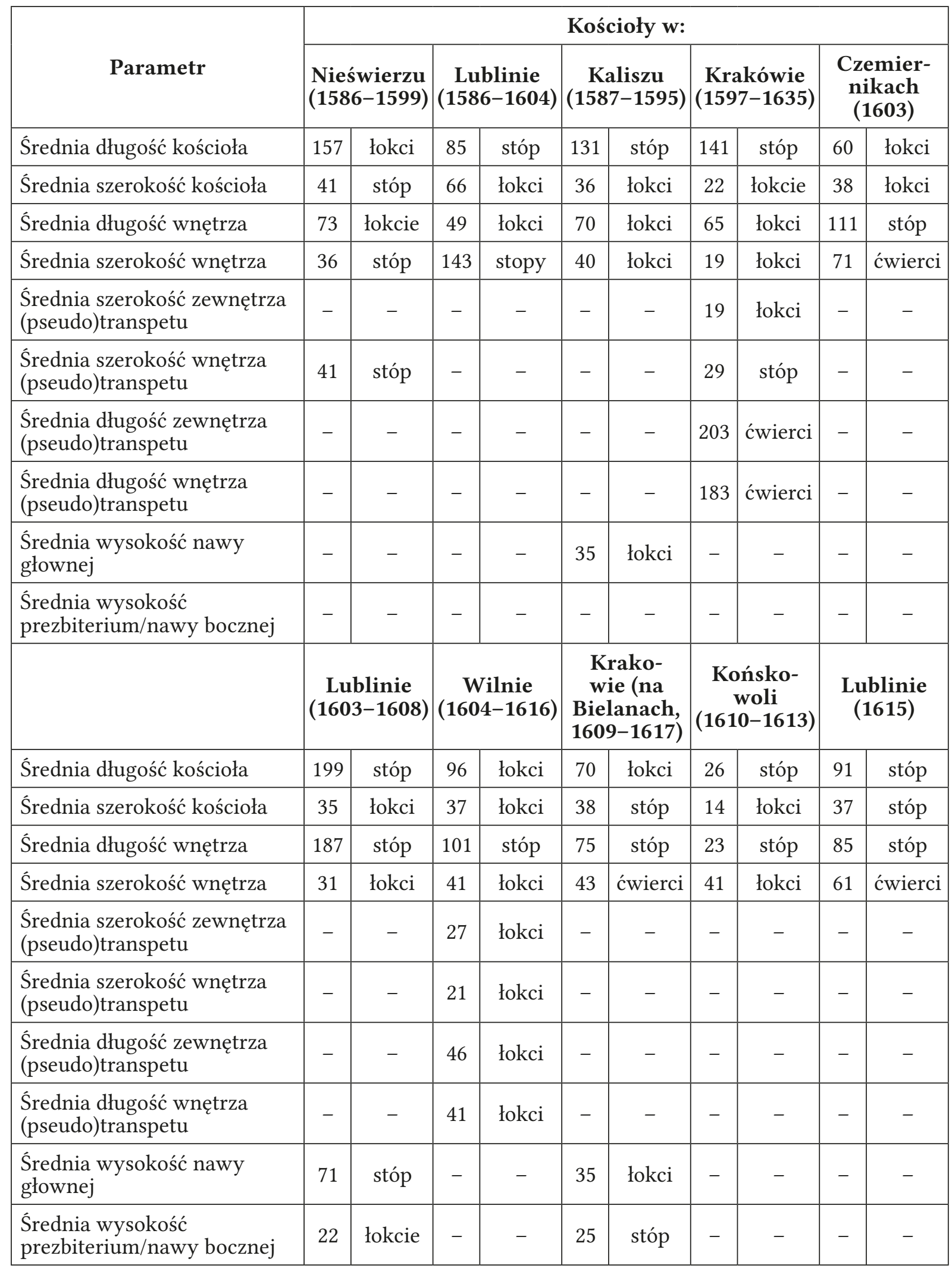




\begin{tabular}{|c|c|c|c|c|c|c|c|c|c|c|}
\hline \multirow[b]{2}{*}{ Średnia długość kościoła } & \multicolumn{2}{|c|}{\begin{tabular}{|c|} 
Pińczowie \\
$(1615-1619)$
\end{tabular}} & \multicolumn{2}{|c|}{$\begin{array}{c}\text { Rzeszowie } \\
(1624-1629)\end{array}$} & \multicolumn{2}{|c|}{$\begin{array}{l}\text { Sierakowie } \\
(1624-1629)\end{array}$} & \multicolumn{2}{|c|}{$\begin{array}{l}\text { Wilnie } \\
(1625)\end{array}$} & \multicolumn{2}{|c|}{\begin{tabular}{|l|} 
Rytwianach \\
$(1625-1637)$ \\
\end{tabular}} \\
\hline & 167 & stóp & 141 & stóp & 76 & łokci & 59 & łokci & 129 & stóp \\
\hline Średnia szerokość kościoła & 41 & stóp & 22 & łokcie & 16 & łokci & 21 & łokci & 169 & stóp \\
\hline Średnia długość wnętrza & 78 & łokci & 65 & łokci & 119 & stóp & 53 & łokcie & 91 & ćwierci \\
\hline Średnia szerokość wnętrza & 31 & stóp & 19 & łokci & 17 & łokci & 47 & stóp & 65 & łokci \\
\hline $\begin{array}{l}\text { Średnia szerokość zewnętrza } \\
\text { (pseudo)transpetu }\end{array}$ & - & - & 19 & łokci & 18 & łokci & - & - & - & - \\
\hline $\begin{array}{l}\text { Średnia szerokość wnętrza } \\
\text { (pseudo)transpetu }\end{array}$ & - & - & 29 & stóp & 13 & łokci & - & - & - & - \\
\hline $\begin{array}{l}\text { Średnia długość zewnętrza } \\
\text { (pseudo)transpetu }\end{array}$ & - & - & 203 & ćwierci & 43 & łokcie & - & - & - & - \\
\hline $\begin{array}{l}\text { Średnia długość wnętrza } \\
\text { (pseudo)transpetu }\end{array}$ & - & - & 183 & ćwierci & 38 & łokci & - & - & - & - \\
\hline $\begin{array}{l}\text { Średnia wysokość nawy } \\
\text { głownej }\end{array}$ & - & - & - & - & 55 & stóp & 25 & łokci & - & - \\
\hline \multirow{2}{*}{$\begin{array}{l}\text { Średnia wysokość } \\
\text { prezbiterium/nawy bocznej }\end{array}$} & - & - & - & - & - & - & - & - & - & - \\
\hline & \multicolumn{2}{|c|}{$\begin{array}{l}\text { Wagłczewie } \\
(1626)\end{array}$} & \multicolumn{2}{|c|}{$\begin{array}{c}\text { Gołębiu } \\
(1628-1636)\end{array}$} & \multicolumn{2}{|c|}{$\begin{array}{l}\text { Kodeniu } \\
(1629-1635)\end{array}$} & \multicolumn{2}{|c|}{$\begin{array}{c}\text { Gidle } \\
(1632-1644)\end{array}$} & \multicolumn{2}{|c|}{$\begin{array}{c}\text { Wilnie } \\
(1634-1653)\end{array}$} \\
\hline Średnia długość kościoła & 89 & stóp & 119 & stóp & 62 & łokcie & 187 & stóp & 145 & stóp \\
\hline Średnia szerokość kościoła & 18 & łokci & 49 & stóp & 43 & stopy & 41 & łokcie & 69 & stóp \\
\hline Średnia długość wnętrza & 71 & stóp & 54 & łokcie & 97 & stóp & 100 & łokci & 53 & łokcie \\
\hline Średnia szerokość wnętrza & 15 & łokci & 60 & łokci & 18 & łokci & 35 & łokci & 59 & stóp \\
\hline $\begin{array}{l}\text { Średnia szerokość zewnętrza } \\
\text { (pseudo)transpetu }\end{array}$ & - & - & - & - & 27 & stóp & 18 & łokci & - & - \\
\hline $\begin{array}{l}\text { Średnia szerokość wnętrza } \\
\text { (pseudo)transpetu }\end{array}$ & - & - & - & - & 9 & łokci & 13 & łokci & - & - \\
\hline $\begin{array}{l}\text { Średnia długość zewnętrza } \\
\text { (pseudo)transpetu }\end{array}$ & - & - & - & - & 42 & łokcie & 86 & łokcie & - & - \\
\hline $\begin{array}{l}\text { Średnia długość wnętrza } \\
\text { (pseudo)transpetu }\end{array}$ & - & - & - & - & 75 & stóp & 83 & lokcie & - & - \\
\hline $\begin{array}{l}\text { Średnia wysokość nawy } \\
\text { głownej }\end{array}$ & 19 & łokci & 189 & stóp & 81 & stóp & - & - & - & - \\
\hline $\begin{array}{l}\text { Średnia wysokość } \\
\text { prezbiterium/nawy bocznej }\end{array}$ & - & - & - & - & 81 & stóp & - & - & - & - \\
\hline
\end{tabular}




\begin{tabular}{|c|c|c|c|c|c|c|c|c|c|c|}
\hline \multirow[b]{2}{*}{ Średnia długość kościoła } & \multicolumn{2}{|c|}{$\begin{array}{c}\text { Grodzisku } \\
(1635-1648)\end{array}$} & \multicolumn{2}{|c|}{$\begin{array}{l}\text { Lwowie } \\
(1642)\end{array}$} & \multicolumn{2}{|c|}{\begin{tabular}{|c|} 
Tarłowie \\
$(1645-1655)$
\end{tabular}} & \multicolumn{2}{|c|}{$\begin{array}{c}\text { Poznaniu } \\
(1649-1701)\end{array}$} & \multicolumn{2}{|c|}{\begin{tabular}{|c|} 
Poznaniu \\
$(1658-1668)$
\end{tabular}} \\
\hline & 183 & stopy & 93 & stopy & 76 & łokci & 88 & łokci & 255 & stóp \\
\hline Średnia szerokość kościoła & 21 & łokci & 15 & łokci & 27 & łokci & 49 & łokci & 67 & stóp \\
\hline Średnia długość wnętrza & 147 & stóp & 105 & stóp & 147 & stóp & 191 & stóp & 243 & stopy \\
\hline Średnia szerokość wnętrza & 17 & łokci & 20 & łokci & 17 & łokci & 55 & łokci & 29 & ćwierci \\
\hline $\begin{array}{l}\text { Srednia szerokość zewnętrza } \\
\text { (pseudo)transpetu }\end{array}$ & 25 & łokci & 15 & łokci & 18 & łokci & - & - & - & - \\
\hline $\begin{array}{l}\text { Średnia szerokość wnętrza } \\
\text { (pseudo)transpetu }\end{array}$ & 41 & stóp & 23 & stopy & 10 & łokci & - & - & - & - \\
\hline $\begin{array}{l}\text { Średnia długość zewnętrza } \\
\text { (pseudo)transpetu }\end{array}$ & 45 & łokci & 65 & stóp & 97 & stóp & - & - & - & - \\
\hline $\begin{array}{l}\text { Średnia długość wnętrza } \\
\text { (pseudo)transpetu }\end{array}$ & 40 & łokci & 51 & stóp & 95 & stóp & - & - & - & - \\
\hline $\begin{array}{l}\text { Średnia wysokość nawy } \\
\text { głownej }\end{array}$ & 23 & łokcie & - & - & 28 & łokci & - & - & - & - \\
\hline \multirow[t]{2}{*}{$\begin{array}{l}\text { Średnia wysokość } \\
\text { prezbiterium/nawy bocznej }\end{array}$} & 48 & łokci & - & - & - & - & - & - & - & - \\
\hline & \multicolumn{2}{|c|}{\begin{tabular}{|c|} 
Warszawie \\
$(1660-1667)$
\end{tabular}} & \multicolumn{2}{|c|}{$\begin{array}{c}\text { Warszawie } \\
(1661-1672)\end{array}$} & \multicolumn{2}{|c|}{$\begin{array}{c}\text { Wilnie } \\
(1668-1675)\end{array}$} & \multicolumn{2}{|c|}{$\begin{array}{c}\text { Warszawie } \\
(1683-1686)\end{array}$} & \multicolumn{2}{|c|}{$\begin{array}{c}\text { Lesznie } \\
(1685-1696)\end{array}$} \\
\hline Średnia długość kościoła & 109 & łokci & 83 & łokcie & 84 & łokcie & 109 & stóp & 149 & stóp \\
\hline Średnia szerokość kościoła & 75 & stóp & 42 & łokcie & 81 & stóp & 31 & łokci & 36 & łokci \\
\hline Średnia długość wnętrza & 191 & stóp & 191 & stóp & 77 & łokci & 38 & łokci & 137 & sóp \\
\hline Średnia szerokość wnętrza & 63 & stopy & 35 & łokci & 36 & łokci & 27 & łokci & 30 & łokci \\
\hline $\begin{array}{l}\text { Średnia szerokość zewnętrza } \\
\text { (pseudo)transpetu }\end{array}$ & - & - & - & - & - & - & - & - & - & - \\
\hline $\begin{array}{l}\text { Średnia szerokość wnętrza } \\
\text { (pseudo)transpetu }\end{array}$ & - & - & - & - & - & - & - & - & - & - \\
\hline $\begin{array}{l}\text { Średnia długość zewnętrza } \\
\text { (pseudo)transpetu }\end{array}$ & - & - & - & - & - & - & - & - & - & - \\
\hline $\begin{array}{l}\text { Średnia długość wnętrza } \\
\text { (pseudo)transpetu }\end{array}$ & - & - & - & - & - & - & - & - & - & - \\
\hline $\begin{array}{l}\text { Średnia wysokośćnawy } \\
\text { głownej }\end{array}$ & - & - & - & - & - & - & - & - & - & - \\
\hline $\begin{array}{l}\text { Średnia wysokość } \\
\text { prezbiterium/nawy bocznej }\end{array}$ & - & - & - & - & - & - & - & - & - & - \\
\hline
\end{tabular}




\begin{tabular}{|l|c|c|c|c|c|c|}
\hline & \multicolumn{2}{|c|}{$\begin{array}{c}\text { Rokitnie } \\
(\mathbf{1 6 9 3})\end{array}$} & \multicolumn{2}{c|}{$\begin{array}{c}\text { Krakowie } \\
(\mathbf{1 6 8 9 - 1 7 0 4 )}\end{array}$} & \multicolumn{2}{|c|}{$\begin{array}{l}\text { Warszawie } \\
(\mathbf{1 7 0 7 - 1 7 1 7})\end{array}$} \\
\hline Średnia długość kościoła & 73 & stopy & 87 & łokci & 74 & łokcie \\
\hline Średnia szerokość kościoła & 85 & stóp & 40 & łokci & 75 & stóp \\
\hline Średnia długość wnętrza & 70 & łokci & 81 & łokci & 60 & łokci \\
\hline Średnia szerokość wnętrza & 79 & stóp & 36 & łokci & 34 & łokcie \\
\hline $\begin{array}{l}\text { Średnia szerokość zewnętrza } \\
\text { (pseudo)transpetu }\end{array}$ & - & - & 52 & łokci & 52 & łokcie \\
\hline $\begin{array}{l}\text { Średnia szerokość wnętrza } \\
\text { (pseudo)transpetu }\end{array}$ & - & - & 46 & łokci & - & - \\
\hline $\begin{array}{l}\text { Średnia długość zewnętrza } \\
\text { (pseudo)transpetu }\end{array}$ & - & - & 19 & łokci & 19 & łokci \\
\hline $\begin{array}{l}\text { Średnia długość wnętrza } \\
\text { (pseudo)transpetu }\end{array}$ & - & - & 16 & łokci & 16 & łokci \\
\hline $\begin{array}{l}\text { Średnia wysokośćnawy } \\
\text { głownej }\end{array}$ & - & - & - & - & 59 & stóp \\
\hline $\begin{array}{l}\text { Średnia wysokość } \\
\text { prezbiterium/nawy bocznej }\end{array}$ & - & - & - & - & - & - \\
\hline
\end{tabular}

Źródło: opr. własne.

Wśród powtórzonych wartości liczbowych wymiarów w kościołach nie ma dużej grupy liczb odpowiadających wartościom liczbowym wymiarów bożnic. Należą do nich przede wszystkim takie liczby, jak: 6, 7, 8, 11, 24, 32, 33, 39, 57, 99, 115, 117, 123. Jest natomiast zbiór wymiarów, zwykle jednokrotnie pojawiających się w kościołach, które nie występują w bożnicach.

\subsubsection{Podsumowanie}

Z zestawienia wymiarów w materiale porównawczym, który stanowią synagogi Ukrainy i Białorusi, wynika, że 33\% z nich pokrywa się z wymiarami analizowanych obiektów z terenu dawnej Polski:.

1) W przypadku wymiarów wyrażonych w łokciach (il. 8.3) wartości liczbowe identyczne w grupie bożnic z terenu Polski i bożnic z terenu Białorusi i Ukrainy stanowią 65,5\%. Dla całego zbioru bożnic najczęściej powtarzającym się wymiarem jest 21 łokci, natomiast w dalszej kolejności znajdują się takie wartości liczbowe, jak: 15, 20, 25, 28 i 33. Częstotliwość powtórzeń wymiarów w obu grupach bożnic jest bardzo wyrównana.

2) W przypadku wymiarów wyrażonych w stopach (il. 8.4) wspólnych jest jedynie $28,6 \%$ tych dotyczących bożnic zlokalizowanych na terenie Polski oraz Białorusi i Ukrainy. Do grupy tej należą wymiary: 27, 35, 37, 39, 53, 55, 57, 63 i 67 stóp. Tym najczęściej występującym są 33 stopy, charakterystyczne dla synagog z terenu Polski. Na kolejnym miejscu znajduje się 
39 stóp, a dalej 25 i 27 stóp i wreszcie 53 i 63 stopy. Rozkład częstotliwości występowania wymiarów w bożnicach na terenie Polski jest znacznie bardziej zróżnicowany niż w bożnicach na Białorusi i Ukrainie, choć dla większości wartości zarówno w jednej, jak i w drugiej grupie obiektów rozkład powtórzeń jest na porównywalnym poziomie.

3) W przypadku wymiarów wyrażonych w ćwierciach (il. 8.5) jedynie 16,2\% odnosi się do bożnic wzniesionych na terenie Polski oraz Białorusi i Ukrainy. W grupie tej znajdują się: 33, 39, 55, 69, 77 i 97 ćwierci. Najczęściej występującym wymiarem są 123 ćwierci, charakterystyczne dla synagog na terenie Polski. Kolejne częste to: 33, 53, 55, 73, 77, 79, 97 ćwierci.

Taki rozkład powtórzeń w grupie badawczej i porównawczej wskazuje jednoznacznie, że podstawową jednostką wymiaru, którą wykorzystywano, był łokieć. Jednocześnie należy zwrócić uwagę, że układ powiązań między wymiarami bożnic znajdujących się na terenie Polski oraz Białorusi i Ukrainy maleje wraz ze wzrostem rozdrobnienia wymiaru podstawowego. Należy jednak pamiętać, że poza wartością liczbową analizowano również jednostkę miary. Wydaje się tym samym, że w przypadku bożnic Ukrainy i Białorusi związek ten jest niewielki, gdyż wynosi zaledwie $1 / 3$. W rozkładzie powtórzeń wymiarów istotne jest również to, że wśród wymiarów wyrażonych w stopach, a przede wszystkim w ćwierciach, największą grupę stanowią te, które pojawiają się jednokrotnie i występują w obu badanych zbiorach.

Z badań związku wymiarów wszystkich synagog składających się na badany zbiór, a więc tych zlokalizowanych na terenie Polski, jak również tych znajdujących się w granicach Białorusi i Ukrainy, z wymiarami XVII- i XVIII-wiecznych kościołów wynika, że w 43,5\% wymiary kościołów i synagog pokrywają się. Ponadto:

1) Wymiary bożnic i kościołów wyrażone w łokciach (il. 8.6) pokrywają się w około $69 \%$. Wymiarami z jednej grupy, które nie posiadają reprezentacji w drugiej grupie, są w przypadku synagog wymiary o wartości: 6, 7, 8, 11, 24, 26 29, 32 i 33 łokci. Wymiarem najczęściej występujacym w obu grupach obiektów jest 19 łokci, charakterystyczne przede wszystkim dla kościołów. Uwagę należy zwrócić także na: 13, 16, 18, 27 i 60 łokci, które znacznie częściej pojawiają się w architekturze sakralnej. Pozostałe wymiary są charakterystyczne raczej dla bożnic.

2) Wymiary bożnic i kościołów wyrażone w stopach (il. 8.7) pokrywają się w około $60 \%$. W grupie wspólnej znajdują się: 23 stopy, 25, 27, 29, 31, 36, 37, 38, 41, 43, 47, 49, 51 i 55 stóp, 63 stopy, 67, 69, 71, 85, 93, 99 i 101 stóp. Wymiarem najczęściej występującym są 33 stopy, charakterystyczne dla synagog zlokalizowanych na terenie Polski. Na kolejnym miejscu znajduje wymiar o wartości 39 stóp. Należy zaznaczyć, że znaczna część wymiarów pojawia się w jednej i w drugiej grupie jednokrotnie. Poza wymiarami 29, 4171 i 85 stóp wszystkie pozostałe są częstsze dla synagog lub pozostają na tym samym poziomie częstotliwości pojawiania się.

3) Wymiary bożnic i kościołów wyrażone w ćwierciach (il. 8.8) pokrywają się jedynie w około 8\%. Dotyczy to pomiarów o wartościach: 29, 61 i 91 ćwierci, które w kościołach są znacznie niedoreprezentowane. W grupie tej ogólnie najczęściej występuje wymiar 123 ćwierci, charakterystyczny dla synagog zlokalizowanych na terenie Polski, a nieco rzadziej: 33, 53, 55, 73, 77, 79, i 97 ćwierci. 


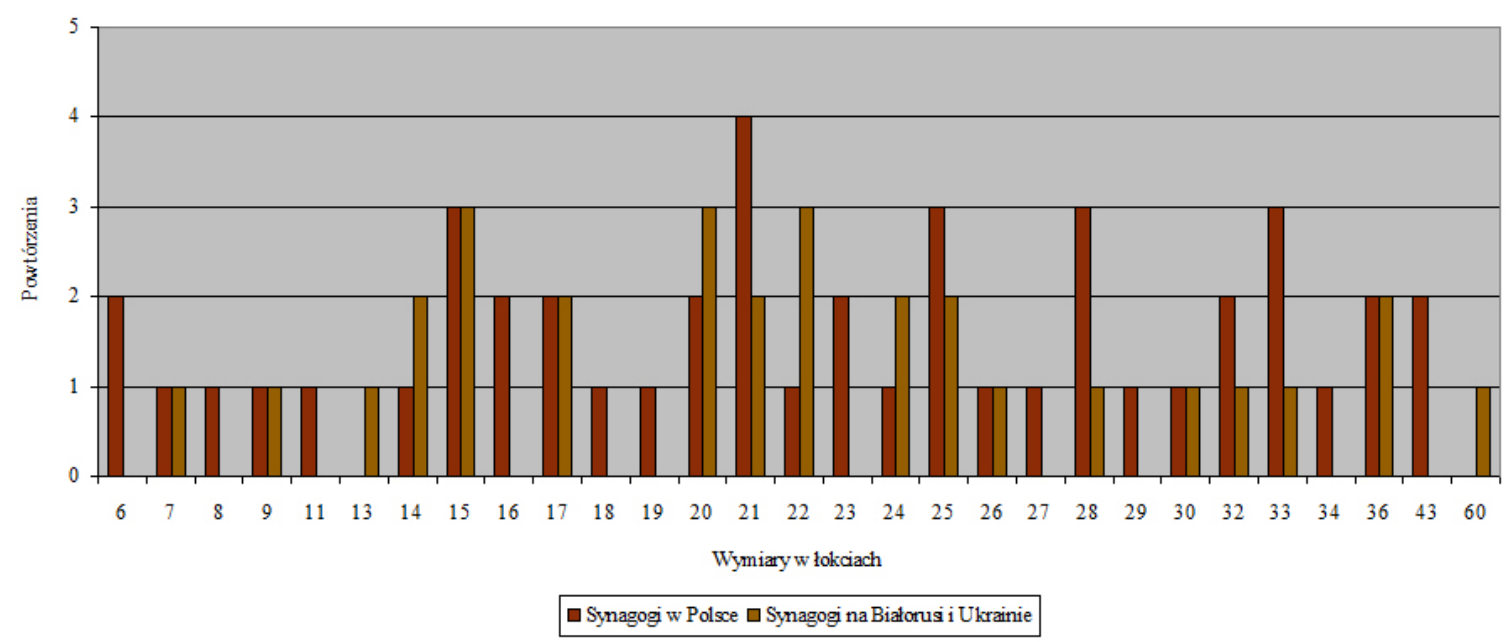

Il. 8.3. Zestawienie powtórzeń wartości liczbowych wymiarów badanych synagog w Polsce oraz na Białorusi i Ukrainie, wyrażonych w łokciach [21]

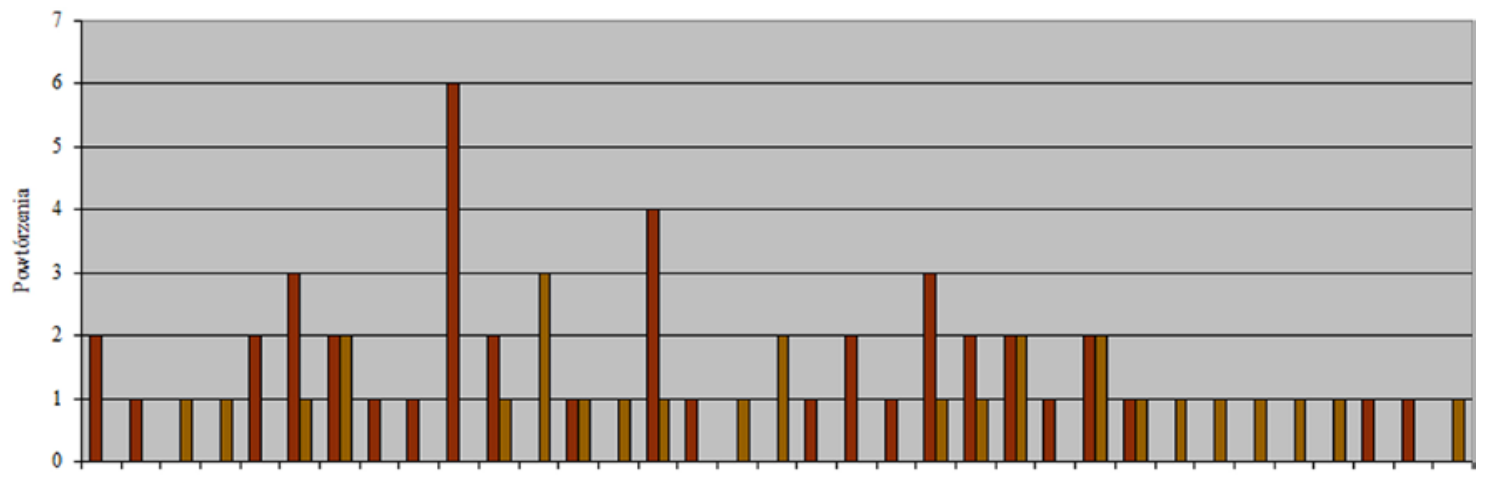

$\begin{array}{lllllllllllllllllllllllllllllllllll}11 & 13 & 19 & 21 & 23 & 25 & 27 & 29 & 31 & 33 & 35 & 36 & 37 & 38 & 39 & 41 & 43 & 45 & 47 & 49 & 51 & 53 & 55 & 57 & 61 & 63 & 67 & 69 & 71 & 77 & 85 & 93 & 99 & 101 & 107\end{array}$

Wymiaryw stopach

口 Synagogi w Polsce u Synagogi na Bialorus i Ukrainie

Il. 8.4. Zestawienie powtórzeń wartości liczbowych wymiarów badanych synagog w Polsce oraz na Białorusi i Ukrainie, wyrażonych w stopach [21]

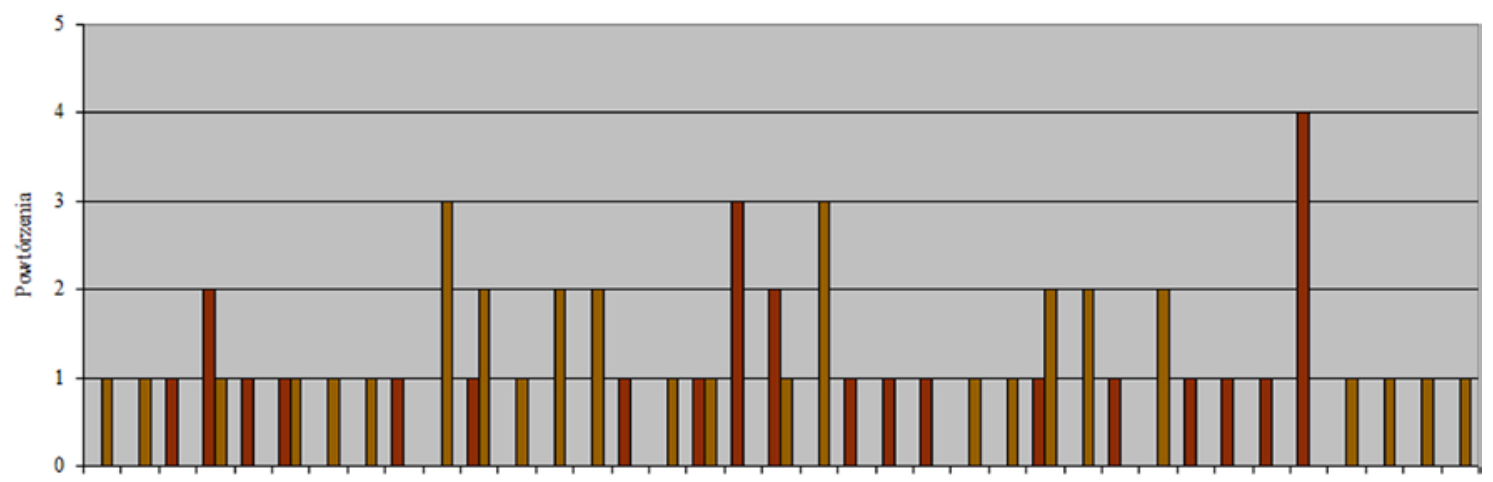

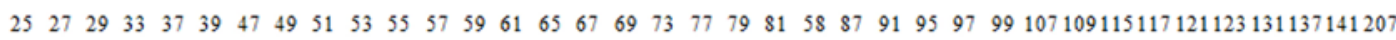

Wymiary w ćwierciach

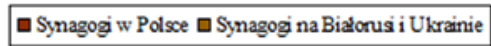

Il. 8.5. Zestawienie powtórzeń wartości liczbowych wymiarów badanych synagog w Polsce oraz na Białorusi i Ukrainie, wyrażonych w ćwierciach [21] 
8. Gematria w XVII- i XVIII-wiecznych synagogach...

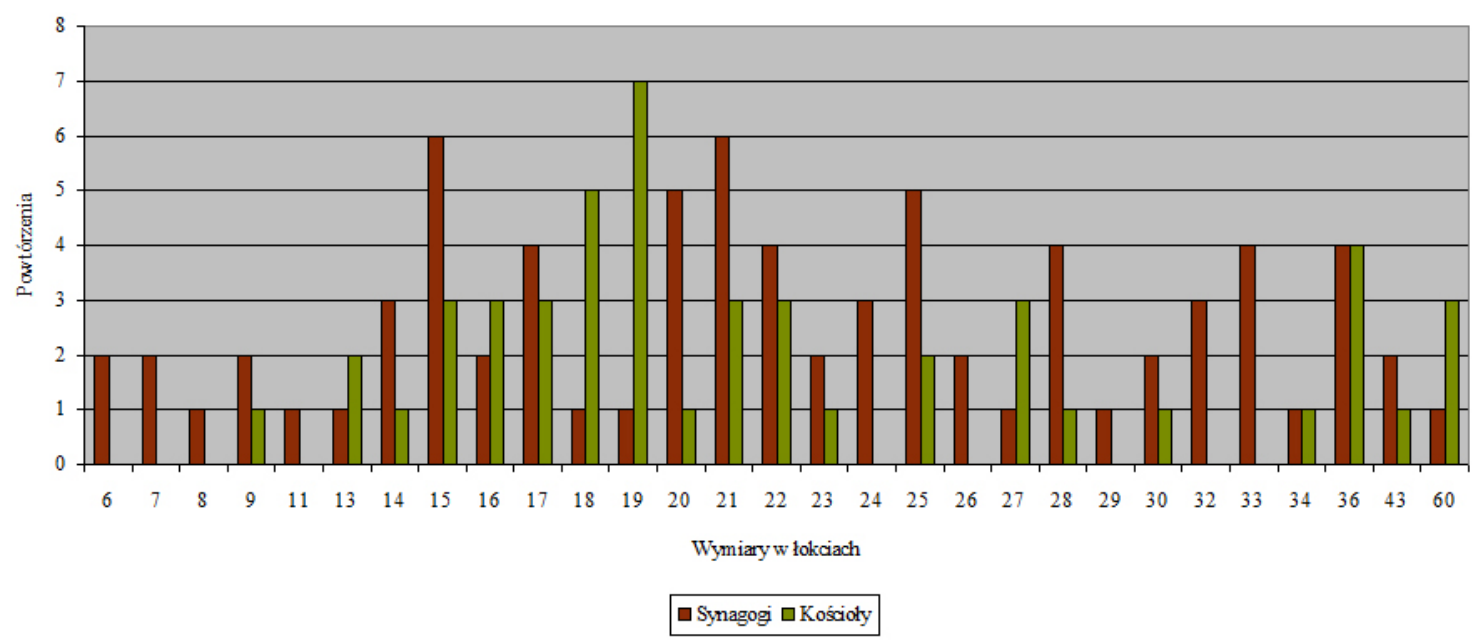

Il. 8.6. Zestawienie powtórzeń wymiarów wszystkich badanych synagog i kościołów, wyrażonych w łokciach [21]

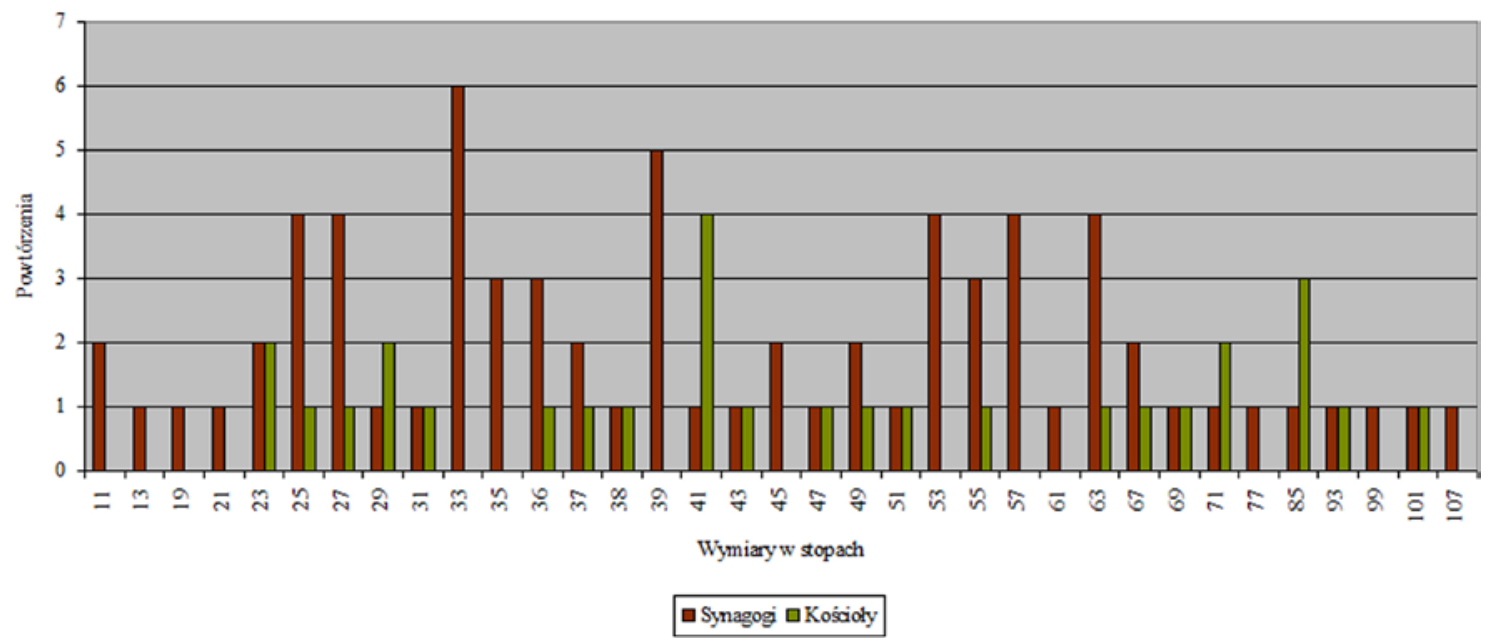

Il. 8.7. Zestawienie powtórzeń wymiarów wszystkich badanych synagog i kościołów, wyrażonych w stopach [21]

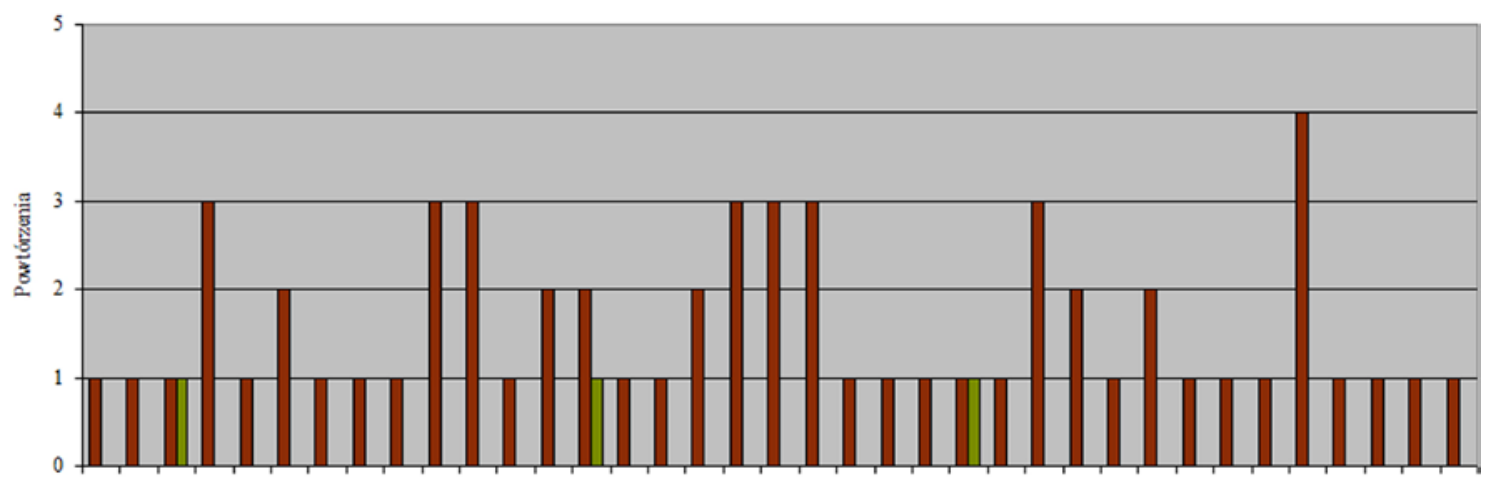

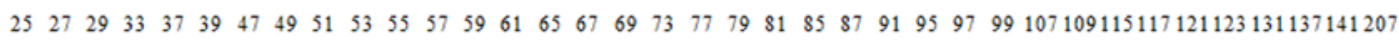
Wymiary w ćwierciach

\section{Synagogi $\square$ Kościoły}

Il. 8.8. Zestawienie powtórzeń wymiarów wszystkich badanych synagog i kościołów, wyrażonych w ćwierciach [21] 
Powtarzalność wymiarów w przypadku synagog znajdujących się w granicach Polski, Ukrainy i Białorusi wynosi więc 33\%, natomiast w przypadku kościołów i synagog na terenie Polski 40,5\%. Z analizy wynika zbieżność wymiarów całego zbioru synagog z XVII- i XVIII-wiecznymi kościołami na poziomie 43,5\%. Zatem na podstawie porównania wymiarów zarówno synagog z różnych obszarów, jak i obiektów sakralnych z obszaru Polski nie można stwierdzić jednoznacznych związków między wymiarami. Należy jednak pamiętać o dwóch istotnych czynnikach, które mogły spowodować takie wyniki analizy: znacznie większych gabarytach chrześcijańskich świątyń w porównaniu do dość małych synagog oraz zupełnie innej kompozycji funkcji i planu budowli reprezentujących jedno i drugie wyznanie. Obiekty tak odmienne wymagały stosowania równie odmiennych wymiarów w procesie kształtowania przestrzeni.

W przypadku porównania bożnic z różnych obszarów należy zaznaczyć, że pomimo ich podobieństwa jedynie w 33\% rozkład częstotliwości występowania wymiarów jest niezwykle zbliżony, co może wskazywać jednocześnie na szerszy zamysł w kształtowaniu architektury bożniczej.

\subsection{Analiza gematryczna}

W toku analizy metrologicznej wykazano, iż pewne wartości miar powtarzają się. Wartości te zostały poddane analizie gematrycznej. Dla danego wymiaru analizowane były wartości wyrażone zarówno w łokciach, stopach, ćwierciach, jak i calach. Dzięki temu uwzględnione zostały wszystkie możliwe kombinacje, które są efektem przeliczenia miar podstawowych (łokcia, stopy, ćwierci), a więc takich najbardziej zbliżonych do łokcia i wyrażających liczbę całkowita.

Badania w tym zakresie opierają się na analizie samej liczby w oderwaniu od jednostki miary. Takie działanie jeszcze lepiej uwidacznia powtarzalność wartości liczbowych.

Jednym z aspektów analizy wartości liczbowych jest częstotliwość ich występowania oraz to, których obiektów dotyczą. Przy opisie uwzględniono, czy dana wartość jest podstawowa, czy przeliczona 225 .

\subsubsection{Częstotliwość występowania poszczególnych wartości pomiarów}

Wartościami charakterystycznymi dla bożnic zlokalizowanych na terenie Polski są liczby:

- 33 i 66*, które pojawiają się jedenastokrotnie w siedmiu obiektach (w: Zamościu, Szczebrzeszynie, Tykocinie, Orli, Dukli, Łańcucie, Siemiatyczach) i należy je uznać za najczęstsze, przy czym liczba 66 jest efektem przeliczenia liczby 33;

- 25 i 50* (w Synagodze Starej w Rzeszowie oraz w synagogach w: Zamościu, Chęcinach, Bobowej, Włodawie, Siemiatyczach) oraz 39 (w synagogach w: Zamościu, Szczebrzeszynie, 
Chęcinach, Lesku, Bobowej oraz w Synagodze Nowomiejskiej w Rzeszowie), które pojawiają się sześciokrotnie;

$-396^{* 226}$ (w synagogach w: Zamościu, Szczebrzeszynie, Tykocinie, Orli, Łańcucie), która pojawia się jeden raz;

- 28 (w synagogach w: Tarnogrodzie (dwukrotnie), Łańcucie, Bobowej*, Dukli*), która pojawia się pięciokrotnie;

- 21, 100* i 600* (w synagogach w Zamościu i Bobowej oraz w Synagodze Starej w Rzeszowie (dwukrotnie)), 23 (w synagogach w: Pińczowie, Szczebrzeszynie, Chęcinach, Orli), 32 (w synagogach w: Tarnogrodzie, Pińczowie*, Szczebrzeszynie*, Bobowej*), 80* (w synagogach w: Szczebrzeszynie, Lesku, Tarnogrodzie oraz w Synagodze Nowomiejskiej w Rzeszowie), 123 i 738* (w synagogach w: Pińczowie, Włodawie, Tykocinie (dwukrotnie)), 132* (w synagogach w: Orli, Dukli, Siemiatyczach oraz w Synagodze Starej w Rzeszowie), 468* (w synagogach w: Zamościu, Szczebrzeszynie, Lesku oraz w Synagodze Nowomiejskiej w Rzeszowie), które pojawiają się czterokrotnie;

- 6 w synagodze w Łańcucie ${ }^{227}$, która pojawia dwukrotnie.

Wartości, które pojawiają się dwu- i trzykrotnie, zostały zebrane w tabeli 8.9.

Tabela 8.9. Wartości liczbowe charakterystyczne dla synagog

\begin{tabular}{|c|c|c|}
\hline \multirow{2}{*}{$\begin{array}{l}\text { Wartość } \\
\text { liczbowa }\end{array}$} & \multicolumn{2}{|c|}{$\begin{array}{c}\text { Lokalizacja synagogi, } \\
\text { w której dana wartość liczbowa wystąpiła: }\end{array}$} \\
\hline & trzykrotnie & dwukrotnie \\
\hline 11 & $\begin{array}{l}\text { Dukla, Orla, Synagoga Stara } \\
\text { w Rzeszowie }\end{array}$ & \\
\hline 14 & & Dukla, Bobowa* \\
\hline 15 & Tarnogród (dwukrotnie), Łańcut & \\
\hline 16 & Pińczów, Szczebrzeszyn i Bobowa* & \\
\hline 17 & & Chęciny, Orla \\
\hline 18,36 & & $\begin{array}{l}\text { Tykocin, Synagoga Nowomiejska } \\
\text { w Rzeszowie }\end{array}$ \\
\hline $20,40^{*}, 480^{*}$ & & Lesko, Tarnogród \\
\hline 22 & $\begin{array}{l}\text { Synagoga Stara w Rzeszowie, Dukla, } \\
\text { Orla }\end{array}$ & \\
\hline 24 & Bobowa, Łańcut* (dwukrotnie) & \\
\hline 26 & & Zamość, Synagoga Stara w Rzeszowie* \\
\hline 27 & Bobowa, Dukla, Siemiatycze & \\
\hline 29 & Szczebrzeszyn, Dukla, Włodawa & \\
\hline 30 & Dukla, Tarnogród*, Łańcut* & \\
\hline
\end{tabular}


8. Gematria w XVII- i XVIII-wiecznych synagogach...

\begin{tabular}{|c|c|c|}
\hline $34,68^{*}, 276^{*}$ & & Chęciny, Orla \\
\hline $35,70^{*}, 264^{*}$ & & Tykocin, Orla \\
\hline 37 & & $\begin{array}{l}\text { Lesko, Synagoga Nowomiejska } \\
\text { w Rzeszowie }\end{array}$ \\
\hline $42^{*}, 84^{*}, 504^{*}$ & $\begin{array}{l}\text { Zamość, Synagoga Nowomiejska } \\
\text { w Rzeszowie, Bobowa }\end{array}$ & \\
\hline $43,86^{*}, 172^{*}$ & & Włodawa, Siematycze \\
\hline 44 & & Orla, Synagoga Stara w Rzeszowie) \\
\hline $46^{*}$ & Chęciny, Pińczów, Szczebrzeszyn & \\
\hline 47 & & Łańcut, Orla* \\
\hline $48^{*}, 96^{*}$ & & Lesko, Dukla \\
\hline 51 & & Szczebrzeszyn, Bobowa \\
\hline $53,106^{*}, 636^{*}$ & $\begin{array}{l}\text { Lesko, Łańcut, Synagoga Nowomiejska } \\
\text { w Rzeszowie }\end{array}$ & \\
\hline $54^{*}$ & Dukla, Siemiatycze, Bobowa & \\
\hline 55 & $\begin{array}{l}\text { Bobowa, Dukla, Synagoga Stara } \\
\text { w Rzeszowie }\end{array}$ & \\
\hline $56^{*}$ i $60^{*}$ & Dukla, Tarnogród, Łańcut & \\
\hline 57 i $684^{*}$ & & Orla, Włodawa \\
\hline 58 & & Włodawa, Szczebrzeszyn \\
\hline $63,126^{*}, 756^{*}$ & & Orla, Lesko \\
\hline $64^{*}$ & Pińczów, Szczebrzeszyn, Tarnogród & \\
\hline $73,438^{*}$ & Pińczów, Włodawa (dwukrotnie) & \\
\hline $77,462^{*}$ & & Włodawa, Synagoga Stara w Rzeszowie \\
\hline $78^{*}$ & Zamość, Lesko, Chęciny & \\
\hline $92^{*}, 384$ & & Pińczów, Szczebrzeszyn \\
\hline $110^{*}, 660^{*}$ & & Dukla, Synagoga Stara w Rzeszowie \\
\hline $112^{*}, 360^{*}, 672^{*}$ & Tarnogród (dwukrotnie), Łańcut & \\
\hline $114^{*}$ & & Orla, Włodawa \\
\hline $144^{*}$ & & Tykocin, Łańcut \\
\hline $156^{*}$ & & Chęciny, Synagoga Stara w Rzeszowie \\
\hline $172^{*}, 1032^{*}$ & & Włodawa, Siemiatycze \\
\hline $300^{*}$ & Chęciny, Włodawa, Siemiatycze & \\
\hline $324^{*}$ & & Dukla, Siemiatycze \\
\hline $792^{*}$ & Orla, Dukla, Siemiatycze & \\
\hline
\end{tabular}

Źródło: opr. własne. 
Niektóre wartości liczbowe występują tylko jeden raz:

- 7, 8, 24, 48* $96^{*}, 108^{*}, 168^{*}, 192^{*}, 234^{*}, 306^{*}, 330^{*}, 576^{*}, 648^{*}$ w synagodze w Bobowej;

- 9, 67, 101, 115, 134* 202* 216* 222* $690^{*} 804^{*} 1212^{*}$ w Synagodze Nowomiejskiej w Rzeszowie;

- 13, 61, 65, 81, 88* $122^{*}, 390^{*}, 486^{*}, 528^{*}$ i $732^{*}$ w Synagodze Starej w Rzeszowie;

- $120^{*}, 174^{*}, 336^{*}, 720^{*}$ w synagodze w Dukli;

$-72^{*}, 432^{*}, 864^{*} \mathrm{w}$ synagodze w Tykocinie;

- $19,38^{*}, 41,76^{*}, 82^{*}, 128^{*}, 456^{*}, 492^{*}$ i $768^{*}$ w synagodze w Tarnogrodzie;

$-31,52^{*}, 62^{*}, 104^{*}, 372^{*}, 624^{*} \mathrm{w}$ synagodze w Zamościu;

$-552^{*}, 612^{*}, 696^{*} \mathrm{w}$ synagodze w Szczebrzeszynie;

- 97, 116* $136^{*}, 204^{*}, 582^{*} 936^{*}$ i $816^{*}$ w synagodze w Chęcinach;

- 99, 117 i 121, 198* $348^{*}, 1180^{*}$ w synagodze we Włodawie;

$-12^{*}, 85,94^{*}, 510^{*}, 564^{*}$ w synagodze w Łańcucie;

- 69 i $87,414^{*}, 522^{*}, 553^{*}$ w synagodze w Pinczowie;

$-107,408^{*}, 642^{*}$ w synagodze w Orli;

- 74*, 444*, 588* w synagodze w Lesku;

- $117,121,702^{*}, 726^{*}$ w synagodze w Siemiatyczach.

\subsubsection{Częstotliwość występowania podstawowych wartości} liczbowych w wymiarach synagog

Liczbą występującą w badanej grupie synagog najczęściej jest 33, które pojawia się jedenastokrotnie w grupie pomiarów wykonanych w siedmiu obiektach. Sześciokrotnie pojawiają się liczby 25 i 39, czterokrotnie: 21, 23 i 123. Inne wartości liczbowe występują trzykrotnie i rzadziej (rys. 8.9-8.10).

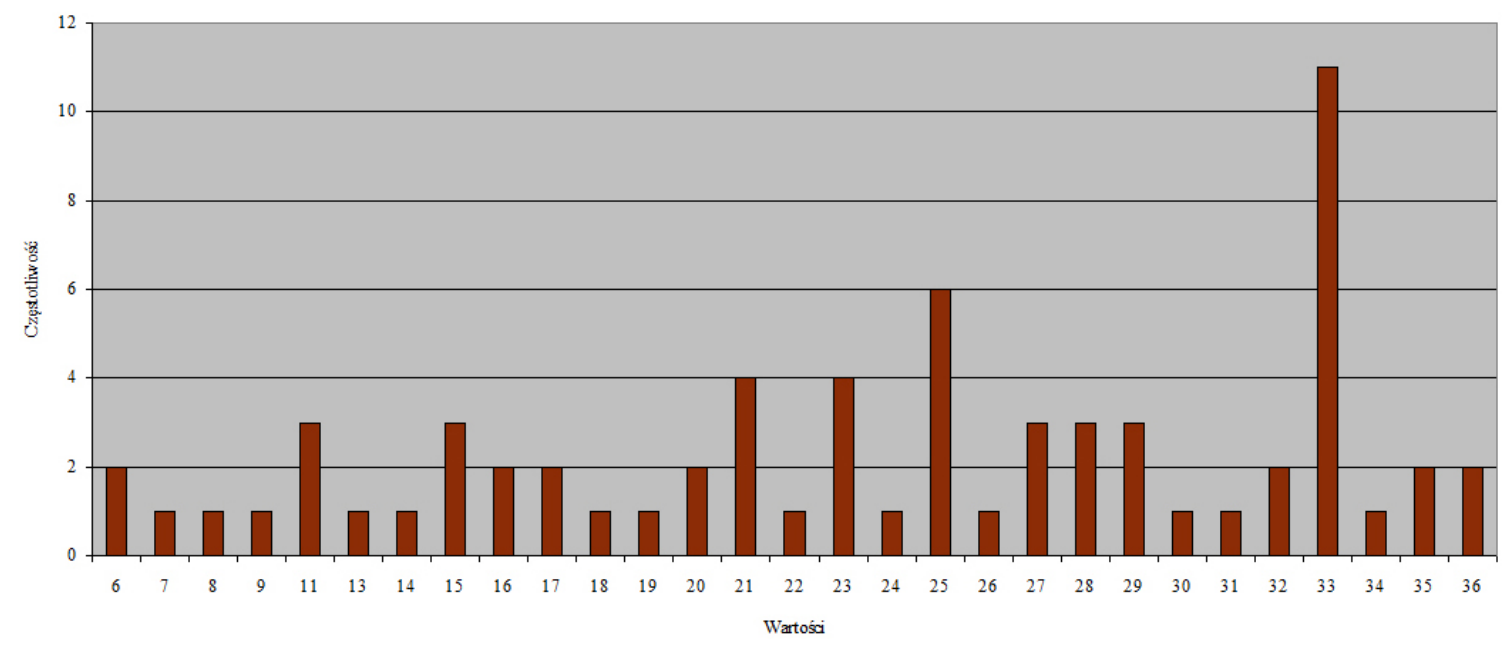

Il. 8.9. Częstotliwość występowania podstawowych wartości liczbowych w grupie wymiarów synagog zlokalizowanych na terenie Polski - cz. 1 [21] 


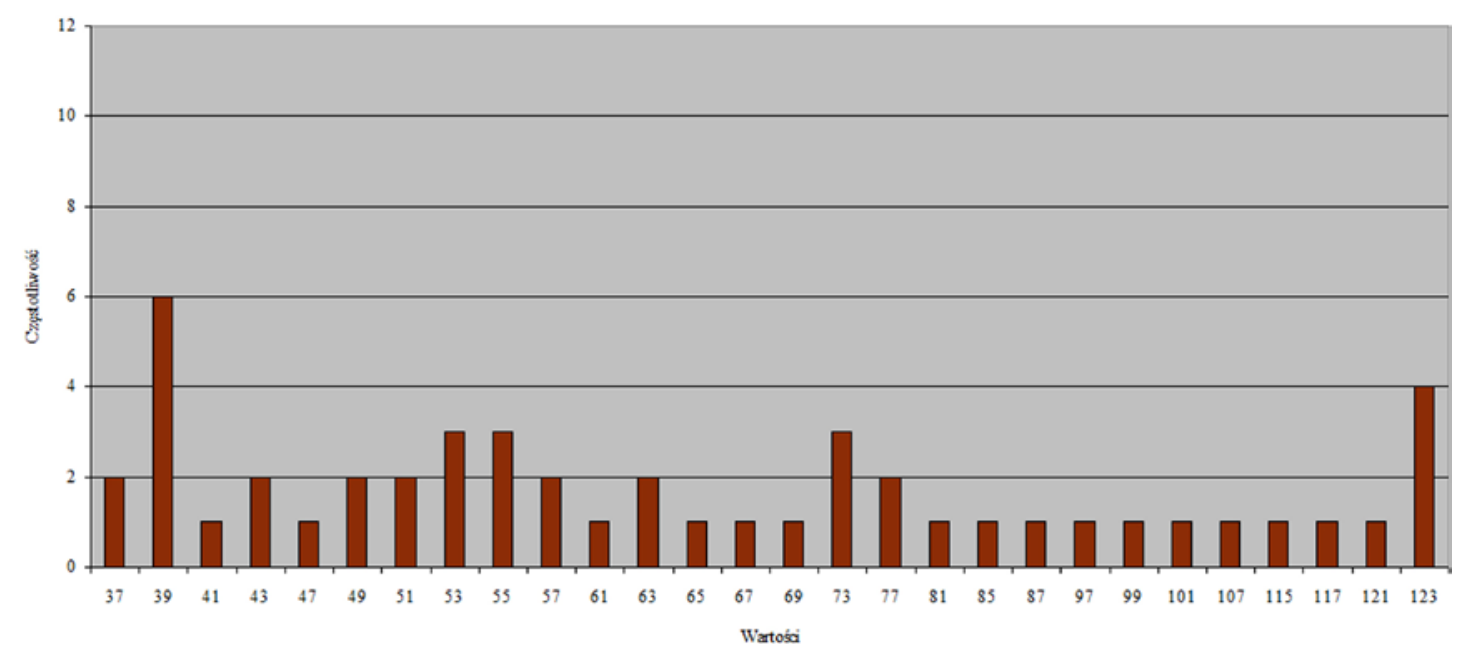

Il. 8.10. Częstotliwość występowania podstawowych wartości liczbowych w grupie wymiarów synagog zlokalizowanych na terenie Polski - cz. 2 [21]

\subsubsection{Częstotliwość występowania podstawowych wartości liczbowych w materiale porównawczym}

Podobnej analizie został poddany materiał porównawczy, który obejmował bożnice znajdujące się na Białorusi i Ukrainie (il. 8.11-8.12). Rozkład częstotliwości występowania podstawowych wartości liczbowych jest zdecydowanie bardziej zrównoważony w przypadku tych obiektów i oscyluje zwykle między trzy a jeden. Najczęściej, bo aż sześciokrotnie, pojawia się liczba 25. Za nią lokują się liczby: 36, 53, 63 reprezentowane pięciokrotnie, 79 i 57 reprezentowane czterokrotnie oraz 33 i 39 reprezentowane w tej grupie jedynie dwukrotnie.

Analiza zbioru synagog zarówno z obszaru obecnej Polski, jak i Białorusi i Ukrainy wskazuje na zwiększenie się częstotliwości występowania kilkunastu wartości (il. 8.13-8.14).

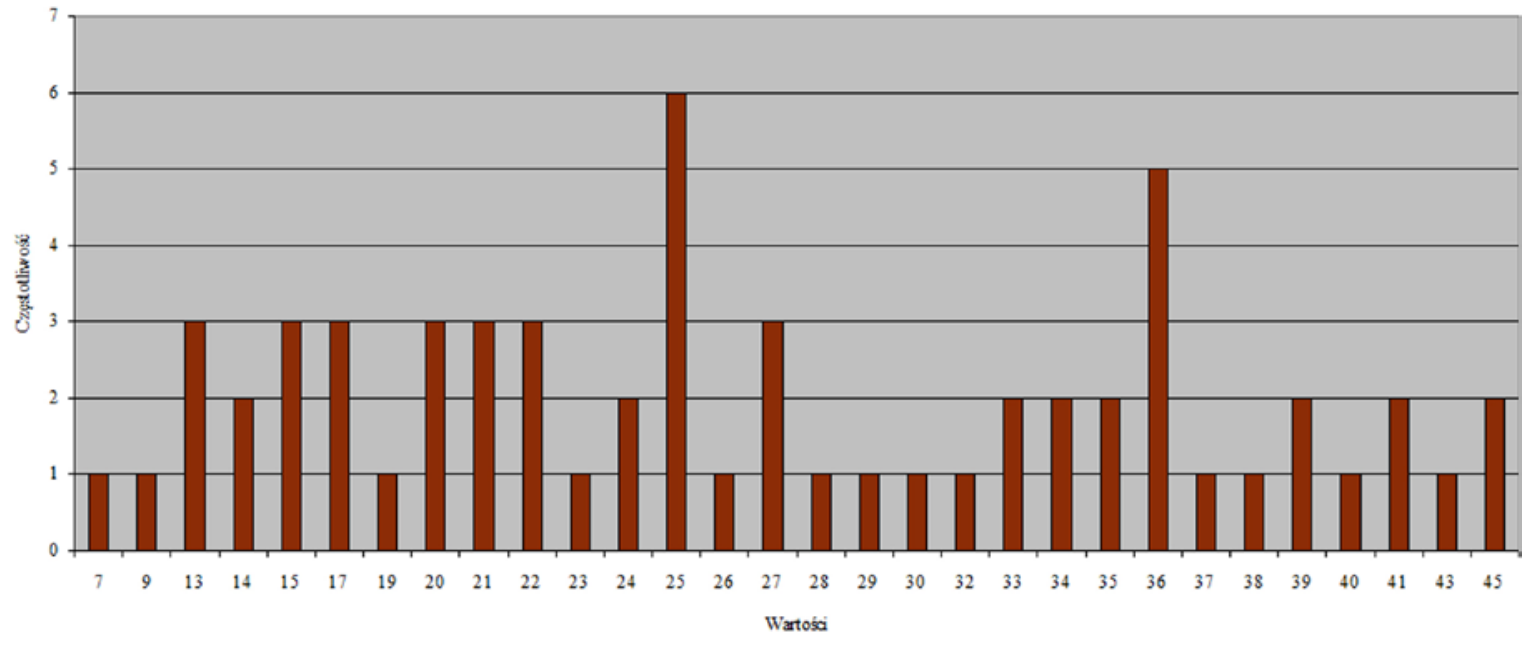

Il. 8.11. Częstotliwość występowania podstawowych wartości liczbowych w grupie wymiarów synagog zlokalizowanych na terenie Białorusi i Ukrainy - cz. 1 [21] 
8. Gematria w XVII- i XVIII-wiecznych synagogach...

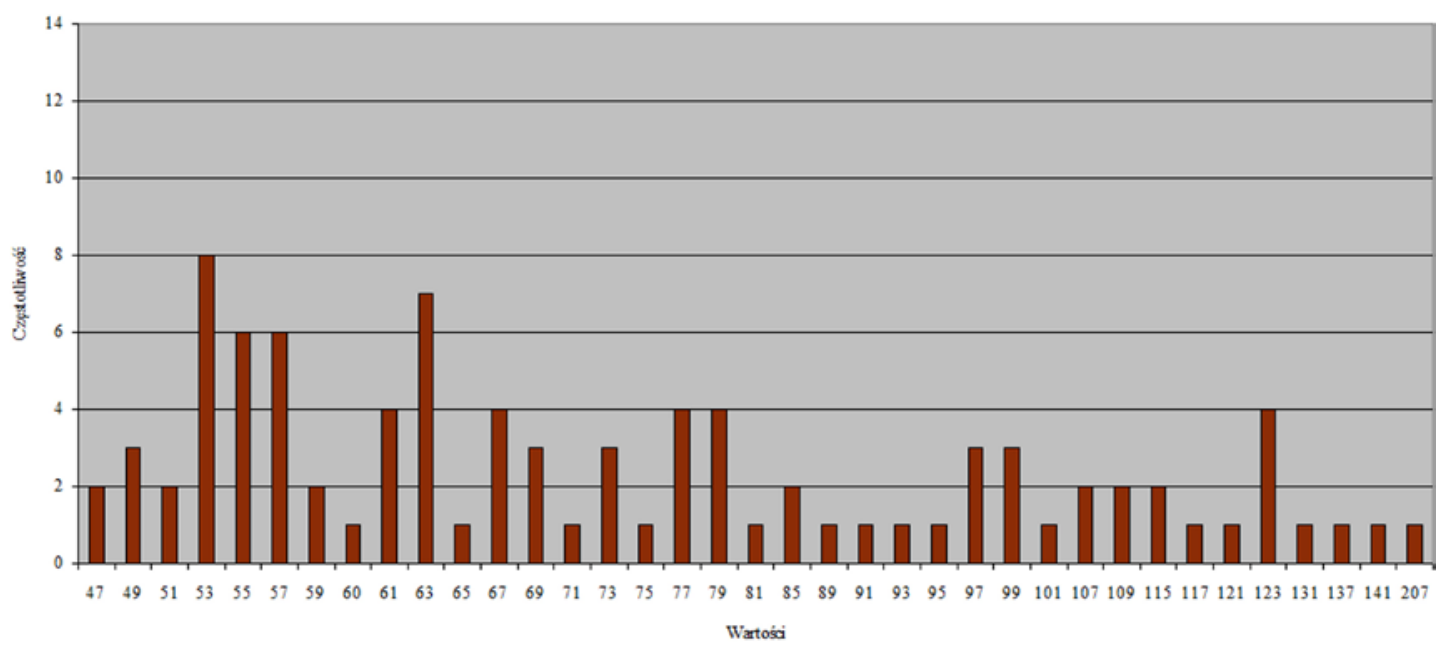

Il. 8.12. Częstotliwość występowania podstawowych wartości liczbowych w grupie wymiarów synagog zlokalizowanych na terenie Białorusi i Ukrainy - cz. 2 [21]

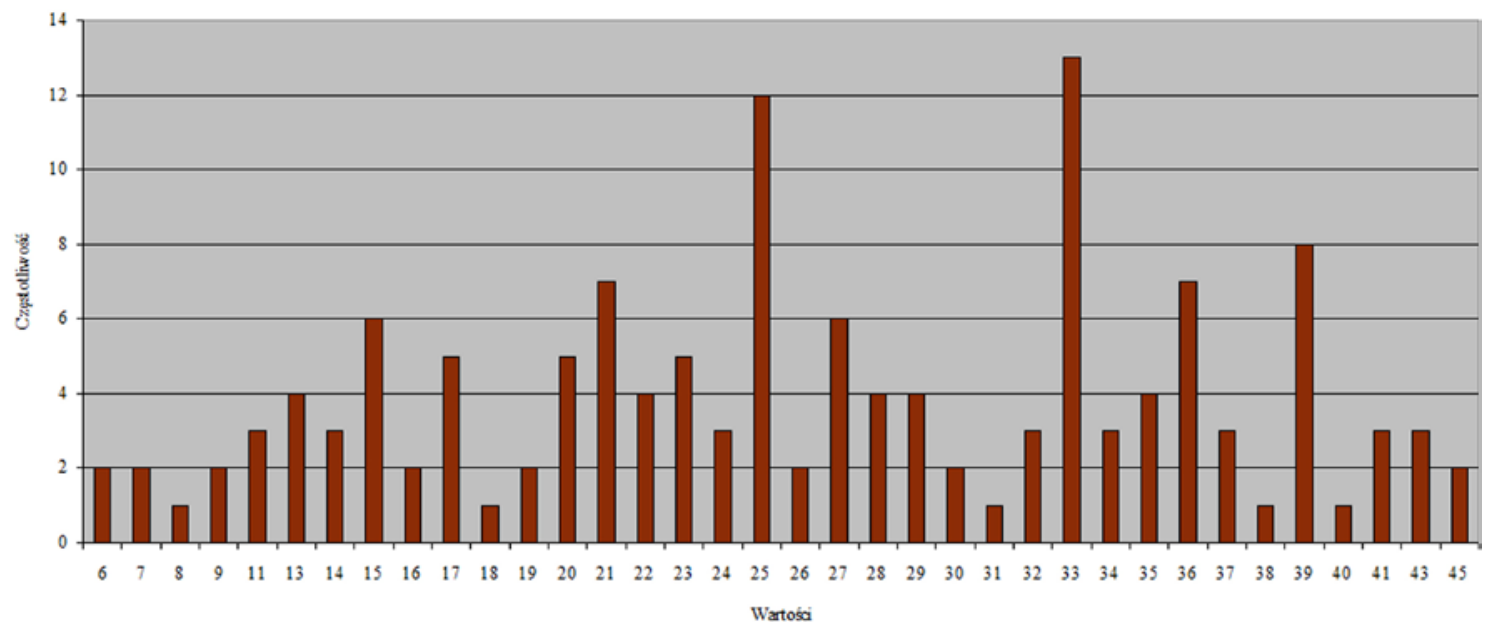

Il. 8.13. Częstotliwość występowania podstawowych wartości liczbowych w grupie wymiarów synagog zlokalizowanych na terenie Polski oraz Białorusi i Ukrainy - cz. 1 [21]

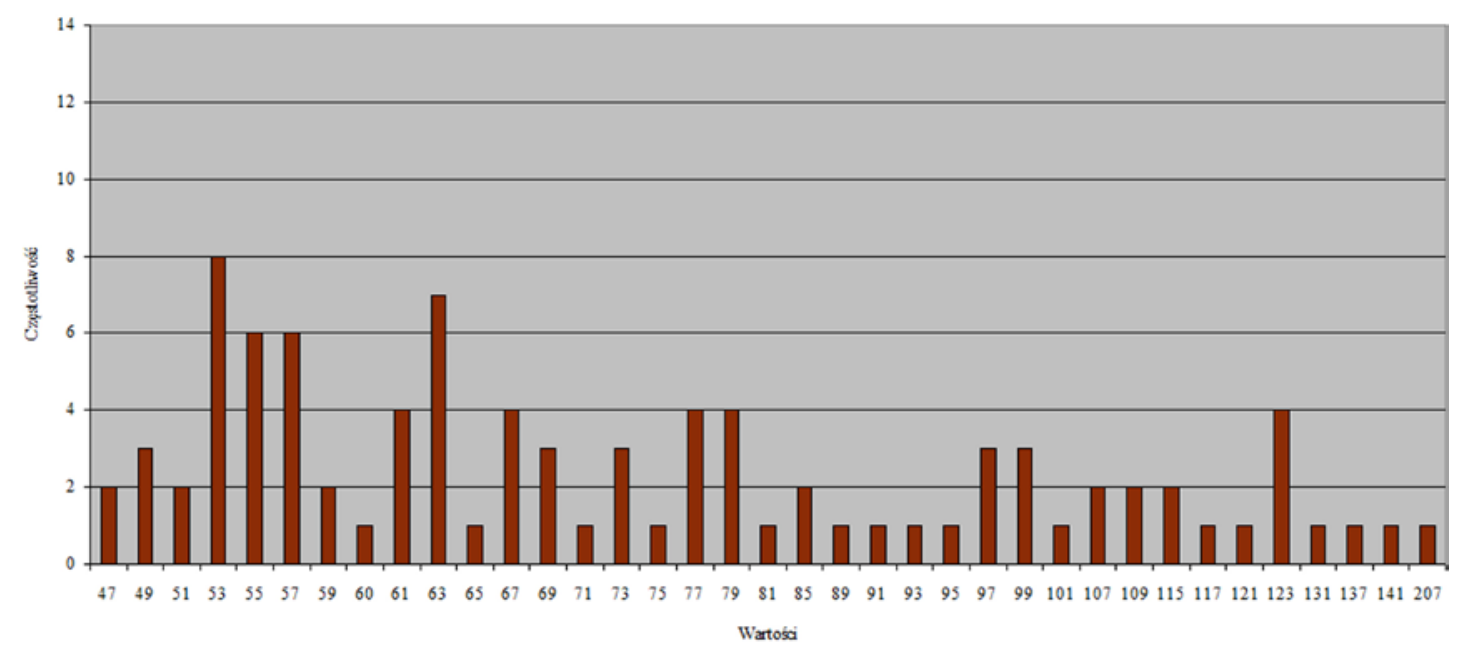

Il. 8.14. Częstotliwość występowania podstawowych wartości liczbowych w grupie wymiarów synagog zlokalizowanych na terenie Polski oraz Białorusi i Ukrainy - cz. 2 [21] 


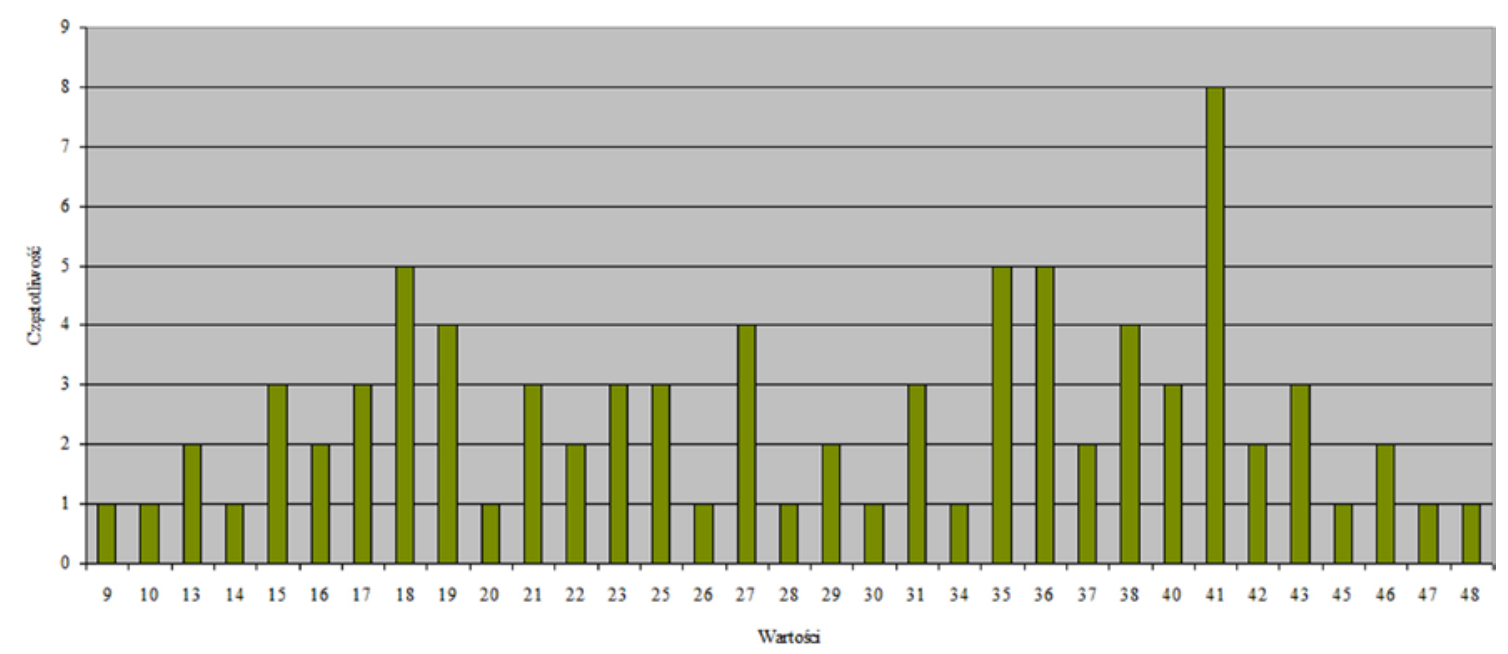

Il. 8.15. Częstotliwość występowania podstawowych wartości liczbowych w grupie wymiarów XVIIi XVIII-wiecznych kościołów [21]

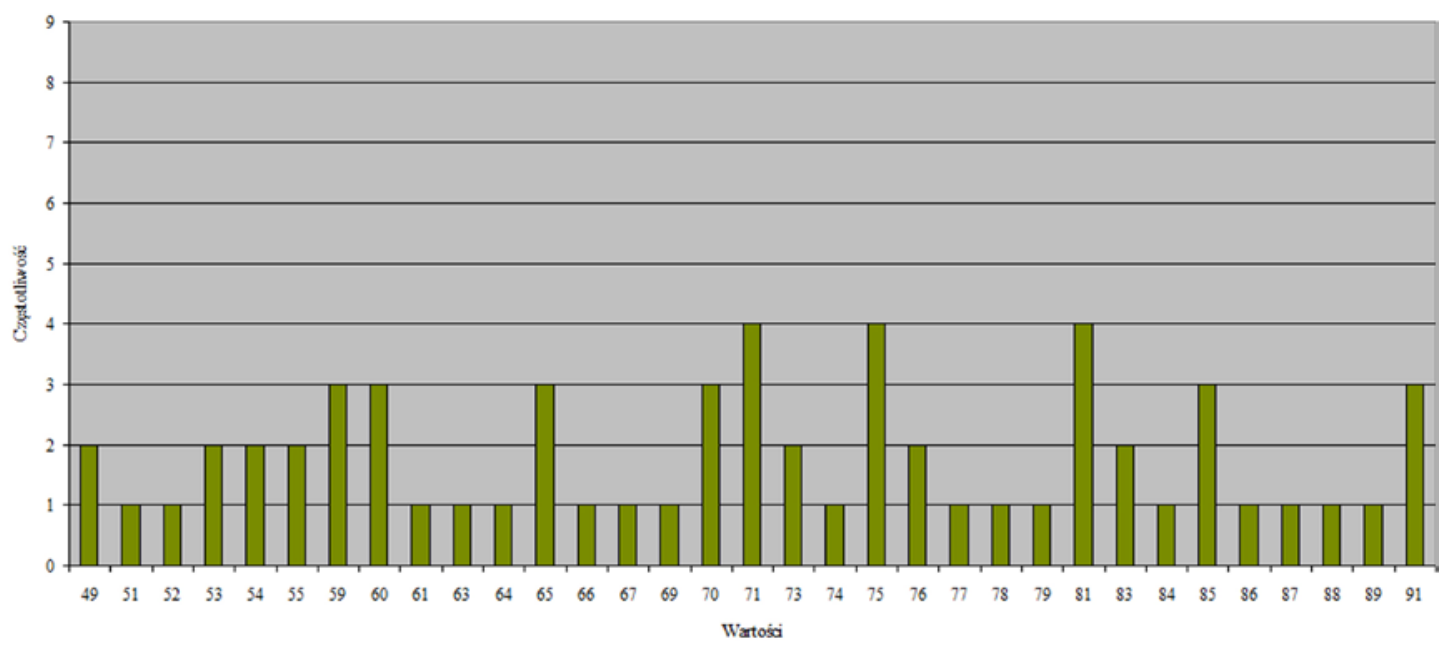

Il. 8.16. Częstotliwość występowania podstawowych wartości liczbowych w grupie wymiarów XVII-i XVIII-wiecznych kościołów - cz. 2 [21]

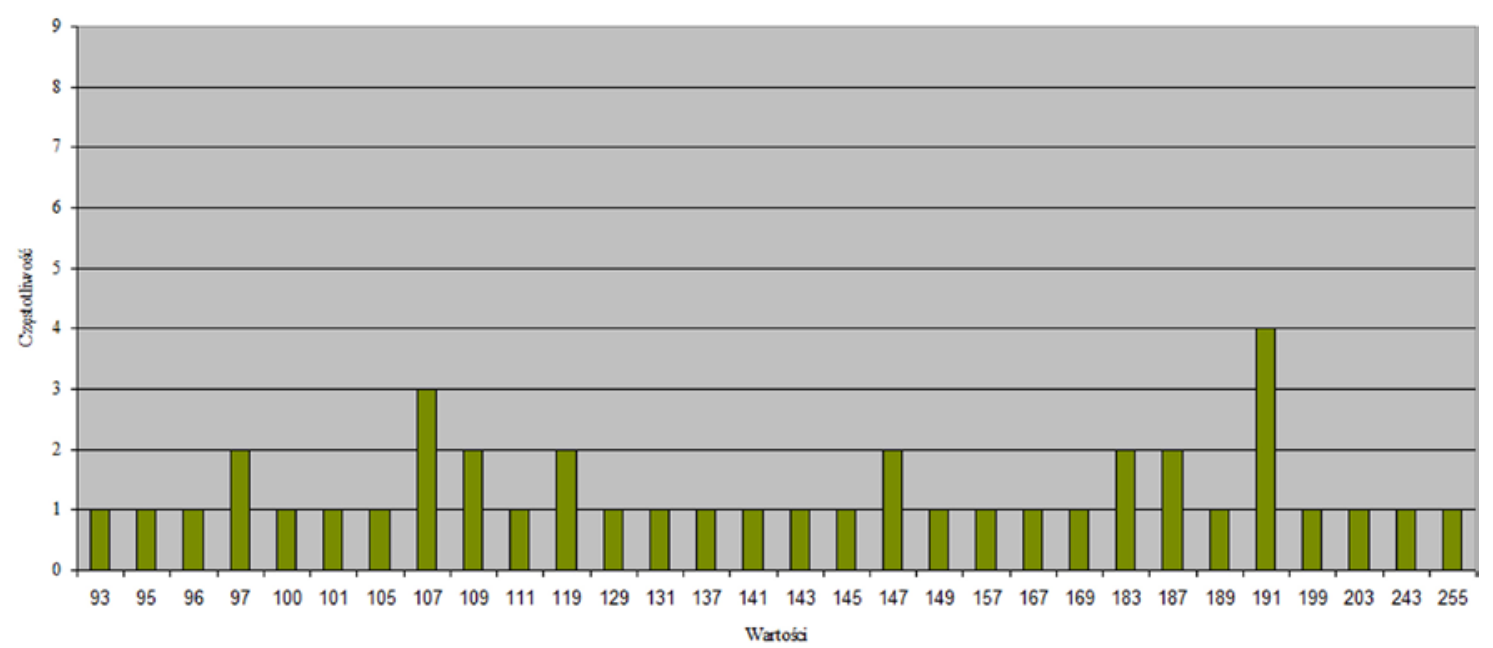

Il. 8.17. Częstotliwość występowania podstawowych wartości liczbowych w grupie wymiarów XVIIi XVIII-wiecznych kościołów - cz. 2 [21] 
Aż trzynastokrotnie, czyli z największą częstotliwością, w grupie tej pojawia się liczba 33. Następnie 12 razy pojawia się liczba 25, osiem razy liczby 39 i 53, siedem razy liczby: 21, 36 i 63, sześć liczby: 15,27, 55, 57, pięć razy liczby: 17, 20, 23, czterokrotnie liczby: 13, 22, 28, 29, 35, 61, 77, 79, 12. Pozostałe wartości pod względem częstotliwości wystąpień mieszczą się w przedziale od trzech do jednego.

Drugim elementem analizy porównawczej były kościoły powstałe w Polsce w XVII i XVIII wieku. Z analizy częstotliwości występowania wartości wymiarów przeprowadzonej dla tego zbioru (il. 8.15-8.17) wynika, że w tej grupie wiodąca jest liczba 41, która pojawiła się aż ośmiokrotnie. Za nią znajdują się zanotowane pięciokrotnie liczby: 18, 35 i 36, , czterokrotnie: 19, 27, 38, 71, 75, 81, 191 oraz trzykrotnie: 15, 17, 21, 23, 25, 31, 40, 59, 60, 65, 70, 85, 91, 107. Najliczniejszymi grupami są zbiory, dla których częstotliwość wynosi jeden lub dwa.

\subsubsection{Podsumowanie}

Przeprowadzając analizę porównawczą częstotliwości wystąpień wartości liczbowych wymiarów XVII- i XVIII-wiecznych kościołów oraz bożnic z tego samego okresu, powstałych w granicach dawnej Polski, należy zwrócić uwagę na kilka prawidłowości.

W grupie wymiarów synagog liczba 33 występuje najczęściej, nie posiada jednak reprezentacji w grupie wymiarów analizowanych kościołów. Podobnie jest w przypadku liczb 39 i 53, a także: $6,7,8,32,99,123,207$, przy czym siedem ostatnich wartości występuje raczej rzadko. Liczba 25 jest nadreprezentowana w grupie wymiarów bożnic (12 wystąpień), natomiast w grupie wymiarów kościołów pojawia się zaledwie trzykrotnie. Liczba 21 występuje siedmiokrotnie w grupie wymiarów bożnic, natomiast w grupie wymiarów kościołów jedynie trzykrotnie. Liczba $20 \mathrm{w}$ grupie wymiarów bożnic pojawia się pięciokrotnie częściej niż w grupie wymiarów kościołów, liczby: 28, 53 i 61 czterokrotnie częściej, a liczby: 34, 55, 69 i 97 trzykrotnie częściej. Dwukrotnie częściej w grupie wymiarów bożnic pojawiają się wartości: 13, 15, 22, 26, 29, 30, 45, 47.

Z porównania wynika również, że pewne wartości liczbowe występują w grupie wymiarów kościołów od około dwóch do czterech razy częściej niż w grupie wymiarów bożnic. Do grupy tej należą liczby: 18, 19, 31, 38, 40, 41, 59, 60, 65, 71, 75, 81, 85, 91, 107.

Wśród 73 przeanalizowanych wartości liczbowych można wyróżnić dwie grupy:

1) Piętnaście wartości liczbowych, które pojawiają się częściej w grupie wymiarów kościołów niż synagog i stanowią 20,5\% całej puli charakterystycznej dla tych drugich.

2) Wartości liczbowe o tej samej częstotliwości występowania w grupie wymiarów zarówno kościołów, jak i synagog. Istotne są w tym przypadku liczby: 16, 49, 89, 93, 95, 101, 109, 131, 137, 147, które stanowią 13,7\% całej puli wielkości charakterystycznych dla wartości liczbowych wymiarów synagog.

Można zatem stwierdzić, że 65,8\% przeanalizowanych wartości liczbowych występuje częściej w grupie wymiarów bożnic niż w kościołów (il. 8.18-8.20). 


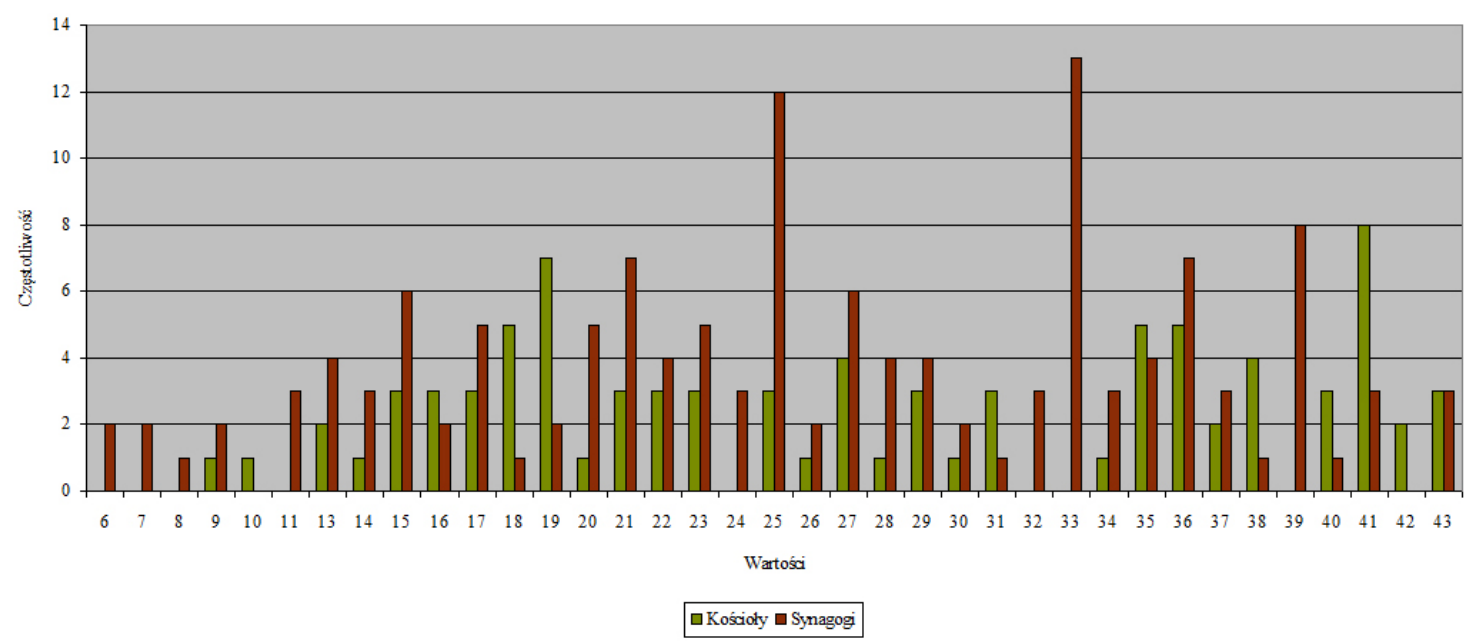

Il. 8.18. Zestawienie częstotliwości występowania podstawowych wartości liczbowych w grupie wymiarów synagog i kościołów - cz. 1 [21]

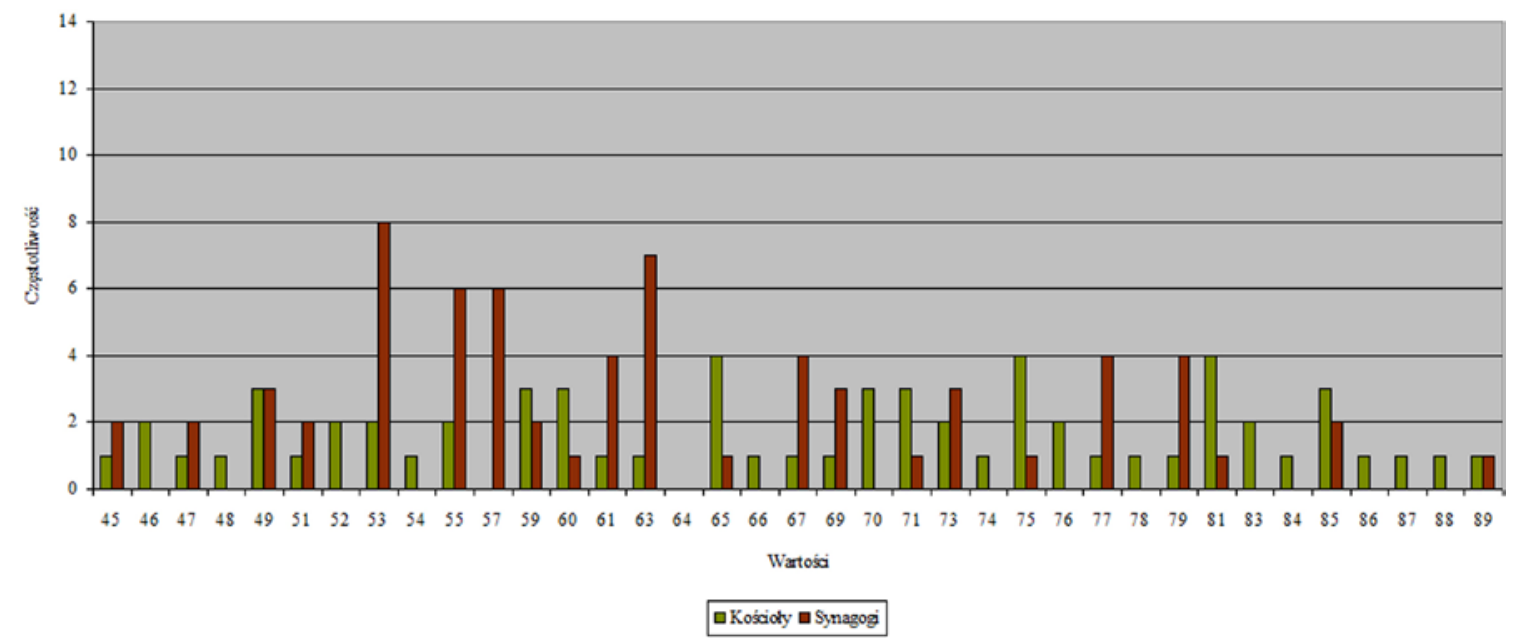

Il. 8.19. Zestawienie częstotliwości występowania podstawowych wartości liczbowych w grupie wymiarów synagog i kościołów - cz. 2 [21]

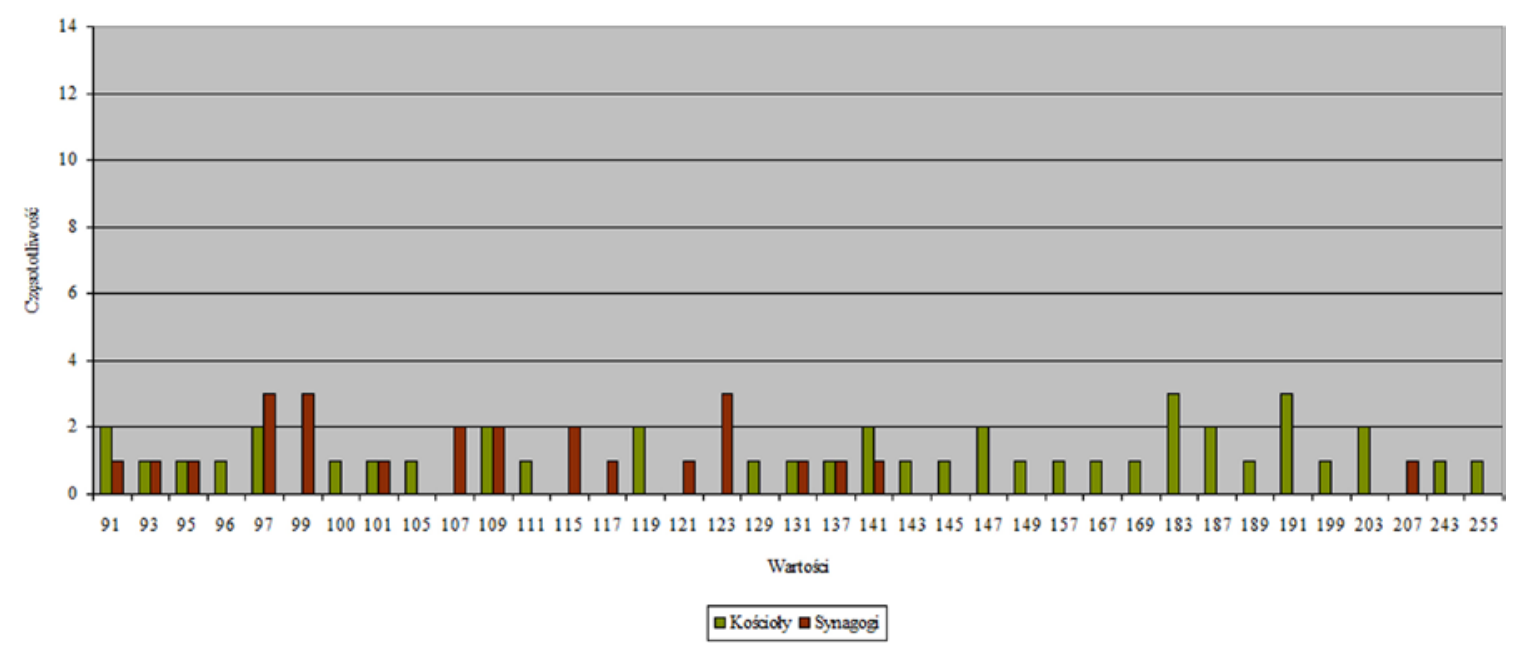

Il. 8.20. Zestawienie częstotliwości występowania podstawowych wartości liczbowych w grupie wymiarów synagog i kościołów - cz. 3 [21] 
Mając już pełen przegląd wartości liczbowych wymiarów oraz częstotliwości ich występowania, warto przeanalizować znaczenie poszczególnych liczb w duchu gematrii oraz zastanowić się nad ich symbolicznym charakterem i intencjonalnością stosowania takich, a nie innych wartości w architekturze synagogalnej.

\subsubsection{Analiza gematryczna modlitw}

Porównując wartości liczbowe w grupie synagog zlokalizowanych w Polsce oraz grupie synagog zlokalizowanych na Ukrainie i Białorusi, należy zwrócić uwagę na znikomą powtarzalność wartości liczbowych. Jednocześnie zarówno w jednej, jak i drugiej grupie brak jest wartości, które mogłyby być ważne z punktu widzenia kombinatoryki kabalistycznej. Niezwykle istotna przy poszukiwaniu znaczenia wartości liczbowych wydaje się analiza modlitw, które odmawiano w trakcie liturgii synagogalnej. Jak już wskazano w podrozdziale 4.1, inskrypcje stanowiły jeden z istotnych elementów wystroju wnętrz synagog, a wśród nich najważniejsze były modlitwy wykorzystywane w trakcie liturgii. Kompozycja modlitw przedstawianych w synagodze wykazuje duży związek z kompozycją Pięcioksięgu [59, s. 744]: są dość niejednorodnymi tworami, które swój sens uzyskują w wyniku połączenia różnych fragmentów. Heterogeniczność kompozycji tekstu liturgicznego wynika - jak się wydaje $\mathrm{z}$ braku jednoznacznych przepisów co do wyboru tekstów i miejsca ich umieszczenia w bożnicy. Jest to zupełnie odwrotnie niż w przypadku lokalizowania przedmiotów stanowiących elementy kultu świątynnego, które uzyskały swoje stałe miejsca w dekoracji.

Analizując dostępne inskrypcje synagogalne, trudno jest określić motywy przewodnie, którymi kierowano się przy wyborze odpowiednich tekstów. Poza kwestią utylitarną - o czym wspomniano powyżej - istotny był również kierunek, w którym zwracano się w trakcie odmawiania danej modlitwy. Właściwie poza kilkoma przykładami tekstów powtarzających się w wielu obiektach (w tym Lecha Dodi), trudno jest znaleźć jeden, który byłby powielany na szeroką skalę. Typowe wydaje się raczej niezwykle indywidualne podejście każdej wspólnoty, chociaż niewątpliwie przeważają modlitwy na święta oraz bardziej powszechne teksty związane z obchodzeniem szabatu. Proporcje jednych do drugich w różnych obiektach są różne. I jak wynika z zachowanych polichromii analizowanych obiektów, w synagodze w Tykocinie z jednej strony zasób tekstów jest dość ubogi, ale z drugiej liczbę modlitw na święta równoważy liczba tych odmawianych w dni powszednie i w czasie szabatu. Inaczej jest w synagodze w Pińczowie, gdzie w obrębie sali męskiej modlitwy na dni powszednie nie tylko przeważają, ale są umieszczone w najbardziej widocznych miejscach. W bożnicy w Łańcucie istotnym elementem są teksty psalmów, które stanowią 30\% wszystkich inskrypcji znajdujących się we wnętrzu. W każdym z obiektów istniał więc pewien zamysł co do przedstawionych treści, jak i ich kompozycji. Nie można jednak określić jednoznacznie grupy tekstów, która byłaby reprezentatywna dla większej grupy obiektów. 
Ze względu na brak bazy, która zawierałaby przykłady dekoracji synagog, do analizy przeprowadzonej w tej części pracy wybrane zostały najważniejsze modlitwy wspólnotowe, a także indywidualne (Szema Israel, Tikkun Chacot). Pod uwagę brane były przede wszystkim te teksty, które w liturgii nabrały znaczenia począwszy od XVII wieku, najpierw pod wpływem między innymi mistycyzmu, a od XVI wieku kabały luriańskiej [68, s. 49] [34, s. 389-390]. Zmiany będące efektem oddziaływania mistycyzmu miały charakter innowacyjny. Nie wpływały jednak na ogólny układ liturgii ani tekstów modlitw, ale dotyczyły raczej wprowadzenia medytacji, hymnów, pieśni i kawwanot [68, s. 49].

Wiek XVII jest okresem, w którym pojawia się wiele drukowanych modlitewników. Szczególna obfitość tego rodzaju publikacji jest w tym okresie widoczna we wschodniej Europie, w okresie rozkwitu społeczności żydowskiej. Pod wpływem kabały luriańskiej oraz prac Natana Spiry i Izajasza Horowitza do modlitewników wprowadzono znaczną ilość treści nacechowanych mistycyzmem [34, s. 390], między innymi hymny figdal, Adon Olam czy pieśń na rozpoczęcie szabatu Lecha dodi.

Analizie poddane zostały w pierwszej kolejności dwie modlitwy: Szema Israel oraz Szemone Esre (Amida). Szema Israel ma charakter modlitwy prywatnej, która jest istotna, ponieważ pełni funkcję wyznania wiary. Zawiera trzy podstawowe prawdy religijne judaizmu: wiarę w jednego Boga, wiarę w nagrodę i karę oraz wiarę w objawienie boże wyrażone za pośrednictwem Tory. Mieści także trzy podstawowe przykazania: miłości Boga, poddania się Jego opatrzności oraz podporządkowania się prawu wyrażonemu w Torze. Szemone Esre (Osiemnaście), która początkowo zawierała osiemnaście błogosławieństw, ma charakter modlitwy publicznej, odmawianej wspólnie przez zgromadzonych w synagodze ${ }^{228}$ [68, s. 49].

W XVII wieku została rozpowszechniona pieśn Lecha dodi (por. podrozdz. 4.2). Napisana przez Salomona ha-Lewi Alkabec w XVI wieku [68, s.128] stała się hymnem na powitanie szabatu. Szczególny charakter tej pieśni przejawia się we włączeniu dzięki niej przestrzeni w modlitwę poprzez odwrócenie się w trakcie śpiewu, przed ostatnią zwrotką w kierunku drzwi, a więc zwykle tyłem do Aron ha-Kodesz. Ponieważ przeprowadzona analiza obejmuje domy zgromadzeń jeszcze z końca XVI wieku, a Lecha dodi jest pieśnią, która w Polsce stała się popularna w drugiej dekadzie XVII wieku, uwagę zwrócono również na modlitwę $\mathrm{Ka}$ balat Szabat (Przyjęcie Szabatu) wprowadzoną około 1600 roku przez Mojżesza Cordovero. Składała się z sześciu Psalmów ${ }^{229}$ o znaczeniu symbolicznym - każdy z nich odpowiadał jednemu z sześciu dni tygodnia, a suma pierwszych liter wersetów psalmów dawała 430, czyli wartość słowa nefesz (dusza). Dodatkowo w psalmach tych Tetragram występował osiemnastokrotnie, czyli z częstotliwością równą pierwotnej liczbie błogosławieństw w Amidzie [68, s. 51].

Wśród przeanalizowanych tekstów znalazł się również hymn figdal. Ten XIII-wieczny pijut (poemat religijny) odmawiano w trakcie porannych i wieczornych nabożeństw. Często łączony był również z Adon Olam. Bazuje na trzynastu prawdach wiary sformułowanych przez Majmonidesa. Innym nabożeństwem, które było efektem wpływu ruchów kabali- 
stycznych w Safedzie, było Tikkun Chacot (nabożeństwo o północy). W trakcie jego trwania, w prawie ciemnym wnętrzu synagogi i zwykle w pozycji siedzącej każdy Żyd indywidualnie, wśród płaczu odmawiał treny o zburzeniu Jerozolimy i rozproszeniu Izraela. Pierwsze informacje o tym obrzędzie można odnaleźć już w Szulchan Aruch [79, Orech Chaim 1,2-4].

Tikkun Chacot jest podzielony na dwie części: Tikkun Rachel i Tikkun Lea, których tytuły pochodzą od imion dwóch żon patriarchy Jakuba. Tikkun Rachel odprawia się, siedząc na podłodze lub niskim stołku. Przed przystąpieniem do tego obrzędu należy zdjąć buty, a głowę posypać popiołem w miejscu tefilinu i przykryć szalem, co wskazuje na akt żałoby. W trakcie Tikkun Lea należy siedzieć na krześle.

Ostatnim tekstem, który poddano analizie, była Pieśń Chwały - Szir Hakawod (Anim Zemirot) - przypisywana rabinowi Jehudzie he-Chasidowi (1150-1217). Jest ona śpiewana przez zgromadzenie, a jej wyjątkowość wynika z tego, że nie odmawia się jej w dni powszednie oraz śpiewa się przy otwartych drzwiach Aron ha-Kodesz.

Analiza gematryczna wskazanych tekstów ma na celu ustalenie, czy i z jaką częstotliwością pojawiają się wartości liczbowe tożsame z wartościami liczbowymi wymiarów charakterystycznymi dla synagog zlokalizowanych na terenie Polski. Może to świadczyć o tym, że pewne wartości liczbowe są bardziej powszechne w stosunku do innych. Przedmiotem badań było również to, czy fragmenty analizowanych modlitw mogły w jakikolwiek sposób stanowić semantyczny ekwiwalent wykazanych powyżej wartości liczbowych wymiarów oraz czy w ciągach znaków odpowiadających słowom modlitw można stwierdzić występowanie ciągów znaków odpowiadających kolejnym wymiarom bożnic.

Analizę tej części oparto na trzech wspomnianych powyżej metodach gematrii. Poniżej każdego tekstu hebrajskiego wskazane są wartości kolejno dla metody absolutnej, uproszczonej i redukcyjnej. Jednocześnie w przypadku każdej metody podana jest sumaryczna wartość każdego fragmentu. Kolorem czerwonym zaznaczono wartości liczbowe, które pojawiły się $\mathrm{w}$ analizowanych obiektach.

\subsubsection{Szema Israel ${ }^{230}$}

Słuchaj, Jisraelu - Haszem jest naszym Bogiem, Haszem jest jedyny.

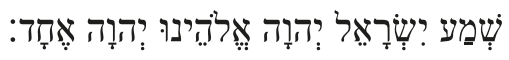

$1118=132610226541410$

$227=132648266450$

$92=131721171014$

Błogosławione imię chwały Jego królestwa na wieki.

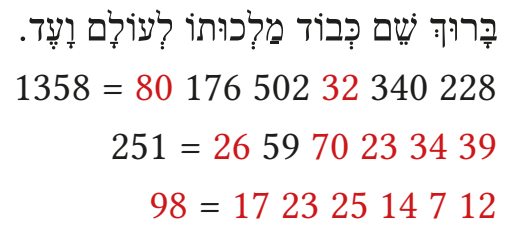


Będziesz kochał Haszem, twojego Boga - całym twoim sercem, całą twoją duszą i z całej twojej mocy.

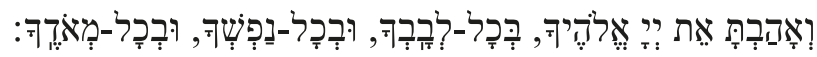

$1644=65584505854526626401414$

$330=29316331272539262336$

$123=11131813971217518$

I te rzeczy, które Ja przykazuję ci dzisiaj - będą w twoim sercu.

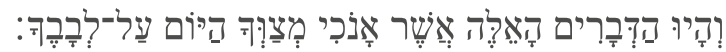

$1282=5410061156815014126127$

$319=272834483642235427$

$121=910162196141818$

Powtarzaj je twoim dzieciom i mów o nich - gdy będziesz siedział w domu i gdy będziesz szedł drogą, i gdy będziesz kładł, i gdy będziesz wstawał.

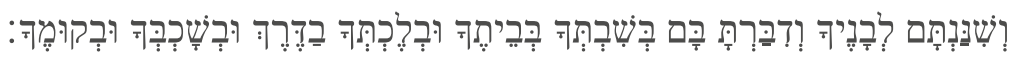
3998 = 17435022647843472442612112846

$524=57533764475815544990$

$155=2117101911136181327$

Przywiąż je jako znak na ręce, i będą ozdobą (tefilin) pomiędzy twoimi oczami.

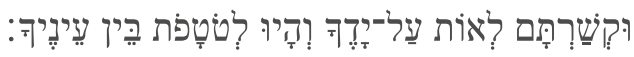
$2394=1606252827341004371046$

$378=61266927252841101$

$126=16833187101420$

I wypisz je na odrzwiach twojego domu, i na twoich bramach.

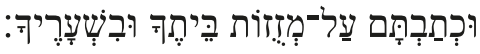

$$
\begin{aligned}
& 2468=608432460100868 \\
& 290=8645552876 \\
& 92=239281022
\end{aligned}
$$

I będzie [tak], jeśli posłuchacie Moich przykazań, które Ja wam dzisiaj ukazuję - by kochać Haszem, waszego Boga, i służyć Mu całym waszym sercem i całą waszą duszą.

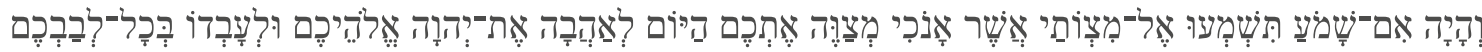

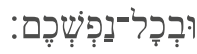
$4503=49058945211810626401436146114181501546316184104126$ $795=7631402546522623253447423642691378501426$ $291=221313728161751616112496244241457$

Dam waszej ziemi deszcz we właściwym czasie, [deszcz] jesienny i [deszcz] wiosenny i zbierzesz twoje zboże i twój moszcz winny twoje, i twoją oliwę.

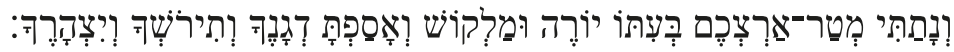

$4538=33193677547482221478351249866$ $596=70903261774146634274$ 
$191=25181425231419181520$

Dam trawę na twoim polu dla twojego bydła i będziesz jadł, i nasycisz się.

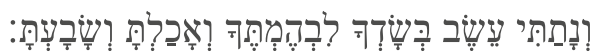

$3296=778457497326372866$

$335=675265383974$

$101=221620111220$

Strzeżcie się, aby nie zwiodły was wasze serca i byście się nie odwrócili, i nie służyli bożkom, i nie składali im pokłonów.

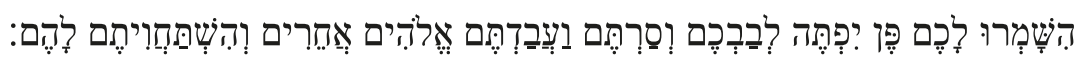
$4183=751175259865227069449513090551$ $601=30113524163764054313665$

$205=124116142722131813920$

[Bo wtedy] zapłonie na was gniew Haszem, zamknie niebo i nie będzie deszczu, a ziemia nie wyda swojego plonu; będziecie wytrąceni z ziemi dobrej, którą Haszem wam dał.

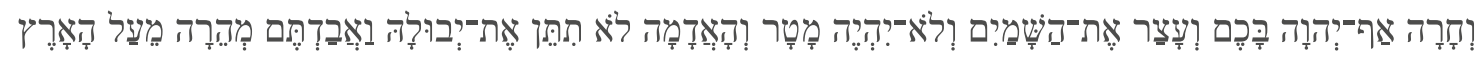

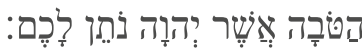

$5539=9050026501212961402504535340185031612493037395401366622681219$ $859=365026422144414348352358133442301962236026261839$ $337=91417621171416211751342515121017524817921$

Weźcie to sobie do waszych serca i do waszych dusz; przywiążcie je jako znak do waszej ręki, i będą ozdobą (tefilin) pomiędzy waszymi oczami.

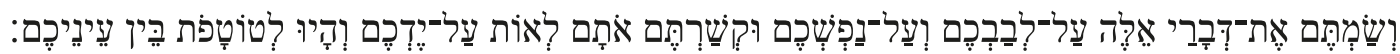
$5150=20062534277410043744110464901069410036216401786$ $775=742675273828413610176344028183623$ $254=20839181110149202216131099521$

Uczcie ich wasze dzieci, mówiąc o nich - gdy będziesz siedział w domu, i gdy będziesz szedł drogą, i gdy będziesz się kładł, i gdy będziesz wstawał.

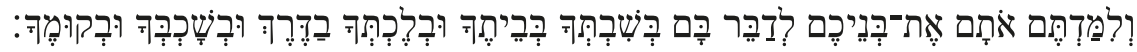
4148 = 17435022647843472442236122401441520 $548=575337644758153850233670$ $161=211710191113611145925$

I wypisz je na odrzwiach twojego domu, i na twoich bramach.

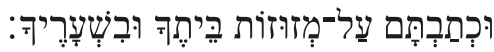
$2474=608432466100868$ $296=8645612876$

$98=239341022$

Aby pomnożyły się wasze dni i dni waszych dzieci na ziemi, którą Haszem przysiągł dać waszym ojcom - jak dni nieba nad ziemią.

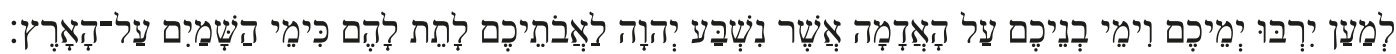


$4099=2961003958075830503264225015510012266120218190$

$751=4428624430567126534228285039573855$

$229=17101781211171717619101412121119$

Powiedział Haszem do Moszego:

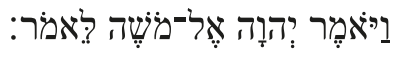

$$
\begin{aligned}
& 930=2713453126257 \\
& 174=4639132650 \\
& 57=1012417410
\end{aligned}
$$

Mów do synów Jisraela i powiedz im, niech uczynią sobie cicit na rogach swoich ubrań, na pokolenia, i [niech] umieszczą na rogach cicit nić [koloru] techelet.

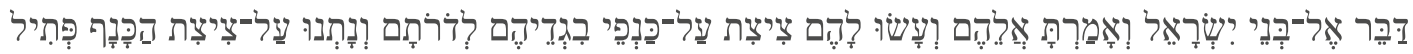

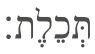

$6335=8505201555901005126746416010059075382766475416231206$

$890=67614768286271375228683049316264261326$

$287=13162023102617191610231222131710848$

To będzie dla was cicit, zobaczycie go i przypomnicie sobie wszystkie przykazania Haszem, będziecie je spełniać i nie zwrócicie się za waszymi sercami i za waszymi oczami, za którymi błądzicie.

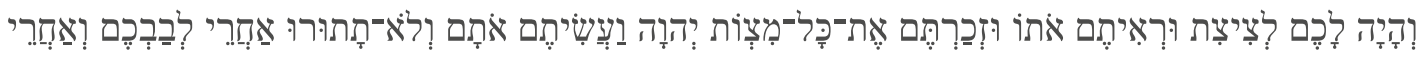

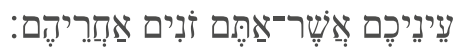

$7853=2641074415012002259421910123744182626536504016734076576209026$ $1049=57443642744540397619368826592323792972803626$ $338=21179620181312221092517235525111826917$

Abyście pamiętali i spełniali wszystkie Moje przykazania, i abyście byli świętymi dla waszego Boga.

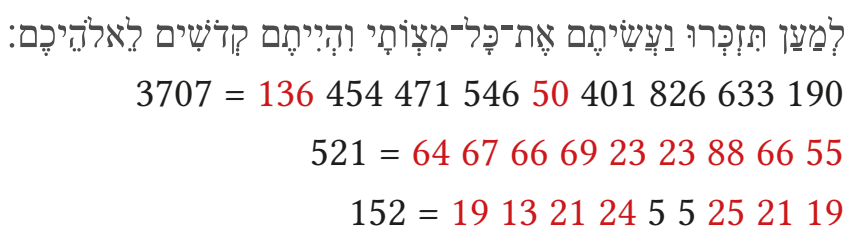

Ja jestem Haszem - wasz Bóg, wyprowadziłem was z ziemi egipskiej, aby być dla was Bogiem, Ja jestem Haszem wasz Bóg.

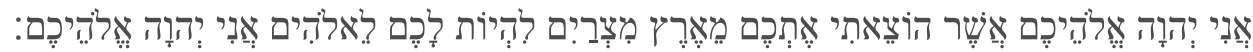
$3228=1062661116904513803314615125011062661$ $627=5226255336557452476242522625$ $204=161771791920161126616177$

Analiza Szema Israel [119] przeprowadzona z zastosowaniem trzech metod gematrii wykazała, że średnie pokrycie wartości liczbowych odpowiadających podstawowym wymiarom wynosi $45 \%$, przy czym metodą absolutną uzyskano $30 \%$, uproszczoną $60 \%$, a redukcyjną 47\%. Dla wszystkich analizowanych wartości średnia wynosi $27 \%$, przy czym metodą abso- 
lutną uzyskano $28 \%$, uproszczoną $34 \%$, a redukcyjną $19 \%$. W wyniku zastosowania trzech metod pokryto $84 \%$ wartości podstaw ow ych i $57 \%$ wszystkich analizowanych wartości liczbowych.

Szczególnie ciekawe jest to, że kilka wartości liczbowych wymiarów analizowanych fragmentów odpowiada wartościom liczbowym wymiarów bożnic. Zależności te stwierdzono jednak tylko przy przeliczeniach wykonanych metodami redukcyjną i uproszczoną, co najprawdopodobniej spowodowane jest wartością wymiarów podstawowych, zamykających się $\mathrm{w}$ przedziale od 6 do 123 . Wartości otrzymane w wyniku przeliczenia zwiększają przedział do 1212. Suma słów we fragmentach przeliczanych metodą absolutną wynosi natomiast znacznie więcej niż wartość liczbowa maksymalnego przeliczonego wymiaru.

Na podstawie analizy metodami uproszczoną i redukcyjną stwierdzono istnienie zależności w synagogach zlokalizowanych w takich miastach, jak:

\section{Pińczów}

Długość synagogi （92): Słuchaj, Jisraelu - Haszem jest naszym Bogiem, Haszem jest jedyny.

(92): I wypisz je na odrzwiach twojego domu, i na twoich bramach.

Szerokość synagogi (123): Będziesz kochał Haszem, twojego Boga - całym twoim sercem, całą twoją duszą i z całej twojej mocy.

\section{Szczebrzeszyn}

Długość sali męskiej (92): Słuchaj, Jisraelu - Haszem jest naszym Bogiem, Haszem jest jedyny.

(92): I wypisz je na odrzwiach twojego domu, i na twoich bramach.

\section{Chęciny}

Szerokość sali męskiej (204): Ja jestem Haszem - wasz Bóg, wyprowadziłem was z ziemi egipskiej, aby być dla was Bogiem, Ja jestem Haszem wasz Bóg.

\section{Tykocin}

Długość sali męskiej (123): Będziesz kochał Haszem, twojego Boga - całym twoim sercem, całą twoją duszą i z całej twojej mocy.

Szerokość sali męskiej (123): Będziesz kochał Haszem, twojego Boga - całym twoim sercem, całą twoją duszą i z całej twojej mocy.

\section{Orla}

Szerokość synagogi (126): Przywiąż je jako znak na ręce, i będą ozdobą (tefilin) pomiędzy twoimi oczami.

Długość sali męskiej (57): Powiedział Haszem do Moszego.

\section{Lesko}

Długość synagogi

(126): Przywiąż je jako znak na ręce, i będą ozdobą (tefilin) pomiędzy twoimi oczami. 
Szerokość synagogi (98): Błogosławione imię chwały Jego królestwa na wieki.

(98): I wypisz je na odrzwiach twojego domu, i na twoich bramach.

\section{Rzeszów (Synagoga Nowomiejska)}

Długość synagogi (101): Dam trawę na twoim polu dla twojego bydła i będziesz jadł, i nasycisz się.

\section{Bobowa}

Wysokość centralnego (330): Będziesz kochał Haszem, twojego Boga - całym twoim sercem, pola całą twoją duszą i z całej twojej mocy.

\section{Dukla}

Szerokość sali męskiej (98): Błogosławione imię chwały Jego królestwa na wieki.

(98): I wypisz je na odrzwiach twojego domu, i na twoich bramach.

Szerokość bimy ～(174): Powiedział Haszem do Moszego.

\section{Włodawa}

Długość sali męskiej (123): Będziesz kochał Haszem, twojego Boga - całym twoim sercem, całą twoją duszą i z całej twojej mocy.

Szerokość sali męskiej (57): Powiedział Haszem do Moszego.

\section{Siemiatycze}

Długość sali męskiej (121): I te rzeczy, które Ja przykazuję ci dzisiaj - będą w twoim sercu.

Częstotliwość występowania poszczególnych wartości liczbowych w Szema Israel dowodzi, że nie mogło ono stanowić jedynej podstawy wartości wymiarów bożnic. Wynika to przede wszystkim z faktu, że częstotliwość ta nie pokrywa się z częstotliwością występowania wymiarów synagog. Wartości najczęstsze w Szema Israel wiążą się z wynikami przeliczeń metodą uproszczoną lub redukcyjną. Generalnie wartości pokrywają się z wymiarami występującymi jeden raz lub powtarzającymi się dwu-, trzy- i czterokrotnie w różnych obiek$\operatorname{tach}^{231}$. W grupie tej brakuje jednak najczęstszych wymiarów lub są słabo reprezentowane. Liczba 33 - charakterystyczna dla siedmiu obiektów - pojawia się tylko raz, w wyniku przeliczeń metodą redukcyjną, podobnie jak liczba 66, która występuje dwukrotnie, w wyniku przeliczeń metodami redukcyjną i uproszczoną. Lepsze są wyniki uzyskane w przypadku wartości liczbowych charakterystycznych dla sześciu obiektów: liczba 25 pojawia się sześciokrotnie w wyniku przeliczeń metodą uproszczoną i siedmiokrotnie w wyniku przeliczeń metodą redukcyjną; liczba 50 pojawia się dwukrotnie w wyniku przeliczeń metodą absolutną i sześciokrotnie w wyniku przeliczeń metodą uproszczoną. Liczba 39 pojawia się siedmiokrotnie w wyniku przeliczeń metodą uproszczoną i raz w wyniku przeliczeń metodą redukcyjną. Liczby 132, 396 i 468, które są również efektem przeliczenia, nie wstępują ani razu. 


\subsubsection{Szemone esre - Amida ${ }^{232}$}

Panie! Otwórz moje wargi, a moje usta będą głosić Twoją chwałę! [137, Ps 51,17]

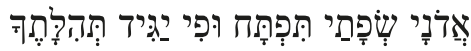

$$
\begin{aligned}
& 2721=855279688879065 \\
& 300=722733697029 \\
& 93=18915241611
\end{aligned}
$$

Błogosławiony jesteś Ty, Haszem, Bóg nasz i Bóg ojców naszych, Bóg Awrahama i Bóg Jicchaka, Bóg Jaakowa, Bóg wielki, potężny i straszliwy, Bóg Najwyższy, który wyświadcza dobrodziejstwa i stwarza wszystko, pamięta o dobroci Praojców i sprowadza wybawiciela dla dzieci ich dzieci, ze względu na swoje Imię, w miłości.

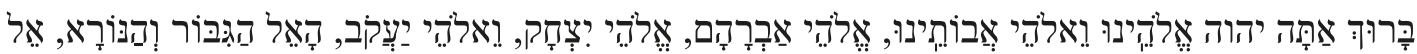

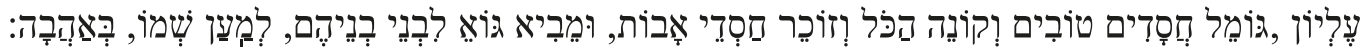

592622882409239551676712279166312682163618252208462484647552102 $4857=153461901079240$ 4438223231375028504050345813523618473455284128613448262839 $1212=154055$

1319171113141319231023222316224251891116191014102516211710 $505=1510$

Zapamiętaj nas na życie, Królu pragnący życia. I zapisz nas w księdze Życia, przez wzgląd na Siebie, Boże Żyjących ${ }^{233}$.

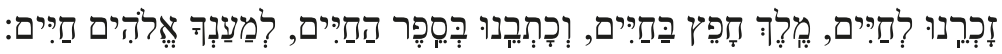
$1982=688621073342484701789098283$

$542=4141664654614343365358$ $200=141421191825162591722$

Królu pomagający. Wybawco i Tarczo.

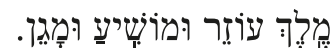
$904=9943228390$

$193=36724936$ $76=1827229$

Błogosławiony jesteś Ty, Haszem, Tarcza Awrahama!

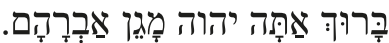

$$
\begin{aligned}
& 1001=2489326406228 \\
& 164=4130262839 \\
& 65=1412171012
\end{aligned}
$$

Ty jesteś potężny na wieki, mój Panie, Ty wskrzeszasz zmarłych, masz władzę, aby zbawiać. 
$361=702228583629593128$

$127=25410131811231310$

Sprowadzający wiatr i spuszczający deszcz ${ }^{234}$.

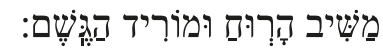

$1185=348266219352$

$186=42593946$

$69=15232110$

Karmiący żyjących poprzez dobroć, przez wielkie miłosierdzie wskrzeszający umarłych, podtrzymujący upadających, leczący chorych uwalniający związanych, podtrzymujący Swoją wiarę pośród tych, którzy śpią w prochu. Kto jest jak Ty, Pan potężnych czynów i kto jest podobny Tobie, Królu, który uśmiercasz i wskrzeszasz i pozwalasz rozkwitnąć zbawieniu.

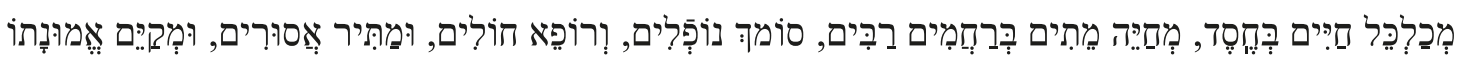

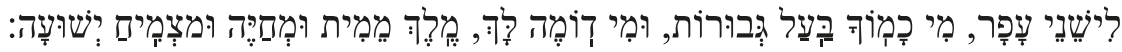
505556617102865035040050319631765694293216126252300490637468140 $6788=3911946949090$ 425836232829593041235367626165714950724545665836294159 $1424=5868$ $497=223224139519112312145171326162017222327189211318201414$ Uświęcimy Twoje Imię w świecie, tak jak uświęcają je na wysokościach Niebios i jak jest napisane przez Twojego Proroka: Zawoła jeden do drugiego i powie:

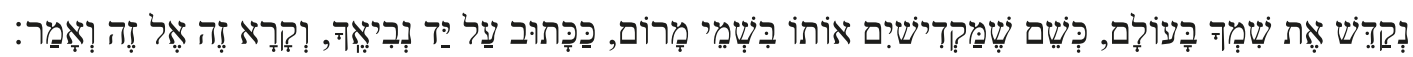
$4832=2471231123078314100448286352413804360148360401454$ $719=4012131246381428525246351114549452358$ $215=1312412101151016161017219229513$

Święty, święty, święty, Haszem Mocy, pełna jest cała ziemia Jego chwały.

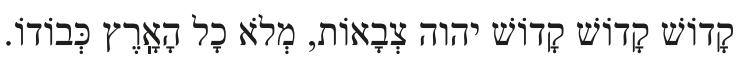
$2210=38296507149926410410410$ $347=294423264926505050$ $131=2017582217141414$

Ci, którzy są naprzeciw tamtych mówią: Błogosławiony.

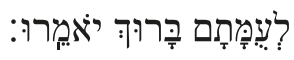
$1065=257228580$

$165=503976$

$48=141222$

Niech będzie błogosławiony majestat Haszem, z Jego miejsca!

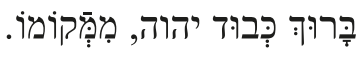

$$
\begin{aligned}
& 518=2322632228 \\
& 158=70262339 \\
& 68=25171412
\end{aligned}
$$


W Twoich świętych pismach jest napisane:

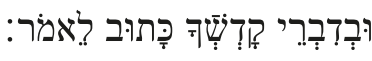

$$
\begin{aligned}
& 1347=271428424224 \\
& 186=46415544 \\
& 51=10141017
\end{aligned}
$$

Haszem będzie królował na wieku, twój Bóg, Syjonie, z pokolenia na pokolenie, chwalmy Boga!

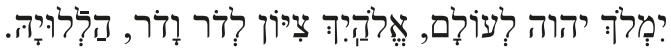

$$
\begin{aligned}
& 1054=842102341566617626100 \\
& 334=5030364839592646 \\
& 127=231292112231710
\end{aligned}
$$

Z pokolenia na pokolenie będziemy oznajmiać Twoją wielkość i przez wszystkie wieki będziemy uświęcać Twoją świętość. Niech Twoja chwała, Boże nasz, nie zniknie z naszych ust, na wieki. Bo Ty jesteś Bogiem, Królem wielkim i świętym.

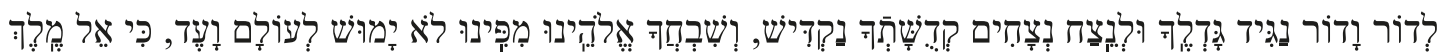

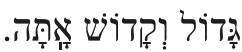
$4533=4064164390313080176356311861023364648241981845767214240$ $888=285625361321265950136048486877635830313642$ $330=10201694317231442421211414273112131815$

Błogosławiony jesteś Ty, Haszem, Bóg święty! (Król święty!) ${ }^{235}$.

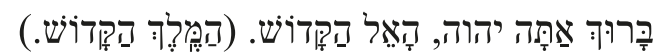
(1170) $1111=(41595) 4153626406228$ (189) $166=(5541) 5518262839$ (72) $67=(1914) 199171012$

Kto jest jak Ty, Ojciec miłosierny, pamiętający w miłosierdziu o Swoich stworzeniach, aby żyły ${ }^{236}$.

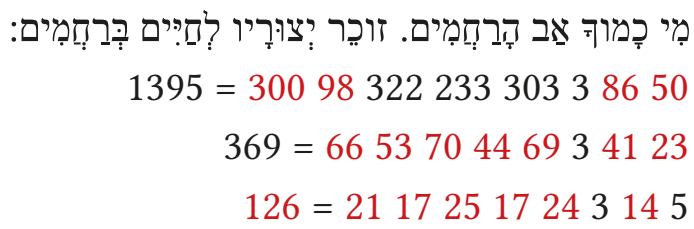

Ty jesteś godny zaufania - ożywiasz umarłych.

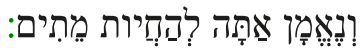

$$
\begin{array}{r}
1502=490459406147 \\
197=58632848 \\
71=13271021
\end{array}
$$

Błogosławiony jesteś Ty, Haszem, który wskrzesza umarłych.

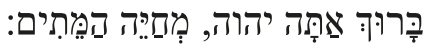

$1218=4956326406228$

$192=6336262839$ 
$75=1818171012$

Ty jesteś święty, i Twoje Imię jest święte, i święci każdego dnia wychwalają Ciebie. Sela!

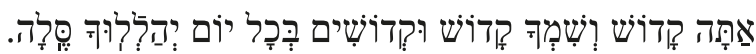
$2326=951015652466410366410406$ $400=325629257950515028$ $130=14201172514151410$

Błogosławiony jesteś Ty, Haszem, Bóg Święty! (Król święty!) $)^{237}$

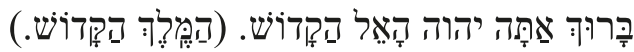
(1170) $1111=(41595) 4153626406228$ (189) $166=(5541) 5518262839$ (72) $67=(1914) 199171012$

Ty obdarzasz człowieka wiedzą i uczysz śmiertelnika rozumienia. Daj nam od Siebie w darze wiedzę, rozumienie i poznanie.

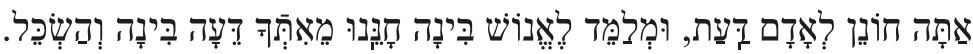

$$
\begin{aligned}
& 2725=36167794611146738712047475114406 \\
& 475=553125474231544842304228 \\
& 196=191316112413182115122410
\end{aligned}
$$

Błogosławiony jesteś Ty, Haszem, który obdarza wiedzą!

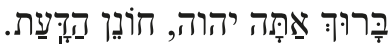

$$
\begin{aligned}
& 1253=47911426406228 \\
& 182=4742262839 \\
& 83=2024171012
\end{aligned}
$$

Spraw byśmy wrócili, nasz Ojcze do Twojej Tory i przyciągnij nas, Królu nasz, do Twojej służby, daj nam powrócić przez pełną skruchę przed Twoje oblicze.

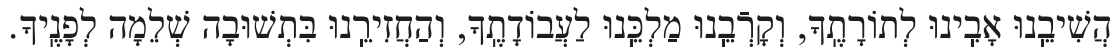

$4112=190375715292532146364105669373$

$629=64515876735667933358$

$224=19152240282022211522$

Błogosławiony jesteś Ty, Haszem, który pragnie skruchy.

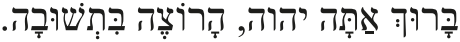

$$
\begin{aligned}
& 1681=71530626406228 \\
& 205=5854262839 \\
& 88=2227171012
\end{aligned}
$$

Przebacz nam, nasz Ojcze, bo zgrzeszyliśmy, odpuść nam Królu nasz, bo zawiniliśmy, Ty bowiem odpuszczasz i przebaczasz.

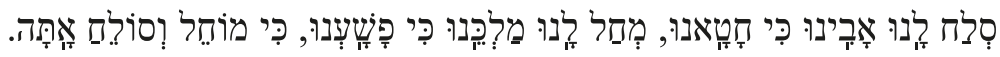
$1833=40611084305063014686787430698698$ 
Błogosławiony jesteś Ty, Haszem, który obficie obdarza przebaczeniem!

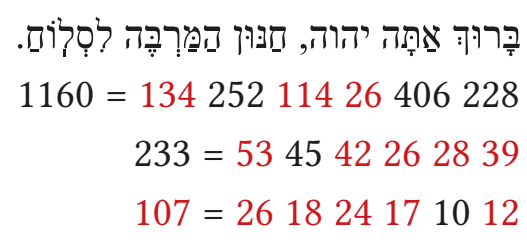

Zobacz naszą nędzę, opowiedz się za nami i wybaw nas szybko, przez wzgląd na Twoje imię, Ty bowiem jesteś potężnym Wybawicielem.

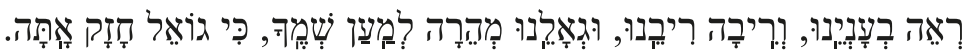
$2372=406115403036019025096268233188206$ $473=283422214555434252436226$ $176=101613391916241616268$

Błogosławiony jesteś Ty, Haszem, odkupiciel Jisraela.

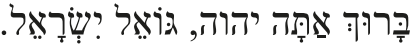

$$
\begin{aligned}
& 1241=54140260406228 \\
& 179=6422262839 \\
& 62=1013171012
\end{aligned}
$$

Odpowiedz nam, Haszem, odpowiedz nam w dniu naszego postu, bo jesteśmy w wielkim utrapieniu ${ }^{238}$.

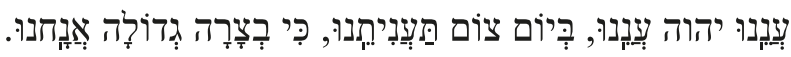

$$
\begin{aligned}
& 2048=11548297309861362817626176 \\
& 437=433045211043731502650 \\
& 194=2521183321913231723
\end{aligned}
$$

Nie bacz na naszą niegodziwość i nie zakrywaj Twojego Oblicza przed nami.

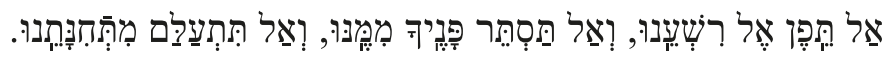

$$
\begin{aligned}
& 4542 \text { = } 954940371361601060376263153031 \\
& 555=9985194652791977135313 \\
& 177=36221019161610234174
\end{aligned}
$$

Nie odwracaj się od naszych błagań, bądź blisko naszego wołania. Niech twoja dobroć będzie nam pociechą. Zanim zawołamy do Ciebie odpowiedz nam, jak to jest powiedziane:

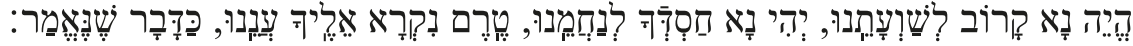

$$
\begin{aligned}
& 3247 \text { = } 591226176613512491849152258623085120 \\
& 610=6137503454426738152597471520 \\
& 205=15102379153120673411611
\end{aligned}
$$

I stanie się, że zanim zawołają, Ja odpowiem jeszcze w czasie gdy będą mówić, Ja wysłucham.

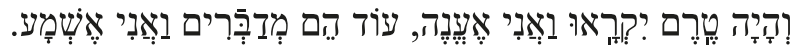

$$
\begin{aligned}
& 1684=4116729645801266731724926 \\
& 379=51316218263631564226 \\
& 145=1513179171813111517
\end{aligned}
$$


Bo Ty, Haszem jesteś tym, który odpowiada w czasie utrapienia, odkupuje i ocala w czasie każdej udręki i zmarnowania.

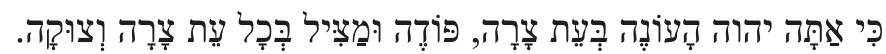
$2660=20729547052176952954721362640630$ 455 = 544338255932434046262821 $194=2716117232316132817103$

Błogosławiony jesteś Ty, Haszem, który odpowiada w czasie strapienia.

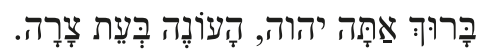
$1563=29547213626406228$ $222=434046262839$ $96=161328171012$

Ulecz nas, Haszem, a będziemy uleczeni, zbaw nas a będziemy zbawienia, Ty bowiem jesteś naszym [powodem] do chwały. Daj całkowite uleczenie wszystkich naszych ran.

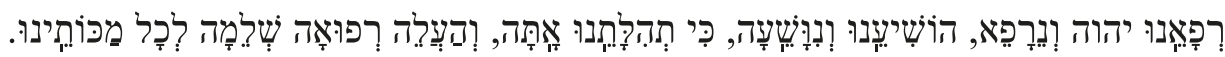

$$
\begin{aligned}
& 4306 \text { = } 532803752921164068913043744733726337 \\
& 679=82355149442881216878582658 \\
& 265=288152226102733233221722
\end{aligned}
$$

Niech będzie Twoją wolą, Haszem, mój Boże i Boże moich ojców, byś zesłał z nieba rychłe, całkowite uleczenie. Uleczenie duszy i uleczenie ciała chorego/chorej (imię chorego/ chorej), syna/córki (imię matki chorego/chorej) pomiędzy innymi chorymi w Jisraelu ${ }^{239}$.

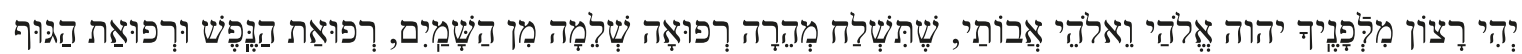

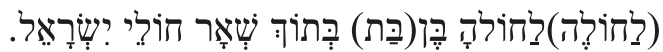
501428 (402) 5279 (79) 9469343568739590375292250103841952462623034625

(7498) $7148=54154$

(1081) $1073=64364241$ (24) 1643 (43) 3172576662275149438441342826775825 (379) $380=1018614$ (6) 725 (25) 22272121179152216211416101723227

Bo Ty jesteś Bóg, Król, Lekarz godny zaufania i miłosierny.

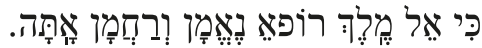
$1289=406304141287903031$ $245=28614244361321$ $89=10251517943$

Błogosławiony jesteś Ty, Haszem, który uzdrawia chorych Twojego ludu, Jisraela.

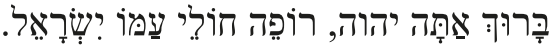

$$
\begin{aligned}
& 1662=5411165426291406228 \\
& 276=64353648262839 \\
& 105=10171821171012
\end{aligned}
$$

Pobłogosław nam, Haszem, Boże nasz Boże, dobrem ten rok i wszystkie jego plony i daj błogosławieństwo (rosę i deszcz na błogosławieństwo) ${ }^{240}$ na ziemi. I nasyć nas Twoim dobrem. Pobłogosław nasz rok jak najlepsze lata. 


\section{Gematria w XVII- i XVIII-wiecznych synagogach...}

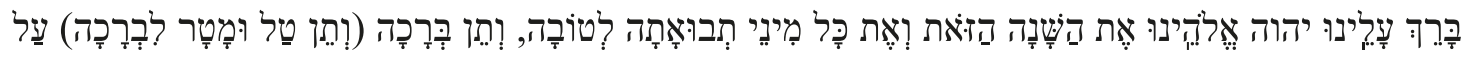

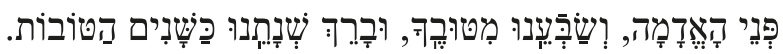
7743455140100 (25725539 456)22745652 141105040741336040110226166222 (6818) $6494=428420806228$ $77394165284128(50482142) 4842345847232935452348265833$ (1078) $977=5069$ (429) $383=321523122329191410(142112$ 15) 1115252211511171852117226 Błogosławiony jesteś Ty, Haszem, który błogosławi lata.

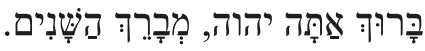

$$
\begin{aligned}
& 1327=40526226406228 \\
& 202=6346262839 \\
& 67=1810171012
\end{aligned}
$$

Zadmij w wielki szofar, na nasze uwolnienie i wznieś sztandar. Aby zgromadzić naszych wygnańców i zbierz nas z czterech krańców świata.

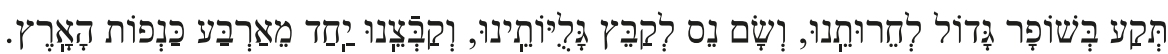
4535 = 2965563132225451522211034670043588570

$692=44705222658351294088256657$ $251=17251613292915111334162112$

Błogosławiony jesteś Ty, Haszem, który zbiera wygnańców Swego ludu, Jisraela.

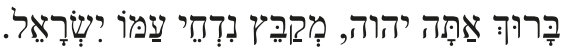

$$
\begin{aligned}
& 1621=5411167223226406228 \\
& 280=64353652262839 \\
& 100=10171816171012
\end{aligned}
$$

Przywróć naszych sędziów, jak na początku, i naszych doradców, jak ongiś, a oddal od nas smutek i wzdychanie, króluj nam Ty sam, Haszem, w dobroci i miłosierdziu, i osądź nas sprawiedliwym sądem.

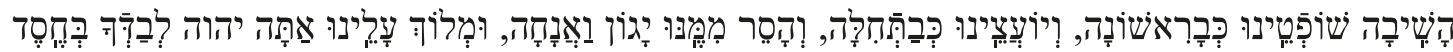

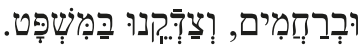
$4449=4312563067456264061661027069136275456248584461322$ $930=626772292926285848343346466086808343$ $408=263127201117102221251519192441263816$

Błogosławiony jesteś Ty, Haszem, Król (Król Sądu) ${ }^{241}$, który kocha sprawiedliwość i sąd.

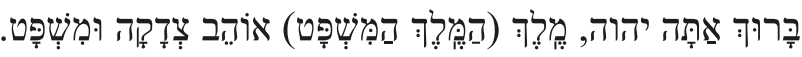
(1830) 1395 = 43519914 (434 91) 9026406228 (329) $255=664614(6545) 36262839$ (145) $111=30191914(2914) 9171012$

Dla oszczerców niech nie będzie nadziei i wszyscy, którzy czynią niegodziwość niech natychmiast przepadną, niech wszyscy oni zostaną prędko odcięci. Rychło wykorzeń przewrotnych, rozbij [ich], pokonaj i poniż, szybko, za naszych dni. 


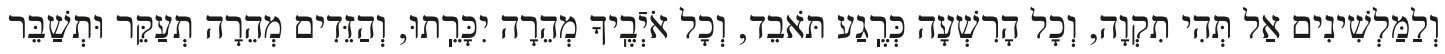

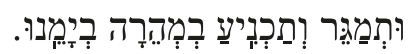
$7359=1082525566499087702507263625043564072935805651141531516$ $1032=45457964717743456943342929506729523713111$ $321=18182519171416271516711111422111610430$

Błogosławiony jesteś Ty, Haszem, który rozbija wrogów i poniża zadufanych.

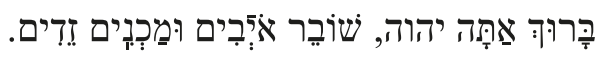
$1458=611666350826406228$ $279=34673649262839$ $99=1622913171012$

Nad sprawiedliwymi, pobożnymi, nad starszyzną Twojego narodu, Domu Jisraela, i nad jego ocalałymi uczonymi, nad sprawiedliwymi konwertytami i nad nami niech wzejdzie Twoje miłosierdzie, Haszem, Boże nasz. Wynagródź wszystkich prawdziwie pokładających ufność w Twoim Imieniu, połącz nasz los z ich losem na zawsze, a nie zawstydzimy się, że Tobie zaufaliśmy.

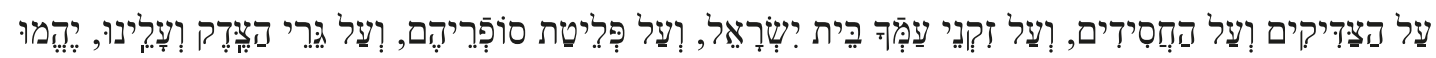

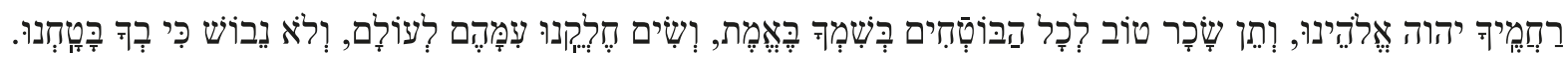
5204561022627861172199213106401529106541412130167106137106259100 $7512=75223035837176155194356443362808017520456$ 195947595038475335175242482662346446333486703464344050346534 $1559=391321437928$

2320231411113581771521171716281961632251610713141629162510 $600=30431610$

Błogosławiony jesteś Ty, Haszem, który wspierasz i umacniasz sprawiedliwych.

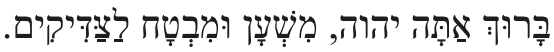

$$
\begin{aligned}
& 1469=2846546026406228 \\
& 281=863864262839 \\
& 110=232919171012
\end{aligned}
$$

Do Jerozolimy, Twojego miasta, wróć w miłosierdziu i zamieszkaj pośrodku niej, jak powiedziałeś. Odbuduj ją prędko, za naszych dni, jako wieczną budowlę i ustanów rychło pośrodku niej tron Dawida.

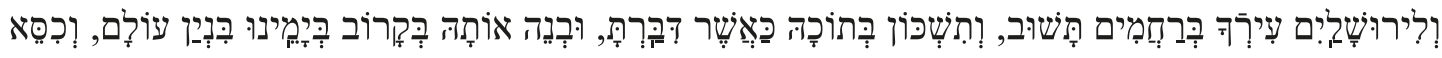

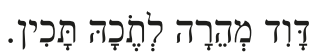
$6729=480455250148714611211831041263606521433782708300300632$ $960=575043143347405549342748534680516657110$ $312=1214161415201319131618128192615211229$ Błogosławiony jesteś Ty, Haszem, odbudowujący Jerozolimę. 


$$
\begin{aligned}
212 & =9227262839 \\
77 & =2018171012
\end{aligned}
$$

Spraw, by szybko wzeszła latorośl Dawida, Twojego sługi, i wznieś jego chwałę, poprzez Twoje zbawienie, bo każdego dnia wyglądamy Twojego zbawienia.

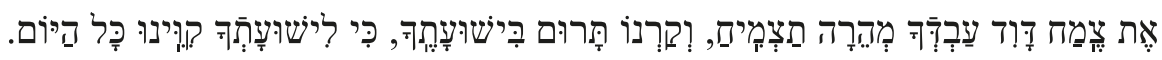
$4412=6150172836308086463625482509614138401$

$668=3423559821886165714333143923$

$227=1651926325162026161514215$

Błogosławiony jesteś Ty, Haszem, który sprawia, że rozkwita chwała zbawienia.

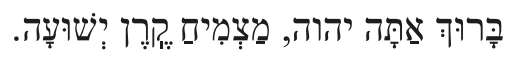

$$
\begin{aligned}
& 1589=39135018826406228 \\
& 266=585362262839 \\
& 95=22826171012
\end{aligned}
$$

Usłysz nasz głos, Haszem, nasz Boże, zlituj się i zmiłuj nad nami, przyjmij miłosiernie i życzliwie naszą modlitwę. Bo Ty jesteś Bogiem, który wysłuchuje modlitw i błagań. I nie odsyłaj nas, Królu nasz, z pustymi rękami sprzed Twojego Oblicza. Ty wysłuchujesz miłosiernie modlitw Twojego ludu, Jisraela.

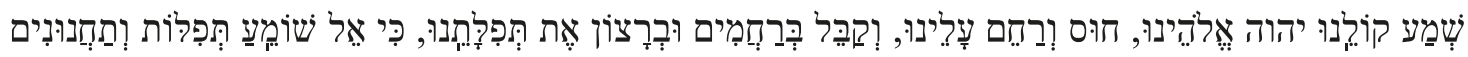

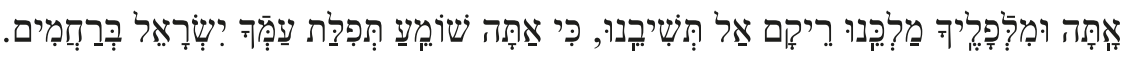
7683135014621640657091641631309664013543001381662547410226192410 $9996=30054113091041640630$

735628217513625681289379561321932366663958472948265750 $1527=666440$ $510=211013192010321482027103925204330530211222202021172114$ Błogosławiony jesteś Ty, Haszem, który wysłuchuje modlitwy.

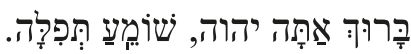
$1591=51541626406228$ $205=5656262839$ $79=2020171012$

Bądź przychylny, Haszem, nasz Boże, Twojemu ludowi, Jisraelowi,i jego modlitwom i przywróć służbę w Najświętszym Miejscu Twojej Świątyni. Przyjmij z miłością i z przychylnością ofiary ogniowe Jisraela i modlitwy [Jisraela] i niech zawsze będzie Ci miła służba Twojego ludu, Jisraela.

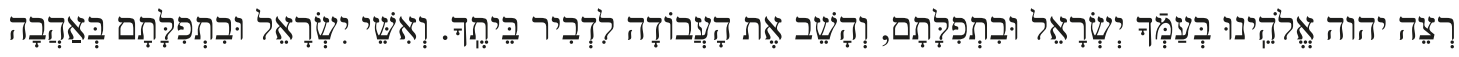

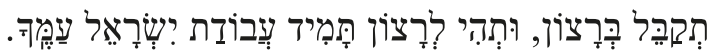

541482454376421348532159585413174322469240131395854113210226295

$$
10151=300186330196486130
$$

$1457=66604270724064504970436055159464384548382324946442482643$ $503=212415253613102313251624101531101191229516311015211716$ 
Boże nasz i Boże naszych ojców, niech się wzniesie i niech przybędzie, i dosięgnie i zjawi się, i będzie przyjęte i wysłuchane, i rozważone i zapamiętane: pamięć o nas i wzgląd na nas, i pamięć o naszych ojcach i pamięć o Masziachu, potomku Dawida, Twojego sługi, i pamięć o Jerozolimie - mieście Twojej świętości, i pamięć o całym Twoim ludzie - Domu Jisraela przed Tobą. Dla ocalenia, dla dobra, dla życzliwości, dla łaskawości, dla miłosierdzia, dla życia i dla pokoju w tym dniu: (Rosz Chodesz) (Święta Pesach) (Święta Sukkot)242.

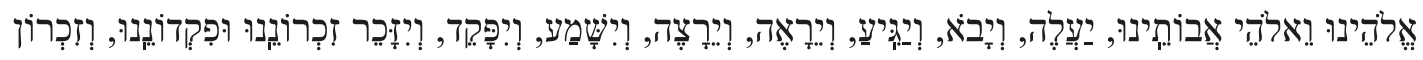

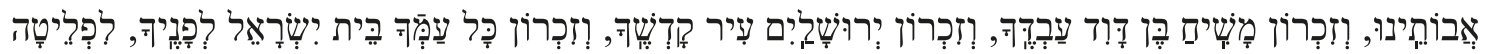

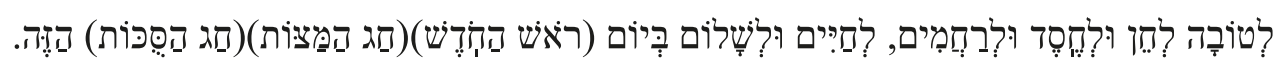
280596289991452358289475289302339243200426311222991911547552102 17 (491 11) (541 11)(317 501) 5841298334108885216419054141213050289424 $(9512)(9502)(9828)=$ 646434402364554692643314165264616486785456665942451943613448 $(2042)(2047)(2052)=17(59$ 11) (64 11) (38 42) 3170538245343465

29191071352810102028151471628252841331820212315181016251621 $(791)(796)(783)=17(2311)(28$ 11) (20 6) 13251728271625

Pamiętaj o nas, Haszem, nasz Boże, w [dniu tym] dla [naszego] dobra, wymień nas w tym dniu w błogosławieństwie i wybaw nas w tym dniu, abyśmy żyli. [Wypowiadając] słowo zbawienia i miłosierdzia zlituj się, okaż łaskę, zmiłuj się nad nami i wybaw nas, bo ku Tobie [są zwrócone] nasze oczy, bo jesteś Bogiem i Królem, łaskawym i miłosiernym.

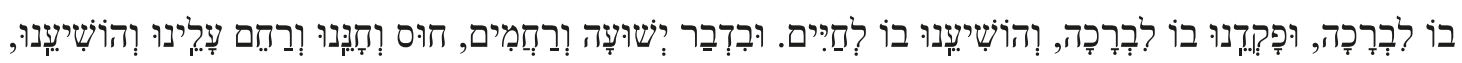

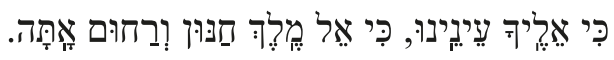
40626011490313619661304531662541207430439121498845325782462578 $4529=$ $1078=2853423613217034218458474829705834538845866508$ $443=102624943257339222030202522161783914830148$ Oby nasze oczy zobaczyły Twój powrót na Syjon w miłosierdziu.

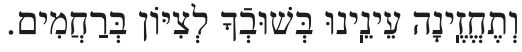
1498 = 300186330196486 $310=6660427072$ $121=2124152536$

Błogosławiony jesteś Ty, Haszem, który ustanawiasz ponownie Swoją Obecność na Syjonie.

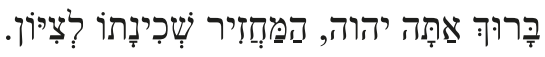
1902 = 18678627026406228 $300=608463262839$ $111=242127171012$

Dziękujemy Tobie, że Ty jesteś Haszem, nasz Bóg i Bóg naszych ojców na wieki wieków. Ty jesteś Opoką naszego życia, Tarczą naszego zbawienia z pokolenia na pokolenie. Będzie- 
my Ci dziękować i głosić Twoją chwałę, za nasze życie, które spoczywa w Twoich rękach, za nasze dusze, które są polecone Tobie, za Twoje cuda, które są z nami każdego dnia, i za Twoje wspaniałe dzieła i dobra, które są z nami o każdej porze wieczorem, rano i w południe. Dobry, bo Twoje miłosierdzie nie ma końca, Miłosierny, bo nie kończy się Twoja dobroć. Od zawsze pokładamy w Tobie nadzieję.

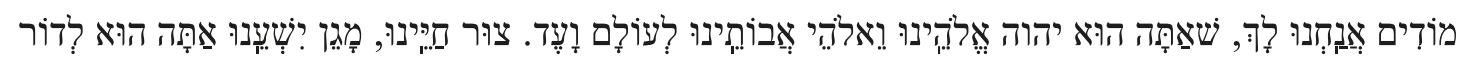

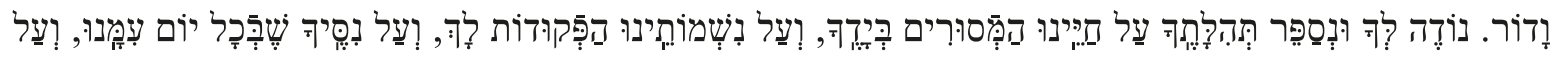

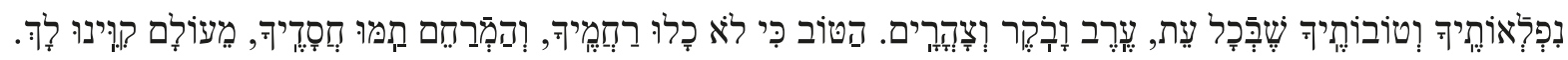
8485539650652162401240643693842968017647552102261270650115100 3022351308272470352459597106166563521401065060186210636361100 $12650=501721861024462992785631$

7910634278248287272232936421228673048442659613448261249234346 $2444=23556042416562291321227247383846729334492946503423$ 5343416928211018275201815121022122117172325162117121352519 $941=519212414291711432227111111103630162211101416$

Dziękujemy Tobie, że Ty jesteś Haszem, nasz Bóg i Bóg naszych ojców, Bóg każdej istoty, który nas kształtuje, kształtuje całe stworzenie. Błogosławieństwa i podziękowania należne są Twojemu wielkiemu i świętemu Imieniu, bo dajesz nam życie i pozwalasz istnieć. Obdarzaj nas życiem, podtrzymuj nasze istnienie i zgromadź naszych wygnańców na dziedzińcach Twojej Świątyni, abyśmy przestrzegali Twoich praw, spełniali Twoją wolę i służyli Tobie całym sercem, dziękując Ci, że możemy Ci dziękować.

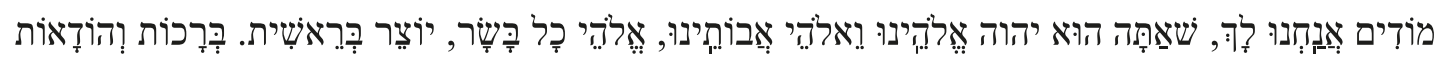

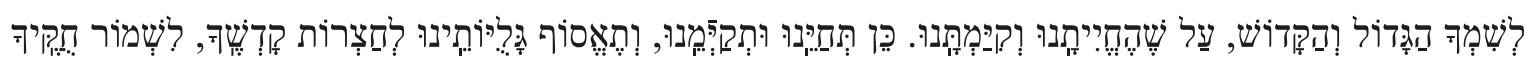

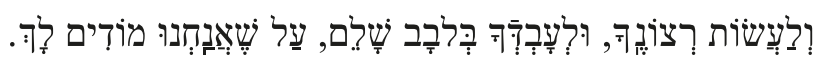

7061278910042148390428628913306502504647552102261270650115100 $13348=5010041510037060132366812138576724434515553612474$

725586836790602590962861305750617654432328613448261249234346 $2053=23466428461851698348$

291218103229312724727331025211232161318751025162117121352519 $730=51928101092424$

Błogosławiony jest Bóg dziękczynień.

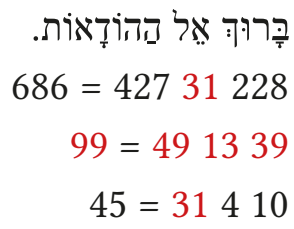

Za cuda i za odkupienie, i za wielkie czyny, i za wybawienie, i za boje, które stoczyłeś dla naszych ojców w tamtych dniach, o tej porze ${ }^{243}$.

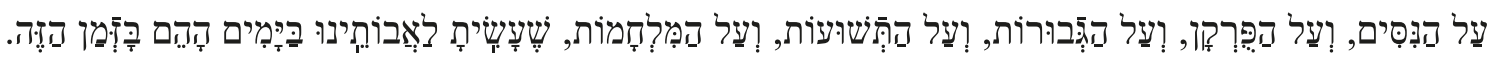
$5315=17995010250510805291061187106622106435106165100$ 


$$
\begin{aligned}
& 824=17362348739079349834643475345728 \\
& 320=17181412281834163516281621162110
\end{aligned}
$$

W dniach Matatjahu syna Jochanana, Arcykapłana Chasmoneusza i jego synów, gdy powstało zbrodnicze królestwo greckie przeciwko Twojemu narodowi - Jisraelowi, by sprawić, aby zapomnieli o Twojej Torze i [by] odwieść ich od ustaw Twojej woli - Ty, w miłosierdziu Swoim wielkim, stanąłeś przy nich w czasie ich ucisku, walczyłeś w ich walce, sądziłeś ich sprawy, mściłeś się [w] ich pomście. Wydałeś potężnych w ręce słabych i licznych w ręce nielicznych, i nieczystych w ręce czystych, i złych w ręce sprawiedliwych, i przewrotnych w ręce zajmujących się Twoją Torą. Uczyniłeś Sobie Imię wielkie i święte w Twoim świecie, a Twojemu narodowi - Jisraelowi dałeś wybawienie wielkie i odkupienie w tym dniu. Potem weszli Twoi synowie do Najświętszego Miejsca Twojego Domu, uprzątnęli Twoją Świątynię, oczyścili Twój Przybytek i zapalili lampy na Twoich świętych dziedzińcach, i ustanowili te osiem dni Chanuki, by dziękować i wychwalać Twoje wielkie Imię 244 .

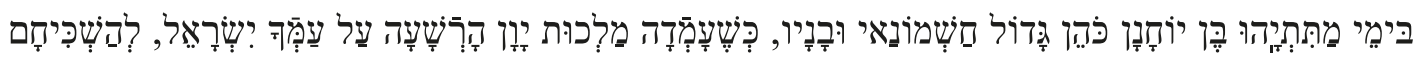

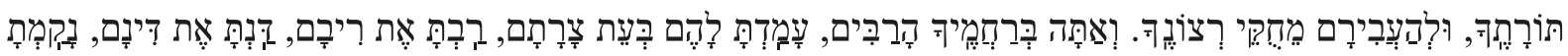

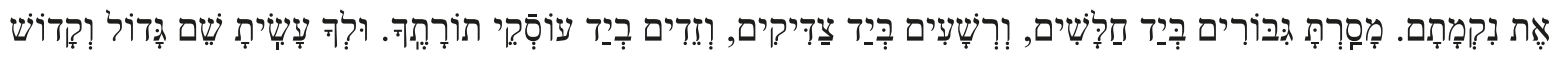

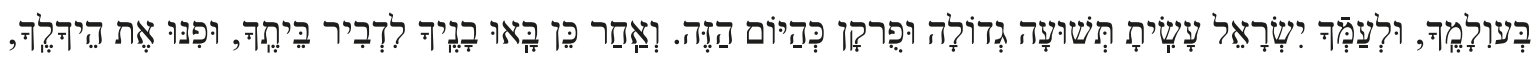

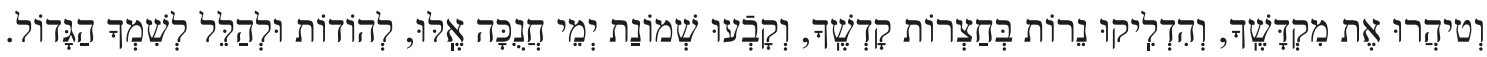
4334078056102624616672541662638816261700630401590104401454252401 6561614644012368540114243224682970215178143648781780541166168416 $28108=48390451378360796184424706$

307069645860562534692981661640741686641654708123684123404523 $4213=30575519383376495576626268235649234345483792535174576$ 1718222125151022242016715111821722207231971816185141451395 $1387=211228102062222103117261452913525912109717$

W dniach Mordechaja i Ester, w Szuszan - stolicy, gdy powstał przeciw nim zbrodniarz Haman [i] planował wyniszczyć, wymordować i wytracić wszystkich Żydów, od młodego do starego, dzieci i kobiety - w jednym dniu: trzynastego dnia dwunastego miesiąca, to jest miesiąca adar, a majątek ich zagrabić. Ty, w miłosierdziu Swoim wielkim, zniweczyłeś jego radę i zniszczyłeś jego zamysły, i odpłaciłeś mu [za] jego czyny [karą] na jego głowę. Powiesili jego i jego synów na drzewie ${ }^{245}$.

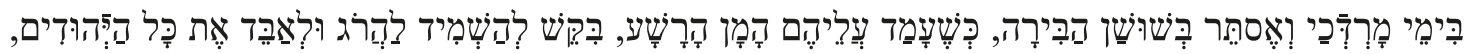

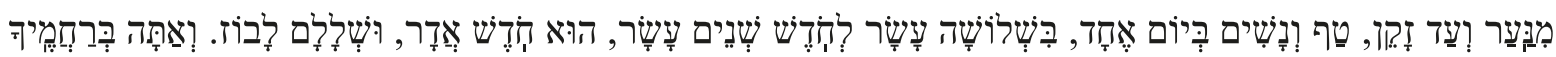

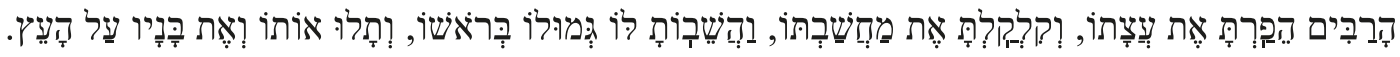
643135840689157803608050401432383894025759215543422265866727462 50985367197564016665664016852572804124540620531212570400342570 $16781=16510068407413442$

331257584557671331642640266353232325406542623556654264645835 $2318=39283229354650401862722390622364506434276425$ 
19715121213181222131319171317182655161320617142020151919138 $806=2110141117191422926275182651914191618$

Za wszystko niech będzie błogosławione i wywyższone Twoje Imię, Królu nasz, zawsze i na wieki.

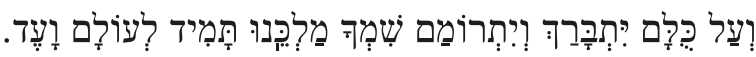
$2746=8017645414636070263290106$ $460=265949564590653634$ $145=1723132092711916$

Zapisz na dobre życie wszystkich należących do Twojego Przymierza ${ }^{246}$.

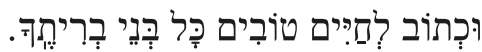

$1343=63262506798434$

$254=652623405347$

$83=1185221720$

A wszystko, co żyje, niech dziękuje Tobie, sela! I niech szczerze wychwala Twoje Imię, Boże - zbawienie nasze i nasza pomocy, sela!

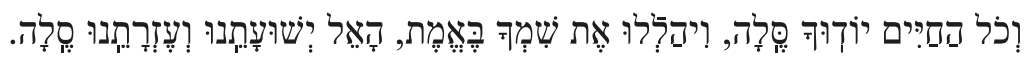
$3273=95739842364433604018795467356$ $537=329195183845235132374629$

$204=143732911952414191911$

Błogosławiony jesteś Ty, Haszem. Twoje Imię jest Dobry i Tobie należy dziękować.

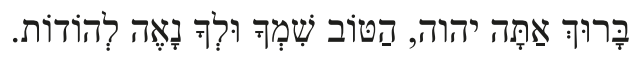
1605 = 45156563602226406228 $264=5520294522262839$ $120=281111922171012$

Boże nasz i Boże naszych ojców, błogosław nas błogosławieństwem tych trzech zdań Tory, spisanej przez Moszego, Twojego sługę, które było wypowiadane ustami Aharona i jego synów - kohenów - Twój święty lud, jak jest powiedziane:

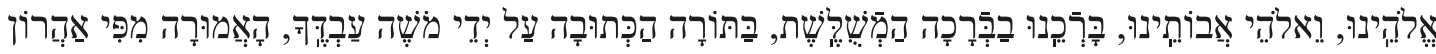

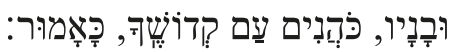
$5482=267430110125742621302579634524100438613107522927847552102$ $928=5161295338464050333924285155944053613448$ $334=151611172019132315126102419221317251621$

Niech Haszem błogosławi cię i strzeże.

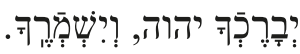
$854=57626252$

$161=812654$ $44=18179$

Niech to będzie [Twoją] wolą 247 . 
8. Gematria w XVII- i XVIII-wiecznych synagogach...

$$
\begin{array}{r}
441=3462570 \\
108=582525 \\
36=2277
\end{array}
$$

Niech Haszem rozjaśni nad tobą Swoje Oblicze i niech zmiłuje się nad tobą.

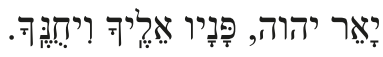

$$
\begin{aligned}
& 538=946114726211 \\
& 187=4931462631 \\
& 70=22720124
\end{aligned}
$$

Niech Haszem zwróci Swoje Oblicze ku tobie i obdarzy cię pokojem.

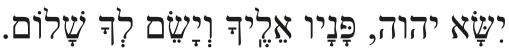

$$
\begin{aligned}
& 1326=376503566114626311 \\
& 264=52235034472632 \\
& 84=1651472055
\end{aligned}
$$

Ustanów pokój, dobro i błogosławieństwo, łaskawość i zmiłowanie i miłosierdzie dla nas i dla całego Jisraela. Pobłogosław nas, nasz Ojcze, wszystkich jak jednego, światłem Twojego Oblicza. Bo w świetle Twojego Oblicza dałeś nam Torę życia, umiłowanie dobroci i sprawiedliwość, błogosławieństwo, miłosierdzie, życie i pokój. I obyś uznał za dobre błogosławić Twój lud, Jisraela, o każdej porze i w każdej godzinie Twoim pokojem.

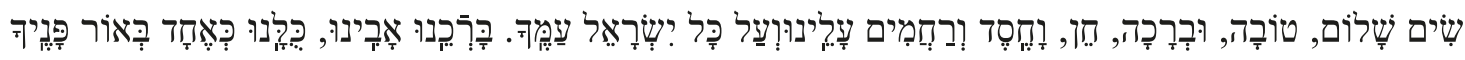

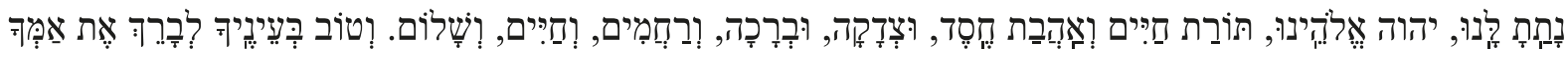

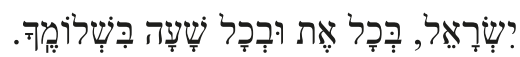

6810061022686850160209331066927813054150106166304785823322376350 $9815=398375584015254161401252162233827430423320572414$

477044522736417048263258522924433353406423345870332244225244 $1778=654231232564252345632358$

222025172518181416211714131611151615171310516222524131722168 $653=20151357107591823$

Obyśmy byli wspomniani i zapisani przed Tobą w Księdze Życia, błogosławieństwa, pokoju i powodzenia, my i cały Twój lud, Dom Jisraela, na dobre życie i na pokój ${ }^{248}$.

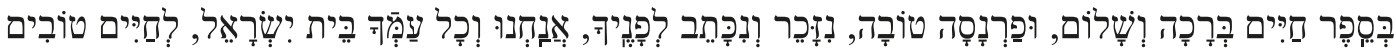

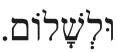
$4218=4126798541412130561151904782772240138222768342$ $843=7040536434402943645552227758384154$ $303=252217107131125191916223222111418$

Błogosławiony jesteś Ty, Haszem, który czyni pokój.

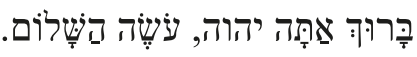

$$
\begin{aligned}
& 1416=38137526406228 \\
& 192=5742262839 \\
& 75=2115171012
\end{aligned}
$$


Błogosławiony jesteś Ty, Haszem, który błogosławi Swój lud, Jisraela, pokojem.

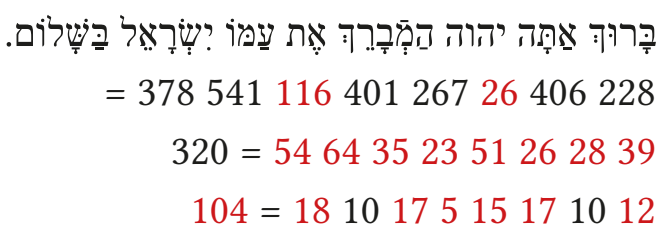

Oby słowa moich ust i myśli mojego serca znalazły uznanie u Ciebie, Haszem, moja Opoko i mój Wybawco.

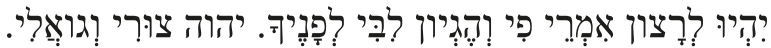

$$
\begin{aligned}
& 1448=563062619042809025137631 \\
& 422=38542664244427447031 \\
& 161=20181719626982513
\end{aligned}
$$

Boże mój, strzeż mojego języka od zła i moich warg od oszukańczej mowy. Niech moja dusza milczy wobec tych, którzy mnie przeklinają. Niech moja dusza będzie jak proch dla każdego. Otwórz moje serce na Twoją Torę, a moja dusza podąży za Twoimi przykazaniami. Prędko unicestwij zamiar i popsuj zamysły tych, którzy planują zło wobec mnie. Uczyń tak ze względu na Twoje Imię, uczyń tak ze względu na Twoją prawicę, uczyń także względu na Twoją świętość, uczyń tak ze względu na Twoją Torę, aby zostali ocaleni Twoi umiłowani, niech wybawi ich Twoja prawica, i odpowiedz mi. Oby słowa moich ust i myśli mojego serca znalazły uznanie u Ciebie, Haszem, moja Opoko i mój Wybawco.

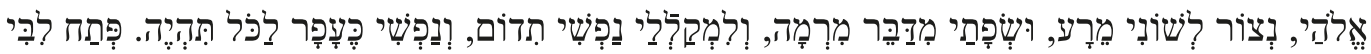

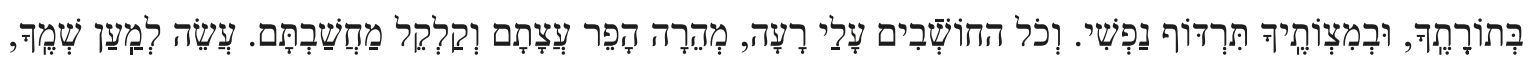

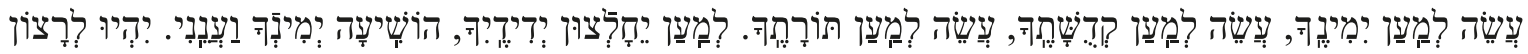

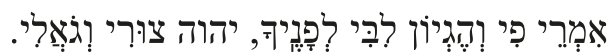

156564406905741028424884208037044645044024628524679631039634646 1103715644069057410284248842080370446450440246285246796310396346

581981901026190375824190375130190375360190375790266600285250275 $18338=503062619042809025137631186130396$ 845139764963586665296269888324474235646845628451397649635828 775542585542455542796869424341386529626988832447423564684562 $3029=32542664244427447031605163496455815542$ 172115122213182221291117243420620158192318172115122213182210 19151419151319159191525142415161411291117243420620158192318 $986=1418171962698251324132713321918$

Ten, który czyni pokój na wysokościach, niech uczyni pokój dla nas i całego Jisraela. I powiedzmy: Amen.

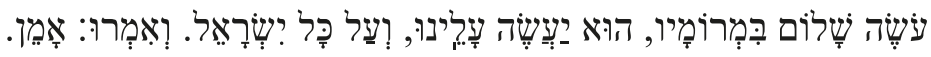
$2659=912535415010616638512304376375$

$481=2846642334585212705242$ $166=101910516221612251615$ 
Oby było Twoją wolą, Haszem, nasz Boże i Boże naszych ojców, by została odbudowana Świątynia, prędko, za naszych dni. Daj nam nasz udział w Twojej Torze. Obyśmy tam służyli w bojaźni, jak za dawnych dni i jak w dawnych latach. Miła będzie dla Haszem ofiara Judy i Jerozolimy jak za dawnych dni i jak w dawnych latach.

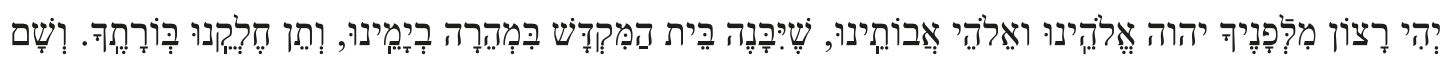

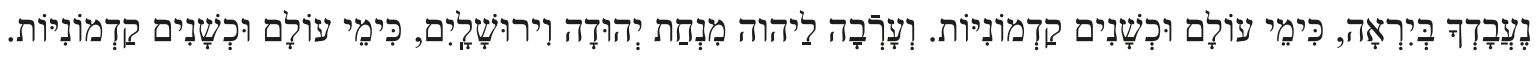
61642614680218146346628194456118252449412367475521022623034625 $8847=616426146806023049856283$ 4744983057384994754744384740615942554562345261344826775825 $1656=9475$

3121208262121202231212081120131623151918177162516211723227

$576=$

Analiza Amidy [119], podobnie jak analiza Szema Israel, pozwoliła stwierdzić istnienie kilku zależności. Średnie pokrycie wartości odpowiadających podstawowym wartościom liczbowym wymiarów wynosi 76\%, przy czym metodą absolutną uzyskano 73\%, uproszczoną $85 \%$, a redukcyjną $69 \%$. Dla wszystkich analizowanych wartości liczbowych średnia wynosi $51 \%$, przy czym metodą absolutną uzyskano 68\%, uproszczoną 51\% , a redukcyjną 35\%. Ogólnie w wyniku zastosowania trzech metod pokryto 95\% wartości podstawowych i $80 \%$ wszystkich analizowanych wartości liczbowych.

Podobnie jak w przypadku Szema Israel kilka wartości liczbowych w analizowanych fragmentach odpowiada wartościom liczbowym wymiarów bożnic. Na podstawie analizy metodami redukcyjną i uproszczoną stwierdzono istnienie zależności w synagogach zlokalizowanych w takich miastach, jak:

\section{Pińczów}

Długość sali męskiej (69): Sprowadzający wiatr i spuszczający deszcz.

\section{Rzeszów (Synagoga Stara)}

Szerokość synagogi (110): Błogosławiony jesteś Ty, Haszem, który wspierasz i umacniasz sprawiedliwych.

Długość sali męskiej (100): Błogosławiony jesteś Ty, Haszem, który zbiera wygnańców Swego ludu, Jisraela.

(600): Nad sprawiedliwymi, pobożnymi, nad starszyzną Twojego narodu, Domu Jisraela, i nad jego ocalałymi uczonymi, nad sprawiedliwymi konwertytami i nad nami niech wzejdzie Twoje miłosierdzie [...].

Szerokość sali męskiej (88): Błogosławiony jesteś Ty, Haszem, który pragnie skruchy.

(44): Niech Haszem błogosławi cię i strzeże.

Wysokość sali męskiej (77): Błogosławiony jesteś Ty, Haszem, odbudowujący Jerozolimę.

Wysokość bimy (65): Błogosławiony jesteś Ty, Haszem, Tarcza Awrahama! 


\section{Zamość}

Długość synagogi

Szerokość synagogi

Wysokość synagogi

Długość sali męskiej

\section{Szczebrzeszyn}

Szerokość synagogi

\section{Chęciny}

Szerokość synagogi

Wysokość synagogi
(104): Błogosławiony jesteś Ty, Haszem, który błogosławi Swój lud, Jisraela, pokojem.

(100): Błogosławiony jesteś Ty, Haszem, który zbiera wygnańców Swego ludu, Jisraela.

(600): Nad sprawiedliwymi, pobożnymi, nad starszyzną Twojego narodu, Domu Jisraela, i nad jego ocalałymi uczonymi, nad sprawiedliwymi konwertytami i nad nami niech wzejdzie Twoje miłosierdzie [...].

(62): Błogosławiony jesteś Ty, Haszem, odkupiciel Jisraela.

(84): Niech Haszem zwróci Swoje Oblicze ku tobie i obdarzy cię pokojem.

(51): W Twoich świętych pismach jest napisane.

(68): Niech będzie błogosławiony majestat Haszem, z Jego miejsca. (300): Błogosławiony jesteś Ty, Haszem, który ustanawiasz ponownie Swoją Obecność na Syjonie.

(300): Panie! Otwórz moje wargi, a moje usta będą głosić Twoją chwałę! [137, Ps 51,17].

Szerokość sali męskiej (A 204): A wszystko, co żyje, niech dziękuje Tobie, sela! I niech szczerze wychwala Twoje Imię, Boże - zbawienie nasze i nasza pomocy, sela!

Wysokość sali męskiej (A 276): Błogosławiony jesteś Ty, Haszem, który uzdrawia chorych Twojego ludu, Jisraela.

\section{Tykocin}

Długość synagogi （72): Błogosławiony jesteś Ty, Haszem, Król święty!

(36): Niech to będzie [Twoją] wolą.

Szerokość synagogi （72): Błogosławiony jesteś Ty, Haszem, Król święty!

(36): Niech to będzie [Twoją] wolą.

\section{Orla}

Szerokość synagogi (126): Kto jest jak Ty, Ojciec miłosierny, pamiętający w miłosierdziu o Swoich stworzeniach, aby żyły.

Wysokość synagogi (68): Niech będzie błogosławiony majestat Haszem, z Jego miejsca. (408): Przywróć naszych sędziów, jak na początku, i naszych doradców, jak ongiś [...].

Szerokość sali męskiej (107): Błogosławiony jesteś Ty, Haszem, który obficie obdarza przebaczeniem.

Wysokość sali męskiej (70): Niech Haszem rozjaśni nad tobą Swoje Obliczę i niech zmiłuje się nad tobą. 
Długość centralnego (276): Błogosławiony jesteś Ty, Haszem, który uzdrawia chorych pola Twojego ludu, Jisraela.

Szerokość centralnego (264): Błogosławiony jesteś Ty, Haszem. Twoje Imię jest Dobry pola i Tobie należy dziękować.

(264): Niech Haszem zwróci Swoje Oblicze ku tobie i obdarzy cię pokojem.

\section{Lesko}

Długość synagogi (A 126): Kto jest jak Ty, Ojciec miłosierny, pamiętający w miłosierdziu o Swoich stworzeniach, aby żyły.

\section{Tarnogród}

Wysokość sali męskiej (A 76): Królu pomagający. Wybawco i Tarczo.

\section{Rzeszów (Synagoga Nowomiejska)}

Długość synagogi (202): Błogosławiony jesteś Ty, Haszem, który błogosławi lata.

Szerokość synagogi (67): Błogosławiony jesteś Ty, Haszem, Bóg święty!

(67): Błogosławiony jesteś Ty, Haszem, który błogosławi lata.

Długość centralnego (222): Błogosławiony jesteś Ty, Haszem, który odpowiada w czasie pola strapienia.

(222): Przebacz nam, nasz Ojcze, bo zgrzeszyliśmy, odpuść nam Królu nasz, bo zawiniliśmy, Ty bowiem odpuszczasz i przebaczasz.

Szerokość centralnego (36): Niech to będzie [Twoją] wolą.

pola

\section{Bobowa}

Długość synagogi

Szerokość synagogi
(108): Niech to będzie [Twoją] wolą.

(100): Błogosławiony jesteś Ty, Haszem, który zbiera wygnańców Swego ludu, Jisraela.

(600): Nad sprawiedliwymi, pobożnymi, nad starszyzną Twojego narodu, Domu Jisraela, i nad jego ocalałymi uczonymi, nad sprawiedliwy mi konwertytami i nad nami niech wzejdzie Twoje miłosierdzie [...].

(48): Ci, którzy są naprzeciw tamtych mówią: Błogosławiony.

(96): Błogosławiony jesteś Ty, Haszem, który odpowiada w czasie strapienia.

(576): Oby było Twoją wolą, Haszem, nasz Boże i Boże naszych ojców, by została odbudowana Świątynia [...].

Szerokość sali męskiej (84): Niech Haszem zwróci Swoje Oblicze ku tobie i obdarzy cię pokojem.

Wysokość sali męskiej (51): W Twoich świętych pismach jest napisane.

Szerokość centralnego (192): Błogosławiony jesteś Ty, Haszem, który wskrzesza umarłych. pola (192): Błogosławiony jesteś Ty, Haszem, który czyni pokój. 
Wysokość centralnego (330): Z pokolenia na pokolenie będziemy oznajmiać Twoją wielkość pola $[\ldots]$.

\section{Dukla}

Szerokość synagogi (120): Błogosławiony jesteś Ty, Haszem. Twoje Imię jest Dobry i Tobie należy dziękować.

Długość sali męskiej (110): Błogosławiony jesteś Ty, Haszem, który wspierasz i umacniasz sprawiedliwych.

Szerokość bimy $\quad$ (44): Niech Haszem błogosławi cię i strzeże.

\section{Włodawa}

Długość synagogi (A 1032): Dla oszczerców niech nie będzie nadziei i wszyscy, którzy czynią niegodziwość niech natychmiast przepadną, niech wszyscy oni zostaną prędko odcięci. Rychło wykorzeń przewrotnych, rozbij [ich], pokonaj i poniż, szybko, za naszych dni.

Szerokość synagogi (99): Błogosławiony jest Bóg dziękczynień.

(99): Błogosławiony jesteś Ty, Haszem, który rozbija wrogów i poniża zadufanych.

Wysokość synagogi (77): Błogosławiony jesteś Ty, Haszem, odbudowujący Jerozolimę.

Wysokość sali męskiej (84): Niech Haszem zwróci Swoje Oblicze ku tobie i obdarzy cię pokojem.

Szerokość centralnego (300): Błogosławiony jesteś Ty, Haszem, który ustanawiasz ponownie pola

Swoją Obecność na Syjonie.

(300): Panie! Otwórz moje wargi, a moje usta będą głosić Twoją chwałę! [137, Ps 51,17].

\section{Siemiatycze}

Długość synagogi

(1032): Dla oszczerców niech nie będzie nadziei i wszyscy, którzy czynią niegodziwość niech natychmiast przepadną, niech wszyscy oni zostaną prędko odcięci. Rychło wykorzeń przewrotnych, rozbij [ich], pokonaj i poniż, szybko, za naszych dni.

Wysokość synagogi (300): Błogosławiony jesteś Ty, Haszem, który ustanawiasz ponownie Swoją Obecność na Syjonie.

(300): Panie! Otwórz moje wargi, a moje usta będą głosić Twoją chwałę! [137, Ps 51,17].

Długość sali męskiej (121): Oby nasze oczy zobaczyły Twój powrót na Syjon w miłosierdziu.

Amida wykazuje znacznie lepszą reprezentatywność wartości liczbowych, które odpowiadają wymiarom bożnic, zwłaszcza w odniesieniu do wymiarów podstawowych. Poza najlepszą reprezentacją wymiarów powtarzających się najrzadziej, również wymiarów najczęstszych jest w tym przypadku znacznie więcej. Liczba 33 pojawia się raz w wyniku zastosowania metody absolutnej, a następnie trzykrotnie w wyniku zastosowania metody reduk- 
cyjnej i piętnastokrotnie $\mathrm{w}$ wyniku zastosowania metody uproszczonej. Liczba 66 pojawia się raz w wyniku przeliczania metodą absolutną i piętnastokrotnie $\mathrm{w}$ wyniku przeliczania metodą uproszczoną. Liczba 25 pojawia się w sumie siedemdziesiąt trzy razy. Liczba 50 jest dość dobrze reprezentowana, bo aż dwudziestokrotnie w przeliczeniach metodą absolutną i trzydziestokrotnie w przeliczeniach metodą uproszczoną. Liczba 39 pojawia się w sumie 38 razy. Liczbą, która występuje niezwykle rzadko (czterokrotnie), jest 396 - jest ona ekwiwalentem liczby 33.

\subsubsection{Lecha dodi ${ }^{249}$}

Chodź, mój miły, naprzeciw narzeczonej, powitajmy Szabat.

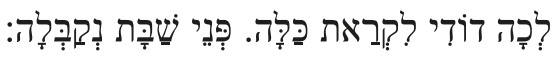

$$
\begin{aligned}
& 1894=187702140557312455 \\
& 292=52454128742428 \\
& 85=1691410111510
\end{aligned}
$$

„Przestrzegaj” i „pamiętaj” - w jednym wypowiedzeniu oznajmił nam Jedyny Bóg.

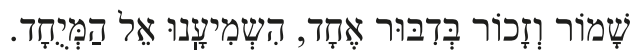

$1591=673148113214239546$

$295=40138513345060$

$124=2243113162315$

Haszem jest Jeden i Jego imię Jeden, dla rozsławienia, dla wspaniałości i dla chwały.

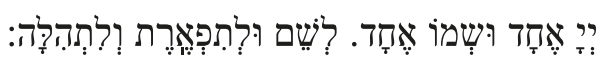

$2361=4761117370133521320$

$300=621004613461320$

$111=2628101319132$

Chodź, mój miły...

Naprzeciw Szabatu [narzeczonej], chodźmy! Bo ona jest źródłem błogosławieństwa.

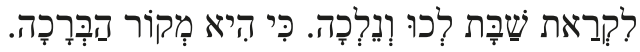

$2224=2323461630111156702731$

$334=4358162148294574$

91=1613732111911

Od początku, od dawna została ustanowiona - koniec stworzenia, pierwsza w zamyśle.

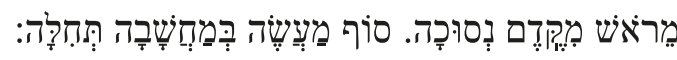

$2227=443357415146141184541$

$346=47515538514955$

$130=20241920241310$

Chodź, mój miły...

Świątynio Króla, miasto królewskie, powstań, wyjdź spośród zniszczenia!

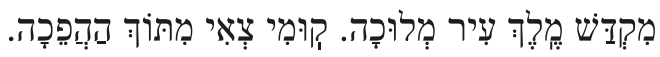


$1753=11546610115610128090444$ $385=4352294847463657$

Dość siedzenia w dolinie płaczu. On zmiłuje się nad tobą.

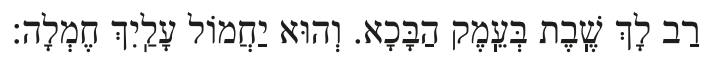

$1519=8313094182821270250202$

$313=384949181950452322$

$115=201322181014954$

Chodź, mój miły...

Otrząśnij się z prochu, powstań, przywdziej swoje wspaniałe szaty, ludu mój.

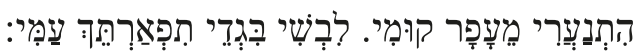

$2863=120110119342156390735$

$397=39931945486687$

$109=1221109122124$

Przez syna Jeszaji betlejemczyka, zbliż się do mojej duszy, wybaw ją!

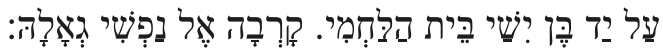

1808 = 3944031307934123202514

$323=216213464834411614$

$98=1217410217575$

Chodź, mój miły...

Obudź się, obudź się! Bo przybywa twoja światłość - powstań, zajaśnij!

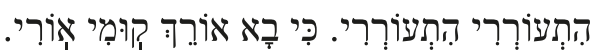

2415 = 217156227330891891

$345=3748383219191$

$93=101211332727$

Ocknij się, ocknij się, wygłoś pieśń! Chwała Haszem nad tobą się objawiła.

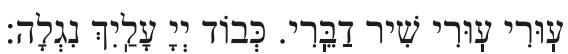
$1568=881302032216510286286$

$317=3449202336515252$

$92=1613214961616$

Chodź, mój miły...

Nie zawstydzisz się i nie doznasz poniżenia. Czemu pochylasz się i czemu jęczysz?

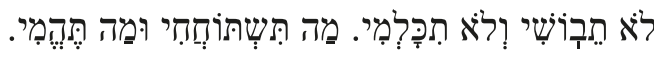

$2969=455511132455003771831$

$360=5024971868196113$

$116=14153491410164$

W tobie schronią się ubodzy mojego ludu, a miasto zostanie odbudowane na swoim wzgórzu.

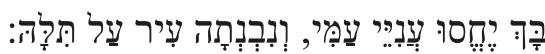




$$
\begin{array}{r}
1694=4351002805131201408422 \\
317=3928466339503913 \\
110=121010271214214
\end{array}
$$

Chodź, mój miły...

I zostaną ograbieni ci, którzy ciebie grabią, i oddalą się ci, którzy cię pożerają.

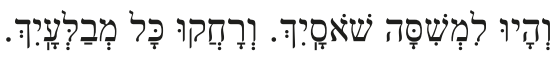

$1389=1725032039143521$

$$
291=642359516621
$$$$
93=19523132112
$$

Cieszyć się będzie twój Bóg, jak narzeczony cieszy się swoją narzeczoną.

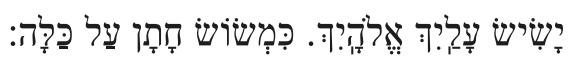
$2095=5510045866666130620$

$322=28284472394962$

$88=1010171812138$

Chodź, mój miły...

W lewo i w prawo rozprzestrzenisz się i będziesz wychwalać Haszem.

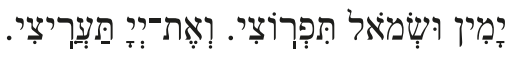
$2480=78020407786377110$

$338=962029935347$

$95=24211301711$

Poprzez człowieka, który będzie potomkiem Pereca, będziemy się radować i cieszyć.

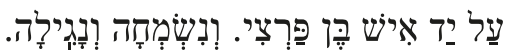
$1370=1044093805231114100$

$272=50676516321428$ $101=23312075510$

Chodź, mój miły...

Wejdź w pokoju, korono męża, z radością i w zachwycie.

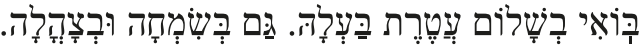

$1719=1383554310767937819$

$288=48491635675419$

$126=3022717221810$

Pośród wiernych drogocennego narodu. Wejdź oblubienico, wejdź oblubienico.

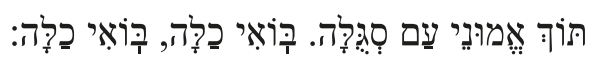

$889=5519551998110107426$

$241=2819281935294439$

$97=1010101017111712$

Średnie pokrycie wartości odpowiadających podstawowym wymiarom wynosi $50 \%$, przy czym metodą absolutną uzyskano $42 \%$, uproszczoną $58 \%$, a redukcyjną $50 \%$. Dla wszystkich analizowanych wartości liczbowych średnia wynosi $24 \%$, przy czym metodą absolutną 
uzyskano $24 \%$, uproszczoną $30 \%$, a redukcyjną 19\%. Ogólnie w wyniku zastosowania trzech metod pokryto $85 \%$ wartości podstaw ow ych i $56 \%$ wszystkich analizowanych wartości liczbowych.

Kilka wartości liczbowych w analizowanych fragmentach odpowiada - podobnie jak w poprzednich modlitwach - wartościom wymiarów bożnic. Na podstawie analizy metodami redukcyjną i uproszczoną stwierdzono istnienie zależności w synagogach zlokalizowanych w takich miastach, jak:

\section{Pińczów}

Długość synagogi (92): Ocknij się, ocknij się, wygłoś pieśń! Chwała Haszem nad toba się objawiła.

\section{Rzeszów (Synagoga Stara)}

Szerokość synagogi (110): W tobie schronią się ubodzy mojego ludu, a miasto zostanie odbudowane na swoim wzgórzu.

Szerokość sali męskiej (88): Cieszyć się będzie twój Bóg, jak narzeczony cieszy się swoją narzeczoną.

\section{Szczebrzeszyn}

Długość synagogi (116): Nie zawstydzisz się i nie doznasz poniżenia. Czemu pochylasz się i czemu jęczysz?

Długość sali męskiej (92): Ocknij się, ocknij się, wygłoś pieśń! Chwała Haszem nad tobą się objawiła.

\section{Chęciny}

Długość synagogi

(97): Pośród wiernych drogocennego narodu. Wejdź oblubienico, wejdź oblubienico.

Wysokość synagogi (300): Haszem jest Jeden i Jego imię Jeden, dla rozsławienia, dla wspaniałość i dla chwały.

\section{Orla}

Szerokość synagogi (126): Wejdź w pokoju, korono męża, z radością i w zachwycie.

\section{Lesko}

Długość synagogi

(126): Wejdź w pokoju, korono męża, z radością i w zachwycie.

Szerokość synagogi

(98): Przez syna Jeszaji betlejemczyka, zbliż się do mojej duszy,

\section{Tarnogród} wybaw ją!

Długość centralnego (360): Nie zawstydzisz się i nie doznasz poniżenia. Czemu pochylasz pola się i czemu jęczysz?

Szerokość centralnego (360): Nie zawstydzisz się i nie doznasz poniżenia. Czemu pochylasz pola się i czemu jęczysz?

\section{Rzeszów (Synagoga Nowomiejska)}

Długość synagogi （101): Poprzez człowieka, który będzie potomkiem Pereca, będziemy się radować i cieszyć. 
Długość sali męskiej (115): Świątynio Króla, miasto królewskie, powstań, wyjdź spośród zniszczenia!

(115): Dość siedzenia w dolinie płaczu. On zmiłuje się nad tobą.

\section{Dukla}

Długość sali męskiej (110): W tobie schronią się ubodzy mojego ludu, a miasto zostanie odbudowane na swoim wzgórzu.

Szerokość sali męskiej (98): Przez syna Jeszaji betlejemczyka, zbliż się do mojej duszy, wybaw ją!

\section{Lańcut}

Wysokość synagogi (360): Nie zawstydzisz się i nie doznasz poniżenia. Czemu pochylasz się i czemu jęczysz?

Szerokość sali męskiej (85): Chodź, mój miły, naprzeciw narzeczonej, powitajmy Szabat.

\section{Włodawa}

Szerokość centralnego (300): Haszem jest Jeden i Jego imię Jeden, dla rozsławienia, dla pola wspaniałość i dla chwały.

\section{Siemiatycze}

Wysokość synagogi (300): Haszem jest Jeden i Jego imię Jeden, dla rozsławienia, dla wspaniałość i dla chwały.

Lecha dodi wykazuje dobrą reprezentatywność wartości liczbowych, które odpowiadają wartościom liczbowym wymiarów bożnic, zwłaszcza tych podstawowych. Dużo jest wartości występujących najrzadziej (dwu-, trzy- i czterokrotnie oraz wartości liczbowych wymiarów podstawowych pojawiających się tylko raz), natomiast tych powtarzających się najczęściej jest niewiele lub w ogóle nie występują. Szczególnie tyczy się to liczby 33, która w modlitwie tej nie pojawia się. Niedoreprezentowane są również liczby: 66 (występuje w sumie trzy razy) oraz 25 (występuje dwa razy). Liczba 50 pojawia się siedmiokrotnie, podobnie jak liczba 39.

\subsubsection{Kabalat szabat ${ }^{250}$}

Chodźmy! Zaśpiewajmy dla Haszem, zakrzyknijmy dla Opoki naszego zbawienia ${ }^{251}$.

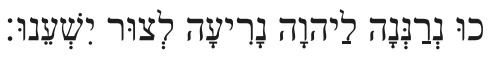

$$
\begin{aligned}
& 1534=4363263355635526 \\
& 340=675665386717 \\
& 112=22202020228
\end{aligned}
$$

Pójdźmy przed Jego oblicze z wdzięcznością i pieśnią zakrzyknijmy do Niego.

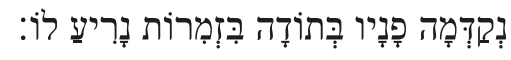

$$
\begin{aligned}
& 1783=36330655417146199 \\
& 289=186070394755 \\
& 109=91525212019
\end{aligned}
$$


Bo Haszem jest wielkim Bogiem i wielkim Królem nad wszystkimi siłami [niebieskimi],

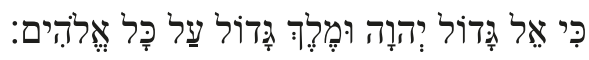
$505=8650100439626433130$ $244=412328254226251321$ $100=145101615171643$

W Jego mocy są tajemnice ziemi i potęgi gór są Jego.

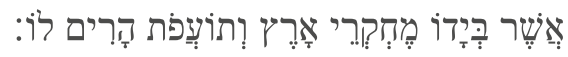
2425 = 3625596229135822501

$328=18488939702242$ $103=912351216136$

Jego jest morze - On je uczynił, i suchy ląd ukształtowała Jego moc.

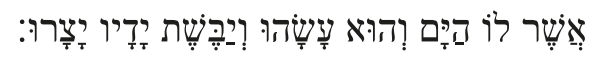
2045 = 30630718381185536501

$399=5430614818281842$

$110=18121621181096$

Chodźmy, oddajmy pokłon, skłońmy się i klęknijmy przed Haszem, który nas uczynił.

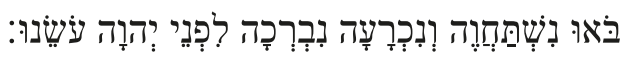
$2028=426261702773517699$

$345=5726535272769$

$138=2117171627319$

Bo On jest naszym Bogiem, a my ludem, który On prowadzi, trzodą pod Jego opieką, dziś, jeśli posłuchamy Jego głosu.

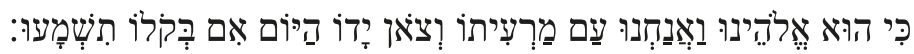

$2324=8161384161201477261101211021230$ $470=783914342039872949481221$

$199=2412516112124113121123$

Nie zatwardzajcie swoich serc jak w Meriwa, jak w Masa na pustyni,

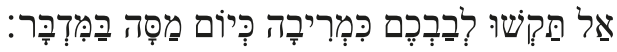

1637 = 248105762779480631

$296=41334061406813$

$89=1415131613144$

gdy wasi ojcowie wystawiali Mnie na próbę, sprawdzali Mnie, choć widzieli Moje cuda.

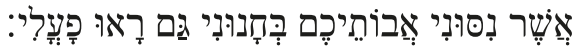

1722 = 19020743126479176501

$318=55271654655942$

$111=19972720236$

Przez czterdzieści lat nie mogłem ścierpieć tamtego pokolenia i powiedziałem: „To są ludzie, których serce błądzi i nie znają Moich dróg”.

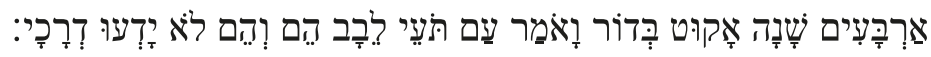




$$
\begin{array}{r}
2328=2349031514534480110247212116355323 \\
438=45361324181648294032354062 \\
159=9184159712111314171317
\end{array}
$$

Przysiągłem w Swoim gniewie, że nie przybędą do Mojej [ziemi] wytchnienia.

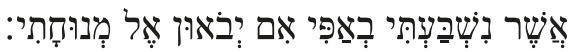
$2081=51431694193832501$

$291=73133314308542$ $92=28415512226$

Śpiewajcie Haszem nową pieśń, śpiewaj Haszem cała ziemio ${ }^{252}$.

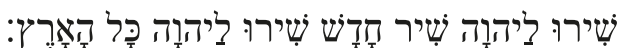
$2312=296505651631251056516$

$341=4423385733513857$

$107=17520121562012$

Śpiewajcie Haszem, błogosławcie Jego Imię, głoście każdego dnia Jego zbawienie.

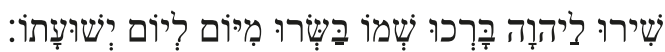
$2628=792869650834622856516$ $387=8141424940393857$ $126=2714151313122012$

Rozgłaszajcie wśród narodów Jego chwałę i Jego cuda pośród wszystkich ludów.

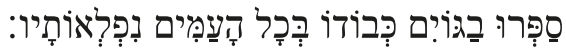
1245 = 583165523861346

$291=885725293458$ $120=34217201622$

Bo Haszem jest wielki i ogromnie sławiony, jest Straszliwy ponad wszystkie moce [niebieskie].

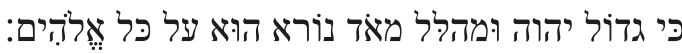

$$
\begin{aligned}
& 760=86501001225745111264330 \\
& 283=41232812411848262521 \\
& 121=14510121492115163
\end{aligned}
$$

Bo wszyscy bogowie [innych] ludów są nicością, to Haszem Uczynił niebiosa.

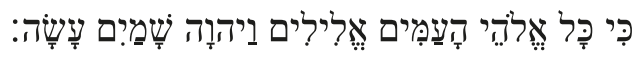
1209 = 37539032121165465030 $318=4257325857282321$ $102=15122313211053$

Chwała i majestat są przed Nim, siła i wspaniałość w Jego Świątyni.

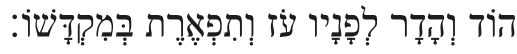

$$
\begin{aligned}
& 2022=45210877717621515 \\
& 285=658823593515 \\
& 114=202514231715
\end{aligned}
$$


Uznajcie Haszem wszystkie rodziny ludzkie, uznajcie chwałę i siłę Haszem.

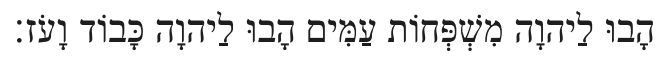
$1247=833256131608375613$

$293=2923381352873813$

$149=2014201316332013$

Uznajcie Haszem, chwałę Jego Imienia, wznieście ofiarę pokarmową i wejdźcie na Jego dziedzińce.

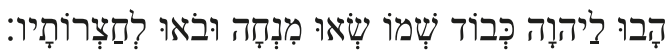

$$
\begin{array}{r}
1622=75015103307325613 \\
299=102154028233813 \\
146=39152210142013
\end{array}
$$

Złóżcie Haszem pokłon w przepychu [Jego] Świątyni, drżyj przed Nim cała ziemio.

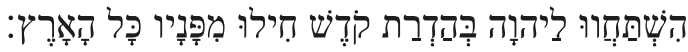

$$
2382 \text { = } 296501865440461156725
$$

$366=4423603644533868$

$141=17524188172032$

Głoście pośród narodów: Haszem króluje, naprawdę utwierdził świat, tak, by się nie zachwiał, On osądzi ludy z prawością.

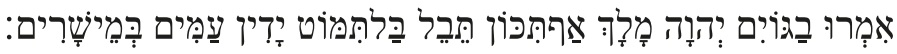
2736 = 60216074487432557902661247 $486=89523864367136263440$ $162=171611289269171613$

Ucieszy się niebo i uraduje się ziemia, wykrzyknie morze i to, co je wypełnia.

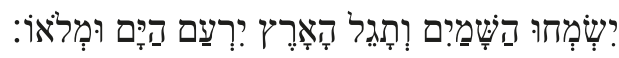
$1952=8355320296439395364$

$332=38285944436258$

$116=20101417161722$

Rozraduje się pole i wszystko, co jest na nim, wtedy[nawet] wszystkie leśne drzewa okażą radość.

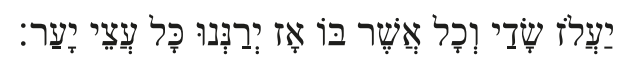
$1820=28017050316850156314117$ $344=46442364842293545$ $110=10175198611818$

Wobec Haszem, gdy nadejdzie, nadejdzie osądzić ziemię. Osądzi świat sprawiedliwością, a ludy prawdą.

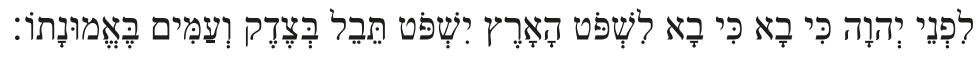
2675 = 50516619643239929641933033026170 $488=645843365744593213212653$ $182=282216921172333331717$ 
Haszem jest królem! Niech uraduje się ziemia, niech ucieszą się liczne wyspy ${ }^{253}$.

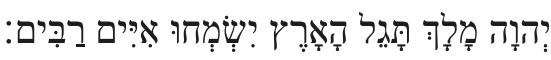

$$
\begin{aligned}
& 1522=25261364296439026 \\
& 280=45345844373626 \\
& 91=97221710917
\end{aligned}
$$

Obłok i ciemność Go otaczają, sprawiedliwość i sąd są podstawą Jego tronu.

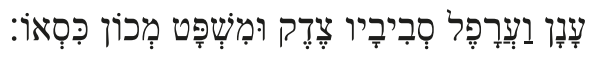

$$
\begin{aligned}
& 1478=8711643519490386170 \\
& 344=33446641457144 \\
& 137=15173014182617
\end{aligned}
$$

Ogień idzie przed Nim i wypala Jego wrogów wokół.

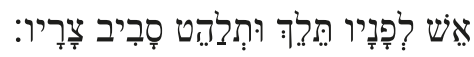
$1757=30674450450176301$

$$
\begin{array}{r}
273=542954455922 \\
92=1811279234
\end{array}
$$

Jego błyskawice rozświetlają świat, ziemia widzi i drży.

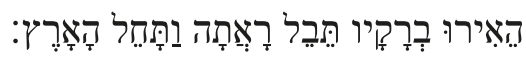
$2318=296444606432318222$

$275=444848365742$ $86=17211291215$

Góry roztapiają się jak wosk przed Haszem, przed Władcą całej ziemi.

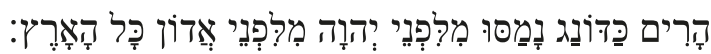
$1347=29650612102621015683255$ $384=442325662666483848$ $150=17516211721212012$

Niebo opowiada o Jego sprawiedliwości i wszystkie ludy widzą Jego chwałę.

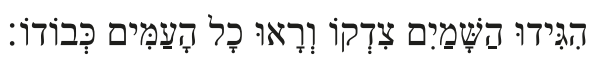
$1089=381655021320039528$ $279=29572333476228$ $117=2021515201719$

[Niech] zawstydzą się wszyscy bałwochwalcy, modlący się do bożków, [gdy] wszystkie siły [niebieskie] składają Mu pokłon.

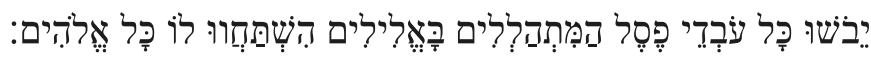
$2204=8650367251235601708650318$ $440=41231868609244322339$ $152=14593215291714512$

Syjon usłyszy i uraduje się, ucieszą się miasta Judy z powodu Twoich sądów, Haszem.

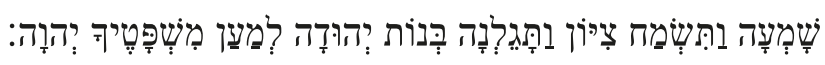
$2982=2645919030458494156754415$ 


$$
\begin{aligned}
& 471=268155304462487055 \\
& 192=172719211726212519
\end{aligned}
$$

Bo Ty, Haszem, jesteś najwyższy nad całą ziemią, wyniesiony bardzo ponad wszystkie siły [niebieskie].

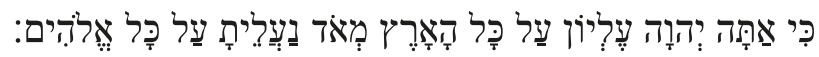
$1915=865010056045296501001662640630$ $412=412328741844232858262821$ $142=14510209175102217103$

Wy, którzy kochacie Haszem - znienawidźcie zło! On strzeże życia Swoich pobożnych i ratuje ich z rąk złoczyńców.

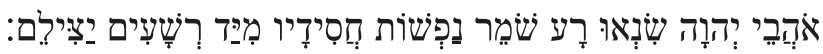

$$
\begin{aligned}
& 2999=18062054988365402703572618 \\
& 479=36802753805436422618 \\
& 155=1817926269915179
\end{aligned}
$$

Światło jest zasiane dla sprawiedliwych i radość dla [ludzi] prawego serca.

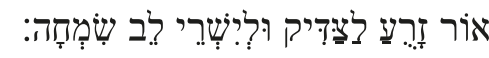
$1659=35332556234277207$

$$
273=471479634327
$$$$
84=2051618169
$$

Cieszcie się, sprawiedliwi, Haszem i dziękujcie, wspominając Jego święte Imię.

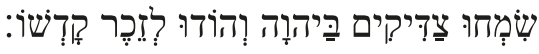

$$
\begin{aligned}
& 1330=4102572728254354 \\
& 277=505027287447 \\
& 115=141427192021
\end{aligned}
$$

Psalm. Śpiewajcie Haszem nową pieśń, bo uczynił cuda. Zbawienia Swego [ludu dokonał] Swoją prawicą i siłą Swojej świętej mocy ${ }^{254}$.

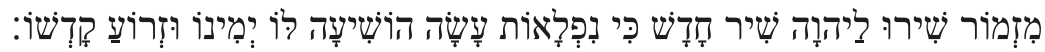

$$
\begin{aligned}
& 3906=410289116363963755673031251056516293 \\
& 612=50555318634272213351385759 \\
& 216=14281792715273156201223
\end{aligned}
$$

Haszem rozsławił Swoje zbawienie, oczom narodów ukazał Swoją sprawiedliwość.

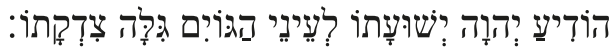

$$
1785=60038641707922695
$$$$
336=69203762812641
$$$$
138=24111917271723
$$

Pamiętał o Swojej dobroci i wierności dla Domu Jisraela, wszystkie krańce ziemi ujrzały zbawienie od naszego Boga.

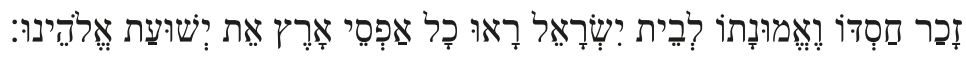
3785 = 1027864012911515020754144250978227 
$527=487523394323276446683338$

$176=212151216591010322411$

Wykrzykuj do Haszem cała ziemio, otwórzcie [usta], śpiewajcie i grajcie.

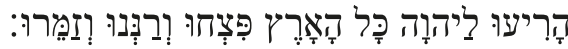

$$
\begin{aligned}
& 1448=2593121842965056291 \\
& 323=52604944233857 \\
& 143=2524311752021
\end{aligned}
$$

Grajcie dla Haszem na harfie, na harfie, z głosem pochwalnej pieśni.

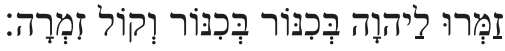

$$
\begin{aligned}
& 1259=25214227827856253 \\
& 278=454353533846 \\
& 107=181617172019
\end{aligned}
$$

Na trąbach i głosem szofaru wykrzykujcie przed Królem - Haszem.

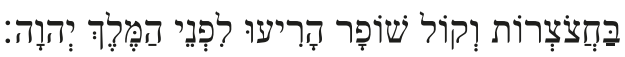

$$
\begin{aligned}
& 2106=2695170291586142 \\
& 378=264153576443 \\
& 144=171417211916
\end{aligned}
$$

Niech zakrzyknie morze i to, co je napełnia, ziemia i jej mieszkańcy.

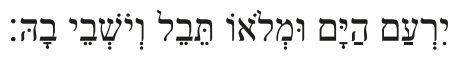

$$
\begin{aligned}
& 1225 \text { = } 73284328355320 \\
& 217=74936382859 \\
& 73=7139201014
\end{aligned}
$$

Rzeki klasną w dłonie, góry zaśpiewają razem radośnie.

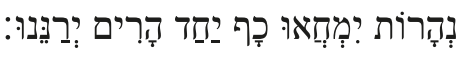

$$
\begin{aligned}
& 1419=3162552210065661 \\
& 267=644822283867 \\
& 96=191213102022
\end{aligned}
$$

Wobec Haszem, który przybywa, by osądzić ziemię. Osądzić świat sprawiedliwością, a ludy prawością.

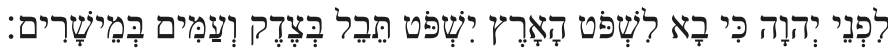

$$
\begin{aligned}
& 2739=60216619643239929641933026170 \\
& 489=895843365744593212653 \\
& 165=1722169211723331717
\end{aligned}
$$

Haszem jest królem! Niech ludy zadrżą. On zasiada na cherubach, niech zatrzęsie się ziemia ${ }^{255}$.

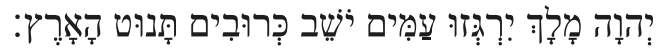

$$
1853=2964652783121602269026
$$$$
350=4451623352463626
$$

$$
125=17241761619917
$$

Haszem jest wielki na Syjonie i wywyższony ponad wszystkie ludy. 


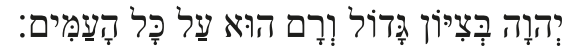
$800=16550100122464315826$ $260=5723281239255026$ $116=215101212162317$

Niech wychwalają Twoje Imię, które jest wielkie, straszliwe i święte.

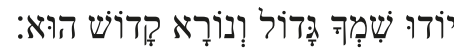
$1114=124102634336026$ $205=125047254526$ $88=12142016917$

Potężny jest Król, kochający sprawiedliwość. Ty ustanowiłeś prawość, Ty uczyniłeś sąd i sprawiedliwość w Jaakowie.

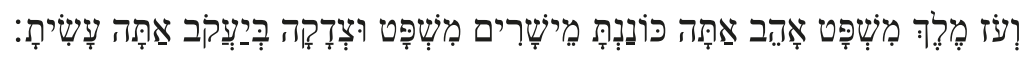
$4146=78040618420542960052640684299083$ $573=69284952608767288603629$ $195=1510132524152210824920$

Wywyższajmy Haszem, naszego Boga, i złóżmy pokłon Jego podnóżkowi, On jest święty.

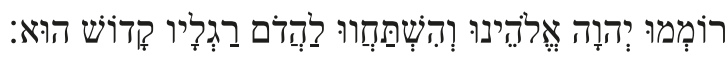
$1901=124102497973110226292$ $353=1250513474482658$ $155=1214151638211722$

Mosze i Aharon pośród Jego kohenów i Szmuel pomiędzy wzywającymi Jego Imienia wołali do Haszem i On im odpowiedział.

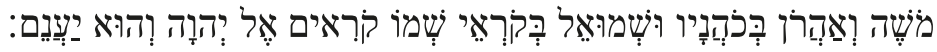
$2338=17018263135134631338393262345$ $457=5318261361405259484639$ $160=1718174913723211912$

W słupie obłoku Bóg przemawiał, przestrzegali Jego świadectw i prawa, które im dał.

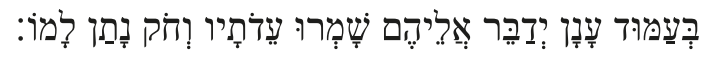
$2320=7650011449054686216170122$ $394=315033586041364441$ $142=13141522151491723$

Haszem, nasz Boże, Ty im odpowiedziałeś, byłeś dla nich przebaczającym Bogiem, [ale] i karałeś ich za wykroczenia.

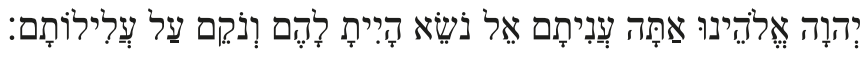
$2868=586100196754253513157040610226$

$474=9128523047361375284826$ $159=28101612119421102117$

Wywyższajmy Haszem, naszego Boga, i złóżmy pokłon ku Jego świętej górze, bo Haszem, nasz Bóg, jest święty. 


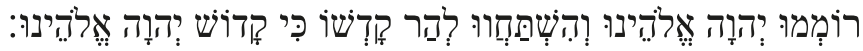

$2364=102264103041023573110226292$

$438=48265021503774482658$

$177=2117143141038211722$

Psalm Dawida. Uznajcie Haszem, synowie potężnych, uznajcie chwałę i moc Haszem² ${ }^{256}$.

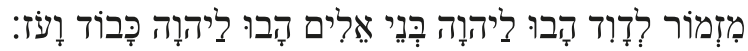

$733=833256138162561344293$

$301=29233813362638132659$

$157=201420139820131723$

Przyznajcie Haszem świętość Jego Imienia, złóżcie pokłon Haszem w potędze świętości.

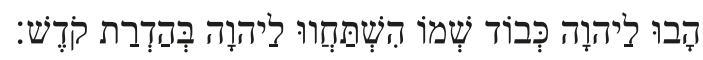

$2243=40461156725346325613$

$317=4453386840233813$

$137=817203213142013$

Głos Haszem nad wodami, Bóg chwały zagrzmiał, Haszem nad wielkimi wodami.

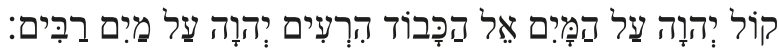

$1218=252901002632537319510026136$

$372=4536282664281341282637$

$138=9910171919414101710$

Głos Haszem w potędze, głos Haszem w majestacie.

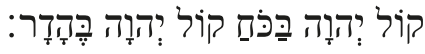

$$
\begin{aligned}
& 565 \text { = } 211261363026136 \\
& 178=312637212637 \\
& 79=131710121710
\end{aligned}
$$

Głos Haszem rozbija cedry - Haszem rozbije cedry Libanu.

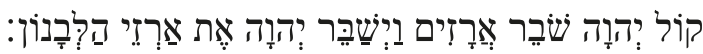

$$
\begin{aligned}
& 2228=1432184012651825850226136 \\
& 356=533823265951432637 \\
& 122=2611517141571710
\end{aligned}
$$

Sprawia, że podskakują jak cielak Liban i Syria, jak młode jednorożce.

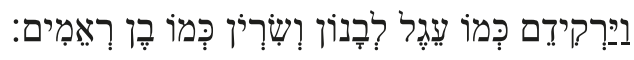
$1652=291526656613810366370$

$365=5716307148313082$

$113=127121721131219$

Głos Haszem roznieca płomienie ognia.

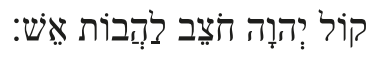

$1006=30144310026136$

$160=2247282637$

$70=420191710$ 
Głos Haszem wstrząsa pustynią, wstrząsa Haszem pustynią Kadesz.

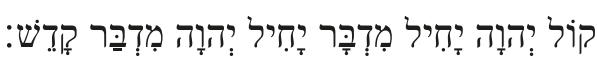

$$
\begin{aligned}
& 1200=40424626582465826136 \\
& 291=4439264039402637 \\
& 102=812171312131710
\end{aligned}
$$

Głos Haszem przeraża łanie i obnaża lasy, a w Jego Świątyni wszyscy głoszą chwałę.

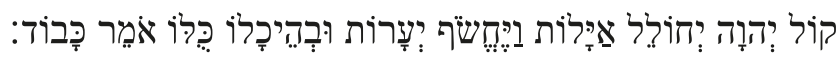
2191 = 3224156796864044478426136

$$
\begin{gathered}
436=23342952746251482637 \\
166=1471125202615211710
\end{gathered}
$$

Haszem włada potopem, Haszem zasiadł jako Król na wieki.

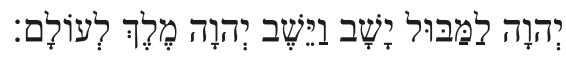

$$
\begin{aligned}
& 1056=176902631831210826 \\
& 264=59362639334526 \\
& 102=239171261817
\end{aligned}
$$

Haszem da Swojemu ludowi siłę, Haszem pobłogosławi Swój lud pokojem.

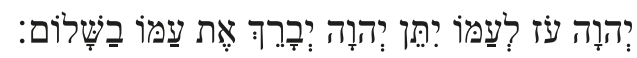
$1862=378116401232264601467726$

$363=543523432646472326$

$125=1817571710201417$

Błagamy! Siłą wielkości Twojej prawicy rozwiąż wiązkę 257.

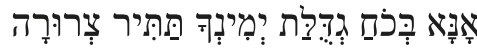
$2160=50110101304373052$

$297=697458412116$

$81=24111314127$

Przyjmij pieśń Swojego ludu, umocnij nas, oczyść nas, o Straszliwy!

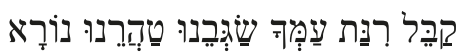
$1800=257270361130650132$

$270=415446405633$

$90=14271913116$

Prosimy, Potężny! Strzeż jak źrenicy tych, którzy poszukują Twojej Jedności.

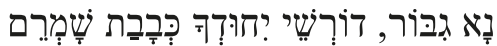

$1834=5804244852021151$

$250=673739613115$

$79=13102116136$

Błogosław ich, oczyszczaj ich, zmiłuj się nad nimi, niech Twoja sprawiedliwość nieustannie ich wynagradza. 


$$
\begin{aligned}
308 & =414974514746 \\
92 & =141320152010
\end{aligned}
$$

Mocarny Święty, przez mnogość Twojego dobra prowadź Swoją społeczność.

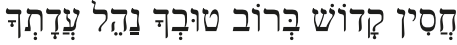

$$
\begin{aligned}
& 1364=4948537210410128 \\
& 239=533128305047 \\
& 95=171319211420
\end{aligned}
$$

Jedyny, godny chwały, zwróć się ku Swojemu ludowi, [ku] tym, którzy pamiętają o Twojej świętości.

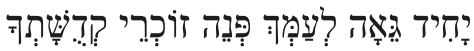

$$
\begin{aligned}
& 1403=824243135160932 \\
& 260=77543652932 \\
& 89=14181816914
\end{aligned}
$$

Przyjmij nasz krzyk i usłysz nasze wołanie, Ty, który znasz to, co ukryte. Błogosławione imię chwały Jego królestwa na wieki.

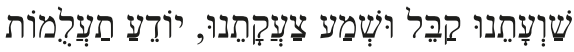

$$
\begin{aligned}
& 3132=94690716416132832 \\
& 396=913695563385 \\
& 135=28183220631
\end{aligned}
$$

Przy zastosowaniu trzech metod gematrii średnie pokrycie wartości liczbowych odpowiadających podstawowym wartościom liczbowym wymiarów wynosi $41 \%$, przy czym metodą absolutną uzyskano 45\%, uproszczoną 46\%, a redukcyjną 33\%. Dla wszystkich analizowanych wartości liczbowych średnia wynosi 68\%, przy czym metodą absolutną uzyskano 54\%, uproszczoną $80 \%$, a redukcyjną $68 \%$. Ogólnie w wyniku zastosowania trzech metod pokryto $96 \%$ wartości p od s taw ow y ch i $69 \%$ wszystkich analizowanych wartości liczbowych.

Kilka wartości analizowanych fragmentów odpowiada wartościom wymiarów bożnic. $\mathrm{Na}$ podstawie analizy metodą redukcyjną i uproszczoną stwierdzono istnienie zależności w synagogach zlokalizowanych w takich miastach, jak:

\section{Pińczów}

Długość synagogi (92): Przysiągłem w Swoim gniewie, że nie przybędą do Mojej [ziemi] wytchnienia.

(92): Ogień idzie przed Nim i wypala Jego wrogów wokół.

(92): Błogosław ich, oczyszczaj ich, zmiłuj się nad nimi, niech Twoja sprawiedliwość nieustannie ich wynagradza.

Szerokość sali męskiej (438): Przez czterdzieści lat nie mogłem ścierpieć tamtego pokolenia i powiedziałem: To są ludzie, których serce błądzi i nie znają Moich dróg.

(438): Wywyższajmy Haszem, naszego Boga, i złóżmy pokłon ku Jego świętej górze, bo Haszem, nasz Bóg, jest święty. 
(73): Niech zakrzyknie morze i to, co je napełnia, ziemia i jej mieszkańcy.

Wysokość sali męskiej (384): Góry roztapiają się jak wosk przed Haszem, przed Władcą całej ziemi.

\section{Rzeszów (Synagoga Stara)}

Długość synagogi (122): Głos Haszem rozbija cedry - Haszem rozbije cedry Libanu.

Szerokość synagogi (110): Jego jest morze - On je uczynił, i suchy ląd ukształtowała Jego moc.

(110): Rozraduje się pole i wszystko, co jest na nim, wtedy[nawet] wszystkie leśne drzewa okażą radość.

Wysokość synagogi (486): Głoście pośród narodów: Haszem króluje, naprawdę utwierdził świat, tak, by się nie zachwiał, On osądzi ludy z prawością. (81): Błagamy! Siłą wielkości Twojej prawicy rozwiąż wiązkę.

Długość sali męskiej (100): Bo Haszem jest wielkim Bogiem i wielkim Królem nad wszystkimi siłami [niebieskimi].

Szerokość sali męskiej (88): Niech wychwalają Twoje Imię, które jest wielkie, straszliwe i święte.

\section{Zamość}

Szerokość synagogi (100): Bo Haszem jest wielkim Bogiem i wielkim Królem nad wszystkimi siłami [niebieskimi].

Wysokość synagogi: (372): Głos Haszem nad wodami, Bóg chwały zagrzmiał, Haszem nad wielkimi wodami.

Długość sali męskiej (84): Światło jest zasiane dla sprawiedliwych i radość dla [ludzi] prawego serca.

Wysokość sali męskiej (396): Przyjmij nasz krzyk i usłysz nasze wołanie, Ty, który znasz to, co ukryte. Błogosławione imię chwały Jego królestwa na wieki.

\section{Szczebrzeszyn}

Długość synagogi

(116:) Ucieszy się niebo i uraduje się ziemia, wykrzyknie morze i to, co je wypełnia.

(116:) Haszem jest wielki na Syjonie i wywyższony ponad wszystkie ludy.

Szerokość synagogi (102): Bo wszyscy bogowie [innych] ludów są nicością, to Haszem Uczynił niebiosa.

(102): Haszem włada potopem, Haszem zasiadł jako Król na wieki.

(612): Psalm. Śpiewajcie Haszem nową pieśń, bo uczynił cuda.

Zbawienia Swego [ludu dokonał] Swoją prawicą i siłą Swojej świętej mocy.

Wysokość synagogi: (384): Góry roztapiają się jak wosk przed Haszem, przed Władcą całej ziemi. 
Długość sali męskiej (92): Przysiągłem w Swoim gniewie, że nie przybędą do Mojej [ziemi] wytchnienia.

(92): Ogień idzie przed Nim i wypala Jego wrogów wokół.

(92): Błogosław ich, oczyszczaj ich, zmiłuj się nad nimi, niech Twoja sprawiedliwość nieustannie ich wynagradza.

Wysokość sali męskiej (396): Przyjmij nasz krzyk i usłysz nasze wołanie, Ty, który znasz to, co ukryte. Błogosławione imię chwały Jego królestwa na wieki.

\section{Tykocin}

Długość synagogi (144): Na trąbach i głosem szofaru wykrzykujcie przed Królem Haszem.

Szerokość synagogi (144): Na trąbach i głosem szofaru wykrzykujcie przed Królem Haszem.

Wysokość sali męskiej (396): Przyjmij nasz krzyk i usłysz nasze wołanie, Ty, który znasz to, co ukryte. Błogosławione imię chwały Jego królestwa na wieki.

Wysokość bimy $\quad$ (70): Głos Haszem roznieca płomienie ognia.

\section{Orla}

Szerokość synagogi (126): Śpiewajcie Haszem, błogosławcie Jego Imię, głoście każdego dnia Jego zbawienie.

Długość sali męskiej (114): Chwała i majestat są przed Nim, siła i wspaniałość w Jego Świątyni.

Szerokość sali męskiej (107): Śpiewajcie Haszem nową pieśn, śpiewaj Haszem cała ziemio. (107): Grajcie dla Haszem na harfie, na harfie, z głosem pochwalnej pieśni.

Wysokość sali męskiej (70): Głos Haszem roznieca płomienie ognia.

Szerokość centralnego (264): Haszem włada potopem, Haszem zasiadł jako Król na wieki. pola

Wysokość centralnego (396): Przyjmij nasz krzyk i usłysz nasze wołanie, Ty, który znasz to, pola co ukryte. Błogosławione imię chwały Jego królestwa na wieki.

\section{Lesko}

Długość synagogi

(126): Śpiewajcie Haszem, błogosławcie Jego Imię, głoście każdego dnia Jego zbawienie.

\section{Tarnogród}

Długość sali męskiej (112): Chodźmy! Zaśpiewajmy dla Haszem, zakrzyknijmy dla Opoki naszego zbawienia.

Szerokość sali męskiej (112): Chodźmy! Zaśpiewajmy dla Haszem, zakrzyknijmy dla Opoki naszego zbawienia.

\section{Rzeszów (Synagoga Nowomiejska)}

Wysokość synagogi (84): Światło jest zasiane dla sprawiedliwych i radość dla [ludzi] prawego serca. 
Długość sali męskiej (115): Cieszcie się, sprawiedliwi, Haszem i dziękujcie, wspominając Jego święte Imię.

Szerokość centralnego (216): Psalm. Śpiewajcie Haszem nową pieśń, bo uczynił cuda.

pola Zbawienia Swego [ludu dokonał] Swoją prawicą i siłą Swojej świętej mocy.

\section{Bobowa}

Szerokość synagogi (100): Bo Haszem jest wielkim Bogiem i wielkim Królem nad wszystkimi siłami [niebieskimi].

Długość sali męskiej (96): Rzeki klasną w dłonie, góry zaśpiewają razem radośnie.

Szerokość sali męskiej (84): Światło jest zasiane dla sprawiedliwych i radość dla [ludzi] prawego serca.

Szerokość centralnego (192): Syjon usłyszy i uraduje się, ucieszą się miasta Judy z powodu pola Twoich sądów, Haszem.

\section{Dukla}

Szerokość synagogi (120): Rozgłaszajcie wśród narodów Jego chwałę i Jego cuda pośród wszystkich ludów.

Wysokość synagogi (336): Haszem rozsławił Swoje zbawienie, oczom narodów ukazał Swoją sprawiedliwość.

Długość sali męskiej (110): Jego jest morze - On je uczynił, i suchy ląd ukształtowała Jego moc.

(110): Rozraduje się pole i wszystko, co jest na nim, wtedy[nawet] wszystkie leśne drzewa okażą radość.

\section{Lańcut}

Długość synagogi （112): Chodźmy! Zaśpiewajmy dla Haszem, zakrzyknijmy dla Opoki naszego zbawienia.

Wysokość sali męskiej (396): Przyjmij nasz krzyk i usłysz nasze wołanie, Ty, który znasz to, co ukryte. Błogosławione imię chwały Jego królestwa na wieki.

Długość bimy (144): Na trąbach i głosem szofaru wykrzykujcie przed Królem Haszem.

Szerokość bimy $\quad$ (144): Na trąbach i głosem szofaru wykrzykujcie przed Królem Haszem.

Wysokość bimy (396): Przyjmij nasz krzyk i usłysz nasze wołanie, Ty, który znasz to, co ukryte. Błogosławione imię chwały Jego królestwa na wieki.

\section{Włodawa}

Długość synagogi: (86): Jego błyskawice rozświetlają świat, ziemia widzi i drży.

Szerokość sali męskiej (114): Chwała i majestat są przed Nim, siła i wspaniałość w Jego Świątyni.

Wysokość sali męskiej (438): Przez czterdzieści lat nie mogłem ścierpieć tamtego pokolenia i powiedziałem: To są ludzie, których serce błądzi i nie znają Moich dróg. 
(438): Wywyższajmy Haszem, naszego Boga, i złóżmy pokłon ku Jego świętej górze, bo Haszem, nasz Bóg, jest święty.

(73): Niech zakrzyknie morze i to, co je napełnia, ziemia i jej mieszkańcy.

Wysokość centralnego (438): Przez czterdzieści lat nie mogłem ścierpieć tamtego pokolenia pola

i powiedziałem: To są ludzie, których serce błądzi i nie znają Moich dróg. (438): Wywyższajmy Haszem, naszego Boga, i złóżmy pokłon ku Jego świętej górze, bo Haszem, nasz Bóg, jest święty.

(73): Niech zakrzyknie morze i to, co je napełnia, ziemia i jej mieszkańcy.

\section{Siemiatycze}

Długość synagogi

(86): Jego błyskawice rozświetlają świat, ziemia widzi i drży"

Długość sali męskiej

(121): Bo Haszem jest wielki i ogromnie sławiony, jest Straszliwy ponad wszystkie moce [niebieskie].

Szerokość sali męskiej (117): Niebo opowiada o Jego sprawiedliwości i wszystkie ludy widzą Jego chwałę.

Kabbalat Szabat wykazuje dobrą reprezentatywność wartości liczbowych, które odpowiadają wymiarom bożnic, zwłaszcza wartościom liczbowym wymiarów podstawowych, występują dwu-, trzy- i czterokrotnie lub są podstawowymi wartościami liczbowymi wymiarów pojawiających się tylko raz. Najczęściej powtarzające się wymiary są dość dobrze lub dobrze reprezentowane. Szczególnie tyczy się to liczb: 25, 33 i 39, które w modlitwie tej pojawiają się w sumie trzynastokrotnie, oraz liczby 50, która występuje dwadzieścia pięć razy. Niedoreprezentowana jest jednak liczba 66, która występuje w sumie pięć razy. Liczba 396, będąca ekwiwalentem wartości 33, pojawia się w modlitwie dwukrotnie.

\subsubsection{Tikkun Chacot ${ }^{258}$}

Tikkun Rachel:

Abym dał płaczącym nad Syjonem zawój zamiast popiołu ${ }^{259}$.

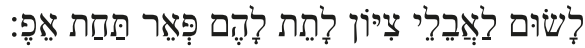

$$
\begin{aligned}
& 2680=818082817583015673376 \\
& 331=1852383056483752 \\
& 106=916111211211016
\end{aligned}
$$

Nad rzekami Babilonu - tam siedzieliśmy i płakaliśmy na wspomnienie Syjonu ${ }^{260}$.

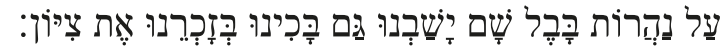

$2476=156401285884336834034661100$

$$
388=48236043165334166728
$$

$136=2152416717772210$

Na wierzbach w tamtej krainie zawiesiliśmy lutnie nasze, 


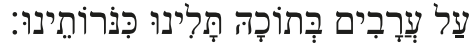

$$
\begin{aligned}
& 2093 \text { = } 742496433322100 \\
& 302=10364466128 \\
& 95=3119191610
\end{aligned}
$$

Bo tam żądali od nas słów pieśni Ci, którzy nas wzięli w niewolę, a ciemiężcy nasi - radości: Śpiewajcie nam jakąś pieśń Syjonu!

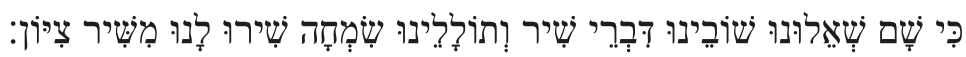

$$
\begin{aligned}
& 4062=1565508651635353851021637439334030 \\
& 597=486432564788513659603421 \\
& 183=21101412203469232473
\end{aligned}
$$

Jakże mamy śpiewać pieśń Pana na obcej ziemi?

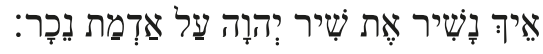
$2343=2704451002651040156031$

$300=4540282651236522$ $75=913101765114$

Jeśli zapomnę cię, Jeruzalem, niech uschnie prawica moja!

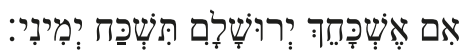
$1824=12072858634941$

$267=5762825214$

$69=121719165$

Niech przylgnie język mój do podniebienia, jeślibym nie pamiętał o tobie, jeślibym nie wyniósł Jeruzalemu nad największą radość moją!

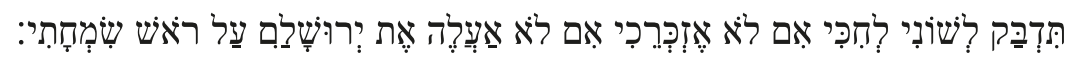

$3824=7585011005864011063141258314168396506$

$548=7442288223341314601314416347$

$152=2061019516451545141811$

Pamiętaj, Panie, synom Edomu dzień Jeruzalemu, gdy wołali: Zburzcie, zburzcie je aż do samych posad!

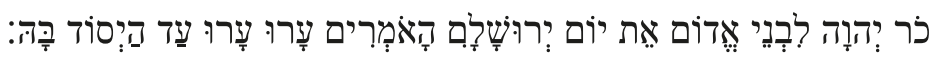

$$
\begin{aligned}
& 2446=7857427627629658656401519226220 \\
& 466=7402042426282292324382631 \\
& 169=72211151517191151511174
\end{aligned}
$$

Córko babilońska, pustoszycielko! Błogosławiony, kto ci odpłaci to, coś nam wyrządziła!

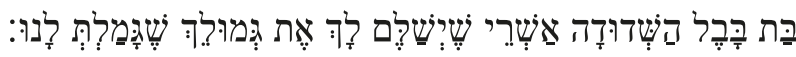

$$
\begin{aligned}
& 3360=86773994015068051132434402 \\
& 408=32714523237752451624 \\
& 120=161718551472776
\end{aligned}
$$

Błogosławiony, kto pochwyci i roztrzaska niemowlęta twoje o skałę. 


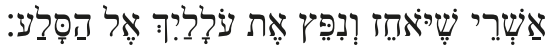

$1820=16531160401226326511$

$299=48136123554752$

$101=21416528207$

Psalm Asafowy. Boże! Poganie wtargnęli do dziedzictwa twego, Znieważyli przybytek twój święty, Jeruzalem zamienili w rumowisko ${ }^{261}$.

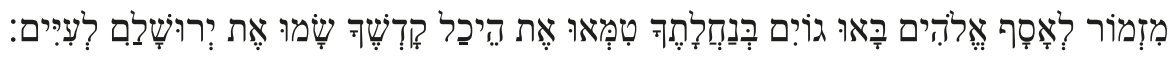
$3567=160586401346424654015651059986171293$ $606=618223405538232969329414559$ $201=1619513101152024149141823$

Trupy sług twoich dali na żer ptactwu niebieskiemu, Ciała wiernych twoich dzikim zwierzętom.

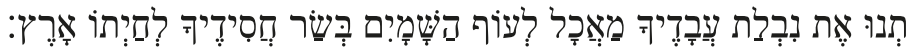
$3476=29145411250235918691106482401456$

$506=3958584362513743502342$

$164=12222271724101614515$

Rozlali krew ich jak wodę wokół Jeruzalemu, Nie było nikogo, kto by ich pogrzebał.

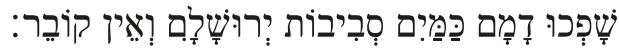

2041 = 3086758648011084406

$349=47318257473055$

$106=11131921111219$

Staliśmy się hańbą dla naszych sąsiadów, Pośmiewiskiem i szyderstwem dla naszego otoczenia.

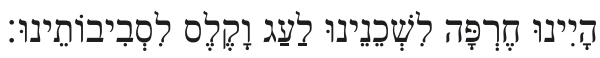

$1715=5761961034662381$

$365=995231885045$

$131=3616132529318$

Dokądże, Panie? Czyż wiecznie gniewać się będziesz? Jak ogień płonąć będzie zapalczywość twoja?

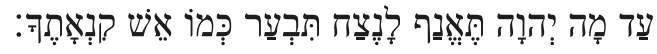

2464 = 57130166672178531264574

$349=672230605254261820$

$124=1341215251817911$

Wylej gniew swój na narody, które cię nie znają, i na królestwa, które nie wzywają imienia twego,

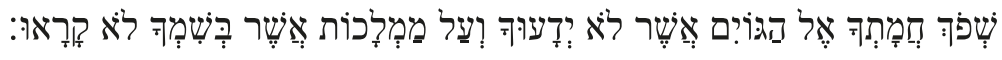
$3448=30731362501536106110315016431468400$

$514=46134742773447134237135849$ $154=104116231620461941813$ 
Albowiem pożarli Jakuba I spustoszyli siedzibę jego!

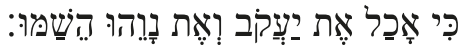

$$
\begin{aligned}
& 1489=351674071824015130 \\
& 220=45312947232421 \\
& 76=18221111563
\end{aligned}
$$

Nie pamiętaj nam dawnych win; Niech nas rychło spotka miłosierdzie twoje, Bośmy bardzo nędzni!

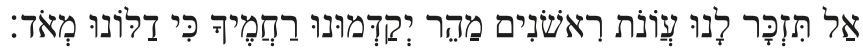

$$
\begin{aligned}
& 2781=4596302782162456015268662731 \\
& 495=1842216272387958326013 \\
& 162=9243172711162214154
\end{aligned}
$$

Wspomóż nas, Boże zbawienia naszego, Dla chwały imienia twego wybaw nas I odpuść grzechy nasze Dla imienia twego!

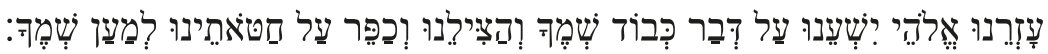

$$
\begin{aligned}
& 3150=3601904841003061973603220610043646333 \\
& 603=45557028547145232628672863 \\
& 225=91934101835914810221027
\end{aligned}
$$

Czemu narody mają mówić: Gdzież jest Bóg ich? Niech jawna będzie wśród narodów w oczach naszych Zemsta za przelaną krew sług twoich!

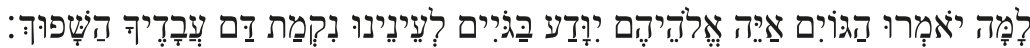

$$
\begin{aligned}
& 2035=41110644590226659091166425775 \\
& 523=604317688238364616375030 \\
& 190=2416814281118197191412
\end{aligned}
$$

Niech dotrze do ciebie jęk więźniów! Mocą ramienia swego uwolnij skazanych na śmierć!

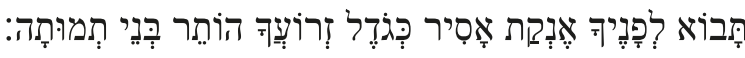

$$
\begin{aligned}
& 3305=8516261130357271551190409 \\
& 434=682653603046566431 \\
& 137=23817241210111913
\end{aligned}
$$

Odpłać sąsiadom naszym siedemkroć urąganie ich, Którym ciebie obrażali, Panie!

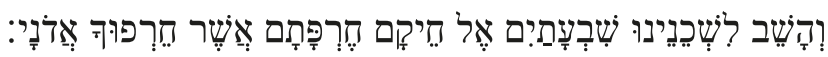
$3398=6531450172815831822466313$

$482=296242805013848834$

$149=1126626144212516$

My zaś, lud twój i owce pastwiska twojego, Będziemy sławić cię na wieki, Będziemy opowiadać chwałę twoją z pokolenia w pokolenie.

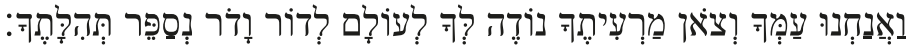

$3124=8553902102401765065740147130121$

$514=7266304259232992394049$ 
$199=182112152352020211331$

Wspomnij, Panie, na to, co się z nami stało! Spójrz i przypatrz się naszej zniewadze 262 .

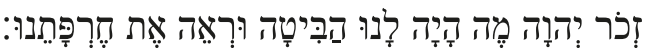
$1792=7444012123186204526227$

$307=872332313220182638$

$136=3351422141191711$

Nasze dziedzictwo przypadło obcym, nasze domy cudzoziemcom.

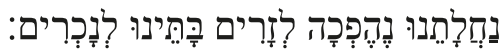

$1809=350468287160544$

$324=8054625276$

$108=1718172531$

Staliśmy się sierotami, bez ojca, nasze matki są jakby wdowy.

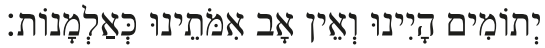

$1711=54750736781506$

$298=79663314574$

$100=25213131820$

Naszą wodę pijemy za pieniądze, musimy płacić za owoce drzew naszych.

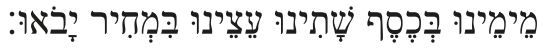

$1589=19260226766162156$

$320=195364734566$

$113=101728191821$

Jarzmo ciąży na karku, omdlewamy, nie dają nam wytchnienia.

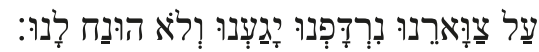

$1174=866937139390353100$

$301=32331949756528$

$139=14241022302910$

Wyciągamy rękę do Egiptu, do Asyrii, by się najeść do syta.

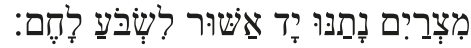

$1887=7840250714506380$

$276=335148145674$

$87=15151252020$

Nasi ojcowie zgrzeszyli, nie ma ich, a my dźwigamy ich winy.

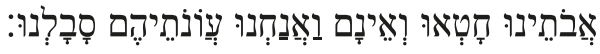

$1450=14858112110724469$

$307=498649442455$

$145=223231172419$

Niewolnicy nami rządzą, nie ma, kto by nas wyrwał z ich ręki.

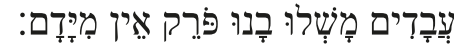

$1095=946138058376126$ 


$$
\begin{array}{r}
240=402556225245 \\
78=13711131618
\end{array}
$$

Swój chleb zdobywamy z narażeniem własnego życia na cios miecza, który zagraża na pustyni.

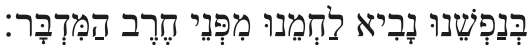

$$
\begin{aligned}
& 1326=25121018013463488 \\
& 282=443054532774 \\
& 111=17121826929
\end{aligned}
$$

Nasza skóra rozpalona jak piec od gorączki głodowej.

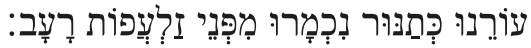

$$
2369=272593180316676332
$$

$371=388054647362$

$128=113518191926$

Kobiety gwałcono na Syjonie, panny w miastach judzkich.

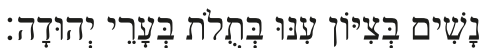
$1828=30282832126158400$

$280=304858365058$

$100=211213182313$

Książęta wieszani byli ich rękami, nie uszanowano powagi starszych.

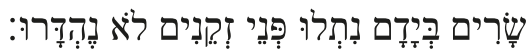

$1735=2653120714048656$

$313=491363415429$

$97=22418141811$

Młodzieńcy musieli nosić kamienie odyńskie, a chłopcy potykali się pod ciężarem drew.

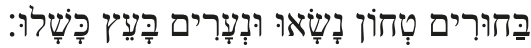

$1590=35616237635773266$

$303=503679423759$

$123=141825152823$

Starcy zaniechali wysiadywania w bramach, a młodzieńcy gry na instrumentach strunowych.

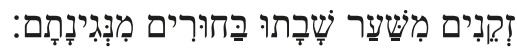

2384 = 593266708610207

$332=8959517063$

$98=2623151618$

Ustała radość naszego serca, nasz taniec zamienił się w pochód żałobny.

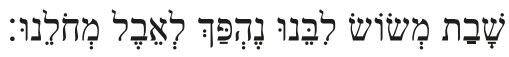

1788 = 1346315588646702

$$
\begin{array}{r}
267=532747346145 \\
96=2692016169
\end{array}
$$


Spadła korona z naszej głowy, biada nam, bo zgrzeszyliśmy!

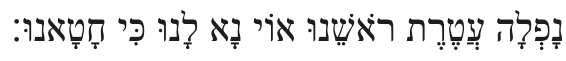

$$
\begin{aligned}
& 1659=7430865117557679165 \\
& 300=3821321517626948 \\
& 120=2931468172221
\end{aligned}
$$

Dlatego chore jest nasze serce, dlatego zaćmione są nasze oczy,

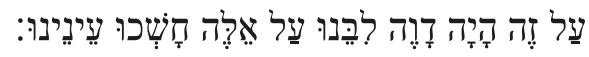

$$
\begin{aligned}
& 901 \text { = } 1963343610088152012100 \\
& 271=704618283415201228 \\
& 127=25199101615111210
\end{aligned}
$$

$\mathrm{Z}$ powodu góry Syjon, że jest spustoszona, że szakale po niej biegają.

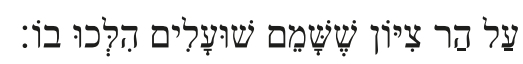
$1666=861456680156205100$

$$
\begin{gathered}
289=8347868482528 \\
100=816241421710
\end{gathered}
$$

Ale Ty, Panie, trwasz na wieki, twój tron z pokolenia w pokolenie.

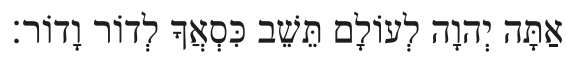

$$
\begin{aligned}
& 1867 \text { = } 21624010170217626406 \\
& 274=36423845592628 \\
& 103=1815119231710
\end{aligned}
$$

Dlaczego chcesz na zawsze zapomnieć o nas, opuścić nas na tak długi czas?

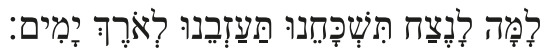
$1923=10025153578417875$

$$
321=464467825230
$$

$114=10831282512$

Spraw, Panie, byśmy wrócili do ciebie, a wrócimy! Odnów nasze dni jak niegdyś!

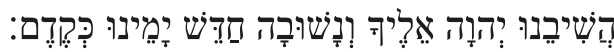

$1421=1641163123696126373$

$305=47533354342658$

$116=1117152771722$

Czyżbyś już zupełnie nas odrzucił? Czy tak bardzo na nas się gniewasz?

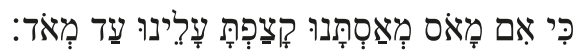
$1684=45741666705571014130$

$307=1820587671291421$

$109=9112222261153$

Spójrz z nieba i popatrz ze swojego świętego, wspaniałego przybytku! Gdzież jest twoja żarliwość i twoja moc? Nawał twoich uczuć i twojego miłosierdzia? Nie stój na ubo$\mathrm{czu}^{263}$ !

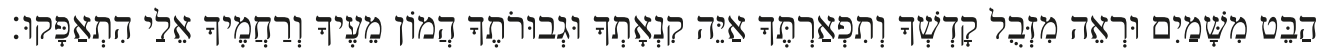




$$
\begin{array}{r}
4650=592412841401016375711611074247921243016 \\
708=7023685038706216995534327016 \\
231=25523142025137271016141616
\end{array}
$$

Ty wszak jesteś naszym ojcem, gdyż Abraham nas nie zna, a Izrael nas nie uznaje! Ty, Panie, jesteś naszym ojcem i naszym Odkupicielem. To jest twoje imię od wieków.

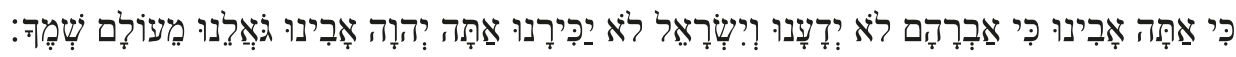

$2965=3601869069264062963154714031248306940630$ $589=45603633262871137050124121332821$

$202=924181517101741623414315103$

Dlaczego dopuściłeś Panie, że zboczyliśmy z twoich dróg, a nasze serca znieczuliłeś na bojaźń przed tobą? Zwróć się znowu ku nam przez wzgląd na twoje sługi, na plemiona, które są twoją własnością!

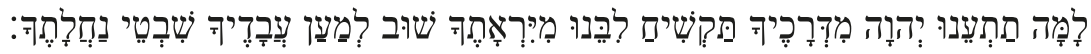
4331 = 5083211061903086718881829426926

$632=6742435529773480692680$ $200=2215161911141617151726$

Dlaczego bezbożni wkroczyli do twojej świętości, nasi nieprzyjaciele podeptali twoją świątynię?

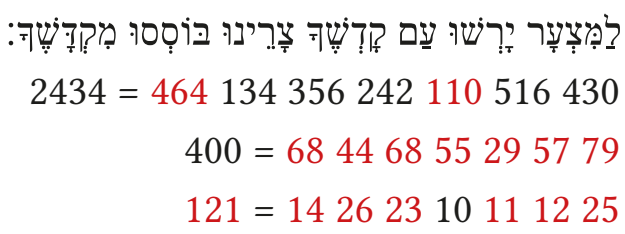

I nie ma nikogo, kto by wzywał twojego imienia, kwapił się do uchwycenia się ciebie, gdyż zakryłeś swoje oblicze przed nami i oddałeś nas w moc naszych grzechów ${ }^{264}$.

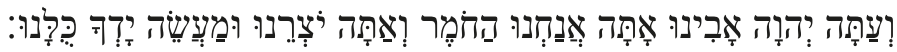
2679 = 106344213564122531154066926481

$456=4325616834464328332649$

$195=167252316192510151722$

Lecz teraz, Panie, Ty jesteś naszym Ojcem, my jesteśmy gliną, a Ty naszym Stwórcą i wszyscyśmy dziełem twoich rąk!

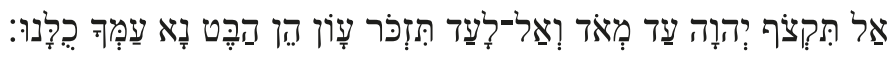
$2098=1061305116551266271043745742667031$ $433=4340151619366032191820267613$ $181=1613616101815141091117224$

Nie gniewaj się, Panie, zanadto i nie pomnij winy na wieki! Ach! Spojrzyj, że my wszyscy jesteśmy twoim ludem.

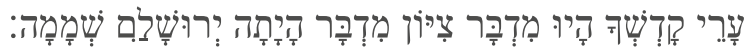

$2764=38558642024615624621424$ $424=5282423948392155$ 


$$
127=1619151221121210
$$

Święte twoje miasta stały się pustynią, Syjon stał się pustynią, Jeruzalem pustkowiem.

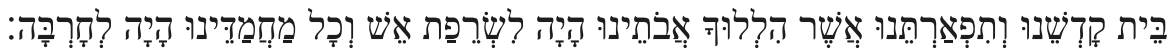
$4886=2452015856301101020469915011143460412$ $647=472068292292205546421086434$ $215=20113211420111919636197$

Święty, wspaniały nasz przybytek, w którym chwalili cię nasi ojcowie, stał się pastwą ognia, a wszystko, co było naszą rozkoszą, leży w gruzach!

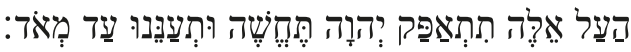

$$
\begin{aligned}
& 2562=45745827132698136105 \\
& 330=1820785626811833 \\
& 132=91133201718915
\end{aligned}
$$

Nakłoń, Boże mój, swojego ucha i usłysz! Otwórz oczy i spójrz na nasze spustoszenia i na miasto, które jest nazwane twoim imieniem! Gdyż nie dla naszej sprawiedliwości zanosimy nasze błaganie przed twoje oblicze, lecz dla obfitego twojego miłosierdzia ${ }^{265}$.

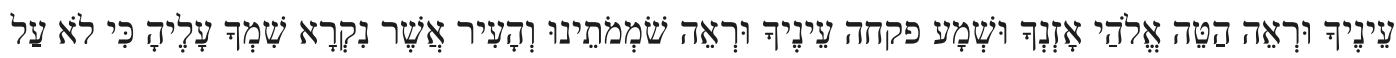

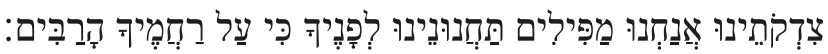
1905802101156601003130115360351501291846212160193416784619212160 $6541=25727810030$ $1303=506228216494754393281321434554425799326149563328193261$ $430=1417103194021253010431699621247141622201510191416$

O Panie, usłysz, o Panie, odpuść! O Panie, dostrzeż i uczyń! Nie zwlekaj przez wzgląd na siebie, mój Boże, bo twoim imieniem nazwane jest to miasto i twój lud!

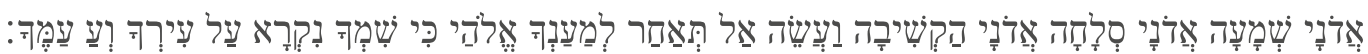
$3759=130763001003513603046210609313814226510365415$ $717=4022572854452128665113476229406555$ $231=131312109931021154211711226519$

Strząśnij z siebie proch, powstań branko jeruzalemska, zdejmij z twojej szyi okowy, wzięta do niewoli córko syjońska! 266

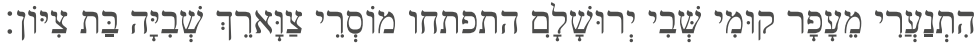
$4586=156402317317316316899586312156390735$ $626=482438566464808233486687$ $194=21611201935196122124$

Na twoich murach, Jeruzalem, postawiłem stróżów: przez cały dzień i przez całą noc, nigdy nie umilkną. Wy, którzy wyznajecie Pana, nie milczcie! $!^{267}$

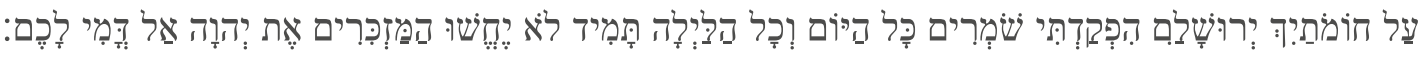
$4339=905431264013223243145480566150590599586484100$ $775=362713262379431349442934237777827028$ $244=994175251841317111651423192510$ 
I nie dajcie mu spokoju, dopóki nie odbuduje Jeruzalemu i dopóki nie uczyni go sławnym na ziemi!

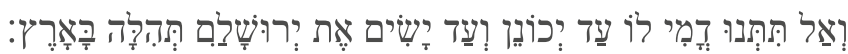
3353 = 2934404405864013608013674365485637

$473=41444482235426552018276419$ $158=1417171959171911991910$

Pan przysiągł na swoją prawicę i na swoje mocne ramię; Już nigdy nie dam twojego zboża na pokarm twoim nieprzyjaciołom, a cudzoziemcy nie będą pili twojego wina, przy którym mozolnie pracowałeś,

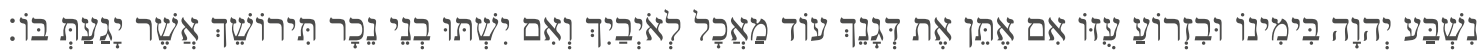
$5177=8483501936270627164773918077401451418329111826422$ $776=851429045265920463726322337142957552653$ $263=8156189814111010171451052030191717$

Lecz ci, którzy zbierają zboże, sami je będą spożywać i wysławiać Pana, a ci, którzy zbierają wino, sami będą je pić w przedsionkach mojej świątyni.

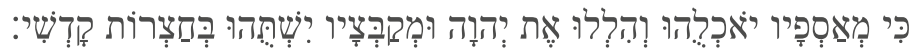
2898 = 41470672125426401777219730 $486=54766474262341456221$ $180=93119291752318263$

Ty powstaniesz, zmiłujesz się nad Syjonem, bo czas zlitować się nad nim, gdyż nadeszła właściwa pora ${ }^{268}$.

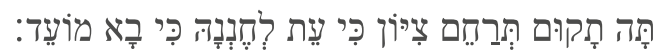
2551 = 12033014347030156648546405

$373=3932153382148636027$

$130=2133231132116159$

Słudzy twoi bowiem kochają jego kamienie i żalą się nad jego ruiną.

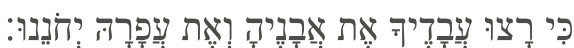
1787 = 1243554076840110629630

$302=5258293223434421$

$113=25221114516143$

Pan buduje Jeruzalem, zgromadza rozproszonych Izraela ${ }^{269}$.

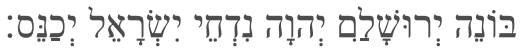
$1428=140541722658663$

$285=506436268227$ $96=141018171918$

Tikkun Lea:

Podnieście, bramy, wierzchy wasze, i podnieście się, bramy prastare, aby wszedł Król chwały! ${ }^{270}$ 


$$
\begin{array}{r}
2601=379019146498313571620307 \\
405=283619475734768028 \\
135=19910202116131710
\end{array}
$$

Któż jest tym Królem chwały? Pan silny i potężny, Pan potężny w boju.

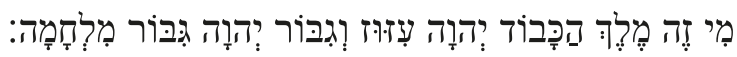
$882=12321126217902637901250$

$306=51312637362628361223$ $162=241317192717199125$

Podnieście, bramy, wierzchy wasze i podnieście się, bramy prastare, aby wszedł Król chwały!

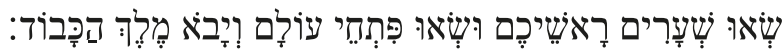

$$
\begin{aligned}
& 2601 \text { = } 379019146498313571620307 \\
& 405=283619475734768028 \\
& 135=19910202116131710
\end{aligned}
$$

Któż jest tym Królem chwały? Pan Zastępów! On jest Królem chwały! Sela.

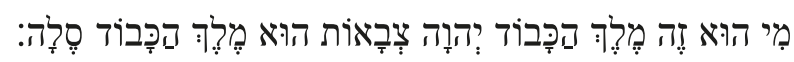
$960=95379012499263790121250$

$294=3228361249262836121223$

$150=1419912221719912125$

Przewodnikowi chóru. Pieśń pouczająca synów Koracha ${ }^{271}$.

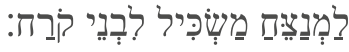

$$
\begin{aligned}
& 1018=30892400218 \\
& 217=47386765 \\
& 64=11111329
\end{aligned}
$$

Jak jeleń pragnie wód płynących, tak dusza moja pragnie ciebie, Boże!

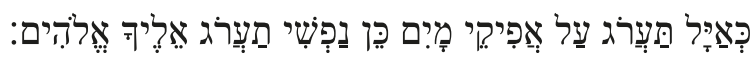
$2455=8661673440709020110067361$ $439=41346162253657286134$

$115=1471617791210167$

Dusza moja pragnie Boga, Boga żywego. Kiedyż przyjdę i ukażę się przed obliczem Boga?

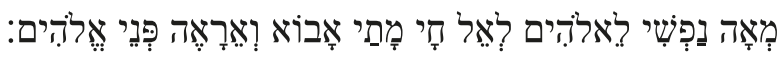
$1580=8614021310450186111644046$ $347=41413310451825536219$ $122=14141510997171710$

Łzy moje są mi chlebem we dnie i w nocy, Gdy mówią do mnie co dzień: Gdzie jest Bóg twój?

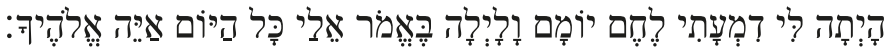

$1716=661661504124381967852440420$

$420=391634232336454233652242$ 
$141=1271655918151520415$

Wspominam to $\mathrm{z}$ wielkim rozrzewnieniem, Jak chodziłem $\mathrm{w}$ tłumie, pielgrzymując do domu Bożego Wśród głosów radości i dziękczynienia tłumu świętującego,

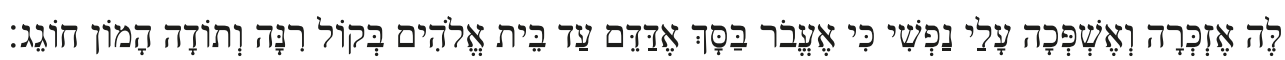
$3171=20101421255138864127449822733044011041223335$ $606=2028433939413420222839216238614417$

$237=2020251212147111310123171125178$

Czemu rozpaczasz, duszo moja, i czemu drżysz we mnie? Ufaj Bogu, gdyż jeszcze sławić go będę: On jest zbawieniem moim i Bogiem moim!

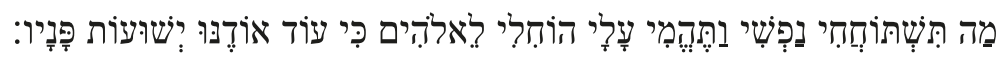
$3478=14679267803011659110461440113245$

$571=478131262153413856629718$ $220=2027221731723112017349$

Dusza moja smuci się we mnie, dlatego wspominam cię z krainy Jordanu i szczytów Hermonu, z gór Misar.

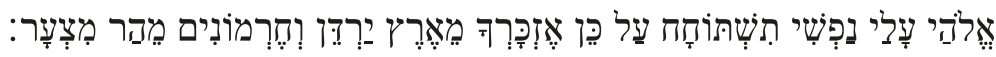

$$
\begin{aligned}
& 3736=40024536026433124870100112244011046 \\
& 613=673890485250252887623828 \\
& 199=22113612161471033171110
\end{aligned}
$$

Głębina przyzywa głębinę w odgłosie wodospadów twoich: wszystkie nawałnice i fale twoje przeszły nade mną.

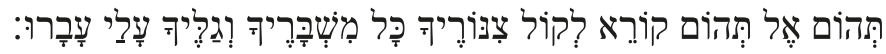

$$
\begin{aligned}
& 2861=278110695725037616630745131451 \\
& 503=4438427723794946461346 \\
& 152=17111514525131019419
\end{aligned}
$$

Za dnia wyznacza Pan łaskę swoją! A w nocy śpiewam mu pieśń, modlę się do Boga życia mego.

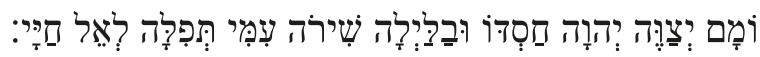

$$
\begin{aligned}
& 1623=286151512051583782611186 \\
& 381=28255639564733263932 \\
& 156=1072012112024172114
\end{aligned}
$$

Mówię do Boga: Skało moja, Dlaczego zapomniałeś o mnie? Dlaczego posępny chodzę, Gdy trapi mnie nieprzyjaciel?

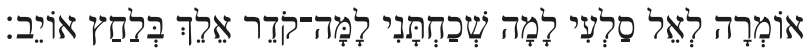

$$
\begin{aligned}
& 1925=1913051304757887517061252 \\
& 395=19402443308630532545 \\
& 134=10226712231217718
\end{aligned}
$$

Jest mi tak, jakby kruszono mi kości, Gdy mnie lżą wrogowie moi, Mówiąc do mnie co dzień; Gdzież jest Bóg twój? 


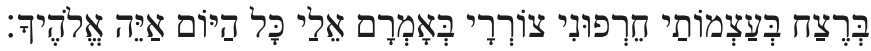

$2295=6616615041283506354618300$

$468=39163423234974758748$

$162=12716551320303321$

Czemu rozpaczasz, duszo moja, I czemu drżysz we mnie? Ufaj Bogu, gdyż jeszcze sławić go będę: On jest zbawieniem moim i Bogiem moim!

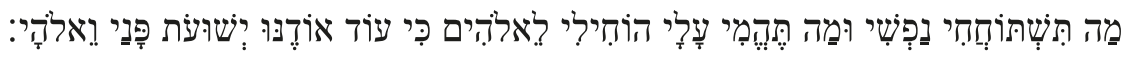
$3573=521407866780301166911045551440113245$

$621=3441753126215351385024629718$

$234=16142122173172411141517349$

Bądź sędzią moim, Boże, i rozstrzygnij spór mój z narodem bezbożnym! Wybaw mnie od ludzi fałszywych i niegodziwych!272

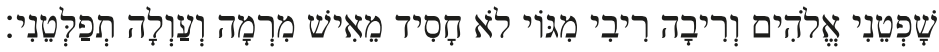

2484 = 57911728535182315922222386449

$504=8445514537133242434171$

$180=3027159194146161426$

Ponieważ Ty jesteś Bogiem moim, ostoją moją, Dlaczego mnie odrzuciłeś? Dlaczego mam chodzić smutny, Gdy nieprzyjaciel mnie dręczy?

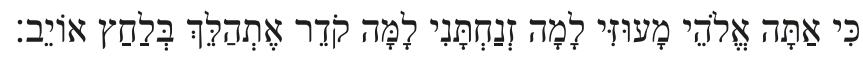
$2199=1913045630475525751334640630$ $417=1940514330753052282821$

$156=10221571230122510103$

Ześlij światło i prawdę swoją, Niech mnie prowadzą, Niech mnie wprowadzą na górę twą świętą I do przybytków twoich.

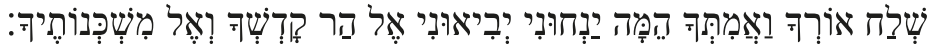
$2848=84637424205318913450467227338$ $490=10819552513536223533841$ $157=27101074172614171114$

Wtedy przystąpię do ołtarza Bożego, Do Boga wesela i radości mojej, I będę cię wysławiał na cytrze, Boże, Boże, mój...!

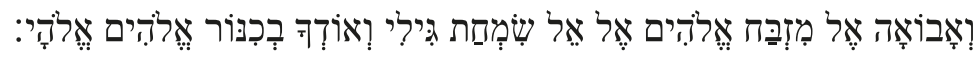
1505 = 46862783753748313186573121 $380=284153283564131341301321$ $155=10141719819441421421$

Czemu rozpaczasz, duszo moja, I czemu drżysz we mnie? Ufaj Bogu, gdyż jeszcze sławić go będę: On jest zbawieniem moim i Bogiem moim!

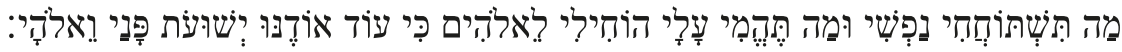
$3578=521407866780301166911045551440113245$ $621=3441753126215351385024629718$ 
Przewodnikowi chóru. Psalm Dawidowy ${ }^{273}$.

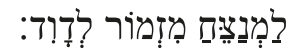

$555=44293218$

$150=265965$

$69=172329$

Niech cię wysłucha Pan w dniu utrapienia, Niech cię wzmocni imię Boga Jakubowego!

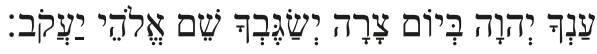

$$
\begin{aligned}
& 1422=182463403352955826140 \\
& 297=4728344743312641 \\
& 99=111071116131714
\end{aligned}
$$

Niech ci ześle pomoc ze świątyni i niech cię wesprze z Syjonu!

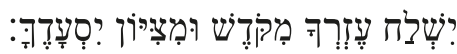
1455 = 164202444297348

$$
285=5667575451
$$$$
96=2031121815
$$

Niechaj wspomni wszystkie dary twoje I niech przyjmie całopalenia twoje. Sela.

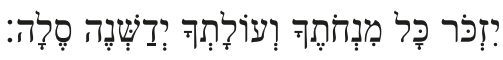

$$
\begin{aligned}
& 1801 \text { = } 9536953251850237 \\
& 298=325473682348 \\
& 100=14182823512
\end{aligned}
$$

Niech ci da to, czego pragnie serce twoje, I niech wypełni każdy twój zamysł!

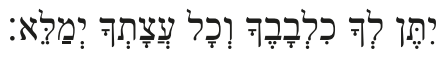

$$
\begin{aligned}
& 1301=81580567450460 \\
& 239=366729382346 \\
& 68=9221111510
\end{aligned}
$$

Będziemy się weselić ze zwycięstwa twego I w imię Boga naszego wzniesiemy sztandary! Niech Pan spełni wszystkie prośby twoje!

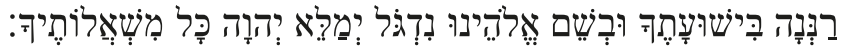

$2614=80750268187102348808305$

$$
445=962326363348428853
$$

$$
148=2451791521152517
$$

Teraz wiem, że Pan wybawił pomazańca swego. Wysłucha go z nieba swego świętego Przez potężną pomoc prawicy swojej.

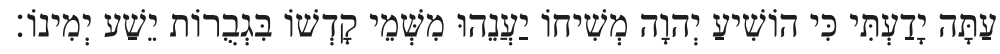
$3830=1163806134103901413642639130494475$

$581=534755505751582658216243$

$194=17111914122422172231716$ 
Jedni chlubią się wozami, drudzy końmi, Lecz my chlubimy się imieniem Pana, Boga naszego.

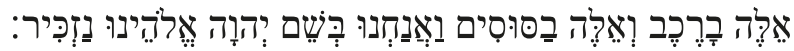

$$
\begin{aligned}
& 1358=287102263421211784222436 \\
& 359=624826324961243518 \\
& 152=172117931251589
\end{aligned}
$$

Zadrżały im kolana i upadli, Lecz my stoimy i trwamy.

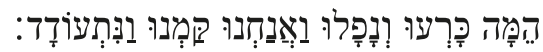

$$
1375 \text { = } 54019612117229650
$$$$
304=725249555323
$$$$
142=361631281714
$$

Panie, królu nasz, pomóż! Wysłuchaj nas w dniu wołania naszego.

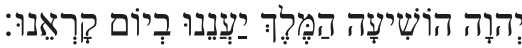

$$
\begin{aligned}
& 1118=357581869539626 \\
& 281=603160416326 \\
& 110=151324142717
\end{aligned}
$$
kają $^{274}$.

Psalm Dawidowy. Pańska jest ziemia i to, co ją napełnia, Świat i ci, którzy na nim miesz-

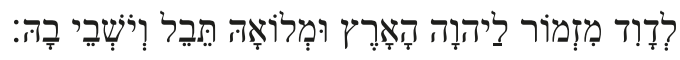
$1544=7328432882965629344$

$$
\begin{gathered}
302=749364344235926 \\
131=71392517202317
\end{gathered}
$$

On bowiem założył ją na morzach I utwierdził ją na rzekach.

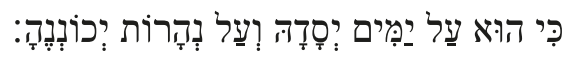
$1229=141661106791001001230$

$$
\begin{gathered}
302=6067343446281221 \\
113=242216161010123
\end{gathered}
$$

Któż może wstąpić na górę Pana? I kto stanie na jego świętym miejscu?

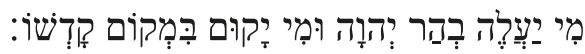

$$
\begin{aligned}
& 1208=410188156562620711550 \\
& 299=5053482926274323 \\
& 101=14171211179165
\end{aligned}
$$

Kto ma czyste dłonie i niewinne serce, Kto nie skłania duszy swej ku próżności i nie przysięga obłudnie.

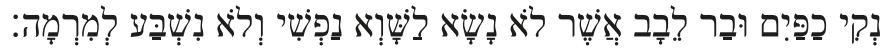

$$
\begin{aligned}
& 2986=315422374403373513150134208150160 \\
& 466=635319624036134216285143 \\
& 133=1817101713946710157
\end{aligned}
$$

Ten dostąpi błogosławieństwa od Pana I sprawiedliwości od Boga, zbawiciela swego, 


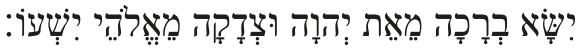

$$
\begin{aligned}
& 1682=3868620526441227311 \\
& 278=53415226363832 \\
& 98=171425179115
\end{aligned}
$$

Takie jest pokolenie tych, co go szukają, Tych, którzy szukają oblicza twego, Boże Jakuba. Sela.

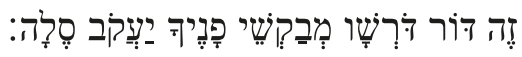

$$
\begin{aligned}
& 1621=9518216045251021012 \\
& 289=32475265513012 \\
& 91=14111611151212
\end{aligned}
$$

Podnieście, bramy, wierzchy wasze, I podnieście się, bramy prastare, Aby wszedł Król chwały.

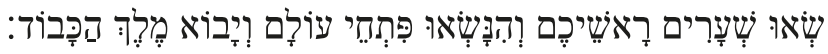
$2662=379025146498368571620307$ $430=283625475753768028$ $151=19916202126131710$

Któż jest tym Królem chwały? Pan silny i potężny, Pan potężny w boju.

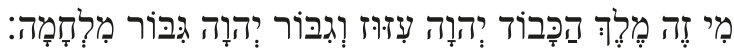

$882=12321126217902637901250$

$306=51312637362628361223$

$162=241317192717199125$

Podnieście, bramy, wierzchy wasze I podnieście się, bramy prastare, Aby wszedł Król chwały!

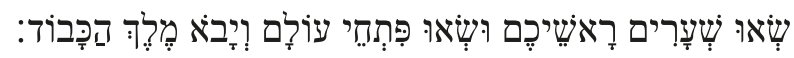
$2601=379019146498313571620307$ $405=283619475734768028$ $135=19910202116131710$

Któż jest tym Królem chwały? Pan Zastępów! On jest Królem chwały! Sela.

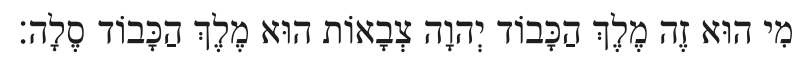
$960=95379012499263790121250$

$294=3228361249262836121223$ $150=1419912221719912125$

Przewodnikowi chóru, z grą na strunach. Psalm. Pieśńn ${ }^{275}$.

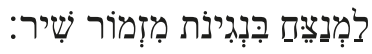

$$
\begin{aligned}
& 1536=510293515218 \\
& 240=51596565 \\
& 78=6232029
\end{aligned}
$$

Niech nam Bóg miłościw będzie I niech nam błogosławi, Niech nad nami rozjaśni oblicze swoje! Sela, 


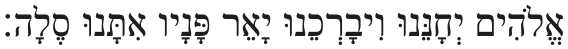

$$
\begin{aligned}
& 1413=9545714621129412486 \\
& 315=32434731695241 \\
& 117=1416204242514
\end{aligned}
$$

Aby poznano na ziemi drogę twoją, Wśród wszystkich narodów zbawienie twoje.

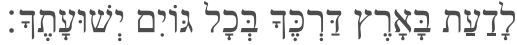

$$
\begin{aligned}
& 1958=8065952244293504 \\
& 284=863225464154 \\
& 86=23147101418
\end{aligned}
$$

Niech sławią cię, Boże, ludy; Niech sławią cię wszystkie ludy!

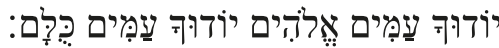

$$
\begin{aligned}
& 588=90160468616046 \\
& 255=365237415237 \\
& 93=91619141619
\end{aligned}
$$

Niech się radują i weselą narody, Gdyż Ty sądzisz ludy sprawiedliwie I kierujesz narodami na ziemi! Sela.

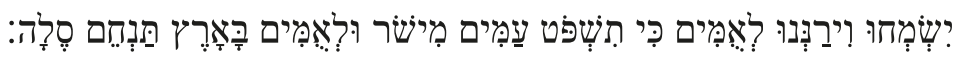

$$
\begin{aligned}
& 3349=9548929312755016078930121322364 \\
& 568=3257415564526921497058 \\
& 181=142114191016243132522
\end{aligned}
$$

Niech sławią cię, Boże, ludy; Niech sławią cię wszystkie ludy!

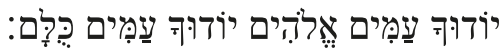

$588=90160468616046$

$255=365237415237$

$93=91619141619$

Ziemia wydała plon swój: Błogosławi nam Bóg, nasz Bóg.

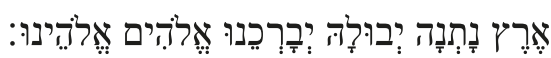

$1325=1028628853505291$

$281=484163355539$

$101=211418171912$

Niech nam Bóg błogosławi, A niech się go boją wszystkie krańce ziemi!

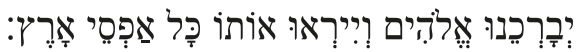
$1512=2911515041323386288$

$297=39432335534163$

$99=1216517171418$

Alleluja. Z całego serca wysławiam Pana W gronie prawych i w zgromadzeniu ${ }^{276}$.

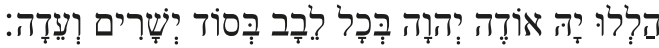

$931=8556072345226161571$

$265=317427162526161535$ 
$121=221118771716617$

Wielkie są dzieła Pana, Godne badania przez wszystkich, którzy je kochają.

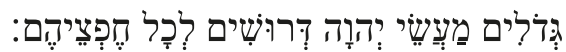

$1406=233805602642087$

$308=713574266042$

$110=35820171515$

Dzieło jego jest okazałe i wspaniałe, A sprawiedliwość jego trwa na wieki.

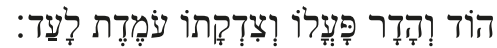

$1640=10451460618621515$

$263=325575513515$

$119=141930241715$

Pamiętnymi uczynił cuda swoje; Łaskawy i litościwy jest Pan.

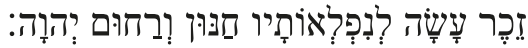

$1615=26260114613375227$

$301=2653421004238$

$130=172624371511$

Daje pożywienie tym, którzy się go boją; Na wieki pamięta o swoim przymierzu.

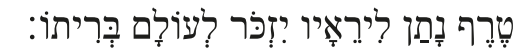

$2077=618176237257500289$

$322=605948595046$

$97=152312141419$

Ukazał ludowi swemu potęgę dzieł swoich, Dając im dziedzictwo narodów.

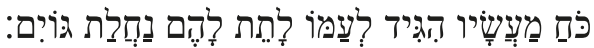

$2074=59488758301462242628$

$328=3256305647226619$

$121=1420121120132110$

Wierność i prawo są dziełami rąk jego, Wszystkie jego nakazy są niezawodne,

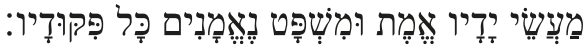

$1773=2065019143544130420$

$342=62236566363060$

$117=265203091215$

Ustanowione na wieki wieków, Pełnione w wierności i prawości.

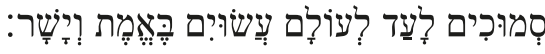
1841 = 516443882426176104176 $320=573822566593268$

$104=12118121231423$

Zesłał odkupienie ludowi swemu, Ustanowił na wieki swoje przymierze. Święte i straszne jest imię jego.

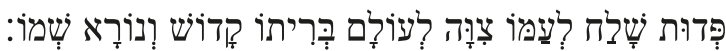




$$
\begin{array}{r}
2888=346263410618176101146338490 \\
422=404750605929474149 \\
161=132014152320201422
\end{array}
$$

Początkiem mądrości jest bojaźń Pana; Wszyscy, którzy ją okazują, są prawdziwie mądrzy. Chwała jego trwa na wieki.

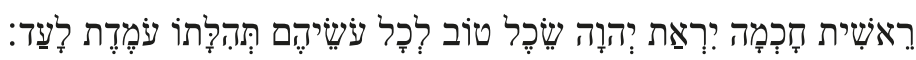
$3952=10451484142580173502661173911$ $505=3255676535174426533774$ $163=1419222081781781911$

Wkoło zatacza się ziemia jak pijany i kołysze się jak budka nocna. Zaciążyło na niej jej przestępstwo, tak że upadnie i już nie powstanie ${ }^{277}$.

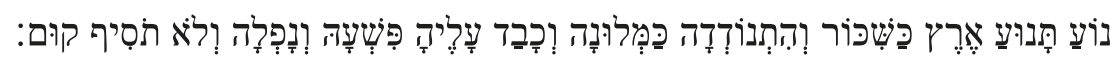
3626 = 1465503717145511532151480546291526126 $629=38641954594323616569395836$ $251=11191027231614253915122218$

I stanie się w owym dniu, że Pan nawiedzi wojsko górne w górze, a królów ziemi na ziemi.

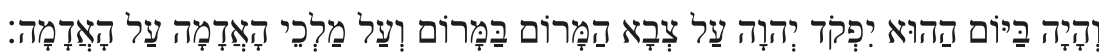

$$
\begin{aligned}
& 1509=551005510010628829129310026194175826 \\
& 474=2828284634545721282650173126 \\
& 213=1910191016182112101714171317
\end{aligned}
$$

Przewodnikowi chóru. Psalm Dawidowy ${ }^{278}$,

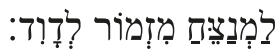

$$
\begin{aligned}
& 555=44293218 \\
& 150=265965 \\
& 69=172329
\end{aligned}
$$

Gdy wdał się z Batszebą i przyszedł do niego prorok Natan.

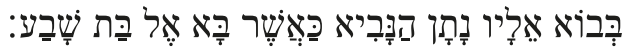

$$
\begin{aligned}
& 1955 \text { = } 372402313521685004711 \\
& 254=39241335332502911 \\
& 83=12643814141111
\end{aligned}
$$

Zmiłuj się nade mną, Boże, według łaski swojej, Według wielkiej litości swojej zgładź występki moje!

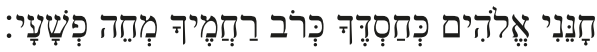

$$
\begin{aligned}
& 1329=4605327822211286118 \\
& 321=64266233494146 \\
& 114=1917176221419
\end{aligned}
$$

Obmyj mnie zupełnie z winy mojej I oczyść mnie z grzechu mego!

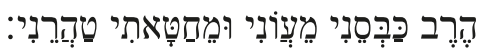




$$
\begin{array}{r}
1273=274474176142207 \\
265=5869595227 \\
103=223323169
\end{array}
$$

Ja bowiem znam występki swoje I grzech mój zawsze jest przede mną.

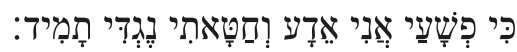
$1581=45467434756146030$

$267=49315621256421$

$$
96=131329127193
$$

Przeciwko tobie samemu zgrzeszyłem I uczyniłem to, co złe w oczach twoich, Abyś okazał się sprawiedliwy w wyroku swoim, Czysty w sądzie swoim.

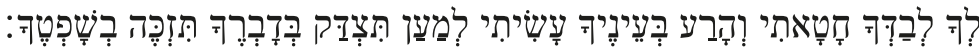

$$
\begin{aligned}
& 3622=4114322285941907901622814285650 \\
& 553=6065396355796347502923 \\
& 184=241812181916182023115
\end{aligned}
$$

Oto urodziłem się w przewinieniu I w grzechu poczęła mnie matka moja.

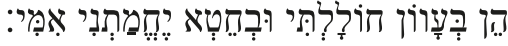

$$
\begin{aligned}
& 1268 \text { = } 515182648413455 \\
& 260=247726704419 \\
& 116=62326252610
\end{aligned}
$$

Oto miłujesz prawdę chowaną na dnie duszy I objawiasz mi mądrość ukrytą.

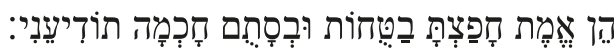

$$
\begin{aligned}
& 2630 \text { = } 5507350842557844455 \\
& 344=82375847653619 \\
& 146=2819222929910
\end{aligned}
$$

Pokrop mnie hizopem, a będę oczyszczony; Obmyj mnie, a ponad śnieg bielszy się stanę.

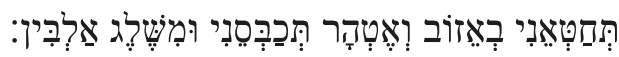

$1731=9337954222118478$

$291=395574411864$

$120=121920231828$

Daj, bym usłyszał radość i wesele, Niech się rozradują kości, które skruszyłeś!

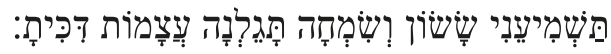

$3423=434606488359656880$

$399=4775565362106$

$129=113020261725$

Zakryj oblicze swoje przed grzechami moimi I zgładź wszystkie winy moje.

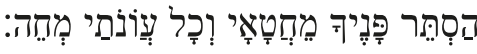

$$
\begin{aligned}
& 1538=535365668160665 \\
& 278=266829415262 \\
& 107=172311231617
\end{aligned}
$$


Serce czyste stwórz we mnie, o Boże, A ducha prawego odnów we mnie!

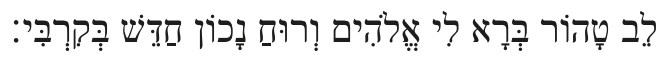
$1553=314312126220864020322032$ $311=533345404122234014$

$113=81518221445225$

Nie odrzucaj mnie od oblicza swego I nie odbieraj mi swego Ducha świętego!

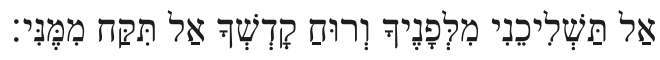
$2404=1405083142422023082031$

$397=50491355407710013$

$109=14134102223194$

Przywróć mi radość z wybawienia twego I wesprzyj mnie duchem ochoczym!

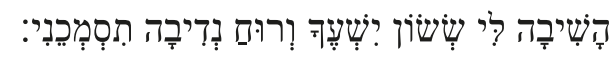
$2289=5807122040065640322$

$345=85354058622243$

$111=2217221317416$

Przestępców będę nauczał dróg twoich, I grzesznicy nawrócą się do ciebie.

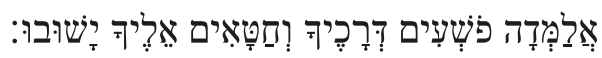

$1293=324617424550080$

$294=453447567735$

$105=18729112317$

Wybaw mnie od winy za krwi przelanie, Boże, Boże zbawienia mego, A język mój z radością wysławiać będzie sprawiedliwość twoją!

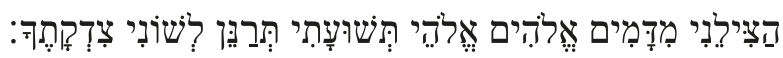

$3357=61439670011864686134195$

$495=7463709728415369$

$144=2018162510141724$

Panie! Otwórz wargi moje, A usta moje głosić będą chwałę twoją!

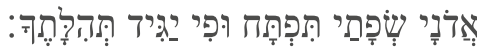

$2721=855279688879065$

$300=722733697029$

$97=18915241611$

Albowiem ofiar nie żądasz, A całopalenia, choćbym ci je dał, nie zechcesz przyjąć.

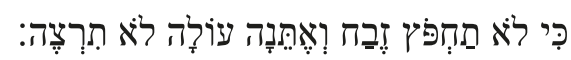

1955 = 69531111462175783130

$281=6513394817651321$

$119=2042121172943$

Ofiarą Bogu miłą jest duch skruszony, Sercem skruszonym i zgnębionym nie wzgardzisz, Boże. 


$$
\begin{array}{r}
2084=414318685552325572148627 \\
365=36134140571462344127 \\
140=184142212517161418
\end{array}
$$

Zechciej w łasce swej dobrze czynić Syjonowi, Odbuduj mury Jeruzalemu!

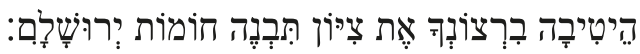

$$
\begin{aligned}
& 2469=58646045715640136841 \\
& 363=82554348237141 \\
& 138=1928162152623
\end{aligned}
$$

Wtedy przyjmiesz prawe ofiary, Ofiary ogniowe i całopalenia, Wtedy ofiarują cielce na ołtarzu twoim.

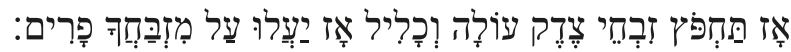

$$
\begin{aligned}
& 1645=33077100116896111194275788 \\
& 412=60412844851394127658 \\
& 178=15231017815211418298
\end{aligned}
$$

Jak długo będzie płacz w Syjonie i pochwała w Jeruzalem? Zmiłuj się nad Syjonem i odbuduj mury Jeruzalem.

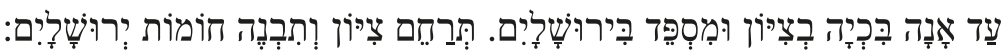

$$
\begin{aligned}
& 3436 \text { = } 596460463156648598190158375674 \\
& 574=9255494863945550282020 \\
& 214=2028222118222823101111
\end{aligned}
$$

Przy zastosowaniu trzech metod gematrii średnie pokrycie za pomocą fragmentów Tikkun Chacot [183] wartości liczbowych odpowiadających podstawowym wartościom liczbowym wymiarów wynosi 85\%, przy czym metodą absolutną uzyskano 93\%, uproszczoną $86 \%$, a redukcyjną $75 \%$. Dla wszystkich analizowanych wartości liczbowych średnia wynosi $54 \%$, przy czym metodą absolutną uzyskano 72\%, uproszczoną 53\%, a redukcyjną 39\%. Ogólnie, w wyniku zastosowania trzech metod pokryto $100 \%$ wartości podstaw ow y ch i $84 \%$ wszystkich analizowanych wartości liczbowych.

Tikkun Chacot jest pierwszą z modlitw, której wartości liczbowe analizowanych fragmentów, jak wykazała ich analiza, odpowiadają wartościom liczbowym wymiarów bożnic, uzyskanym metodą absolutną. Zależności tego rodzaju stwierdzono również na podstawie analizy metodami redukcyjną i uproszczoną, a dotyczą one synagog zlokalizowanych w takich miastach, jak:

\section{Pińczów}

Szerokość synagogi (123): Młodzieńcy musieli nosić kamienie odyńskie, a chłopcy potykali się pod ciężarem drew.

Wysokość synagogi (87): Wyciągamy rękę do Egiptu, do Asyrii, by się najeść do syta.

Długość sali męskiej (69): Jeśli zapomnę cię, Jeruzalem, niech uschnie prawica moja!

(69): Przewodnikowi chóru. Psalm Dawidowy.

Wysokość sali męskiej (64): Przewodnikowi chóru. Pieśń pouczająca synów Koracha. 


\section{Rzeszów (Synagoga Stara)}

Długość synagogi （122:) Dusza moja pragnie Boga, Boga żywego. Kiedyż przyjdę i ukażę się przed obliczem Boga?

Szerokość synagogi (110): Panie, królu nasz, pomóż! Wysłuchaj nas w dniu wołania naszego.

(110): Wielkie są dzieła Pana, Godne badania przez wszystkich, którzy je kochają.

Wysokość synagogi (486): Lecz ci, którzy zbierają zboże, sami je będą spożywać i wysławiać Pana, a ci, którzy zbierają wino, sami będą je pić w przedsionkach mojej świątyni.

Długość sali męskiej (100): Staliśmy się sierotami, bez ojca, nasze matki są jakby wdowy. (100): Z powodu góry Syjon, że jest spustoszona, że szakale po niej biegają.

(100): Niechaj wspomni wszystkie dary twoje I niech przyjmie całopalenia twoje. Sela.

Długość bimy $\quad$ (156): Za dnia wyznacza Pan łaskę swoją! A w nocy śpiewam mu pieśń, modlę się do Boga życia mego.

(156): Ponieważ Ty jesteś Bogiem moim, ostoją moją, Dlaczego mnie odrzuciłeś? Dlaczego mam chodzić smutny, Gdy nieprzyjaciel mnie dręczy?

Szerokość bimy (132): Święty, wspaniały nasz przybytek, w którym chwalili cię nasi ojcowie, stał się pastwą ognia, a wszystko, co było naszą rozkoszą, leży w gruzach.

\section{Zamość}

Długość synagogi

(104): Ustanowione na wieki wieków, Pełnione w wierności i prawości. Szerokość synagogi: (100): Staliśmy się sierotami, bez ojca, nasze matki są jakby wdowy. (100): Z powodu góry Syjon, że jest spustoszona, że szakale po niej biegają.

(100): Niechaj wspomni wszystkie dary twoje I niech przyjmie całopalenia twoje. Sela.

Długość sali męskiej (504): Bądź sędzią moim, Boże, I rozstrzygnij spór mój z narodem bezbożnym! Wybaw mnie od ludzi fałszywych i niegodziwych!

Szerokość sali męskiej (78): Niewolnicy nami rządzą, nie ma, kto by nas wyrwał z ich ręki.

(78): Przewodnikowi chóru, z grą na strunach. Psalm. Pieśń.

\section{Szczebrzeszyn}

Długość synagogi

(116:) Spraw, Panie, byśmy wrócili do ciebie, a wrócimy! Odnów nasze dni jak niegdyś!

(116:) Oto urodziłem się w przewinieniu I w grzechu poczęła mnie matka moja. 
Wysokość synagogi: (64): Przewodnikowi chóru. Pieśń pouczająca synów Koracha.

\section{Chęciny}

Długość synagogi

Szerokość synagogi

Wysokość synagogi

Długość sali męskiej
(97): Książęta wieszani byli ich rękami, nie uszanowano powagi starszych.

(97:) Daje pożywienie tym, którzy się go boją; Na wieki pamięta o swoim przymierzu.

(97): Panie! Otwórz wargi moje, A usta moje głosić będą chwałę twoją! (136): Nad rzekami Babilonu - tam siedzieliśmy I płakaliśmy na wspomnienie Syjonu.

(136): Wspomnij, Panie, na to, co się z nami stało! Spójrz i przypatrz się naszej zniewadze.

(68): Niech ci da to, czego pragnie serce twoje, I niech wypełni każdy twój zamysł!

(300): Jakże mamy śpiewać pieśń Pana na obcej ziemi?

(300): Spadła korona z naszej głowy, biada nam, bo zgrzeszyliśmy.

(300): Panie! Otwórz wargi moje, A usta moje głosić będą chwałę twoją!

(156): Za dnia wyznacza Pan łaskę swoją! A w nocy śpiewam mu pieśń, modlę się do Boga życia mego.

(156): Ponieważ Ty jesteś Bogiem moim, ostoją moją, Dlaczego mnie odrzuciłeś? Dlaczego mam chodzić smutny, Gdy nieprzyjaciel mnie dręczy?

(78): Niewolnicy nami rządzą, nie ma, kto by nas wyrwał z ich ręki.

(78): Przewodnikowi chóru, z grą na strunach. Psalm. Pieśń.

Wysokość sali męskiej (276): Wyciągamy rękę do Egiptu, do Asyrii, by się najeść do syta.

\section{Tykocin}

Długość synagogi

(144): Wybaw mnie od winy za krwi przelanie, Boże, Boże zbawienia mego, A język mój z radością wysławiać będzie sprawiedliwość twoją!

Szerokość synagogi (144): Wybaw mnie od winy za krwi przelanie, Boże, Boże zbawienia mego, A język mój z radością wysławiać będzie sprawiedliwość twoją!

Długość sali męskiej (123): Młodzieńcy musieli nosić kamienie odyńskie, a chłopcy potykali się pod ciężarem drew.

Szerokość sali męskiej (123): Młodzieńcy musieli nosić kamienie odyńskie, a chłopcy potykali się pod ciężarem drew.

Wysokość bimy (420): Łzy moje są mi chlebem we dnie i w nocy, Gdy mówią do mnie co dzień: Gdzie jest Bóg twój?

\section{Orla}

Długość synagogi

(132): Święty, wspaniały nasz przybytek, w którym chwalili cię nasi ojcowie, stał się pastwą ognia, a wszystko, co było naszą rozkoszą, leży w gruzach. 
Wysokość synagogi (408): Córko babilońska, pustoszycielko! Błogosławiony, kto ci odpłaci to, coś nam wyrządziła!

(68): Niech ci da to, czego pragnie serce twoje, I niech wypełni każdy twój zamysł!

Długość sali męskiej (114): Dlaczego chcesz na zawsze zapomnieć o nas, opuścić nas na tak długi czas?

(114): Zmiłuj się nade mną, Boże, według łaski swojej, Według wielkiej litości swojej zgładź występki moje!

Szerokość sali męskiej (107): Zakryj oblicze swoje przed grzechami moimi I zgładź wszystkie winy moje.

Wysokość sali męskiej (420): Łzy moje są mi chlebem we dnie i w nocy, Gdy mówią do mnie co dzień: Gdzie jest Bóg twój?

Długość centralnego (276): Wyciągamy rękę do Egiptu, do Asyrii, by się najeść do syta. pola:

\section{Lesko}

Szerokość synagogi (588): Niech sławią cię, Boże, ludy; Niech sławią cię wszystkie ludy! (98): Starcy zaniechali wysiadywania w bramach, a młodzieńcy gry na instrumentach strunowych.

(98): Ten dostąpi błogosławieństwa od Pana I sprawiedliwości od Boga, zbawiciela swego.

Długość sali męskiej (106): Abym dał płaczącym nad Syjonem zawój zamiast popiołu. (106): Rozlali krew ich jak wodę wokół Jeruzalemu, Nie było nikogo, kto by ich pogrzebał.

Szerokość sali męskiej (78): Niewolnicy nami rządzą, nie ma, kto by nas wyrwał z ich ręki.

(78): Przewodnikowi chóru, z grą na strunach. Psalm. Pieśń.

\section{Tarnogród}

Długość synagogi (64): Przewodnikowi chóru. Pieśń pouczająca synów Koracha. (128): Nasza skóra rozpalona jak piec od gorączki głodowej.

Szerokość synagogi (64): Przewodnikowi chóru. Pieśń pouczająca synów Koracha. (128): Nasza skóra rozpalona jak piec od gorączki głodowej.

Wysokość sali męskiej (76): Albowiem pożarli Jakuba I spustoszyli siedzibę jego!

\section{Rzeszów (Synagoga Nowomiejska)}

Długość synagogi (101): Błogosławiony, kto pochwyci i roztrzaska niemowlęta twoje o skałę.

(101): Któż może wstąpić na górę Pana? I kto stanie na jego świętym miejscu?

(101): Ziemia wydała plon swój: Błogosławi nam Bóg, nasz Bóg.

Szerokość synagogi (134): Mówię do Boga: Skało moja, Dlaczego zapomniałeś o mnie?

Dlaczego posępny chodzę, Gdy trapi mnie nieprzyjaciel? 
Wysokość synagogi (504): Bądź sędzią moim, Boże, I rozstrzygnij spór mój z narodem bezbożnym! Wybaw mnie od ludzi fałszywych i niegodziwych!

Długość sali męskiej (115): Jak jeleń pragnie wód płynących, Tak dusza moja pragnie ciebie, Boże!

Szerokość sali męskiej (106): Abym dał płaczącym nad Syjonem zawój zamiast popiołu, a także fragment: Rozlali krew ich jak wodę wokół Jeruzalemu, Nie było nikogo, kto by ich pogrzebał.

\section{Bobowa}

Długość synagogi (108): Nasze dziedzictwo przypadło obcym, nasze domy cudzoziemcom. Szerokość synagogi (100): Staliśmy się sierotami, bez ojca, nasze matki są jakby wdowy. (100): Z powodu góry Syjon, że jest spustoszona, że szakale po niej biegają.

(100): Niechaj wspomni wszystkie dary twoje I niech przyjmie całopalenia twoje. Sela.

Wysokość synagogi (234): Czemu rozpaczasz, duszo moja, I czemu drżysz we mnie? Ufaj Bogu, gdyż jeszcze sławić go będę: On jest zbawieniem moim i Bogiem moim.

Długość sali męskiej (96): Ustała radość naszego serca, nasz taniec zamienił się w pochód żałobny.

(96): Pan buduje Jeruzalem, Zgromadzą rozproszonych Izraela.

(96): Niech ci ześle pomoc ze świątyni I niech cię wesprze z Syjonu!

(96): Ja bowiem znam występki swoje I grzech mój zawsze jest przede mną.

Szerokość sali męskiej (504): Bądź sędzią moim, Boże, I rozstrzygnij spór mój z narodem bezbożnym! Wybaw mnie od ludzi fałszywych i niegodziwych!

Wysokość sali męskiej (306): Któż jest tym Królem chwały? Pan silny i potężny, Pan potężny w boju.

Wysokość centralnego (330): Święty, wspaniały nasz przybytek, w którym chwalili cię nasi pola ojcowie, stał się pastwą ognia, a wszystko, co było naszą rozkoszą, leży w gruzach.

\section{Dukla}

Długość synagogi

(132): Święty, wspaniały nasz przybytek, w którym chwalili cię nasi ojcowie, stał się pastwą ognia, a wszystko, co było naszą rozkoszą, leży w gruzach.

Szerokość synagogi (120): Córko babilońska, pustoszycielko! Błogosławiony, kto ci odpłaci to, coś nam wyrządziła!

(120): Pokrop mnie hizopem, a będę oczyszczony; Obmyj mnie, a ponad śnieg bielszy się stanę.

(120): Spadła korona z naszej głowy, biada nam, bo zgrzeszyliśmy. 
Długość sali męskiej (110): Panie, królu nasz, pomóż! Wysłuchaj nas w dniu wołania naszego.

(110): Wielkie są dzieła Pana, Godne badania przez wszystkich, którzy je kochają.

Szerokość sali męskiej (98): Starcy zaniechali wysiadywania w bramach, a młodzieńcy gry na instrumentach strunowych.

(98): Ten dostąpi błogosławieństwa od Pana I sprawiedliwości od Boga, zbawiciela swego.

Wysokość sali męskiej (324): Nasze dziedzictwo przypadło obcym, nasze domy cudzoziemcom. Długość bimy (132): Święty, wspaniały nasz przybytek, w którym chwalili cię nasi ojcowie, stał się pastwą ognia, a wszystko, co było naszą rozkoszą, leży w gruzach.

\section{Lańcut}

Długość bimy

(144): Wybaw mnie od winy za krwi przelanie, Boże, Boże zbawienia mego, A język mój z radością wysławiać będzie sprawiedliwość twoją!

Szerokość bimy (144): Wybaw mnie od winy za krwi przelanie, Boże, Boże zbawienia mego, A język mój z radością wysławiać będzie sprawiedliwość twoją!

\section{Włodawa}

Długość synagogi: (86): Aby poznano na ziemi drogę twoją, Wśród wszystkich narodów zbawienie twoje.

Szerokość synagogi: (99): Niech cię wysłucha Pan w dniu utrapienia, Niech cię wzmocni imię Boga Jakubowego!

(99): Niech nam Bóg błogosławi, A niech się go boją wszystkie krańce ziemi!

Długość sali męskiej (123): Młodzieńcy musieli nosić kamienie odyńskie, a chłopcy potykali się pod ciężarem drew.

Szerokość sali męskiej (114): Dlaczego chcesz na zawsze zapomnieć o nas, opuścić nas na tak długi czas?

(114): Zmiłuj się nade mną, Boże, według łaski swojej, Według wielkiej litości swojej zgładź występki moje!

Szerokość centralnego (300): Jakże mamy śpiewać pieśń Pana na obcej ziemi? pola

(300): Spadła korona z naszej głowy, biada nam, bo zgrzeszyliśmy. (300): Panie! Otwórz wargi moje, A usta moje głosić będą chwałę twoją!

\section{Siemiatycze}

Długość synagogi

Szerokość synagogi
(86): Aby poznano na ziemi drogę twoją, Wśród wszystkich narodów zbawienie twoje.

(132): Święty, wspaniały nasz przybytek, w którym chwalili cię nasi ojcowie, stał się pastwą ognia, a wszystko, co było naszą rozkoszą, leży w gruzach. 
Wysokość synagogi (300): Jakże mamy śpiewać pieśń Pana na obcej ziemi?

(300): Spadła korona z naszej głowy, biada nam, bo zgrzeszyliśmy.

(300): Panie! Otwórz wargi moje, A usta moje głosić będą chwałę twoją!

Długość sali męskiej (121): I nie ma nikogo, kto by wzywał twojego imienia, kwapił się do uchwycenia się ciebie, gdyż zakryłeś swoje oblicze przed nami i oddałeś nas w moc naszych grzechów.

(121): I nie ma nikogo, kto by wzywał twojego imienia, kwapił się do uchwycenia się ciebie, gdyż zakryłeś swoje oblicze przed nami i oddałeś nas w moc naszych grzechów.

(121): Alleluja. Z całego serca wysławiam Pana W gronie prawych i w zgromadzeniu.

(121): Ukazał ludowi swemu potęgę dzieł swoich, Dając im dziedzictwo narodów.

Szerokość sali męskiej (117): Niech nam Bóg miłościw będzie I niech nam błogosławi, Niech nad nami rozjaśni oblicze swoje! Sela.

(117): Wierność i prawo są dziełami rąk jego, Wszystkie jego nakazy są niezawodne.

Wysokość sali męskiej (324): Nasze dziedzictwo przypadło obcym, nasze domy cudzoziemcom.

Tikkun Chacot wykazuje najlepszą reprezentatywność wartości liczbowych, które odpowiadają wartościom liczbowym wymiarów bożnic, zwłaszcza tym podstawowym. Jak w poprzednich przypadkach, wartości liczbowe występujące dwu-, trzy- i czterokrotnie oraz wartości liczbowe wymiarów podstawowych pojawiające się tylko raz są najlepiej reprezentowane. Najczęściej powtarzające się wymiary są dość dobrze reprezentowane. Szczególnie tyczy się to liczby 33, która do tej pory występowała dość rzadko. W Tikkun Chacot pojawia się siedemnastokrotnie w wynikach otrzymanych metodą redukcyjną oraz pięciokrotnie $\mathrm{w}$ wynikach otrzymanych metodą uproszczoną. Niedoreprezentowana jest liczba 66, która występuje pięciokrotnie w wynikach otrzymanych metodą absolutną i ośmiokrotnie w wynikach otrzymanych metodą uproszczoną. Liczba 25 pojawia się w sumie czterdzieści pięć razy. Wartość 50 jest dość dobrze reprezentowana, bo występuje w sumie aż czterdzieści jeden razy. Liczba 39 pojawia się dwudziestokrotnie, ale jedynie w przypadku zastosowania metody uproszonej. Liczbą, która występuje niezwykle rzadko, bo zaledwie trzykrotnie, jest 396.

\subsubsection{6. figdal $^{279}$}

Chwała i uwielbienie Bogu żywemu: On jest i nie ma ograniczeń w czasie dla Jego istoty.

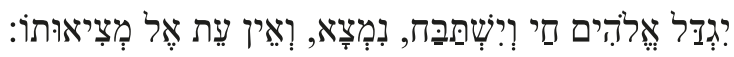




$$
\begin{gathered}
361=761338314669184129 \\
136=3141113192491411
\end{gathered}
$$

On jest jeden i nie ma jedności podobnej do jego jedności; niepojęty jest On i niekończąca jest Jego jedność.

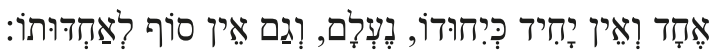

$$
\begin{aligned}
& 1067=455146614919054326713 \\
& 320=593825225545323113 \\
& 158=32207131927141313
\end{aligned}
$$

Nie ma żadnej formy cielesnej, ani istoty: nie możemy porównać nic do Niego w Jego świętości.

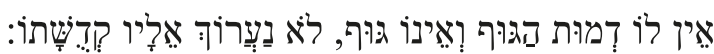

$$
\begin{aligned}
& 2037=81047346318973944503661 \\
& 363=72296713263731451825 \\
& 147=18112241719221897
\end{aligned}
$$

Był przed wszystkim, co stworzono - nawet pierwsze: ale jego istnienie nie ma początku.

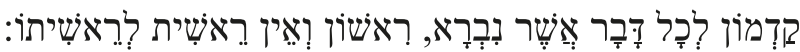
3722 = 947911675772535012068056 $455=927431623742263556$

$113=201113171068820$

Oto On jest Panem wszechświata: wszelkiemu stworzeniu naucza o Swojej wielkość i niezależności.

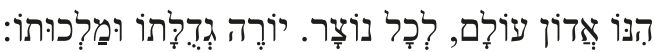

$$
\begin{aligned}
& 1866=508443221346801466161 \\
& 354=7647414835472525 \\
& 147=312014228201616
\end{aligned}
$$

Bogaty dar Swojego proroctwa dawał ludziom z własnego wyboru, w którym był wielki.

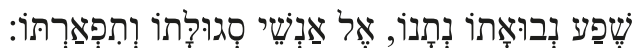
$3411=109350536131506465450$ $378=94644613565154$ $135=3128104202418$

Gdyż jeszcze nigdy nie pojawił się w Izraelu prorok podobny do Mojżesza, który miał oglądać jego podobieństwo.

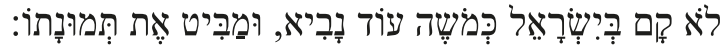

$$
\begin{aligned}
& 2592=90240167638036554314031 \\
& 360=832340272650663213 \\
& 117=27522917141254
\end{aligned}
$$

Prawo prawdy dał Bóg Swemu ludowi z ręki Swego proroka, który był wierny w swoim domu. 


$$
\begin{array}{r}
2866=4181416914100311465004411006 \\
373=40423314281347503670 \\
121=13151551042014916
\end{array}
$$

Bóg nie zmienił i nie zmieni Swojego prawa po wieki dla wszystkich.

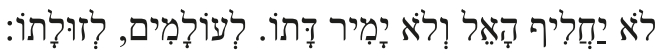

$$
\begin{aligned}
& 1617=479226410260373613831 \\
& 339=6582325319185713 \\
& 123=2928148109214
\end{aligned}
$$

On obserwuje i zna nasze sekretne myśli: on zna koniec rzeczy zanim jeszcze zaistnieją.

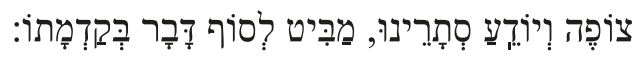

1998 = 5522061766172696181

$351=66265034874246$

$144=2182316242428$

On obdarza miłosierdziem człowieka według jego pracy; On daje niegodziwemu według jego niegodziwości.

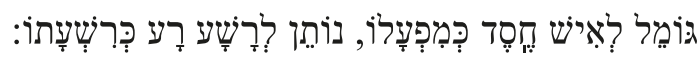

$$
\begin{aligned}
& 3110=9962706005062467234179 \\
& 437=9636695675274434 \\
& 140=24915203018816
\end{aligned}
$$

On wyśle swego pomazańca na końcu czasów, aby odkupić tych, którzy czekają końca - Jego zbawienia.

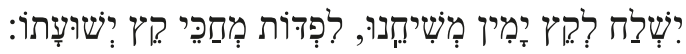

$$
\begin{aligned}
& 2672=79219078520414110220348 \\
& 440=8137426172474951 \\
& 143=2710152527111315
\end{aligned}
$$

W obfitości Swojego miłosierdzia Bóg wskrzesi zmarłych. Błogosławione na wieki będzie jego wielkie imię.

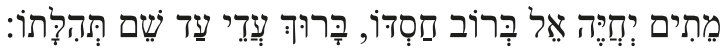

$$
\begin{aligned}
& 2409=8413407484228782103133490 \\
& 357=67342030393330133358 \\
& 132=227111212241241513
\end{aligned}
$$

Przy zastosowaniu trzech metod gematrii średnie pokrycie wartości odpowiadających podstawowym wymiarom wynosi $41 \%$, przy czym metodą absolutną uzyskano $25 \%$, uproszczoną 58\%, a redukcyjną 40\%. Dla wszystkich analizowanych wartości średnia wynosi $22 \%$, przy czym metodą absolutną uzyskano $19 \%$, uproszczoną $31 \%$, a redukcyjną $17 \%$. Ogólnie w wyniku zastosowania trzech metod pokryto $86 \%$ wartości p o d s t a w o w y c h i $51 \%$ wszystkich analizowanych wartości liczbowych.

W wyniku analizy metodą uproszczoną w synagogach zlokalizowanych w wymienionych poniżej miastach stwierdzono następujące zależności: 


\section{Pińczów}

Szerokość synagogi (123): Bóg nie zmienił i nie zmieni Swojego prawa po wieki dla wszystkich.

\section{Rzeszów (Synagoga Stara)}

Szerokość bimy

\section{Chęciny}

Szerokość synagogi

\section{Tykocin}

Długość synagogi

Szerokość synagogi

Długość sali męskiej
(132): W obfitości Swojego miłosierdzia Bóg wskrzesi zmarłych. Błogosławione na wieki będzie jego wielkie imię.

(136): Chwała i uwielbienie Bogu żywemu: On jest i nie ma ograniczeń w czasie dla Jego istoty.

(144): On obserwuje i zna nasze sekretne myśli: on zna koniec rzeczy zanim jeszcze zaistnieją.

(144): On obserwuje i zna nasze sekretne myśli: on zna koniec rzeczy zanim jeszcze zaistnieją.

(123): Bóg nie zmienił i nie zmieni Swojego prawa po wieki dla wszystkich.

Szerokość sali męskiej (123): Bóg nie zmienił i nie zmieni Swojego prawa po wieki dla wszystkich.

\section{Orla}

Długość synagogi

(132): W obfitości Swojego miłosierdzia Bóg wskrzesi zmarłych. Błogosławione na wieki będzie jego wielkie imię.

\section{Tarnogród}

Długość synagogi

(64): Przewodnikowi chóru. Pieśń pouczająca synów Koracha

(128): Nasza skóra rozpalona jak piec od gorączki głodowej.

Długość centralnego (360): Gdyż jeszcze nigdy nie pojawił się w Izraelu prorok podobny pola do Mojżesza, który miał oglądać jego podobieństwo.

Szerokość centralnego (360): Gdyż jeszcze nigdy nie pojawił się w Izraelu prorok podobny pola do Mojżesza, który miał oglądać jego podobieństwo.

\section{Dukla}

Długość synagogi

(132): W obfitości Swojego miłosierdzia Bóg wskrzesi zmarłych. Błogosławione na wieki będzie jego wielkie imię.

Długość bimy (132):W obfitości Swojego miłosierdzia Bóg wskrzesi zmarłych. Błogosławione na wieki będzie jego wielkie imię.

\section{Lańcut}

Wysokość synagogi (360): Gdyż jeszcze nigdy nie pojawił się w Izraelu prorok podobny do Mojżesza, który miał oglądać jego podobieństwo.

Długość bimy (144): On obserwuje i zna nasze sekretne myśli: on zna koniec rzeczy zanim jeszcze zaistnieją. 
Szerokość bimy

\section{Włodawa}

Długość sali męskiej

\section{Siemiatycze}

Szerokość synagogi

Długość sali męskiej

(132): W obfitości Swojego miłosierdzia Bóg wskrzesi zmarłych. Błogosławione na wieki będzie jego wielkie imię.

(121): Prawo prawdy dał Bóg Swemu ludowi z ręki Swego proroka, który był wierny w swoim domu.

Szerokość sali męskiej (117): Gdyż jeszcze nigdy nie pojawił się w Izraelu prorok podobny do Mojżesza, który miał oglądać jego podobieństwo.

W figdal [182] najlepiej reprezentowane są wartości występujące w synagogach najrzadziej, natomiast niedoreprezentowane są te najczęściej powtarzające się. Wartość 33 pojawia się czterokrotnie. Niedoreprezentowane są liczby 66 oraz 39, które w wynikach otrzymanych metodą uproszczoną występują odpowiednio dwa razy i jeden raz. Liczba 25 pojawia się sześciokrotnie, a 50 trzykrotnie. Liczbą, która w wynikach nie pojawia się w ogóle, jest 396.

\subsubsection{Szir Hakawod - Anim Zemirot ${ }^{280}$}

Chazan: Zanucę pieśni i utkam śpiewy, bo do Ciebie tęskni moja dusza.

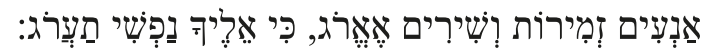

$$
\begin{aligned}
& 2809=6734406130205566663171 \\
& 415=6162342125807854 \\
& 109=1617737172418
\end{aligned}
$$

Wszyscy: Dusza moja pragnie cienia Twojej ręki, by poznać cały sekret Twojej istoty.

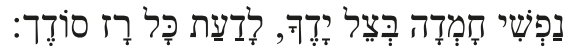

$$
\begin{aligned}
& 1504=90207505043412257440
\end{aligned}
$$$$
289=3627235425323062
$$$$
109=1895187142117
$$

C: Ilekroć mówię o Twojej chwale, moje serce łaknie Twojej miłości.

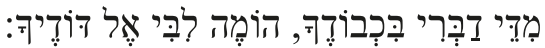

$$
\begin{aligned}
& 497=443142565421654 \\
& 200=35132429363627 \\
& 83=1746201899
\end{aligned}
$$

W: Dlatego rozgłoszę o Tobie wspaniałości i Twoje Imię uczczę miłosnymi pieśniami.

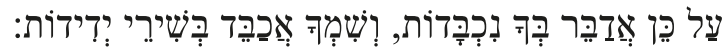

$$
\begin{array}{r}
2230=434522273664822220770100 \\
340=566318515913272528
\end{array}
$$


$106=2099152349710$

C: Opowiem o Twojej chwale, choć Cię nie widziałem. Ukażę Cię i opiszę Cię, choć Cię nie pojąłem.

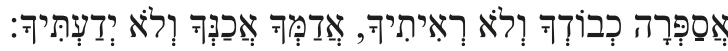

$$
\begin{aligned}
& 1783=5143791656413752346 \\
& 343=7319372974193458 \\
& 109=1910101111101622
\end{aligned}
$$

W: Przez Twoich proroków, przez zgromadzenia Twoich sług, objawiłeś piękno chwały Twojego majestatu.

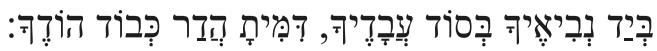
$1017=3532209454106729316$

$261=2623294943274816$ $108=171411131618127$

C: Twoją wielkość i Twoją potęga ukazują poprzez moc Twoich czynów.

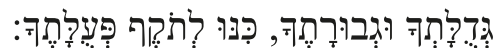
$2380=60061076637457$

$301=7870317052$ $94=2416132516$

W: Opisują Cię, ale nie takim, jaki jesteś, porównują Cię według Twoich czynów.

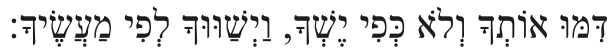
$1862=4401203483301103742750$ $332=7139604238194023$ $107=171224611101314$

C: Przedstawiają Cię w licznych Wizjach, ale Ty jesteś Jedyny we wszystkich ich wyobrażeniach.

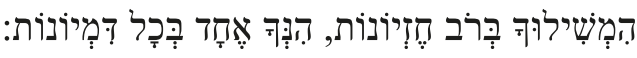

$$
\begin{aligned}
& 1758=516521375487204411 \\
& 318=75251330732478 \\
& 129=307131237624
\end{aligned}
$$

W: Widzą w Tobie starość i młodość, włosy Twojej głowy, i siwe, i czarne.

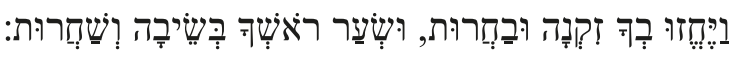
$3179=9203195215766221622237$ $398=8340536364451337$

$146=29138182818428$

C: Starego w dniu sądu, młodego w dniu bity, jak wojownika, który ma silne ręce.

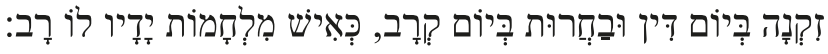
$2389=2023630524331302586226458162$

$427=2218307443413164283145$ $148=491229751328101318$ 
W: Okolony hełmem zbawienia, który na jego głowie. Przybywa na ratunek Jego prawica i święte ramię.

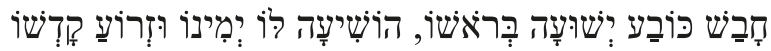

$$
\begin{aligned}
& 2555 \text { = } 4102891163639650939198310 \\
& 413=505553186350583531 \\
& 161=14281792714221713
\end{aligned}
$$

C: Jego głowa jest pełna rosy światła [Tory], Jego loki kropli nocy [Niebiańskiego błogosławieństwa].

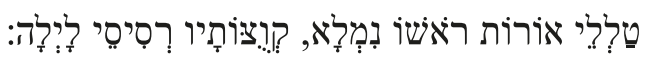
$2353=7534061812150761379$ $382=39708740485543$ $121=12163313121916$

W: On będzie wysławiony przez mnie, bo mnie ukochał. I będzie dla mnie koroną piękna.

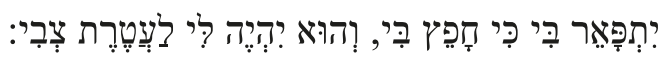
$1822=102709403018121783012691$ $337=30792230181243211270$ $121=1225412183253316$

C: Kształt diademu z czystego złota na Jego głowie, na czole wyryte Jego święte Imię.

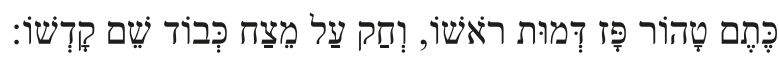
$2858=4103403213810011450745087220460$

$410=5034233928334845244046$ $158=147142110151218152210$

W: Dla wdzięku i dla chwały, dla piękna i wspaniałości, Jego lud nałożył mu koronę.

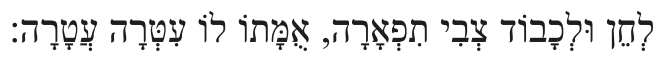
$1995=284284364476861026888$

$410=5050184265304134$ $141=232391520122316$

C: Sploty na jego głowie są [niezmienne] jak w dniach młodości, Jego loki to czarne kędziory.

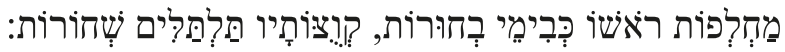

$4223=92091061862282507564$

$497=83918764464878$

$164=29193328101233$

W: Siedziba sprawiedliwości jest ozdobą Jego majestatu, oby wyniósł ją do najwyższej Swojej radości.

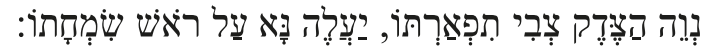
$2970=75450110051115108710219961$

$387=704228154388304625$

$135=2561061625121916$ 
C: Oby Jego umiłowany lud był koroną w Jego ręce, królewskim diademem, dumą wspaniałości.

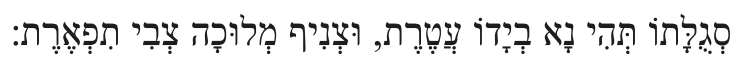

$3186=10811021012366792251415499$

$423=823047656722153758$

$153=19122029221361022$

W: Nosił ich od dzieciństwa, ozdobił ich koroną, bo byli drodzy w Jego oczach, dlatego ich zaszczycił.

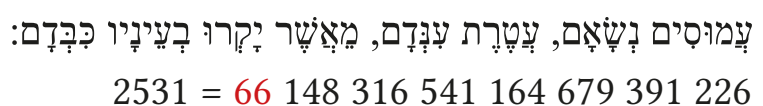

$434=3058555547674973$

$137=1222101020221328$

C: Jego chwała [jak tefilin] spoczywa na mnie, a moja chwała [w Boskim tefilinie] na Nim i On jest blisko mnie, gdy wołam do Niego.

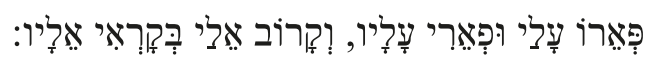
$1445=4731341314116297110207$

$320=2952235344543827$

$95=1175171718119$

W: Biały [w miłosierdziu] i czerwony [w sprawiedliwości], obleczony w czerwone [od krwi] odzienie, gdy miażdży [jak prasa] przemierzając Edom.

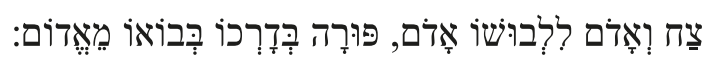

$1199=9117232291453745198$

$272=3717434818592426$

$137=191716219231517$

C: Ukazał węzeł tefilinu skromnemu [Moszemu], gdy obraz Haszem [zostaje objawiony] jego oczom.

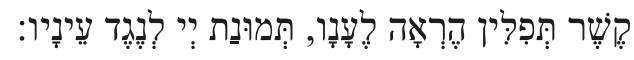

$2686=1461520896156211570600$

$400=5633207748317560$

$121=20872232113216$

W: Upodobał Sobie Swój lud, pochwała skromnych. Ten, który mieszka pośród pochwał, jest wysławiany w nich.

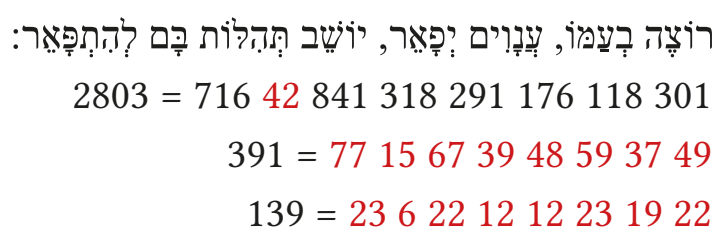

C: Początek Twoich słów jest prawdą, czytamy to już w pierwszych słowach Tory. Pokolenie za pokoleniem Ty szukasz ludu, który szuka Ciebie.

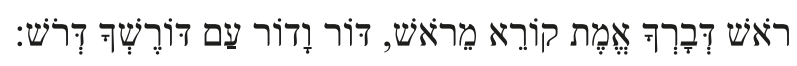




$$
\begin{array}{r}
3586=504530110216210541307441226501 \\
418=45622936305546363742 \\
112=91711181210109106
\end{array}
$$

C: Przyjmij moje niezliczone pieśni składane przed Tobą, a moja radość zbliży się do Ciebie.

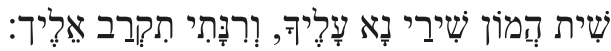

$$
\begin{aligned}
& 2941=6170266613051520101710 \\
& 385=3463724915613853 \\
& 88=79181367208
\end{aligned}
$$

W: Oby moja pochwała była koroną Twojej głowy, a moja modlitwa przyjęta jak kadzidło.

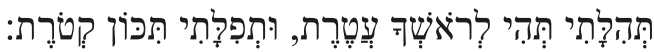

$$
4601 \text { = } 709476926679551415845
$$$$
452=70538967653771
$$$$
119=16172622111017
$$

C: Oby droga była w Twoich oczach pieśń biednego, jak pieśni śpiewane nad ofiarami składanymi Tobie.

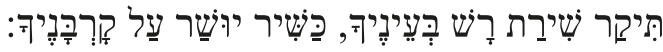

$$
\begin{aligned}
& 3810=382100516530162500910710 \\
& 471=7628576263417371 \\
& 84=1310128185108
\end{aligned}
$$

W: Niech moje błogosławieństwo wzniesie się do Tego, który jest Hojny, który stworzył i ukształtował - Potężnego Sprawiedliwego.

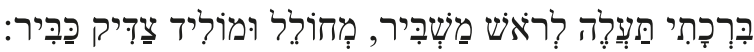

$$
\begin{aligned}
& 2866 \text { = } 23220496114552531505632 \\
& 436=4351515166545562 \\
& 121=71524241291911
\end{aligned}
$$

C: Ku mojemu błogosławieństwu skiń głowę i przyjmij je do Siebie jak najlepsze kadzidło.

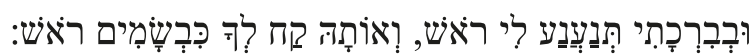
$3310=5014125010841850140640640$ $421=427023274042228273$ $115=6165922642819$

W: Oby moja modlitwa była Ci przyjemna, bo moja dusza tęskni do Ciebie.

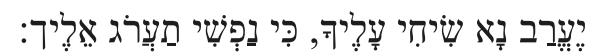
$1995=616734403013032851282$ $339=3461622149491548$

$$
87=7161731313612
$$

W Szir Hakawod [119] pokrycie wartości odpowiadających wartościom liczbowym podstawowych wymiarów wynosi $58 \%$, przy czym metodą absolutną uzyskano $32 \%$, uproszczoną $72 \%$, a redukcyjną $60 \%$. Dla wszystkich analizowanych wartości liczbowych średnia wynosi 
$34 \%$, przy czym metodą absolutną uzyskano 37\%, uproszczoną 36\%, a redukcyjną 28\%. Ogólnie, w wyniku zastosowania trzech metod pokryto $87 \%$ wartości podstaw ow ych i $56 \%$ wszystkich analizowanych wartości liczbowych. Przedstawione wyniki są podobne do tych uzyskanych w przypadku Lecha dodi.

Kilka wartości liczbowych analizowanych fragmentów odpowiada wartościom liczbowym wymiarów bożnic. Zależności te stwierdzono - podobnie jak w poprzedniej modlitwie - na poziomie analizy redukcyjnej w synagogach zlokalizowanych w takich miastach, jak:

\section{Pińczów}

Wysokość synagogi (87): Oby moja modlitwa była Ci przyjemna, bo moja dusza tęskni do Ciebie.

\section{Rzeszów (Synagoga Stara)}

Szerokość sali męskiej (88): Przyjmij moje niezliczone pieśni składane przed Tobą, a moja radość zbliży się do Ciebie.

\section{Orla}

Szerokość sali męskiej (107): Opisują Cię, ale nie takim, jaki jesteś, porównują Cię według Twoich czynów.

\section{Lesko}

Długość sali męskiej (106): Dlatego rozgłoszę o Tobie wspaniałości i Twoje Imię uczczę miłosnymi pieśniami.

\section{Tarnogród}

Długość sali męskiej (112): Początek Twoich słów jest prawdą, czytamy to już w pierwszych słowach Tory. Pokolenie za pokoleniem Ty szukasz ludu, który szuka Ciebie.

Szerokość sali męskiej (112): Początek Twoich słów jest prawdą, czytamy to już w pierwszych słowach Tory. Pokolenie za pokoleniem Ty szukasz ludu, który szuka Ciebie.

\section{Rzeszów (Synagoga Nowomiejska)}

Długość sali męskiej (115): Ku mojemu błogosławieństwu skiń głowę i przyjmij je do Siebie jak najlepsze kadzidło.

Szerokość sali męskiej (106): Dlatego rozgłoszę o Tobie wspaniałości i Twoje Imię uczczę miłosnymi pieśniami.

Wysokość sali męskiej (84): Oby droga była w Twoich oczach pieśń biednego, jak pieśni śpiewane nad ofiarami składanymi Tobie.

\section{Bobowa}

Długość synagogi (108): Przez Twoich proroków, przez zgromadzenia Twoich sług, objawiłeś piękno chwały Twojego majestatu.

Szerokość sali męskiej (84): Oby droga była w Twoich oczach pieśń biednego, jak pieśni śpiewane nad ofiarami składanymi Tobie. 


\section{Lańcut}

Długość synagogi

Szerokość synagogi

Długość sali męskiej

\section{Siemiatycze}

Długość sali męskiej

(112): Początek Twoich słów jest prawdą, czytamy to już w pierwszych słowach Tory. Pokolenie za pokoleniem Ty szukasz ludu, który szuka Ciebie.

(106): Dlatego rozgłoszę o Tobie wspaniałości i Twoje Imię uczczę miłosnymi pieśniami.

(94): Twoją wielkość i Twoją potęga ukazują poprzez moc Twoich czynów!

(121): On będzie wysławiony przez mnie, bo mnie ukochał. I będzie dla mnie koroną piękna.

(121): Jego głowa jest pełna rosy światła [Tory], Jego loki kropli nocy [Niebiańskiego błogosławieństwa].

(121): Ukazał węzeł tefilinu skromnemu [Moszemu], gdy obraz

Haszem [zostaje objawiony] jego oczom.

(121): Niech moje błogosławieństwo wzniesie się do Tego, który jest Hojny, który stworzył i ukształtował - Potężnego Sprawiedliwego.

Szir Hakawod wykazuje bardzo słabą reprezentatywność wartości liczbowych, które odpowiadają wymiarom bożnic, zwłaszcza wymiarom podstawowym. Najczęściej powtarzające się wymiary są dość słabo reprezentowane. Szczególnie tyczy się to liczby 33, która pojawia się dwukrotnie w metodzie redukcyjnej oraz trzykrotnie w uproszczonej. Niedoreprezentowana jest również liczba 66, która występuje trzykrotnie. Liczba 25 pojawia się dziesięć razy. Liczba 50 pojawia się trzykrotnie w wynikach badań przeprowadzonych metodą absolutną i dwukrotnie w wynikach badań przeprowadzonych metodą redukcyjną. Liczba 39 pojawia się jedynie raz w wynikach badań przeprowadzonych metodą uproszoną. Wartością liczbową, która pojawia się również tylko jeden raz, jest 396.

\subsubsection{Podsumowanie}

Badania dotyczące gematrii jako jednego z aspektów architektury judaizmu składały się z dwóch następujących po sobie części: analizy metrologicznej (będącej niejako wstępem) oraz analizy gematrycznej (opierającej się na poszukiwaniu znaczenia wartości wymiarów w wyselekcjonowanych tekstach modlitw). W wyniku analizy metrologicznej stwierdzono, że aż 75\% wymiarów synagog jest powtarzalnych. Co ciekawe, taka sama wartość występuje $\mathrm{w}$ materiale porównawczym, a więc w grupie synagog zlokalizowanych na obszarze Ukrainy i Białorusi. Gdyby brać pod uwagę cały zbiór badanych obiektów, wówczas powtarzalność wartości liczbowych miar funkcjonujących w dawnej Polsce w grupie analizowanych wymiarów wyniosłaby $91 \%$. 


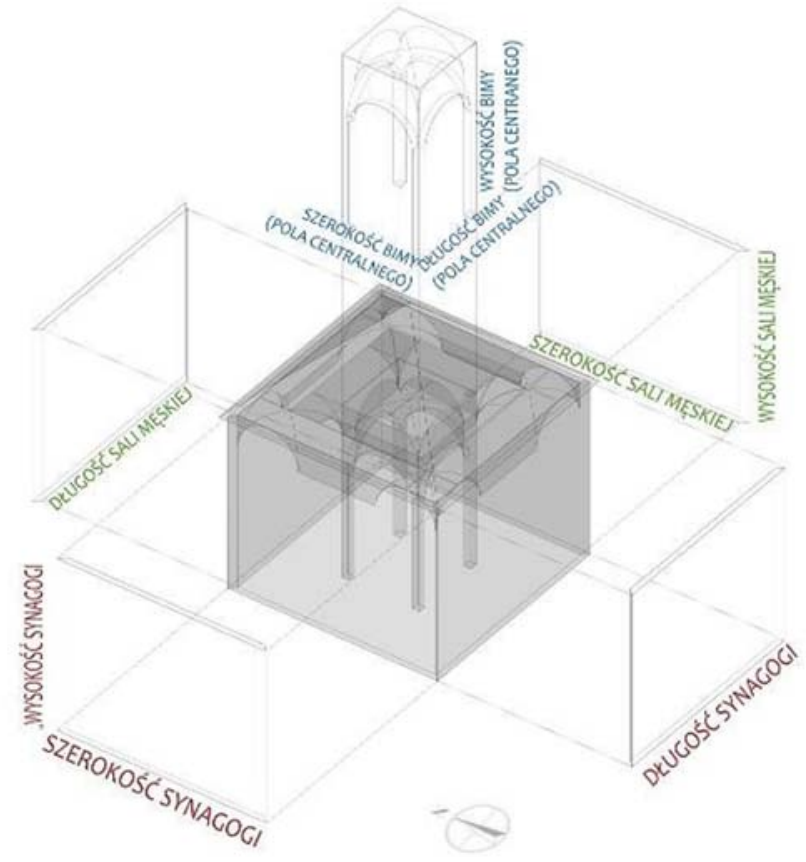

Il. 8.21. Schemat graficzny rozmieszczenia fragmentów modlitw odpowiadających wartości liczbowej określonych wymiarów synagog [21]

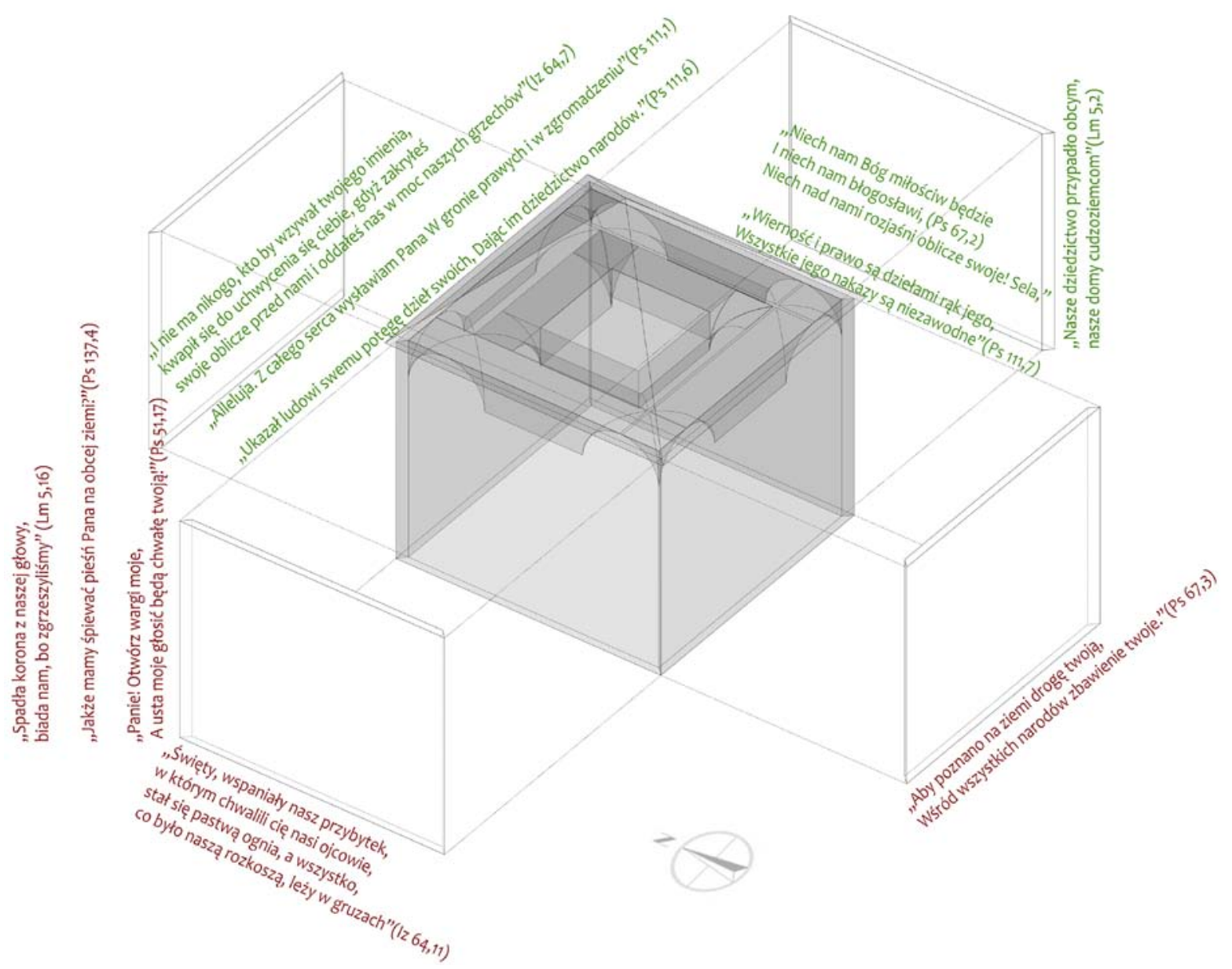

Il. 8.22. Schemat graficzny fragmentów modlitwy Tikkun Chacot, odpowiadających określonym wymiarom synagogi w Siemiatyczach [21] 


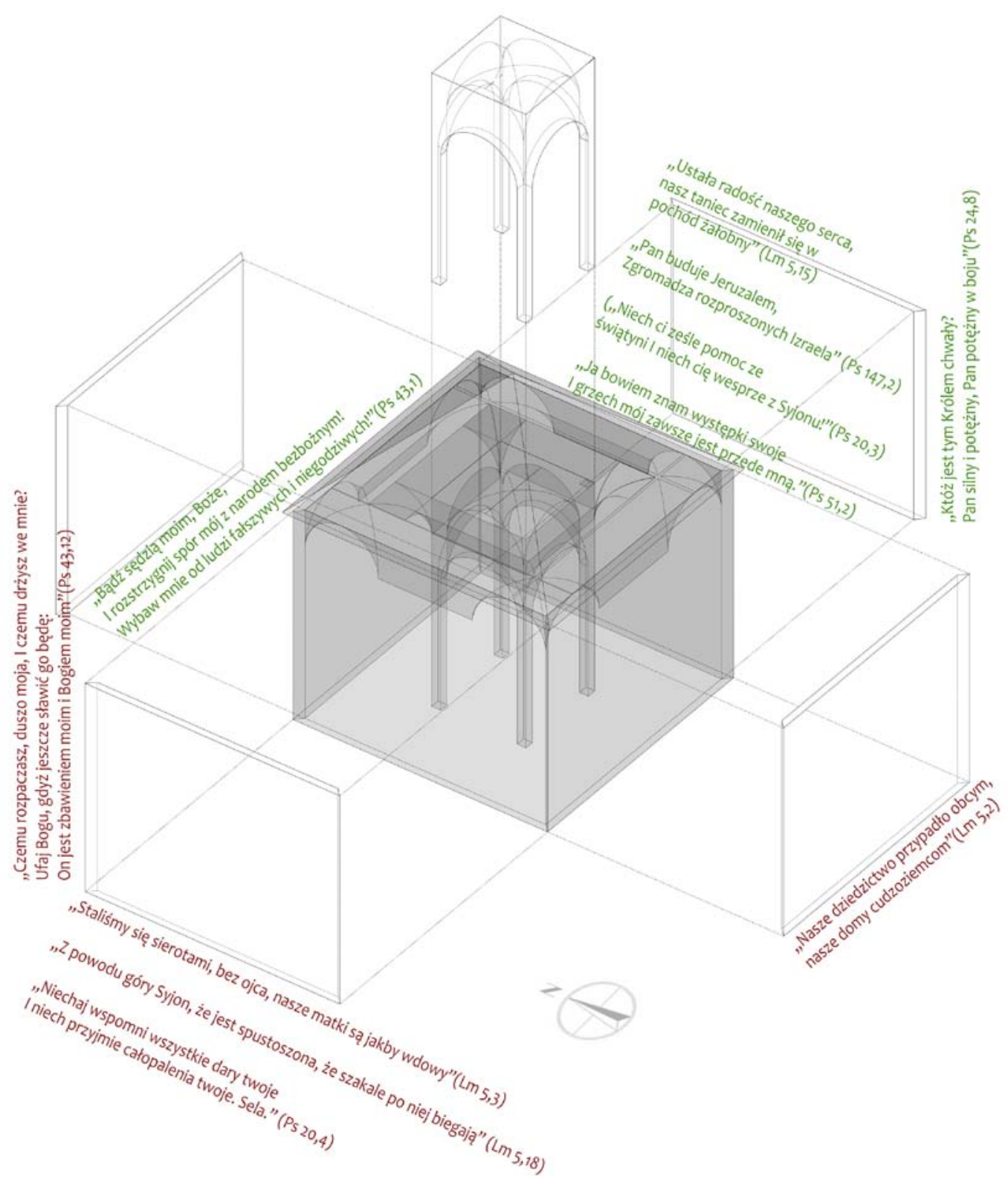

Il. 8.23. Schemat graficzny fragmentów modlitwy Tikkun Chacot, odpowiadających określonym wymiarom synagogi w Bobowej [21]

Istotny jest również inny wynik analizy metrologicznej, a mianowicie konkretyzacja datowania i konkretyzacja rozwarstwienia chronologicznego obiektów w oparciu o miary funkcjonujące w dawnej Polsce. Stwierdzono, że synagoga w Siemiatyczach, która została rozmierzona w łokciu warszawskim, wbrew doniesieniom Avierbucha nie mogła powstać w 1755 roku [5, s. 563]. Młodsza o co najmniej cztery lata okazała się również synagoga w Łańcucie. Potwierdzono również zaproponowane przez Janusza Kaczyńskiego [75] rozwarstwienie chronologiczne synagogi w Orli. Pozwala ono stwierdzić z cała pewnością, że pole centralne, sklepienie oraz nadbudowę ścian zewnętrznych wykonano z zastosowaniem łokcia warszawskiego, co wskazuje na 4. ćwierć XVIII wieku jako czas jego powstania. 


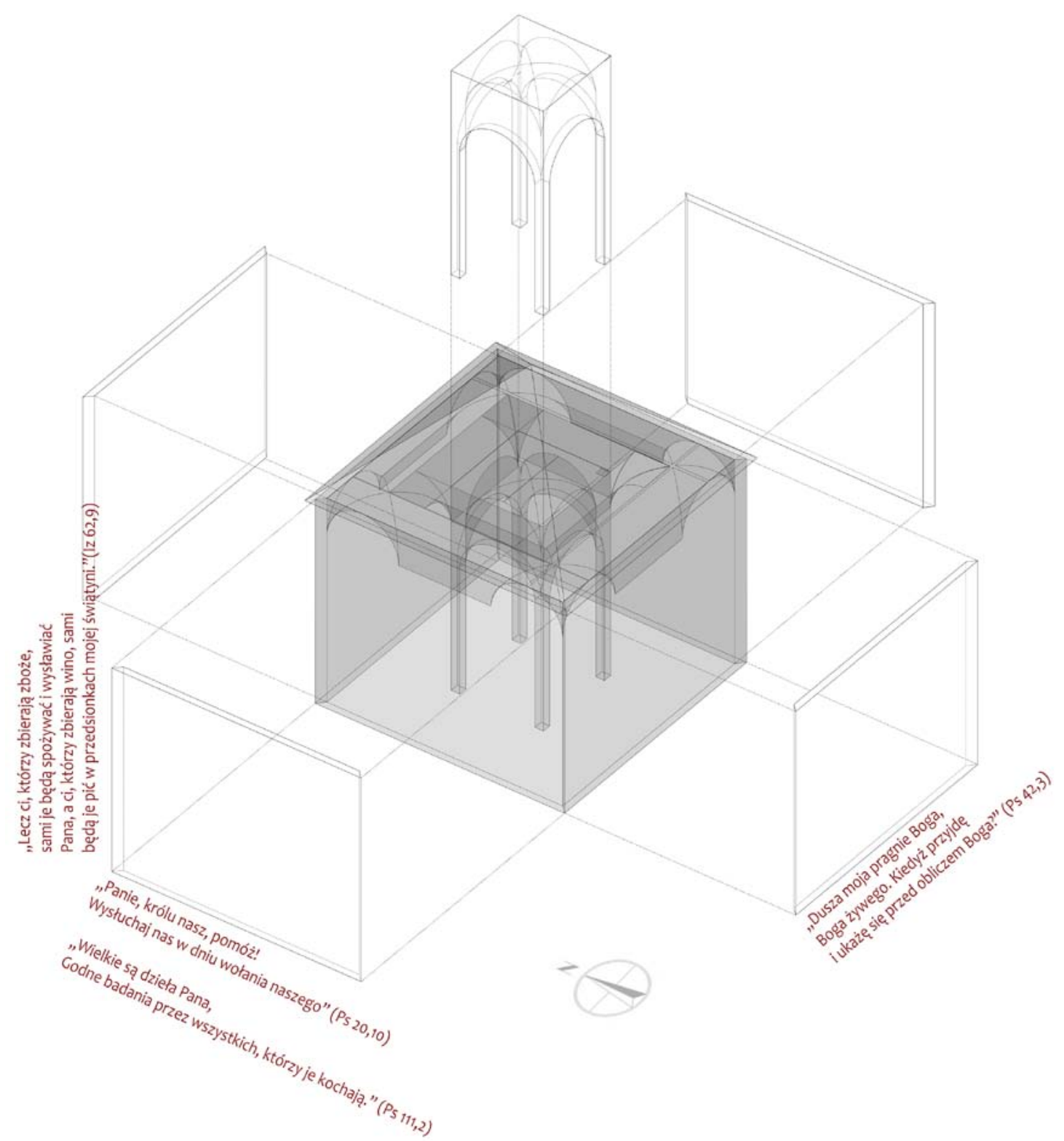

Il. 8.24. Schemat graficzny fragmentów modlitwy Tikkun Chacot, odpowiadających określonym wymiarom Synagogi Starej w Rzeszowie [21]

Porównując wartości liczbowe wymiarów synagog z grupy kontrolnej, czyli zlokalizowanych na terenie Białorusi i Ukrainy, z wartościami liczbowymi wymiarów synagog wzniesionych na terenie Polski można stwierdzić znaczną powtarzalność w grupie wymiarów rozmierzanych w łokciach. Wniosek ten wydaje się mało zaskakujący ze względu na fakt, że łokieć był w owym czasie podstawową miarą. Jednocześnie należy zwrócić uwagę, że mniej oczywisty układ powiązań między wymiarami bożnic z obszaru Polski oraz z obszaru Białorusi i Ukrainy maleje tym bardziej, im bardziej rozdrabniany jest wymiar podstawowy.

W oparciu o materiał, który stanowiły XVII- i XVIII-wieczne kościoły stwierdzono, że aż $64 \%$ analizowanych wymiarów jest charakterystycznych dla synagog i nie pojawia się 


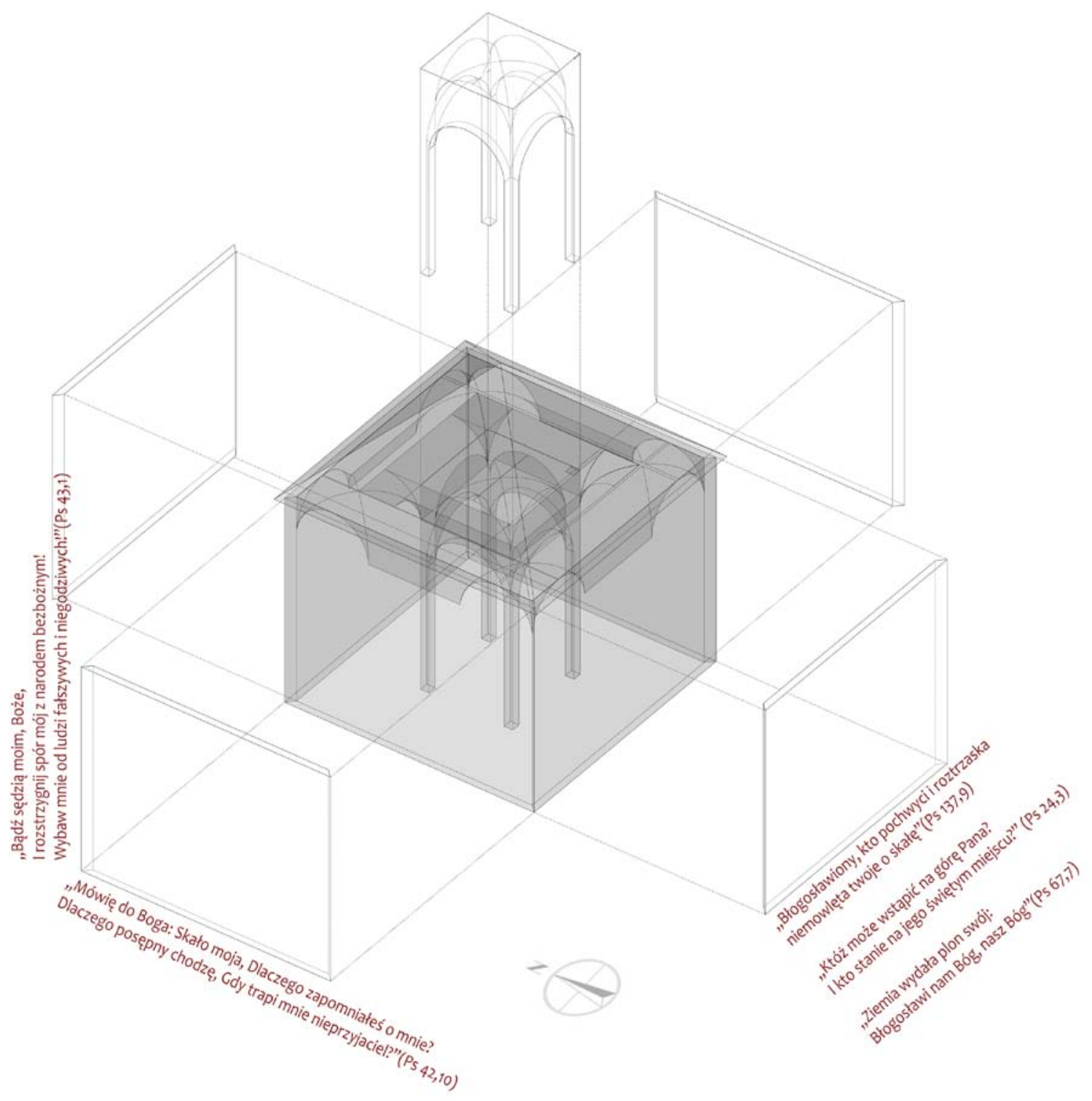

Il. 8.25. Schemat graficzny fragmentów modlitwy Tikkun Chacot, odpowiadających określonym wymiarom Synagogi Nowomiejskiej w Rzeszowie [21]

w ogóle w kościołach. Wpływ na taki, a nie inny rozkład wartości liczbowych mogą mieć niewielkie w porównaniu z kościołami gabaryty synagog oraz ich zupełnie inna kompozycja funkcji i planu. Tak odmienne obiekty wymagały stosowania odmiennych wymiarów w procesie kształtowania przestrzeni.

W przypadku porównania synagog z różnych obszarów należy zaznaczyć, że pomimo podobieństwa wymiarów jedynie w $33 \%$ rozkład częstotliwości ich występowania jest niezwykle zbliżony, co może wskazywać jednocześnie na szerszy zamysł w kształtowaniu architektury synagogalnej.

Przedstawione argumenty nie tłumaczą jednak niezwykle częstego występowania w wymiarach bożnic pewnych wartości liczbowych, a więc abstraktu pozbawionego jednostki. 


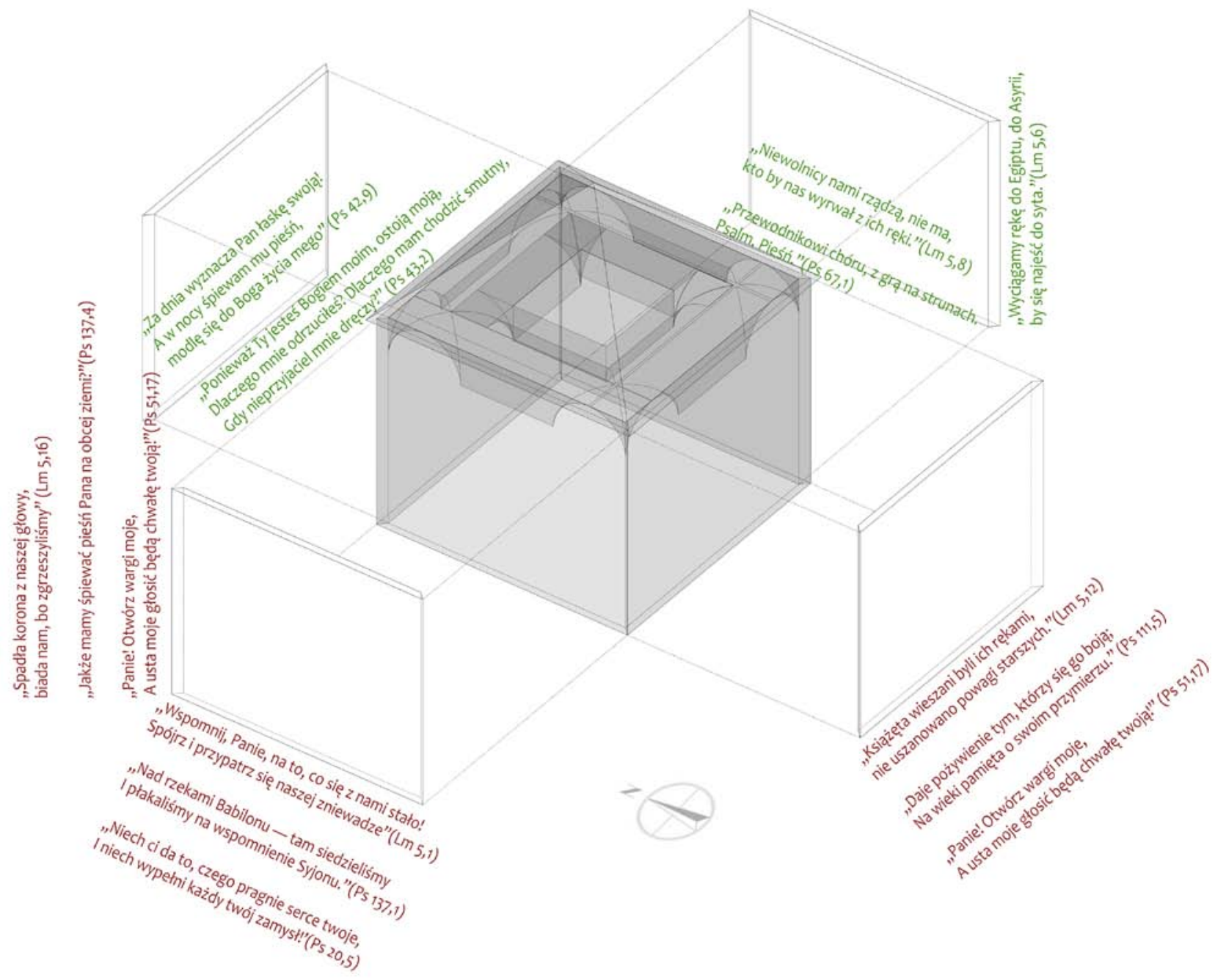

Il. 8.26. Schemat graficzny fragmentów modlitwy Tikkun Chacot, odpowiadających określonym wymiarom synagogi w Chęcinach [21]

W wyniku analizy porównawczej stwierdzono, że jedynie 34,2\% wartości liczbowych pojawia się w wymiarach synagog częściej lub z taką samą częstotliwością jak w wymiarach kościołów. Jednocześnie jednak liczba 33 jest dobrze reprezentowana w grupie synagog, natomiast nie pojawia się w wymiarach analizowanych kościołów. Podobnie jest w przypadku liczb 39 i 53, a także: 6, 7, 8, 32, 99, 123, 207.

Odpowiedzi na pytanie o przyczynę tak dużej różnorodności wartości liczbowych w wymiarach synagog wzniesionych na obszarze Polski dostarczyła analiza gematryczna tekstów tych modlitw, które w judaizmie posiadają szczególne znaczenie, a zyskały na znaczeniu w XVII i XVIII wieku. Z tej części analizy wynika, że modlitwami wyróżniającymi się pod względem wartości średniego pokrycia w zakresie podstawowych wartości liczbowych pojawiających się w wymiarach synagog są Tikkun Chacot (85\%) i Amida (76\%). Pozostałe modlitwy: Szir Hakawod (58\%), Kabbalat Szabat i figdal (41\%) wypadają znacznie gorzej. Jeżeli byłyby brane pod uwagę wszystkie wartości, czyli miary podstawowe wraz z przeliczeniami, 


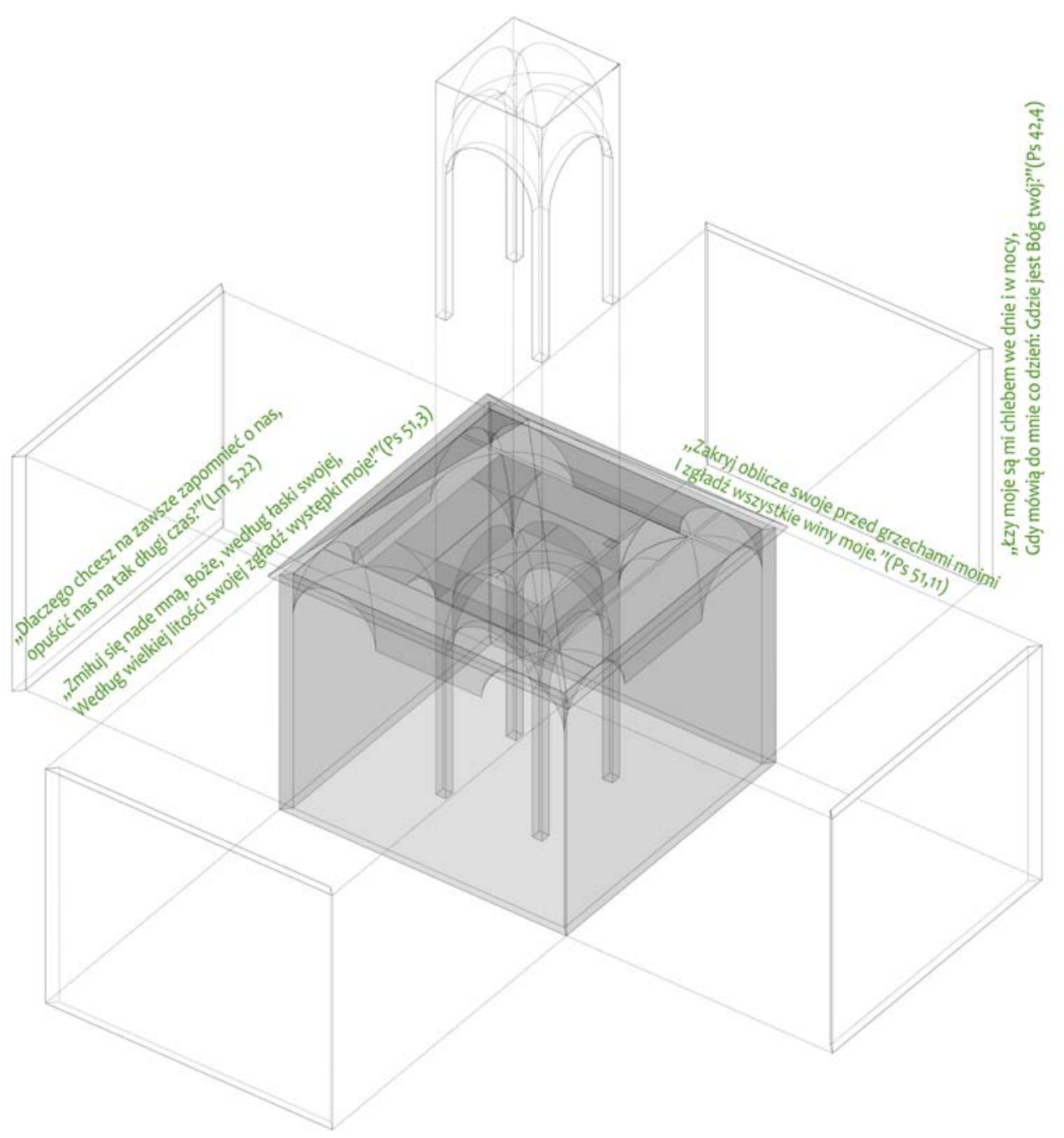

Il. 8.27. Schemat graficzny fragmentów modlitwy Tikkun Chacot, odpowiadających określonym wymiarom synagogi w Orli [21]

największe średnie pokrycie zostałoby uzyskane w przypadku Kabbalat Szabat (68\%), a w dalszej kolejności Tikkun Chacot (54\%) i Amidy (51\%). Również wówczas istniałaby znacząca przepaść w stosunku do pozostałych analizowanych modlitw, w których pokrycie wszystkich wymiarów wynosi od 34\% (Szir Hakawod) do 22\% (figdal).

Wydaje się jednak, że bardziej interesującym parametrem jest pokrycie wartości liczbowych w wyniku zastosowania wszystkich metod gematrycznych. Na pierwsze miejsce wysuwa się Tikkun Chacot, które wykazuje 100\% zbieżności dla wartości podstawowych i $84 \%$ dla wszystkich analizowanych wartości liczbowych. Kolejnymi modlitwami w tej grupie są Amida i Lecha dodi, wykazujące zbieżność na poziomie $95 \% \mathrm{w}$ zakresie wartości podstawowych i $80 \%$ w zakresie wszystkich analizowanych wartości liczbowych. Również Kabbalat Szabat wydaje się istotna, ale głównie ze względu na wartości podstawowe zbieżne w 96\%. W przypadku wszystkich wymiarów wypada już jednak znacznie słabiej, gdyż pokrywa jedynie $69 \%$ wartości liczbowych. Szema, Szir Hakawod i figdal są na dość porównywalnym poziomie, 


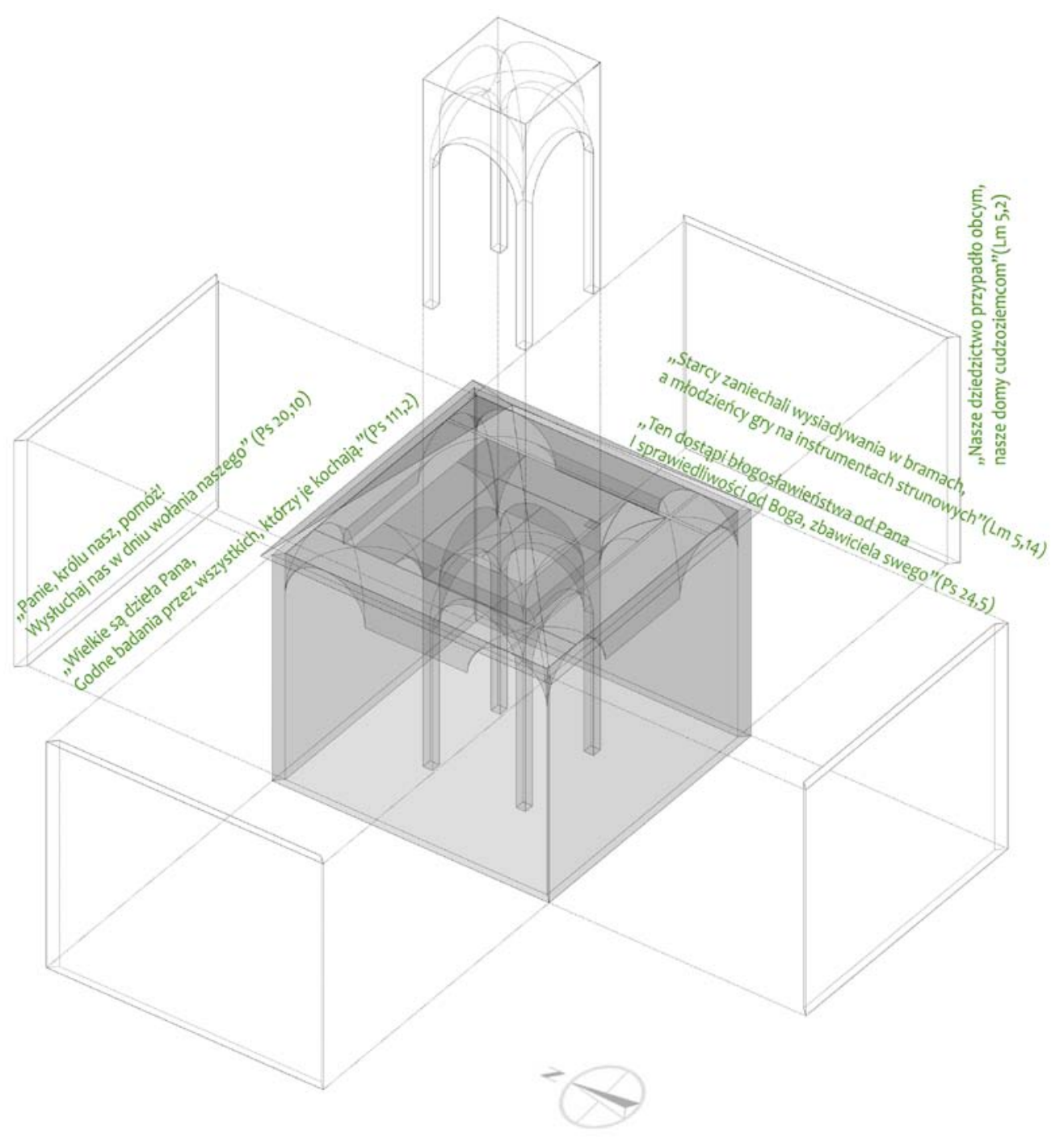

Il. 8.28. Schemat graficzny fragmentów modlitwy Tikkun Chacot, odpowiadających określonym wymiarom synagogi w Dukli [21]

gdyż pokrywają odpowiednio: $84 \%, 87 \%$ i $86 \%$ wartości podstawowych oraz $57 \%, 56 \%$ i $51 \%$ wszystkich analizowanych wartości liczbowych.

Analiza wystąpień najczęściej pojawiających się wymiarów wykazuje, że liczba 33 najczęściej pojawia się w Tikkun Chacot (22 razy). Pozostałe wymiary nakierowują w pierwszej kolejności na Amidę, a następnie na Tikkun Chacot. Najsłabiej reprezentowana jest modlitwa Lecha Dodi.

Statystyka ta wskazuje, że podstawowe wartości liczbowe są reprezentowane na poziomie $80 \%$ we wszystkich przeanalizowanych modlitwach. Nie można jednak na podstawie tylko tych wyników stwierdzić, że stanowią one ważny argument za stosowaniem odpowiednich wartości liczbowych w wymiarach bożnic. Istotne są również fragmenty oraz ciągi wyrazowe, w przypadku których suma liter odpowiada poszczególnym wartościom liczbowym wymiarów. 


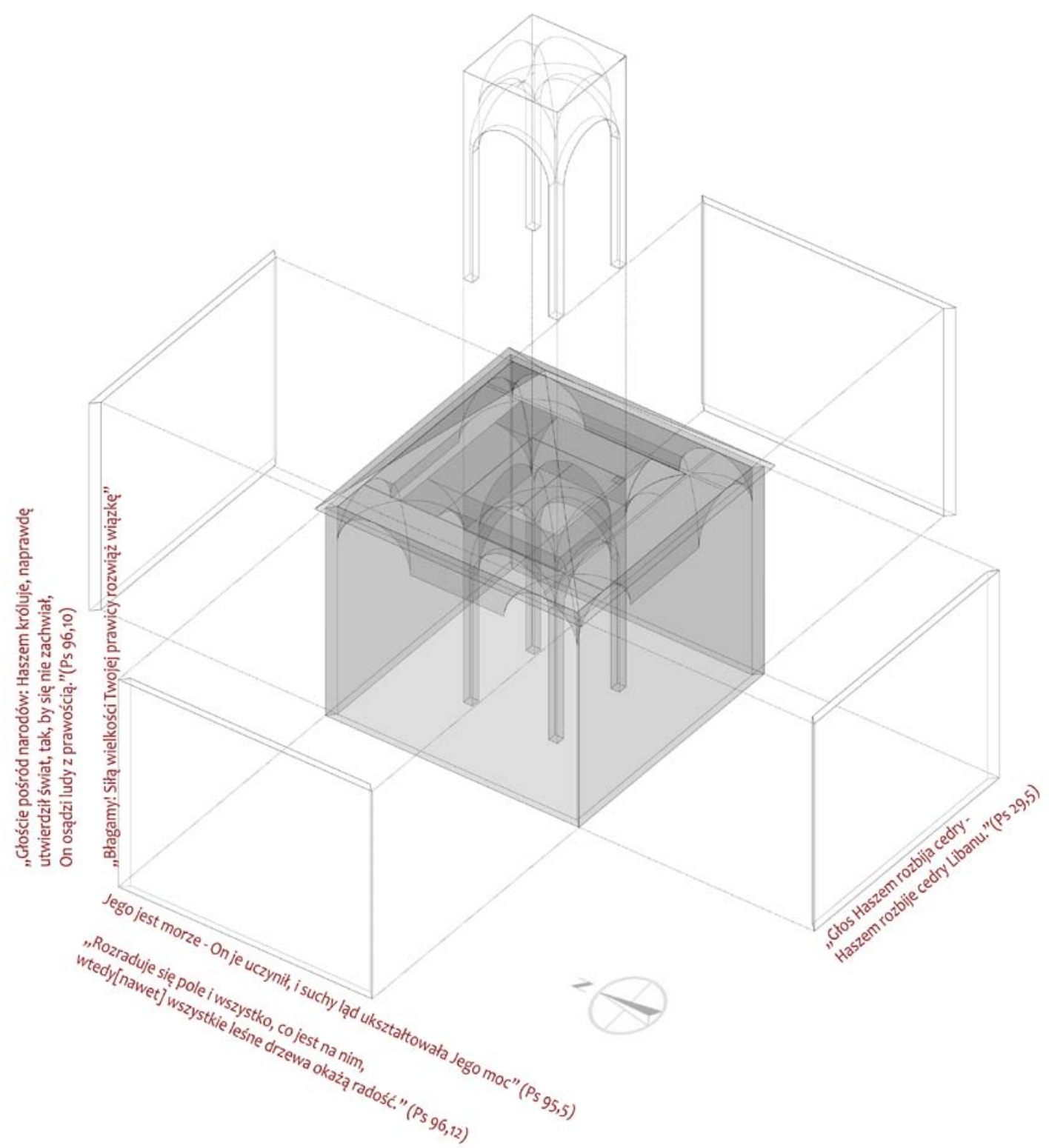

Il. 8.29. Schemat graficzny fragmentów modlitwy Kabbalat Szabat, odpowiadających określonym wymiarom Synagogi Starej w Rzeszowie [21]

Na podstawie danych uzyskanych w wyniku analizy modlitw udało się stworzyć dość komplementarny obraz wymiarów kilku obiektów, złożony z wymiarów poziomych synagogi, sali męskiej, pola centralnego lub wszystkich przeanalizowanych wymiarów zewnętrznych lub wewnętrznych. Wartości liczbowe i kryjące się pod nimi fragmenty modlitw w przypadku każdego z omawianych obiektów opisują jego przynajmniej dwa powiązane ze sobą wymiary.

We wszystkich omówionych przykładach przynajmniej raz pojawia się wymiar o wartości liczbowej powiązanej z którymś z wymienionych wersów lub kilka niepowiązanych ze sobą wartości liczbowych. Przedstawienie tych zależności przeprowadzono dwutorowo. $\mathrm{Z}$ jednej strony $\mathrm{w}$ trakcie analizy modlitw zestawiono wartości liczbowe otrzymane dla po- 


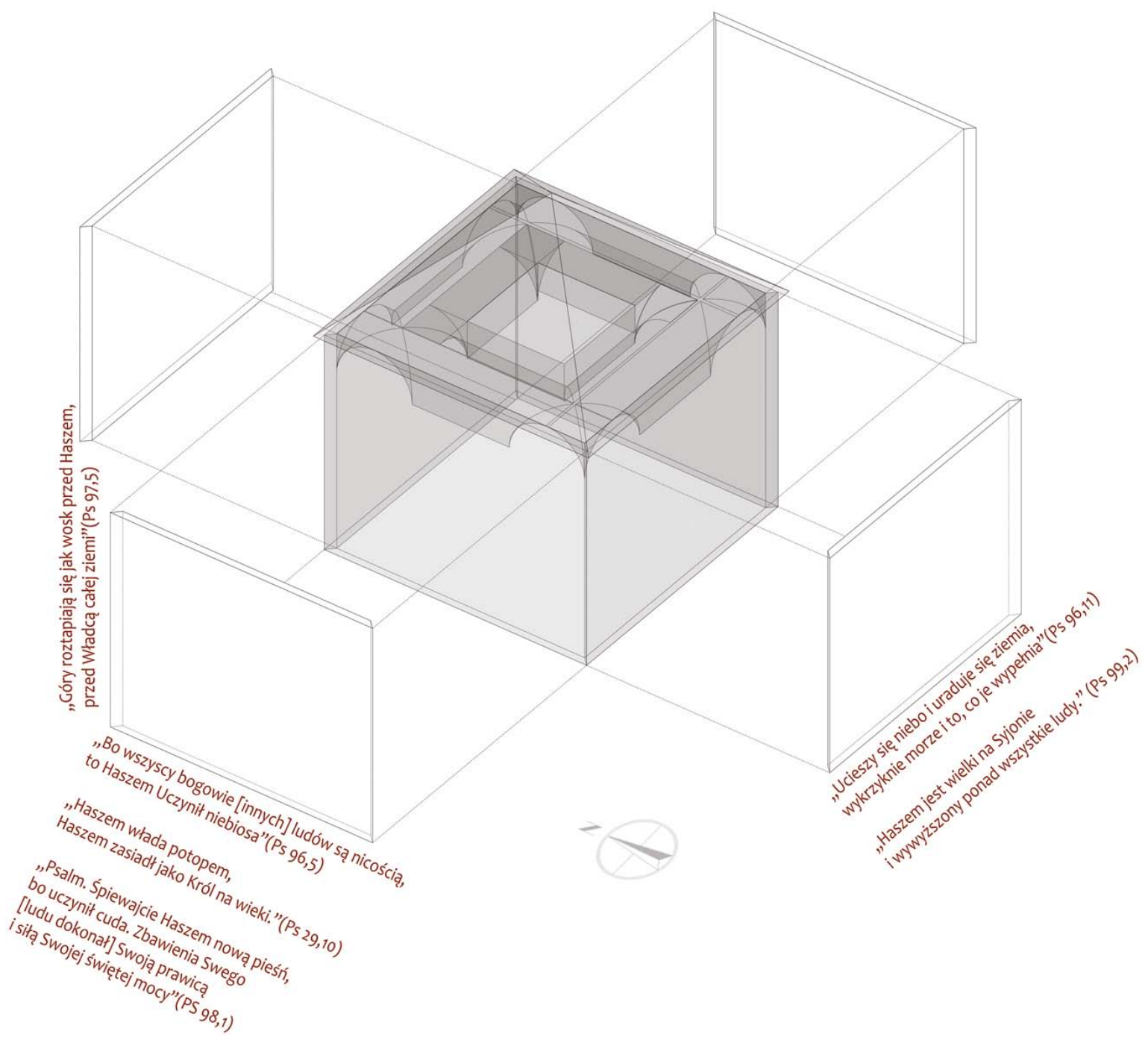

Il. 8.30. Schemat graficzny fragmentów modlitwy Kabbalat Szabat, odpowiadających określonym wymiarom synagogi w Szczebrzeszynie [21]

szczególnych fraz i oznaczające wymiary każdego obiektu. Z drugiej strony w formie graficznej (il. 8.22-8.46) przedstawiono najistotniejsze zależności dla każdej z modlitw w oparciu o konkretne obiekty ${ }^{281}$. Sposób opisu konkretnych wymiarów na schematach graficznych jest zobrazowany na ilustracji 8.21. Rozpoczynając od Tikkun Chacot, a więc modlitwy w 100\% pokrywającej podstawowe wartości liczbowe poddane analizie, należy zwrócić uwagę przede wszystkim na kilka obiektów.

Pełne pokrycie wartości liczbowych wymiarów synagogi z wartościami liczbowymi obliczonymi dla fragmentów modlitwy uzyskuje się w przypadku synagog w Siemiatyczach (il. 8.22) i Bobowej (bez bimy) (il. 8.23). Oznacza to, że dla każdego wymiaru wewnętrznego i zewnętrznego wskazany został co najmniej jeden fragment modlitwy. Pozostałe obiekty z całej grupy tych, które zostały przebadane, można podzielić na: 


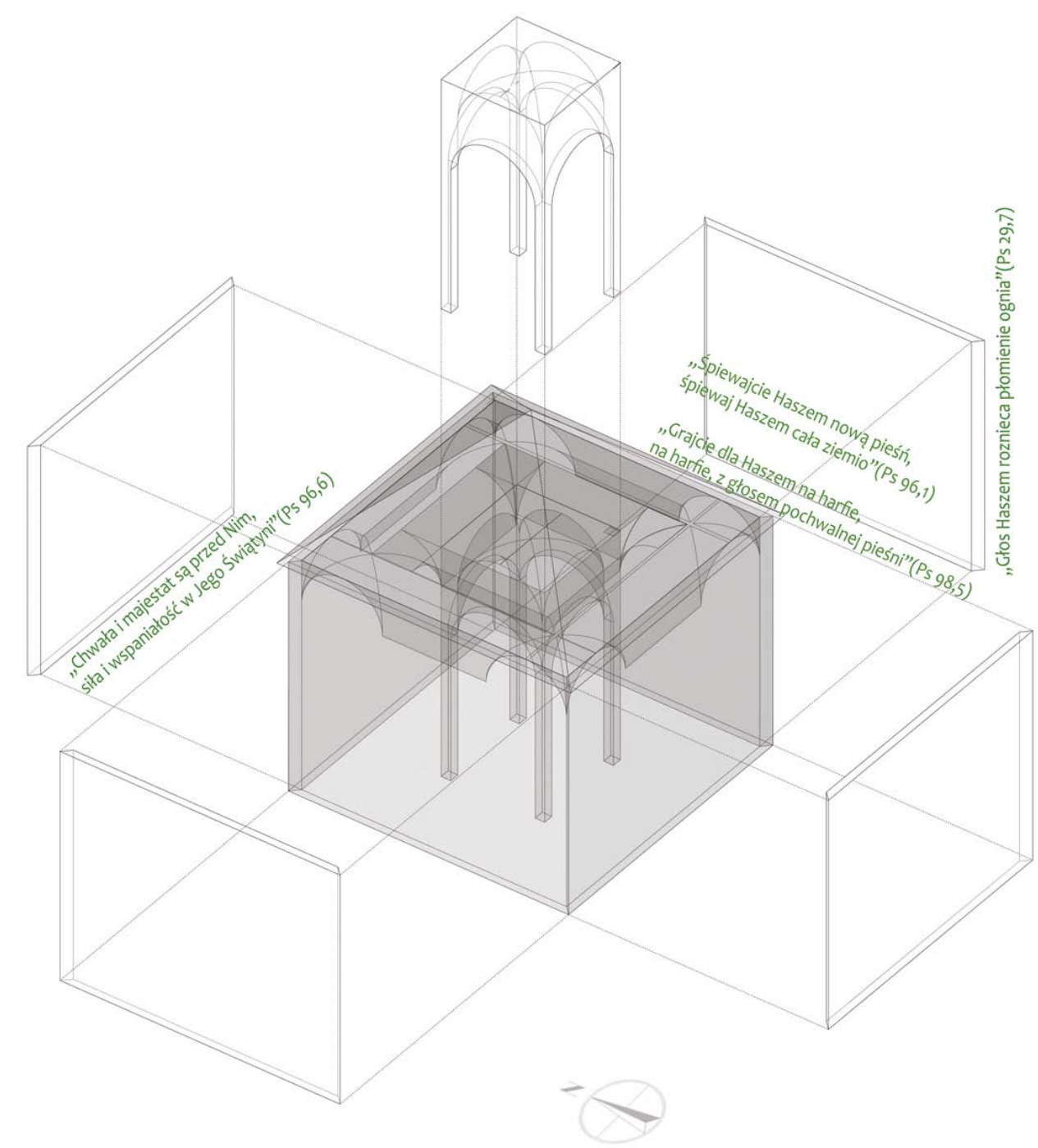

Il. 8.31. Schemat graficzny fragmentów modlitwy Kabbalat Szabat, odpowiadających określonym wymiarom synagogi w Orli [21]

1) Obiekty, których wszystkie trzy wymiary zewnętrzne posiadają ekwiwalent w formie wersu modlitwy: Synagoga Stara (il. 8.24) i Synagoga Nowomiejska w Rzeszowie (il. 8.25), synagoga w Chęcinach (il. 8.26).

2) Obiekty, których wszystkie trzy wymiary wewnętrzne posiadają ekwiwalent w formie wersu modlitwy: synagoga w Orli (il. 8.27) i synagoga w Dukli (il. 8.28).

Wśród analizowanych obiektów są też takie, których dwa powiązane ze sobą wymiary mają ekwiwalent semantyczny. Wymienić należy synagogi w: Pińczowie (szerokość i wysokość synagogi, długość i wysokość sali męskiej), Zamościu, Tykocinie i Włodawie (długość i szerokość synagogi, długość i szerokość sali męskiej), Szczebrzeszynie (długość i wysokość synagogi), Lesku (długość i szerokość sali męskiej), Łańcucie (długość i szerokość bimy).

Można zatem stwierdzić, że Tikkun Chacot może być punktem wyjścia przy rozmierzaniu synagog. Świadczy o tym fakt, że w czternastu z piętnastu analizowanych obiektów 


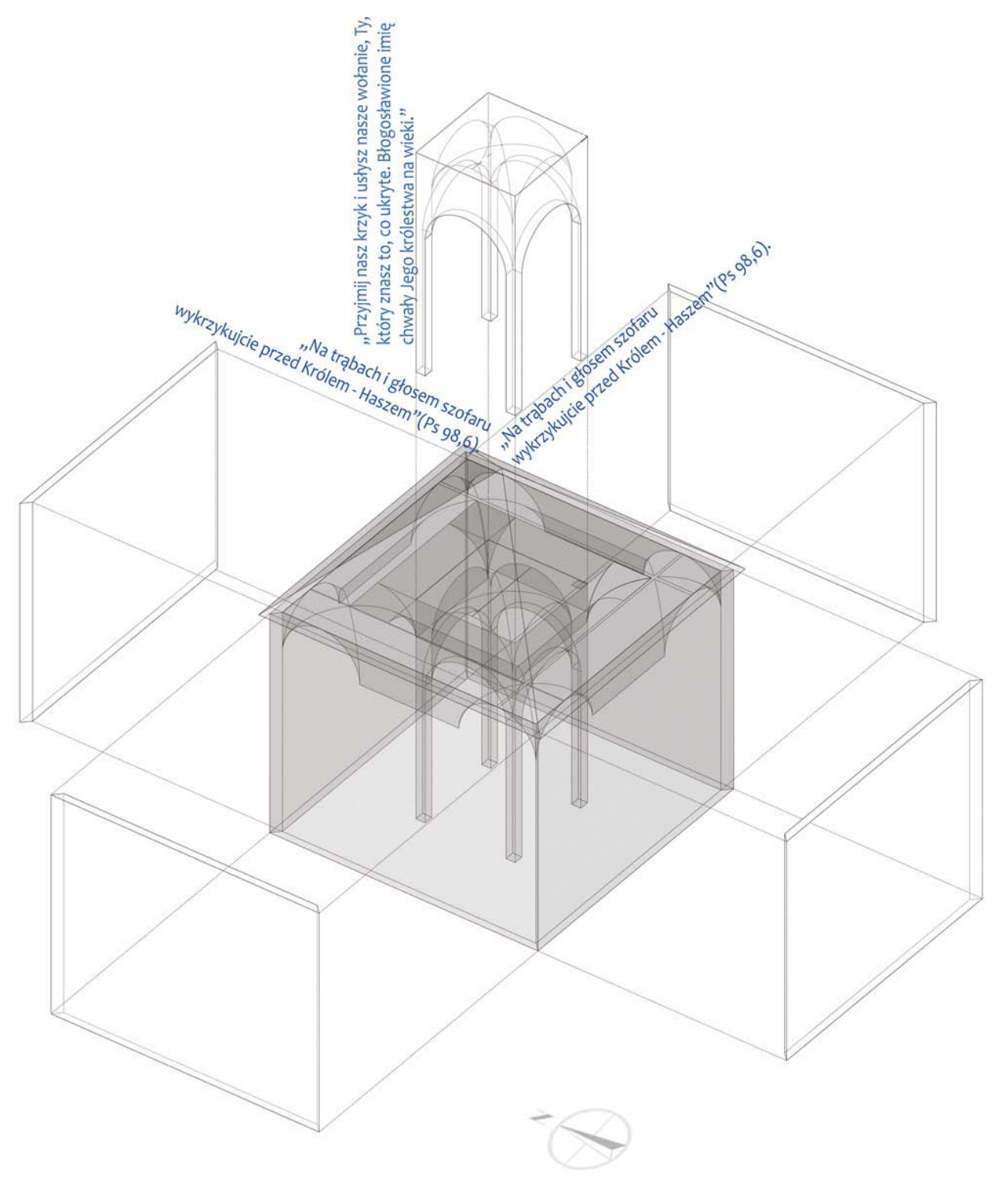

Il. 8.32. Schemat graficzny fragmentów modlitwy Kabbalat Szabat, odpowiadających określonym wymiarom synagogi w Łańcucie [21]

występują co najmniej dwa powiązane ze sobą wymiary, które posiadają ekwiwalent semantyczny zawarty w tej modlitwie.

Modlitwą drugą w kolejności pod względem największego pokrycia podstawowych wartości liczbowych jest Kabbalat Szabat. Jej fragmenty odpowiadają wartości liczbowej wymiarów zewnętrznych Synagogi Starej w Rzeszowie (il. 8.29) i synagogi w Szczebrzeszynie (il. 8.30), wymiarów wewnętrznych synagogi w Orli (il. 8.31) oraz wymiarów bimy w synagodze w Łańcucie (il. 8.32).

Dość dużą grupę stanowią również synagogi, w przypadku których ekwiwalent językowy mają dwa powiązane z sobą wymiary. Do tego zbioru należy zaliczyć bożnice w: Pińczowie (szerokość i wysokość sali męskiej), Zamościu (szerokość i wysokość synagogi, długość 


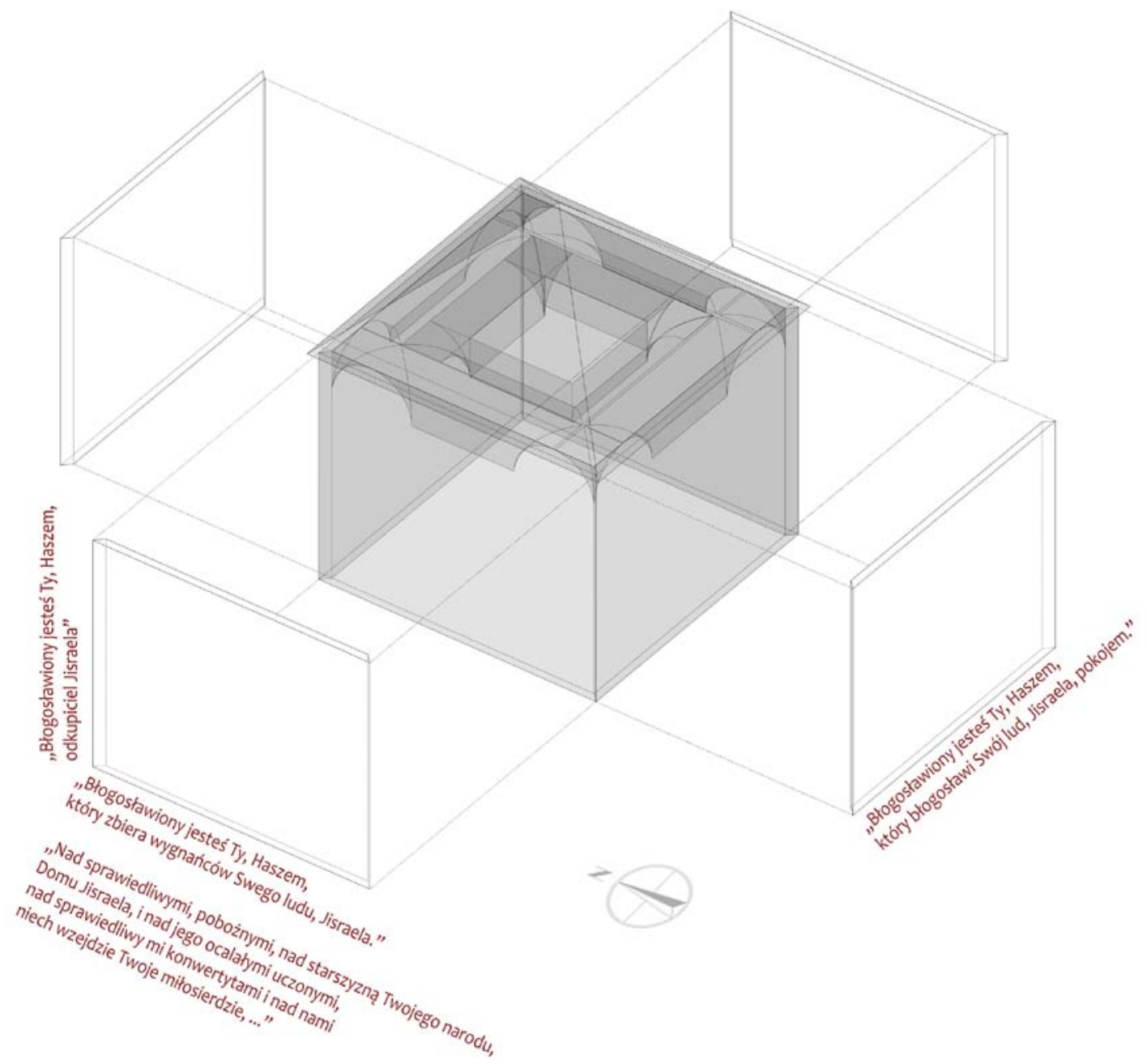

Il. 8.33. Schemat graficzny fragmentów modlitwy Amida, odpowiadających określonym wymiarom synagogi w Zamościu [21]

i wysokość sali męskiej), Tykocinie (długość i szerokość synagogi), Tarnogrodzie, Bobowej i Siemiatyczach (długość i szerokość sali męskiej), Dukli (wysokość i szerokość synagogi), Włodawie (szerokość i wysokość sali męskiej).

Modlitwa Kabbalat Szabat jest zbieżna pod względem dwóch powiązanych z sobą wymiarów z dwunastoma z piętnastu obiektów. W przeciwieństwie do modlitwy Tikkun Chacot nie ma przykładów pełnego pokrycia wymiarów obiektów.

Całkowitego lingwistycznego obrazu synagog nie daje również trzecia z modlitw - Amida. Z pewnością można jednak wyróżnić cztery obiekty, w przypadku których uzyskiwany jest całościowy obraz zewnętrza lub wnętrza obiektu. Te pierwsze reprezentują synagogi w Zamościu (il. 8.33) i Włodawie (il. 8.34), do drugich Synagoga Stara w Rzeszowie (il. 8.35) i synagoga w Bobowej (il. 8.36). Istnieje również grupa obiektów, które zawierają w sobie odpowiedniki językowe dwóch powiązanych ze sobą wymiarów. Należą do niej synagogi w: Chęcinach (szerokość i wysokość synagogi, szerokość i wysokość sali męskiej), Tykocinie 


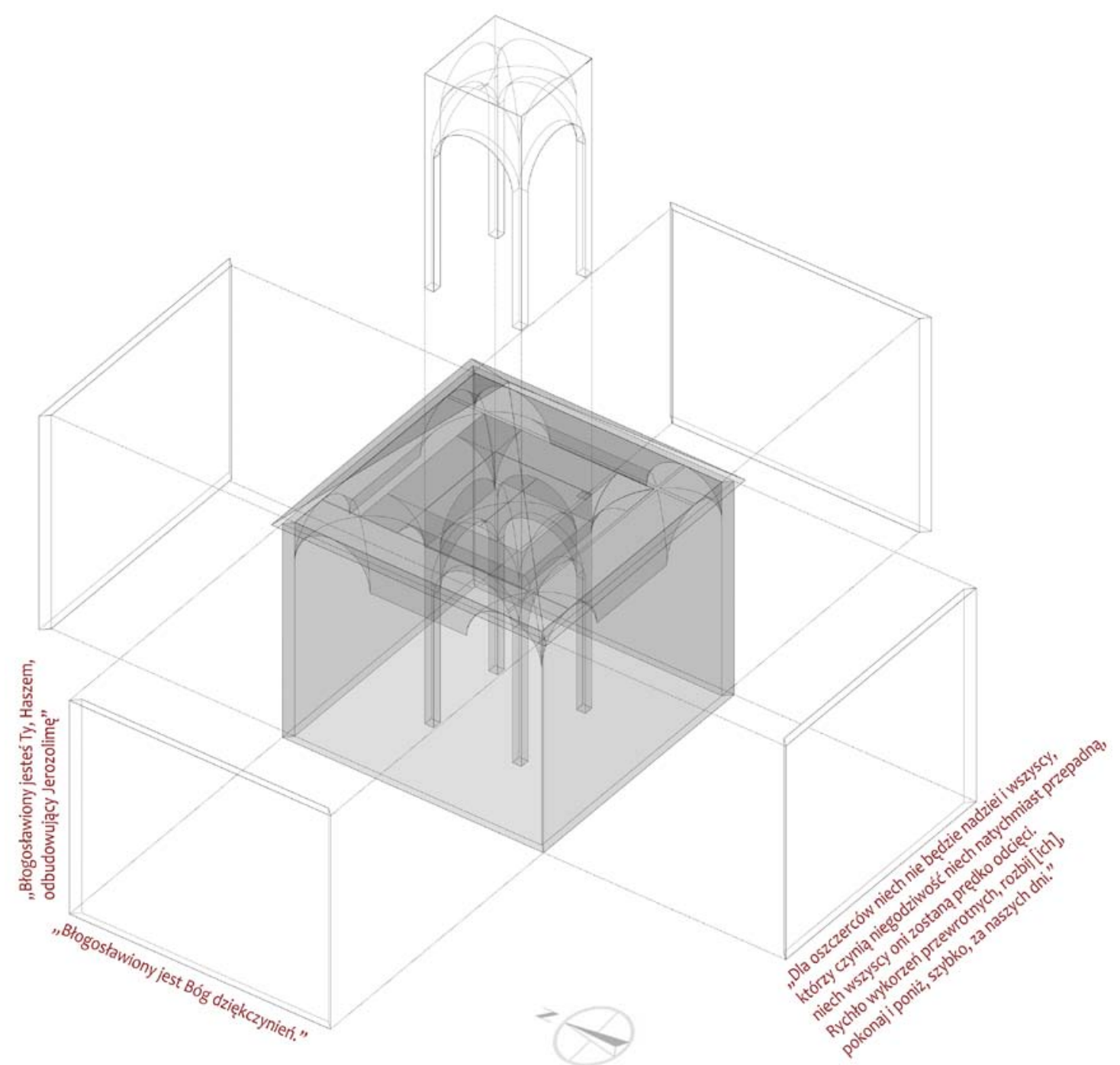

Il. 8.34. Schemat graficzny fragmentów modlitwy Amida, odpowiadających okreslonym wymiarom synagogi we Włodawie [21]

(długość i szerokość synagogi), Orli (szerokość i wysokość synagogi, szerokość i wysokość sali męskiej, długość i szerokość centralnego pola), Rzeszowie (Synagoga Nowomiejska długość i szerokość synagogi, długość i szerokość centralnego pola), Siemiatyczach (długość i wysokość synagogi).

Uwzględniając modlitwę Amida, z całego analizowanego zbioru synagog można wybrać również dziewięć obiektów, w których co najmniej dwa powiązane ze sobą wymiary mają ekwiwalent lingwistyczny.

Pomimo ogólnie wielu wartości liczbowych wymiarów mających swoje odpowiedniki w treści modlitwy, Szir Hakawod jest mocno niedoreprezentowane pod względem liczby fragmentów modlitwy, które można do nich przypisać. W sumie fragmenty te odpowiadają zwykle pojedynczym wymiarom jedynie dziewięciu obiektów. W trzech przypadkach istnieje możliwość zestawienia fraz $\mathrm{z}$ powiązanymi ze sobą wymiarami. 


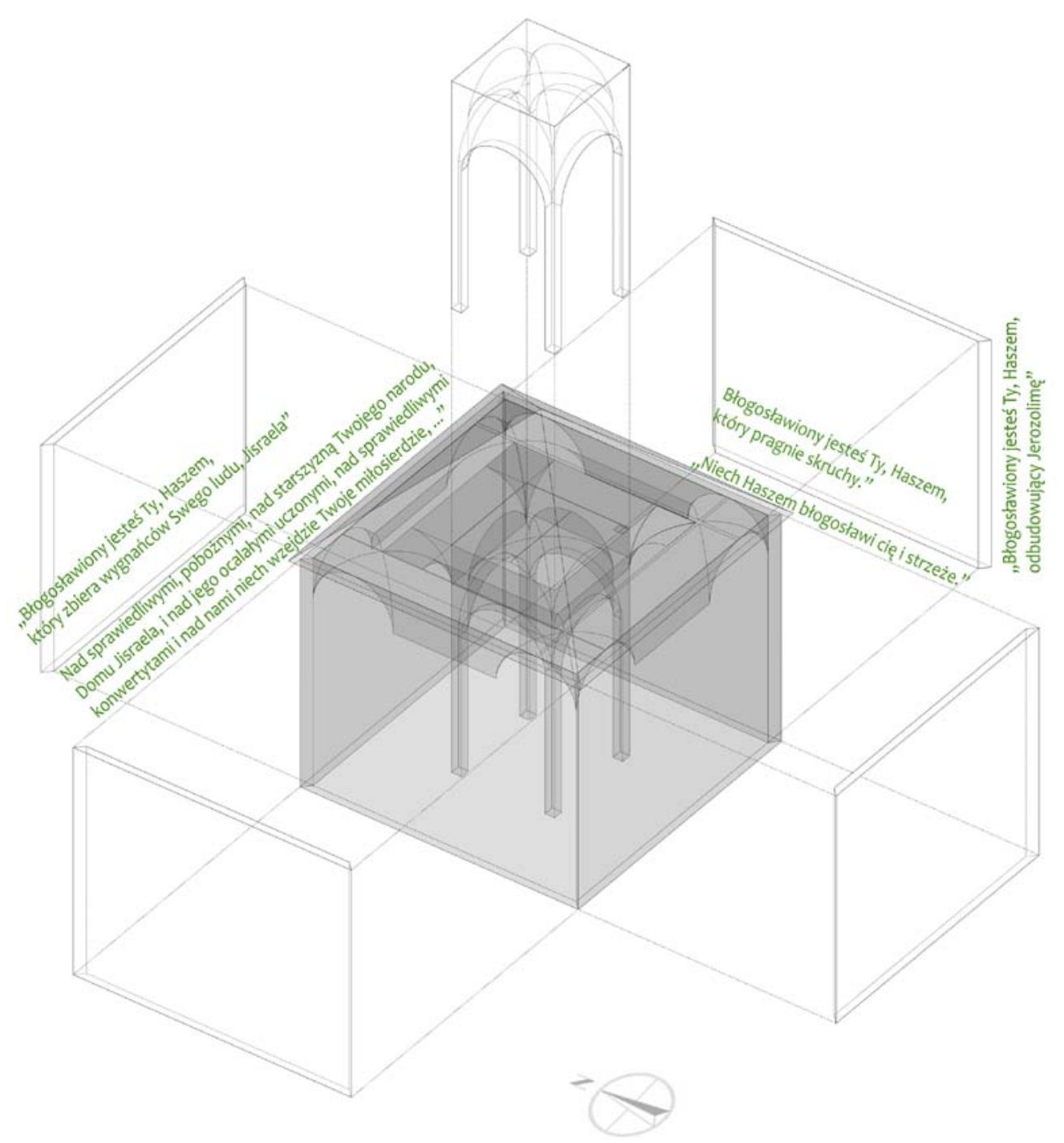

Il. 8.35. Schemat graficzny fragmentów modlitwy Amida, odpowiadających określonym wymiarom Synagogi Starej w Rzeszowie [21]

W dwóch obiektach są to tylko dwa wymiary: w synagodze w Tarnogrodzie jest to długość i szerokość sali męskiej, natomiast w synagodze w Łańcucie długość i szerokość całego budynku. Jedynie wnętrze Synagogi Nowomiejskiej (il. 8.37) przedstawia całościowy obraz lingwistyczny.

Modlitwy Szir Hakawod nie można traktować jako źródła gematrycznego obrazu wymiarów znacznej grupy obiektów. Odwzorowanie liczbowe pojedynczych fraz w niektórych wymiarach większości obiektów wskazuje, że mogła ona stanowić raczej podstawę konkretnej budowli, którą w tym przypadku jest Synagoga Nowomiejska w Rzeszowie, niż uniwersalny wzór wszystkich obiektów.

Analiza Lecha dodi, Figdal i Szema wykazała we wszystkich trzech modlitwach obrazy lingwistyczne dla najwyżej dwóch powiązanych wymiarów. Nie ma natomiast całościowego obrazu wymiarów zewnętrznych, wewnętrznych lub centralnego pola (bimy). W modli- 


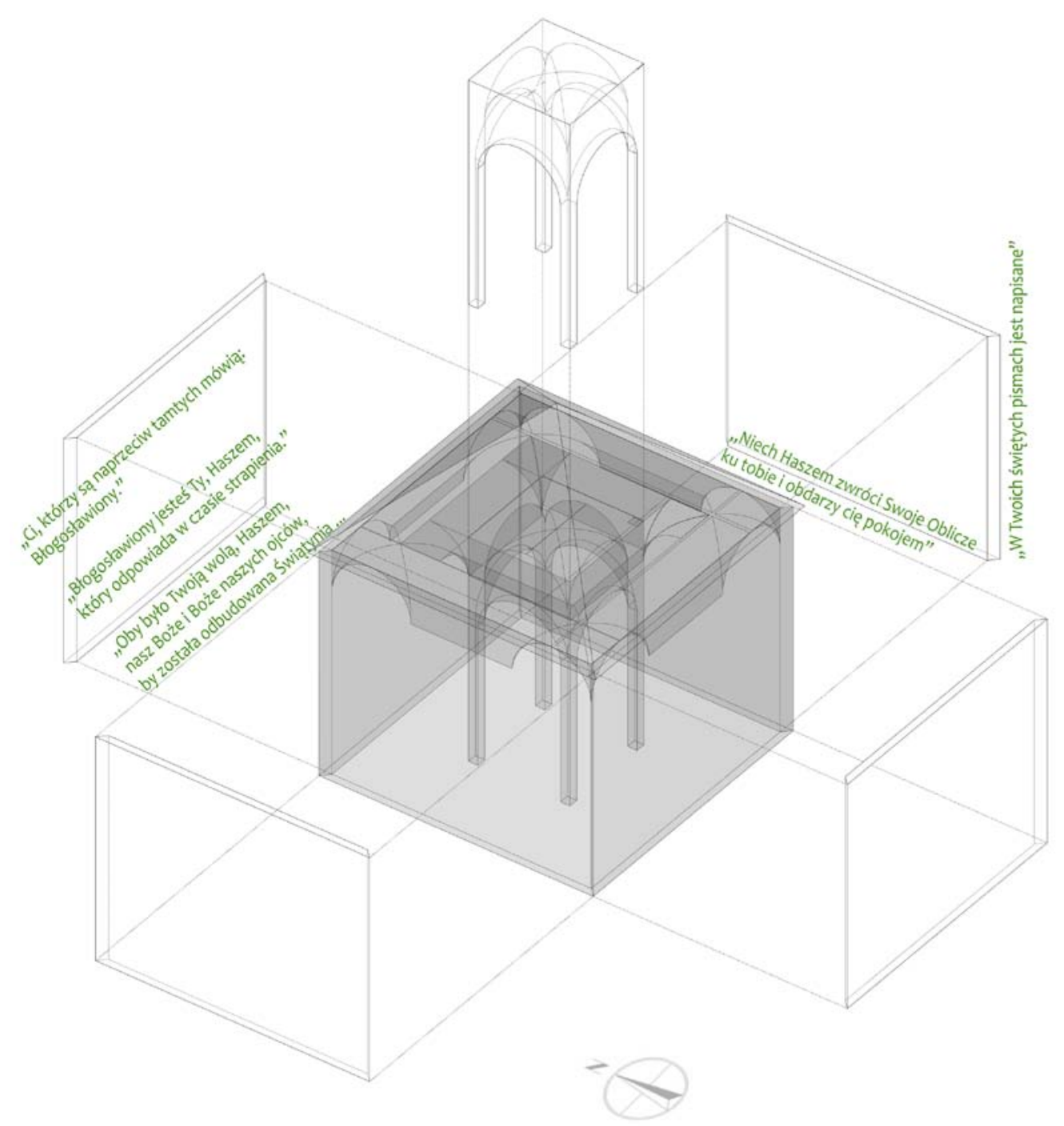

Il. 8.36. Schemat graficzny fragmentów modlitwy Amida, odpowiadających określonym wymiarom synagogi w Bobowej [21]

twie Lecha dodi stwierdzono zestawy wartości liczbowych dwóch parametrów synagog w: Chęcinach (długość i wysokość synagogi), Lesku (długość i szerokość synagogi), Tarnogrodzie (długość i szerokość centralnego pola), Dukli (długość i szerokość sali męskiej). Również w modlitwie figdal odnaleziono takie zestawy odnoszące się do bożnic w: Tykocinie (długości i szerokość synagogi, długość i szerokość sali męskiej), Tarnogrodzie i Łańcucie (długość i szerokość centralnego pola), Siemiatyczach (długość i szerokość sali męskiej). Pary wymiarów z Szema powiązano natomiast z wymiarami synagog w: Pińczowie, Lesku (długość i szerokość synagogi), Tykocinie i Włodawie (długość i szerokość sali męskiej).

Wymienione modlitwy, Lecha dodi, figdal i Szema, nie mogą posiadać istotnego znaczenia. Można je jednak traktować jako element uzupełniający znaczeniowo modlitwy: Tikkun Chacot, Kabbalat Szabat i Amida.

Na podstawie opisanych wyników analiz można sformułować kilka zależności: 


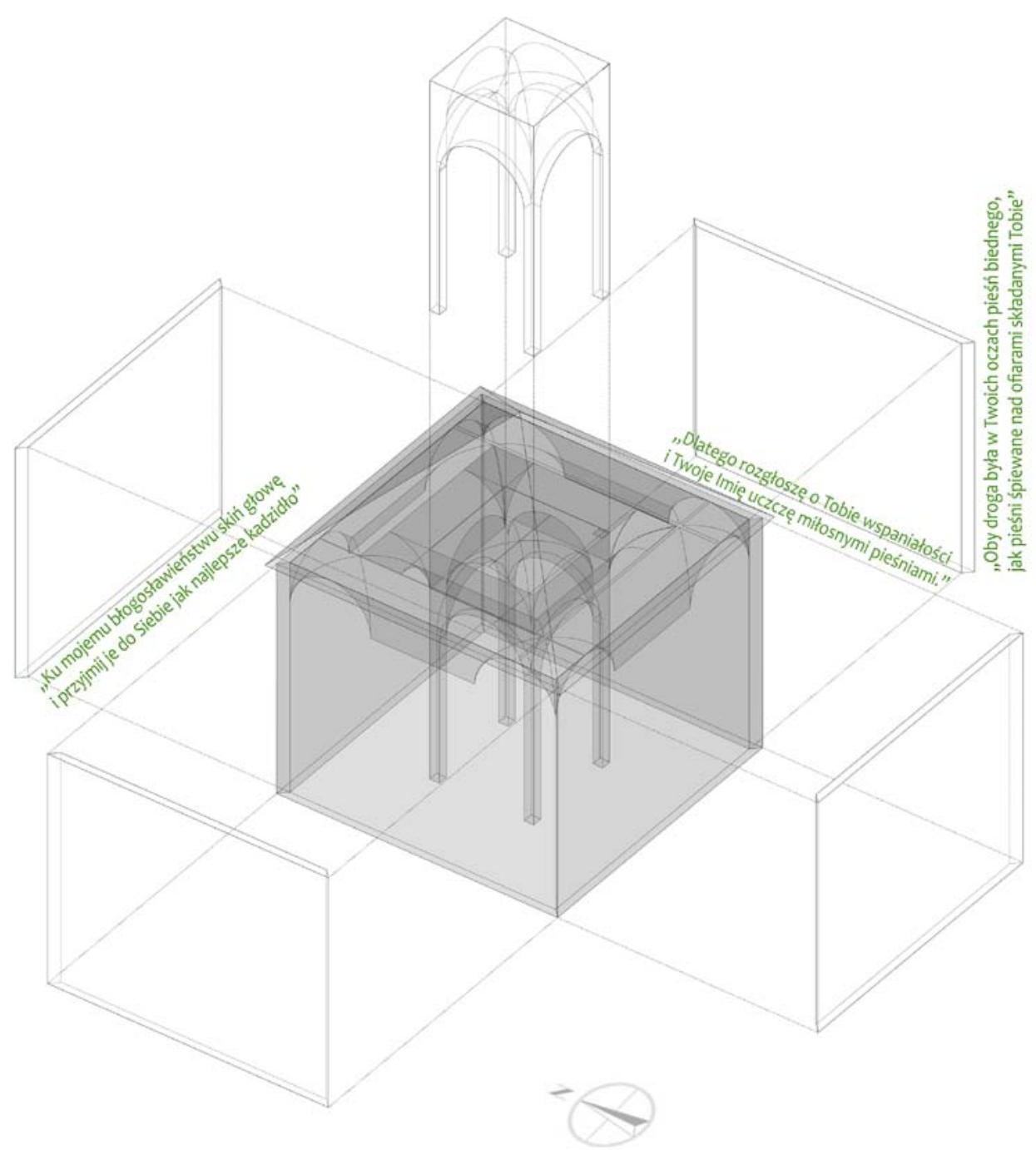

Il. 8.37. Schemat graficzny fragmentów modlitwy Szir Hakawod, odpowiadających określonym wymiarom Synagogi Nowomiejskiej w Rzeszowie [21]

1) Wszystkie wymiary bożnic w Siemiatyczach i w Bobowej (bez pola centralnego) są zbieżne z wartością liczbową fragmentów modlitwy Tikkun Chacot.

2) Istnieją obiekty, których wymiary zewnętrzne i wewnętrzne (w tym wymiary bimy) zostały ustalone w oparciu o przeanalizowane modlitwy. Podstawowym założeniem dla tej zależności jest komplementarność znaczeń wymiarów, a więc znalezienie grup ekwiwalentów lingwistycznych dla jak największej liczby wymiarów w jak najmniejszej liczbie modlitw. Przykładem mogą być w synagogi w: Pińczowie i Zamościu (Tikkun Chacot, Kabbalat Szabat), Rzeszowie Synagoga Stara (Tikkun Chacot, Kabbalat Szabat, Amida), Chęcinach i Bobowej (Tikkun Chacot, Amida), Orli (Tikkun Chacot, Szir Hakawod, Amida), Łańcucie (Lecha dodi, Szir Hakawod, Kabbalat Szabat). W większości obiektów oraz w większości wymiarów wnętrza bądź zewnętrza najważniejszą rolę odgrywają modlitwy: Amida i Tikkun Chacot, choć podstawę stanowi zwykle modlitwa Tikkun Chacot, której fragmenty określają znaczną część 
wymiarów w wielu obiektach. Pozostałe modlitwy zawierają zwykle jedynie uzupełnienie brakujących wymiarów. Należy pamiętać, że niektórym wymiarom odpowiadają fragmenty w kilku modlitwach.

W synagodze w Pińczowie (il. 8.38) cztery z sześciu wymiarów są zbieżne z wartością liczbową fragmentów Tikkun Chacot, a trzy z wartością liczbową fragmentów Kabbalat Szabat. W synagodze w Zamościu (il. 8.39) podobna liczba wymiarów stanowi ekwiwalent wartości liczbowej fragmentów Tikkun Chacot, ale tylko cztery wymiary odpowiadają wartości liczbowej fragmentów Kabbalat Szabat. W Synagodze Starej w Rzeszowie (il. 8.40) sześć z dziewięciu wymiarów może być przyporządkowanych do fragmentów Tikkun Chacot, a pięć odnosi się do Amidy. W przypadku synagogi w Chęcinach (il. 8.41) i Bobowej (il. 8.42) stosunek liczby wymiarów do odpowiadających im pod względem wartości liczbowej fragmentów z Amidy i Tikkun wynosi odpowiednio cztery do czterech i siedem do siedmiu. Dodatkowo wysokość synagogi w Chęcinach ma wartość identyczną jak znajdujący się w obu modlitwach fragment: „Panie! Otwórz wargi moje, A usta moje głosić będą chwałę twoją!”282. W Orli (il. 8.43) sześć wymiarów ma ekwiwalenty lingwistyczne w Tikkun Chacot, po pięć w Amidzie

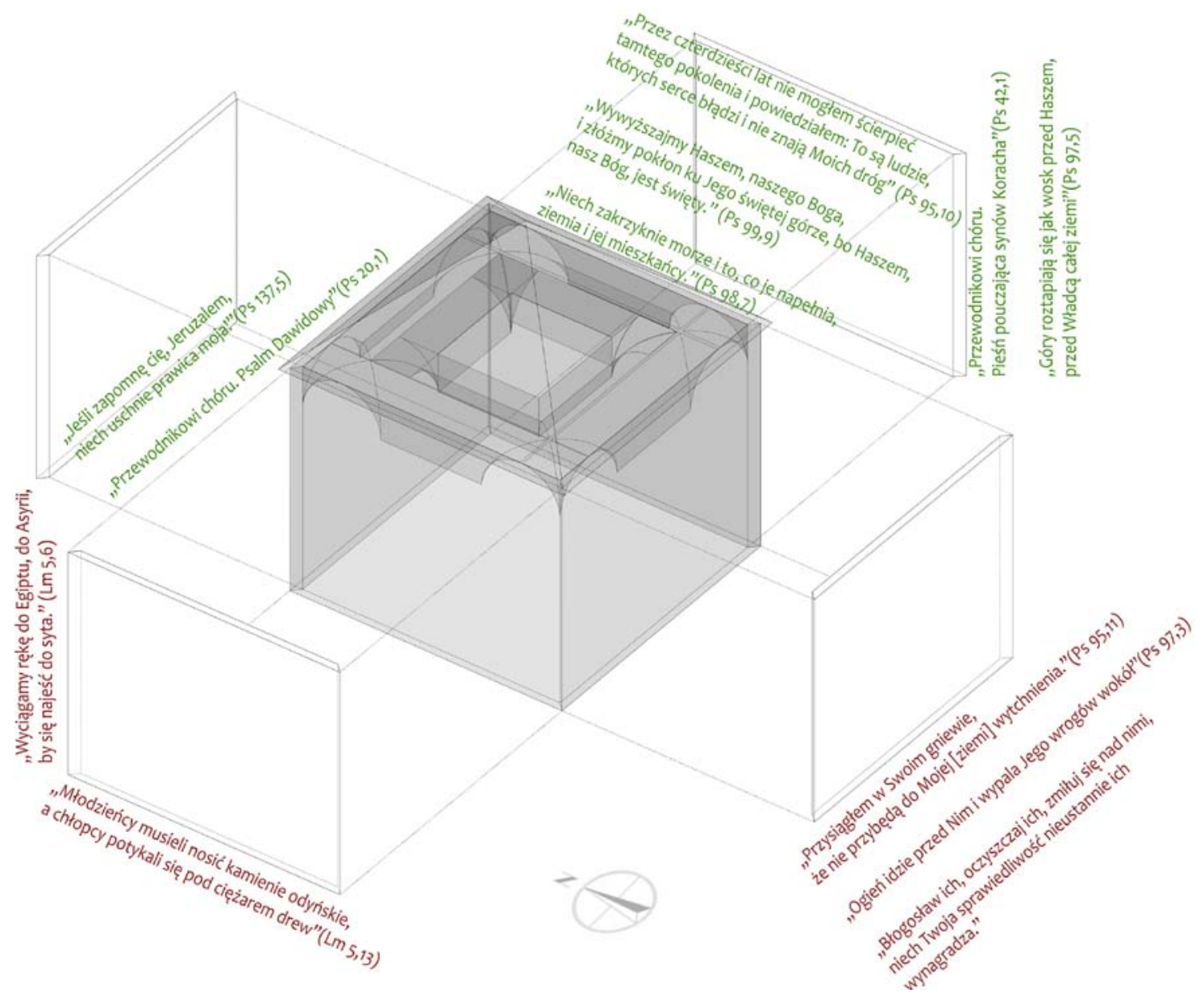

Il. 8.38. Schemat graficzny ekwiwalentów lingwistycznych wymiarów synagogi w Pińczowie w oparciu o modlitwy Tikkun Chacot i Kabbalat Szabat [21] 


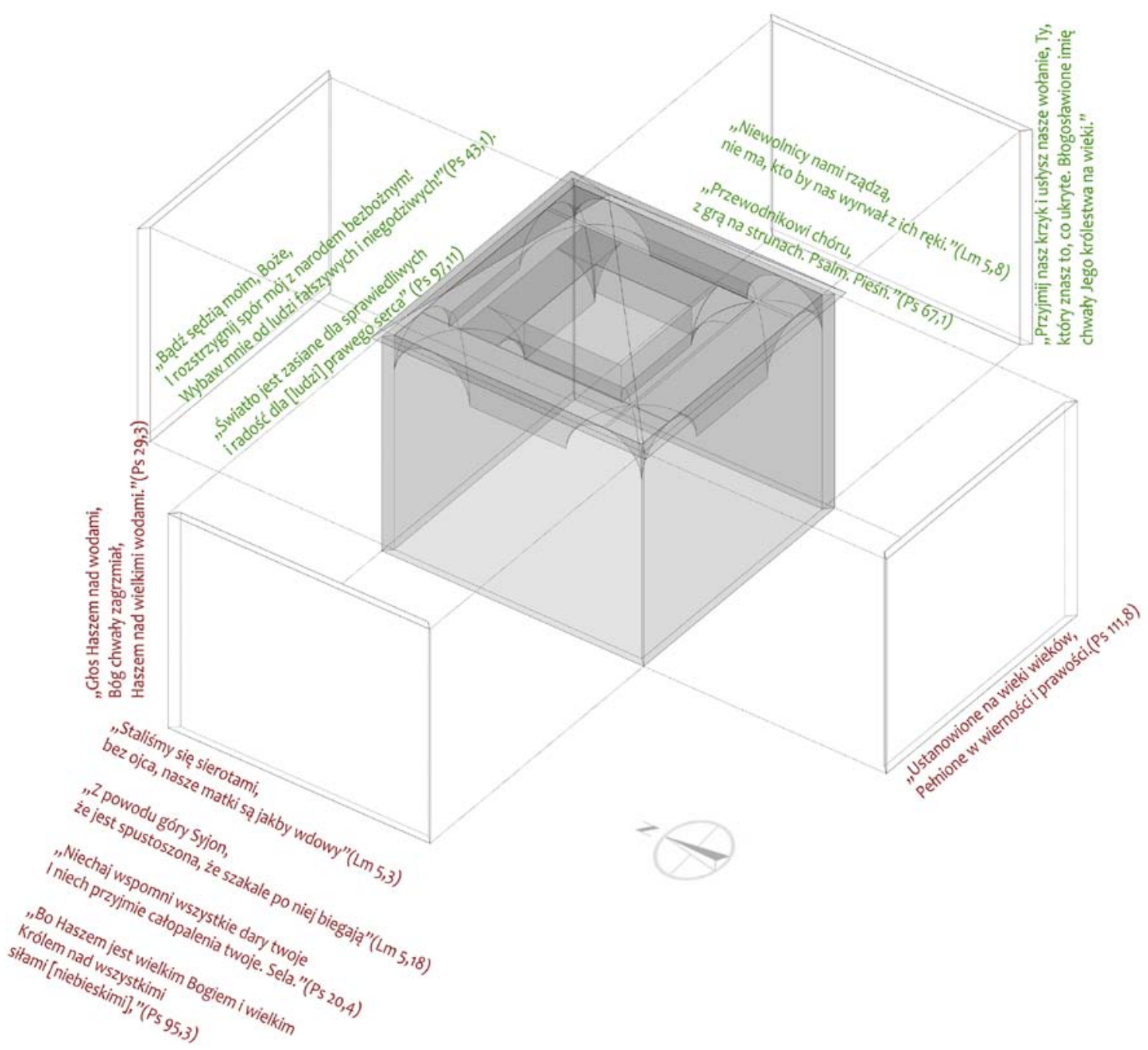

Il. 8.39. Schemat graficzny ekwiwalentów lingwistycznych wymiarów synagogi w Zamościu w oparciu o modlitwy Tikkun Chacot i Kabbalat Szabat [21]

i Szir Hakawod. W bożnicy w Łańcucie (il. 8.44) pięć wymiarów pokrywa się z wartością liczbową fragmentów modlitwy Kabbalat Szabat, trzy inne z wartością liczbową fragmentów Szir Hakawod, a dwa fragmentów Lecha Dodi.

Jak wynika z opisu badań, znaleziono w sumie ekwiwalenty lingwistyczne wszystkich wymiarów dziewięciu z piętnastu obiektów. W przypadku ośmiu synagog odnoszono się do połączonych fragmentów różnych modlitw, które w większości są wersami zaczerpniętymi z psalmów i innych ksiąg Tanachu. Jedynie synagoga w Siemiatyczach jest szczególna, ponieważ wszystkie analizowane wartości liczbowe wymiarów tworzą dość jednorodny obraz, nakierowujący na Tikkun Chacot.

Należy w tym miejscu zwrócić uwage jeszcze na zależność, którą można zaobserwować w ciągach liczbowych, będących zapisem wszystkich analizowanych fragmentów modlitw. Wartości liczbowe słowoform występujących w tych ciągach mają swoje odpowiedniki w dwóch obiektach, przy czym dwie z nich dotyczą tego samego obiektu. 


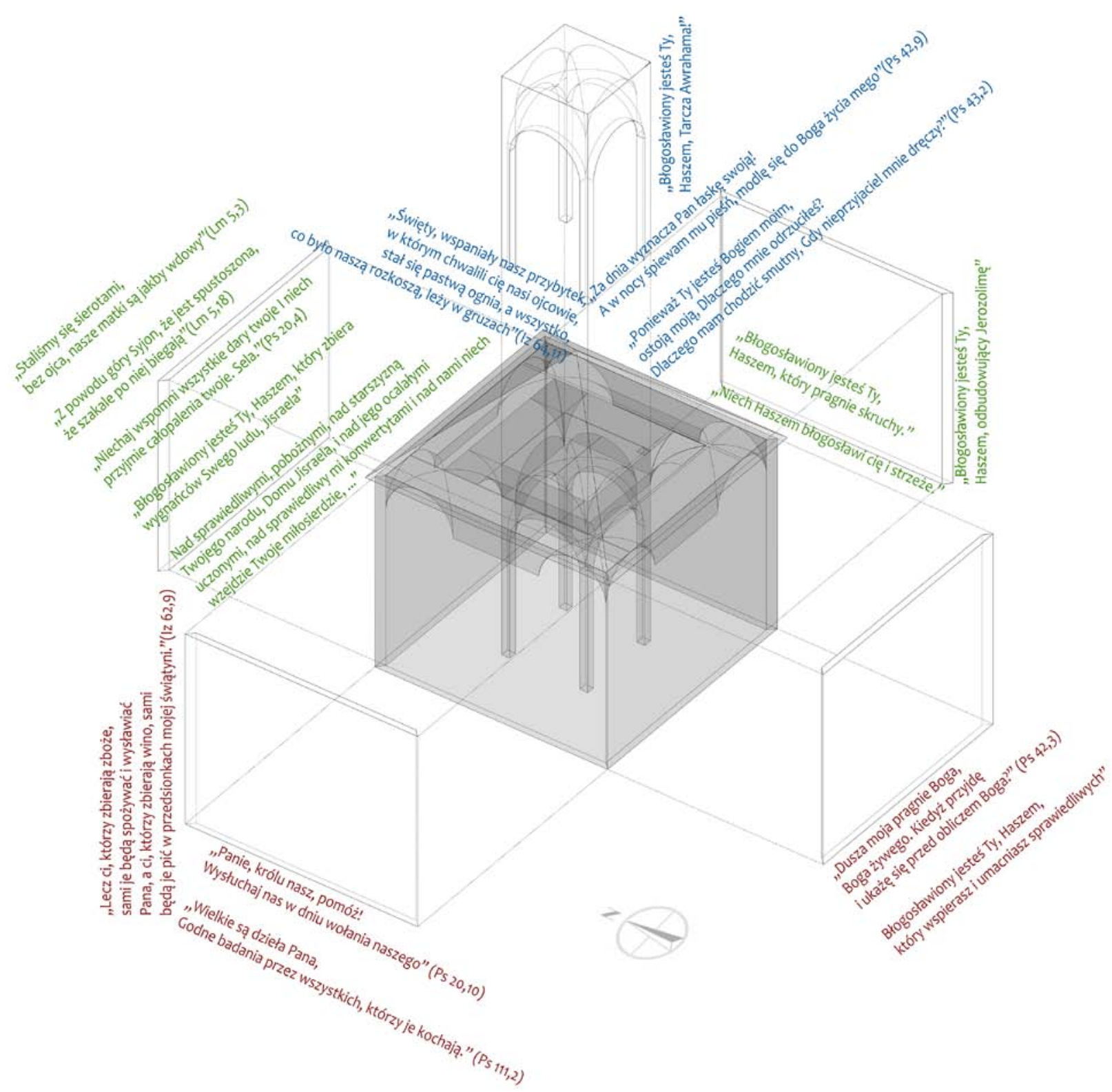

Il. 8.40. Schemat graficzny ekwiwalentów lingwistycznych wymiarów Synagogi Starej w Rzeszowie w oparciu o modlitwy Tikkun Chacot i Amida [21]

Pierwszym obiektem jest synagoga w Bobowej (il. 8.45), w której słowa: elohecha, bechal lewawecha (hebr. אלהיך בכל לבבך - twojego Boga - całym twoim sercem) występujące po sobie we fragmencie Szema Israel: „Będziesz kochał Haszem, twojego Boga - całym twoim sercem, całą twoją duszą i z całej twojej mocy"283 mają wartość liczbową odpowiednio 3925 i 27 i odnoszą się kolejno do wysokości, szerokości i długości synagogi.

Drugim obiektem jest synagoga w Tarnogrodzie (il. 8.46). Pierwsza z dwóch ważnych w przypadku tego obiektu zależności dotyczy dwóch wartości liczbowych fragmentów modlitw: 28 i 19 (il. 8.46), będących jednocześnie wymiarami wnętrza sali męskiej. Pierwsza jest długością i szerokością sali męskiej, druga zaś wysokością jej wnętrza. Ciąg wyrazów 


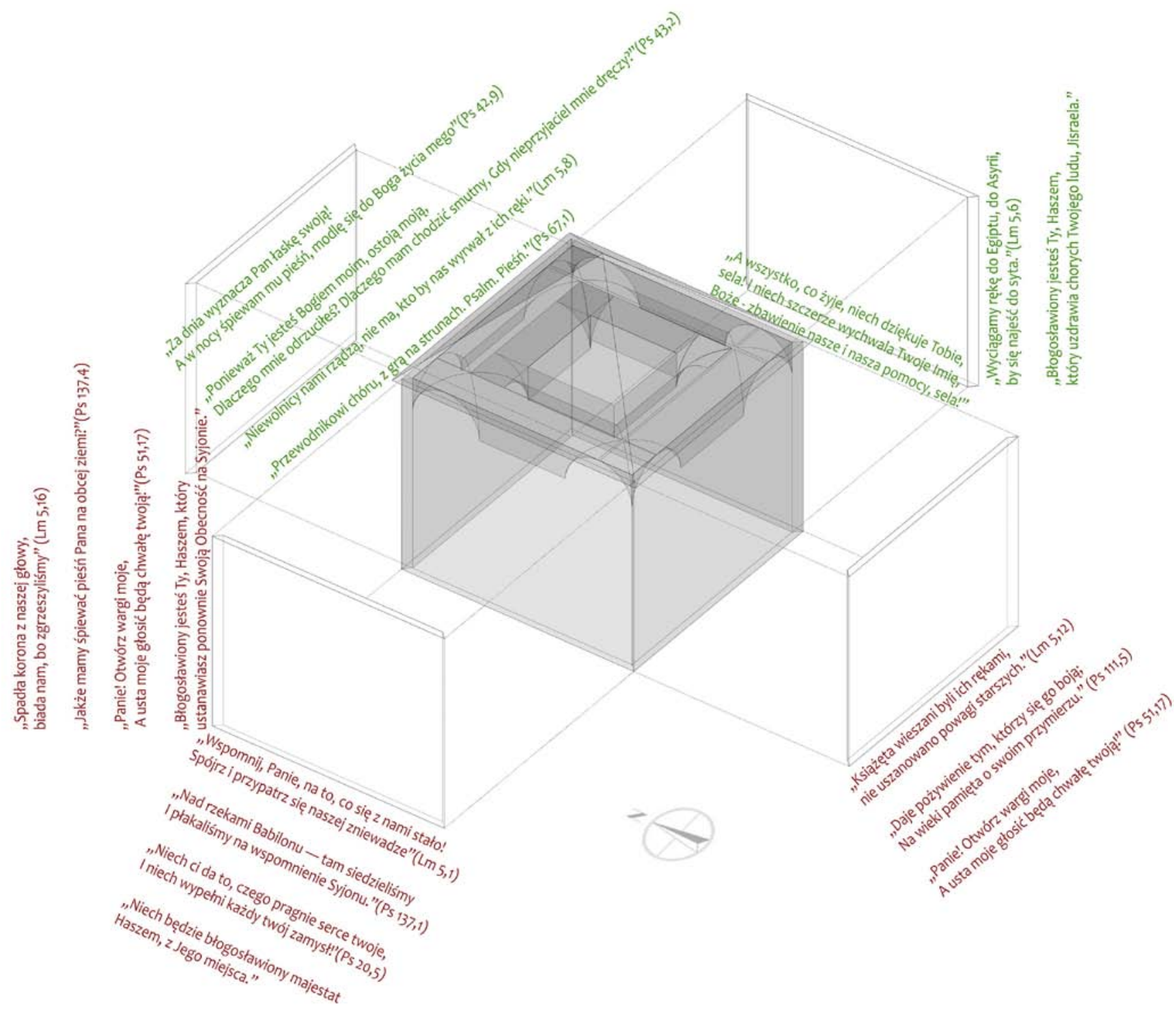

Il. 8.41. Schemat graficzny ekwiwalentów lingwistycznych wymiarów synagogi w Chęcinach w oparciu o modlitwy Tikkun Chacot i Amida [21]

składający się z tych dwóch liczb zawarty jest w wersecie Lecha dodi: „Pośród wiernych drogocennego narodu. Wejdź oblubienico, wejdź oblubienico”, a dokładniej we fragmencie: „[...] oblubienico, wejdź oblubienico [...]” (hebr. כלה, בואי כלה - chala, bo’i chala). Druga zależność jest związana z dwoma wartościami liczbowymi: 15 i 20, z których pierwsza określa długość i szerokość centralnego pola, a druga jego wysokość. Ciąg liczb 15 i 20 zawarty w Tikkun Chacot kryje się w słowach: „[...] dime’ati lechem jomam [...]” (hebr. דמעתי לחם יומם - łzy chlebem we dnie $)^{284}$.

Powyższy opis daje obraz wszelkich powiązań gematrycznych między wybranymi obiektami a wybranymi tekstami modlitw.

Analiza ciągów liczbowych z pewnością nie wykazuje komplementarności znaczeń. $\mathrm{W}$ następujących po sobie słowoformach nie można więc odnaleźć znaczenia wszystkich 


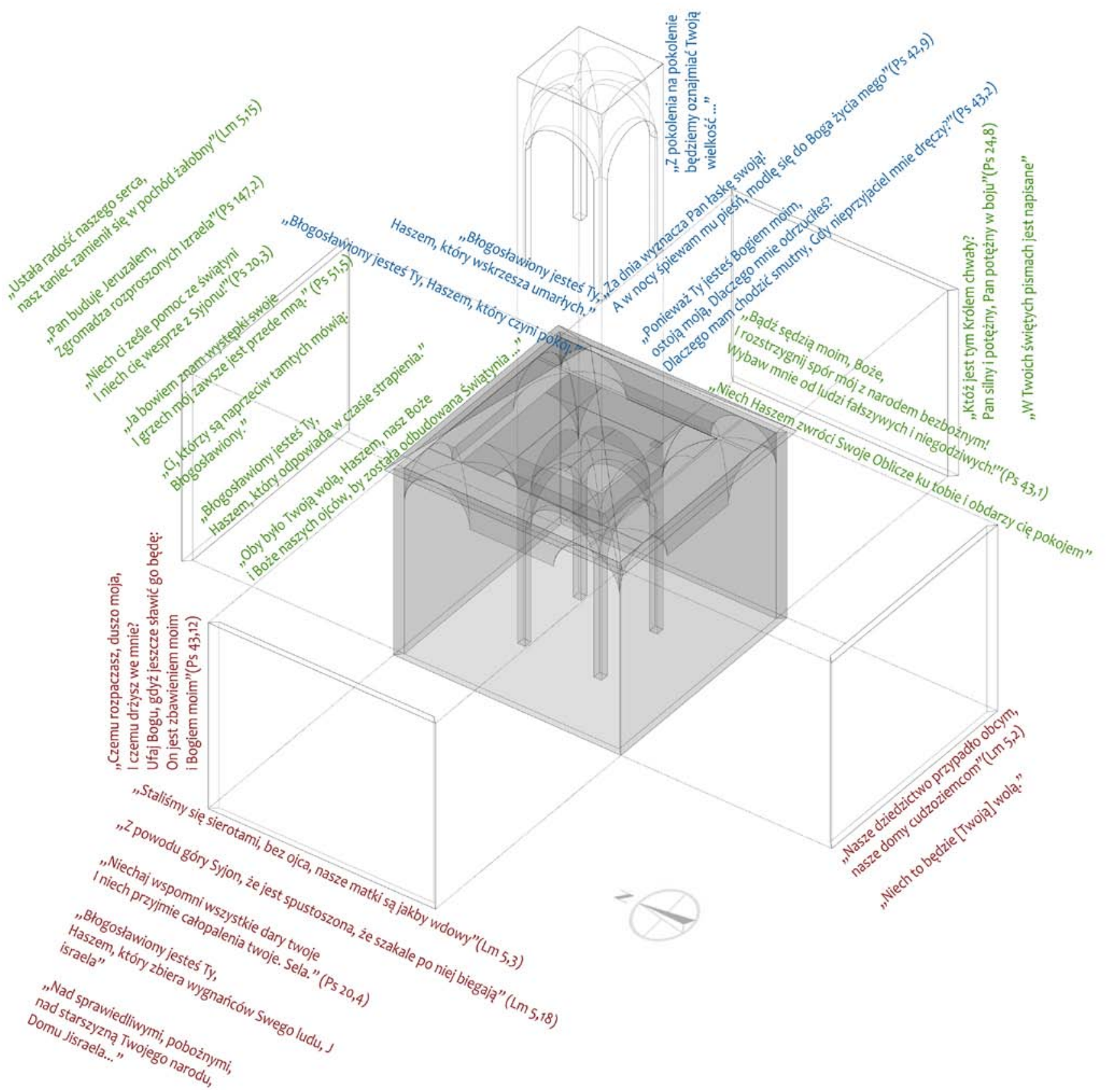

Il. 8.42. Schemat graficzny ekwiwalentów lingwistycznych wymiarów synagogi w Bobowej w oparciu o modlitwy Tikkun Chacot i Amide [21]

wymiarów. Wyjątek stanowią jedynie trzy przypadki, sprowadzające się do dwóch obiektów, w których związek ten jest jednak dość ograniczony. Otrzymano trzy ciągi składające się z maksymalnie trzech wartości liczbowych. Wydaje się zatem, że taki wynik jest niewystarczający przede wszystkim w kontekście znaczeń, które ze sobą owe słowoformy niosą. Pomimo że taka zależność pojawia się, to w przypadku tej zasady być może niezbędne byłoby szukanie źródła konkretnych wymiarów stosowanych w synagogach gdzie indziej. 


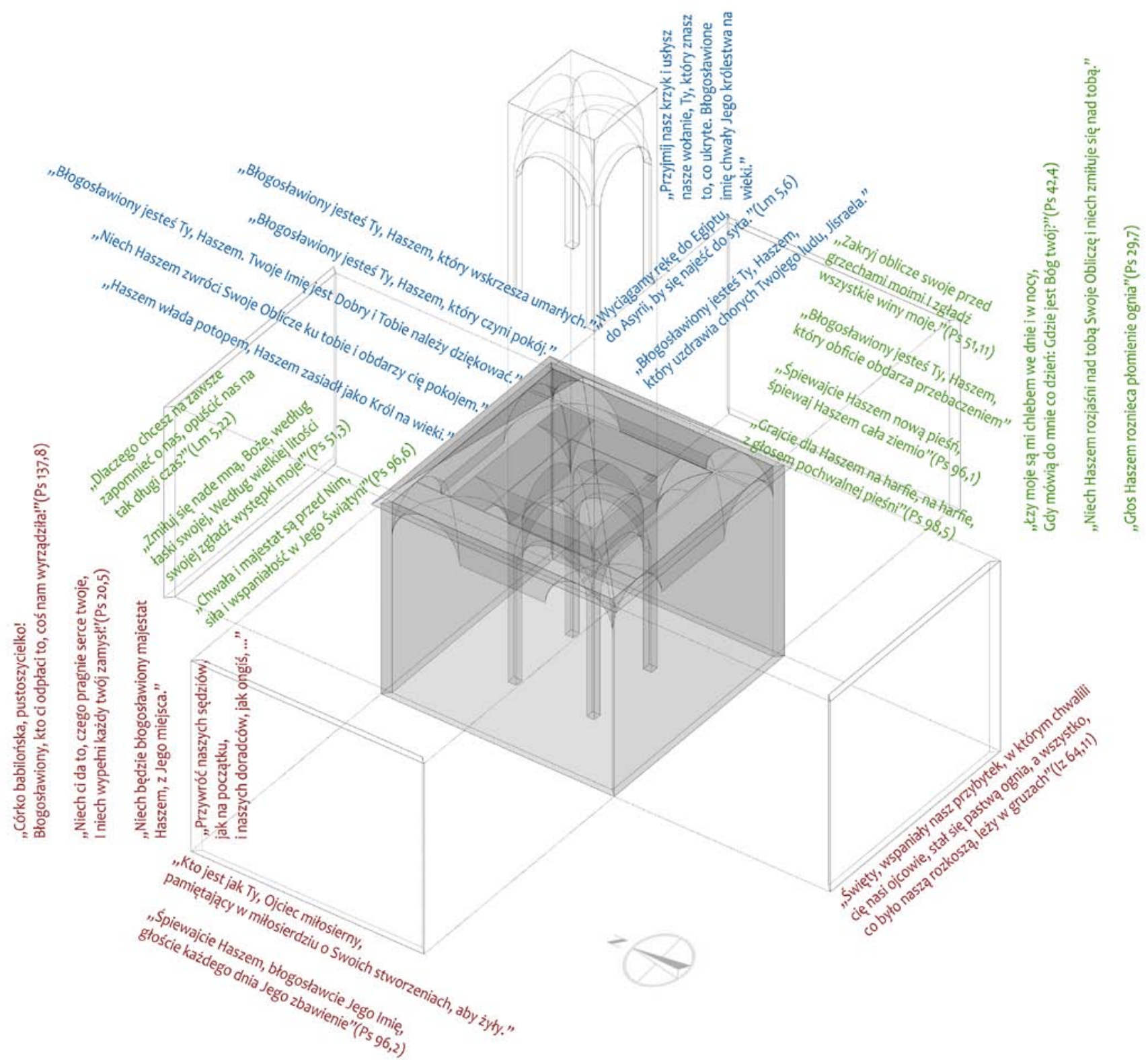

Il. 8.43. Schemat graficzny ekwiwalentów lingwistycznych wymiarów synagogi w Orli w oparciu o modlitwy: Tikkun Chacot, Amida i Szir Hakawod [21]

W przypadku sumarycznych wartości liczbowych całych fragmentów modlitw należy stwierdzić, że jedynie w przypadku synagogi w Siemiatyczach udało się przypisać wszystkim wymiarom lingwistyczne odpowiedniki w oparciu o modlitwę Tikkun Chacot. W pozostałych ośmiu przypadkach wymiary zostały określone na podstawie fragmentów różnych modlitw, choć w wielu przypadkach każda modlitwa z osobna generowała znaczenie dla znacznej części wymiarów każdej z badanych synagog. We wszystkich tych obiektach istnieje możliwość wyboru, spośród wskazanych dla każdego wymiaru fragmentów, takich wersetów, które utworzą logiczną całość. Zastosowanie zatem zależności gematrycznych przy wznoszeniu bożnic może być o tyle prawdopodobne, że można je wykazać na przykładzie dziewięciu 


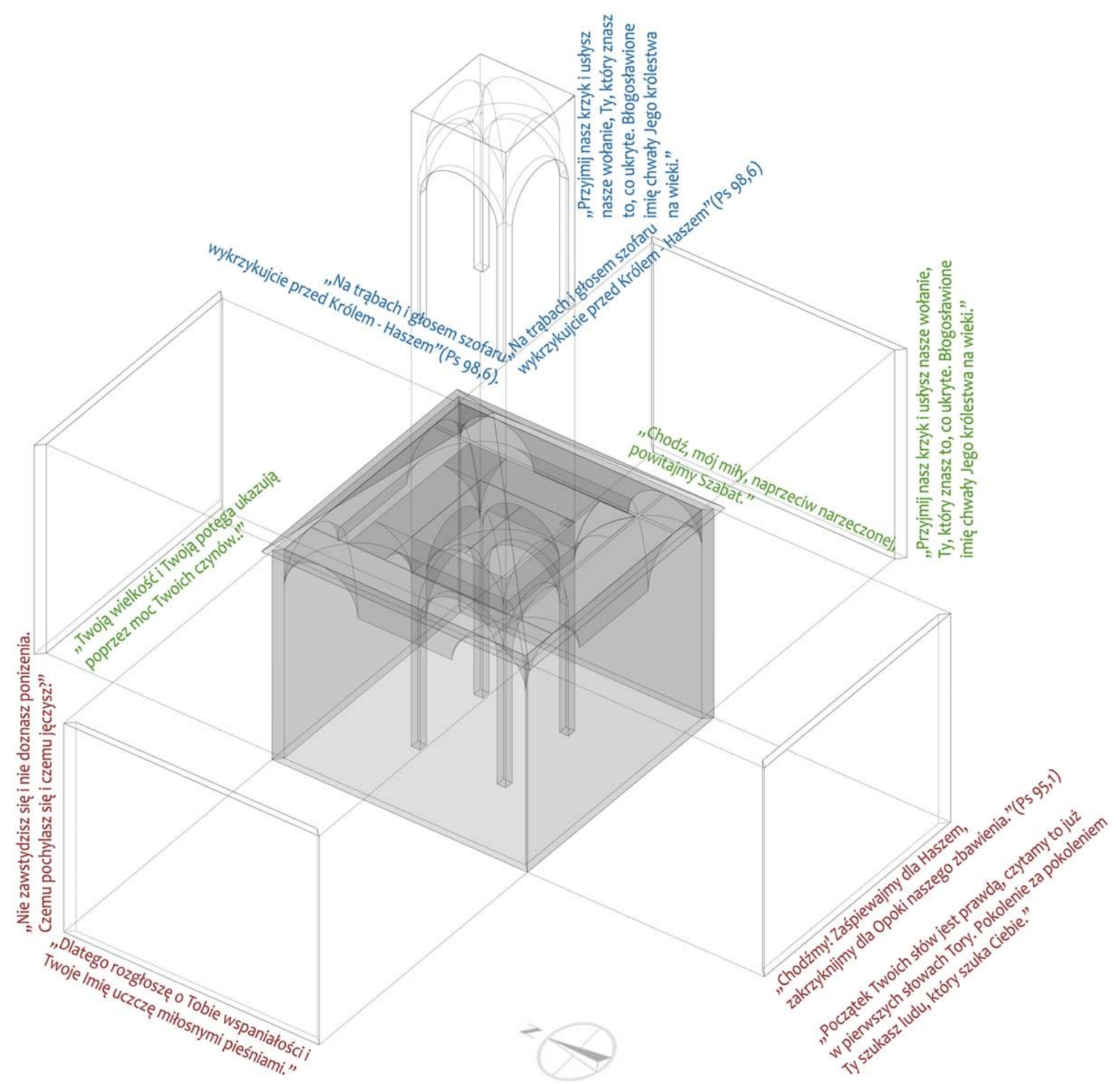

Il. 8.44. Schemat graficzny ekwiwalentów lingwistycznych wymiarów synagogi w Łańcucie w oparciu o modlitwy: Lecha dodi, Szir Hakawod i Kabbalat Szabat [21]

z piętnastu obiektów. Należy jednak zwrócić uwagę na otwartą ze swej nautry sferę interpretacji - efektem analizy kolejnych tekstów liturgicznych mogłoby bowiem być rozbudowanie zbioru fragmentów modlitw stanowiących ekwiwalent każdego z wymiarów. Jeżeli jednak nie brać by pod uwagę możliwości łączenia fragmentów różnych modlitw w jednym obiekcie - co wydaje się być niezasadne - wówczas jedynym przypadkiem pozostaje nadal bożnica siemiatycka, która stanowi mimo wszystko obiekt wyjątkowy.

W celu oszacowania, czy korelacja fragmentów analizowanych modlitw z wymiarami synagog nie jest przypadkowa, należy przytoczyć wartości z rachunku prawdopodobieństwa. Sprawdzając, jaka jest szansa trafienia trzech wymiarów, które mają pokrycie w wartościach liczbowych fragmentów omawianych modlitw, należy stwierdzić, że największa przypadko- 


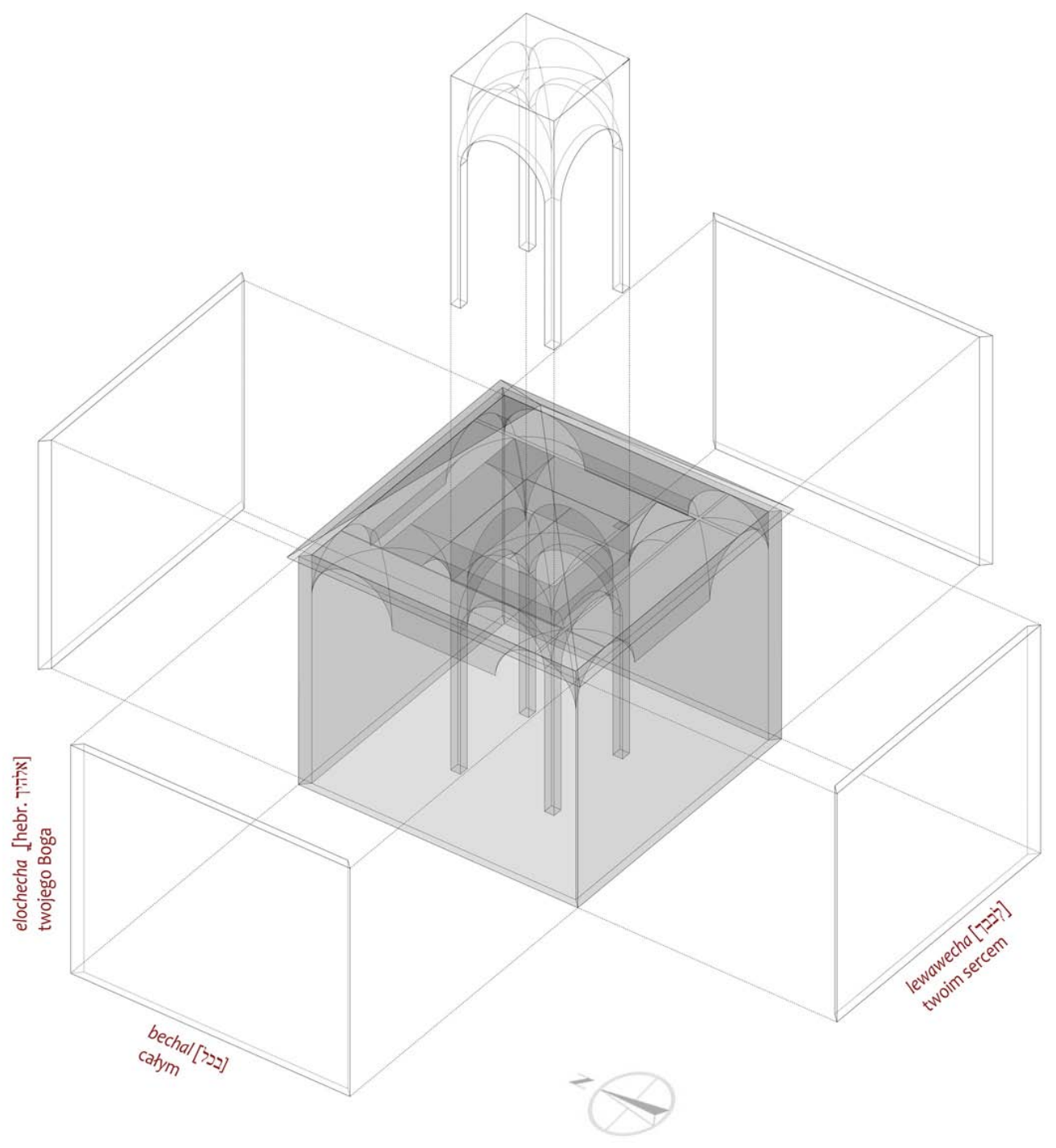

Il. 8.45. Schemat graficzny ekwiwalentów lingwistycznych w wymiarach synagogi w Bobowej [21]

wość cechuje figdal (1:286), Lecha dodi (1:969), Szema (1:1330). Kolejnymi modlitwami, dla których określono prawdopodobieństwo wystąpienia trzech wartości, byłyby: Szir Hakawod (1:4495), Kabbalat Szabat (1:57115), Amida (1:91881) i Tikkun Chacot (1:529369). Wydaje się zatem, że nie można mówić o przypadku w odniesieniu do wystąpienia trzech wymiarów i odpowiadających im fragmentów modlitw. W odniesieniu do Tikkun Chacot można pokusić się o określenie prawdopodobieństwa korelacji sześciu fragmentów, jak chociażby w synagodze w Siemiatyczach. Szansa na trafienie sześciu wartości liczbowych, które odpowiadałyby jednocześnie sześciu fragmentom tej modlitwy, jest jak 1:13172431272.

Na podstawie powyższych analiz można zatem stwierdzić, że gematria wywarła wpływ na parametry synagog wznoszonych na obszarze Polski. Dowodzi tego związek między znaczną grupą fragmentów a wymiarami synagog oraz opowieści, które utworzyły te fragmenty 


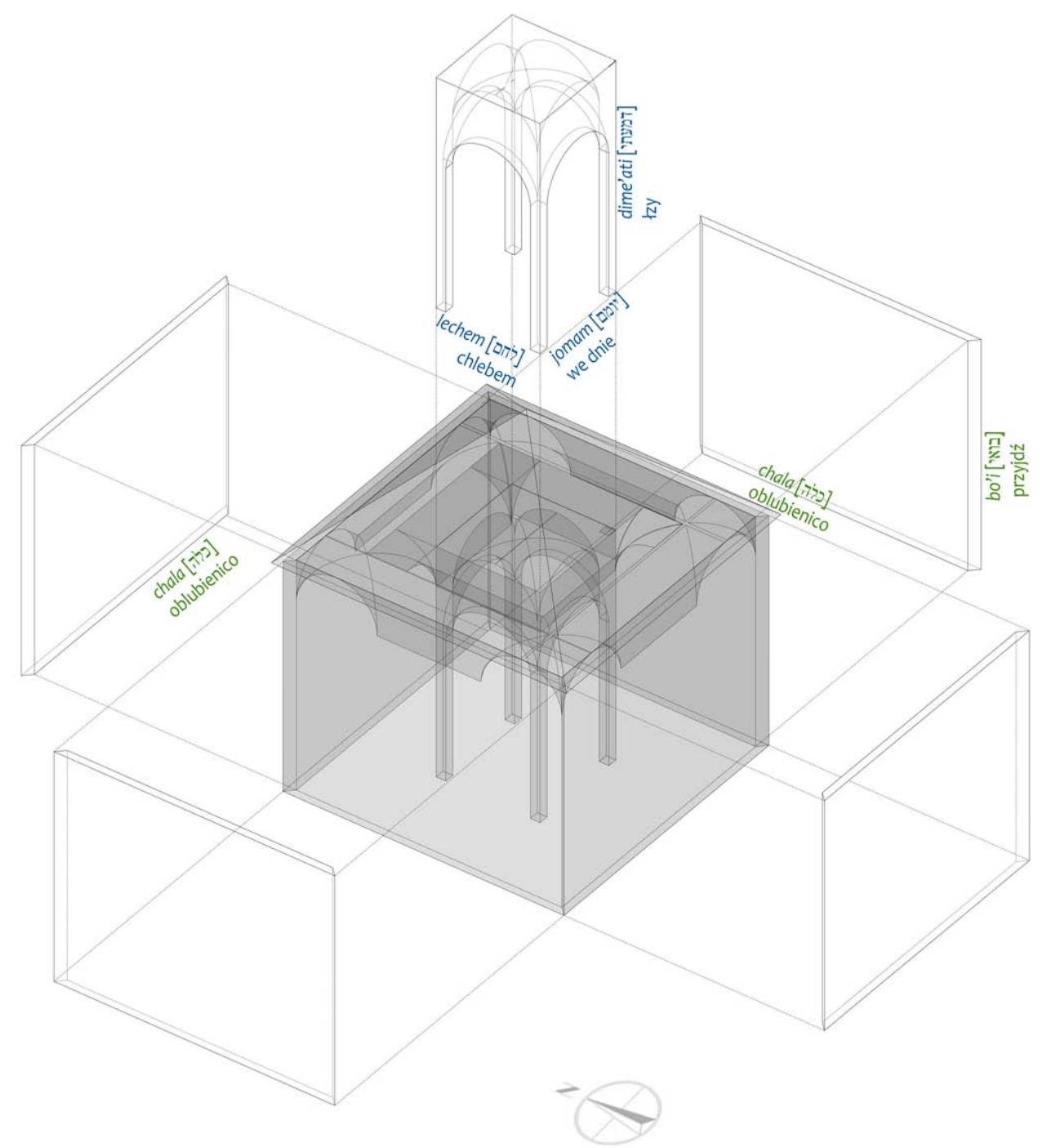

Il. 8.46. Schemat graficzny ekwiwalentów lingwistycznych w wymiarach synagogi w Tarnogrodzie [21]

w ramach każdego z badanych obiektów, i wynikające z nich dodatkowe, ukryte znaczenie. Problemów nastręcza jedynie jednoznaczna interpretacja każdego z Bet ha-Kneset. Jedynym semantycznie jednorodnym obiektem była synagoga w Siemiatyczach, co do której wątpliwości rozwiewa odniesienie do Tikkun Chacot.

\section{Przypisy}

204 „Wtedy Bóg rzekł: »Niechaj się stanie światłość!«” [184, Rdz 1,3]. Stwórcza moc słowa uzyskuje swój wyraz w tym wersecie. Majmonides podaje, że słowo amar może oznaczać: (1) mowę, (2) myślenie (jak w wyrażeniu: amar belibo - powiedział w swoim sercu, co rozumieć należy jako pomyślał sobie) oraz (3) chcenie i wolę - w szczególności w odniesieniu do Boga w Maase Bereszit, tj. pierw- 


\section{Gematria w XVII- i XVIII-wiecznych synagogach...}

szym rozdziale pierwszej księgi Tory. Vide: The Guide for the Perplexed by Moses Maimonides Translated from the Original Arabic, thum. M. Frielander, Londyn 1904, More newuchim I, 65.

205 Określenie sefer jest utożsamiane przez Ouaknina z literami alfabetu.

${ }^{206}$ Synagoga w Lesku, jak wynika z dokumentów powojennych, nie posiada okapu. Inwentaryzacja synagogi w Dukli nie daje możliwości odtworzenia kształtu sklepienia bimy, gdyż ta została zniszczona poniżej oparcia sklepienia.

${ }^{207}$ Sytuacja taka miała miejsce w Łucku, gdzie dominikanie zakwestionowali wysokość synagogi i jej odległość od kościoła.

${ }^{208} \mathrm{~W}$ pinkasie gminy tykocińskiej jest m.in. informacja o przebudowie synagogi po pożarze w $1736 \mathrm{r}$.

${ }^{209}$ Zygmunt III obwarował w ten sposób budowę synagogi w Łucku.

${ }^{210}$ Wykazał to Jerzy Baranowski w trakcie analizy metrologicznej.

${ }^{211} \mathrm{~W}$ dokumentacji inwentaryzacyjnej i projektowej synagogi w Szczebrzeszynie długość sali męskiej na osi wschód-zachód różni się znacznie. W dokumentacji synagogi w Zamościu podane są trzy różne wymiary sali męskiej, przy czym jeden z nich jest większy na osi północ-południe, a powinien być na osi wschód-zachód.

${ }^{212}$ Synagogi w: Dukli, Lesku, Łańcucie, Orli, Rzeszowie (Synagoga Stara), Szczebrzeszynie, Tarnogrodzie, Tykocinie.

213 Synagogi w: Chęcinach, Pińczowie, Rzeszowie (Synagoga Nowomiejska), Siemiatyczach.

${ }^{214} \mathrm{~W}$ sytuacji, w której rozbieżność poszczególnych wymiarów dla danego kierunku różniła się w granicach 1 ćwierci (maksymalne odchylenie wymiarów), przyjmowano wartość średniej geometrycznej. Dla rozbieżności mniejszej niż 1 cal przyjmowano wymiar jednej ze ścian (wschodniej lub południowej). W wyniku obliczania średniej geometrycznej dla dużych rozbieżności wymiarów otrzymywano zwykle wartość bliską jednemu z nich, którą przyjmowano do analizy.

${ }^{215}$ Wejście do Synagogi Nowomiejskiej w Rzeszowie przed II wojną światową i po jej zakończeniu znajdowało się poniżej terenu okalającego obiekt.

${ }^{216} \mathrm{~W}$ związku z wymianą sklepienia, które zawaliło się, wprowadzono nowe słupy w innym rozstawie niż pierwotne oraz przemurowano ściany, wprowadzając lizeny, na których oparte zostały gurty sklepienia.

${ }^{217}$ Wymiary pobrane z przekroju poziomego piętra synagogi w Tarnogrodzie są większe niż wymiary rzutu przyziemia. Może to być spowodowane odchyleniem się ścian od pionu, gdyż nie następuje zwężanie grubości ścian synagogi ku górze.

${ }^{218}$ Wysokość sali synagogi w Zamościu różni się o $16 \mathrm{~cm} \mathrm{w}$ dwóch dokumentacjach, które dzieli nie więcej niż 10 lat. Należy zaznaczyć, że punkt odniesienia jest ten sam, a większa wysokość pojawia się w starszej dokumentacji.

${ }^{219} \mathrm{~W}$ części obiektów, które powstały przed 1764 r., można stwierdzić istnienie pewnych elementów, których wymiary zostały określone z zastosowaniem miary warszawskiej.

${ }^{220}$ Avierbuch, Siemiatycka synagoga i przekazy o niej, [w:] ,Jewriejskaja Starina” 1911, nr 4, s. 563; informację tę powtarzają inni autorzy. 


\section{Gematria w XVII- i XVIII-wiecznych synagogach...}

${ }^{221}$ Serdeczne podziękowania należą się dr. Vladimirowi Levinowi i dr. Sergieyowi Kravtsovowi za udostępnienie materiałów inwentaryzacyjnych synagog w: Ostrogu, Husiatynie, Żółkwi, Samborze, Szepietówce, Sokalu, Zbarażu, Grzymałowie, Czortkowie, Izabelinie, Stolinie i Dubnie.

${ }^{222}$ Kościoły przyjęte do analizy: kolegiata w Nieświerzu (1586-1599), kościół jezuitów w Lublinie (1586-1604), kościół jezuitów w Kaliszu (1587-1595), kościół św. Piotra i Pawła w Krakowie (1597-1635), kościół parafialny w Czemiernikach (1603), kościół bernardynów w Lublinie (1603-1608), kościół jezuitów w Wilnie (1604-1616), kościół kamedułów na Bielanach w Krakowie (1609-1617), kościół szpitalny w Końskowoli (1610-1613), kościół parafialny w Lublinie (1615), kolegiata na Mirowie w Pińczowie (1615-1619), kościół bernardynów w Rzeszowie (1624-1629), kościół bernardynów w Sierakowie (1624-1629), kościół bernardynek w Wilnie (1625),kościół kamedułów w Rytwianie (1625-1637), kościół kanoników regularnych w Wągłczewie (1626), kościół parafialny w Gołębiu (1628-1636), kościół parafialny w Kodeniu (1629-1635), kościół dominikanów w Gidle (1632-1644), kościół karmelitów w Wilnie (1634-1653), kościół parafialny w Grodzisku (1635-1648), kościół karmelitanek we Lwowie (1642), kościół parafialny w Tarłowie (1645-1655), kościół jezuitów w Poznaniu (1649-1701), kościół bernardynów w Poznaniu (1658-1668), kościół bernardynów w Warszawie (1660-1667), kościół karmelitów w Warszawie (1661-1672), kościół św. Piotra i Pawła na Antokolu w Wilnie (1668-1675), kościół kapucynów w Warszawie (1683-1686), kościół parafialny w Lesznie (1685-1696), kościół parafialny w Rokitnie (1693), kolegiata św. Anny w Krakowie (1689-1704), kościół paulinów w Warszawie (1707-1717).

${ }^{223}$ Szerokość centralnego pola wymienionych synagog.

${ }^{224}$ Długość pola centralnego wymienionych synagog.

225 Dla wartości przeliczonych przy nazwach obiektów lub przy wartościach umieszczono gwiazdkę (*).

${ }^{226}$ Efekt przeliczenia liczby 33 tokci na cale.

227 Podobnie tylko w związku z synagogą w Łańcucie pojawia się przeliczona wartość liczbowa 12 .

${ }^{228} \mathrm{~W}$ ok. 100 r. dodano dziewiętnaste błogosławieństwo.

229 Były to Psalmy 95-99 i 29.

${ }^{230}$ Tłumaczenie oraz tekst modlitwy za: Modlitewnik żydowski, modlitwy na dni powszednie i na Szabat, z tłumaczeniem na jezzyk polski, red. S. Pecaric, Kraków 2005, s. 76-80 [dalej: Modlitewnik żydowski].

${ }^{231}$ Ta zależność jest charakterystyczna dla większości analizowanych obiektów.

${ }^{232}$ Tłumaczenie oraz tekstu modlitwy za: Modlitewnik żydowski, op. cit., s. 83-100.

${ }^{233}$ Fragment dodawany między Rosz Haszana a fom Kipur.

${ }^{234}$ Fragment dodawany między Szemi Aceret a Pesach.

${ }^{235}$ Zamiast: Bóg święty! między Rosz Haszana a Jom Kipur mówi się: Król święty!

${ }^{236}$ Fragment dodawany między Rosz Haszana a fom Kipur.

${ }^{237}$ Zamiast: Bóg święty! między Rosz Haszana a fom Kipur mówi się: Król święty!

${ }^{238}$ Wersy ten i pięć kolejnych są odmawiane w dni postu. 
${ }^{239}$ Modlitwa za chorych.

${ }^{240}$ Od chol hamoed Pesach do 4. grudnia wymawia się: błogosławieństwo, a od 4. grudnia do Pesach: rosę i deszcz na błogosławieństwo.

${ }^{241}$ Pomiędzy Rosz Haszana a fom Kipur mówi się: Król sądu.

${ }^{242}$ Ten i kolejny fragment wypowiadane są w Rosz Chodesz i chol hamoed.

${ }^{243}$ Fragment dodawany na Chanukę i Purim.

${ }^{244}$ Fragment dodawany na Chanukę.

${ }^{245}$ Fragment dodawany na Purim.

${ }^{246}$ Fragment dodawany między Rosz Haszana a fom Kipur.

${ }^{247}$ Fragment dodawany również po dwóch kolejnych wezwaniach.

${ }^{248}$ Ten i kolejny fragment dodawane są między Rosz Haszana a fom Kipur.

${ }^{249}$ Fragment ten jest refrenem i pojawia się w tekście co trzeci wers - w sumie dziesięciokrotnie.

250 Tlumaczenie oraz tekst modlitwy za: Modlitewnik żydowski, op. cit., s. 326-330.

${ }^{251}$ Wersy ten i dziesięć kolejnych pochodzą z Księgi Psalmów. Vide: [137, Ps 95, 1-11].

${ }^{252}$ Wersy ten i dwanaście kolejnych pochodzą z Księgi Psalmów. Vide: [137, Ps 96, 1-13].

${ }^{253}$ Wersy ten i jedenaście kolejnych pochodzą z Księgi Psalmów. Vide: [137, Ps 97, 1-12].

254 Wersy ten i osiem kolejnych pochodzą z Księgi Psalmów. Vide: [137, Ps 98, 1-9].

255 Wersy ten i osiem kolejnych pochodzą z Księgi Psalmów. Vide: [137, Ps 99, 1-9].

${ }^{256}$ Wersy ten i dziesięć kolejnych pochodzą z Księgi Psalmów. Vide: [137, Ps 29, 1-11]. Psalm ten należy odmawiać ze szczególnym skupieniem i w pozycji stojącej.

${ }^{257}$ Siedem kolejnych linijek pijutu zawiera po sześć słów. Wg tradycji kabalistycznej pierwsze litery tych słów to czterdzieści dwie litery składające się na jedno z imion Boga.

${ }^{258}$ Tekst modlitwy w oparciu o: Tikkun Chatzot - The Midnight Rite, Tikkun Rachel, Tikkun Leah with Psalms, Readings and Confession, ed. S.Z. of Liadi. Dostępne w Internecie: http://opensiddur.org [dostęp: 15.11.2015]

${ }^{259}$ Wers pochodzi z Księgi Izajasza. Vide: [137, Iz 61,3].

${ }^{260}$ Dziewięć kolejnych wersów pochodzi z Księgi Psalmów. Vide: [137, Ps 137,1-9].

${ }^{261}$ Wersy ten i dwanaście kolejnych pochodzą z Księgi Psalmów. Vide: [137, Ps 79, 1-13].

${ }^{262}$ Wersy ten i dwadzieścia jeden kolejnych pochodzą z Lamentacji. Vide: [137, Lm 5, 1-22].

${ }^{263}$ Wersy ten i trzy kolejne pochodzą z Księgi Izajasza. Vide: [137, Iz 63, 15-18].

${ }^{264}$ Wersy ten i pięć kolejnych pochodzą z Księgi Izajasza. Vide: [137, Iz 64, 7-11].

265 Ten i kolejny wers pochodzą z Księgi Daniela. Vide: [137, Dn 9, 18-19].

${ }^{266}$ Wers pochodzi z Księgi Izajasza. Vide: [137, Iz 52, 2]. W odpowiedzi na wersety lamentu, pod-

czas odmawiania modlitwy należy w tym momencie wstać i wypowiedzieć wersety pociechy.

${ }^{267}$ Fragmenty ten i trzy kolejne pochodzą z Księgi Izajasza. Vide: [137, Iz 62, 6-9].

${ }^{268}$ Ten i kolejny fragment pochodzą z Księgi Psalmów. Vide: [137, Ps 102, 14-15].

${ }^{269}$ Wers pochodzi z Księgi Psalmów. Vide: [137, Ps 147, 2].

${ }^{270}$ Fragmenty ten i trzy kolejne pochodzą z Księgi Psalmów. Vide: [137, Ps 24, 7-10].

${ }^{271}$ Fragmenty ten i jedenaście kolejnych pochodzą z Księgi Psalmów. Vide: [137, Ps 42, 1-12]. 


\section{Gematria w XVII- i XVIII-wiecznych synagogach...}

${ }^{272}$ Fragmenty ten i cztery kolejne pochodzą z Księgi Psalmów. Vide: [137, Ps 43, 1-5].

${ }^{273}$ Fragmenty ten i dziewięć kolejnych pochodzą z Księgi Psalmów. Vide: [137, Ps 20, 1-10].

${ }^{274}$ Fragment ten i dziewięć kolejnych pochodzą z Księgi Psalmów. Vide: [137, Ps 24, 1-10].

${ }^{275}$ Wersy ten i siedem kolejnych pochodzą z Księgi Psalmów. Vide: [137, Ps 67, 1-8].

276 Fragmenty ten i dziewięć kolejnych pochodzą z Księgi Psalmów. Vide: [137, Ps 111, 1-10].

277 Ten i kolejny fragment pochodzą z Księgi Izajasza. Vide: [137, 24, 20-21].

${ }^{278}$ Fragmenty ten i dwadzieścia kolejnych pochodzą z Księgi Psalmów. Vide: [137, Ps 51, 1-21].

279 Tekst za: The Standard Prayer Book, ed. S. Singer, New York 1915, s. 178-179.

${ }^{280}$ Tłumaczenie oraz tekst modlitwy za: Modlitewnik żydowski, op. cit., s. 494-496.

${ }^{281}$ Należy pamiętać, że wartościom liczbowym wymiarów w obiektach mogą odpowiadać również inne fragmenty każdej z modlitw, ale niewykazane na schematach po to, aby uczytelnić wskazywane zależności. Vide: zestawienia przy analizie każdej modlitwy.

${ }^{282}$ Wers pochodzi z Księgi Psalmów. Vide: [137, Ps 51,17].

${ }^{283}$ Wers pochodzi z Księgi Powtórzonego Prawa. Vide: [137, Pwt 6,5].

${ }^{284}$ Wers pochodzi z Księgi Psalmów. Vide: [137, Ps 42,4]. 


\section{GEMATRIA I INNE FENOMENY ARCHITEKTURY JUDAIZMU}

Niniejsza monografia jest omówieniem fenomenów architektury judaizmu, ze szczególnym podkreśleniem jednego z nich - gematrii. Podjęta w niej próba określenia ram oraz charakteru tego wyjątkowego systemu numerologii została dokonana w oparciu o wybrane przykłady architektury synagogalnej z XVII i XVII wieku, zlokalizowane na obszarze obecnej Polski.

Wśród aspektów dotyczących architektury synagogalnej na uwagę zasługują przede wszystkim trzy z nich: złożoność obiektów, ich binarny charakter oraz swego rodzaju dualizm tożsamościowy, przejawiający się w opozycji: wnętrze - zewnętrze, które stały się przyczyną wytworzenia niezwykle oryginalnego rozwiązania centralnego miejsca kultu w diasporze. Synagoga nie jest zatem typowa pod względem architektonicznym. Jej oryginalność i siła wypływają z układu funkcjonalnego, podporządkowanego przepisom prawa halachicznego, z których najważniejsze są regulacje dotyczące orientacji i lokalizacji Aron ha-Kodesz oraz bimy. Niezwykłe bogactwo form architektonicznych, które pojawiały się już od czasów starożytnych, stanowiło jedynie kostium dla dwóch podstawowych typów układów przestrzennych, będących konsekwencją lokalizacji wspomnianych wyżej elementów. Dla każdego z typów rozwinięto konkretne układy funkcjonalne. W obrębie społeczności aszkenazyjskiej w okresie od średniowiecza do XVIII wieku wykształciło się jedynie pięć takich schematów. Ich charakterystycznym elementem jest wykorzystanie również rodzimych form w kształtowaniu dekoracji, które stanowiły bardziej element kamuflażu (w przypadku elewacji) niż przejaw ruchów asymilacyjnych.

Po okresie średniowiecza, dla którego charakterystyczne były rozwiązania dwunawowe sześciopolowe i jednoprzestrzenne, oraz renesansu, w którym większy nacisk kładziony był na otwarty plan centralny w formie kwadratu, XVII i XVIII wiek był czasem występowania synagog opartych na czterech głównych odmianach planów. Należały do nich bożnice:

1) jednonawowe (synagogi: Kupa, Izaaka, Poppera w Krakowie);

2) jednoprzestrzenne na planie kwadratu (synagogi w: Chęcinach, Zamościu, Szczebrzeszynie, Tomaszowie Lubelskim);

3) z bimą-podporą (synagogi w: Tarnowie, Rzeszowie (Synagoga Stara), Łucku, Pińsku, Słonimiu, Tykocinie, Nowogródku, Przeworsku, Dukli, Przysusze);

4) dziewięciopolowe (synagogi we Lwowie, a także w: Ostrogu, Wilnie, Rzeszowie (Synagoga Nowomiejska), Bobowej, Żółkwi, Brodach, Włodawie).

W XVI wieku rozpoczęło się więc zdecydowane odchodzenie od średniowiecznych planów dwunawowych na rzecz planów centralnych. Tendencja ta była zapewne podyktowana 
poszukiwaniem przez społeczność żydowską idealnego rozwiązania przestrzeni sali męskiej. Jako że plan podłużny jest kontynuacją rozwiązań wcześniejszych, w badaniach brany były pod uwagę przede wszystkim różne odmiany planu centralnego. Plan kwadratu był wzorcem silnie rozpowszechnionym już od starożytności, a przykładami jego zastosowania są Kiryat Sefer (I w. p.n.e.) i Masada (I w. n.e.). Działania Żydów, jeśli chodzi o zastosowanie planu na rzucie kwadratu, mogły mieć niezależne podłoże. Ze względu na zafascynowanie planem centralnym w renesansie oraz wpływ muratorów chrześcijańskich na architekturę bożnic, można odnieść wrażenia, że Żydzi zaadaptowali to rozwiązanie do swoich potrzeb. Koncepcja ta pojawia się bowiem w myśli żydowskiej i prawdopodobnie to na jej podstawie wytworzono $\mathrm{w}$ konsekwencji monumentalne wnętrza zarówno z bimą-podporą, jak i dziewięciopolowe.

Stosowanie kwadratu jako podstawowego elementu planu sali męskiej285 doprowadziło do wytworzenia układu centralnego, a konkretniej koncentrycznego z jednej i orientowanego $\mathrm{z}$ drugiej strony ${ }^{286}$. Koncentryczność planu została najlepiej podkreślona w obiektach dziewięciopolowych, jak i w tych z bimą-podporą. Aspekt ten był obecny w myśli żydowskiej. Opisany został już w traktacie rabina Dawida ben Jehudy he-Chasida, a spopularyzowany prawdopodobnie pod wpływem kabały luriańskiej. W późniejszym okresie pojawił się w wielu pismach kabalistycznych [66]. Dlatego zasadne wydaje się przypuszczenie o celowym wykorzystaniu koncentrycznego planu z podkreśloną architektonicznie formą bimy-podpory. $\mathrm{Z}$ jednej strony wzorzec taki jest elementem odpowiadającym wyobrażeniowej strukturze sacrum i profanum, która ujawniona w czasach prehistorycznych pozostała niezmieniona i stała się uniwersalnym schematem w niemalże wszystkich religiach. Z drugiej strony koncepcje koncentryczne można odnaleźć w Księdze Sprawiedliwych, pismach Mojżesza Isserlesa czy właśnie schemacie Jehudy he-Chasida, co świadczy o zakorzenieniu tej koncepcji $\mathrm{w}$ tradycji żydowskiej. Z pewnością początkiem takiego traktowania przestrzeni jest nakaz związany z lokalizowaniem bimy w centrum. Wzbogacenie jednak tej zasady o plan centralny powoduje wykształcenie planu koncentrycznego, który stał się swego rodzaju archetypem. W rozwiązanie to wpisują się synagogi nie tylko z bimą-podporą, ale również synagogi dziewięciopolowe, w których podkreślenie wolnostojącej bimy następuje za pomocą ram wytworzonych ze słupów podtrzymujących sklepienie.

Rozważając kwestię genezy planu dziewięciopolowego oraz planu z bimą-podporą, można z pewnością odnieść się do kilku źródeł. W przypadku bimy-podpory punktem wyjścia mogły być schematy konstrukcyjne kościołów o proweniencji bizantyjskiej i kościołów o strukturach filarowych. Również pewne wzorce mogły zawierać traktaty architektoniczne, w tym przede wszystkim traktat Sebastiano Serlia. Wydaje się jednak, że najbardziej prawdopodobne odniesienia stanowią bima z Aleppo i rysunki z hagad, które przypuszczalnie zostały wzbogacone o europejską myśl konstrukcyjną w zakresie wsparcia sklepienia. Należy stwierdzić, że bima-podpora była rozwiązaniem niespotykanym w obiektach kultu w innych religiach i w swojej oryginalnej formie uzyskała znaczenie symboliczne: rozumiano ją jako wieżę i łączono z migdal etz. Znaczenie symboliczne wiązano z opisem Merkawy w wizji Eze- 
chiela, który uzupełniony o opisy z Sefer fecira utożsamiał cztery słupy z czterema istotami wozu tronowego. Inną ważną symbolikę niosła ze sobą koncepcja zawarta w Zoharze, zgodnie z którą bima należy traktować jako kanał łączący rzeczywistości, co sprowadza jej znaczenie do axis mundi. Inne symboliczne znaczenie zostaje przedstawione pod postacią chupy. Ta metafora uzyskuje uzasadnienie w pieśni Lecha dodi, gdzie bima jest rozumiana jako baldachim, pod którym lud Izraela bierze za żonę Szabat (Szechine). W przypadku symboliki chupy, biorąc pod uwagę wzorce w postaci cyborium ${ }^{287}$ oraz nikły związek gematryczny wymiarów bożnic z wyżej wymienioną modlitwą, koncepcja ta wydaje się jednak mocno dyskusyjna.

Zdania badaczy dotyczące żródeł planu dziewięciopolowego są podzielone: jedni stwierdzali, że jest efektem rozwoju planu z bimą-podporą [192], drudzy, że należy go traktować jako autorski pomysł Jakuba Medliniego, oparty na rekonstrukcji świątyni jerozolimskiej wykonanej przez dwóch jezuitów: Jana Baptystę Villalpanda i Hieronima Prada [94]. Wydaje się, że aspekt świątyni jest widoczny w architekturze synagog. Odnosi się on do symbolicznego traktowania synagogi jako kontynuacji i substytutu kultu świątynnego, jednak w odmiennej od niego formie, a ujawnia się zwłaszcza w symbolicznym traktowaniu elementów składających się na przestrzeń synagogi.

Świątynia jest niezwykle silnie zakorzeniona w religii żydowskiej. Stanowi centralne miejsce judaizmu. Jej opis można odnaleźć w kilku miejscach w Tanachu, choć na pierwszy plan wysuwa się opis zawarty w Księdze Ezechiela, który zafascynował nie tylko Żydów, ale również chrześcijan. Fakt, że świątynia zajmowała centralne miejsce, stanowił powód powstania niezliczonych opisów i analiz oraz graficznych rekonstrukcji. Świątynia opisana w wizji Ezechiela stanowiła ważny punkt w rozważaniach chrześcijańskich uczonych, zwłaszcza w epoce renesansu. Doprowadziło to do stworzenia przez Villalpanda i Prada wspomnianej już wcześniej, najbardziej znanej graficznej rekonstrukcji, która miała stać się podstawą dziewięciopolowego planu synagog w latach 20. XVII wieku. W kontekście założeń planu dziewięciopolowego i jego pojawiania się znacznie wcześniej w bożnicach sefardyjskich wydaje się jednak, że następuje powrót do znanego społeczności żydowskiej wzorca z XIV wieku. Natomiast zakorzenienie planu dziewięciopolowego również na obszarze Rzeczpospolitej powoduje, że prawdopodobne wydaje się wykorzystanie istniejącego wzorca dziewięciopolowego przy modyfikacji synagogi z bimą-podporą. Przemiana ta wydaje się o tyle zasadna, że z pewnością rozwiązywała problem związany z uzyskaniem odpowiedniej akustyki we wnętrzu bożnicy. Bima-podpora, w wyniku zbliżenia słupów, wytwarzała martwe pole dźwiękowe o zdecydowanie większej powierzchni. Rozsunięcie słupów w planie dziewięciopolowym skutkowało zaś zmniejszeniem powierzchni stref w synagodze, w których dźwięk był słabiej słyszalny. Należy zatem stwierdzić, że związek ze świątynią został zasygnalizowany na poziomie proporcji, oraz symboliki. W przypadku ostatniego elementu niezwykle istotna jest pozycja Aron ha-Kodesz. Ze względu na nazewnictwo i pełnioną rolę szafę na rodały można porównać z Arką Przymierza.

Należy zwrócić uwagę, że plan z bimą-podporę jest również szczególnym przykładem planu dziewięciopolowego o maksymalnie pomniejszonym polu centralnym. Biorąc pod uwa- 
gę zastosowanie w bożnicach z bimą-podporą zasady złotej proporcji, należy uznać założenie bożnic dziewięciopolowych o podziale na równe pola jako anachronizm. Zapóźnienie planu dziewięciopolowego w stosunku do planu z bimą-podporą wynika z podziału na równe pola, charakterystycznego dla architektury średniowiecza. Zastosowanie złotego cięcia przy planowaniu bożnic z bimą-podporą spowodowało uzyskanie doskonałej proporcji na miarę architektury klasycznej. Na zasadzie boskiej proporcji opiera się również koncepcja Villalpanda. W analizie świątyni jerozolimskiej wydaje się ona nadrzędna w stosunku do planu dziewięciopolowego, a układ świątyni staje się elementem wynikowym zastosowania boskiej proporcji. Źródłem złotego podziału w judaizmie jest prawdopodobnie Tanach. Jak wskazano w niniejszej monografii, koncepcja ta pojawia się w kilku miejscach Biblii hebrajskiej. Zatem aby móc przyjąć za źródło planu dziewięciopolowego bożnic rekonstrukcję Villalpanda, należałoby poszukiwać - z równą siłą co podziału na dziewięć pól - zasady złotej proporcji. O rozpropagowaniu tej zależności w architekturze bożniczej pod wpływem wspomnianej rekonstrukcji trudno mówić przede wszystkim ze względu na fakt, że pierwszy Bet ha-Kneset zgodny z zasadą złotej proporcji powstał w XIV wieku. Na gruncie polskim pierwsze obiekty tego typu zostały wzniesione już w końcu XVI wieku (bożnice z bimą-podporą w Tarnowie i Lublinie czy synagoga jednoprzestrzenna w Pińczowie), a teoretyczne rekonstrukcje świątyń stały się popularne w latach 20. XVII wieku.

Wracając jednak do wspomnianej już zasady złotego podziału czy, inaczej mówiąc, boskiej proporcji, którą stosowano w bożnicach lokalizowanych na obszarze Polski. Do tej pory badacze nie zwracali uwagi na wykorzystywanie jej w architekturze synagogalnej. Zastosowanie złotego cięcia w bożnicach z bimą-podporą, a następnie jego częściowe przejęcie w rozwiązaniach obiektów o charakterze dziewięciopolowym wskazuje na kontynuację myśli w architekturze bożniczej. Bożnice znajdujące się na terenie Polski są pod tym względem ewenementem. Trudno jest znaleźć taki typ obiektu, który stanowiłby wzór budowli wznoszonych w różnych miejscach na przestrzeni dwustu lat i za każdym razem z tak ogromną wiernością zasadzie złotego podziału. W niniejszej monografii zwrócono uwagę na szczególny charakter tego rozwiązania, wynikający przede wszystkim z podziału kwadratu, który do XVII wieku nie był stosowany w sposób konsekwentny w jednej grupie obiektów.

Złota proporcja charakteryzowała architekturę i sztukę od starożytności, jednak nie opisano jej w żadnym z traktatów architektonicznych do lat 30. XVIII wieku ${ }^{288}$. Nawet praca Luki Paciolego z 1507 roku $^{289}$ nie mogłaby stanowić źródła tego zjawiska w architekturze bożniczej z dwóch powodów: traktat ten nie odnosił się wprost do stosowania złotej proporcji w architekturze, a symbolika zaproponowana przez autora w odniesienia do trójosobowego Boga skreślała czerpanie przez ludność żydowską z dzieł chrześcijańskich uczonych. Dodatkowym argumentem jest również fakt, że pierwszą synagogą, w której z całą pewnością stwierdzono stosowanie złotej proporcji jest synagoga w Tomar (XIV w.). Oznacza to, że zaznaczanie się wpływu zasady zachowania złotej proporcji na kulturę żydowską przebiegało niezależnie $^{290} \mathrm{i}$ dotyczyło raczej wspomnianych opisów przybytku zawartych w Tanachu. W związku 
z tym opierano się zapewne na uproszczonej i przybliżonej wartości wyrażonej proporcją 3:5. W tym kontekście należy zwrócić uwagę nie tylko na rozplanowanie sali męskiej zgodnie z zasadą złotego podziału kwadratu, ale również na proporcje wymiarów bożnic. Podobnie jak w przypadku Arki Przymierza, ołtarza czy pałacu Salomona wiążą się one ze stosunkiem wysokości do jednego z wymiarów rzutu. I tak w bożnicach w Zamościu i Szczebrzeszynie złota zasada dotyczy zewnętrznych wymiarów synagogi, natomiast w synagogach w: Chęcinach, Orli i Dukli wnętrza sali męskiej. Być może zastosowanie takiej symboliki i proporcji mogło przywodzić na myśl próbę uświęcenia bożnicy ${ }^{291}$.

Z pewnością pojawienie się zasady złotego podziału w architekturze synagog na obszarze Polski może wskazywać na jej elitarny charakter. Po raz pierwszy została ona uwzględniona w architekturze bożniczej w Polsce w budowli w Pińczowie, która w idealny sposób naśladuje podział wnętrza Kaplicy Zygmuntowskiej na Wawelu. Stosowana była także w architekturze zakonów kontrreformacyjnych, na przykład: jezuickich, karmelickich i kamedulskich. W ich przypadku widoczny jest niezwykle skomplikowany schemat podziałów, wynikający z proporcji korpusu nawowego. W synagogach z bimą-podporą następowało wykorzystanie wszystkich walorów podziału planu kwadratu, w efekcie czego powstawała niezwykle czysta i podstawowa forma podziału. Bożnice zlokalizowane w granicach Rzeczpospolitej były w tym czasie realizowane przez muratorów chrześcijańskich i przy udziale społeczności żydowskiej. Być może geneza tego zjawiska w grupach różnych obiektów była odmienna. Być może rozpropagowanie tego nurtu w architekturze polskiej mogło nastąpić również pod wpływem Komasków. Przykładem byłaby Brama Brzeska oraz kościół bernardynów autorstwa Jakuba Balina. Oznaczałoby to, że elitarne rozwiązanie spowszedniało i mogło pojawić się również w dziełach mniej znaczących artystów. Faktem jest jednak, że w architekturze kościołów parafialnych nie stwierdzono złotego podziału.

Na przykładzie twórczości Jakuba Balina czy dzieł Jana Wolfa widać również wkroczenie do architektury porządku salomonowego. Trudno jest jednak wiązać występowanie tego zjawiska z rekonstrukcją świątyni według Villalpanda. Kościół bernardynów autorstwa Balina powstał w latach 1603-1608, a kolegium jezuickie we Lwowie, w którego bibliotece znajdowało się dzieło Villalpanda powołano do życia w 1608 roku. Również zetknięcie się Balina z dziełem jezuity we Włoszech jest raczej niemożliwe, tym bardziej że od 1590 roku Balin działał już w Polsce. Tym samym należy tłumaczyć to zjawisko raczej manierystycznym zabiegiem polegającym na mieszaniu porządków architektonicznych niż czysto celowym działaniem opartym na wykształconym przez Villalpanda wzorcu.

Analiza kościołów i synagog powstających w XVII i XVIII wieku wykazuje poza różnym sposobem stosowania złotej proporcji również różnice w stosowanych wymiarach, a co za tym idzie wartościach liczbowych, które kryją się w tych wymiarach. Wymiary synagog opisane zostały wartościami liczbowymi mieszczącymi się w mocno ograniczonym zbiorze, w którym 21, 23, 25, 33, 39 i 123 występowało niezwykle często. U podstaw takiego schematu może znajdować się układ funkcjonalny i gabaryty obiektu. Tłumaczy to jednak stosowanie konkretnego 
wymiaru, a nie wartości liczbowych. Przyjmując ten punkt widzenia, należy stwierdzić, że rozkład wymiarów i rozkład wartości znacznie się od siebie różnią, co z kolei wskazuje na znacznie częstsze występowanie pewnych wartości liczbowych niż związanych z nimi wymiarów ${ }^{292}$. Pomocna przy próbie wyjaśnienia takiego stan rzeczy jest przede wszystkim liturgika synagogalna i teksty modlitw, z których większość zyskała na znaczeniu w analizowanym okresie. Z pewnością można stwierdzić silne związki z tekstami modlitw: Tikkun Chacot ${ }^{293}$, Kabbalat Szabat i Amida. W przypadku badanej grupy obiektów zwracają uwagę przede wszystkim frazy związane z wygnaniem [137, Iz 64,7; Lm 5,2-3. 6. 13. 16; Ps 42,7; 95,10; 137,4] oraz ze świątynią jerozolimską i Jeruzalem [137, Iz 62,9; 64,1. 11, Ps 20,3; 147,2). Równie ważne, o ile nie ważniejsze, wydają się fragmenty odnoszące się do Boga [137, Ps 20,4. 10; 24,8; 29,3. 7; 42,3; 43,2. 11-12; 67,1-3; 95,3; 97,3. 5; 111,2. 6-7) i wskazujące na oddawanie mu czci [137, Ps 42,9 $43,1 ; 51,17 ; 95,1 ; 96,1-2.5 .8 ; 98,7 ; 99,9 ; 111,1)$. W tej ostatniej grupie znajdują się również fragmenty modlitw zaczynające się od słów: „Błogosławiony jesteś Haszem [...]”.

Ciekawy jest lingwistyczny sposób podejścia do wymiarów synagog. W wymiarach zewnętrznych zdecydowanie częściej można odnaleźć liczbowe odpowiedniki fragmentów modlitw odnoszących się do wygnania i tęsknoty za świątynią i Jeruzalem. Pozostałe trzy z wyżej wymienionych grup, przy czym najczęściej dotyczy to wyrażeń sławiących Boga, odnoszą się do wymiarów wewnętrznych, w tym pól centralnych i bim. Świadczy to o szczególnym sposobie traktowania synagogi jako obiektu charakteryzującego się binarnością. Z jednej strony pojawia się uświęcone, nastawione na liturgię wnętrze, które w zamyśle, chwali Boga i wspomina jego przymioty oraz świątynie, z drugiej zewnętrze przypominające o tym, że Żyd jest tułaczem, utracił świątynię i ojczyznę, a w chwili obecnej znajduje się na obcej ziemi. Aspekt binarności zostaje dodatkowo podkreślony w dekoracji. Układ sali męskiej został uzupełniony jednorodną kompozycją ścian, opartą na horyzontalnym trójpodziale. Formy dekoracyjne i bogactwo motywów stosowanych w salach męskich spowodowały, że wnętrze miało zdecydowanie większe znaczenie niż zewnętrze bożnicy. Świadczy to również o dwojakim charakterze obiektu, którego zewnętrze nawiązywało zwykle do dekoracji europejskich wykonanych w duchu konkretnej epoki, natomiast wnętrze przyozdobione było charakterystycznymi dla judaizmu motywami, często o charakterze symbolicznym. Wśród najpopularniejszych przedstawień znajdowały się zwierzęta, prawdopodobnie zaczerpnięte z Perek Szira [199]. Wśród dekoracji znajdowały się również wspomniane sprzęty świątynne. Istotną rolę w dekoracji odgrywały również inskrypcje, zwykle zawierające modlitwy, które stanowiły istotny substytut niedozwolonych w synagodze przedstawień figuratywnych. Wydaje się ponadto, że sposób polichromowania bożnic i użyta kolorystyka mogą być traktowane jako swoiście żydowskie. Wykazuje ona związek z opisami kolorów zawartymi w Tanachu. Ta zbieżność nastręcza problemów zwłaszcza przez wzgląd na brak jednoznacznych informacji dotyczących tej tematyki. Jednak paleta barw zarówno tych wymienionych w Tanachu, jak i użytych w synagogach składała się wyłącznie z kolorów podstawowych i w dużej mierze z tych, które uzyskiwano z ogólnie dostępnych pigmentów organicznych. Trzeba jednak stwierdzić, że sposób polichromowa- 
nia bożnic może wskazywać na zakorzenienie w tradycji żydowskiej, zwłaszcza ze względu na poszerzenie palety barw w wyniku rozbielania kolorów podstawowych.

Podstawową cechą architektury judaizmu jest binarność i dualizm tożsamościowy. Binarność sprowadzała się do opozycji wnętrza i zewnętrza. Poprzez symbolikę, kompozycję planu i dekorację, opierającą się na motywach żydowskich, odniesieniach do świątyni jerozolimskiej - tak pod względem dekoracji, jak i dobranych wymiarów i proporcji - wnętrze stanowiło przestrzeń dla rytuału społecznego i religijnego. Jest to przestrzeń służąca chwaleniu Boga. $\mathrm{Z}$ drugiej strony było zewnętrze związane z wzorcami architektury europejskiej. W wyrazie gematrycznym można doszukać się opozycji swój - obcy. Wskazany układ opozycji binarnej odnosi się jednoznacznie do aspektu dualizmu tożsamościowego, związanego z wzorcem przestrzeni symbolicznej. Przestrzeń wnętrza jest elementem architektury judaizmu. Zewnętrze i forma należą do świata chrześcijańskiego. Forma w tym przypadku jest granicą, która należąc do świata chrześcijańskiego, nie należy do architektury judaizmu. Forma ogranicza jednak przestrzeń żydowską i w tym względzie przestaje przynależeć światu chrześcijańskiemu. Inaczej mówiąc, należy do wszystkich i nie należy do nikogo. Patrząc na to zagadnienie z punktu widzenia przestrzeni i formy należy powiedzieć, że przestrzeń jest elementem związanym z judaizmem, podczas gdy forma jest elementem obcym, choć wynika niejako z układu przestrzennego. Podlega ona układowi wnętrza, do którego jednak nie należy. Analiza architektury jest analizą formy. Analiza przestrzeni jest analizą form, które tę przestrzeń kreują. Architektura judaizmu wykształciła niezwykłą metafizyczną architekturę i sztukę. Opiera się ona przede wszystkim na sensie semantycznym, który płynie z formy, a nie na samej formie. Posiada aspekt substancji. Forma jest elementem obcym, którego z pewnością nie można nazwać typowo żydowskim czy wynikającym z judaizmu. Odnosi się to zarówno do formy synagogi, jak i formy dekoracji. Pozostaje zatem substancja, a więc układ przestrzenny, i , podobnie jak w przypadku dekoracji, treść, którą ta ze sobą niesie. Dociera się tym samym do określenia architektury judaizmu jako architektury opartej na semantyce, związanej z gematrycznym obrazem formy. Z punktu widzenia historyków architektury analizowana jest bardziej przestrzeń w oderwaniu od formy, która ją tworzy. Wszak akt projektowania opiera się na nadaniu substancji formy. Zatem judaizm, idąc nieco na przekór teorii przestrzeni symbolicznej, wykształcił niezwykle ciekawy aspekt architektury, w którym istotna jest przestrzeń par excellence. Uwalnia się tym samym od elementów, które stanowią granice tej przestrzeni, a które w gruncie rzeczy mogłyby nie istnieć.

\section{Przypisy}

${ }^{285} \mathrm{Na}$ planie kwadratu lub bardzo zbliżonym do kwadratu wzniesiono sale męskie synagog w: Tykocinie i Tarnogrodzie, Siemiatyczach, Orli, Pińczowie, Zamościu, Rzeszowie (Nowomiejska), Włodawie, Dukli, Łańcucie, Rzeszowie (Stara), Chęcinach, Szczebrzeszynie. 


\section{Gematria i inne fenomeny architektury judaizmu}

${ }^{286} \mathrm{~W}$ tym przypadku schemat ten można byłoby odnieść do planu centralno-podłużnego. Należy jednak zaznaczyć, iż całość opiera się na pewnym układzie wyobrażeniowych powiązań między elementami przestrzeni wynikających z liturgii.

${ }^{287}$ Wiadomo o trzech cyboriach, które powstały w Polsce do XVII w.

${ }^{288}$ Zasady wykreślania tej proporcji zostały określone dopiero w traktacie Guarino Guariniego. Jak wskazano, proporcje uzyskane przez tego autora odbiegały jednak od złotego podziału.

${ }^{289}$ Pierwszy traktat w całości dotyczący boskiej proporcji.

${ }^{290}$ Można również przypuszczać, że czerpano z wzorców muzułmańskich, choć raczej mało prawdopodobne jest oddziaływanie tego wzorca na architekturę synagog wznoszonych na terenie Polski.

${ }^{291}$ Podobne przejawy uświęcenia mogło stanowić stosowanie sprzętów świątynnych w wystroju bożnic.

${ }^{292}$ Przykładem są dwa wymiary: 33 stopy i 33 ćwierci. Oba różnią się od siebie, w związku z czym powstają dwa zbiory jednoelementowe. Jednak biorąc pod uwagę samą wartość liczbową 33, można stworzyć już jeden zbiór dwuelementowy.

${ }^{293}$ Faktem jest, że związki między Tikkun Chacot i Kabbalat Szabat z wymiarami Polskich bożnic powstałych w XVII i XVIII w. mogą być wątpliwe. Argumentem stojącym za ta tezą może być, że zarówno jedna, jak i druga modlitwa opracowane zostały w początku XVII w. w Safedzie. Zatem trudno jest sądzić, że w tym samym czasie pojawiły się w Polsce. Należy jednak zaznaczyć, że Tikkun i Kabbalat stanowią w znacznej mierze zbiór fragmentów Psalmów i ksiąg zawartych w Tanachu. Oznacza to jedynie, że czerpano z tego samego źródła, oraz, że sposób myślenia Żydów polskich był zatem niezwykle podobny do sposobu myślenia twórców wymienionych modlitw. 


\section{BIBLIOGRAFIA}

\section{Publikacje i inne źródła archiwalne}

[1] Abrams I., Jewish Life in the Middle Ages, London, New York 1896.

[2] Alberti L. B., L'Architettura, Florencja 1550.

[3] Amiet P., Art of the Ancient Near East, New York 1980.

[4] Atkinson K., Fudaism, Philadelphia 2004.

[5] Avierbuch, Siemiatycka synagoga i przekazy o niej, „Jewriejskaja Starina” 1911, nr 4, s. 563-567.

[6] Bałaban M., Bóżnice obronne na wschodnich kresach Rzeczypospolitej, „Studia Historyczne”, Warszawa 1927, s. 93-99.

[7] Bałaban M., Mistyka i ruchy mesjańskie wśród Żydów w dawnej Rzeczypospolitej, [w:] Żydzi w Polsce odrodzonej: działalność społeczna, gospodarcza, oświatowa i kulturalna, t. 1, red. I. Schiper, A. Tartakower, A. Hafftka, Warszawa 1932, s. 255-280.

[8] Bałaban M., Zabytki historyczne Żydów w Polsce, Warszawa 1929.

[9] Bar-Lew J., Kabała pieśń duszy, wprowadzenie do żydowskiego mistycyzmu, Kraków 2006.

[10] Baranowski J., O zabytkowej synagodze w Tykocinie, „Biuletyn ŻIH” 1960, nr 34, s. 158-190.

[11] Baranowski J., Synagoga w Chmielniku, „Biuletyn ŻIH” 1960, nr 36, s. 95-106.

[12] Baranowski J., Zabytkowe bożnice we Wtodawie i Chęcinach, „Biuletyn ŻIH” 1959, nr 29, s. 58-71.

[13] Bergman E., Aims and Future Directions of Research on Easter European Synagogues, [w:] Jewish Architecture in Europe, eds. A. Cohen-Mushlin, H.H. Thies, Petersburg 2010, s. 93-100.

[14] Bergman E., Jagielski J., Zachowane synagogi i domy modlitwy w Polsce: katalog, Warszawa 1996.

[15] Bershon M., Dyplomatariusz dotyczący Żydów w dawnej Polsce na źródtach archiwalnych osnuty (1388-1782), Warszawa 1910.

[16] Bershon M., Kilka słów o dawniejszych bożnicach drewnianych w Polsce. Z. [1]-3, Warszawa 1885.

[17] Biblia: Pismo Święte Starego i Nowego Testamentu (Biblia Warszawska), Dostępny w Internecie: http://www.ezb-szczecinek.pl/Biblia_C.pdf [dostęp: 15.08.2015].

[18] Bloom M., Żydowski mistycyzm a magia, Kraków 2011.

[19] Boussora K., Mazous S., The Use of the Golden Section in the Great Mosque at Kairouan, „Nexus Network Journal” 2004, Vol. 6, No. 1, s. 7-16.

[20] Breier A., Eisler M., Grunwald M., Holzsynagogen in Polen, Wien 1934.

[21] Brykowska M., Pustelnia w Czernej, „Biuletyn Historii Sztuki” 1981, nr 2, s. 176-178.

[22] Cesarino C., Vitruvius' Architectura, Como 1521.

[23] Czechowicz B., Książęcy mecenat artystyczny na Śląsku u schytku średniowiecza, Warszawa 2005. 


\section{Bibliografia}

[24] Dawidowicz D., Batej kneset be-Polin we-churbanam, Jerozolima 1960.

[25] Dawidowicz D., Cijuri-kir be-wate-keneset be-Polin, Jerozolima 1968.

[26] d'Aviler A.C., Cours d'architecture, Paris 1738.

[27] de Chambari F., Parallele de l'architecture antique et de la moderne avec un recueil des dix principaux autheurs qui ont ecrit des cinq orders, Paris 1650.

[28] de Lange N., An Introduction to fudaism, Cambidge 2002.

[29] de Sagredo D., Medidas del Romano, Toledo 1526.

[30] Deinna W., L'ex-votto de Cypsélos à Delphes: Le symbolisme du palmier et des grenoulles, [w:] „Radical History Review" 1951, No. 139, s. 162-207.

[31] Deupi V., Architectural Temperence: Spain and Rome, 1700-1759, Londyn 2015.

[32] Dornseiff F., Das Alphabet im Mystik und Magie, Warszawa 2001.

[33] Dürer A., Underweysung der messung, mit den zirckel un richtscheyt, in Linien ebnen unnd gantzen corporen, 1525.

[34] Elbogen I., Der jüdische Gottesdienst in seiner geschichtlichen Entwicklung, Leipzig 1913.

[35] Eliade M., Historia wierzeń i idei religijnych, t. 3, Warszawa 1995.

[36] Encyklopedia Judaica, ed. Fred Skolnik, New York, San Francisco, London.

[37] Endres F. C., Schimmel A., Das Mysterium der Zahl, München 1984.

[38] Espinosa-Villegas M.Á., The Mediterranean Sephardi Pattern and Its Influence on The National fewish Idea of Architecture, [w:] Fewish Architecture in Europe, eds. A. Cohen-Mushlin, H.H. Thies, Petersburg 2010, s. 75-91.

[39] Euclide's Elements: The Whole Fifteen Books Compendiously Demonstrated, ed. I. Barrow, London 1705.

[40] Even-Shoshan A., A New concordance of the Bible : thesaurus of the language of the Bible: Hebrew and Aramaic roots, words, proper names, phrases, and synonyms, Jerozolima 1985.

[41] Evers B., Thoenes C., Théorie de l'architecture de la renaissance à nos jours: 117 traités présentés dans 89 études, Köln 2003.

[42] Flatto S., The Kabbalistic Culture of Eighteenth-Century Prague: Ezekiel Landau (the 'Noda Biyehudah') and his Contemporaries, Oxford-Portland 2010.

[43] Flawiusz J., The Antiquities of the Jews, transl. W. Whiston, London-New York 1900.

[44] Frenkiel J., Chasydyzm wśród Żydów dawnej Rzeczypospolitej [w:] Żydzi w Polsce odrodzonej: dziatalność społeczna, gospodarcza, oświatowa i kulturalna, t. 1, red. I. Schiper, A. Tartakower, A. Hafftka, Warszawa 1932, s. 281-288.

[45] Freundlich A., Soffer O., Documentation and survey of the synagogue structure, Safed 2003, Dostępny w Internecie: http://www.iaa-conservation.org.il/Projects_Item_eng.asp?id=10\&subject_id=6\& site_id=4, [dostęp: 29.11.2014].

[46] Frings M., The Golden Section in Architectural Theory, „Nexus Network Journal” 2002, Vol. 4, No. 1, s. 9-32.

[47] Ghyka M.C., Ztota Liczba. Rytuat i rytmy pitagorejskie w rozwoju cywilizacji zachodniej, Kraków 2001. 


\section{Bibliografia}

[48] Gloger Z., Budownictwo drzewne i wyroby z drzewa w dawnej Polsce, t. 1, Warszawa 1907.

[49] Goldberg J., Jewish Privileges in the Polish Commonwealth: Charters of Rights Granted to Jewish Communities in Poland-Lithuania in the Sixteenth to Eighteenth Centuries, Jerozolima1985.

[50] Goldberg J., Poles and Jews in the 17th and 18th Centuries: Rejection or Acceptance, ,Jahrbücher für Geschichte Osteuropas: Neue Folge” 1973, Vol. 22, Nr. 2, s. 248-282.

[51] Goldberg J., Żydowski Sejm Czterech Ziem w społecznym i politycznym ustroju dawnej Rzeczypospolitej, [w:] Żydzi w dawnej Rzeczypospolitej: materiaty $z$ konferencji „Autonomia Żydów w Rzeczypospolitej Szlacheckiej” 22-26 IX 1986, red. A. Link-Lenczowski, T. Dolański, s. 44-58.

[52] González V., Lamas M.C., Regal B., Rutas románicas en Galicia/2, Madrid 1997.

[53] Gorlin A., Kabbalah in art and architecture, New York 2013.

[54] Grotte A., Deutsche, böhmische und polnische Synagogentypen vom XI. bis Anfang des XIX. Fahrhunderts, Berlin 1915.

[55] Guarini. G, Architettura civile, Torino 1737.

[56] Hamlin A.D.F., A History of Ornament: Ancient and Mediva, New York 1913.

[57] he-Chasid J. ben S., Sefer Chasidim: Parma $3280 \mathrm{H}$.

[58] Hersey G.L., Architecture and Geometry in the Age of the Baroque, Chicago-London 2000.

[59] Hoffman L.A, Jewish Liturgy and Jewish Scholarship: Method and Cosmology, [w:] The Oxford Handbook of Jewish Studies, eds. M Goodman, J. Cohen, D. Sorkin, Oxford 2002, s. 733-755.

[60] Hubka T.C., Medival Themes in the Wall-Paitings of 17th and 18th-Century Polish Wooden Synagogues, [w:] Imagining the Self, Imagining the Other: Visual Representation and Jewish-Christian Dynamics in the Middle Ages and Early Modern Period, ed. E. Frojmovic. Leiden-Boston-Köln 2002, s. 213-235.

[61] Hubka T.C., Resplendent Synagogue: Architecture and Worship in an Eighteenth-century Polish Community, Hanover, London 2003.

[62] Hudzik D., Halicka cerkiew świętego Pantelejmona. Niezwykty zabytek architektury sakralnej Rusi Kijowskiej, [w:] „Archeo UW” 2014, nr 2, s. 34-48.

[63] Hundert G., Żydzi w Rzeczypospolitej Obojga Narodów w XVIII wieku. Genealogia nowoczesności, Warszawa 2007.

[64] Idel M., Kabała Nowe perspektywy, Kraków 2006.

[65] Idel M., Kabbalistic Prayer and Colors, [w:] Approaches to Fudaism in Medieval Times, part 3, ed. D. Blumenthal, Atlanta 1988, s. 17-27.

[66] Idel M., Visualization of Colors, I: David ben Yehudah he-H asid's Kabbalistic Diagram, „Ars Judaica” 2015, nr 11, s. 31-54.

[67] Idel M., White Letters: From R. Levi Isaac of Berditchev,s Views to Podtmodern Hermeneutics, „Modern Judaism" 2006, Vol. 26, No. 2, s. 169-192.

[68] Idelshon A.Z., Jewish Liturgy and its Development, Dover 1995.

[69] Ivanyk S., Mileny Rudnickiej próba rekonstrukcji systemu estetyki Leona Battisty Albertiego, „Semina Scientorum" 2012, nr 12, s. 21-33.

[70] Janson A.F. Janson H.W., History of Art: The Western Tradition, Upper Saddle River 2003. 


\section{Bibliografia}

[71] Jarrassé D., Synagogues: architecture and fewish identity, Paris 2001.

[72] Jarrassé D., The Reflection of the Temple in French Synagogues, [w:] Jewish Architecture in Europe, eds. A. Cohen-Mushlin, H.H. Thies, Petersburg 2010, s. 67-74.

[73] Jewish Architecture in Europe, eds. A. Cohen-Mushlin, H.H. Thies, Petersburg 2010.

[74] Kaczynski B.M., Illustrations of Tabernacle and Temple Implements in the "Postilla in Testamentum Vetus” of Nicolaus de Lyra, „The Yale University Library Gazette” 1973, Vol. 48, No. 1, s. 1-11.

[75] Kaczyński J., Budynek dawnej synagogi, Badania architektoniczne, Białystok 1985, mps WUOK w Białymstoku, syg. N4055.

[76] Kadish S., "Sha'ar ha-Shamayim”: London's Bevis Markus Synagogue and the Sephardi Architectural Heritage, [w:] Jewish Architecture in Europe, eds. A. Cohen-Mushlin, H.H. Thies, Petersburg 2010, s. 229-242.

[77] Kameraz-Kos N., Święta i obyczaje żydowskie, Warszawa 2002.

[78] Kania I., Opowieści Zoharu. O kabale i Zoharze, Kraków 2012.

[79] Karo J., Szulchan Aruch, Dostępny w Internecie: http://www.torah.org/advanced/shulchan-aruch/ [dostęp: 29.11.2014].

[80] Kaźmierczyk A., Jews, Nobles and Canon Law in the 18th Century, „Biuletyn Polskiej Misji Historycznej” 2014, nr 9, s. 215-245.

[81] Kaźmierczyk A., Polscy biskupi wobec Żydów w XVIII w., [w:] Rzeczpospolita wielu wyznań: materiaty z międzynarodowej konferencji, Kraków, 18-20 listopada 2002, red. A. Kaźmierczyk [i in.], Kraków 2002, s. 349-356.

[82] Kaźmierczyk A., Sejmy i Sejmiki szlacheckie wobec Żydów w drugiej połowie XVII wieku, Warszawa 1994.

[83] Keßler K., Halakhic Rules in Synagogue Achitecture, [w:] Jewish Architecture in Europe, eds. A. Cohen-Mushlin, H.H. Thies, Petersburg 2010, s. 243-256.

[84] Klein R., Nineteenth-Century Synagogue Typology in Historic Hungary, [w:] fewish Architecture in Europe, eds. A. Cohen-Mushlin, H.H. Thies, Petersburg 2010, s. 117-130.

[85] Klenovský J., An Introduction to the History and Architecture of Bohemia and Moravian Synaogue, [w:] Jewish Architecture in Europe, eds. A. Cohen-Mushlin, H.H. Thies, Petersburg 2010, s. 135-146.

[86] Kordys J., Mózg i znaki, Warszaw 1991.

[87] Kotz J., Wzorzec przestrzeni symbolicznej i jego manifestacje, „Teka Komisji Architektury Urbanistyki Studia Krajobrazowe", Lublin 2007, s. 57-70.

[88] Kowalczyk J., Sebastiano Serlio a sztuka polska: o roli wtoskich traktatów architektonicznych $w$ dobie nowożytnej, Wrocław 1973.

[89] Kowalczyk J., Porzadek salomonowy w polskiej architekturze nowożytnej, [w:] Claret Opus. Studia z dziejów sztuki dedykowane Mieczysławowi Zlatowi, red. L. Kalinowski, S. Mossakowski, Z. Ostrowska-Kębłowska, Wrocław 1998, s. 225-236.

[90] Krautheimer R., Introduction to an „Iconography of Mediaeval Architecture“, „Journal of the Warburg and Courtauld Institutes" 1942 , Vol. 5, s. 1-33.

[91] Krautheimer R., Mittelalterische Synagoge, Berlin 1927. 


\section{Bibliografia}

[92] Kravtsov S.R., Gothic Survival in Synagogues in Eastern Europe, [w:] Jewish Architecture in Europe, eds. A. Cohen-Mushlin, H.H. Thies, Petersburg 2010, s. 101-108.

[93] Kravtsov S.R., Jewish identities in synagogue architecture of Galicia and Bukovina, „Ars Judaica” 2010, No. 6, s. 81-100.

[94] Kravtsov S.R., Juan Bautista Villalpando and Sacred Architecture in the Seventeenth Century, „Journal of the Society of Architectural Historians" 2005, Vol. 64, No. 3, s. 312-339.

[95] Kravtsov S.R., O proiskhozhdenii deviatipolevykh kamennykh sinagog, [w:] Evreiskoie iskusstvo v evropeiskom kontekste, ed. I. Rodov, Jerusalem-Moskwa 2002, s. 191-204.

[96] Kravtsov S.R., Reconstruction of the Temple by Charles Chipiez and its applications in architecture, „Ars Judaica” 2004, No. 4, s. 25-42.

[97] Kravtsov S.R., Synagogue Architecture in Lithuania, [w:] Synagogues in Lithuania: a catalogue. $A-M$, eds. A. Cohen-Mushlin [et al.], Wilno 2010, s. 43-72.

[98] Krinsky C.H., Is there a Jewish Architecture?, [w:] Jewish Architecture in Europe, ed. A. Cohen-Mushlin, H.H. Thies, Petersburg 2010, s. 353-364.

[99] Krinsky C.H., Synagogues of Europe: Architecture, History, Meaning, Cambridge 1985.

[100] Kristeva J., Language, the Unknown: An Initiation into Linguistics, London 1989.

[101] Kubiak A., Zabytkowa architektura żydowska w Polsce. Cz. 1, „Biuletyn ŻIH” 1953, nr 2-3(6-7), s. $122-170$.

[102] Kubiak A., Zabytkowa architektura żydowska w Polsce. Cz. 2, „Biuletyn ŻIH” 1953, nr 4(8), s. 73-96.

[103] Kunkel R., Łużyniecka E., Świeykowski Z., Architektura opactw cysterskich: matopolskie filie Morimond, Wrocław 2010.

[104] Künzl H., Jüdische Kunst: von der biblischen Zeit bis zur Gegenwart, München 1992.

[105] Lakovidis S.E., Late Helladic Citadels on Mainland Greece, Leiden 1983.

[106] Lamey T., Bimot in Polish stone synagogues until 1650: Forms, Function, and Religious Aspects [w:] fewish Architecture in Europe, red. A. Cohen-Mushlin, H.H. Thies, Petersburg 2010, s. 109-116.

[107] Lamey T., Die Stellung des polnischen Steinsynagogenbaus in Europa im 16. und 17. FahrhundertVersuch einer Annäherung, „Aschkenaz - Zeitschrift für Geschichte und Kultur der Juden“ 2004, Nr. 14, s. 412-446.

[108] Lamey T., Zur Genese der „Stütz-Bimah“ im frühneuzeitlichen polnischen Synagogenbauam Beispiel der Synagoge in Przemyśl, Braunschweig 2010, praca doktorska, mps Biblioteka Uniwersytetu w Braunschweig.

[109] Lechowski A., Wroczyńska E., Wielka Synagoga w Tykocinie, Białystok 2004.

[110] Levin V., Synagogues in Lithuania: A Historical Overview, [w:] Synagogues in Lithuania: a catalogue. A-M, eds. A. Cohen-Mushlin [et al.], Wilno 2010, s. 17-42.

[111] Lorenz E., Dokumentacja konserwatorska zabytków. Synagoga Tarnogród, Zamość 1986, mps WUOK w Lublinie, delegatura w Zamościu, syg. N024.

[112] Loukomski G. K., Jewish art in European synagogues: from the Middle Ages to the eighteenth century, London 1947. 


\section{Bibliografia}

[113] Łużyniecka E., Architektura Klasztorów cysterskich, Wrocław 2002.

[114] Mann V. B., Spiritual and Jewish ceremonial Art, [w:] Jewish Spirituality and Divine Law, eds. A. Mintz, L.H. Schiffman, New Jersey, 2005.

[115] Mańkowska-Zawadzka H., Sprawozdanie z przebiegu badań konserwatorskich zabytkowej synagogi w Lesku, mps WUOK w Przemyślu, delegatura w Krośnie.

[116] Milburn R., Early Christian Art and Architecture, Berkley-Los Angeles 1988.

[117] Miller H., The Iconography of Palm in Greek Arts: Significance and Symbolism, Berkley 1979.

[118] Miłobędzki A., Architektura polska XVII wieku, Warszawa 1980.

[119] Modlitewnik żydowski, modlitwy na dni powszednie i na Szabat, z tlumaczeniem na język polski, red. S. Pecaric, Kraków 2005.

[120] Mokłowski K., Sztuka ludowa w Polsce, Lwów 1903.

[121] Morawski M., Synod piotrkowski w roku 1589, Włocławek 1937.

[122] Morgenstern J., O osadnictwie Żydów w Zamościu na przełomie XVI i XVII w., „Biuletyn ŻIH” 1962, nr 43-44, s. 3-17.

[123] Narkiss B., Sacred Spades: Inerrelations Between Jewish, Christian, and Moslem Architecture, [w:] fewish Architecture in Europe, eds. A. Cohen-Mushlin, H.H. Thies, Petersburg 2010, s. 41-52.

[124] Offenberg A.K., Jacob Jehuda Leon (1602-1675) and his Model of the Temple, Jewish-Christian Relations in the $17^{\text {th }}$ Century. Studies and Documents, eds. J. van den Berg, E.G.E. van der Wall, Dordrecht 1988, s. 95-115.

[125] O'Kane B., The Nine-Bay Plan in Islamic Architecture: Its Origin, Development and Meaning, [w:] Studies in Honor of Arthur Upham Pope, ed. A. Daneshvari, Costa Mesa 2006, s. 189-244.

[126] Ouaknin M. A., Tajemnice kabaty, Warszawa 2006.

[127] Pacioli L., Divina proportione. Opera ... con varie questione de secretissima scientia, Wenecja 1509.

[128] Pacioli L., Divina Proportione. Die Lehre vom Goldenen Schnitt. Nach der venezianischen Ausgabe vom fahre 1509, übers. von C. Winterberg, Wiedeń 1889.

[129] Pakentreger A., Identyfikacja i rekonstrukcja inskrypcji starohebrajskich i aramejskich w synagodze Wielkiej w Tykocinie, „Biuletyn ŻIH” 1982, nr 3-4, s. 99-108.

[130] Paulus S., Die Architektur der Synagoge im Mittelalter: Überlieferung und Bestand, Petersburg 2007.

[131] Penkala A., Synagoga i gmina w Szydtowie, „Biuletyn ŻIH” 1982, nr 1-2, s. 57-70.

[132] Pevsner N., Historia architektury europejskiej, Warszawa 1976.

[133] Piechotkowie K. i M., Bożnice drewniane, Warszawa 1957.

[134] Piechotkowie K. i M., Bramy Nieba: Bożnice murowane na ziemiach dawnej Rzeczypospolitej, Warszawa 1999.

[135] Piechotkowie K. i M., Polichromie polskich bożnic drewnianych, „Polska Sztuka Ludowa” 1989, vol. 43, z. 1-2, s. 65-87.

[136] Pirkej Awot (Sentencje Ojców), przeł. M. Friedman, „Literatura na świecie. Talmud” 1988, numer specjalny. 


\section{Bibliografia}

[137] Pismo Święte Starego i Nowego Testamentu w przekł. z języków oryginalnych, oprac.zespół biblistów polskich z inicjatywy Benedyktynów Tynieckich, tłum. ksiąg W. Borowski [i in.], red. K. Dynarski, red. nauk. A. Jankowski [et al.], Poznań 2003.

[138] Pomarański R., Zamość - Stare miasto. Synagoga. Sprawozdanie z nadzoru archeologicznego, Zamość 2010, mps WUOK w Lublinie delegatura w Zamościu, syg. 5391.

[139] Pradus H., Villalpandus J.B., In Ezechielem explanationes et apparatus urbis ac templi Hierosolimitani. Commentarii et emag-inibus illustratus opus..., Vol. 2, Rzym, 1596-1604.

[140] Rabens M., Baroque Visions of the Temple of Jerusalem, „Oz: Journal of the Collage of Architecture, Planning \& Design Kansan State University" 1995, Vol. 17, s. 38-43.

[141] Rambam: Mishneh Torah - Sefer Avahar, red. E. Touger, New York 1997.

[142] Ringelblum E., Dzieje zewnętrzne Żydów w dawnej Rzeczypospolitej, [w:] Żydzi w Polsce odrodzonej: działalność społeczna, gospodarcza, oświatowa i kulturalna, t. 1, red. I. Schiper, A. Tartakower, A. Hafftka, Warszawa 1932, s. 37-80.

[143] Rodov I, Ars brevis, vita lonca: On Preservation of Synagogue Art, „Studia Hebraica” 2011, No. 9-10, s. 91-111.

[144] Rodov I., Dragons: A Symbol of Evil in European Synagogue Decoration?, „Ars Judaica” 2005, No. 1, s. 63-84.

[145] Rodov I., The Eagle, its Twin Heads and Many Faces: Synagogue Chandeliers Surmounted by Double-Headed Eagles, „Studia Rosenthaiana” 2004, No. 37, s. 77-129.

[146] Rodov I., The King of the King of Kings: Images of Rulership in Late Medival and Early Modern Christian Art and Synagogue Design, [w:] Interaction between fudaism and Christianity in history, religion, art and literature, eds. M. Poorthuis, J. Schwartz, J. Turner, Leiden-Boston 2009, s. 457-476.

[147] Rodov I., Papal Lions on the Torah Ark: A Heraldic Symbol Converted, „Materia giudaica rivista dell'Associazione Italiana per lo Studio del Giudaismo” 2012/2013, Vol. XVII-XVIII, s. 215-227.

[148] Rodov I. The Development of Medieval and Renaissance Sculptural Decoration in Ashkenazi Synagogues from Worms to the Cracow Area Thesis Submitted for the Degree Doctor of Philosophy to the Senate of the Hebrew University of Ferusalem, Jerozolima 2003.

[149] Rodov I., The Torah ark in Renaissance Poland: a Jewish revival of classical antiquity, Boston 2013.

[150] Rodov I., Tower-Like Torah Arks, the Tower of Strenght and the Architecture of the Messianic Temple, [w:] „Journal of the Warburg and Courtauld Institutes” 2010, Vol. LXIII, s. 65-89.

[151] Rodov I., Winged Image of the Divine: A Comparative Note on Catholic, Orthodox, and fewish Art in Early Modern Ukraine, „Judaica Ukrainica” 2014, No. 3, s. 105-127.

[152] Rodov I., „With Eyes toward Zion:” Visions of the Holy Land in Romanian Synagogues, „Quest Issues in Contemporary Jewish History : journal of Fondazione CDEC" 2006, No. 3, s. 138-173.

[153] Rosenau H., The Synagogue and Protestant Church Architecture, „Journal of the Warburg and Courtauld Institutes" 1940/1941, Vol. 4, No. 1/2, s. 80-84.

[154] Rosenau W., Jewish ceremonial institutions and customs, New York 1925.

[155] Rosman M., Innovative Tradition: Jewish Culture in the Polish -Lithuanian Commonwealth, [w:] Culture of the Jews.A New History, ed. D. Biale, New York 2002, s. 519-570. 


\section{Bibliografia}

[156] Rosman M., Żydzi Pańscy. Stosunki magnacko-żydowskie w Rzeczpospolitej w XVIII wiek, Warszawa 2005

[157] Serlio S., Extraordinario libro di architettura, Wenecja 1560.

[158] Schedel H., Liber cronicarum cum figuris et ymaginibus, Norymberga 1493.

[159] Schiffman L.H., The courtyards of the house of the Lord: studies on the Temple scroll, Leiden 2008.

[160] Schiper I., Sztuka plastyczna u Żydów dawnej Rzeczypospolitej, [w:] Żydzi w Polsce odrodzonej: działalność społeczna, gospodarcza, oświatowa i kulturalna, t. 1, red. I. Schiper, A. Tartakower, A. Hafftka, Warszawa 1932.

[161] Scholem G., Mistycyzm żydowski i jego główne kierunki, Warszawa 2007.

[162] Simon H. i M., Geschichte der jüdische Philosophie, Berlin 1984.

[163] Slater J., Smith T. R.,, Architecture Classic and Early Christian, Aleksandria 1896.

[164] Sokolova A., Shtetl House and Synagogues: From the History of Architecture to Stories about Architectural Monument, [w:] Jewish Architecture in Europe, eds. A. Cohen-Mushlin, H.H. Thies, Petersburg 2010, s. 159-174.

[165] Stamm E., Miary dtugości w dawnej Polsce, Warszawa 1935.

[166] Stawicka K., Dokumentacja konserwatorska, Tykocin. Synagoga, Warszawa 1977, mps Muzeum Podlaskie w Białymstoku, oddział w Tykocinie.

[167] Stern E., Excavations at Tel Mevorakh: The Bronze Age, Jerusalem 1984.

[168] Synagogues in Lithuania: a catalogue. A-M, eds. A. Cohen-Mushlin [et al.], Wilno 2010.

[169] Synagogues in Lithuania: a catalogue. N-Z, ed. A. Cohen-Mushlin [et al.], Wilno 2012.

[170] Sztajer S., Werbalne mity kosmogoniczne, „Zeszyty Filozoficzne” 2003, nr 10-11, s. 129-161.

[171] Sztuka romańska. Architektura, rzeźba, malarstwo, red. R. Toman, Kraków 2000.

[172] Szyszko-Bohusz A., Materiaty do architektury bożnic w Polsce, [w:] Prace Komisji Historii Sztuki, t. 4, Warszawa-Wilno-Kraków 1930, s. 1-25.

[173] Talmud Babiloński, Dostępny w Internecie: http://halakhah.com [dostęp: 29.11.2014].

[174] Teller A., Rabbis Without a Function? The Polish Rabbinate and the Council of Four Lands in the Sixteenth to Eighteenth Centuries, [w:] Jewish religious leadership: image and reality, ed. J. Wertheimer, New York 2004, s. 371-400.

[175] Teller A., The laicization of Early Modern Jewish Society: The Development od the Polisch Communal Rabbinate in the $16^{\text {th }}$ Century, [w:] Schöpferische Momente des europäischen fudentums : in der frühen Neuzeit, Hg. M. Graetz, Heidelberg 2000, s. 333-349.

[176] Teller A., The Schtetl as an Arena for Polish-fewish Integration in the Eighteenth Century, „Polin: Studies in Polish Jewry" 2004, Vol. 17, s. 29-40.

[177] Teller A., Tradition and Crisis? Eighteenth-Century Critiques of the Polish-Lithuanian Rabbinate, „Jewish Social Studies: History, Culture, Society” 2011, Vol. 17, No. 3, s. 1-39.

[178] The Grove encyclopedia of medieval art and architecture, part 2, ed. C. Hourihane, Oxford 2012.

[179] The Guide for the Perplexed by Moses Maimonides Translated from the Original Arabic, transl. M. Frielander, Londyn 1904.

[180] The fewish Encyclopedia, part 4, ed. I. Singer, New York 1903. 


\section{Bibliografia}

[181] The Letter Of Aristeas, ed. R.H. Charles, Oxford 1913.

[182] The Standard Prayer Book, ed. S. Singer, New York 1915.

[183] Tikkun Chatzot - The Midnight Rite, Tikkun Rachel, Tikkun Leah with Psalms, Readings and Confession, ed. S.Z. of Liadi. Dostępny w Internecie: http://opensiddur.org/wp-content/uploads/ 2010/08/Tikkun-\%E1\%B8\%A4atzot-Nusa\%E1\%B8\%A5-Ha-Ari-\%E1\%B8\%A4aBaD.pdf [dostęp: 15.11.2015]

[184] Tora, red. I. Cyklow, Kraków 1895.

[185] Trzciński A., Wystrój sztukatorski i malarski synagogi w Łańcucie, [w:] Od starożytności do wspótczesności. Język - literatura - kultura. Księga poświęcona pamięci profesora ferzego Woronczaka, red. Irena Kamińska-Szamaj, Wrocław 2004, s. 247-280.

[186] Trzciński A., Zachowane wystroje malarskie bożnic w Polsce, „Studia Judaica” 2010, R. 4, nr 1-2(78), s. 67-95.

[187] Trzciński A., Wodziński M., Wystrój malarski synagogi w Pińczowie. Cz. 1, „Studia Judaica” 1999, R. 2, nr 1(3), s. 87-102.

[188] Trzciński A., Wodziński M., Wystrój malarski synagogi w Pińczowie. Cz. 2, „Studia Judaica” 2000, R. 3, nr 1(5), s. 91-98.

[189] Ulanowski B., Materiaty do historii ustawodawstwa synodalnego w wieku XVI, Kraków 1895.

[190] Wierciński A., Przez wodę i ogień: Biblia i Kabała, Kraków 1996.

[191] Wischntzer R., Maimonides' Drawings of the Temple, „Journal of Jewish Art”, 1974, No. 1. s. 16-27.

[192] Wischnitzer R., Symbole und Gestalten der jüdischen Kunst : mit 6 Farbigen Tafeln und 81 Abbildungen, Berlin 1935.

[193] (Bernstein)-Wischnitzer R., Synagogen im ehemaligen Königreich Polen, mit acht Abbildungen nach Zeichnungen der Verfasserin, [w:] Das Buch von den polnischen Fuden., Hg. S.J. Agnon,

A. Eliasberg, Berlin 1916, s. 87-105.

[194] Wischnitzer R., The Architecture of the European Synagogue, Philadelphia 1964.

[195] Witruwiusz M. P., O architekturze ksiag dziesięć, Warszawa 1999.

[196] Yaniv B., Galami ec jehudim ba-mizrach eropa, „Zion: A Quarterly for Research in Jewish History" 2012, Vol. 77, No. 1, s. 31-66.

[197] Yaniv B., „Kise chawod marom”: al icuw aronot kodesz ba-mizrach eropa ma-mean ha-szmore asar, „Tarbiz: A Quarterly for Jewish Studiem” 2012, Vol. LXXX, No. 3, s. 427-461.

[198] Yaniv B., Motiw szloszet ha-ktarim be-aronat ha-kodesz szel mizrach eropa, [w:] Kenishta: Studies of the Synagogue World, part 2, ed. J. Tabory, Ramat-Gan 2003, s. 67-87.

[199] Yaniv B., Praising the Lord: Discovering a Song of Ascents on Carved Torah Arks in Eastern Europe [w:] „Ars Judaica” 2006, nr 2, s. 1-20.

[200] Yaniv B., The Hidden Messade of the Hares in the Talons of the Eagle, „AJS Review”2012, Vol. 36, No. 2, s. 281-294.

[201] Zajczyk Sz., Architektura barokowych bożnic murowanych w Polsce, „Biuletyn Historji Sztuki i Kultury: kwartalnik wydawany przez Zakład Architektury Polskiej i Historji Sztuki Politechniki Warszawskiej” 1933, vol. 1, nr 4, s. 186-195. 


\section{Bibliografia}

[202] Zlat M., Zamek piastowski w Brzegu, Opole 1988

[203] Zuchold G.-H., Friedrich Wilhelm IV. und das byzantinische Gott-Königtum. Seine Kirchenentwürfe als Modell einer "Kirche der Zukunft” in Preußen, „Zeitenblicke” 2010, Vol. 9, Nr. 3, Dostępny w Internecie: http://www.zeitenblicke.de/2010/3/Zuchold/index_html, URN:urn:nbn:de: 0009-9-27552 [dostęp: 23.12.2013].

\section{Ilustracje}

[1] Beth Hatefutsoth, Photo Archive, Jerusalem

[2] Cesariano C., Vitruvius' Architectura, Como 1521.

[3] Enciclopedia del románico en Castilla y León - Provincja León, eds. M.A.G. Guinea et al., Aguilar de Campoo 2002-2009, s. 258.

[4] Freundlich A., Soffer O., Documentation and survey of the synagogue structure, Safed 2003.

[5] Haggadah shel Pesah (Barcelona Hagadah), Barcelona 1325-1350, fol. 065v.

[6] Haggadah shel Pesah (Floersheim Hagadah), Włochy 1502, fol. 28v.

[7] Haggadah shel Pesah (Kaufmann Hagadah), Katalonia XIV w., fol. 42r.

[8] Haggadah shel Pesah (Sister Hagadah), Barcelona 1325-1374, fol. 17v.

[9] http://www.geocities.ws/cdesastre2000/Renacemento/BrunellAlberti/Alberti/Mantuainterior.jpg, [dostęp: 10.06.2013].

[10] http://kunsthistorie.com/galleri/index.php?album=Italia\%2FRoma\%2FSS.Cosmas.og.Damian\& sortby=name\&order=asc/ [dostęp: 18.08.2013].

[11] https://commons.wikimedia.org/wiki/File:Altar_of_Santi_Bonifacio_e_Alessio_(Rome).jpg [dostęp: 22.11.2013],

[12] https://commons.wikimedia.org/wiki/File:P\%C3\%A9rigueux_(FR),_interieur_Cath\%C3\%A9drale _St.Front.jpg [dostęp: 25.05.2012].

[13] https://commons.wikimedia.org/wiki/File:San_crisogono,_interno_01.jpg, [dostęp: 01.03.2016]

[14] https://commons.wikimedia.org/wiki/File:Sant\%27Agnese_fuori_le_mura_DSCF6844_17.jpg [18.10.2013],

[15] https://commons.wikimedia.org/wiki/File:Santo_Spirito_Innen_Florenz-3.jpg [12.05.2015],

[16] https://commons.wikimedia.org/wiki/File:Sanpetroniointerior.jpg [dostęp: 22.11.2013].

[17] https://commons.wikimedia.org/wiki/File:SanSalvatore03.jpg [dostęp: 10.06.2013].

[18] https://fr.wikipedia.org/wiki/Fichier:Napoli_BW_2013-05-16_10-55-34.jpg [dostęp: 11.04.2014].

[19] Kielisiński W.K., 1838, za: K. i M. Piechotka, Bramy Nieba: Bożnice murowane na ziemiach dawnej Rzeczypospolitej, Warszawa 1999, il. 364.

[20] Krinsky C.H., Synagogues of Europe: Architecture, History, Meaning, Cambridge 1985, s. 339, il. 186.

[21] Michalski M.

[22] Opr. własne na podstawie planów: A. Miłobędzki, Architektura Polska XVII wieku, Warszawa 1980. 


\section{Bibliografia}

[23] Opr. własne na podstawie: M. Idel, Visualization of Colors, I: David ben Yehudah he-H asid's Kabbalistic Diagram, „Ars Judaica” 2015, No. 11, il. 1a.

[24] Palladio A., I Quattro Libri dell'Architettura, Wenecja 1570, s. 14.

[25] Piechotkowie K. i M., Bramy Nieba: Bożnice murowane na ziemiach dawnej Rzeczypospolitej, Warszawa 1999.

[26] Regnart V., 1650, [w:] G.G. de Rossi, Insignium Romae Templorum Prospectus Exteriores Interioresque, a Celebrioribus Architectis Inventi, Roma 1683, mps: Bibliotheca Hertziana Dg 532-2830

[27] Serlio S., Di Architettura, vol. 2, Wenecja 1584, s. 37, Idem, Di Architettura, Vol. 3, s. 98.

[28] Serlio S., Di Architettura, vol. 4, Wenecja 1584, s. 185.

[29] Serlio S., Extraordinario libro di architettura, Wenecja 1560, tab. XIII.

[30] Villalpandus J.B., Pradus H., In Ezechielem explanationes et apparatus urbis ac templi Hierosolimitani. Commentarii et emag-inibus illustratus opus tribus tomis distinctum, Vol. 2, Rome 1596-1604.

[31] Vogel Z., ok. 1797 r., Gabinet Rycin Biblioteki Uniwersyteckiej w Warszawie, Inw. zb. d. 10173.

[32] Wischnitzer R., Maimonides' drawings of the Temple, „Journal of Jewish Art” 1974, No. 1, s. 27, il. 15.

[33] www.loc.gov/item/2001701006/ [dostęp: 25.05.2012].

[34] Zuchold G.-H., Friedrich Wilhelm IV. und das byzantinische Gott-Königtum. Seine Kirchenentwürfe als Modell einer "Kirche der Zukunft” in Preußen, w: „Zeitenblicke” 2010, Vol. 9, Nr. 3. Dostępny w Internecie: http://www.zeitenblicke.de/2010/3/Zuchold/index_html, URN:urn:nbn:de:0009-9-27552 [dostęp: 23.12.2013]. 


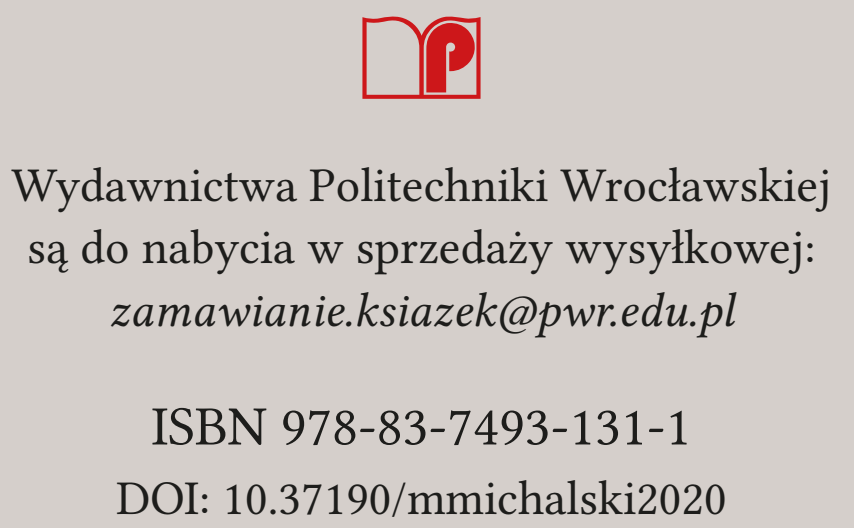

